\title{
Organización de la diversidad genética de los cítricos
}

\author{
Andrés García Lor, Julio 2013 \\ Supervisores: Luis Navarro Lucas, Patrick Ollitrault \\ Tutor: Ismael Rodrigo Bravo
}

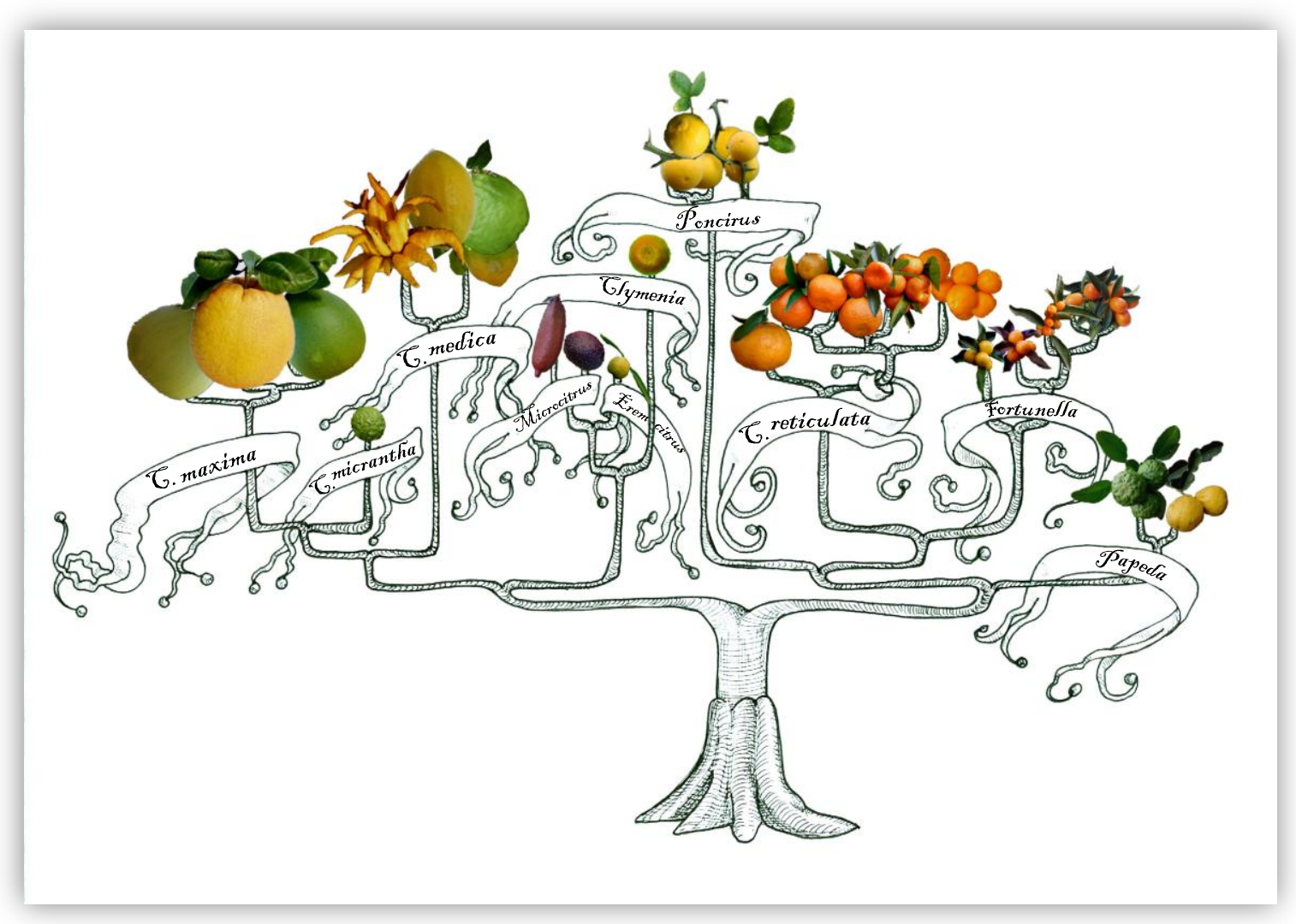

ivia

UNIVERSITAT

instituto valenciano de investigaciones agrarias 


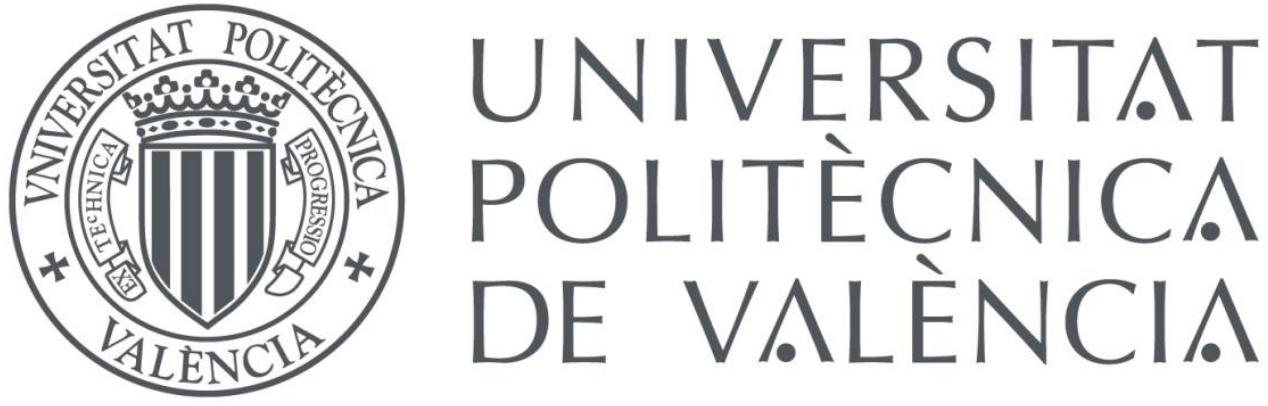

Departamento de Biotecnología

\title{
Organización de la diversidad genética de los cítricos
}

\section{$\underline{\text { Tesis doctoral }}$}

Presentada por:

Andrés García Lor

\author{
Dirigida por: \\ Dr. Patrick Ollitrault \\ Dr. Luis Navarro Lucas
}

VALENCIA, JULIO 2013 



\section{AGRADECIMIENTOS}

Bueno, pues parece que ya llegó el final de mi tesis, y ante mí, una nueva página en blanco, los agradecimientos, y por dónde empiezo? y a quién pongo? Tantas cosas han pasado y tanta gente en el camino que es complicado resumirlo. Espero no dejarme nada ni a nadie.

Todo esto empezó aquel día (19/01/2004) en el que emprendí mi aventura en Wageningen (pueblo universitario en Holanda, para los despistados), a donde fui a hacer mi trabajo final de carrera. Es allí donde comencé a sentir el gusanillo de la ciencia y donde se empezó a forjar una vocación que hasta día de hoy sigue en pie. Por aquellas tierras viví muchísimas experiencias y conocí a grandes amigos (inolvidable). Al año siguiente continué con mi vena científica y el espíritu viajero aterrizando en Redhill (pueblo pequeñito al sur de Inglaterra) donde estuve seis meses en los laboratorios de una brewery (centro de investigación de cerveza, "mola") donde también hice muy buenos amigos y aprendí muchas cosas. Además, casualidades de la vida, conocí a la que actualmente es mi novia, Ana.

De vuelta a la terreta mis dos años en el IBMCP. En la universidad empecé mi idilio con los cítricos y compartí laboratorio con grandes compañeros. Además me llevé la amistad de mucha gente, los "ibmceperos".

Después de esta aventura llegué al IVIA. Lo primero, y para no perder las costumbres, quiero agradecer la oportunidad que me brindó Luis Navarro al concederme la beca para poder realizar la tesis doctoral bajo su dirección, y por supuesto, quiero hacer una mención especial a Patrick Ollitrault, que además de codirector de mi tesis, le consideró como mi padre científico. Sin él esta tesis no hubiera sido la misma, muchas gracias por todo. Muchas gracias a mis evaluadores externos y los miembros del tribunal. También quiero dar las gracias a François Luro, quien me acogió en Córcega y me ayudó como a uno más de la gran familia francesa del INRA en San Giuliano (Yann, Gilles, Paul-Eric, Isabelle... et tous les stagiaires). Allí conocí también al que además de un muy buen amigo, es actualmente compañero en el IVIA, Franck. Me gustaría dar las gracias a mis colegas franceses de Montpellier, donde estuve dos semanas, que me enseñaron algunas de las herramientas utilizadas en la tesis.

Durante los últimos cinco años que he pasado en el IVIA, he vivido mil y una experiencias, almuerzos, cenas, paellas de San Isidro, fiestas, alquerías, conversaciones de pasillo, cafés, mudanza de laboratorio (pasamos a denominarnos Francia),... que he compartido con lo que para mí es la gran familia del IVIA, empezando por mis compis de laboratorio que ya no están, Mari Cruz, Rosa, María, Regina, y los que siguen, José (un crack), Franck, Frédérique, Marta, Juan, Gema, Houssem (gracias a todos y cada uno de vosotros por haberme ayudado en algún momento de esta tesis, un pedacito de ella es vuestra). También quiero recordar a los que ahora son "ex-ivias", Esther, Jorge, Giovanni, Inma, Álida, Marta, Águeda, Lucia.... y por supuesto a los que siguen, Jesús, Pablo, Vero, "las leandras" (Ana, Elsa, Nuria, Berta, Montse), Diana, Ezequiel, el equipo de cultivo (Pablo, Toni, Pepe, Vio, Carmen, Juana Mari, Ana, Cloti, Marga,......). También quiero recordar a aquellos que han tenido un paso más o menos largo por el IVIA (Caroline, Jean Baptiste, Hager...) y al personal del IVIA con el que en un momento $u$ otro también he compartido algunos momentos (investigadores, vigilantes, administración, limpieza). También mencionar a mis amigos de siempre: bankitos, FTK, agrónomos, biotecnólogos, equipo de fútbol... que alguna vez me han preguntado: ¿Qué es lo que haces? ¿Para qué sirve?...

Por último, dedicarle esta tesis a mi familia, mis padres y mi hermana, siempre han estado y estarán ahí. Y por supuesto a mi cítrico favorito, mi media naranja, Ana. 



\section{RESUMEN}

Citrus es el género de la subfamilia Aurantioideae de mayor importancia económica. Su origen es la región sureste de Asia, en un área que incluye China, India y la península de Indochina y los archipiélagos de los alrededores. Aunque se han realizado múltiples estudios, la taxonomía del género Citrus aun no está bien definida, debido al alto nivel de diversidad morfológica encontrado en este grupo, la compatibilidad sexual entre sus especies y la apomixis de muchos genotipos. En la presente tesis doctoral se ha estudiado una amplia diversidad del género Citrus, especies relacionadas y otros taxones de la subfamilia Aurantioideae, para poder aclarar su organización y filogenia mediante el empleo de diferentes tipos de marcadores moleculares y métodos de genotipado. Más concretamente, el germoplasma de mandarino juega un papel muy importante en la mejora de variedades y patrones, pero su organización genética no está bien definida. Por lo tanto, se ha realizado un análisis en profundidad de su diversidad y organización genética.

El desarrollo de marcadores moleculares de Inserción-Deleción (indel), por primera vez en cítricos, ha permitido demostrar su utilidad para estudios de diversidad y filogenia en el género Citrus. En combinación con los marcadores de tipo microsatélite (SSR), se ha cuantificado la contribución de los tres principales taxones de cítricos $(C$. reticulata, $C$. maxima and $C$. medica) a los genomas de las especies secundarias y cultivares modernos. También se ha definido su estructura genética a partir de los datos obtenidos en la secuenciación de 27 fragmentos de genes nucleares relacionados con la biosíntesis de compuestos que determinan la calidad de los cítricos y genes relacionados con la respuesta de la planta a estreses abióticos. El análisis de la filogenia nuclear ha permitido determinar la relación existente entre la especie $C$. reticulata y Fortunella, que se diferencian claramente del grupo formado por las otras dos principales especies de cítricos (C. maxima y $C$. medica). Este resultado está en concordancia con el origen geográfico de las especies estudiadas. A partir de este estudio, se han desarrollado marcadores moleculares de tipo SNP con un alto valor filogenético, que han sido transferidos a géneros relacionados de los cítricos. Estos marcadores han dado un resultado muy positivo en el género Citrus y serán de gran utilidad para el establecimiento de la huella genética del germoplasma en un nivel de diversidad más amplio.

Se ha estudiado la organización genética dentro del germoplasma mandarino (198 genotipos de tipo mandarino pertenecientes a dos colecciones, INRA-CIRAD e IVIA), así como la introgresión de otros genomas mediante el uso de 50 y 24 marcadores de tipo SSR y indel, respectivamente, además de cuatro marcadores indel mitocondrial (ADNmt). Se ha observado que muchos genotipos, que se creía que eran mandarinos puros, presentan introgresión de otros genomas ancestrales. Dentro del germoplasma de mandarino, se han identificado a nivel nuclear cinco grupos parentales, a partir de los cuales se originaron muchos genotipos, dando lugar a estructuras hibridas complejas. Se ha observado incluso, genotipos con un origen maternal no mandarino, determinado por los marcadores de ADNmt.

La presente tesis doctoral ha aportado nueva información sobre las relaciones filogenéticas entre las especies del género Citrus, géneros cercanos, así como de las especies secundarias. Además, se han desarrollado nuevos marcadores moleculares que se complementan entre sí. Se ha establecido una nueva organización genética del germoplasma mandarino y se han caracterizado adecuadamente las dos colecciones de cítricos en estudio. Por lo tanto, todas estas contribuciones, ayudarán a los programas de mejora para la obtención de nuevas variedades de cítricos de alta calidad y permitirán optimizar la conservación y uso de los recursos genéticos existentes, así como su caracterización genética y fenotípica. 



\section{RESUM}

El gènere Citrus és sens dubte el més important de la subfamília Aurantioideae a nivell econòmic. Es creu que s'originà en la regió del sud-est d'Àsia, en una àrea que inclou la Xina, l'Índia, la península d'Indoxina i els arxipèlags dels voltants. Malgrat que s'hagen fet molts estudis, la taxonomia dels cítrics és encara controvertida degut a la gran diversitat morfològica que hi ha dins d'aquest grup, la compatibilitat sexual entre espècies i l'apomixi de molts genotipus. En aquesta tesi doctoral s'ha estudiat una àmplia diversitat dins del gènere Citrus, de relatius dels cítrics i d'altres taxa de la subfamília Aurantioideae, per tal d'aclarir la seua organització i filogènia mitjançant la utilització de diferents tipus de marcadors moleculars $i$ vàries plataformes de genotipat. A més a més, el germoplasma de les mandarines juga un paper molt important en la millora genètica de portaempelts i cultivars, però la seua organització genètica no es encara prou coneguda. Per tant, s'ha analitzat a fons la seua diversitat.

Per primera volta en els cítrics, s'han desenvolupat marcadors nuclears "InsertionDeletion" (indel), que han permès demostrar la seua utilitat per fer estudis de diversitat $i$ filogènia dins del gènere Citrus. En combinació amb marcadors del tipus SSR, s'ha pogut quantificar la contribució de les tres taxa més importants dels cítrics (C. reticulata, $C$. maxima i C. medica) als genomes de espècies secundàries i de cultivars moderns. També s'ha determinat la seua estructura genètica mitjançant les dades obtingudes en seqüenciar 27 gens nuclears responsables de la biosíntesi de compostos relacionats amb la qualitat dels cítrics i de gens involucrats en la resposta a estrès de les plantes. Les anàlisis filogenètiques nuclears han mostrat que $C$. reticulata i Fortunella formen una clada clarament diferenciada d'una altra que inclou dos altres taxa bàsics de cítrics cultivats ( $C$. maxima i $C$. medica), cosa que està d'acord amb l'origen geogràfic de les espècies que s'han estudiat. Aquest estudi ens ha permès desenvolupar marcadors moleculars de tipus SNP que tenen un gran valor filogenètic i analitzar la seua transferibilitat a altres gèneres relacionats genèticament. Aquests funcionen molt bé dins del gènere Citrus i seran molt útils per al "fingerprinting" de germoplasma a un nivell de diversitat molt més ampli.

S'ha estudiat la organització genètica del germoplasma de les mandarines (198 genotipus 'mandarin-like' de dues col-leccions de germoplasma, INRA-CIRAD i IVIA), i la seua introgressió per altres taxa per mitjà de 50 i 24 SSRs i de marcadors indels nuclears respectivament, i quatre indels mitocondrials (ADNmt). S'ha vist que molts genotipus, que es creia que eren mandarines pures, contenen en els seus genomes introgressió d'altres taxa bàsiques. S'han establert cinc grups parentals en el germoplasma analitzat. A més, molts genotipus es deuen haver originat de creuaments entre aquestes mandarines, cosa que ha donat lloc a una estructura híbrida molt complexa. I a més, segons s'ha establert per mitjà de marcadors ADNmt, alguns genotipus de mandarina tenen un origen matern que no és de tipus mandarina.

Aquesta tesi doctoral ha proporcionat nova informació sobre les relacions filogenètiques dels taxa dins del gènere Citrus i d'espècies relacionades, com també d'espècies secundaries de tipus comercial. S'han desenvolupat nous grups de marcadors complementaris. S'ha establert l'organització genètica del germoplasma de les mandarines així com una adequada caracterització de dues col-leccions de germoplasma de cítrics. Per tant, aquestes contribucions ajudaran a la millora genètica de nous cultivars de cítrics de qualitat i contribuirà a optimitzar la conservació i caracterització dels recursos genètics de cítrics tant a nivell genètic com fenotípic. 

Citrus is by far the most economically important genus of the subfamily Aurantioideae. It is believed to have originated in the south-eastern region of Asia, in an area that includes China, India and the Indochinese peninsula and nearby archipelagos. Although many different studies have been done, Citrus taxonomy is still controversial due to the large degree of morphological diversity found within this group, the sexual compatibility between the species and the apomixis of many genotypes. In this $\mathrm{PhD}$ thesis a broad diversity within the Citrus genus, citrus relatives and other taxa from the Aurantioideae subfamily has been studied in order to clarify their organization and phylogeny using different types of molecular markers and different genotyping platforms. The mandarin germplasm plays a major role in citrus rootstock and cultivar breeding, but its genetic organization is still largely unknown. Therefore, an analysis in depth of diversity and organization has been done.

The development of nuclear Insertion-Deletion (indel) markers, for the first time in citrus, has allowed us to demonstrate its utility for diversity and phylogenetic studies in the genus Citrus. In combination with SSR markers, the contribution of three basic edible taxa $(C$. reticulata, C. maxima and C. medica) to the genomes of secondary species and modern cultivars has been quantified. Their mosaic genetic structure has also been determined from the data obtained by sequencing 27 nuclear genes involved in the biosynthesis of quality compounds of citrus and genes involved in plant stress response. Nuclear phylogenetic analysis revealed that $C$. reticulata and Fortunella form a clade that is clearly differentiated from the clade that includes two other basic taxa of cultivated citrus (C. maxima and $C$. medica), which is consistent with the geographic origin of the species studied. From this study, SNP molecular markers with a high phylogenetic value has been developed and tested for transferability into genetically related genera. They performed very well within the Citrus genus and should be useful for germplasm fingerprinting at a much broader diversity level.

The genetic organization within the mandarin germplasm (198 'mandarin-like' genotypes from two germplasm collections, INRA-CIRAD and IVIA), and its introgression by other taxa was studied with 50 and 24 nuclear SSRs and indel markers respectively, and four mitochondrial (mtDNA) indels. It has been shown that many genotypes, believed to be pure mandarins, have introgression from other basic taxa in their genomes. Five parental groups have been determined within the germplasm analysed. Moreover, many genotypes have been originated from the cross between these mandarins, leading to a very complex hybrid structures. Furthermore, some mandarin genotypes have a non-mandarin maternal origin as determined by mtDNA markers.

This $\mathrm{PhD}$ thesis has released new information about the phylogenetic relationships of taxa within the Citrus genus and relative species, as well as secondary commercial species. New sets of complementary markers had been developed. The genetic organization of the mandarin germplasm was revealed and a proper characterization of two citrus germplasm collections was obtained. These contributions will help in the breeding of new, high-quality citrus cultivars and will contribute to optimizing the conservation and characterization at genetic and phenotypic levels of the citrus genetic resources. 



\section{RÉSUMÉ}

Le genre Citrus est de loin le genre le plus important du point de vue économique de la sous-famille des Aurantioideae (Famille des Rutacées). Les Citrus seraient originaires du SudEst asiatique, dans une zone comprenant la Chine, l'Inde, la péninsule indochinoise et les archipels voisins. Malgré un grand nombre d'études réalisées, la taxonomie des Citrus reste un sujet très controversé du fait de la grande diversité morphologique observée, de la compatibilité sexuelle entre espèces et de l'apomixie de nombreux génotypes. Dans ce travail de thèse une importante diversité du genre Citrus et d'autres genres apparentés de la sous-famille des Aurantioideae, ont été étudiés afin de clarifier leur organisation et leur phylogénie en utilisant différents types de marqueurs et de plateformes de génotypage. Par ailleurs, nous avons fait une analyse particulièrement poussée de la diversité génétique des mandarines car, malgré le rôle particulièrement important que joue ce groupe d'agrumes dans la sélection de porte-greffe et l'amélioration variétale, son organisation génétique est encore mal connue.

Le développement, pour la première fois sur agrumes, de marqueurs nucléaires d'insertion-délétion (indel) nous a permis de démontrer leur utilité dans l'étude de la diversité phylogénétique des Citrus. Ces marqueurs, en association avec des marqueurs SSR, ont permis de quantifier la contribution des trois taxons de bases $(C$. reticulata, $C$. maxima et $C$. medica) dans le génome des espèces secondaires et des variétés cultivées. Leur structure génétique en mosaïque a également été déterminée à partir des données obtenues par le séquençage de 27 gènes nucléaires impliqués dans la biosynthèse de composés influençant la qualité des agrumes et dans la réponse au stress des plantes. L'analyse phylogénétique nucléaire a révélé que $C$. reticulata et Fortunella forment un clade clairement différencié du clade comprenant les autres taxons de base des agrumes cultivés ( $C$. maxima et $C$. medica), ce qui est cohérent avec l'origine géographique des espèces étudiées. A partir de cette étude nous avons développé des marqueurs moléculaires SNP à haute valeur phylogénétique et testé leur transférabilité aux autres genres apparentés. Ces marqueurs ont parfaitement fonctionné au sein du genre Citrus et devraient être également utiles pour l'identification variétale au sein des collections, sur une diversité beaucoup plus large.

L'organisation génétique des mandarines [198 variétés de type « mandarine » provenant de deux collections d'agrumes : Inra-Cirad (Haute-Corse, France) et Ivia (Valence, Espagne)], et les introgressions d'autres taxons au sein de ces mêmes mandarines ont été étudiées à l'aide de 50 marqueurs SSRs, de 24 indels nucléaires et de quatre indels mitochondriaux (ADNmt). II a été démontré que de nombreux génotypes, considérés comme des mandarines pures, présentaient en fait des introgressions d'autres taxons de base dans leur génome. Cinq groupes parentaux ont été déterminés parmi les génotypes analysés. De nombreux génotypes sont issus de croisement entre ces différentes mandarines, créant ainsi des structures hybrides très complexes. De plus, certaines mandarines n'ont pas une origine maternelle " mandarine ", tel que le démontre les marqueurs d'ADNmt.

Dans le cadre de ce travail de thèse ont été publiées de nouvelles informations sur les relations phylogénétiques entre les différents taxons du genre Citrus et apparentés ainsi qu'entre les espèces secondaires cultivées. Des nouveaux sets de marqueurs complémentaires ont été développés. L'organisation génétique des mandarines a été détaillée et une caractérisation fiable des deux collections (France et Espagne) a pu être réalisée. Ces différentes contributions pourront ainsi aider au travail de sélection de nouvelles variétés d'agrumes de haute qualité et permettra d'optimiser la conservation et la caractérisation génétique et phénotypique des ressources génétiques agrumes. 

INDEX

INTRODUCCIÓN

OBJECTIVOS 31

CHAPTER 1: Comparative use of indel and SSR markers in deciphering the interspecific structure of cultivated citrus genetic diversity: a perspective for genetic association studies. Molecular Genetics and Genomics (2012) 287: 77-94.

CHAPTER 2: A nuclear phylogenetic analysis: SNPs, indels and SSRs deliver new insights into the relationships in the 'true citrus fruit trees' group (Citrinae, Rutaceae) and the origin of cultivated species. Annals of Botany (2013) 111: 1-19.

Annex chapter 2: Clymenia's phylogeny within the 'true citrus fruit trees'.

CHAPTER 3: Citrus (Rutaceae) SNP markers based on Competitive Allele-Specific PCR; transferability across the Aurantioideae subfamily. Applications in Plant Sciences (2013) 4: doi:10.3732/apps.1200406.

CHAPTER 4: Genetic diversity analysis and population-structure of the mandarin germplasm by nuclear (SSRs, indel) and mitochondrial markers. Submitted.

DISCUSSION

CONCLUSIONS 



\section{INTRODUCCIÓN}


1. IMPORTANCIA ECONÓMICA DE LOS CÍTRICOS. 1

2. CENTRO DE ORIGEN Y DIFUSIÓN DE LOS CÍTRICOS.

3. CLASIFICACIÓN BOTÁNICA Y ORIGEN GENÉTICO DE LOS CÍTRICOS. 3

3.1. Clasificación botánica de la subfamilia Aurantioideae. 3

3.2. Descripción general de los principales géneros de los cítricos verdaderos.

3.3. Clasificación del género Citrus. $\quad 5$

3.4. Origen genético de las especies cultivadas de cítricos.

3.5. La situación particular de la clasificación de los mandarinos. 8

4. MEJORA GENÉTICA DE LOS CÍTRICOS. 9

4.1. Mejora de patrones. 10

4.2. Mejora de variedades. 11

4.3. Problemas en la mejora de los cítricos. $\quad 11$

4.4. Calidad del fruto de los cítricos; biosíntesis de metabolitos primarios y secundarios.

4.4.1. Azúcares y acidez en los cítricos $\quad 13$

4.4.1.1 Biosíntesis de los azúcares y los ácidos $\quad \mathbf{1 3}$

4.4.2. Flavonoides y antocianos $\quad 15$

4.4.2.1. Biosíntesis de los flavonoides y antocianos $\quad 15$

4.4.3. Carotenoides $\quad 16$

4.4.3.1. Biosíntesis de los carotenoides $\quad 16$

5. RECURSOS FITOGENÉTICOS EN CÍTRICOS.

5.1. Conservación de los recursos fitogenéticos. 19

5.2. Manejo de los recursos fitogenéticos. $\quad 20$

5.2.1. Localización de la variabilidad disponible para un germoplasma. $\quad 20$

5.2.2. Introducción del material. $\quad 20$

5.2.3. Mantenimiento de la colección. $\quad 21$

5.2.4. Caracterización y evaluación. $\quad 21$

5.2.5. Documentación y bases de datos.

5.2.6. Utilización de los recursos de los bancos de germoplasma.

5.2.6.1. Colecciones nucleares. 23

5.2.6.2. Genética de asociación. $\quad 24$

6. HERRAMIENTAS MOLECULARES EXISTENTES EN CÍTRICOS. 26

6.1. Marcadores moleculares. $\quad 26$

6.2. Recursos genómicos de cítricos. 29 


\section{IMPORTANCIA ECONÓMICA DE LOS CÍTRICOS.}

Los cítricos son el principal cultivo frutal del mundo, con una superficie cultivada superior a 8,6 millones de hectáreas y una producción de casi 124 millones de toneladas en 2010, superando a cultivos como la banana, las manzanas o la vid (FAOSTAT, 2012). China es el mayor productor de cítricos (cerca de 24 millones de toneladas), seguido de Brasil, Estados Unidos, India, Méjico y España con más de 6 millones de toneladas. Las naranjas son los cítricos más cultivados ( $56 \%$ de la producción), le siguen las mandarinas (17\%), limones y limas $(12 \%)$, los pomelos $(10 \%)$ y otros cítricos $(6 \%)$. Las naranjas solo son superadas en producción por las bananas y ligeramente por las manzanas.

El $20 \%$ de la producción citrícola mundial procede de la cuenca Mediterránea. Esta es una de las áreas mundiales más importantes en horticultura. Su clima templado, con veranos cálidos y secos, y los inviernos húmedos y suaves, han sido importantísimos en el desarrollo de la horticultura. La industria frutícola ha sido una pieza clave en el desarrollo de la región. Según la FAO, el tamaño de este sector se extiende en alrededor de 6 millones de hectáreas y una producción anual de cerca de 50 millones de toneladas. Los frutos templados forman el grupo más importante, con un $40 \%$ del área cultivada y un $50 \%$ de la producción, mientras que los frutos secos cubren el $36 \%$ del área, aunque solo contribuyen un $4 \%$ en la producción. Los cítricos cubren un $18 \%$ de área y un $40 \%$ de la producción; los frutos tropicales, en cambio, son poco importantes en la cuenca Mediterránea (Fideghelli and Sansavini, 2002).

En España, el cultivo frutal con mayor producción son los cítricos (más de 6 millones de toneladas; $306.000 \mathrm{Ha}$.), seguido de lejos por los melocotones y nectarinas (1.1 ton.; 80.000 Ha.). Entre los cítricos, las naranjas son las de mayor producción y superficie dentro de los cítricos $(52.8 \%)$, seguidas por las mandarinas (34.6\%), limones $(11.4 \%)$, pomelos $(1.0 \%)$ y otros cítricos (0.1\%) (http://www.magrama.gob.es). La Comunidad Valenciana es la mayor productora de cítricos en España, seguida de Andalucía y la Región de Murcia. De acuerdo a la FAO, España es el principal exportador de cítricos para fruta fresca en el mundo, destinando más de la mitad de su producción a la exportación.

\section{CENTRO DE ORIGEN Y DIFUSIÓN DE LOS CÍTRICOS.}

Se han formulado diferentes hipótesis acerca del origen de los cítricos. En general, se está de acuerdo en que las especies de cítricos y géneros afines son originarios de las regiones tropicales y subtropicales del Sureste Asiático y del Archipiélago Malayo, desde donde se distribuyeron a otros continentes donde se han cultivado (Webber et al., 1967; Calabrese 1992).

El centro principal de origen de los cítricos según Tanaka (1954) sería la zona del noroeste de India y Burma, considerando a China como un centro de distribución secundario. Además, propuso una línea teórica que divide el origen de las distintas especies. Esta línea va desde el borde noroeste de India, por encima de Burma, hasta el sur de la isla de Hainan. 
Especies como el cidro, el limón, la lima o la zamboa se originaron al sur de esta línea y especies como las mandarinas, Fortunella o Poncirus al norte de la misma. Swingle and Reece (1967) propuso como centro de origen del género Citrus las regiones tropicales y subtropicales de Asia y el Archipiélago Malayo. Calabrese (1998) indicó que el núcleo principal de origen de los cítricos era China, desde donde se empezó a distribuir por la parte oriental y de aquí siguió los pasos de la civilización.

Los primeros datos escritos acerca de los cítricos se remontan alrededor del año 2400 a.C. en China (capítulo del libro "Tribute to Yu"), así como alrededor del año 800 a.C. en la India (texto religioso "Vajaseneyi sambita"). En estos textos se empezó a hablar de las mandarinas de pequeño tamaño, de los kumkuats (Fortunella), las zamboas (C. maxima) y del "Yuzu" (C. junos), a las cuales se les atribuían usos de tipo medicinal e incluso milagroso (Praloran, 1977). Desde este centro indo-chino primitivo, los cítricos se distribuyeron con mayor facilidad hacia el sudeste (Malasia) y el oeste (valle del Indo) que hacia el nordeste. Se cree que los cítricos se pudieron difundir alrededor del tercer milenio a.C. a través de las relaciones comerciales entre la civilización de Mohandjodaro (Indo) y la baja Mesopotamia.

El cidro fue el primer cítrico conocido en Europa, alrededor del año 300 a.C. (Swingle and Reece, 1967). Durante el viaje de Alejandro Magno (334-323 a.C.) los sabios griegos describieron el cidro como "Manzana de Media" o "Manzana de Persia", y no como fruta de Mesopotamia. También existe controversia en la hipótesis de que los egipcios conocían el cidro entre los años 1500 y 1200 a.C. y su paso hacia Europa debido a sus relaciones comerciales. El cultivo del cidro se extendió desde Persia hasta Palestina alrededor del año 136 a.C., utilizado como ofrenda por los judíos en la fiesta de los Tabernáculos. Las colonias judías contribuyeron a su difusión por la cuenca Mediterránea, llegando a Grecia en el siglo III a.C. y a Italia en el siglo I d.C.

En la difusión del resto de cítricos tuvieron un papel importante los árabes. El naranjo amargo existía en Persia en el 1030 y en Sicilia alrededor del 1094. El limonero se introdujo en el siglo XII y las limas en el siglo XIII. La importación del naranjo dulce a Europa fue obra de los genoveses hacia el 1400, así como de los portugueses en 1548 (Zaragoza, 2007). Los cítricos se difundieron desde el mediterráneo por tres vías: los árabes hacia África entre los siglos XI y XIII, Cristóbal Colón los introdujo en Haití en 1493 y los anglo-holandeses los introdujeron en el Cabo en 1654. Con el descubrimiento de América y su conquista paulatina, se produjo la implantación de los cítricos en Méjico (1518), Brasil (1540), Florida (1565), Perú (1609) o Texas (1890). Los colonos de la primera flota llevaron naranjas, limas y limones desde Brasil a Australia en 1769. Las mandarinas no fueron introducidas en Europa hasta el inicio del siglo XIX.

En cuanto a la introducción de los cítricos en España, el cidro es también el primer cítrico del que se tienen noticias (en torno al siglo VII), siendo lo más probable que fuera introducido a través de Italia y cultivado en algunas regiones del litoral mediterráneo español. 
Probablemente los comerciantes árabes introdujeron el naranjo amargo en España hacia los siglos X y XI (Zaragoza, 2007).

El limonero se supone que llegó a España al mismo tiempo o poco después que el naranjo amargo. El geópono toledano Ibn Bassal (1048-1075) cita por primera vez al limonero, junto al cidro y el naranjo amargo, en su Libro de Agricultura. Posteriormente, hacia finales del siglo XI o comienzos del siglo XII destacados geóponos andalusíes citan en sus tratados de agricultura la zamboa, diferenciándola claramente del cidro, del naranjo amargo y del limonero (Zaragoza, 2007).

Pese a que se cree que los genoveses introdujeron el naranjo dulce a mediados del siglo XV a través de sus rutas comerciales con Oriente, fueron los portugueses los que contribuyeron a su difusión en la península lbérica, al importar de China semillas de variedades de naranja dulce de calidad (Zaragoza, 2007). En cuanto a las mandarinas se tienen referencias de su introducción a mediados del siglo XIX desde Italia (Zaragoza, 2007). Por lo que respecta al pomelo, se empieza a cultivar en la primera mitad del siglo XX (Herrero et al., 1996).

\section{CLASIFICACIÓN BOTÁNICA Y ORIGEN GENÉTICO DE LOS CÍTRICOS.}

\subsection{Clasificación botánica de la subfamilia Aurantioideae.}

Por norma general los taxonomistas consideran que las especies de cítricos pertenecen al orden Geraniales, la familia Rutaceae y la subfamilia Aurantioideae. Aurantioideae está considerada como un grupo monofilético según varios autores (Scott et al., 2000; Groppo et al., 2008; Morton, 2009). Según Scott et al. (2000) y Bayer et al. (2009) Ruta parece ser hermana de Aurantioideae. Más aún, Groppo et al. (2008) sugieren que Aurantioideae debería ser reconocida como una tribu e incluirla en una subfamilia junto con Rutoideae, Toddalioideae y Flindersioideae. Pese a que se han sido publicados recientemente nuevos datos sobre la clasificación botánica de Aurantioideae (Bayer et al., 2009; Morton, 2009), sigue existiendo una considerable controversia sobre la división en tribus, subtribus, géneros y especies. Según Swingle and Reece (1967) dentro de esta subfamilia existen dos tribus: Clauseneae con cinco géneros y Citreae con 28. La tribu Clauseneae es más primitiva que la Citreae. Dentro de esta última tribu, la subtribu Citrinae está compuesta de tres grupos, siendo el más importante el de los cítricos verdaderos, donde encontramos los seis géneros más cercanos a los cítricos, incluidos estos (Fortunella, Eremocitrus, Poncirus, Clymenia, Microcitrus y Citrus; Tabla 1). 
Tabla 1. Clasificación de la subfamilia Aurantioideae (según Swingle and Reece, 1967).

\begin{tabular}{|c|c|c|c|}
\hline Tribu & \multirow{2}{*}{\multicolumn{2}{|c|}{$\begin{array}{l}\text { Subtribu } \\
\text { Micromelinae }\end{array}$}} & Género \\
\hline \multirow[t]{5}{*}{ Clauseneae } & & & Micromelium \\
\hline & \multirow{3}{*}{\multicolumn{2}{|c|}{ Clauseneae }} & Glycosmis \\
\hline & & & Clausena \\
\hline & & & Murraya \\
\hline & \multicolumn{2}{|l|}{ Merrillinae } & Merrillia \\
\hline \multirow[t]{29}{*}{ Citreae } & \multirow{9}{*}{\multicolumn{2}{|c|}{ Triphasilinae }} & Wenzelia \\
\hline & & & Monanthocitrus \\
\hline & & & Oxanthera \\
\hline & & & Merope \\
\hline & & & Tripashia \\
\hline & & & Pamburus \\
\hline & & & Luvunga \\
\hline & & & Paramingnya \\
\hline & & & Wenzelia \\
\hline & \multirow[t]{13}{*}{ Citrinae } & Cítricos primitivos & Severinia \\
\hline & & & Pleiospermium \\
\hline & & & Burkillanthus \\
\hline & & & Limnocitrus \\
\hline & & & Hesperethusa \\
\hline & & Cítricos próximos & Citropsis \\
\hline & & & Atalantia \\
\hline & & Cítricos verdaderos & Fortunella \\
\hline & & & Eremocitrus \\
\hline & & & Poncirus \\
\hline & & & Clymenia \\
\hline & & & Microcitrus \\
\hline & & & Citrus \\
\hline & \multirow{7}{*}{\multicolumn{2}{|c|}{ Balsamocitrinae }} & Swinglea \\
\hline & & & Aegle \\
\hline & & & Afraegle \\
\hline & & & Aeglopsis \\
\hline & & & Balsamocitrus \\
\hline & & & Feronia \\
\hline & & & Feroniella \\
\hline
\end{tabular}

3.2. Descripción general de los principales géneros de los cítricos verdaderos.

Fortunella se caracteriza por tener frutos de tamaño pequeño con la corteza dulce y comestible, posee de 3 a 7 ovarios loculares y vesículas delgadas; las hojas son duras con muchas glándulas y aceites esenciales. Los árboles tienen hojas perennes; algunos son de tamaño arbustivo y otros pueden tener un tamaño considerable. Son tolerantes al frío debido a su floración más tardía que la de las especies de Citrus. Son plantas muy atractivas, por lo que también se cultivan como ornamentales. Su origen es el sureste de China. Está constituido por cuatro especies: Fortunella margarita (Lour.) Swing., F. japonica (Thunb.) Swing., F. polyandra (Ridl.) Tan. y F. hindsii (Champ.) Swing. (Krueger and Navarro, 2007).

Eremocitrus es un género monoespecífico (Eremocitrus glauca (Lindl.) Swing). Las hojas son de color gris-verdoso, gruesas y con pelos en ambos lados. Las flores están sueltas o en ramilletes, con ovarios entre 3-5 lóculos, similares a Fortunella. Los frutos son ovoides o piriformes, con vesículas delgadas. Es nativo de zonas desérticas de Australia y tolerante al frío y a la sequía. 
Poncirus (Poncirus trifoliata (L.) Raf.) es el único miembro con hojas trifoliadas y caducas, con peciolos alados y brotes florales formados en el principio del verano, que en invierno están protegidos por escamas (Swingle and Reece, 1967). Los ovarios poseen de 6 a 8 lóculos. Los frutos son pubescentes y las vesículas tienen gran cantidad de aceites esenciales. Según Swingle podría representar el ancestro putativo de de los cítricos verdaderos que se difundió hacia el norte de China, adaptando sus características morfológicas y de resistencia a condiciones extremas de frío invernal. Se utiliza principalmente como patrón y como ornamento.

Clymenia es posiblemente el género más primitivo dentro de los cítricos verdaderos. Tiene hojas que se parecen a las de algún género de la subtribu Triphasiinae. Las flores tienen discos alargados y entre 10 y 20 estámenes y sépalos. Las vesículas de la pulpa son de forma subglobosa o piriforme, que en su gran mayoría están adheridas a las paredes radiales de los segmentos del fruto (14-16). Originalmente se consideró dentro del género Citrus, pero tanto Swingle (1939) como (Tanaka 1954), lo consideraron fuera de éste. Un estudio reciente (Berhow et al., 2000) sugiere su carácter híbrido, entre Fortunella y Citrus, basándose en datos bioquímicos y taxonómicos.

Microcitrus posee un follaje dimórfico, con flores pequeñas y unas vesículas de la pulpa subglobosas que los diferencia del género Citrus. Posee gotas de aceites en las vesículas de la pulpa. Los árboles son de tamaño pequeño, tipo arbustivo y con frutos generalmente alargados. Es nativo de zonas desérticas de Australia y en consecuencia es semi-xerófito y puede soportar largas sequías. El género Microcitrus está constituido por seis especies: Microcitrus australasica (F. Muell.) Swing., M. australis (Planch.) Swing., M. garrowayi (F.M. Bail.) Swing, M. inodora (F.M. Bail.) Swing., M. maideniana (Domin) Swing. y M. warburgiana (F.M. Bail.) Tan. (Krueger and Navarro, 2007).

Citrus presenta un amplio rango de caracteres y a su vez una gran variabilidad dentro de ellos. La maduración de los frutos es desde muy temprana hasta muy tardía en la temporada. El tamaño de los frutos varía desde muy pequeños, como algunas mandarinas (alrededor de $5 \mathrm{~cm}$.), hasta los más grandes como las zamboas o algunos cidros $(15-25 \mathrm{~cm}$.). La forma tanto de los frutos como de las hojas, así como el porte y el crecimiento de los árboles y el contenido en semillas son altamente variables.

\subsection{Clasificación del género Citrus.}

Citrus es el género con la taxonomía más complicada y el de mayor importancia económica de la subfamilia Aurantioideae. Las dos clasificaciones de los cítricos más comúnmente empleadas son las de Swingle and Reece (1967) y la de Tanaka (1954, 1961). El primero dividió el género Citrus en dos subgéneros, Citrus y Papeda, que incluían 10 y 6 especies respectivamente. Estos dos subgéneros se separaban por sus características morfológicas y los componentes químicos de sus flores, hojas y frutos. Tanaka publicó en 1954 
"Species Problem in Citrus", dividiendo el género Citrus en dos subgéneros, Archicitrus y Metacitrus, 8 secciones, 13 subsecciones, 8 grupos, dos subgrupos, dos microgrupos y 145 especies. Años después, en 1961, añadió dos nuevas subsecciones, otro grupo y 12 nuevas especies, hasta un total de 157 especies. La mayor diferencia entre las dos clasificaciones es que Tanaka realizó una descripción de los cítricos muy exhaustiva, llevándole a dividir las mandarinas en 36 especies. Por el contrario, Swingle incluyó en la especie C. reticulata Blanco a todas las mandarinas con excepción de C. tachibana (Mak.) Tanaka y C. indica Tan.. Hodgson (1967) propuso una nueva clasificación, con 36 especies divididas en 4 grupos: frutos ácidos, grupo de las naranjas, grupo de las mandarinas y otros. Más recientemente, Mabberley (1997) propuso una nueva clasificación de los cítricos comestibles reconociendo 3 especies y 4 grupos híbridos.

Estudios basados en caracteres bioquímicos (Scora, 1975) y morfológicos (Barret and Rhodes, 1976) sugerían que la mayoría de especies del género Citrus son probablemente híbridos directos o híbridos sucesivos de tres especies ancestrales (C. medica L. -cidro-, C. reticulata -mandarinas- y C. maxima (Burm.) Merr. -zamboas-). Estudios basados en diversidad morfológica (Ollitrault et al., 2003) y en metabolitos secundarios (Fanciullino et al., 2006a) confirmaron la importancia de estas tres especies en el origen de la mayoría de cítricos comestibles y la contribución mayor de la diferenciación entre estas especies en la diversidad fenotípica global de los cítricos. Además, C. micrantha Wester (Papeda) es considerado un ancestro de la lima mejicana (C. aurantifolia (Christm.) Swing) (Federici et al., 1998; Nicolosi et al., 2000; Ollitrault et al., 2012a).

Los cidros tienen semillas monoembriónicas. Son árboles de tamaño pequeño, de tipo arbusto, sensibles al frío. Las hojas son glabras, elípticas-ovaladas ó ovaladas-lanceoladas, con los márgenes serrados, peciolo no alado (al contrario que las otras especies de cítricos) y no articulado con el resto de la hoja. Las inflorescencias son en racimo con flores de color morado. Los ovarios son cilíndricos con 10-13 lóculos. Los frutos son alargados, oblongos ó ovalados, de superficie lisa o a veces arrugada, con corteza muy gruesa, segmentos pequeños y con bastantes semillas. Su uso más extendido es en confituras, además de utilizarse como encurtidos y sus aceites esenciales destilados.

Las zamboas tienen semillas monoembriónicas. Los árboles tienen de 5 a 15 metros de altura, ramas angulares a menudo pubescentes. Las hojas son alargadas, ovaladas o elípticoovaladas con peciolo alado. Las flores son alargadas, crecen individualizadas, en grupos axilares o en inflorescencias subterminales. Tienen ovario globoso con muchos segmentos. Los frutos son de diversos tamaños, formas y colores, tanto interno como externo. Tienen una piel muy gruesa y unas vesículas alargadas no adheridas entre sí.

Las mandarinas son árboles de tamaño variable, con espinas y ramificaciones finas. Las hojas son lanceoladas, las flores se presentan individuales o en inflorescencias no ramificadas. Los frutos son generalmente achatados, con piel fina y suave, fácilmente separable de los segmentos. En los mandarinos podemos encontrar especies con semillas 
monoembriónicas y otras con semillas poliembriónicas. A partir de datos existentes en nuestro grupo se ha observado que las mandarinas con semillas monoembriónicas son de origen híbrido, pudiendo por tanto, proceder el carácter de monoembrionía de los parentales de tipo no mandarino introgresados en estos genotipos, siendo el principal candidato C. maxima.

El grupo papeda incluye especies silvestres de cítricos. Los peciolos son largos y alados. Las flores son pequeñas, con estambres libres, ya que no hay fusión de los haces del sépalo lateral con la nervadura central del pétalo. En los frutos, las vesículas de la pulpa tienen numerosas gotas de aceite acre, que les hace tener un sabor amargo, por lo que las especies de este grupo no son comestibles.

Como se ha descrito en los párrafos anteriores, se tiene un amplio conocimiento de los taxones básicos del género Citrus a nivel morfológico, así como del origen de las especies cultivadas de cítricos. Sin embargo, no se conoce la contribución exacta de las especies ancestrales a las especies cultivadas y además, sus relaciones filogenéticas no están bien definidas.

\subsection{Origen genético de las especies cultivadas de cítricos.}

Como se ha comentado en el apartado anterior, las tres especies que han dado lugar a la mayoría de cítricos cultivados son: $C$. maxima, $C$. medica y $C$. reticulata, junto con el papeda C. micrantha en el caso de la lima.

Trabajos realizados mediante diferentes tipos de marcadores moleculares, como isoenzimas (Herrero et al., 1996; Ollitrault et al., 2003), RFLP (Federici et al., 1998), RAPD, SCAR (Nicolosi et al., 2000), AFLP (Liang et al., 2007), SSR (Luro et al., 2001; Barkley et al., 2006; Ollitrault et al., 2010) o SNPs (Ollitrault et al., 2012a), apoyan las siguientes teorías sobre el origen de las principales especies secundarias:

Los naranjos dulces (C. sinensis (L.) Osb.) están emparentados con C. reticulata, pero muestran rasgos introgresados en su genoma procedentes del ancestro C. maxima (Nicolosi, 2007). La relación más cercana con $C$. reticulata sugiere que los naranjos dulces no son híbridos directos, sino que probablemente sean híbridos retrocruzados de primera o segunda generación con el genoma de mandarina (Barrett and Rhodes, 1976; Nicolosi et al., 2000). Roose et al. (2009) sugieren que $C$. sinensis proviene de un retrocruce 1 (BC1) [(C. maximax C. reticulata) $\times$ C . reticulata)]. Esta misma hipótesis se postula en el trabajo de secuenciación del genoma de la naranja (Xu et al., 2013). Sin embargo, un reciente trabajo de nuestro grupo (Garcia-Lor et al., 2013a) contradice estas hipótesis y propone que los dos parentales de la naranja son híbridos inter-específicos.

El naranjo amargo (C. aurantium) parece un híbrido natural entre mandarino y zamboa (Scora, 1975; Barrett and Rhodes, 1976; Nicolosi et al., 2000; Uzun et al., 2009). 
El pomelo (C. paradisi Macf.) es una especie muy cercana a $C$. maxima y pudo resultar del cruce espontáneo entre C. maxima y C. sinensis (Barrett and Rhodes, 1976; Scora et al., 1982; de Moraes et al., 2007; Ollitrault et al., 2012a).

Diversos análisis del genoma cloroplástico (Green et al., 1986; Nicolosi et al., 2000) y mitocondrial (Froelicher et al., 2011) indicaron que C. maxima aportó el cloroplasto y el citoplasma en el origen de estas tres especies (naranjo dulce, naranjo amargo y pomelo).

Existen datos que confirman las relaciones genéticas existentes entre $C$. medica y $C$. limon Osb. (limones) (Froelicher et al., 2011). Marcadores cloroplásticos y nucleares indican qué los genomas de $C$. reticulata y $C$. maxima contribuyen también a la génesis del limón. Nicolosi et al. (2000) propuso que esta especie surgió del cruce directo entre $C$. aurantium y $C$. medica. Esta teoría fue apoyada por Gulsen and Roose (2001a) y Ollitrault et al. (2012a).

En el caso de la lima 'Mejicana' (C. aurantifolia), datos moleculares (Federici et al., 1998; Nicolosi et al., 2000; Ollitrault et al., 2012a) apoyan la idea de Torres et al. (1978) de que es un híbrido entre C. medica y una variedad de Papeda. Nicolosi et al. (2000) propuso la hipótesis de que la lima mejicana tiene como parental al papeda C. micrantha. El origen de otras limas es desconocido.

Pese a los estudios realizados hasta el momento, hay un escaso conocimiento de la contribución exacta de las especies ancestrales al genoma nuclear de las especies secundarias ( $C$. sinensis, $C$. limon, $C$. aurantium, $C$. paradisi y $C$. aurantifolia) y a los híbridos procedentes de los programas de mejora genética del siglo XX.

\subsection{La situación particular de la clasificación de los mandarinos.}

El germoplasma de mandarino fue clasificado como $C$. reticulata por Swingle and Reece (1967), al igual que Mabberley (1997). Por contra, Webber (1943) clasificó las mandarinas en 4 grupos: king, satsuma, mandarina y tangerina. Tanaka (1954) dividió los mandarinos en 5 grupos que incluían un total de 36 especies, basándose en cambios morfológicos del árbol, hojas, flores y frutos. El grupo 1, incluye a $C$. nobilis Lour. (cultivares tipo King), C. unshiu Marc. (satsumas), y C. yatsushiro Hort. ex Tanaka; el grupo 2 lo forman $C$. keraji Hort. ex Tanaka, C. oto Hort. ex Yuichiro y C. toragayo Hort. ex Yuichiro); el grupo 3 contiene 14 especies, incluyendo algunas de las más importantes económicamente: $C$. reticulata ('Ponkan'), C. deliciosa Tenore ('Willowleaf' o 'Mandarino común'), C. clementina Hort. ex Tanaka (clementinas) y C. tangerina Hort. ex Tanaka ('Dancy'); en el grupo 4 incluye a C. reshni Hort. ex Tanaka ('Cleopatra'), C. sunki Hort ex Tanaka ('Sunki') y C. tachibana; y en el grupo 5 incluye las especies C. depressa Hayata ('Shekwasha') y C. lycopersicaeformis (Lush.) Hort. ex Tanaka. Otro autor que estudió el grupo de las mandarinas fue Hodgson (1967), que sugirió la agrupación en 4 especies: C. unshiu (satsuma), C. reticulata ('Ponkan', 'Dancy', 'Clementine'), C. deliciosa ('Willowleaf'), y C. nobilis ('King'). 
Como se ha comentado anteriormente, el grupo mandarino es considerado uno de los tres principales grupos ancestrales de los cítricos cultivados (Barret and Rhodes, 1976; Nicolosi et al., 2000; Krueger and Navarro, 2007). El centro de diversificación de C. reticulata está en Asia, comprendiendo desde Vietnam a Japón. Es un grupo muy polimórfico, como se ha podido observar mediante marcadores moleculares (Coletta Filho et al., 1998; Luro et al., 2004) y caracteres fenotípicos, ya sea la pomología del fruto o la tolerancia a factores bióticos y abióticos. Además, en algunos grupos de cultivares como las 'satsumas' y las 'clementinas', cuya diversidad es debida a acumulaciones de mutaciones somáticas (Cameron and Frost, 1968), la dificultad para su caracterización a nivel molecular es mayor, ya que los marcadores moleculares existentes hasta el momento no permiten diferenciar estos genotipos.

Pese a la gran cantidad de información existente, hay muy pocos datos disponibles con respecto a la organización intraespecífica de $C$. reticulata y los determinantes de su diversidad fenotípica. Estos temas se han abordado en la presente tesis doctoral. Además, esta información es necesaria para optimizar la explotación de los recursos fitogenéticos y la mejora genética de este grupo.

\section{MEJORA GENÉTICA DE LOS CÍTRICOS.}

La mejora genética de los cítricos se dirige tanto a la obtención de nuevas variedades como a patrones y tiene como objetivos generales la introducción de resistencia o tolerancia a estreses bióticos y abióticos y la mejora de la calidad de los frutos.

Los cítricos están afectados por importantes estreses de tipo abiótico causados por la diversidad climática y de suelos existentes a nivel mundial. La salinidad afecta seriamente al desarrollo vegetativo y reproductivo, así como a la producción (Storey and Walker, 1999). La sequía en áreas templadas, como la cuenca Mediterránea, produce un decrecimiento de los procesos vegetativos, como la caída de hojas (Tudela and Primo-Millo, 1992), se ven afectados el potencial hídrico y la conductancia estomática (Gómez-Cadenas et al., 1996), así como una disminución de la cantidad y calidad del fruto (Yakushiji et al., 1998). Otra de las preocupaciones de la citricultura es la clorosis férrica, que afecta al 20-50\% de los árboles en la cuenca Mediterránea, asociada a suelos calcáreos y básicos (Jaeger et al., 2000). En otras zonas los suelos ácidos son un problema (Ollitrault and Navarro, 2012). Las heladas y las altas temperaturas son también una causa importante de pérdidas en la producción (Krueger and Navarro, 2007).

Los cítricos sufren importantes pérdidas económicas por distintos estreses bióticos causados por patógenos y plagas. Entre los virus más importantes se puede mencionar el Citrus tristeza virus (CTV) que produce un decaimiento general de árboles de mandarino, naranjo dulce y pomelo injertados sobre naranjo amargo llegando a producirles la muerte (Moreno et al., 2008), el Citrus Tatter Leaf Virus (CTLV) que causa problemas de incompatibilidad en patrones trifoliados o el Citrus Sudden Death Associated Virus (CSDAV), 
que causa la muerte de naranjos dulces injertados en lima Rangpur. Los cítricos también están afectados por numerosos viroides, entre los que destaca el Citrus exocortis viroid causante de la exocortis, que en árboles injertados sobre patrones sensibles produce poco desarrollo general, escamas en la corteza del patrón y también hace perder hojas jóvenes y disminuye el número de brotes y frutos (Duran-Vila et al., 1988).

Las bacterias causan gravísimos daños en los cítricos. La Candidatus Liberibacter sp. produce la enfermedad del Huanglongbing, presente en Asia, Brasil y EEUU (Bové, 2006) que es la más grave de las que afectan a los cítricos y que en algunas zonas está impidiendo el cultivo. La Xanthomonas axonopodis pv. citri (Hasse) produce la cancrosis de los cítricos en Suramérica, algunos estados de EE.UU. y Asia, causando importantes mermas en la producción y problemas de cuarentena en el comercio de frutos (Das, 2003).

En cuanto a enfermedades fúngicas, el oomiceto Phytophtora sp., que puede causar la gomosis o el aguado (Cacciola and Lio, 2008), está extendido en muchas regiones. En África encontramos la cercosporiosis (Phaemularia angolensis (De Carvalho \& O. Mendes) P.M. Kirk), que causa daños significativos en hojas y frutos (Ollitrault and Luro, 2001). La mancha negra de los cítricos es una enfermedad causada por el hongo Guignardia citricarpa que tiene lugar en zonas de clima subtropical, causando una reducción de la cantidad de fruta producida y de su calidad y problemas de cuarentena en la comercialización de fruta (Kotzé, 1981). En cuanto a la cuenca Mediterránea, el mal seco (causada por el hongo Phoma tracheiphila (Petri) L.A. Kantsch. \& Gikaschvili) es una enfermedad fúngica importante en los limoneros y algunos patrones (Perrotta and Graniti, 1988). También es un problema la Alternaria en algunos cultivares de tipo mandarino, como Fortune (Vicent et al., 2000; Vicent et al., 2004; Cuenca et al., 2012).

Los cítricos también están afectados por numerosas plagas que causan mermas en la producción, problemas en la comercialización de frutos y su control con pesticidas produce daños en el medio ambiente y residuos en los frutos perjudiciales para el consumidor. Entre las más importantes se pueden citar: algunos arácnidos, insectos como la mosca blanca o la mosca del Mediterráneo (Ceratitis capitata), pulgones, cochinillas, etc.

\subsection{Mejora de patrones.}

Uno de los principales objetivos de la mejora en patrones es su adaptación a las condiciones ambientales existentes en el área de cultivo (suelos salinos o alcalinos, ácidos, inundados, secos, concentración de caliza, tolerancia al frio) y a los patógenos del suelo.

Algunas de las necesidades comunes en la mayoría de las áreas de cultivo son que los nuevos patrones presenten tolerancia a enfermedades como la tristeza, al oomiceto Phytophthora sp. o a los nematodos, principalmente.

Otro de los caracteres importantes en los patrones, es la alta producción de semilla con una elevada poliembrionía, lo que facilita la propagación (reproducción apomíctica que impide 
la formación de embriones sexuales) y la uniformidad de las plantas obtenidas en vivero. Además, los patrones tienen que causar una rápida entrada en producción de la variedad y una elevada productividad de fruta de calidad. El control del vigor del árbol es actualmente un importante objetivo en muchos programas con la finalidad de realizar plantaciones muy densas de árboles de pequeño porte (Ollitrault and Navarro, 2012).

\subsection{Mejora de variedades.}

Los objetivos de la mejora genética de variedades varían ostensiblemente en función de las demandas del mercado, las condiciones ambientales en las áreas de producción y el destino de la fruta producida.

En la industria del zumo es importante una mejora en el contenido en zumo y azúcares, el color y la elevada productividad.

Como preocupaciones más importantes para el comercio de fruta fresca en la actualidad son, la calidad pomológica del fruto (tamaño, color, facilidad de pelado), la calidad organoléptica (aroma, sabor, acidez, azúcares), la ausencia de semillas (autoincompatibilidad gametofítica, esterilidad femenina o masculina, partenocarpia), la extensión del periodo de cosecha, así como la calidad nutricional (vitamina C, carotenoides, compuestos fenólicos) que en la actualidad es considerada como criterio de selección en algunos proyectos de mejora (Ollitrault and Navarro, 2012).

La mejora también va encaminada a la resistencia o tolerancia a diversas enfermedades, como el Huanglonbing, la cancrosis, cercosporiosis, mal seco, o el hongo Alternaria alternata, un gran problema aparecido recientemente en la citricultura española, que ha producido graves daños a los cultivos de la variedad 'Fortune' principalmente.

En cuanto a la mejora de las especies secundarias (naranja dulce, limones, pomelos), la falta de diversidad genética y elevada heterocigosis imposibilita la mejora por hibridación sexual y solo queda la selección de mutaciones espontáneas o inducidas o la transformación genética. En el caso de las mandarinas, donde hay una elevada diversidad, además de la selección de mutaciones (clementinas, satsumas), la selección mediante programas de mejora por hibridación sexual ha permitido la obtención de nuevas variedades tanto a nivel diploide como triploide (Russo et al., 2004; Williams and Roose, 2004; Tokunaga et al., 2005; Navarro et al., 2006b; Aleza et al., 2010; Cuenca et al., 2010).

\subsection{Problemas en la mejora clásica de los cítricos.}

Los cítricos presentan algunas características en su biología reproductiva muy peculiares, como son la apomixis, la incompatibilidad sexual (de algunos genotipos), la esterilidad, la elevada heterocigosis, etc., que dificultan la mejora genética. 
La apomixis es la producción de embriones (a partir de la nucela) sin que ocurra meiosis ni fertilización y que dan lugar a plantas genéticamente idénticas a la madre. En los genotipos apomícticos se da un proceso sexual y asexual en el mismo rudimento seminal, formándose semillas con un embrión zigótico y uno o varios nucelares. Habitualmente, los embriones de origen nucelar son más vigorosos que los zigóticos, los cuales no completan su desarrollo y abortan frecuentemente. Este fenómeno, complica la obtención de poblaciones elevadas de híbridos para seleccionar genotipos superiores (Davies and Albrigo, 1994).

Otro problema de la biología reproductiva de los cítricos, es la esterilidad gamética parcial o total en los óvulos y/o en el polen, lo que imposibilita su empleo como parentales en los programas de mejora. También, existen genotipos que presentan incompatibilidad sexual, lo que dificulta la obtención de híbridos (Soost, 1969; Soost and Cameroon, 1975).

La alta heterocigosidad existente en muchas especies de cítricos, provoca una progenie sexual muy variable (Herrero et al., 1996; Ollitrault et al., 2003). Por lo tanto, es difícil reunir en un híbrido los caracteres deseados de los parentales. Además del problema de la depresión por endogamia, que muchas veces se observa en la progenie híbrida (Barrett and Rhodes, 1976).

Otros factores que limitan la mejora genética clásica son, el largo periodo de juvenilidad de los cítricos (4-8 años), el desconocimiento del modo de herencia de la mayoría de caracteres agronómicos de interés, la escasez de marcadores relacionados con estos caracteres y la producción de semillas en la mayoría de híbridos.

Además de todos estos problemas, no disponemos de un conocimiento exhaustivo de la diversidad genética que permitiría la selección de nuevos parentales y facilitaría la planificación de los programas de mejora.

\subsection{Calidad del fruto de los cítricos; biosíntesis de metabolitos primarios y} secundarios.

La calidad organoléptica (aroma, sabor, acidez, azúcares) y las características pomológicas de las variedades (facilidad de pelado, ausencia de semillas, apariencia externa) son parámetros fundamentales en todos los proyectos de mejora (Navarro et al., 2006a). Además, la calidad nutricional se está empezando a plantear como objetivo en algunos programas en aspectos relacionados con el contenido en vitamina $\mathrm{C}$, carotenoides y compuestos polifenólicos, ya que poseen efectos beneficiosos para la salud humana (Del Caro et al., 2004; Dhuique-Mayer et al., 2005). En los cítricos, se conocen las rutas de biosíntesis que dan lugar a los diferentes compuestos determinantes de la calidad del fruto, pero no se conoce la diversidad existente en los genes implicados en su biosíntesis, así como su posible diferenciación a nivel evolutivo.

Por lo tanto, la secuenciación de genes que codifican para enzimas clave en las rutas de biosíntesis de azúcares, ácidos, flavonoides, y carotenoides en una amplia representación 
de la diversidad genética de los cítricos, ayudará a aclarar las relaciones filogéneticas existentes entre las especies del género Citrus y afines y podría servir para comprender las diferencias en su acumulación existentes entre ellas.

\subsubsection{Azúcares y acidez en los cítricos.}

Los principales carbohidratos existentes en el zumo son la sacarosa, la fructosa y la glucosa. En la mayoría de cítricos la sacarosa es el azúcar más abundante (Sanz et al., 2004). Los ácidos orgánicos son los principales responsables de la acidez en los cítricos, siendo el ácido cítrico el más abundante, seguido de ácido málico (Sadka et al., 2001).

A lo largo de la maduración del fruto, se observan habitualmente tres fases de desarrollo (Albertini, 2006): una primera fase de multiplicación celular con un aumento del tamaño del fruto rápido, una segunda fase de crecimiento celular iniciada por una síntesis de azúcares y ácidos orgánicos en el tonoplasto (duración variable en función de la variedad) y la fase final de maduración donde se producen diversas reacciones fisiológicas, como el cambio de color de la piel. El ácido cítrico aumenta muy rápidamente al principio del desarrollo del fruto y disminuye en la maduración. Los azúcares, en cambio, se acumulan mayoritariamente en la segunda y tercera fase del desarrollo del fruto (Erickson et al., 1968). Generalmente, los cítricos se agrupan en dos clases según su acidez: un grupo compuesto por las naranjas, las mandarinas, los zamboas y los pomelos, que son frutos dulces con un poco de acidez; y otro grupo (limones, limas y cidros) que son muy ácidos y contienen pocos azúcares (Webber et al., 1967).

\subsubsection{Biosíntesis de los azúcares y los ácidos.}

La variación en la concentración de azúcares solubles y de los ácidos orgánicos a lo largo del desarrollo del fruto, depende del equilibrio entre la síntesis, la degradación y el desarrollo de estos metabolitos (Tucker, 1993). Por lo tanto, los mecanismos de regulación de la glicólisis, el ciclo de Krebs y el almacenamiento vacuolar son esenciales. Las enzimas que codifican para los genes implicados en estos procesos son las encargadas de la conversión de hexosas en hexosas fosfato, de fructosa-6fosfato en fructosa-1,6-bifosfato, y de fosfoenolpiruvato (PEP) en piruvato (Plaxton, 1996; Copeland and Turner, 1987), además de las fosfofructoquinasas (PKF) dependientes de ATP y $\mathrm{PPi}$, la fosfoenolpiruvato carboxilasa (PEPC) y la fosfoenolpiruvato carboxikinasa (PEPCK), la malato deshidrogenasa (MDH) y el enzima málico (EMA). En la figura 1 se muestra la biosíntesis de azúcares, que se produce en el citosol y la biosíntesis de ácidos que se produce en las mitocondrias.

El ácido cítrico procedente del ciclo de Krebs está también fuertemente regulado. Las enzimas citosólicas que codifican para el gen aconitasa (ACO) y la isocitrato deshidrogenasa (IDH) están implicadas en el catabolismo del citrato de origen 
mitocondrial. El citrato que no es metabolizado, puede ser acumulado en la vacuola, lo cual influye en el pH, que es regulado en los diferentes estadios de desarrollo del fruto. Por medio de los mecanismos de regulación del citrato en la vacuola, el transportador de citrato $+\mathrm{H}^{+}$(TRPA) permite el flujo de citrato de la vacuola al citoplasma (Shimada et al., 2006). De esta manera, este gen controla la homeostasis vacuolar del citrato y regula la acidez de los frutos de cítricos. Los azúcares son fuertemente regulados. La sacarosa puede abastecer la glicólisis o ser transportada a la vacuola. También puede ser catabolizada en glucosa y fructosa mediante la ácido invertasa (INVA) (Kubo et al., 2001).

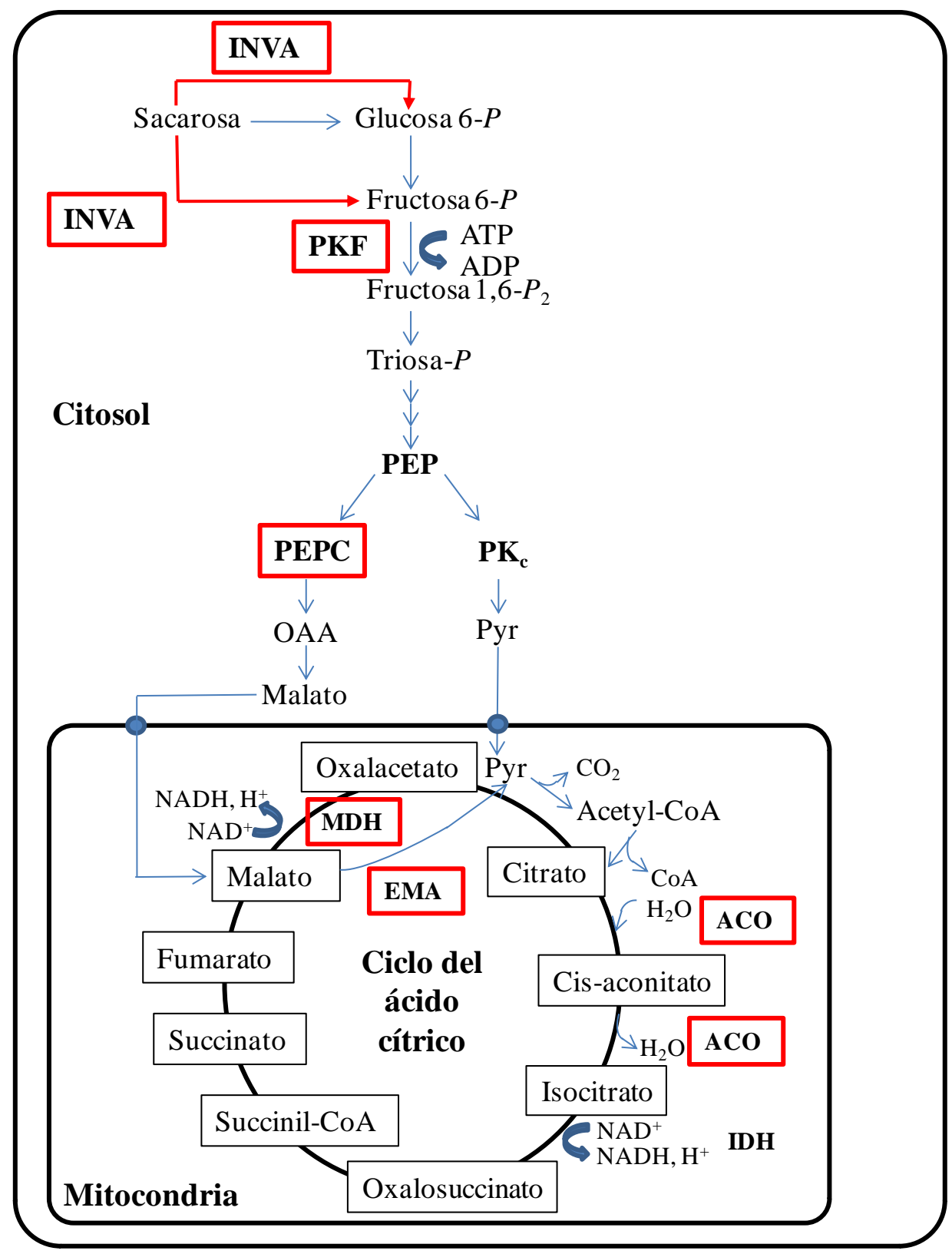

Figura 1. Biosíntesis de azúcares y ácidos. Los genes secuenciados en la tesis codifican para las enzimas recuadradas en rojo. 


\subsubsection{Flavonoides y antocianos.}

Los flavonoides son compuestos que juegan un papel importante en la resistencia de las plantas a la foto-oxidación de la luz ultravioleta, intervienen en el transporte de auxina, son atrayentes de los polinizadores y pueden dar el color a las hojas, frutos, semillas y a las flores (Winkel-Shirley, 2001) y además, afectan el sabor del fruto. En humanos, han mostrado una alta capacidad antioxidante (Kaur et al., 2001), previenen algunos desordenes cardiovasculares (Gross, 2004), tienen actividad antiinflamatoria (HyunPyo et al., 2004) y antialérgica (Middleton y Kandaswami, 1992), entre otras cosas. Por todo esto, se han realizado muchos estudios para modificar su biosíntesis en plantas (Tucker, 2003; Schijlen et al., 2004; Yonekura-Sakakibara and Saito, 2006; Koca et al., 2009). Los frutos de cítricos contienen un amplio rango de flavonoides (principalmente flavanonas y flavonas/oles), que suponen una de las fuentes importantes de compuestos fenólicos en nuestra dieta (Erlund, 2004). La cuantificación de flavonoides ha permitido la diferenciación entre algunos cítricos. Gaydou et al. (1987) diferenciaron mandarinas y naranjas, Mouly et al. (1994) distinguieron entre el limón, lima, pomelo y naranja dulce, Nogata et al. (2006) diferenciaron entre 42 especies y cultivares del género Citrus, más dos Fortunella y un Poncirus.

\subsubsection{Biosíntesis de los flavonoides y antocianos.}

La biosíntesis de flavonoides (Winkel-Shirley, 2001; Bogs et al., 2006) (Figura 2) comienza con la catalización de naringenina chalcona mediante la chalcona sintasa (CHS) y la siguiente conversión en naringenina flavanona a través de la chalcona isomerasa (CHI). A continuación, la adición de grupos hidroxil y/o metil dan lugar a diversas flavanonas, las cuales pueden ser transformadas en flavonoles en varias conversiones enzimáticas; estos compuestos pueden ser glicosilados. Los más importantes en cítricos son las flavanonas, y las que dan el sabor son las glicosiladas (Mclntosh et al., 1990). En especies de cítricos como las mandarinas y las naranjas dulces, solo contienen rutinosidos (sin sabor), mientras que zamboa contiene solo flavanonas neohesperidosidas, que le confiere amargura (Kawaii et al., 1999). Frydman et al. (2004) aislaron el gen (1,2 ramnosil transferasa) responsable de la biosíntesis de los flavonoides que producen la amargor de los cítricos (zamboas y pomelos).

Por otra parte, encontramos las antocianinas, que son compuestos fenólicos que dan lugar al color rojo en el caso de las naranjas sanguinas (Lo Piero et al., 2005). Estos compuestos comparten parte de la ruta de biosíntesis de los flavonoides que se ramifica para dar lugar a las antocianinas a partir de flavanonas (Figura 2). 


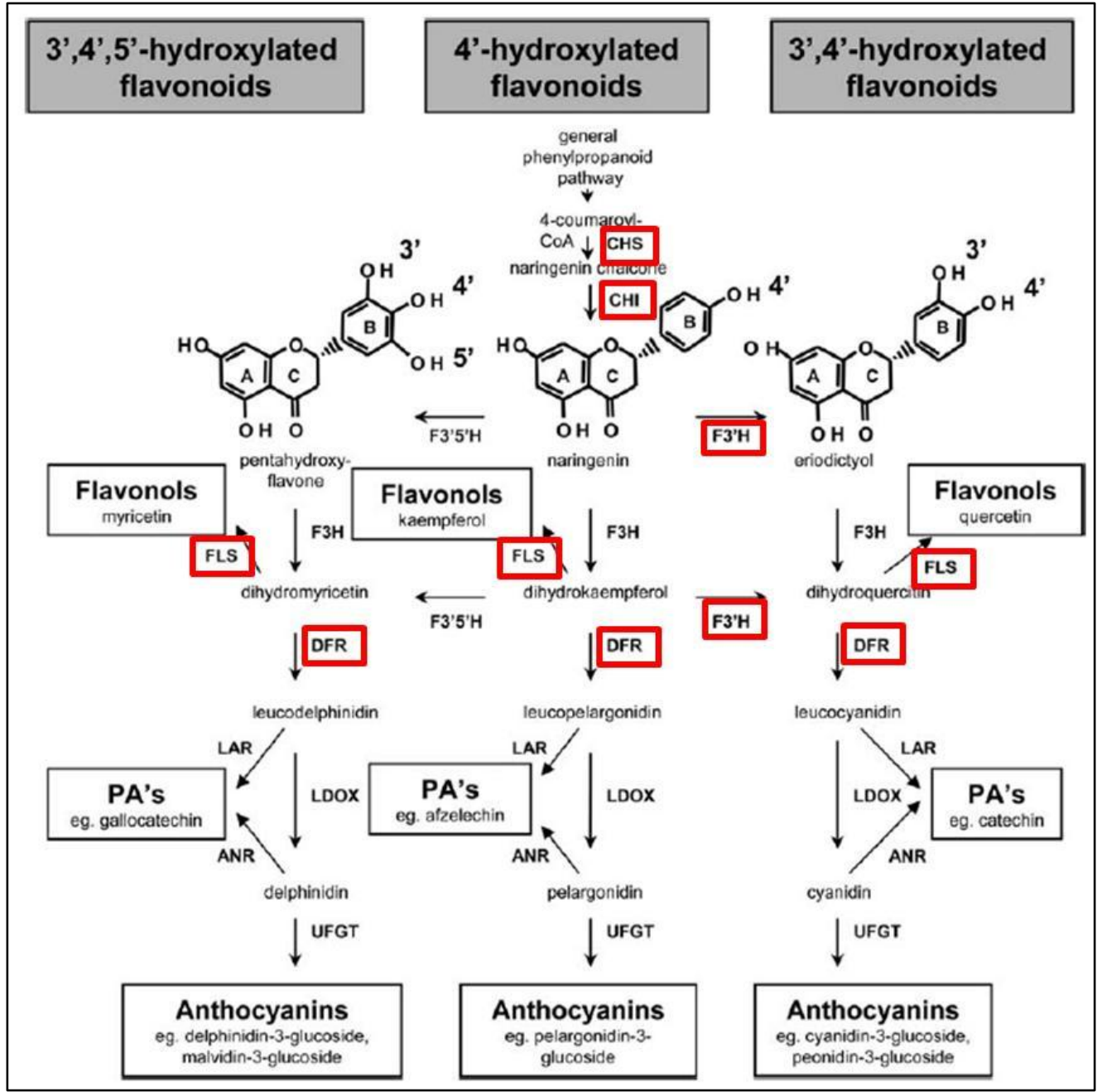

Figura 2. Biosíntesis de flavonoides (Bogs et al., 2006). Los genes secuenciados en la tesis codifican para las enzimas recuadradas en rojo.

\subsubsection{Carotenoides.}

Los carotenoides son pigmentos sintetizados en plantas, algas y algunas cianobacterias, que juegan un papel muy importante en el aparato fotosintético, protegiéndolas de daños oxidativos producidos por la luz. También participan en el sistema de captación de luz (Goodwin, 1980; Demmig-Adams et al., 1996). En plantas se acumulan en los cromoplastos y juegan un papel importante en la coloración del fruto, la raíz o el tubérculo y en su calidad nutricional. Los carotenoides son utilizados como atrayentes de polinizadores y agentes de dispersión de polen. También sirven de precursores de la vitamina A, esencial en la dieta humana y animal, así como de antioxidantes, los cuales previenen contra ciertas enfermedades cardiovasculares o cáncer (Olson, 1989; Rao and Rao, 2007).

\subsubsection{Biosíntesis de los carotenoides.}

La ruta de biosíntesis de carotenoides (Figura 3) ha sido bien descrita por numerosos trabajos (Sandmann, 2001; Fanciullino, 2007). Los carotenoides son sintetizados en los 
plástidos por enzimas codificados en el núcleo. El precursor de los caroteniodes, y también de hormonas como las giberelinas, es el geranilgeranil difosfato (GGPP). La condensación de dos moléculas de GGDP dan lugar al fitoeno, de 40 carbonos (incoloro), reacción catabolizada por la fitoeno sintasa (PSY). A continuación, este sufre 4 desaturaciones, catalizadas por la fitoeno desaturasa (PDS) y la $\zeta$-caroteno desaturasa (ZDS), que lo convierten en licopeno (color rojo). En plantas superiores, la circularización del licopeno en $\beta$-caroteno y a-caroteno es un paso crucial en la ramificación de la ruta de biosíntesis (Cunningham et al., 1996; Hirschberg, 2001). Esta reacción es catalizada por una enzima (LCY-b) para obtener $\beta$-caroteno en dos pasos.

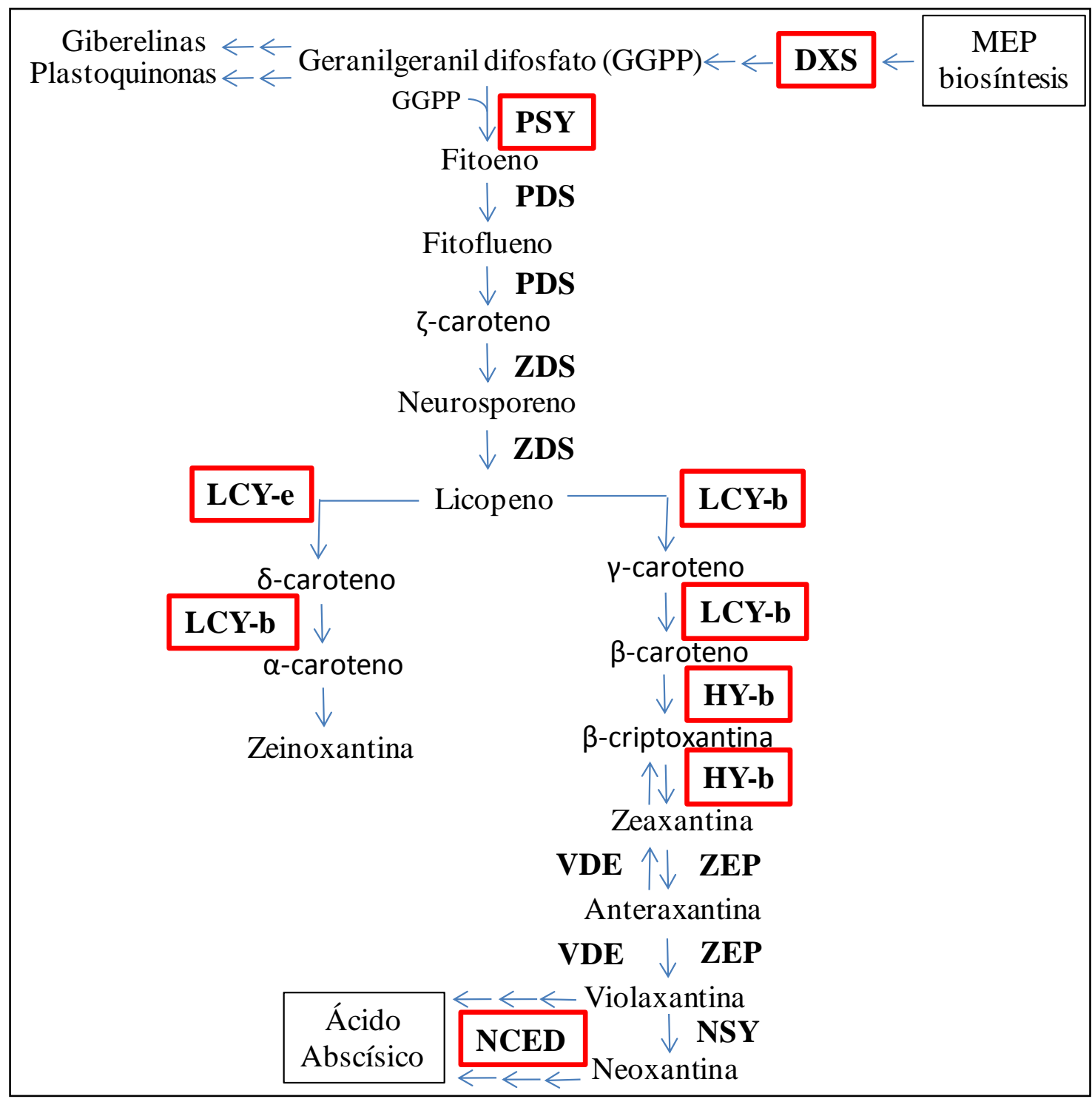

Figura 3. Biosíntesis carotenoides. Los genes secuenciados en la tesis codifican para las enzimas recuadradas en rojo.

En cambio, para obtener $\alpha$-caroteno se necesitan dos enzimas, la licopeno $\varepsilon$ - ciclasa (LCY-e) y la licopeno $\beta$-ciclasa (LCY-b). Siguiendo esta parte de la ruta, se obtiene la luteína (xantofilas) tras dos hidroxilaciones catalizadas por la $\varepsilon$-caroteno hidroxilasa 
(HY-e) y la $\beta$-caroteno hidroxilasa (HY-b). En la otra parte de la ruta, otras xantofilas se producen a partir de la hidroxilación de $\beta$-caroteno y la epoxidación catalizada por la zeaxantina epoxidasa (ZEP). La violaxantina puede ser de-epoxidada a zeaxantina a través de la anteraxantina por la violaxantina de-epoxidasa (VDE) (Gilmore and Yamamoto, 1993). A partir de la zeaxantina se puede obtener ácido abcísico en sucesivas reacciones. La biosíntesis de carotenoides y su regulación ha sido estudiada en varias especies de plantas, como Arabidopsis (Hyoungshin et al., 2002), tomate (Isaacson et al., 2002) o pimiento (Bouvier et al., 1998) entre otras. A partir de estudios en tomate, se piensa que la regulación de la ruta es principalmente a nivel transcripcional (Bramley, 2002). Regulación post-transcripcional, por retroalimentación o por hormonas (etileno), se han sugerido como mecanismos para explicar la acumulación de carotenoides. En cítricos, se han realizado diversos estudios en algunas especies para clarificar la regulación de la producción de carotenoides (Rodrigo et al., 2004; Kato et al., 2006; Fanciullino et al., 2008; Alquézar et al., 2009), pero es necesaria más información a nivel intra e interespecífico.

\section{RECURSOS FITOGENÉTICOS EN CÍTRICOS.}

En el año 2001, se firmó el Tratado Internacional sobre los Recursos Fitogenéticos para la Alimentación y la Agricultura, el cual señala la importancia que reviste la conservación y el uso sostenible de los recursos fitogenéticos, así como su prospección, recolección, caracterización, evaluación y documentación para garantizar una producción de alimentos diversificada, sostenible y nutricionalmente diversa (FAO, 2001). En este contexto, los bancos de germoplasma (conservación ex situ) desarrollan un papel esencial en el que se hace necesario proteger y mantener los recursos fitogenéticos que constituyen las fuentes de variabilidad para la obtención de nuevas variedades en un contexto socio-económico en constante evolución. Los principales Bancos de Germoplasma mundiales del género Citrus se encuentran situados en Japón, China, EEUU, Francia y España. En Japón existen seis colecciones donde se mantienen más de 1200 genotipos, destacando el gran número de genotipos de mandarino que se conservan, principalmente del grupo satsumas (Krueger and Navarro, 2007). En el banco de germoplasma de China hay aproximadamente 1000 accesiones mantenidas ex situ (Liu and Deng, 2007). La Citrus Variety Collection (http://www.citrusvariety.ucr.edu/) de la Universidad de Riverside en California (EEUU) contiene más de 1000 genotipos del género Citrus y afines (Barkley et al., 2006). La colección INRACIRAD existente en el Institut National de la Recherche Agronomique (INRA), San Giuliano (Córcega, Francia), cuyo germoplasma es uno de los más ricos en variedades del grupo mandarino, consta con alrededor de 1100 accesiones de cítricos y géneros afines, incluyendo Citrus (cidros, zamboas, mandarinas y papedas), Poncirus, Fortunella, Microcitrus, Eremocitrus... además de híbridos intra- e interespecíficos. La colección existente en el Instituto Valenciano de Investigaciones Agrarias (IVIA), Moncada (Valencia, España), incluye alrededor 
de 600 genotipos, entre los cuales están la mayoría de los cultivares modernos de mandarina, especies del género Citrus y también especies de géneros afines de la subfamilia Aurantioideae. Esta colección también posee los genotipos de la misma dentro de un recinto de malla para evitar la transmisión de enfermedades, la contaminación con los patógenos transferidos por vectores y mantener "árboles iniciales" de los programas de certificación para la propagación comercial de plantas producidas en los viveros comerciales. La colección del IVIA se caracteriza morfológicamente de forma continua con los descriptores del IPGRI y UPOV y esto permite eliminar posibles genotipos duplicados, que suponen un problema frecuente en la mayoría de las colecciones de germoplasma de cítricos.

\subsection{Conservación de los recursos fitogenéticos de cítricos.}

Las semillas son el método de conservación y distribución más conveniente en los bancos de germoplasma, siendo la conservación de semilla desecada en condiciones de baja humedad y almacenada a baja temperatura la forma más extendida de la colecciones ex situ. Las semillas que se pueden conservar de esta manera se les llama "ortodoxas" (Roberts, 1973). La mayoría de especies de plantas se conservan de esta manera. Las condiciones técnicas para el mantenimiento de semillas ortodoxas están descritas por la FAO/IPGRI (Genebank Standards, 1994).

Sin embargo, muchas especies de origen tropical y subtropical (aguacate, mango, cacao, etc.), así como algunas leñosas (género Quercus, Castanea, Citrus, etc.) tienen semillas sensibles al proceso de desecación y conservación en bajas temperaturas, por lo que no pueden ser conservadas mediante este método debido a la pérdida de viabilidad. Este tipo de semillas se denominan "recalcitrantes" (Chin and Roberts, 1980). El problema de estas especies es que la conservación de los recursos genéticos requiere el mantenimiento de plantas.

La selección humana y la propagación vegetativa han llevado a la generación de variedades élite de cítricos, pero ha producido la pérdida de muchos genotipos silvestres originales. Además, la diversidad genética en los centros de origen está en peligro por la pérdida de hábitat debido a la deforestación, presión poblacional, turismo, etc., como sucede en India o China. Por ello, es necesaria una conservación ex situ de los recursos fitogenéticos. Debido a que las semillas de los cítricos son de tipo recalcitrante, las colecciones de germoplasma existentes se mantienen mediante plantas en campo y en algunos casos también en recintos de malla, lo cual conlleva unos gastos elevados.

Una alternativa para el mantenimiento de germoplasma de especies con semillas recalcitrantes es la conservación in vitro (Engelmann, 1997). En cítricos se han puesto a punto procedimientos de crioconservación de callos embriógenicos y embriones (Duran-Vila, 1995; González-Arnao, 2003) y el Banco de Germoplasma del IVIA mantiene una colección callos embriogénicos crioconservados de unos 60 genotipos. Muy recientemente, se ha abierto la 
posibilidad de conservación mediante la criopreservación de ápices y la regeneración de plantas mediante microinjerto de ápices caulinares in vitro (Volk et al., 2012).

\subsection{Manejo de los recursos fitogenéticos.}

Para la conservación de los recursos fitogenéticos de cítricos (Krueger and Navarro, 2007), se han de seguir los siguientes pasos: localización de nuevos genotipos para aumentar la diversidad del banco de germoplasma, introducción, mantenimiento, caracterización y evaluación, documentación y establecimiento de bases de datos.

5.2.1. Localización de nuevos genotipos para aumentar la variabilidad del banco de germoplasma.

Lo primero es la identificación y localización de las fuentes de nuevo material a introducir mediante la exploración de áreas de diversidad, selección de genotipos cultivados o nuevos, o por intercambio entre centros de conservación.

\subsubsection{Introducción del material.}

Los cítricos pueden verse afectados por hongos, bacterias, plagas y por un alto número de patógenos (virus, viroides) que se transmiten por injerto. Por ello, el movimiento de germoplasma entre distintas áreas geográficas supone un peligro por la posible introducción de plagas y enfermedades. Para evitarlo, la introducción de material cítricos está legalmente regulado en la mayoría de los países y en los más importantes la importación solo se puede realizar a través de Estaciones de Cuarentena (Krueger and Navarro, 2007). Por norma general, se exige un certificado fitosanitario de las autoridades del país de procedencia, una inspección rigurosa del material a la llegada al país de destino y medidas adicionales de aislamiento, análisis de patógenos o procedimientos de cuarentena integrales según los países (Krueger and Navarro, 2007). En el IVIA existen programas de saneamiento (material procedente del mismo país) y cuarentena (material procedente de otros países) basados en técnicas de cultivo in vitro (Navarro et al., 1975, 1981; Navarro, 2005) que han permitido establecer unos controles fitosanitarios del material existente en el banco de germoplasma. Para realizar este tipo de programas se requiere personal especializado y unas instalaciones adecuadas (invernaderos, recintos de malla, laboratorios, etc.) que no siempre están disponibles y que en la mayoría de los casos no dependen de los bancos de germoplasma lo que dificulta la introducción de nuevo material. 


\subsubsection{Mantenimiento de la colección.}

Como se ha comentado anteriormente, los cítricos tienen semillas recalcitrantes por lo que los recursos fitogenéticos se conservan generalmente mediante colecciones de plantas. En el caso que sea posible, las colecciones de campo deberían tener una réplica en otra ubicación. Existen también casos en los que hay colecciones duplicadas en recintos de malla, como ocurre en los Bancos de Germoplasma del IVIA y del USDA en Riverside, California. Los métodos existentes de crioconservación aún no son suficientemente efectivos para sustituir a las plantas, por lo que solo en raras ocasiones los bancos de germoplasma poseen una colección crioconservada. Las colecciones en campo deben poseer al menos dos copias de cada accesión para su caracterización y evaluación.

Las colecciones de plantas libres de patógenos mantenidas en el interior de recintos de malla se pueden utilizar como material inicial para la propagación comercial de plantas en viveros en el contexto de programas de certificación (Navarro et al., 2002; Lee et al., 2004; Navarro, 2005). En España, la colección protegida en recintos de malla del banco de germoplasma ha sido el origen de 144 millones de plantones sanos vendidos por los viveros a los agricultores en los últimos 30 años. Este tipo de utilización constituye una fuente de ingresos adicional para los bancos de germoplasma.

\subsubsection{Caracterización y evaluación.}

Este aspecto es muy importante para una buena utilización de los recursos de un banco de germoplasma. Un primer paso es el establecimiento de un pasaporte para cada accesión, que incluye información acerca de su origen, parentales, método de introducción del material (varetas, semillas, etc.) o nombre científico, de forma que cada genotipo esté bien identificado. Un segundo paso es la caracterización morfológica de los genotipos mediante descriptores adecuados, siendo los más empleados los del International Plant Genetic Resources Institute (IPGRI, 1999), que tienen descriptores de pasaporte (origen, claves de registro,...), de manejo (multiplicación, regeneración,...), de localización y características medioambientales de la colección (clima, tipo suelo, plagas y enfermedades prevalentes,...), de caracterización de los genotipos (caracteres vegetativos, de hojas, flores, frutos y semillas) y de evaluación (susceptibilidad a estreses bióticos y abióticos). La caracterización realizada con estos descriptores tiene un elevado costo por la necesidad de contar con personal especializado y de realizar la evaluación durante varios años para eliminar la influencia de las condiciones climáticas de años concretos. Además, la información proporcionada puede ser criticable debido a los posibles cambios (morfológicos, crecimiento vegetativo, etc.; Reuter and Ríos-Castaño, 1969; Reuther, 1973; Germanà and Sardo, 1988) que se pueden producir por la ubicación geográfica y el clima. Sin embargo, tienen una gran utilidad para el manejo de bancos de germoplasma concretos, ya que permiten comparar las características de los distintos genotipos en un mismo ambiente y para detectar duplicaciones de genotipos. De 
hecho, la caracterización con estos descriptores es el único procedimiento fiable para comparar y en su caso descartar genotipos producidos por mutaciones espontáneas en campo, que es el origen de la mayoría de los genotipos de cítricos de las especies secundarias. En la práctica hay muy pocos bancos de germoplasma de cítricos que apliquen esta metodología, pero en el del IVIA está dando unos resultados excelentes.

La evaluación de aspectos como resistencia a factores bióticos y abióticos es prácticamente imposible de realizar en una colección completa (excepto en los casos que se puede hacer una observación directa) porque requiere la realización de experimentos específicos. Este problema podría solventarse con el establecimiento de una colección nuclear para el estudio de este tipo de caracteres.

El uso de marcadores moleculares para la caracterización y el manejo de los bancos de germoplasma está cada vez más implantado (Gulsen and Roose, 2001a, c; Varshney et al., 2005; Wang et al., 2005; Barkley et al., 2006). Mediante la caracterización molecular se pretende clarificar las relaciones taxonómicas entre las accesiones de la colección, estudiar la estructura de la diversidad y establecer las relaciones genéticas entre entradas. Esto nos puede permitir plantear estrategias de recolección (adquisición de nuevo material) o generar una colección nuclear (caracterización y uso). Además, la caracterización molecular nos permite un mejor mantenimiento de la colección a través de la detección de redundancias, evaluación de la erosión genética e identificación de errores de etiquetado, sinonimias o homonimias (Viruel, 2010). En cítricos, el problema reside en el caso de las especies secundarias y algunos mandarinos en las que los genotipos se han originado por mutación espontanea y no se pueden distinguir mediante los marcadores moleculares existentes hasta el momento, y la única forma de distinción es por sus características morfológicas y organolépticas.

En el apartado 6 analizaremos más en profundidad los distintos tipos de marcadores moleculares empleados en cítricos, así como los recursos genómicos existentes en la actualidad.

\subsubsection{Documentación y bases de datos.}

Los métodos de documentación han ido evolucionando con el tiempo influenciados por la tecnología. Pese al gran uso de los ordenadores en la actualidad, todavía se siguen tomando datos en libretas de campo o papeles, que pueden perderse, deteriorase o producirse errores al pasar los datos al dispositivo electrónico. Por todo ello, se debe tener mucho cuidado en la toma de datos, copias de seguridad del material almacenado, etc. Las bases de datos son importantes para el manejo y funcionamiento de los bancos de germoplasma y también se debe tener mucho cuidado con su almacenamiento y protección. La presente tesis doctoral ha aportado una gran cantidad de información a la base de datos que se está generando en el IVIA. 


\subsubsection{Utilización de los recursos de los bancos de germoplasma.}

El conjunto de genotipos de un banco de germoplasma ofrece un amplio recurso de genes relacionados con resistencia a enfermedades, estreses, producción, calidad del fruto, etc., que son imprescindibles para la mejora genética, la investigación y también para la propagación del material (Krueger and Navarro, 2007). Por ello, es muy importante tener disponible un germoplasma bien caracterizado para una buena planificación de los programas de mejora. Además de la mejora genética, los bancos de germoplasma nutren las investigaciones de otras disciplinas, como la fisiología, biología o la fitopatología, que a su vez pueden repercutir con sus resultados en nuevas vías de investigación para los programas de mejora.

\subsubsection{Colecciones nucleares.}

Como colección nuclear $(\mathrm{CN})$ se entiende un número limitado de muestras que representan, con la menor redundancia posible, la diversidad genética de una especie cultivada (Brown, 1989). Además una CN pretende reducir los costes de mantenimiento y el uso ineficaz de una colección completa (colección base), debido a la existencia de duplicaciones y/o redundancias y la imposibilidad por su elevado costo de analizar en profundidad todos los genotipos de un banco germoplasma (Grenier et al., 2000; van Hintum et al., 2000). Por lo general se considera que una $C N$ debería contener entre un 5-10\% de las accesiones presentes en la colección completa y tener representados al menos el $70 \%$ de los alelos, sin redundancias (Brown, 1989).

Antiguamente el establecimiento de $\mathrm{CN}$ se realizaba principalmente con datos fenotípicos y de pasaporte de las variedades, pero esto entrañaba ciertos problemas debidos a la falta de información de pasaporte, datos erróneos y los cambios debidos a efectos ambientales (Tanksley and McCouch, 1998; Hu et al., 2000). Actualmente los marcadores moleculares se están convirtiendo en la herramienta más usada para el establecimiento de CN, AFLP (Fajardo et al., 2002; van Treuren et al., 2006), RAPD (Ghislain et al., 1999; Marita et al., 2000), SNP (Mckhann et al., 2004) o SSR (Ellwood et al., 2006; Hao et al., 2006).

Se han propuesto diferentes métodos para la selección de genotipos de una CN, desde el muestreo aleatorio (Brown, 1989), al muestreo estratificado (Peeters and Martinelli, 1989; Johnson and Hodgkin, 1999). Este muestreo estratificado puede basarse en datos morfológicos, fisiológicos y agronómicos (Malosetti and Abadie, 2001), bioquímicos (Grauke et al., 1995) o moleculares (Ghislain et al., 1999).

Para la creación de una $\mathrm{CN}$ se pueden seguir, como ejemplo, los pasos descritos por van Hintum et al. (2000).

La principal utilidad de una $\mathrm{CN}$ es facilitar la caracterización y evaluación de ciertos caracteres que sería muy costoso de realizar en todos los genotipos del banco, si su 
número es elevado. Además, las $\mathrm{CN}$ pueden estar enfocadas para distintos usos: mantenimiento de la diversidad global de una colección (Escribano et al., 2008), evaluación de caracteres diversos para obtener nuevas fuentes en estudios de mejora (Yan et al., 2009; Agrama and Yan, 2009), resistencias a enfermedades (Pessoa-Filho et al., 2010) o estudios de genética de asociación (Pino Del Carpio et al., 2011). Estos últimos pretenden buscar loci asociados a caracteres fenotípicos (resistencias, calidad) a nivel del genoma entero, si existe una buena cobertura de marcadores moleculares y un bajo desequilibrio de ligamiento (Zhang et al., 2009), o en genes candidatos, si no hay suficiente densidad de marcadores (Fournier-Level et al., 2009). Con respecto a las $\mathrm{CN}$, es interesante indicar que hay algoritmos que permiten reducir la estructuración de la población y el desequilibrio de ligamiento entre loci asociados a esta estructura poblacional, siendo una situación favorable para realizar estudios de genética de asociación (Breseghello and Sorrells, 2006).

En cítricos, no se ha desarrollado hasta el momento ninguna $\mathrm{CN}$ en ninguna de las tres principales especies ancestrales (C. maxima, C. medica, C. reticulata) que han dado lugar a la mayor parte de la variabilidad existente de cítricos cultivados. Únicamente, Bernet et al. (2008) realizaron una $\mathrm{CN}$ en una especie secundaria (C. aurantium) para el estudio de la resistencia al virus de la tristeza. De las especies $C$. maxima, $C$. medica y $C$. reticulata existe una amplia diversidad en las zonas de origen, que aconsejaría el establecimiento de CN para su adecuada gestión. No obstante, la variabilidad existente de $C$. maxima y $C$. medica es escasa en la gran mayoría de los bancos de germoplasma. Por otra parte, la diversidad genética en las especies secundarias, como las naranjas, los pomelos, las limas, los limoneros y algunas mandarinas híbridas (clementinas, satsumas) es muy escasa, ya que la diversidad fenotípica existente se ha generado por mutaciones somáticas espontáneas, que generalmente no se pueden diferenciar por marcadores moleculares. Por ello en estas especies no es posible el establecimiento de $\mathrm{CN}$ y tan solo es aconsejable el establecimiento de colecciones basadas en caracteres morfológicos y fenotípicos. En las dos colecciones estudiadas en la presente tesis doctoral (IVIA, INRA/CIRAD), la variabilidad existente de $C$. maxima y $C$. medica es relativamente escasa, mientras que es elevada en $C$. reticulata, y además su mejora está basada en la hibridación sexual, que favorece al aumento continuo de su diversidad. Por lo tanto, en nuestro caso particular es recomendable el establecimiento de una $\mathrm{CN}$ de $C$. reticulata, que será posible a partir de los datos moleculares obtenidos en esta tesis doctoral.

\subsubsection{Genética de asociación.}

La genética de asociación se entiende como todo enfoque cuyo objetivo es detectar y/o localizar variables genéticas causales implicadas en la variación de un carácter de interés en un conjunto de individuos o germoplasma (Rafalski, 2010). Para realizar el 
estudio de asociación se emplean marcadores moleculares para caracterizar una región de interés, así como medidas fenotípicas y en ocasiones de covariables (como pueden ser diferentes ambientes de evaluación fenotípica). Se trata por tanto, de identificar las zonas del genoma que presenten una diversidad alélica significativamente correlacionada con la variación del carácter (Zhu et al., 2008). La genética de asociación se conoce también como mapeo del desequilibrio de ligamiento (LD), que explota la variación fenotípica y genética presente en una población natural, diferente de lo que se conoce como mapeo de genes que controlan caracteres cuantitativos o QTLs (Quantitative Trait Loci), que están basados en poblaciones segregantes. Estudios de genética de asociación basados en el LD han tenido éxito en diversas especies de plantas cultivadas, como maíz (Thornsberry et al., 2001), Arabidopsis (Zhao et al., 2007) o sorgo (Casa et al., 2008), que poseen unas colecciones de germoplasma muy amplias.

Un problema que se presenta en este tipo de estudios es la estructura poblacional ( $\mathrm{Yu}$ and Buckler, 2006; Abdurakhmonov and Abdukarimov, 2008), que puede provocar asociaciones erróneas, debido a una estratificación fuerte de la población. Factores como los sistemas de mejora y la historia de la domesticación de los cultivos, son determinantes en la estructura poblacional del LD.

La resolución del mapeo por LD en una población, así como la densidad de marcadores moleculares necesarios y los métodos estadísticos a emplear, depende de la diversidad genética, la extensión del desequilibrio y las relaciones existentes entre los individuos de una población (Zhu et al., 2008). En el caso de especies autógamas, la extensión del LD es alto (Arabidopsis, Nordborg et al., 2002; arroz, Garris et al., 2003; y sorgo, Deu and Glaszmann, 2004), lo que conlleva una resolución del mapeo baja, pero la densidad de marcadores necesaria es menor. Por el contrario, en las especies alógamas, con posibilidad de polinización cruzada [maíz, Remington et al., 2001; álamo, Ingvarsson (2005); abeto noruego, Rafalski and Morgante (2004)] el LD decae en distancias cortas, por lo que la resolución del mapeo se espera alta, pero un elevado número de marcadores es necesario.

Por todo ello, es muy importante establecer la distancia a lo largo de la cual permanece el LD en una población, así como su estructura, para conocer la viabilidad de un estudio de genética de asociación. En cítricos, no se tiene un conocimiento previo a la realización de la presente tesis doctoral acerca del alcance del LD en el género Citrus ni tampoco a nivel intraespecífico. 


\section{HERRAMIENTAS MOLECULARES EXISTENTES EN CÍTRICOS.}

Como se ha comentado con anterioridad, la caracterización molecular del material vegetal es fundamental tanto para el manejo de los recursos fitogenéticos existentes en un banco de germoplasma, como para ayudar a la mejora genética. Por ello, en los siguientes apartados se explican las distintas herramientas y recursos existentes para el estudio de los cítricos.

\subsection{Marcadores moleculares.}

En las pasadas dos décadas la evolución en el diseño de marcadores moleculares para estudios de diversidad y de filogenia (entre otros usos) en plantas ha sido importante. En cuanto a los marcadores empleados en cítricos, podemos citar los siguientes ejemplos:

AFLP (Amplification Fragment Lenght Polymorphism). Se basan en la detección de fragmentos de restricción de ADN mediante amplificación por PCR, utilizando cebadores homólogos a la secuencia de los adaptadores y de las dianas de restricción de las enzimas utilizadas previamente para digerir el ADN. Entre las ventajas de los AFLPs destacan su abundancia, generan gran cantidad de bandas por PCR (50 a 100 fragmentos) y no se necesita información previa de secuencia. Su principal problema radica en que son dominantes, los patrones de bandas no siempre son claros y en el caso de que los fragmentos producidos tengan el mismo tamaño, no significa que sean homólogos (Pang et al., 2007). Scarano et al., (2003) los utilizaron en combinación con marcadores SSR para la identificación de plántulas cigóticas de limón. Pang et al. (2007) los emplearon para un estudio de filogenia en el género Citrus y afines.

IRAP (Inter-Retrotransposon Amplified Polymorphism). Estos marcadores se obtienen por amplificación de un fragmento del genoma situado entre dos retrotransposones (elementos móviles que se encuentran en gran número distribuidos aleatoriamente en el genoma de las plantas) mediante cebadores específicos de secuencia homologa a este. Su gran ventaja es que son muy polimórficos, pero muchos de estos polimorfismos son dominantes. Bretó et al. (2001) observaron en cítricos que los polimorfismos basados en elementos transponibles son más abundantes que los basados en marcadores de secuencia aleatoria o en microsatélites. Podrían ser útiles para la diferenciación varietal dentro de grupos como naranja o clementina. Posteriormente, Biswas et al. (2010) los emplearon en el análisis genético de 48 variedades del género Citrus y géneros afines.

ISSR (Inter Simple Sequence Repeat). Se basan en secuencias repetidas en tándem, microsatélites, en base a los cuales, se diseña un cebador con secuencia homologa y al que se le añaden dos nucleótidos aleatorios extras. De esta manera se amplifica una región situada entre dos microsatélites cercanos que incluyan los nucleótidos complementarios. No es necesario tener información previa de la secuencia y presentan una alta reproducibilidad. Como desventajas, la homología de las bandas es incierta y son marcadores dominantes. Fang et al. 
(1997, 1998), Gulsen and Roose (2001a, b) y Yang et al. (2010), son algunos de los que han empleado estos marcadores en cítricos, entre otras cosas, para estudios de diversidad genética y las relaciones filogenéticas entre especies del género Citrus.

RAPD (Random Amplified Polymorphic DNA). Estos marcadores se basan en la amplificación del ADN genómico mediante PCR utilizando un único cebador (10 nucleótidos) de secuencia aleatoria. Se pueden obtener en gran cantidad y en poco tiempo al no necesitar información de secuencia previa. Fueron de los primeros marcadores de ADN usados en cítricos (Luro et al., 1995; Federici et al., 1998) los emplearon en el análisis de 32 accesiones de cítricos y tres de Microcitrus y Nicolosi et al. (2000) analizó 36 accesiones pertenecientes al género Citrus y una de cada uno de los géneros afines, Poncirus, Fortunella, Microcitrus y Eremocitrus. También fueron usados para la diferenciación de plantas zigóticas y nucelares de tangerina (Bastianel et al., 1998) y de naranjo amargo (Rao et al., 2008) y en algunos estudios de mapeo genético (de Oliveira et al., 2004; Gulsen et al., 2010). Su mayor problema es la baja reproducibilidad y su dominancia, por lo que actualmente son poco utilizados.

CAPS (Cleaved Amplified Polymorphic Sequences). El polimorfismo se detecta mediante la digestión de un fragmento de ADN amplificado por PCR que puede separarse en un gel de poliacrilamida. Permiten detectar polimorfismos de tipo SNPS o InDels. Son marcadores codominantes y reproducibles, que necesitan poca cantidad de ADN. En cítricos fueron aplicados para estudios de los genomas citoplásmicos (Lotfy et al., 2003) y nucleares (Omura et al., 2000).

RFLP (Restriction Fragment Length polymorphism). Detectan fragmentos de ADN polimórficos que sirven de dianas para enzimas de restricción. Suelen segregar como marcadores codominantes, se encuentran en cualquier región del genoma y son altamente polimórficos. Las desventajas son su elevado coste económico, la necesidad de usar bastante tiempo para analizar los datos y de un conocimiento previo de secuencias. Luro et al. (1995) los emplearon junto con los RAPD en la diferenciación entre plántulas de origen cigótico o nucelar, así como para evaluar la variabilidad genética intraespecífica en naranjas y mandarinas. Federici et al. (1998) los emplearon en el análisis de 88 accesiones representantes del género Citrus, algunos híbridos y especies de géneros afines. Cai et al. (1994) los emplearon para establecer los primeros mapas genéticos de cítricos.

SSRs (Simple Sequence Repeats). Estos marcadores, también llamados microsatélites, son secuencias de repeticiones en tándem que se presentan de forma consecutiva en un número variable, por lo que tienen un alto nivel de polimorfismo. Además, se comportan como marcadores codominantes y están dispersos aleatoriamente en el genoma. Todo esto les ha permitido ganar mucha importancia en genética de plantas por su reproducibilidad entre laboratorios. En cítricos y géneros relacionados, los SSRs se han desarrollado a partir de genotecas genómicas (Kijas et al., 1995; Ahmad et al., 2003; Novelli et al., 2006; Froelicher et al., 2008), ESTs (Bausher et al., 2003; Chen et al., 2008; Luro et al., 2008) y secuencias de BACend (Ollitrault et al., 2010). Estos marcadores han demostrado ser 
muy útiles en estudios de diversidad genética de cítricos en combinación con observaciones fenotípicas (Kijas et al., 1995; Luro et al., 2001, 2008; de Oliveira et al., 2002; Corazza-Nunes et al., 2002; Pang et al., 2003; Golein et al., 2005; Barkley et al., 2006). El principal inconveniente es la necesidad de conocer la secuencia adyacente al microsatélite. Además, Barkley et al. (2009) mostraron que la homoplasia puede limitar la utilidad de los marcadores microsatélites en la identificación del origen filogenético de los fragmentos de ADN.

SNPs (Single Nucleotide Polymorphisms). Son polimorfismos de variación en la secuencia de ADN de un solo nucleótido. Su abundancia y distribución a lo largo del genoma (Brookes, 1999) les otorga una ventaja frente a otros marcadores, además de su reproducibilidad entre laboratorios. Son marcadores de tipo codominante, pero requieren un conocimiento previo de la secuencia a analizar. Con las técnicas actuales de secuenciación, cada vez más económicas, los están convirtiendo en unos marcadores muy importantes para el desarrollo de mapas genéticos saturados, identificación de cultivares, detección de asociaciones genotipo/fenotipo o selección asistida por marcadores (Botstein and Risch, 2003; Morales et al., 2004; Xing et al., 2005; Lijavetzky et al., 2007; Ollitrault et al., 2012b). En cítricos, se han realizado diversos trabajos de detección de SNPs por secuenciación en naranja Novelli et al. (2006), en clementina (Terol et al., 2008) y satsumas (Dong et al., 2010). Una vez identificados los SNPs se puede hacer un genotipado masivo con micromatrices (Ollitrault et al., 2012a) o genotipados basados en PCR competitiva entre alelos (KASPar). Otras técnicas utilizadas para genotipado son los SSCPs (Single Strand Conformation Polymorphisms; Olivares-Fuster et al., 2007; Simsek et al., 2011) que se basan en las diferencias en la conformación de la estructura terciaria del ADN que el cambio nucleotídico produce. Se pueden analizar un elevado número de muestras en poco tiempo, pero requiere unas condiciones rigurosas de ensayo y una secuenciación previa.

Indel (Inserción o Deleción). Estos marcadores por lo general surgen de la inserción de retrotransposones u otros elementos móviles, por el desfase de una secuencia simple en la replicación o eventos de retrocruzamiento desiguales. Generalmente tienen poca frecuencia de homoplasia, y además, hay poca probabilidad de que dos mutaciones por indel ocurran en el mismo lugar y con la misma longitud, por lo que permiten una identidad descendiente a descendiente (Britten et al., 2003). Otra ventaja es su fácil genotipado mediante PCR y electroforesis (Vasemägi et al., 2010). Este tipo de marcadores ha sido utilizado en estudios genéticos en trigo (Raman et al., 2006), arroz (Hayashi et al., 2006) y poblaciones naturales (Väli et al., 2008), pero no en cítricos. En la presente tesis se ha demostrado su aplicabilidad e interés para estudios filogenéticos en cítricos (Garcia-Lor et al., 2012a) con indels identificados a nivel intra e interespecífico en secuencias de genes. Otros InDels han sido desarrollados recientemente en 'Clemenules' a partir de secuencias de BACend (Ollitrault et al., 2012a).

Marcadores de polimorfismos en secuencia de ADN cloroplástico (ADNcp) (Abkenar et al., 2004; Nicolosi et al., 2000; Jung et al., 2005; de Araújo et al., 2003) y de ADN mitocondrial (ADNmt) (Froelicher et al., 2011) han permitido realizar estudios de filogenia maternal, ya que 
estos genomas heredados de la madre son muy conservados. También se han empleado con este propósito los mencionados SSCP (Olivares-Fuster et al., 2007).

Pese a existir una gran información con diversos tipos de marcadores, en la presente tesis doctoral se pretende ampliar los recursos moleculares en cítricos mediante el desarrollo de nuevos marcadores moleculares (SSRs, indels, SNPs) y su aplicación para la caracterización de especies del género Citrus y afines.

\subsection{Recursos genómicos de cítricos.}

Los primeros datos genómicos en cítricos se publicaron en algunas revisiones como las de Gmitter et al. (2007), Talon and Gmitter Jr. (2008) and Tadeo et al. (2008). Actualmente, los recursos genómicos (http://www.citrusgenome.ucr.edu/, 2004; http://www.citrusgenomedb.org/, 2009) incluyen más de medio millón de ESTs, la mayoría de naranjo dulce ( $\approx 90 \%)$, seguido por las procedentes de clementina (Forment et al., 2005; Terol et al., 2008), Poncirus, satsuma y otras variedades (Shimizu et al., 2009; Delseny et al., 2010); también existen micromatrices de alta densidad en distintas plataformas para estudios de expresión y de genotipado (Shimada et al., 2005; Terol et al., 2007; Martinez-Godoy et al., 2008; Shimizu et al., 2011; Ollitrault et al., 2012a), varias librerías de BACs (Terol et al., 2008), un mapa físico de naranjo dulce y mapas de ligamiento para clementina, naranjo dulce y zamboa entre otros (Ollitrault et al., 2012b; http://www.citrusgenomedb.org/tools/map/cmap).

Además, se ha secuenciado el genoma de un haploide de clementina mediante la tecnología Sanger y un genoma diploide de naranjo dulce mediante la técnica de pirosecuenciación 454 de Roche. Estos recursos se encuentran disponibles en el portal phytozome (2011) del instituto JGI (http://www.phytozome.net/) y en la base de datos del genoma de cítricos (http://www.citrusgenomedb.org/). Paralelamente se ha publicado el genoma de naranjo dulce con la plataforma de Illumina GAll (Xu et al., 2012) y otros genomas (Shimizu et al., 2012; Terol et al., 2012). En la web "http://citrus.hzau.edu.cn/" (2011) se encuentra anotado el genoma de la naranja. Todos estos recursos y herramientas permitirán a los genéticos y mejoradores utilizar más eficazmente distintas características de los cítricos en los programas de mejora. 



\section{OBJETIVOS}





\section{OBJETIVOS DE LA TESIS DOCTORAL}

El conocimiento del origen de las especies cultivadas del género Citrus está actualmente bien establecido, considerándose como especies ancestrales a $C$. reticulata, $C$. maxima, C. medica y C. micrantha (Barret and Rhodes, 1976, Nicolosi et al., 2000; Krueger and Navarro, 2007). Cruzamientos entre estas cuatro especies han dado lugar a la mayoría de especies secundarias e híbridos recientes. Sin embargo, pese a toda esta información, las relaciones filogenéticas entre las especies ancestrales del género Citrus y de los géneros afines de los cítricos verdaderos no son bien conocidos. De hecho, los géneros Citrus, Fortunella, Poncirus, Microcitrus, Eremocitrus y Clymenia, pese a tener una diferenciación morfológica evidente, son sexualmente compatibles, lo que les ha permitido cruzarse y generar nueva variabilidad a lo largo de la historia. Sin embargo, el nivel de diferenciación genética entre y dentro de los taxones básicos del género Citrus y los géneros afines no está bien definido.

Tampoco está clara cuál es la organización filogenética del genoma de las especies secundarias y si la organización que resulta de la evolución de los cítricos cultivados es compatible con estudios de asociación entre diversidad fenotípica y polimorfismo molecular basados en el desequilibrio de ligamiento (LD) o en el origen filogenético de genes candidatos.

Como se ha comentado anteriormente existen dos clasificaciones principales de los cítricos, las de Swingle y Tanaka, que tienen una visión muy diferente del grupo mandarino. El germoplasma de mandarino, clasificado como C. reticulata por Swingle and Reece (1967), tiene como centro de diversificación Asia, desde Vietnam a Japón. Es un taxon muy polimórfico, tanto con marcadores moleculares (Luro et al., 2004), como caracteres fenotípicos (morfología o tolerancia a factores bióticos y abióticos). Algunos autores suponen que el germoplasma mandarino esta introgresado por otras especies (Barkley et al., 2006). Pese a ello, hay muy pocos datos disponibles respecto a la organización interespecífica del grupo mandarino y los determinantes de su diversidad intraespecífica. Esta información es fundamental para optimizar el manejo y la utilización de los recursos existentes en las colecciones de germoplasma y para establecer en un futuro próximo una colección nuclear, con la finalidad de facilitar la realización de estudios de evaluación de diversos caracteres fenotípicos, de resistencia o tolerancia a estreses bióticos y abióticos y abordar estudios de genética de asociación. También facilitará la selección de parentales para utilizar en los programas de mejora genética.

Para aportar nuevos conocimientos en (1) la organización genética del genero Citrus y su compatibilidad con estudios de genética asociación, (2) la filogenia de los cítricos verdaderos y la implicación de la evolución en el polimorfismo de genes candidatos para caracteres de calidad y (3) la estructura genética y el origen del germoplasma mandarino, la tesis doctoral se enfoca a los siguientes objetivos específicos: 


\section{Estudio de la organización de la diversidad genética en el género Citrus.}

Considerando los posibles problemas de homoplasia que pueden presentar los SSRs se pretende comparar el valor de marcadores nucleares de tipo microsatélite (SSRs) y de Inserción-Deleción (indels), para estudios de diversidad a nivel inter- e intraespecífico. Los marcadores indel no se han desarrollado hasta el momento en cítricos y se cree que podrían ser muy útiles para estudiar la diversidad genética interespecífica y el origen filogenético de las especies. Una colección de 90 genotipos representativos de tres especies ancestrales $(C$. reticulata, $C$. maxima y $C$. medica) y de especies cultivadas de cítricos será genotipada con estos dos tipos de marcadores, para estimar la contribución de cada especie ancestral al genoma de las especies secundarias. El posicionamiento de los marcadores moleculares en un mapa genético nos permitirá establecer el nivel de desequilibrio de ligamiento (LD) dentro del género Citrus tanto a nivel inter- como intracromosómico y por lo tanto la posibilidad de realizar estudios de asociación en este género.

Además, entre todos los marcadores empleados, se pretende seleccionar un pequeño grupo que se encuentren dispersos en el genoma y representen de manera fiable la diversidad existente en los cítricos, para poder realizar genotipados sistemáticos de colecciones de forma rápida y económica.

\section{Estimación del nivel de diferenciación genómica entre los cítricos verdaderos y su filogenia nuclear; evolución y herencia de genes candidatos para calidad en las especies cultivadas.}

Se pretende identificar polimorfismos mediante la secuenciación de genes candidatos (determinantes de la calidad de los cítricos y algunos involucrados en la respuesta a diferentes estreses) para estudiar la filogenia de los cítricos verdaderos, la estructura de las especies secundarias del género Citrus, su origen y su filogenia, los posibles eventos de diferenciación a nivel evolutivo en los genes candidatos y la identificación de un conjunto de SNPs con un fuerte poder de diferenciación filogenético, que sirvan de herramienta para estudios futuros.

La transferibilidad de este conjunto de SNPs, obtenido en un panel de especies reducido, a los cítricos verdaderos y a géneros lejanos (subfamilia Aurantioideae) mediante un método de "PCR competitiva entre alelos específicos" será objeto de estudio en la presente tesis doctoral.

\section{Determinación de la estructuración de la diversidad del germoplasma de mandarino.}

Con la finalidad de tener un mejor conocimiento del origen y de la organización genética del grupo mandarino, se ha realizado un amplio estudio con marcadores nucleares 
(SSR y indel) y mitocondriales de 198 genotipos de mandarino, junto con 25 genotipos representativos de las otras especies de cítricos verdaderos, existentes en los bancos de germoplasma del Institut National de la Recherche Agronomique (INRA) y del Instituto Valenciano de Investigaciones Agrarias (IVIA). Se pretende estimar la introgresión de otras especies en el germoplasma mandarino e identificar mandarinos verdaderos.

Una vez definida la estructura del germoplasma de mandarinos, se procederá a la cuantificación de la contribución de los grupos observados (además de los genomas de especies ancestrales) al resto de genotipos en estudio. Los resultados obtenidos se usarán para confirmar o desmentir la clasificación existente en las bases de datos, así como detectar redundancias en las colecciones.

Este estudio de estructuración será la base de futuros análisis de desequilibrio de ligamiento (LD) con perspectivas de realizar estudios de genética de asociación, y además de la implementación de una colección nuclear de mandarinos.

Una vez definidos los objetivos, los resultados de la presente tesis doctoral se han estructurado en los siguientes capítulos, que corresponden a artículos publicados en revistas científicas:

CAPITULO 1: Comparative use of indel and SSR markers in deciphering the interspecific structure of cultivated citrus genetic diversity: a perspective for genetic association studies. Molecular Genetics and Genomics (2012) 287: 77-94. Objetivo 1.

CAPITULO 2: A nuclear phylogenetic analysis: SNPs, indels and SSRs deliver new insights into the relationships in the 'true citrus fruit trees' group (Citrinae, Rutaceae) and the origin of cultivated species. Annals of Botany (2013) 111: 1-19. Objetivo 2.

Annex chapter 2: Clymenia's phylogeny within the 'true citrus fruit trees'.

CAPITULO 3: Citrus (Rutaceae) SNP markers based on Competitive Allele-Specific PCR; transferability across the Aurantioideae subfamily. Applications in Plant Sciences (2013) 4: doi:10.3732/apps.1200406. Objetivo 2.

CAPITULO 4: Genetic diversity analysis and population-structure analysis of mandarin germplasm by nuclear (SSRs, indel) and mitochondrial markers.

Submitted. Objetivo 3. 



\section{CHAPTER 1}

Comparative use of indel and SSR markers in deciphering the interspecific structure of cultivated citrus genetic diversity: a perspective for genetic association studies.

Andres Garcia-Lor, François Luro, Luis Navarro and Patrick Ollitrault

Molecular Genetics and Genomics (2012) 287: 77-94 



\section{Abstract}

Genetic stratification associated with domestication history is a key parameter for estimating the pertinence of genetic association study within a gene pool. Previous molecular and phenotypic studies have shown that most of the diversity of cultivated citrus results from recombination between three main species: $C$. medica (citron), $C$. reticulata (mandarin) and $C$. maxima (pummelo). However, the precise contribution of each of these basic species to the genomes of secondary cultivated species, such as $C$. sinensis (sweet orange), C. limon (lemon), C. aurantium (sour orange), C. paradisi (grapefruit) and recent hybrids is unknown. Our study focused on: (1) the development of Insertion-Deletion (indel) markers and their comparison with SSR markers for use in genetic diversity and phylogenetic studies; (2) the analysis of the contributions of basic taxa to the genomes of secondary species and modern cultivars and (3) the description of the organisation of the citrus gene pool, to evaluate how genetic association studies should be done at the cultivated citrus gene pool level.

Indel markers appear to be better phylogenetic markers for tracing the contributions of the three ancestral species, whereas SSR markers are more useful for intraspecific diversity analysis. Most of the genetic organisation of the Citrus gene pool is related to the differentiation between $C$. reticulata, C. maxima and C. medica. High and generalised LD was observed, probably due to the initial differentiation between the basic species and a limited number of interspecific recombinations. This structure precludes association genetic studies at the genus level without developing additional recombinant populations from interspecific hybrids. Association genetic studies should also be affordable at intraspecific level in a less structured pool such as $C$. reticulata. 


\section{INTRODUCTION}

Genetic association studies based on linkage disequilibrium (LD) are similar to quantitative trait locus (QTL) mapping. However, whereas QTL mapping considers only variations between two crossed individuals, LD mapping exploits the phenotypic and genetic variation present across a natural population. This method has been successfully applied in studies of cultivated plants (Thornsberry et al., 2001; Casa et al., 2008; Zhu et al., 2008). However, the presence of population stratification and an unequal distribution of alleles within these groups can result in spurious associations (Abdurakhmonov and Abdukarimov, 2008). Breeding systems and domestication history are determinant factors of the LD structure in cultivated species germplasm. The extent of LD is generally higher for species with selfing mating system (Arabidopsis, Nordborg et al., 2002; rice, Garris et al., 2003; and sorghum, Deu and Glaszmann 2004) than for outcrossing organisms (maize, Remington et al., 2001; populus, Ingvarsson 2005; and Norway spruce, Rafalski and Morgante 2004). To our knowledge, no data are available for LD in agamic complexes.

Citrus is one of the most important fruit crops in the world, and its diversity (Krueger and Navarro, 2007) and origin (Webber et al., 1967; Calabrese, 1992) have been widely studied. The taxonomy of citrus remain controversial, due to the conjunction of broad morphological diversity, total sexual interspecific compatibility within the genus and partial apomixis of many cultivars. Fixing complex genetic structures through seedling propagation via apomixis has led some taxonomists to consider clonal families of interspecific origin as new species (Scora 1975). Two major systems are widely used to classify Citrus species: the Swingle and Reece (1967) classification that considers 16 species and Tanaka's (1961) one that identifies 156 species. More recently, Mabberley (1997) proposed a new classification of edible citrus recognising 3 species and four hybrid groups. In this paper, we will use the Swingle and Reece (1967) classification system. Indeed, this taxonomic system is widely used in the citrus scientist community and, as mentioned below, mostly agrees with molecular data.

Despite the difficulties involved in establishing a consensual classification of edible citrus, most authors now agree on the origins of most cultivated forms. Early studies by Scora (1975) and Barrett and Rhodes (1976) based on biochemical and morphological polymorphisms, respectively, suggested that most of the cultivated citrus originated from three main species (C. medica L., citrons; C. reticulata Blanco, mandarins; and C. maxima (Burm.) Merr., pummelos). More recent studies involving the diversity of morphological characteristics (Olitrault et al., 2003) and secondary metabolites (Fanciullino et al., 2006a) confirmed that the majority of the phenotypic diversity of edible citrus results from the differentiation between these three basic taxa. Isoenzymes (Herrero et al., 1996; Ollitrault et al., 2003), RFLP (Federici et al., 1998), RAPD, SCAR (Nicolosi et al., 2000), AFLP (Liang et al., 2007) and SSR (Luro et al., 2001; Barkley et al., 2006) molecular markers generally support the following conclusions for the origin of the other cultivated Citrus species (Nicolosi, 2007): (1) C. sinensis (L.) Osb. (sweet oranges) and $C$. aurantium L. (sour oranges) are related with $C$. reticulata but display 
introgressed traits and markers of $C$. maxima. The closer relation with $C$. reticulata suggests that they are not direct hybrids but are probably backcrossed hybrids of first or second generation crosses with the $C$. reticulata gene pool. Analysis of chloroplastic (Green et al., 1986, Nicolosi et al., 2000) and mitochondrial genomes (Froelicher et al., 2011) indicate a $C$. maxima maternal phylogeny. (2) C. paradisi Macf. (grapefruits) is close to C. maxima, and could result from hybridization between C. maxima and C. sinensis (Barrett and Rhodes 1976, Scora et al., 1982, de Moraes et al., 2007). (3) C. medica is clearly a progenitor of C. aurantifolia (Christm.) Swing (limes) and C. limon Osb. (lemons). Chloroplast and nuclear data analysis indicate that the genetic pools of $C$. reticulata and $C$. maxima also contributed to the genesis of C. limon. Nicolosi et al. (2000) proposed that this species resulted from direct hybridisation between $C$. aurantium and C. medica. This assumption is supported by Gulsen and Roose (2001a) and Fanciullino et al. (2007). The origin of C. aurantifolia is more controversial. However, molecular data (Federici et al., 1998; Nicolosi et al., 2000) support the hypothesis of Torres et al. (1978) that the Mexican lime is a hybrid between C. medica and a Papeda species. Nicolosi et al. (2000) proposed that $C$. micrantha might be the parental Papeda. These previous molecular studies have provided a better understanding of citrus maternal phylogeny, hybrid origin and parentage determination of many species. However, little is known about the precise contribution of the basic edible species to the nuclear genome constitution of secondary cultivated species (C. sinensis, C. limon, C. aurantium, C. paradisi and C. aurantifolia) and recent hybrids from twentieth century breeding programs. Furthermore, the impact of this domestication history on global genetic organisation and the extent of linkage disequilibrium (LD) on the Citrus gene pool have not been studied. The distance over which LD persists is a fundamental parameter to determine how association studies may be conducted on a gene pool. Regarding the important phenotypic differentiation between the basic taxa and the interspecific origin of most cultivated citrus, a better knowledge of the contribution of the nuclear genome of the basic taxa to the secondary species and modern cultivated citrus, as well as the analysis of the LD extent, appear as prerequisites to undergo association studies in the Citrus gene pool.

Among the codominant markers used for citrus genetic studies, simple sequence repeats (SSRs) (Luro et al., 2001, 2008; Gulsen and Roose, 2001a; Barkley et al., 2006; Ollitrault et al., 2010) are regarded as powerful tools because they are highly polymorphic, codominant, generally locus-specific and randomly dispersed throughout the plant genome. Thus, the use of mapped SSR markers should be particularly useful to analyse the extent of LD. However, Barkley et al. (2009) showed that homoplasy may limit the usefulness of SSR markers in identifying the phylogenetic origin of DNA fragments in citrus. Insertion or deletion (indel) markers generally have low frequency of homoplasy. Indeed, there is a sufficiently low probability of two indel mutations of exactly the same length occurring at the same genomic position, that shared indels can confidently be related to identity-by-descent. In general, indels arise from the insertion of retroposons or other mobile elements, slippage in simple sequence replication or unequal crossover events (Britten et al., 2003). At the technical level, indels can 
be genotyped with simple procedures based on size separation after targeted PCR (Vasemägi et al., 2010). Indels have been used successfully for genetic studies in wheat (Raman et al., 2006), rice (Hayashi et al., 2006) and natural populations (Väli et al., 2008).

Our study focused on three basic species (C. medica, C. reticulata and C. maxima), the secondary species that they generated ( $C$. sinensis, $C$. aurantium, $C$. paradisi and $C$. lemon) and some known or putative interspecific hybrids. Twelve indel markers were developed from gene sequencing, and their polymorphism organisation was compared with 50 SSR markers. Next, the complete set of markers was used to answer the following three questions: (1) what is the intraspecific diversity of indel markers and are they more useful than SSRs as tag of DNA fragments in studies of phylogenetic origin? (2) What is the contribution of the three basic edible taxa to the genomes of secondary species and modern cultivars? (3) Are the genetic organisation of the Citrus gene pool and the extent of linkage disequilibrium adapted for association genetics? Furthermore, we propose a subset of markers (core markers) for quick and inexpensive systematic germplasm genotyping that maintains most of the organisation and intraspecific polymorphism information. 


\section{MATERIALS AND METHODS}

\section{Interspecific indel polymorphism research}

\section{Plant material and DNA extraction}

With the objective to identify indel polymorphism differences between the basic citrus taxa, we selected two cultivars of $C$. medica (Corsican and Buddha's hand citrons), two cultivars of $C$. reticulata (Cleopatra and Willow Leaf mandarins) and two cultivars of $C$. maxima (Chandler and Pink pummelos). High molecular weight genomic DNA was extracted from leaf samples using the DNeasy Plant Mini Kit (Qiagen S.A.; Madrid, Spain) according to the manufacturer's instructions.

\section{Gene sequence amplification and sequencing}

Primers were designed from EST sequences corresponding to 16 genes available in public databases. Thirteen genes [chalcone isomerase $(\mathrm{CHI})$, chalcone synthase (CHS), flavonol synthase (FLS), malic enzyme (EMA), malate dehydrogenase (MDH), vacuolar citrate/H+ symporter (TRPA), phosphoenolpyruvate carboxylase (PEPC), phosphofructokinase (PKF), lycopene $\beta$-cyclase (LCY2), $\beta$-carotene hydroxylase (Hy-b), phytoene synthase (PSY), 1 deoxyxylulose 5-phosphate synthase (DXS) and lycopene $\beta$-cyclase (LCYB)] are involved in primary and secondary metabolite biosynthesis pathways that determine the quality of citrus fruit (sugars, acids, flavonoids and carotenoids). In addition, 3 candidate genes for salt tolerance [CAX1 (cation/ $\mathrm{H}_{+}$membrane antiporter), AtGRC (raffinose synthase) and AVP (vacuolar $\mathrm{H}+$ pyrophosphatase)] were used. Primers (Table 1 ) were designed to amplify fragments with a length between 166 and 1,201 bp. The PCR mixture consisted of $1 \mathrm{ng} / \mu \mathrm{l}$ template DNA, $0.2 \mathrm{mM}$ dNTPs, $0.2 \mu \mathrm{M}$ forward primer, $0.2 \mu \mathrm{M}$ reverse primer, 10x PCR buffer (Fermentas), $1.5 \mathrm{mM} \mathrm{MgCl}_{2}$ and $0.027 \mathrm{U} / \mu \mathrm{l}$ Taq DNA polymerase (Fermentas), in a final volume of $15 \mu \mathrm{l}$. PCR reactions were carried out with the following program: 5 min at $94^{\circ} \mathrm{C} ; 40$ cycles of $30 \mathrm{~s}$ at $94^{\circ} \mathrm{C}, 30 \mathrm{~s}$ at $50-58^{\circ} \mathrm{C}$ and $2 \mathrm{~min}$ at $72^{\circ} \mathrm{C}$ with a final extension of $4 \mathrm{~min}$ at $72^{\circ} \mathrm{C}$.

Amplicons of the six selected genotypes were sequenced by the Sanger method from the $5^{\prime}$ end using dideoxynucleotides labelled by fluorescence (Big Dye Terminator Cycle Sequencing Kit v3.1). The sequencing reaction was carried out in a thermal cycler ( $A B I$ GeneAmp PCR System 9700), and the resolution and analysis of the labelled products were performed in a capillary sequencer (ABI 3100). 
Table 1. Primers of candidate genes

\begin{tabular}{|c|c|c|c|c|c|c|c|}
\hline $\begin{array}{l}\text { Process } \\
\text { involved }\end{array}$ & Gene & Primers & AT & $\begin{array}{l}\text { High-quality } \\
\text { sequence } \\
\text { (bp) }\end{array}$ & $\begin{array}{l}\text { EST size } \\
\quad(b p)\end{array}$ & $\begin{array}{l}\text { Genomic } \\
\text { size (bp) }\end{array}$ & $\begin{array}{l}\text { Genebank } \\
\text { accessions }\end{array}$ \\
\hline \multirow{3}{*}{$\begin{array}{l}\text { Flavonoids } \\
\text { biosynthesis }\end{array}$} & Chalcone isomerase & $\begin{array}{l}\text { F:TTGTTCTGATGGCCTAATGG } \\
\text { R:AAAGGCTGTCACCGATGAAT }\end{array}$ & 55 & 647 & 721 & 721 & aCL6103Contig1 \\
\hline & Chalcone synthase & $\begin{array}{l}\text { F:GATGTTGGCCGAGTAATGCT } \\
\text { R:ATGCCAGGTCCAAAAGCTAA }\end{array}$ & 55 & 565 & 659 & 659 & aCL6909Contig1 \\
\hline & Flavonol synthase & $\begin{array}{l}\text { F:GGAGGTGGAGAGGGTCCAAG } \\
\text { R:GGGCCACCACTCCAAGAGC }\end{array}$ & 55 & 710 & 763 & 763 & AB011796 \\
\hline \multirow{3}{*}{$\begin{array}{c}\text { Acids } \\
\text { biosynthesis }\end{array}$} & Malic enzyme & $\begin{array}{l}\text { F:ACATGACGACATGCTTCTGG } \\
\text { R:CGTAGCCACGCCTAGTTCAT }\end{array}$ & 55 & 420 & 166 & 420 & CB417399 \\
\hline & Malate dehydrogenase & $\begin{array}{l}\text { F:ATGGCCGCTACATCAGCTAC } \\
\text { R:TGCAACCCCCTTTTCAATAC }\end{array}$ & 55 & 705 & 1209 & 1250 & DQ901430 \\
\hline & Vacuolar citrate/H+ symporter & $\begin{array}{l}\text { F:GGCGCCACTCCTACCTTCCC } \\
\text { R:CGGTCATTGAAGAGTGCTCCCC }\end{array}$ & 58 & 715 & 987 & 1300 & EF028327 \\
\hline \multirow{2}{*}{$\begin{array}{c}\text { Sugars } \\
\text { biosynthesis }\end{array}$} & Phosphoenolpyruvate carboxylase & $\begin{array}{l}\text { F:AGCCAATGGGATTTCTGACA } \\
\text { R:GCCAAGCCACACAGGTAAAT }\end{array}$ & 55 & 669 & 1201 & 2000 & EF058158 \\
\hline & Phosphofructokinase & $\begin{array}{l}\text { F:CGCCGACCTCAGTCCCGTC } \\
\text { R:GCTGCACGCCCCATAAGCCG }\end{array}$ & 58 & 630 & 807 & 1650 & AF095520 \\
\hline \multirow{7}{*}{$\begin{array}{l}\text { Carotenes } \\
\text { biosynthesis }\end{array}$} & Lycopene $\beta$-cyclase & $\begin{array}{l}\text { F:GCATGGCAACTCTTCTTAGCCCG } \\
\text { R:AGCTCGCAAGTAAGGCTCATTCCC }\end{array}$ & 55 & 725 & 850 & 850 & FJ516403 \\
\hline & $\beta$-Carotene hydroxylase & $\begin{array}{l}\text { F:AGCCCTTCTGTCTCCTCACA } \\
\text { R:CCGTGGAATTTATCCGAGTG }\end{array}$ & 55 & 675 & 787 & 1600 & $\begin{array}{l}\text { AF315289 } \\
\text { AF296158 }\end{array}$ \\
\hline & Phytoene synthase & F:GCTCGTTGATGGGCCTAATGC & 58 & 560 & 727 & 2100 & $\begin{array}{l}\text { AB037975, } \\
\text { AF220218 }\end{array}$ \\
\hline & & R:CGGGCGTAAGAGGGATTTTGC & & & & & AF152892 \\
\hline & 1-deoxyxylulose 5-phosphate synthase & $\begin{array}{l}\text { F:GGCGAGGAAGCGACGAAGATGG } \\
\text { R:GGATCAGAACTGGCCCTGGCG }\end{array}$ & 58 & 590 & 935 & 1500 & aCL303Contig1 \\
\hline & Lycopene $\beta$-cyclase & F:GAATTCTTGCCCCAAGTTCA & 55 & 710 & 1206 & 1500 & $\begin{array}{l}\text { AY166796, } \\
\text { AF152246 }\end{array}$ \\
\hline & & R:TATGGGCCACAAATCTTTCC & & & & & AY644699 \\
\hline \multirow{3}{*}{$\begin{array}{c}\text { Salt } \\
\text { stress } \\
\text { tolerance }\end{array}$} & Cation/H+ membrane antiporter & $\begin{array}{l}\text { F:GTTGCTGATGCTACAGATG } \\
\text { R:CCTCTCTCTCTTCTTTACCG }\end{array}$ & 50 & 840 & 805 & 1800 & aCL1735Contig1 \\
\hline & Raffinose synthase & $\begin{array}{l}\text { F:CATGCGGAAAAGATGTACC } \\
\text { R:CAGCAAGGCTGTCCATAAC }\end{array}$ & 52 & 740 & 804 & 1800 & aCL3302Contig1 \\
\hline & Vacuolar $\mathrm{H}+$ pyrophosphatase & $\begin{array}{l}\text { F:GCATATGCTCCCATCAGTG } \\
\text { R:CAGGCTCCTGTCTGTTTGAG }\end{array}$ & 53 & 800 & 831 & 1650 & aCL5319Contig1 \\
\hline
\end{tabular}

High-quality sequence resulted from cleaning the alignments. aCLxxxxContig1, sequences were obtained from the Citrus Functional Genomics Project (CFGP), http://bioinfo.ibmcp.upv.es/genomics/cfgpDB/; the rest of the sequences were obtained from the National Center for Biotechnology Information (NCBI).

(AT) Annealing Temperature. 
Indel identification and design of new primers for diversity studies

BioEdit (Hall, 1999) was used to align sequences from which indel polymorphisms were identified. For genes with indel polymorphisms, new primer pairs in conserved regions flanking the indel polymorphism were designed using Primer3 software (http://biotools.umassmed.edu/bioapps/primer3) (Table 2) to amplify fragments smaller than 350 bp that were subsequently analysed in a capillary fragment analyser (see below).

Table 2. Characteristics of indel markers

\begin{tabular}{|c|c|c|c|c|}
\hline $\begin{array}{l}\text { Marker } \\
\text { name }\end{array}$ & Gene & Primers & AT & $\begin{array}{l}\text { Fragment } \\
\text { size (bp) }\end{array}$ \\
\hline IDCHI & Chalcone isomerase & $\begin{array}{l}\text { F:TTTCCTCTTGCTTTACGTGT } \\
\text { R:GTCACAGGTAACGGATTTTC }\end{array}$ & 55 & $146-196$ \\
\hline IDEMA & Malic enzyme & $\begin{array}{l}\text { F:CTCTTTCTGCTTCCTGACATC } \\
\text { R:GCCGGTGAATAAAACACAAC }\end{array}$ & 55 & $263-277$ \\
\hline IDTRPA & Vacuolar citrate/H+ symporter & $\begin{array}{l}\mathrm{F}: \text { CCCTCGTTCTTGGTAGCTTT } \\
\text { R:TTATGCATCCACATGCTCAC }\end{array}$ & 55 & 306-309 \\
\hline IDLCY2 & Lycopene $\beta$-cyclase & $\begin{array}{l}\mathrm{F}: \text { CGCAAATAATTGATTCAACA } \\
\text { R:GATGATCACGTCATATCGAA }\end{array}$ & 50 & $220-226$ \\
\hline IDHYB1 & $\beta$-Carotene hydroxylase & $\begin{array}{l}\mathrm{F}: \text { AAAAACAAAGCACCCAGAT } \\
\mathrm{R}: \text { GCCACCAGAACCTGTAATAA }\end{array}$ & 53 & $192-213$ \\
\hline IDHYB2 & $\beta$-Carotene hydroxylase & $\begin{array}{l}\text { F:TTTGGCACATTTGCTCTCTCT } \\
\text { R:AAAGAAGCATGCCACAGAGC }\end{array}$ & 55 & $305-307$ \\
\hline IDPSY & Phytoene synthase & $\begin{array}{l}\mathrm{F}: C C T G T C G A C A T T C A G G T T A G \\
\text { R:CTCATCACATCTTCGGTCTC }\end{array}$ & 55 & $246-249$ \\
\hline IDPEPC1 & Phosphoenolpyruvate carboxylase & $\begin{array}{l}\text { F:TTTTGAACAATCGGCTAATGG } \\
\text { R:TTGCTGGAAGAGAGACTCCAA }\end{array}$ & 55 & $231-259$ \\
\hline IDPEPC2 & Phosphoenolpyruvate carboxylase & $\begin{array}{l}\text { F:TTGGAGTCTCTCTTCCAGCAA } \\
\text { R:GTGAGAGCCACAATGCAAAA }\end{array}$ & 55 & $128-153$ \\
\hline IDCAX & Cation/H+ membrane antiporter & $\begin{array}{l}\text { F:TAAGCTGCATTTAACCCTTT } \\
\text { R:GCAATTGGGAGATAGTCAAT }\end{array}$ & 55 & $237-243$ \\
\hline IDAtGRC & Raffinose synthase & $\begin{array}{l}\text { F:GGCAATGAAAACAATGAGAT } \\
\text { R:TTTCAAGATTGTTGGTCCTC }\end{array}$ & 55 & $208-225$ \\
\hline IDAPV & Vacuolar $\mathrm{H}+$ pyrophosphatase & $\begin{array}{l}\text { F:CAGCTATTGGAAAGGTTTGT } \\
\text { R:GGAGACAGGCATAAAACATC }\end{array}$ & 55 & $156-163$ \\
\hline
\end{tabular}

(AT) Annealing temperature

\section{Diversity analysis}

Plant material

Ninety genotypes from the citrus germplasm bank of IVIA (Spain) and INRA/CIRAD (France) were used for the diversity study with SSR and indel markers (Online Resource 1). According to the Swingle and Reece classification system (1967), 45 genotypes belong to the three ancestral species (29 C. reticulata, $10 \mathrm{C}$. maxima and $6 \mathrm{C}$. medica) and 11 genotypes represented the secondary species $(2 \mathrm{C}$. aurantium, 4 C. sinensis, 2 C. paradisi and 3 C. limon). Seventeen accessions are supposed of interspecific origin from their morphology or previous molecular data $(46-50,53-55,65-66,81,84-89)$ even some of them were classified by Swingle and Reece (1967) as pure species. The last 17 accessions are hybrids from twentieth century breeding projects $(67-80 ; 82,83,90)$.

\section{Genotyping}

Sixty-seven SSR markers were tested on the citrus population selected for our study. Fifty markers presented proper and clear results (Online Resource 2; Kijas et al., 1997; Froelicher et al., 2008; Luro et al., 2008; Aleza et al., 2011; Cuenca et al., 2011; Kamiri et al., 
2011) and were used for the diversity study. Forty-seven of them were included in the clementine genetic map (Ollitrault et al., 2012b) and were well distributed between and within all linkage groups. In addition, twelve indel markers were analysed. One of them (TRPA) is located in the clementine genetic map (linkage group 2).

Amplification by polymerase chain reaction ( $P C R$ ) was performed using wellRED forward oligonucleotides (Sigma-Aldrich; Saint-Louis, USA) for analysis with a capillary genetic fragment analyser (CEQ/GeXP Genetic Analysis Systems; Beckman Coulter; Fullerton, USA). PCR was performed in a final volume of $15 \mu \mathrm{l}$. Each PCR reaction consisted of $1 \mathrm{ng} / \mu \mathrm{l}$ template DNA, $0.2 \mathrm{mM}$ dNTPs, $0.2 \mu \mathrm{M}$ wellRED dye-labelled forward primer, $0.2 \mu \mathrm{M}$ of non-dye-labeled reverse primer, 10x PCR buffer (Fermentas), $1.5 \mathrm{mM} \mathrm{MgCl}_{2}$ and $0.027 \mathrm{U} / \mu \mathrm{l}$ Taq DNA polymerase (Fermentas). PCR reactions were carried out with the following program: $5 \mathrm{~min}$ at $94^{\circ} \mathrm{C}$; 40 cycles of $30 \mathrm{~s}$ at $94^{\circ} \mathrm{C}, 30 \mathrm{~s}$ at 55 or $50^{\circ} \mathrm{C}$ (depending on the primer) and $1 \mathrm{~min}$ at $72^{\circ} \mathrm{C}$ with a final extension of $4 \mathrm{~min}$ at $72^{\circ} \mathrm{C}$.

Denaturation and capillary electrophoresis were carried out on a Capillary Gel Electrophoresis CEQ ${ }^{\text {TM }} 8000$ Genetic Analysis System using linear polyacrylamide according to the manufacturer's instructions (Beckman Coulter Inc.). Genetic analysis system software (GenomeLab ${ }^{\mathrm{TM}}$ GeXP version 10.0) was used for data collection and analysis. Alleles were sized based on a DNA size standard (400 bp).

\section{Data analysis}

Neighbour-joining (NJ) analysis

Population diversity organisation was analysed with DARwin software (Perrier and Jacquemoud-Collet, 2006). For each primer, bands were scored as allelic data to calculate the genetic dissimilarity matrix using the simple matching dissimilarity index $\left(d_{i-j}\right)$ between pairs of accessions (units):

$$
d_{i-j}=1-1 / L \sum_{l=1}^{L} m_{l} / 2
$$

where $d_{i-j}$ is the dissimilarity between units $i$ and $j, L$ is the number of loci and $m_{l}$ is the number of matching alleles for locus $l$. From the dissimilarity matrix obtained, a weighted $\mathrm{NJ}$ tree (Saitou and Nei, 1987) was computed using the Dissimilarity Analysis and Representation for Windows (DARwin5) software version 5.0.159, and the robustness of branches was tested using 10,000 bootstraps.

To establish the genetic structure with the core set of markers, NJ under topological constraints was used. It is a modified version that forces the a priori known topology of a subset of samples and positions additional subsets on the previous organisation. Secondary species and modern cultivars were positioned under the constraint of a tree based on basic taxa. 
Severinia buxifolia (Poir.) Ten, a species related to citrus, was used to root NJ trees.

\section{Principal coordinates analysis (PCoA)}

It was performed using the software GENEALEX6 (Peakall and Smouse 2006). The data from molecular markers was used to obtain the pairwise genetic distance matrix, which was standardised and used for PCoA analysis.

\section{Population structure}

It was inferred with the Structure version 2.3.3 program (http://cbsuapps.tc.cornell.edu/structure), which implements a model-based clustering method using genotype data (Pritchard et al., 2000; Falush et al., 2003). According to the general agreement on the origin of cultivated species (Scora, 1975); Barrett and Rhodes, 1976), we considered an initial structure between three populations $(K=3)$ : mandarin (29 samples), pummelo (10 samples) and citron (6 samples), assuming that the analysed genotypes are derived from these three ancestral taxa. The relative proportion of these ancestral populations in the secondary species and hybrids was assigned based on this assumption of an admixture model. Correlated allele frequencies were determined from the estimates of the three ancestral populations defined in this work. Ten runs of structure were performed with 500,000 steps of burning followed by $1,000,000$ Monte Carlo Markov Chain (MCMC) repetitions.

\section{$F_{\text {stat }}$ parameters}

$F_{\text {is }}, F_{\text {it }}$ and $F_{\text {st }}$ were calculated with the software program GENETIX v. 4.03 based on the parameters of Wright (1969) and Weir and Cockerham (1984).

\section{Linkage disequilibrium}

For multiallelic loci, LD between two loci is commonly measured by the $D^{\prime}$ estimate (Gupta et al., 2005). D' values for each pair of markers were estimated on the whole data set using the software program PowerMarker v. 3.25 (Liu and Muse, 2005). D' values vary from 0 (total random association between alleles of the two considered loci) to 1 (total LD). The $p$ value for obtaining the significance of D' was estimated by the exact test.

\section{Selection of a subset of markers for quick genotyping}

The methodology described by Jombart et al. (2010) was employed to obtain a small number of markers (core set) with good interspecific and intraspecific differentiation for quick and accurate genotyping. The procedure is based on a discriminant analysis of principal 
components (DAPC). Data from molecular markers are transformed with a PCoA, and the matrix obtained is employed to perform a discriminant analysis (DA). These results are used to calculate the allele contribution to the main axes, and the alleles with the highest contribution are selected. Expected heterozygosity was used as an extra parameter to select primers that allow good intraspecific differentiation. 


\section{RESULTS}

\section{Interspecific indel polymorphism research and indel marker development}

For the 16 genes a total of 10,701 bp by genotypes were successfully sequenced and aligned (Table 1), allowing the identification of 12 indel polymorphic loci in 10 genes. Specific indel polymorphisms were encountered in four loci in $C$. medica and another four loci in $C$. maxima, whereas the other indel polymorphisms were detected in different groups.

New primers were designed to analyse the indel diversity of these 12 loci (Table 2). In this diversity study, four loci (IDCHI, IDEMA, IDHYB1 and IDLCY2) had novel alleles not present in the six genotypes initially sequenced. Amplicons of genotypes with these new alleles were sequenced, as described previously, to analyse the origin of this pluri-allelism (Online Resource 3). At locus IDCHI, a new polymorphism was found in heterozygosis in $C$. sunki, another one was found in IDEMA (genotype C. sunki and others in heterozygosis), one at IDHYB1 in Cleopatra mandarin and other genotypes in heterozygosis and the last polymorphism was found in homozygosis at locus IDLCY2 in C. sunki and other genotypes in heterozygosis. Indel allele sequences of the ten analysed genes are given in Online Resource 3. For multi-allelic loci, the variation of amplicon size is due to variation in size of the same indel (IDCHI, IDHYB1 and IDLCY2) or several indels between the two primer sites (IDCHI, IDHYB2 and IDCAX). Three loci (IDPSY, IDPEPC2 and IDAVP) displayed intra-taxon polymorphisms only in C. medica, and the other three loci (IDHYB2, IDPEPC1 and IDATGRC) displayed intra-taxon polymorphisms only in C. maxima. Polymorphisms in loci IDTRPA, IDLCY2 and IDHYB1 may be due to copy number variations of SSRs.

\section{Indel analysis}

A total of 32 alleles were detected from the indel markers. The average number of alleles per locus was 2.67. Genetic diversity statistics were calculated for each indel marker in the entire population and for different citrus groups, including C. reticulata, C. medica and $C$. maxima (Online Resource 4). The allele number varied between 2 (for 7 loci) and 5 for IDCAX. IDCAX displayed the highest diversity $\left(H_{\mathrm{e}}=0.69\right)$ related to different alleles in the three ancestral taxa. IDAVP $\left(H_{\mathrm{e}}=0.12\right)$ was the least informative marker, as it differentiated only varieties from the citron subpopulation. The best markers for genotype differentiation within mandarins, pummelo and citron were IDCAX, IDPEPC1 and IDCHI, respectively. $F_{\text {stats }}$ parameters (Wright, 1969; Weir and Cockerham, 1984) were estimated to analyse the differentiation between the three ancestral taxa (C. maxima, $C$. medica and $C$. reticulata). $F_{\text {is }}$ values varied from -0.474 for IDAVP to 0.125 for IDCHI. For four loci, it was not possible to calculate the $F_{\text {is }}$ parameter because the loci were monomorphic in each of the ancestral taxa. With the exception of IDAVP, the $F_{\text {is }}$ value confirms a situation close to the Hardy-Weinberg equilibrium within each species. In contrast, $F_{\text {it }}$ values with a high average $(0.730)$ showed that, in the whole population (of the subset of the three ancestral taxa), the inbreeding coefficient is 
higher than within taxa for almost all of the markers, indicating an important organisation between taxa. Only IDTRPA had a low value $(-0.149)$ with two alleles shared by $C$. maxima and C. reticulata. The high $F_{\text {st }}$ average value $(0.766)$ and the $F_{\text {st }}$ value of each locus (excluding IDTRPA) confirms that the inter-taxa differentiation contributes much more to the global inbreeding than does the intra-taxa component. Thus, a large portion of the total variation is explained by the differentiation between populations.

Average data over all indel loci are given in Table 3. The average $F_{\mathrm{W}}$ value (0.433) shows a high deficit of observed heterozygous individuals in the population. Indeed, the whole population had an observed heterozygosity of 0.18 , which is $38 \%$ lower than the expected heterozygosity (0.29), suggesting an organisation in differentiated sub-gene pools with limited gene flows. Individually, the different taxa had an observed heterozygosity similar to the expected. C. reticulata was the most polymorphic $\left(H_{\mathrm{e}}=0.13\right)$ and heterozygous $\left(H_{0}=0.14\right)$ ancestral taxon, and C. maxima was the least polymorphic and heterozygous $\left(H_{0}=H_{\mathrm{e}}=0.07\right)$ ancestral taxon.

Table 3. Statistical summary of the diversity of indel and SSR markers

\begin{tabular}{|c|c|c|c|c|c|c|c|c|c|c|c|c|c|c|c|c|}
\hline \multirow[t]{2}{*}{$\begin{array}{c}\text { Marker } \\
\text { type }\end{array}$} & \multicolumn{4}{|c|}{ All citrus accessions } & \multicolumn{3}{|c|}{ C. reticulata } & \multicolumn{3}{|c|}{ C. maxima } & \multicolumn{3}{|c|}{ C. medica } & \multicolumn{3}{|c|}{3 basic taxa } \\
\hline & $N$ & $H_{0}$ & $H_{\mathrm{e}}$ & $F_{\mathrm{W}}$ & $N$ & $H_{0}$ & $H_{\mathrm{e}}$ & $N$ & $H_{0}$ & $H_{\mathrm{e}}$ & $N$ & $H_{0}$ & $H_{\mathrm{e}}$ & $F_{\text {is }}$ & $F_{\text {it }}$ & $F_{\text {st }}$ \\
\hline InDel & 2.67 & 0.18 & 0.29 & 0.433 & 1.58 & 0.14 & 0.13 & 1.25 & 0.07 & 0.07 & 1.25 & 0.09 & 0.09 & -0.148 & 0.730 & 0.766 \\
\hline SSR & 8.10 & 0.59 & 0.71 & 0.175 & 5.02 & 0.56 & 0.56 & 3.36 & 0.50 & 0.52 & 1.94 & 0.17 & 0.28 & 0.030 & 0.454 & 0.434 \\
\hline
\end{tabular}

Mean values are represented in the table

$N$ Allele number, $H_{0}$ Heterozygosity observed, $H_{\mathrm{e}}$ Heterozygosity expected, $F_{\mathrm{w}}$ Wright fixation Index over the whole population, $F_{\text {is }}, F_{\text {it }}$ and $F_{\text {st }}$ Weir and Cockerham Index over the subset of $C$. maxima, $C$. medica and $C$. reticulata accessions

\section{SSR analysis}

The same genetic diversity parameters were calculated for each individual SSR marker, the entire population and for the different specified Citrus groups (Online Resource 5). A total of 405 alleles were detected with the SSR markers. The average number of alleles and $H_{\mathrm{e}}$ per locus was 8.1 and 0.71 , respectively. The allele number varied between 3 (for loci MEST107, CAC15 and CAC23) and 14 (MEST56). TAA41 was the most informative marker with a He of 0.86 , and CAC15 was the least informative marker $(\mathrm{He}=0.39$ ). Most of the markers (48 out of 50) showed $H_{\mathrm{e}}$ values higher than 0.5 . When analysing the organisation among the three basic taxa, $F_{\text {is }}$ values varied from -0.114 for CAC23 to 0.594 for mCrCIR05A04. The overall $F_{\text {is }}$ value was close to zero (0.030), confirming that few deviations from the Hardy-Weinberg equilibrium occurred within each basic taxon. In contrast, high $F_{\text {it }}$ and $F_{\text {st }}$ values for almost all markers (averages of 0.454 and 0.434 , respectively) are evidence of high differentiation between the 3 basic taxa.

Average data over all indel loci are given in Table 3. The population displayed a deficit of average observed heterozygosity $\left(H_{0}=0.59\right)$ compared with the expected value under Hardy-Weinberg equilibrium $\left(H_{\mathrm{e}}=0.71\right)$. This finding is confirmed by the average $F_{\mathrm{W}}$ value 
(0.175). Each of the 3 basic taxa had an observed heterozygosity close to the expected value. C. reticulata was the most diverse $\left(H_{\mathrm{e}}=0.56\right)$ and heterozygous $\left(H_{0}=0.56\right)$ ancestral taxa, but citron was the lowest $\left(H_{\mathrm{e}}=0.28\right.$ and $\left.H_{0}=0.17\right)$.

\section{Comparative diversity structure displayed by indels and SSRs}

The genetic parameters for indel and SSR markers, respectively, were as follows: allele number per locus ranged from 2 to 5 and from 3 to 14, observed heterozygosity average was 18 and $59 \%$ and the percentage of varieties differentiated among the whole population was $57.78 \%$ (52 out of 90 ) and $91.11 \%$ (82 out of 90 ). The distribution of $H_{\mathrm{e}}$ and $F_{\mathrm{st}}$ between the three basic taxa (Figure 1) confirmed that indel markers are less polymorphic than are SSR markers (lower $H_{\mathrm{e}}$ values) but allow a better differentiation between ancestral species (higher $F_{\mathrm{st}}$ values). Statistics for the three ancestral groups were calculated for both types of primers (Table 3). Expected and observed heterozygosity were similar for both types of markers but were lower
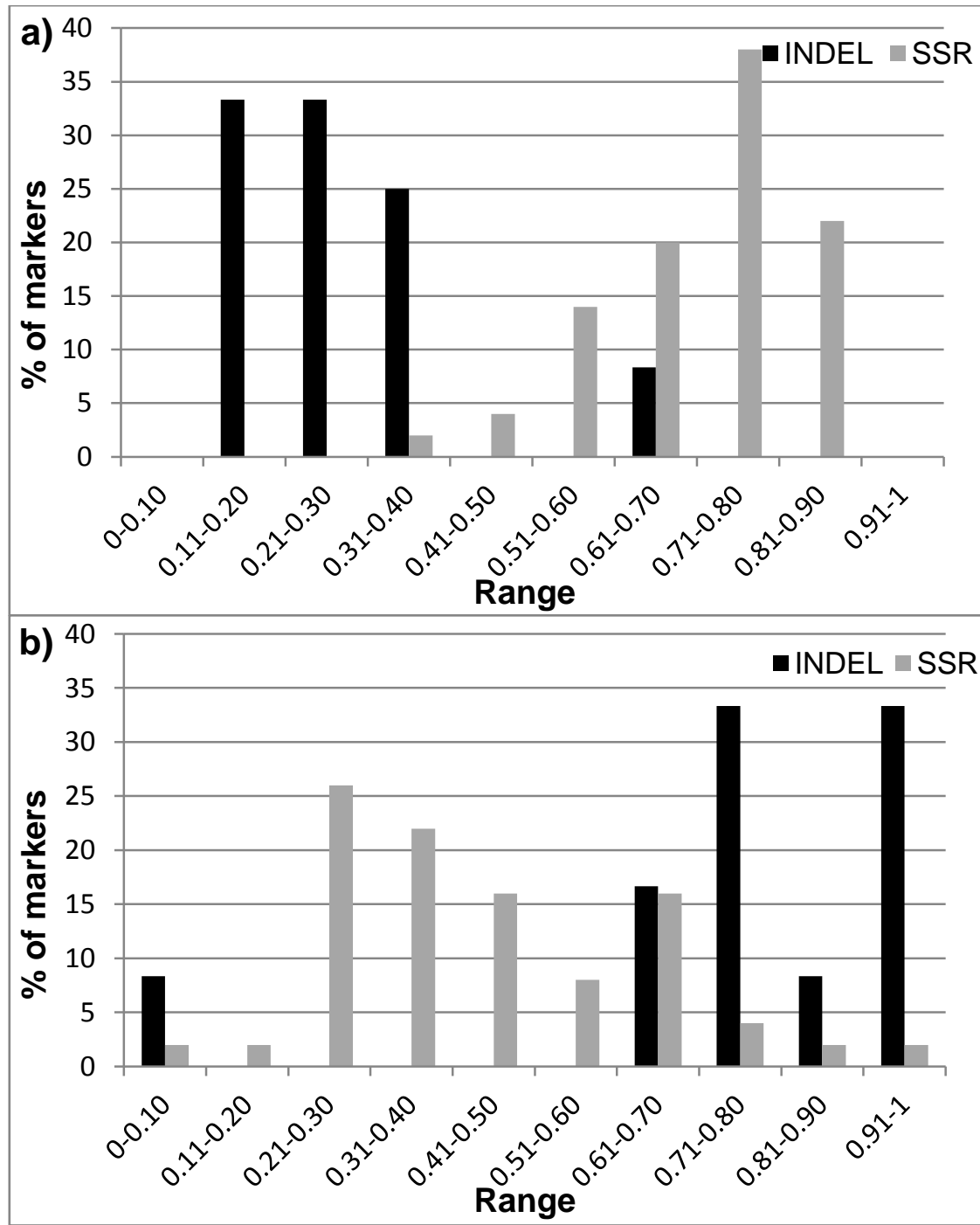

Figure 1. Comparison between indel and SSR markers of the expected heterozygosity $\left(H_{\mathrm{e}}\right)$ and the genetic differentiation index $\left(F_{\mathrm{st}}\right)$ between ancestral taxa. a) Expected heterozygosity, b) genetic differentiation index 
for indels than SSRs within each taxon. With SSR markers, all accessions of $C$. medica and $C$. maxima were fully differentiated, whereas $96.7 \%$ of intervarietal differentiation was obtained within C. reticulata. The indel intervarietal differentiations were 100, 40 and $53.3 \%$ within $C$. medica, C. maxima and C. reticulata, respectively. Twelve out of 50 SSR and 7 out of 12 indel markers displayed significant deficits of heterozygous genotypes in the whole sample set (Online resources 4 and 5).

The $F_{\text {st }}$ value was estimated for each pair of basic taxa, and it was systematically higher with indel than SSR markers. The least differentiated species were $C$. reticulata and $C$. maxima ( $F_{\text {st }}$ of 0.373 and 0.422 for SSR and indel, respectively), followed by $C$. reticulata/ $C$. medica (0.427 and 0.758 ) and C. maxima/C. medica (0.484 and 0.844). All of these data support the conclusion that indel markers yield higher inter-taxa discrimination compared with SSR markers.

Both $\mathrm{NJ}$, figure 2 and principal coordinates analysis PCoA, figure 3 analyses revealed a clear differentiation between the three ancestral citrus taxa for both kinds of markers.

NJ trees (Figure 2) clearly separated C. medica and C. maxima from C. reticulata. For indel markers (Figure 2a), C. medica was the best defined group and showed good bootstrap support in all branches of its cluster, and all of the samples were differentiated. The C. maxima group formed a well-defined clade, but only four profiles were differentiated among ten accessions. The intraspecific diversity of $C$. reticulata was not well resolved (low bootstrap support), perhaps due to the high number of hybrids (within mandarin) in the sample set. Fourteen genotypes were differentiated among the 29 mandarins.

SSRs allowed a complete intercultivar differentiation for C. maxima and C. medica, whereas only two C. reticulata cultivars (East India SG and Vohangisany Ambodiampoly) were not differentiated (Figure 2b).

NJ analysis confirmed higher intraspecific diversity with SSRs than with indel markers. The lower differentiation obtained with indels may be partly due to the lower number of these markers. However, it is also clearly explained by their lower allelic diversity, which is observed mostly at the interspecific level. Clustering was stronger with indel than with SSR markers, but SSRs allowed a better intra-cluster differentiation between accessions.

PCoA (Figure 3) is more adapted than tree representation in describing the organisation of genetic diversity when hybrids between differentiated groups are frequent in the sample. In our study, PCoA allowed us to have a better idea of the relative contribution of the three basic taxa to the genome constitutions of secondary species and modern hybrids. Almost all of the existing variability (92.10\%) is represented in the first two axes for indels (Figure 3a), but only $75.89 \%$ variability is represented for SSRs (Figure $3 b$ ). This result confirms that higher interspecific organisation is determined using indel markers. For these markers, the $C$. medica group (and its hybrids with citron as one parent) was strongly differentiated from $C$. reticulata (and its hybrids) and C. maxima by axis 1 , whereas the C. maxima group was differentiated from the 

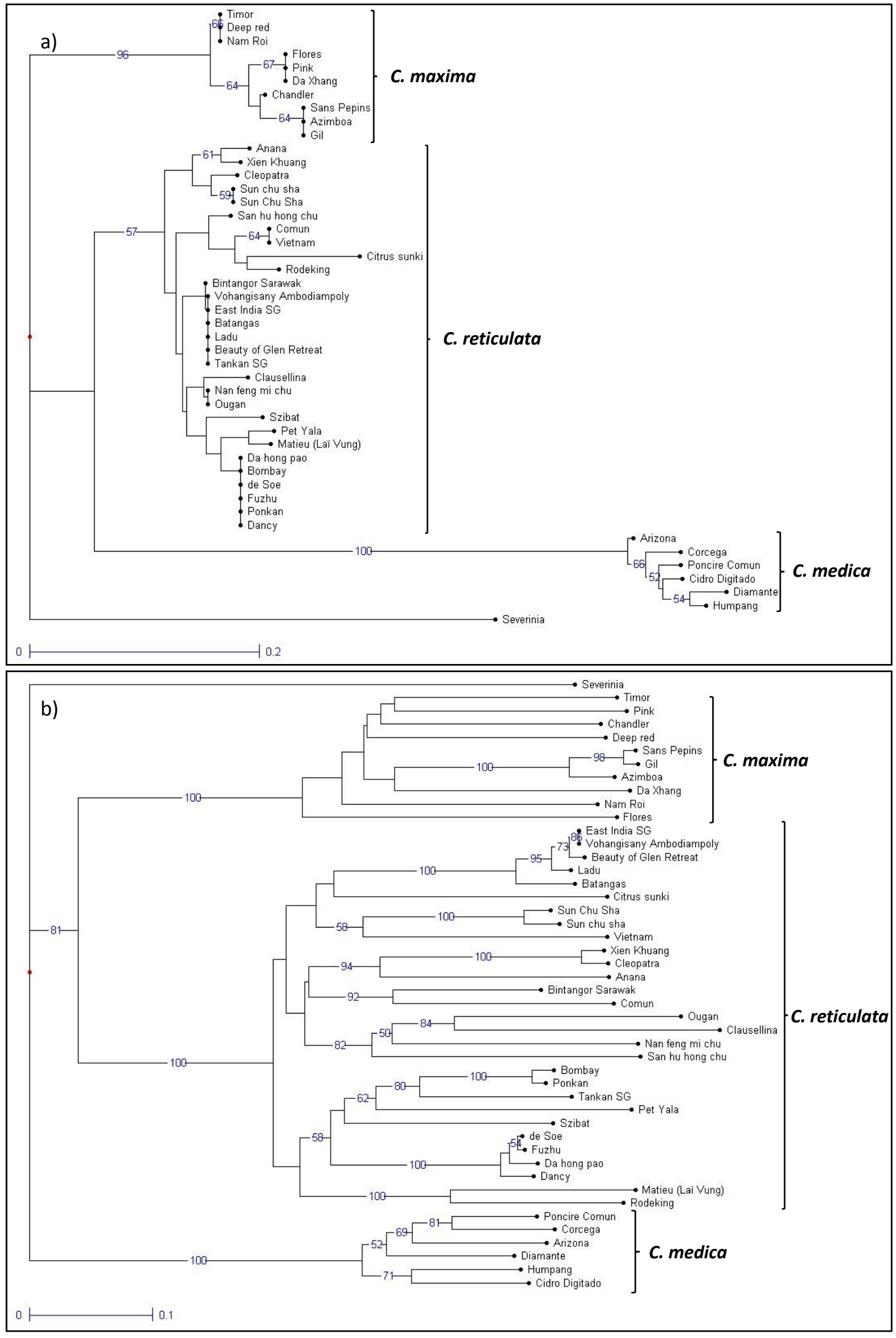

Figure 2. NJ bootstrap consensus trees of 45 accessions of citrus ( 3 ancestor groups) including one outgroup Severinia buxifolia. Numbers are bootstrap values over 50 based on 10,000 resampling. a) Indel markers data, b) SSR markers data 


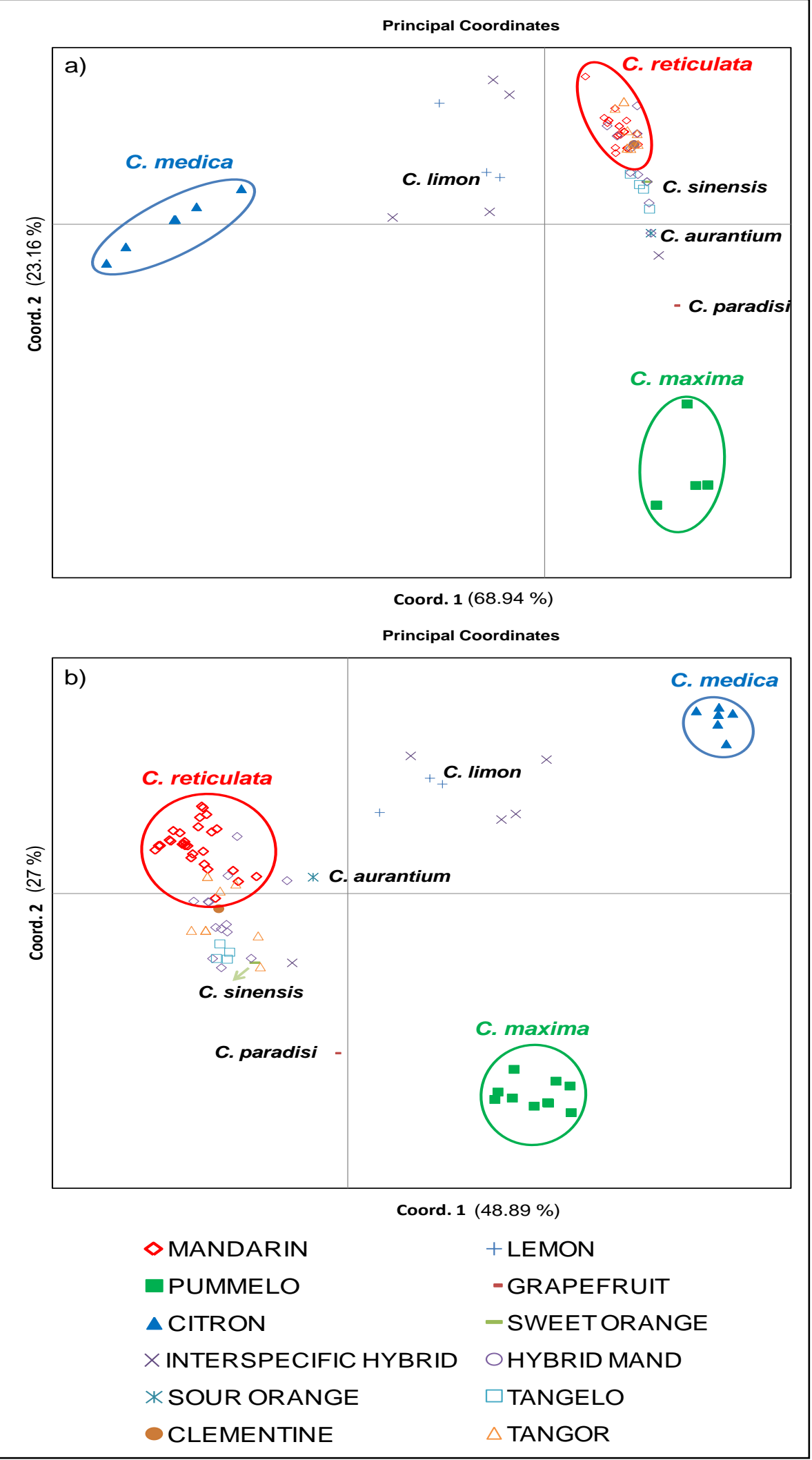

Figure 3. Organization of cultivated Citrus genetic diversity; principal coordinates analysis. a) Indel markers data, b) SSR markers data. Mandarin (samples 1-29), pummelo (samples 30-39), citron (samples 40-45), interspecific hybrids (samples 46-50), sour orange (samples 51-52), clementine (samples 53-54), lemon (samples 56-58), grapefruit (samples 59-60), sweet orange (samples 61-64), hybrid mandarins (samples 67-76), tangelo (samples 77-80) and tangor (samples 81-90). Sample number assignment can be found in Online Resource 1 
other species by axis 2. C. paradisi varieties and Bali hybrid, mandarin Suntara and $C$. aurantium (the last two had exactly the same position), in this order, were closer to C. maxima with indel markers than with SSR markers. Tangors (mandarin $\mathrm{x}$ sweet orange) were closer to the $C$. reticulata cluster and Tangelos (mandarin $\times$ grapefruit) were closer to $C$. maxima, as expected from their origin. Clementines were close to $C$. reticulata accessions and some hybrids that have clementines as a parent.

For SSRs, C. medica was differentiated from C. maxima by axis 1 , and the C. reticulata group was differentiated from $C$. medica by axis 2. C. reticulata accessions were more dispersed around the axis based on SSR markers than with indel markers. As $C$. sinensis, $C$. aurantium appeared much more related to $C$. reticulata than to $C$. maxima, C. limon was clearly positioned between the $C$. medica gene pool and $C$. aurantium. Some hybrids derived from $C$. medica (Poncil, Rhobs el Arsa, Kadu Mul and Damas) were positioned in a similar place, suggesting that these hybrids share similar origins as $C$. limon. Tangor was the most dispersed group, Murcott and Umatilla were the closest varieties to $C$. reticulata and Ortanique was the closest to $C$. maxima. Tangelos were similarly distanced between them. Clementines were close to the $C$. reticulata gene pool, whereas $C$. paradisi was the secondary species closest to C. maxima.

Contribution of the ancestral taxa to secondary species and modern hybrids; analysis with structure software

PCoA analysis provided some information on the relative contribution of the three basic taxa to the genome constitution of the secondary ones, confirming the status of $C$. medica, $C$. reticulata and $C$. maxima as parental gene pools of the other species and modern hybrids in this study. Assuming an admixture model between the three ancestral species, the relative proportion of ancestral taxa genomes in the secondary species and recent hybrids was inferred using the Structure version 2.3.3 software (Figure 4) with the complete set of data (SSRs + Indels).

Citrus limon and hybrids with C. medica as parents (Poncil, Rhobs el Arsa, Kadu Mul and Damas) have the greatest average contribution from $C$. medica (46\%). Contributions of $C$. medica lower than $2.5 \%$, which was observed for C. sinensis, C. aurantium, C. paradisi, Bali pummelo, Clementine and Temple, can probably be considered artefacts and related to the relatively low number of representative genotypes of the basic taxa and probable lack of intrataxa diversity. Citrus paradisi is the secondary species with the highest contribution from $C$. maxima ( $60 \%$ ), followed by C. aurantium (30\%), C. sinensis (25\%), tangelo group (20\%), tangor group (10\%) and clementines (7\%). Citrus aurantium varieties displayed seven rare alleles, five of which were shared with Suntara mandarin (two of them were also shared with $C$. limon), one was shared with $C$. limon and another one was only present in $C$. aurantium. 
The contributions of the ancestral groups to the secondary species obtained with the Structure software was compared with direct estimations performed with the specific allele from the SSR and indel markers derived from the mandarin, pummelo and citron groups (Table 4). No significant difference was found between the two methods of evaluation. It is interesting to note that no specific allele from C. medica was observed in C. sinensis, C. paradisi, Bali pummelo, Clementine and Temple, which confirms that the low values estimated for the same genotypes with Structure were not significant.

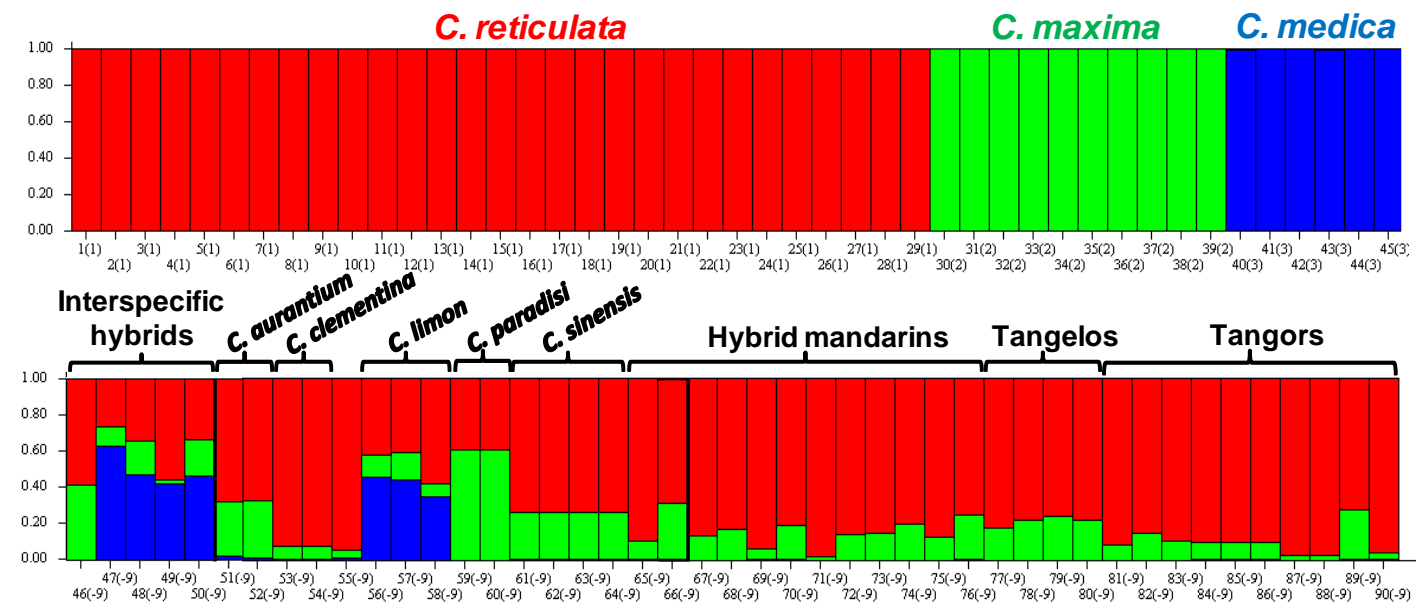

Figure 4. Relative contribution of basic taxa to secondary species and modern cultivars; structure analysis with $K=3$ as initial hypothesis, considering SSR and indel data. In parenthesis are indicated the reference population assignment for the admixture model $1 \mathrm{C}$. reticulata population, 2 C. maxima population, 3 C. medica population, -9 population with unknown contribution from ancestors. Sample number assignment can be found in Online Resource 1

Table 4. Contribution of the ancestral taxa to secondary species; comparison between direct estimation from interspecific discriminant allele and the estimation from Structure software (admixture model).

\begin{tabular}{|c|c|c|c|c|c|c|c|c|c|c|c|c|}
\hline \multirow[t]{2}{*}{ Latin name } & \multirow[t]{2}{*}{ Common name } & \multicolumn{3}{|c|}{$\begin{array}{l}\text { SSR + InDel } \\
\text { allele specific } \\
\text { from }\end{array}$} & \multirow{2}{*}{$\begin{array}{c}\text { Total } \\
\text { informative } \\
\text { alleles }\end{array}$} & \multicolumn{3}{|c|}{$\begin{array}{l}\text { Direct estimation from } \\
\text { discriminant alleles }\end{array}$} & \multicolumn{3}{|c|}{ Structure data } & \multirow[b]{2}{*}{$x^{2}$} \\
\hline & & $\mathbf{R e}$ & $\mathrm{Ma}$ & $\mathrm{Me}$ & & $\operatorname{Re}(\%)$ & $\mathrm{Ma}(\%)$ & $\operatorname{Me}(\%)$ & $\operatorname{Re}(\%)$ & $\mathrm{Ma}(\%)$ & $\mathrm{Me}(\%)$ & \\
\hline C. aurantium & Sevillano & 32 & 16 & 1 & 49 & 65.31 & 32.65 & 2.04 & 67.2 & 30.6 & 2.2 & 0.10 \\
\hline C. clementina & Clemenules & 49 & 1 & 0 & 50 & 98 & 2 & 0 & 92 & 7.1 & 0.9 & 2.48 \\
\hline C. limon & Eureka Frost & 21 & 4 & 22 & 47 & 44.68 & 8.51 & 46.8 & 41.6 & 12.1 & 46.3 & 0.61 \\
\hline C. limon & Lisbon Limoneira & 20 & 6 & 22 & 48 & 41.67 & 12.50 & 45.8 & 40.3 & 14.7 & 45 & 0.19 \\
\hline C. paradisi & Marsh & 21 & 22 & 0 & 43 & 48.84 & 51.16 & 0 & 38.6 & 60.9 & 0.5 & 2.05 \\
\hline C. sinensis & Valencia late delta & 37 & 5 & 0 & 42 & 88.10 & 11.90 & 0 & 73.3 & 25.6 & 1.1 & 4.79 \\
\hline x C. maxima & Bali & 28 & 18 & 0 & 46 & 60.87 & 39.13 & 0 & 58.4 & 41.1 & 0.6 & 0.37 \\
\hline x C. medica & Poncil & 14 & 5 & 26 & 45 & 31.11 & 11.11 & 57.8 & 26.3 & 10.8 & 62.9 & 0.59 \\
\hline x C. medica & Rhobs el Arsa & 15 & 9 & 20 & 44 & 34.09 & 20.45 & 45.5 & 33.6 & 18.7 & 47.7 & 0.12 \\
\hline x C. medica & Kadu Mul & 31 & 0 & 23 & 54 & 57.41 & 0 & 42.6 & 54.9 & 2.7 & 42.3 & 1.52 \\
\hline x C. medica & Damas & 11 & 8 & 24 & 43 & 25.58 & 18.60 & 55.8 & 33.6 & 18.7 & 47.7 & 1.42 \\
\hline x C. reticulata & Citrus daoxianensis & 50 & 1 & 0 & 51 & 98.04 & 1.96 & 0 & 94.1 & 4.1 & 1.8 & 1.57 \\
\hline
\end{tabular}

\section{Linkage disequilibrium}

Based on the data obtained with the 50 SSR markers distributed along the genome, the extent of genome-wide LD was estimated by $D^{\prime}$ for the whole population. indel markers were not selected for this analysis because they were not mapped. $D$ ' values ranged from 0.11 to 0.9 for interchromosome pairs of loci and from 0.21 to 0.94 for intrachromosome pairs (Figure 5). The average D' estimates for marker pairs within and between chromosomes were 0.56 and 0.51 , respectively. For interchromosome and intrachromosome marker pairs, 65.69 and $53.68 \%$ of 
the $D^{\prime}$ values were over 0.5 , respectively. The percentage of significant $\mathrm{p}$ values was very high for marker pairs within and between chromosomes: 99.27/99.26\% (< 5\%) and 97.08/97.89\% (< $1 \%)$, respectively. When analysing the relation between LD and genetic distances between markers (Figure 6), it appears that there is a high LD even between distant markers with a limited LD decay with increasing distances. The distribution of the interchromosome $D^{\prime}$ is highly similar. The mean value of $D$ ' was 0.5161 for the whole population and all marker pairs.

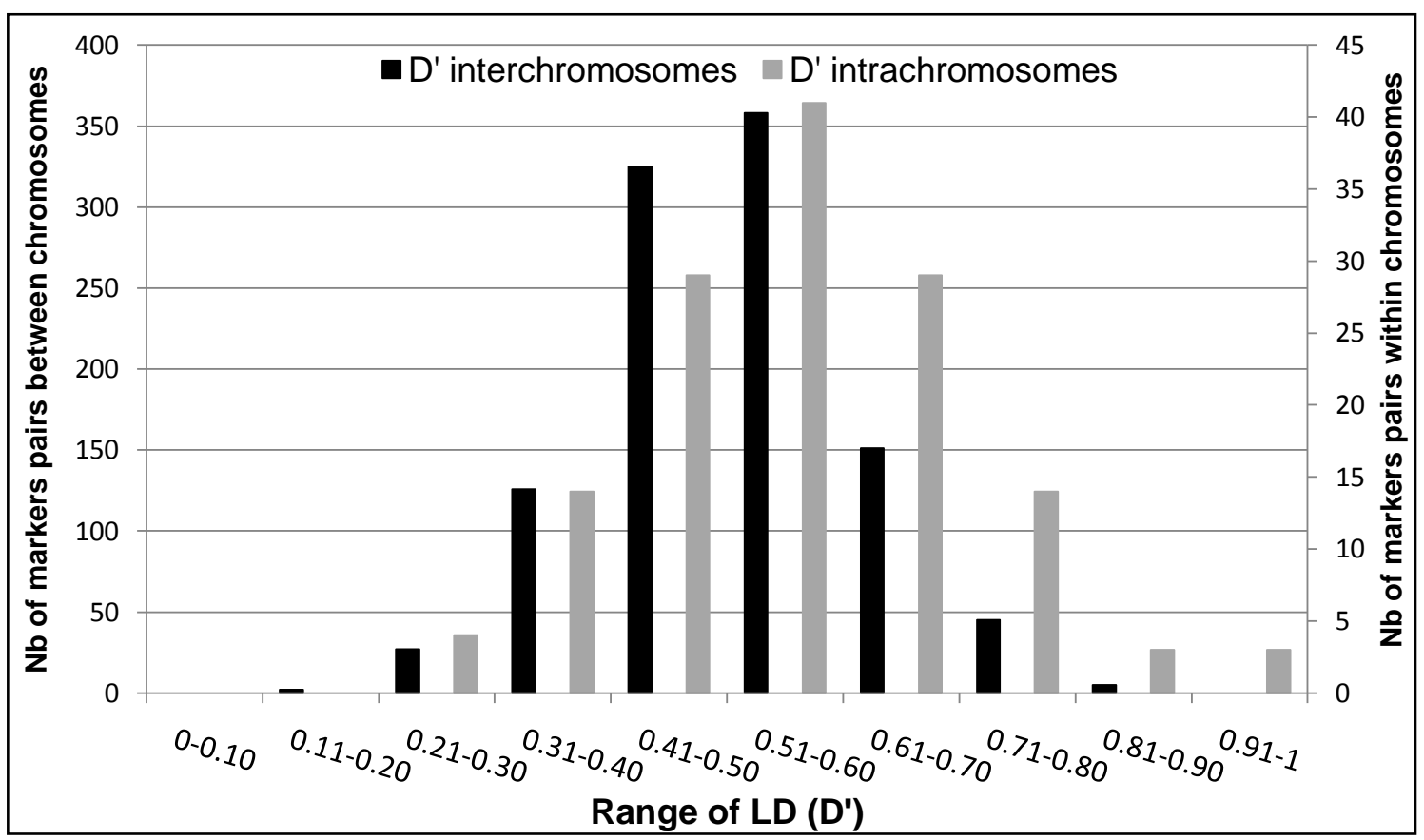

Figure 5. Linkage disequilibrium for marker pairs within a same linkage group (grey) and between markers located in different chromosomes (black)

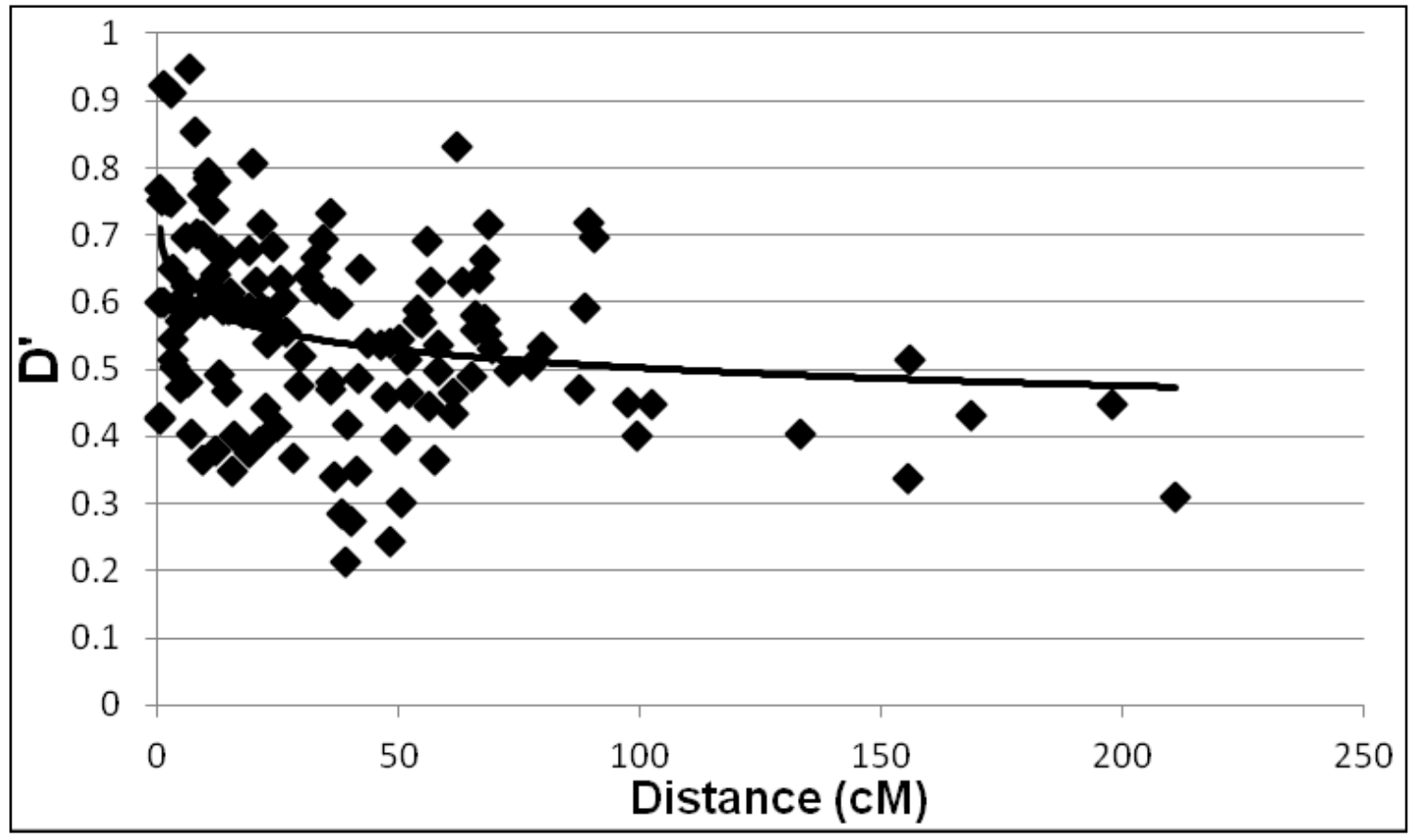

Figure 6. Relation between LD in the population for all markers pairs within chromosomes and genetic distances (Clementine genetic map; Ollitrault et al., 2012b) 
Selection of a subset of markers for quick genotyping

Identifying a subset of markers that can differentiate new accessions and study their origin could be useful for quick and inexpensive genotyping. In this study, the parameters used to select the subset of markers were high locus contribution to F1 and F2 coordinates of the PCoA analysis (interspecific organisation), high expected heterozygosity (global diversity displayed by the marker) and limited LD between the selected markers to avoid excessive redundant information between markers (Online Resource 6). A total of nine markers were selected: mCrCI02D04b and MEST431 were selected for their high contribution to the F1 component (which distinguished $C$. reticulata from the other two ancestors), IDCHI and IDCAX have a high contribution to F2 (axis which differentiates between $C$. medica and the other ancestors), mCrCl07F11 and mCrCl07D06 contributed in both axes (it is helpful to distinguish individuals that are intermediate) and MEST488, TAA41 and mCrCI02G12 were selected for their high expected heterozygosity. Six out of the nine linkage groups were represented by the selected marker subset. With these nine markers, the three ancestors groups were clearly differentiated (Online Resource 7). Samples in the C. medica group were fully separated, whereas in C. maxima, only 'Gil' and 'Sans Pepins' cultivars could not be differentiated. C. reticulata within diversity was slightly less resolved than with the whole marker set (6 mandarins were not distinguished). The average observed and expected heterozygosity values were 56 and $64 \%$, respectively, and the $F_{\mathrm{W}}$ was 0.163 . 


\section{DISCUSSION}

Citrus indel markers are less polymorphic but display higher interspecies differentiation than do SSR markers

Indels are generally considered to be interesting polymorphisms for genetic studies. However, despite increasing molecular resources in citrus, such as EST sequence information (Forment et al., 2005; Terol et al., 2007), HarvEST software Version 1.32 of "HarvEST:Citrus" (http://www.harvest-web.org) and genomic sequence information (Terol et al., 2008), no specific study has been conducted prior to the present work to analyse the value of nuclear indels as genetic markers in Citrus. We searched for indel polymorphisms in the three basic taxa $(C$. reticulata, C. maxima and $C$. medica) by sequencing PCR products obtained from 13 genes. Primers were designed to amplify 150-350 bp fragments flanking the 12 identified indels, and amplicon size variation was studied by capillary electrophoresis on a sample of 90 genotypes of the Citrus genus.

The frequency of indels per $\mathrm{kb}$ in citrus was 0.71 and 5.22 in exon and intron sequences, respectively. More sequence polymorphisms were found in non-coding regions than in coding regions. Similar results have been observed in other species. In Brassica, 0.45 and $7.42 \mathrm{indel} / \mathrm{kb}$ were found in exons and introns, respectively (Park et al., 2010). In melon, indels occurred less frequently in introns (approximately $0.60 / \mathrm{kb}$ ) and no indel was found inside coding regions (Morales et al., 2004). In maize, 0.43 and 11.76 indels/kb were found in coding and non-coding regions, respectively (Ching et al., 2002).

The mean number of alleles per locus was 2.83 with a maximum of five alleles at the IDCAX locus. Seven of the twelve markers were diallelic. Retroposon movements, such as Alu or the L1 element, are known to generate such diallelic indels (Watkins et al., 2001). In our study, pluri-allelism was caused by differences in indel size or the presence of several indels in the amplified fragments. Indels with a size that is not a multiple of 3 are uncommon in exons but relatively common in introns (Mills et al., 2006; The Arabidopsis Genome Initiative, 2000).

Almost $60 \%$ of the whole set of samples were differentiated with the 12 indel markers. A better differentiation may be obtained with more indels; however, the low mean number of alleles per locus may be a limitation compared with techniques using multi-allelic markers, such as SSRs. Indeed, we found a mean value of 8.1 alleles per locus for SSRs. With higher allelic diversity and intra-taxon diversity, SSRs are more informative than indels at the intraspecific level. The number of repeats in microsatellites evolves at a high rate (Weber and Wrong, 1993; Jarne and Lagoda, 1996), which can vary depending on the number of repeats or base composition (Bachtrog et al., 2000). Thus, there are generally good markers for intra-population diversity analysis, as we observed at the intra-taxon level. However, due to this important rate of variation, homoplasy should be relatively frequent, as demonstrated in Citrus (Barkley et al., 2009), and should limit the value of SSRs as phylogenetic markers. Our results confirmed this 
hypothesis, as we observed that indel markers displayed a much higher differentiation between the three basic taxa than SSRs, with $F_{\text {st }}$ value averages of 0.77 and 0.43 , respectively. The structure of the whole sample diversity was higher for indels with a fixation index value $\left(F_{\mathrm{w}}\right.$; Wright, 1978) of 0.433 and 0.175 for SSRs. Interestingly, the three indel markers (IDTRPA, IDLCY2 and IDHYB1) that may result from variation in copy number of SSRs showed lower $F_{\mathrm{st}}$ value than the average. Therefore, these three markers provide less inter-taxa differentiation than the other indels. The PCA also confirmed a higher level of structure of the diversity displayed by indels markers than by SSRs with 92.2 and $75 \%$ of the whole diversity, respectively, represented by the first two axes.

Thus, we can conclude that, in the Citrus genus, indel markers are less polymorphic than SSRs but display a higher organisation of genetic diversity at the interspecific level. From the 50 SSRs and 12 indels we have selected a core set of 9 markers (2 indels and 7 SSRs) that keep the interspecific structure, as well as a significant part of the intraspecific polymorphism information. These markers should be useful for the rapid and inexpensive assignment of a new germplasm variety to its genetic group or identification of its potential hybrid origin.

Indels play a major role in sequence divergence between closely related DNA sequences in animals, plants, insects and bacteria. Indels are responsible for many more unmatched nucleotides than are base substitutions, and human genetic data suggests that indels are a major source of gene defects (Britten et al., 2003). Indels in coding regions probably have functional roles and are considered to be a significant source of evolutionary change in eucaryotic and bacterial evolution (Britten et al., 2003). Indels in genes with functional diversity between alleles should be highly useful for marker-assisted selection (Raman et al., 2006) or QTL mapping (Vasemägi et al., 2010). Using the increasing amounts of sequence information acquired by new technologies (454-Roche, SOLiD system-Applied biosystems or Solexa-lllumina), the development of PCR-based indel markers will become an important source of genetic markers that are easy and inexpensive to use in phylogenetic and genetic association studies in Citrus.

\section{The genetic constitution of secondary species and modern hybrids}

In agreement with previous molecular studies (Barkley et al., 2006; Luro et al., 2008), no intercultivar polymorphism was found at intraspecific level for $C$. sinensis, $C$. aurantium and C. paradisi, whereas these species are highly heterozygous $\left(H_{0}\right.$ values of $0.47,0.50$ and 0.44 , respectively). This finding confirms that most of the intervarietal polymorphisms within these secondary species arise from punctual mutation or movement of transposable elements (Bretó et al., 2001). These types of mutations are unlikely to be detected with SSR or indel markers. The three lemon cultivars were differentiated. However, lemons cv 'Lisbon' and cv 'Eureka' only differed for five markers. 
PCA using SSR or indel markers confirmed that the differentiation between $C$. reticulata, C. maxima and C. medica gene pools was the structuring factor of the analysed edible citrus germplasm. Secondary species and modern tangor and tangelo cultivars (which display higher heterozygosity than $C$. reticulata, C. maxima and C. medica) take intermediary positions between the three basic taxa, confirming their hybrid status. Structure analysis with an admixture model considering $C$. reticulata, $C$. maxima and $C$. medica at the origin of all analysed germplasm allowed us to estimate the contribution of these taxa to the genomes of secondary species, modern cultivars and some genotypes of unclear origin.

Two accessions initially considered as representative of $C$. maxima and C. medica (Bali pummelo and Poncil citron, respectively) were discarded by structure analysis from the ancestor species and positioned as hybrids. Bali seemed to be a hybrid between $C$. reticulata and $C$. maxima (genome contributions of 57 and $43 \%$, respectively) and Poncil seemed to be a trihybrid from C. medica (63\%), C. reticulata (26\%) and C. maxima (11\%).

As proposed by Roose et al. (2009), we found that sweet orange (C. sinensis) exhibits close to $75 \%$ C. reticulata and $25 \%$ C. maxima contribution and thus should be the result of a backcross 1 ( $\mathrm{BC} 1)$ [(C. maxima $\times$ C. reticulata) $\times$ C. reticulata]. These contributions differ from the ones estimated by Nicolosi et al. (2000) where $C$. sinensis shared half of its markers with $C$. reticulata and the other half with C. maxima and in Barkley et al. (2006) where only $6-8 \%$ of its genome arose from C. maxima.

It is believed that grapefruit (C. paradisi) arose from a cross between pummelo and sweet orange in the West Indies where they were introduced after Christopher Columbus discovered the new world (Barrett and Rhodes, 1976; Nicolosi et al., 2000). Grapefruit displays a contribution of $61 \%$ from C. maxima and $39 \%$ from C. reticulata, which are values that are close to the theoretical average values (62.5 and $37.5 \%$, respectively) expected for a $C$. maxima $\times[(C$. maxima $\times$ C. reticulata $) \times C$. reticulata $]$ hybrid.

Sour orange (C. aurantium) is thought to be derived from hybridisation between $C$. maxima and C. reticulata gene pools (Nicolosi et al., 2000; Barkley et al., 2006; Uzun et al., 2009). Our analysis with Structure suggests that it showed a greater contribution from $C$. reticulata $(68 \%)$ than did C. maxima $(30 \%)$ and a bit of C. medica $(2 \%)$. Seven rare alleles were found in $C$. aurantium that were not present in the analysed germplasm of the three main ancestors. However, five of them were found in the accession 'Suntara' mandarin. Furthermore, 'Suntara' and $C$. aurantium share the same alleles at most loci. Thus, there is a high probability that $C$. aurantium and 'Suntara' mandarin share parentage, but we do not have sufficient evidences to conclude whether 'Suntara' is a parent or a hybrid from $C$. aurantium. The small contribution of $C$. medica (2\%) can probably be considered an artefact by estimation with Structure software, due to an underrepresentation of $C$. maxima and $C$. reticulata diversity. It is likely that $C$. aurantium is a $\mathrm{BC} 1$ (C. maxima $\times$ (C. maxima $\times$ C. reticulata)).

In agreement with its putative C. aurantium x C. medica origin (Nicolosi et al., 2000; Gulsen and Roose, 2001a), we found that lemons (C. limon) cv. 'Eureka' and 'Lisbon' had a 
complex tri-hybrid structure from C. reticulata (41\%), C. medica (45\%) and C. maxima (13\%). The argument that $C$. aurantium is one parent is reinforced by the fact that these two lemons shares three rare alleles with $C$. aurantium.

Mandarin-like varieties are an increasing component of the citrus fresh fruit market and include $C$. reticulata hybrids, known or supposed tangors (hybrids between $C$. reticulata and $C$. sinensis) and tangelos (hybrids between $C$. reticulata and $C$. paradisi). The clementine, a variety selected from a seedling of "Common mandarin" one century ago in Algeria, is the most popular variety of mandarin in the Mediterranean Basin. Most of its genome is inherited from $C$. reticulata, but it seems to have been introgressed in small part from C. maxima (6\%). The allelic constitution of clementine is in agreement with the hypothesis of a "Common mandarin" $\mathrm{x} C$. sinensis hybridisation (Deng et al., 1996; Nicolosi et al., 2000). In addition, the 'Temple', 'Ellendale', 'Murcott' and 'King' varieties have been considered as tangor. These varieties showed close to $90 \%$ contribution of the $C$. reticulata genome and $10 \%$ contribution of the $C$. maxima genome, as expected for hybrids between $C$. reticulata and $C$. sinensis. Moreover, they shared most of their alleles with these two species. Our results confirm the hypothesis of Swingle (1943), Coletta Filho et al. (1998) and Nicolosi et al. (2000) regarding the origin of 'King'. As expected, tangelos had a greater contribution of C. maxima than tangors (approximately 20\%).

Of the genotypes of uncertain origin, we found that $C$. daoxianensis is mostly of $C$. reticulata origin (94\%). This result is in agreement with $\mathrm{Li}$ et al., (1992), who considered C. daoxianensis to be a wild mandarin. 'Rhobs el Arsa' was considered by Federici et al., (1998) to be a cross between $C$. aurantium and $C$. medica, as are lemons. Our results are in agreement with this hypothesis. The origin of 'Kadu Mul' has not been reported previously. Our results prompt the hypothesis that 'Kadu Mul' arose from a cross $C$. medica $\times$ C. reticulata, as we found that 'Kadu Mul' exhibits 42.3 and $54.9 \%$ contribution from C. medica and C. reticulata, respectively.

This study showed that the ancestral $C$. reticulata group contributes to a great proportion of the genomes of secondary species and recent hybrids. The facultative apomixis exhibited by all secondary species probably arose from the $C$. reticulata germplasm.

Cultivated citrus: a highly structured gene pool with generalised linkage disequilibrium that is not favourable for global association genetic studies

Previous molecular studies (Herrero et al., 1996, Federici et al., 1998; Nicolosi et al., 2000; Luro et al., 2001; Ollitrault et al., 2003; Barkley et al., 2006; Liang et al., 2007) have provided evidence of a strong diversification between the ancestral taxa of all cultivated forms. Therefore, the analysis of the organisation of cultivated citrus and the study of the LD organisation of the genome were necessary to estimate how association studies should be conducted in Citrus. 
Our analysis of $F_{\text {stat }}$ parameters in the subset of the three basic taxa genotypes ( $C$. reticulata, C. medica and C. maxima) with non-significant $F_{\text {is }}$ value but high $F_{\text {it }}$ and $F_{\text {st }}$ values confirms the important structure of the allelic diversity between these taxa. The interspecific differentiation was particularly high using indel markers. Eleven of 50 SSR markers and 7 of 12 indel markers displayed significant deficits of heterozygous genotypes in the whole sample. This indicates a strong population subdivision (Hartl and Clark, 1997) and, therefore, a low gene flow between $C$. medica, $C$. reticulata and $C$. maxima. The differentiation between these sexually compatible taxa can be explained by the foundation effect in three geographic zones and by an initial allopatric evolution. Citrus maxima originated in the Malay Archipelago and Indonesia, $C$. medica evolved in North-eastern India and the nearby region of Burma and China and $C$. reticulata diversification occurred over a region including Vietnam, Southern China and Japan (Webber et al., 1967; Scora, 1975). Later on, human activity facilitated migration and hybridization among the differentiated gene pools of the basic taxa. However, the partial apomixis observed in most of the secondary species has strongly limited the interspecific gene flow.

Using 50 mapped SSR markers, we found that the LD decay was very slow as the distance increased in a same linkage group. Moreover, a similar distribution of LD was found when considering LD within or between linkage groups $\left(65.69\right.$ and $53.68 \%$ of the $D^{\prime}$ values > 0.5 , respectively). $99.3 \%$ of significant $p$ values $(<0.05)$ were observed both within and between linkage groups. This LD structure confirms that the history of cultivated Citrus (initial allopatric differentiation of basic taxa followed by a limited number of interspecific meiosis) is not a favourable situation for association genetic studies. Indeed, significant LD between polymorphisms on different chromosomes may produce associations between a marker and a phenotype, even though the marker is not physically linked to the locus responsible for the phenotypic variation. Similar population structures exist in many crops where the complex breeding history and limited gene flow found in most wild plants have created complex stratification (Flint-Garcia et al., 2003; Abdurakhmonov and Abdukarimov, 2008). LD between unlinked loci primarily happens due to the occurrence of distinct allele frequencies with different ancestry in an admixed or structured population when predominant parents exist in germplasm groups. This was the case in our sample representative of the cultivated Citrus genus. Statistical methodologies have been developed to properly interpret the results of association tests when using such structured populations (Pritchard et al., 2000; Reich and Goldstein, 2001; Price et al., 2006; Yu et al., 2006). However, to be applied properly, these methods require that a significant part of the structured population results from recombination between the ancestral genomes with sufficient meiosis events to reduce the initial extent of LD, whereas the actual cultivated citrus germplasm arises from a limited number of such inter-ancestry meiosis. This result precludes LD-based association study at the genus level without developing additional interspecific hybrids, such as BC1 or F2, between ancestral taxa or hybrids of the secondary species. In addition, the potential use of genetic association studies within basic species should be explored, particularly in $C$. reticulata where useful polymorphisms (resistance to biotic and 
abiotic constraints and some quality factors) have been identified. Moreover, markers with a higher rate of identity-by-descent, such as indels or SNPs, should be more useful than SSRs for genetic association studies.

\section{CONCLUSIONS}

This work achieves for the first time in c0itrus, the development of indel markers as an important tool for diversity and phylogenetic studies in citrus. Indel markers appear to be better phylogenetic markers for tracing the contributions of the three ancestral species to the secondary species and modern cultivars, whereas SSR markers are more useful for intraspecific diversity analysis. Most of the genetic organisation of the Citrus gene pool is related to the differentiation between $C$. reticulata, C. maxima and $C$. medica. High and generalised LD was observed, probably due to the initial differentiation between the basic species and a limited number of interspecific meiosis. This structure precludes association genetic studies at the genus level without developing additional recombinant populations from interspecific hybrids. Association genetic studies should also be affordable at intraspecific level in a less structured pool such as $C$. reticulata. 
ONLINE RESOURCES CHAPTER 1 

Online Resource 1. Genotypes classification

\begin{tabular}{|c|c|c|c|c|}
\hline Common name & Group & Swingle system & Accession & Collection \\
\hline Comun & Mandarin & C. reticulata Blanco & 154 & IVIA \\
\hline Anana & Mandarin & C. reticulata Blanco & 390 & IVIA \\
\hline Ponkan & Mandarin & C. reticulata Blanco & 482 & IVIA \\
\hline Sun chu sha & Mandarin & C. reticulata Blanco & 483 & IVIA \\
\hline Dancy & Mandarin & C. reticulata Blanco & 434 & IVIA \\
\hline Clausellina & Mandarin & C. reticulata Blanco & 19 & IVIA \\
\hline Fuzhu & Mandarin & C. reticulata Blanco & 571 & IVIA \\
\hline Cleopatra & Mandarin & C. reticulata Blanco & 385 & IVIA \\
\hline Citrus sunki & Mandarin & C. reticulata Blanco & 239 & IVIA \\
\hline Bintangor Sarawak & Mandarin & C. reticulata Blanco & 0100683 & INRA/CIRAD \\
\hline Vohangisany Ambodiampoly & Mandarin & C. reticulata Blanco & 0100437 & INRA/CIRAD \\
\hline San hu hong chu & Mandarin & C. reticulata Blanco & 0100769 & INRA/CIRAD \\
\hline Nan feng mi chu & Mandarin & C. reticulata Blanco & 0100839 & INRA/CIRAD \\
\hline Vietnam & Mandarin & C. reticulata Blanco & 0100800 & INRA/CIRAD \\
\hline Rodeking & Mandarin & C. reticulata Blanco & 0100431 & INRA/CIRAD \\
\hline Ladu & Mandarin & C. reticulata Blanco & 0100595 & INRA/CIRAD \\
\hline Batangas & Mandarin & C. reticulata Blanco & 0100057 & INRA/CIRAD \\
\hline Bombay & Mandarin & C. reticulata Blanco & 0100518 & INRA/CIRAD \\
\hline East India SG & Mandarin & C. reticulata Blanco & 0100414 & INRA/CIRAD \\
\hline Xien Khuang & Mandarin & C. reticulata Blanco & 0100868 & INRA/CIRAD \\
\hline Ougan & Mandarin & C. reticulata Blanco & 0100680 & INRA/CIRAD \\
\hline de Soe & Mandarin & C. reticulata Blanco & 0100653 & INRA/CIRAD \\
\hline Pet Yala & Mandarin & C. reticulata Blanco & 0100694 & INRA/CIRAD \\
\hline Szibat & Mandarin & C. reticulata Blanco & 0100596 & INRA/CIRAD \\
\hline Beauty of Glen Retreat & Mandarin & C. reticulata Blanco & 0100261 & INRA/CIRAD \\
\hline Da hong pao & Mandarin & C. reticulata Blanco & 0100591 & INRA/CIRAD \\
\hline Tankan SG & Mandarin & C. reticulata Blanco & 0100524 & INRA/CIRAD \\
\hline Mathieu (Laï Vung) & Mandarin & C. reticulata Blanco & ¿? & INRA/CIRAD \\
\hline Sun Chu Sha & Mandarin & C. reticulata Blanco & 0100786 & INRA/CIRAD \\
\hline Azimboa & Pummelo & C. maxima (L.) Osb. & 420 & IVIA \\
\hline Deep red & Pummelo & C. maxima (L.) Osb. & 277 & IVIA \\
\hline Pink & Pummelo & C. maxima (L.) Osb. & 275 & IVIA \\
\hline Chandler & Pummelo & C. maxima (L.) Osb. & 207 & IVIA \\
\hline Gil & Pummelo & C. maxima (L.) Osb. & 321 & IVIA \\
\hline Da Xhang & Pummelo & C. maxima (L.) Osb. & 589 & IVIA \\
\hline Nam Roi & Pummelo & C. maxima (L.) Osb. & 590 & IVIA \\
\hline Flores & Pummelo & C. maxima (L.) Osb. & 0100673 & INRA/CIRAD \\
\hline Timor & Pummelo & C. maxima (L.) Osb. & 0100707 & INRA/CIRAD \\
\hline Sans Pepins & Pummelo & C. maxima (L.) Osb. & 0100710 & INRA/CIRAD \\
\hline Arizona & Citron & C. medica L. & 169 & IVIA \\
\hline Corcega & Citron & C. medica L. & 567 & IVIA \\
\hline Cidro Digitado & Citron & C. medica L. & 202 & IVIA \\
\hline Diamante & Citron & C. medica L. & 560 & IVIA \\
\hline Poncire Commun & Citron & C. medica L. & 0100701 & INRA/CIRAD \\
\hline Humpang & Citron & C. medica L. & 0100722 & INRA/CIRAD \\
\hline Bali & Hybrid & x C. maxima $\mathrm{L}$. & 663 & INRA/CIRAD \\
\hline Poncil & Hybrid & x C. medica L. & 151 & IVIA \\
\hline Rhobs el Arsa & Hybrid & C. aurantium L. x C. medica L. & 0110244 & INRA/CIRAD \\
\hline Kadu Mul & Hybrid & C. medica L. x C. maxima (L.) Osb. & 0100717 & INRA/CIRAD \\
\hline Damas & Hybrid & C. aurantium L. x C. medica L. & 0100837 & INRA/CIRAD \\
\hline Sevillano & Sour orange & C. aurantium L.? & 117 & IVIA \\
\hline Bouquet de Fleurs & Sour orange & C. aurantium L.? & 139 & IVIA \\
\hline Clemenules & Clementine & C. reticulata Blanco & 22 & IVIA \\
\hline Oronules & Clementine & C. reticulata Blanco & 132 & IVIA \\
\hline Citrus daoxianensis & Mandarin & C. reticulata Blanco & 359 & IVIA \\
\hline Eureka Frost & Lemon & C. limon (L.) Burm. f. & 297 & IVIA \\
\hline Lisbon Limoneira & Lemon & C. limon (L.) Burm. f. & 214 & IVIA \\
\hline Lemon meyer & Lemon & C. limon (L.) Burm. f. & 145 & IVIA \\
\hline Marsh & Grapefruit & C. paradisi Macf. & 176 & IVIA \\
\hline Star Ruby & Grapefruit & C. paradisi Macf. & 197 & IVIA \\
\hline Shamouti & Sweet orange & C. sinensis (L.) Osb. & 270 & IVIA \\
\hline Valencia late delta & Sweet orange & C. sinensis (L.) Osb. & 363 & IVIA \\
\hline Lane late & Sweet orange & C. sinensis (L.) Osb. & 198 & IVIA \\
\hline Sanguinelli & Sweet orange & C. sinensis (L.) Osb. & 34 & IVIA \\
\hline Temple & Mandarin & Tangor? & 81 & IVIA \\
\hline Suntara & Mandarin & C. reticulata Blanco & 0110251 & INRA/CIRAD \\
\hline C-54-4-4 & Hybrid & (C. reticulata $\times($ C.reticulata $\times$ C.sinensis $))$ & 453 & IVIA \\
\hline Fairchild & Hybrid & (C. reticulata $\times(C$. paradisi $\times$ C. reticulata $)$ ) & 83 & IVIA \\
\hline Fallglo & Hybrid & (C. reticulata $\times(C$. paradisi $\times$ C. reticulata $) \times C$. reticulata $)$ & 466 & IVIA \\
\hline Fortune & Hybrid & (C. reticulata $\times$ C. reticulata) & 80 & IVIA \\
\hline Kara & Hybrid & (C. reticulata $\times$ C. reticulata) & 218 & IVIA \\
\hline Nova & Hybrid & (C. reticulata $\times(C$. paradisi $\times$ C. reticulata) & 74 & IVIA \\
\hline Osceola & Hybrid & (C. reticulata $\times(C$. paradisi $\times$ C. reticulata $))$ & 573 & IVIA \\
\hline Page & Hybrid & (C. paradisi $\times$ C. reticulata) $\times$ C. reticulata) & 79 & IVIA \\
\hline Sunburst & Hybrid & $\begin{array}{l}((\text { C. reticulata } \times \text { (C. paradisi } \times \text { C. reticulata }) \\
\times((\text { C. reticulata } \times(C \text {. paradisi } \times \text { C. reticulata }))\end{array}$ & 200 & IVIA \\
\hline Wallent & Hybrid & Chance seedling & 404 & IVIA \\
\hline Mapo & Tangelo & (C. deliciosa Ten. x C. paradisi Macf.) & 190 & IVIA \\
\hline Minneola & Tangelo & (C. paradisi Macf. x C. tangerina Hort. ex Tan.) & 84 & IVIA \\
\hline Orlando & Tangelo & (C. paradisi Macf. x C. tangerina Hort. ex Tan.) & 101 & IVIA \\
\hline Seminole & Tangelo & (C. paradisi Macf. x C. tangerina Hort. ex Tan.) & 348 & IVIA \\
\hline King & Tangor & C. reticulata Blanco & 477 & IVIA \\
\hline Avasa 9 & Tangor & (C. reticulata $\times$ C. sinensis) & 405 & IVIA \\
\hline Dweet & Tangor & (C. reticulata $\times$ C. sinensis) & 165 & IVIA \\
\hline
\end{tabular}




\begin{tabular}{llll} 
Ellendale & Tangor & (C.reticulata x C. sinensis) & 194 \\
Ellendale leng & Tangor & (C.reticulata x C. sinensis) & 353 \\
Ellendale taranco & Tangor & (C.reticulata x C. sinensis) & 575 \\
Murcott & Tangor & (C.reticulata x C. sinensis) & 196 \\
Murcott sin semillas & Tangor & (C.reticulata x C. sinensis) & IVIA \\
Ortanique & Tangor & (C.reticulata x C. sinensis) & 371 \\
Umatilla & Tangor & (C. reticulata x C. sinensis) & IVIA \\
IVIA & IVIA \\
\hline
\end{tabular}

(IVIA) Banco de Germoplasma de Cítricos del Instituto Valenciano de Investigaciones Agrarias (IVIA) Apartado Oficial 46113 Moncada, Valencia, Spain.

(INRA/CIRAD) INRA/CIRAD Citrus Germplasm, Centre Inra de Corse, F-20230 San Giuliano, France 
Chapter 1: Online resources

Online Resource 2. SSRs markers characteristics

\begin{tabular}{|c|c|c|c|c|c|c|}
\hline Marker name & Reverse sequence & Forward sequence & AT & Size & $\begin{array}{c}\text { EMBL } \\
\text { Accession }\end{array}$ & Published \\
\hline MEST121 & TCCCTATCATCGGCAACTTC & CAATAATGTTAGGCTGGATGGA & 55 & 177-189 & DY275927 & Luro et al. 2008 \\
\hline MEST1 & CAAGCСTCTCTCTTTAGTCCCA & AGTTCTTTGGTGCTTCAGGC & 55 & $170-190$ & DY262452 & New primer \\
\hline MEST431 & GAGCTCAAAACAATAGCCGC & CATACCTCCCCGTCCATCTA & 55 & $331-345$ & DY291553 & New primer \\
\hline TAA15 & GAAAGGGTTACTTGACCAGGC & CTTCCCAGCTGCACAAGC & 55 & $164-204$ & & Kijas et al. 1997 \\
\hline mCrClR02D09 & AATGATGAGGGTAAAGATG & ACCCATCACAAAACAGA & 55 & $226-240$ & FR677569 & Cuenca et al. 2011 \\
\hline TAA41 & AGGTCTACATTGGCATTGTC & ACATGCAGTGCTATAATGAATG & 55 & $127-162$ & & Kijas et al. 1997 \\
\hline mCrCIR06B07 & CGGAACAACTAAAACAAT & TGGGCTTGTAGACAGTTA & 50 & $96-108$ & AM489745 & Froelicher et al. 2008 \\
\hline mCrCl01C07 & GTCACTCACTCTCGCTCTTG & TTGCTAGCTGCTTTAACTTT & 55 & $260-298$ & AJ567394 & Froelicher et al. 2008 \\
\hline mCrCIR05A05 & CGGAACAACTAAAACAAT & TGGGCTTGTAGACAGTTA & 50 & $144-179$ & FR677580 & Cuenca et al. 2011 \\
\hline $\mathrm{mCrClR04H06}$ & GGACATAGTGAGAAGTTGG & CAAAGTGGTGAAACCTG & 55 & $184-196$ & FR677579 & Cuenca et al. 2011 \\
\hline MEST46 & GAACCAGAATCAGAACCCGA & GGTGAGCATCTGGACGACTT & 55 & $230-256$ & & New primer \\
\hline CAC15 & TAАATCTCСАСТСТGСАAАAGC & GATAGGAAGCGTCGTAGACCC & 55 & $168-180$ & & Kijas et al. 1997 \\
\hline $\mathrm{mCrClR03C08}$ & CAGAGACAGCCAAGAGA & GCTTCTTACATTCCTCAAA & 55 & $200-225$ & FR677576 & Cuenca et al. 2011 \\
\hline CAC23 & ATCACAATTACTAGCAGCGCC & TTGCATTGTAGCATGTTGG & 55 & $240-260$ & & Kijas et al. 1997 \\
\hline MEST256 & CATTAAAATATCCGTGCCGC & GAGCAAGTGCGTTGTTGTGT & 55 & $200-230$ & DY290355 & New primer \\
\hline $\mathrm{mCrCl02G12}$ & AAACCGAAATACAAGAGTG & TCCACAAACAATACAACG & 55 & $240-260$ & FR677575 & Froelicher pers com \\
\hline MEST131 & SACGTGTCAAACCA & GCTGTCACGTTGGGTGTATG & 55 & $120-150$ & DY276912 & New primer \\
\hline mCrCl03D12a & GCCATAAGCCCTTTCT & СССАСАACСАТСАСС & 50 & $240-280$ & FR677577 & Aleza et al. 2011 \\
\hline $\mathrm{mCrCl02D04b}$ & СТСТСТTTССССАТTAGA & AGCAAACCCCACAAC & 50 & $199-229$ & FR677564 & Kamiri et al. 2011 \\
\hline mCrClR03G05 & CCACACAGGCAGACA & CCTTGGAGGAGCTTTAC & 50 & $199-228$ & FR677578 & Cuenca et al. 2011 \\
\hline mCrCIR07D06 & CCTTTTCACAGTTTGCTAT & TCAATTCCTCTAGTGTGTGT & 55 & 164-197 & FR677581 & Cuenca et al. 2011 \\
\hline MEST15 & GAAGCGGAGGTGG & ААТTCTCTTGACTC & 55 & $192-210$ & FC912829 & New primer \\
\hline MEST104 & CCTTA & AAAAGATGGGGCCTTGTG & 55 & $240-260$ & DY273697 & New $p$ \\
\hline mCrCIR01F08a & ATGAGCTAAAGAGAAGAGG & GGACTCAACACAACACAA & 50 & $128-156$ & AM489737 & Froelicher et al. 2008 \\
\hline MEST88 & GCCTGTTTGCTTTCTCTTTCTC & ATGAGAGCCAAGAGCACGAT & 55 & $99-130$ & DY271576 & New primer \\
\hline mCrCl05A04 & AAACGAGACAAGACCAAC & ІСТССССТСАСТ & 55 & $245-268$ & FR692372 & Froelicher pers com \\
\hline mCrCIR07E12 & TGTAGTCAAAAGCATCAC & GATTCCTGACTTTA & 50 & $106-146$ & AM489750 & Froelicher et al. 2008 \\
\hline MEST115 & СССССТСТТСТТТСАСАСАА & GGTGAGCAGCCATCTTCTTC & 55 & $147-167$ & DY274953 & New primer \\
\hline mCrCIR06A12 & $\triangle \triangle C T C \triangle \triangle A C T T C$ & TCCTT & 50 & 84-102 & 9742 & Froelicher et al. 2008 \\
\hline MEST56 & AGTCCGC & AAGAGAGCGAGAG & 55 & $129-145$ & DY267791 & Aleza et al. 2011 \\
\hline $\mathrm{mCrCl04H12}$ & TTCСТСТАСАACTACAACCA & АТТАТССТСААССТССАА & 50 & $179-194$ & FR692371 & Froelicher pers com \\
\hline MEST192 & GATCATCTAGCATACA & ATCAACACATC & 55 & $200-240$ & DY283129 & Aleza et al. 2011 \\
\hline mCrClR02F12 & TTTCTCTGATG & TTT & 55 & $116-144$ & FR677570 & Cuenca et al. 2011 \\
\hline Ci01D11 & GCAAAACAAGCAGACTACAAAT & AGGACAGATGACCCAGATGACA & 55 & $214-230$ & AJ567397 & Froelicher et al. 2008 \\
\hline MEST488 & CACGCTCTTGACTTTCTCCC & CTTTGCGTGTTTGTGCTGTT & 55 & $133-164$ & DY297637 & New primer \\
\hline mCrCIR01E02 & TGAATGGTACGGGAAATGC & GGTGGAGAGGAT & 55 & $172-184$ & AM489735 & Froelicher et al. 2008 \\
\hline mCrClR01C06 & GGACCACAACAAAGACAG & TGGAGACACAAAGAAGAA & 50 & $131-170$ & AJ567393 & Cuenca et al. 2011 \\
\hline TAA1 & GACAACATCAACAACAGCAAGAGC & AAGAAGAAGAGCCCCCATTAGC & 55 & $161-180$ & & Kijas et al. 1997 \\
\hline MEST107 & GCTGAGATGGGGATGAAAGA & CCCCATCCTTTCAACTTGTG & 55 & $183-201$ & DY & New primer \\
\hline mCrClR03B07 & САССТТТСССТ & TGAGGGACTAAACAGCA & 55 & $263-279$ & FR677573 & Cuenca et al. 2011 \\
\hline Ci07C07 & TATCCAGTTTGTAAATGAG & TGATATTTGATTAGTTTGG & 50 & $243-258$ & AJ567409 & Froelicher et al. 2008 \\
\hline mCrClR02A09 & ACAGAAGGTAGTATTTTAGGG & TTGTTTGGATGGGAAG & 55 & $151-177$ & FR677568 & Cuenca et al. 2011 \\
\hline mCrClR02G02 & CAATAAGAAAACGCAGG & TGGTAGAGAAACAGAGGTG & 55 & $110-138$ & FR677572 & Cuenca et al. 2011 \\
\hline $\mathrm{Ci02F07}$ & GCAGCGTTTGTTTTCT & TGCTGGTTTTCAGATACTT & 55 & $188-215$ & AJ567406 & Froelicher et al. 2008 \\
\hline mCrClR07B05 & TTTGTTCTTTTTGGTCTTTT & CTTTTCTTTCCTAGTTTCCC & 50 & $218-254$ & AM489747 & Froelicher et al. 2008 \\
\hline mCrCIR01F04a & AAGCATTTAGGGAGGGTCACT & TGCTGCTGCTGTTGTTGTTCT & 55 & $190-228$ & AM489736 & Froelicher et al. 2008 \\
\hline & CCAACTGACACTAATCCTCTTC & CCTCTCTGGCTTCTGGATTG & 55 & $110-128$ & DY271447 & New primer \\
\hline Ci07C09 & GACCCTGCCTCCAAAGTATC & GTGGCTGTTGAGGGGTTG & 55 & $258-274$ & AJ567410 & Froelicher et al. 2008 \\
\hline mCrClR07F11 & TACTTTGCTTTGAG & AAAAAAAT & 50 & $146-176$ & FR677567 & Kamiri et al. 2011 \\
\hline Сi02B07 & CAGCTCAACATGAAAGG & TTGGAGAACAGGATGG & 50 & $178-212$ & AJ567403 & Froelicher et al. 2008 \\
\hline
\end{tabular}

(AT) Annealing temperature 


\section{Online Resource 3. InDel sequence alignment found in candidate genes}

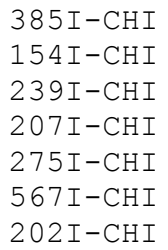

$385 \mathrm{I}-\mathrm{CHI}$ $154 \mathrm{I}-\mathrm{CHI}$ $239 \mathrm{I}-\mathrm{CHI}$ $207 \mathrm{I}-\mathrm{CHI}$ $275 \mathrm{I}-\mathrm{CHI}$ $567 \mathrm{I}-\mathrm{CHI}$ 202I-CHI

$385 \mathrm{I}-\mathrm{CHI}$ $154 \mathrm{I}-\mathrm{CHI}$ 239I-CHI $207 \mathrm{I}-\mathrm{CHI}$ 275I-CHI $567 \mathrm{I}-\mathrm{CHI}$ 202I-CHI

$385 \mathrm{I}-\mathrm{CHI}$ $154 \mathrm{I}-\mathrm{CHI}$ 239I-CHI 207I-CHI 275I-CHI $567 \mathrm{I}-\mathrm{CHI}$ 202I-CHI

385I-EMA 154 I-EMA 207I-EMA 275I-EMA 567I-EMA 202I-EMA

385I-EMA 154 I-EMA 207I-EMA 275I-EMA 567I-EMA 202I-EMA

385I-EMA 154 I-EMA 207I-EMA 275I-EMA 567I-EMA 202I-EMA
TTTCCTCTTGCTTTACGTGTAATAATAATAAATTAACAATACAGGTGCATTAAATATTTA 60 TTTCCTCTTGCGTTACGTGTAATGATAATAAATTAACAATACAGGTGCATTAAATATTTA 60 TTTCCTCTTGCGTTACGTGTAATA----------------CAGGTGCATTAAATATTTA 43 TTTCCTCTTGCGTTACGTGTAATAATAATAAATTAACAATACAGGTGCATTAAATATTTA 60 TTTCCTCTTGCGTTACGTGTAATAATAATAAATTAACAATACAGGTGCATTAAATATTTA 60

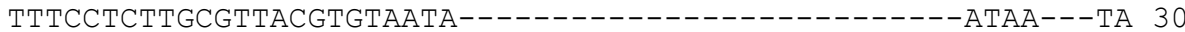
TTTCCTCTTGCGTTACGTGTAATA----------------------ATAAATTTA 33

AATTCACACTATCCGTATGGGAATCCTTTCCCGTCATAAACGCTGCTTAAAGAGTAGTCA 120 AATTCACACTATCCGTATGGGAATCCTTTTCCGTCATAAACGCTGCTTAAAGAGTAGTGA 120 AATTCACACTATCCGTATGGGAATCCTTTCCCGTCATAAACGCTGCTTAAAGAGTAGTCA 103 AATTCACACTATCCGTATGGGAATCCTTTTCCGTCATAAACGCTGCTTAAAGAGTAGTCA 120 AATTCACACTATCCGTATGGGAATCCTTTTCCGTCATAAACGCTGCTTAAAGAGTAGTCA 120 AATTAGCAATACAGGTG---------------CATTAAA--TATTTAAAGAGTAGTCA 71 AATTCCCACTATCCGTATGAGAATCCTTTTCCGTCATAAACGCTGCTTAAAGAGTGGTCA 93

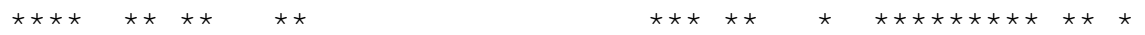

ACGTCAGTACTACACTCAAAATCTAAAACAGAATCCAACAGAAGACACCAACGGCGAAAA 180 ACGTCAGTACTTCACTCAAAATCTAAAACAGAATCCAACAGAAGAAACCAACGGCGAAAA 180 ACGTCAGTACTACACTCAAAATCTAAAACAGAATCCAACAGAAGACACCAACGGCGAAAA 163 ACGTCAGTACTNCACTCAAAATCTAAAACAGAATCCAACAGAAGAAACCAACGGCGAAAA 180 ACGTCAGTACTNCACTCAAAATCTAAAACAGAATCCAACAGAAGAAACCAACGGCGAAAA 180 ACGTCAGCACTTCAATCAAAATCTAAAACAGAATCCAACAGAAGAAACCAACGGCGAAAA 131 ACGTCAGTACTTCACTCAAACTCTAAAACAGAATCCAACAGAAGAAACCAACGGCGAAAA 153

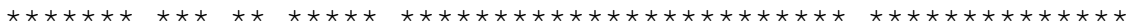

TCCGTTACCTGTGAC 195

TCCGTTACCTGTGAC 195

TCCGTTACCTGTGAC 178

TCCGTTACCTGTGAC 195

TCCGTTACCTGTGAC 195

TCCGTTACCTGTGAC 146 TCCGTTACCTGTGAC 168

$\star \star \star \star * \star * \star * \star * \star * \star * \star * \star$

CTCTTTCTGCTTCCTGACATCTAAATTATATGAATAGGCTTTTGTTG----------TCA 50 CTCTTTCTGCTTCCTGACATCTAAATTATATGAATAGGCTTTTGTTG---_------TCA 50 CTCTTTCTGCTTCCTGACATCTAAATTATATGAATAGGCTTTTGTTG----------TCA 50 CTCTTTCTGCTTCCTGACATCTAAATTATATGAATAGGCTTTTGTTG---------TCA 50 CTCTTTCTGCTTCCTGACATCTAAATTATATGAATAGGCTTTTGTTGTCAATTGTTGTCA 60 CTCTTTCTGCTTCCTGACATCTAAATTATATGAATAGGCTTTTGTTGTCAATTGTTGTCA 60 $* * * * * * * * * * * * * * * * * * * * * * * * * * * * * * * * * * * * * * * * * * * * * * *$ *

AATGGACTGAAATAATTAGGATGCAACAGAAATTAACTGCATGTTGCACCACCATTTAAG 110 AATGGACTGAAATAATTAGGATGCAACAGAAATTAACTGCATATTGCACCACCATTTAAG 110 AATGGACTGAAATAATTAGGATACAACAGAAATTAACTGCATATTGCACCACCATTTAAG 110 AATGGACTGAAATAATTAGGATACAACAGAAATTAACTGCATATTGCACCACCATTTAAG 110 AATGGACTGAAATAATTAGGATACAACAGAAATTAACTGCATATTGCACCACCATTTAAG 120 AATGGACTGAAATAATTAGGATACAACAGAAATTAACTGCATATTGCACCACCATTTAAG 120

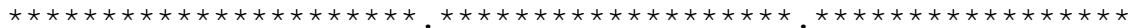

AACAGTTTGTTACAATGTGAACAAGTCCACTGGAAAAATCCATTAACAAATATTTGAATT 170 AACAGTTTGTTACAATGTGAACAAGTCCACTGGAAAAATCCATTAACAAATATTTGAATT 170 AACAGTTTGTTACAATGTGAACAAGTCCACTGGAAAAATCCATTAACAAATATTTGAATT 170 AACAGNTTGTTACAATGTGAACAAGTCCACTGGAAAAATCCATTAACAAATATTTGAATT 170 AACAGTTTGTTACAATGTGAACAAGTCCACTGGAAAAATCCCTTGACAAAAATTTGAATT 180 AACAGTTTGTTACAATGTGAACAAGTCCACTGGAAAAATCCCTTGACAAAAATTTGAATT 180

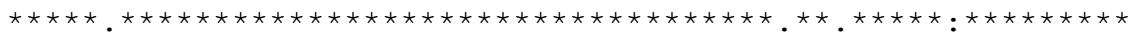


385I-EMA 154 I-EMA 207I-EMA 275I-EMA 567 I-EMA 202I-EMA

385I-EMA 154 I-EMA 207I-EMA 275I-EMA 567I-EMA 202I-EMA

AGCCGTGAACGTAAGTGTTCTCTTGGCAAACGTGTAAAATCNTTAGAGCTTGTTTACTTG 230 AGCCGTGAACGTAAGTGTTCTCTTGGCAAACGTGTAAAATCATTAGAGCTTGTTTACTTG 230 AGCCGTGAACGTAAGTGTTCTCTTGGAAAACGTGTAAAATCGTTAGAGCTTGTTTACTTG 230 AGCCGTGAACGTAAGTGTTCTCTTGGAAAACGTGTAAAATCGTTAGAGCTTGTTTACTTG 230 AGCCGTGAACGTAAGTGTTCTCTTGGAAAACGTGTAAAATCGTTAGAGCTTGTTTACTTG 240 AGCCGTGAACGTAAGTGTTCTCTTGGAAAACATGTAAAATCGTTAGAGCTTGTTTACTTG 240

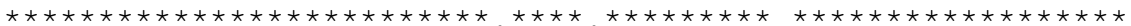

GTGATTGATAAACTAGTTGTGTTTTATTCACCGGC 265 GTGATTGATAAACTAGTTGTGTTTTATTCACCGGC 265 GCGATTGATAAACTAGTTGTGTTTTATTCACCGAC 265 GCGATTGATAAACTAGTTGTGTTTTATTCACCGAC 265 GCGATTGATAAACTAGTTGTGTTTTATTCACCGAC 275 GCGATTGATAAACTAGTTGTGTTTTATTCACCGAC 275

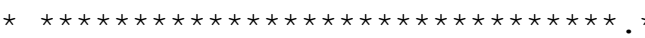

$385 I-T R P A$ $154 I-T R P A$ 207I-TRPA $275 I-T R P A$ $567 I-T R P A$ 202I-TRPA

$385 I-T R P A$ $154 I-T R P A$ 207I-TRPA $275 I-T R P A$ $567 I-T R P A$ 202I-TRPA

$385 I-T R P A$ $154 I-T R P A$ $207 I-T R P A$ 275I-TRPA $567 I-T R P A$ 202I-TRPA

385I-TRPA $154 I-T R P A$ 207I-TRPA 275I-TRPA $567 I-T R P A$ 202I-TRPA

385I-TRPA $154 I-T R P A$ 207I-TRPA 275I-TRPA $567 I-T R P A$ 202I-TRPA

385I-TRPA 154 I-TRPA 207I-TRPA 275I-TRPA $567 I-T R P A$ 202I-TRPA
CCCTCGTTCTTGGTAGCTTTATTCTTGCTCTCGCCGTTGAGCACTACAACATTCACAGAA 60 CCCTCGTTCTTGGTAGCTTTATTCTTGCTCTCGCCGTTGAGCACTACAACATTCACAGAA 60 CCCTCGTTCTTGGTAGCTTTATTCTTGCTCTTGCCGTTGAGCACTACAACATTCACAAAA 60 CCCTCGTTCTTGGTAGCTTTATTCTTGCCCTTGCCGTTGAGCACTACAACATTCACAAAA 60 CCCTCGTTCTTGGTAGCTTTATTCTTGCTCTTGCCGTTGAGCACTACAACATTCACAAAA 60 CCCTCGTTCTTGGTAGCTTTATTCTTGCTCTTGCCGTTGAGCACTACAACATTCACAAAA 60

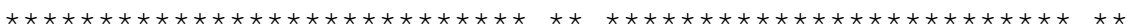

GATTGGCCTTAAATGTAAGTTCCCATAATGCATCATCATCATCATGTCATTAATCGTTAC 120 GATTGGCCTTAAATGTAAGTTCCCATAATGCATCATCATCATCATGTCATTAATCGTTAC 120 GATTGGCCTTAAATGTAAGTTCCCGTAATGCATCATCATCATCATGTCATTAATTGTTAC 120 GATTGGCCTTAAATGTAAGTTCCCGTAATGCATCATCATCATCATGTCATTAATTGTTAC 120 GATTGGCCTTAAATGTAAGTTCCCGTAATGCATCATCATCATCATGTCATTAATTGTTAC 120 GATTGGCCTTAAATGTAAGTTCCCGTAATGCATCATCATCATCATGTCATTAATTGTTAC 120

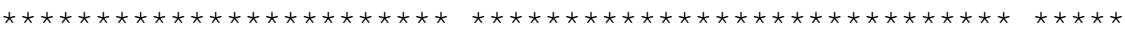

GATTTCTTTTTCAGAAAAATTATCAGTGACAAAAGATGAATTAATTATGTATGGACAATC 180 GATTTCTTTTTCAGAAAAATTATCAGTGACAAAAGATGAATTAATTATGTATGGACAATC 180 GATTTCTTTTTCAGAAAAATTATCAGTGACAAAAGATGAATTAATTATGTATGGACAATC 180 GATTTCTTTTTCAGAAAAATTATCAGTGACAAAAGATGAATTAATTATGTATGGACAATC 180 GATTTCTTTTTCAGAAAAATTATCAGTGACAAAAGATGAATTAATTATGTATGGACAATC 180 GATTTCTTTTTCAGAAAAATTATCAGTGACAAAAGATGAATTAATTATGTATGGACAATC 180

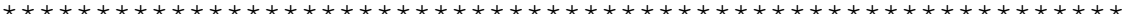

CTATACCATATAATATATATTAATAACTACAGATAACTATTCTATTCTGTGGAGAGCCAA 240 CTATACCATATAATATATATTAATAACTACAGATAACTATTCTATTCTGTGGAGAGCCAA 240 CNATACCATATAATATATATTAATAACTACCGATAACTATTCTATTCTGTGGANAGCCAA 240 CTATACCATATA---NANNNTANTAACNACTNATNACTANTNTANTCTGCGGAGANCNNA 237 CTATACCATATAATTTATATTAATAACTACAGATAACTATTCTATTCTGTGGAGAGCCAA 240 CTATACCATATAATTTATATTAATAACTACAGATAACTATTCTATTCTGTGGAGAGCCAA 240

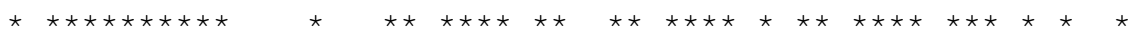

TGAATCCGCCCTTGCTGCTTCTTGGGATATGTGGCACGACAGCATTCGTGAGCATGTGGA 300 TGAATCCGCCCTTGCTGCTTCTTGGGATATGTGGCACGACAGCATTCGTGAGCATGTGGA 300 TGAATCCGCCCTTGCTGCTTCTTGGGATATGTGGCACGACAGCATTCCTGAACATGTGGA 300 NGAAGNNNCCCNNGCTGCTNCTTGGGNNAAGAGGNGNGACNACATNCTTNATNATGNGGA 297 TGAATCCGCCCTTGCTGCTTCTTGGGATATGTGGCACGACAGCATTCGTGAGCATGTGGA 300 TGAATCCGCCCTTGCTGCTTCTTGGGATATGTGGCACGACAGCATTCGTGAGCATGTGGA 300

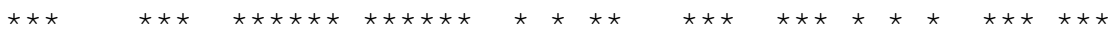

TGCATAA 307

TGCATAA 307

TGCATAA 307

NGNTNNA 304

TGCATAA 307

TGCATAA 307 
$385 \mathrm{I}-\mathrm{PEPC} 1$ $154 \mathrm{I}-\mathrm{PEPC} 1$ 207 I-PEPC1 275I-PEPC1 $567 \mathrm{I}-\mathrm{PEPC} 1$ $202 I-P E P C 1$

385I-PEPC1 154 I-PEPC 1 $207 I-P E P C 1$ 275I-PEPC1 $567 I-P E P C 1$ 202I-PEPC1

385I-PEPC1 154 I-PEPC1 207I-PEPCI 275I-PEPC1 $567 \mathrm{I}-\mathrm{PEPC} 1$ 202I-PEPC1

$385 I-P E P C 1$ $154 \mathrm{I}-\mathrm{PEPC} 1$ 207 I-PEPC1 275I-PEPC1 $567 \mathrm{I}-\mathrm{PEPC} 1$ 202I-PEPC1

385I-PEPC1 $154 \mathrm{I}-\mathrm{PEPC} 1$ 207I-PEPC1 275I-PEPC1 567 I-PEPCI 202I-PEPC1

385I-PEPC2 $154 I-P E P C 2$ $207 I-P E P C 2$ 275I-PEPC2 $567 I-P E P C 2$ 202I-PEPC2

385I-PEPC2 $154 \mathrm{I}-\mathrm{PEPC} 2$ 207I-PEPC2 275I-PEPC2 $567 \mathrm{I}-\mathrm{PEPC} 2$ 202I-PEPC2

385I-PEPC2 $154 \mathrm{I}-\mathrm{PEPC} 2$ $207 I-P E P C 2$ 275I-PEPC2 $567 I-P E P C 2$ 202I-PEPC2
TTTTGAACAATCGGCTAATGGTAGATATTGTACCAACTTTTTATATGTAATATGAAATTT 60 TTTTGAACAATCGGCTAATGGTAGATATTGTACCAACTTTTTATATGTAATATGAAATTT 60 TTTTGAACAATCGGCTAATGGTAGATATTGTACCAACTTTTTATATGTAATATGAAATTT 60 TTTTGAACAATCGGCTAATGGTAGATATTGTACCAACTTTTTATATGTAATATGAAATTT 60 TTTTGAACAATCGGCTAATGGTAGACATTGTACCAACTTTTTATATGTAATATGAAATTT 60 TTTTGAACAATCGGCTAATGGTAGACATTGTACCAACTTTTTATATGTAATATGAAATTT 60

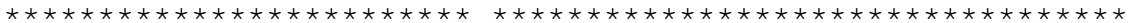

TGGTTATTTAT-----------------------GTAGCCTTATTTATTGGAAAGT 93 TGGTTATTTAT-_-_-_-_-_-_-_-_-_-_-_-_GTAGCCTTATTTATTGGAAAGT 93 TGGTTATTTATATGTAATATGAAATTTTGGTTATTTTTGTAGTCTTATTTATTGGAAAGT 120 TGGTTATTTATATGTAATATGAAATTTTGGTTATTTTTGTAGTCTTATTTATTGGAAAGT 120 TGGTTATTTAT------------------------GTAGCCTTATTTATTGGAAAGT 93

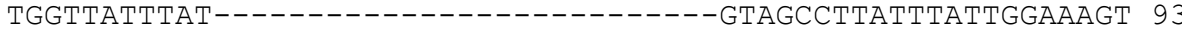

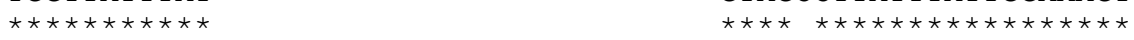

GCATTTAAGAACTGAGAAGGCATAGAATATTCCATTAGGTTTGAAGAAATTCATTGCTCT 153 GCATTTAAGAACTGAGAAGGCATAGAATATTCCATTAGGTTTGAAGAAATTCATTGCTCT 153 GCATTTAAGAACTGAGAAGGCATAGAATATTCCACTAGGTTTGAAGAAATTCATTGCTCT 180 GCATTTAAGAACTGAGAAGGCATAGAATATTCCACTAGGTTTGAAGAAATTCATTGCTCT 180 GCATTTAAGAACTGAGAAGGCATAGAATATTCCACTAGGTTTGAAGGAATTCATTGCTCT 153 GCATTTAAGAACTGAGAAGGCATAGAATATTCCACTAGGTTTGAAGGAATTCATTGCTCT 153

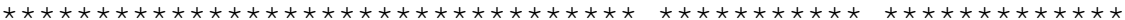

TTAAGTCAGCTTTAAGTGAATATCCTTGTTATAAACTTTAGTGAGAGTGAATGCATTGGA 213 TTAAGTCAGCTTTAAGTGAATATCCTTGTTATAAACTTTAGTGAGAGTGAATGCATTGGA 213 TTAAGTCAGCTTTAAGTGAATATCCTTGTTATAAACTTTAGTGAGAGTGAATGCATTGGA 240 TTAAGTCAGCTTTAAGTGAATATCCTTGTTATAAACTTTAGTGAGAGTGAATGCATTGGA 240 TTAAGTCAGCTTTAAGTGAATATCCTTGTTATAAACTTTAGTGAGAGTGAATGCATTGGA 213 TTAAGTCAGCTTTAAGTGAATATCCTTGTTATAAACTTTAGTGAGAGTGAATGCATTGGA 213

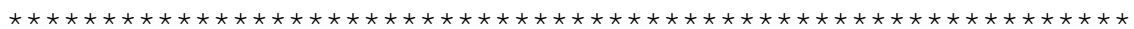

GTCTCTCTTCCAGCAA 229 GTCTCTCTTCCAGCAA 229 GTCTCTCTTCCAGCAA 256 GTCTCTCTTCCAGCAA 256 GTCTCTCTTCCAGCAA 229 GTCTCTCTTCCAGCAA 229

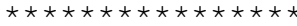

TTGGAGTCTCTCTTCCAGCAATTTGCTATTTTATATGAAGTTCTCTTTCCCACAACAGAC 60 TTGGAGTCTCTCTTCCAGCAATTTGCTATTTTATATGAAGTTCTCTTTCCCACAACAGAC 60 TTGGAGTCTCTCTTCCAGCAATTTGCTATTTTATATGAAGTTCTCTTTCCCATAACAGAC 60 TTGGAGTCTCTCTTCCAGCAATTTGCTATTTTATATGAAGTTCTCTTTCCCATAACAGAC 60 TTGGAGTCTCTCTTCCAGCAATTTGCTATTTTATATGAAGTTCTCTTTCCCATAACAGAC 60 TTGGAGTCTCTCTTCCAGCAATTTGCTATTTTATATGAAGTTCTCTTTCCCATAACAGAC 60

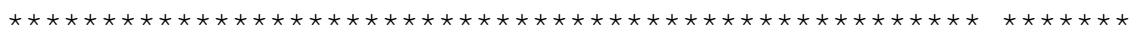

TAGCTGAGCTTCAATTTTATTTTCTTTTCTGAATGAGTTTTGAAAATATTCGATAGGAC 120 TAGCTGAGCTTCAATTTTGATTTTCTTTTCTGAATGAGTTTTGAAAATATTCGATAGGAC 120 TAGCTAAGCTTCAATTTTGATTTTCTTTTCTGAATGAATTTTGAAAATATTCGATAGGAC 120 TAGCTAAGCTTCAATTTTGATTTCTTTTCTGAATGAATTTTGAAAATATTCGATAGGAC 120 TAGCTAAGCTTCAATTTTGA-_-_-_-_-_-_-_-_-_-_-AAATATTCGATAGGAC 96

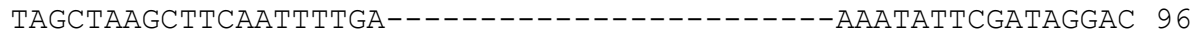

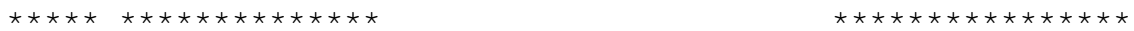

AATACTGAAATTTTTGCATTGTGGCTCTCAC 151 AATACTGAAATTTTTGCATTGNGGCTCTCAC 151 AATACTGAAATTTTTGCATTGTGGCTCTCAC 151 AATACTGAAATTTTTGCATTGTGGCTCTCAC 151 AATACTGAAATTTTGCATTGTGGCTCTCAC 127 AATACTGAAATTTTTGCATTGTGGCTCTCAC 127

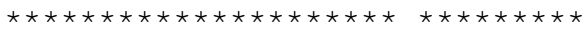


Chapter 1: Online resources

$385 I-L C Y 2$ 154 I-LCY2 $239 I-L C Y 2$ 207I-LCY2 $275 I-L C Y 2$ $567 I-L C Y 2$ 202I-LCY2

$385 I-L C Y 2$ 154 I-LCY2 $239 I-L C Y 2$ 207I-LCY2 $275 I-L C Y 2$ $567 I-L C Y 2$ 202I-LCY2

$385 I-L C Y 2$ $154 I-L C Y 2$ $239 I-L C Y 2$ 207I-LCY2 $275 I-L C Y 2$ $567 I-L C Y 2$ $202 I-L C Y 2$

$385 I-L C Y 2$ $154 \mathrm{I}-\mathrm{LCY} 2$ $239 I-L C Y 2$ 207 I-LCY2 $275 I-L C Y 2$ 567 I-LCY2 $202 I-L C Y 2$
CGCAAATAATTGATTCAACATCATCACATTCATTTTCGCTATTTCCATTAGGCCGCCAAA 60 CGCAAATAATTGATTCAACATCATCACCTTCATTTTCCCTATTTCCATTAGGCCGCCAAA 60 CGCAAATCATTGATTCAACATCGTCCCATTCATTTTCCCTATTTCCATTAGGCCGCCAAA 60 CGCAAATAATTGATTCAACATCATCACCTTCATTTTCCCTATTTCCATTAGGCCGCCAAA 60 CGCAAATAATTGATTCAACATCATCACCTTCATTTTCCCTATTTCCATTAGGCCGCCAAA 60 CGCAAATAATTGATTCAACATCATCACATTCATTTTCGCTATTTCCATTAGGCCGCCAAA 60 CGCAAATAATTGATTCAACATCATCACATTCATTTTCGCTATTTCCATTAGGCCGCCAAA 60

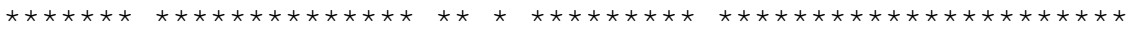

ATGCATGTTCAAGAAAGGCGGATCATCATCATCAT---CACAGGATCCGGACAAGCAAGT 117 ATGCATGTTCAAGAAAGGCGGATCATCATCATCAT---CACAGGATCCGGACAAGCAAGT 117 ATGCGTGTTCAAGAAAGGCGGGTCGTCATCATCGC------AGGATCCGGACAAGCAAGT 114 ATGCATGTTCGAGAAAGGCGGATCATCATCATCAT---CACAGGATCCGGACAAGCAAGT 117 ATGCATGTTCNAGAAAGGCGGATCATCATCATCAT---CACAGGATCCGGACAAGCAAGT 117 ATGCATGTTCAAGAAAGGCGGATCATCATCATCATCATCACAGGATCCGGACAAGCAAGT 120 ATGCATGTTCAAGAAAGGCGGATCATCATCATCATCATCACAGGATCCGGACAAGCAAGT 120

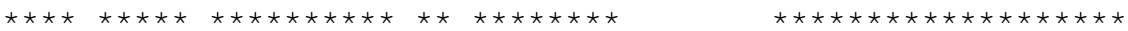

TTGGTAACTTCCTAGAGTTGACACCGGAGTCGGAACCTGAATTCTTAGTCTTTGATCTCC 177 TTGGTAACTTCCTAGAGTTGACACCGGAGTCGGAACCTGAATTCTTAGNCTTTGATCTCC 177 TTGGTAACTTCCTAGAGTTGACACCGGAGTCGGAACCTGAATTGTTAGACTTTGATCTCC 174 TTGGTAACTTCCTAGAGTTGACACCGGAGTCGGTACCTGAATTCTTAGACTTTGATCTCC 177 TTGGTAACTTCCTAGAGTTGACACCGGAGTCGGTACCTGAATTCTTAGACTTTGATCTCC 177 TTGGTAACTTCCTAGAGTTGACACCGGAGTCGGAACCTGAATTCTTAGACTTTGATCTCC 180 TTGGTAACTTCCTAGAGTTGACACCGGAGTCGGAACCTGAATTCTTAGACTTTGATCTCC 180

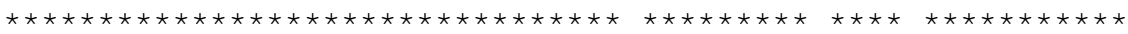

CCTGGTTTCATCCGTCCGATCGTATTCGATATGACGTGATCATC 221 CCTGGTTTCATCCGTCCGATCGTATTCGATATGACGTGATCATC 221 CCTGGTTTCATCCATCCGATCGTATTCGATATGACGTGATCATC 218 CCTGGTTTCATCCGTCCGATCGTATTCGATATGACGTGATCATC 221 CCTGGTTTCATCCGTCCGATCGTATTCGATATGACGTGATCATC 221 CCTGGTTTCATCCGTCCGATCGTATTCGATATGACGTGATCATC 224 CCTGGTTTCATCCGTCCGATCGTATTCGATATGACGTGATCATC 224

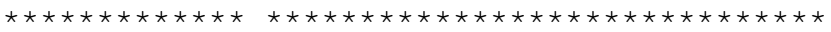

$385 I-H Y B 1$ 154 I-HYBI 207I-HYB I 275I-HYB I 567 I-HYB 1 202I-HYBI

385I-HYB I $154 \mathrm{I}-\mathrm{HYB} 1$ $207 I-H Y B I$ 275I-HYB 1 $567 \mathrm{I}-\mathrm{HYB} 1$ 202I-HYB

385I-HYB 1 $154 \mathrm{I}-\mathrm{HYB} 1$ 207I-HYB 1 275I-HYB 1 567 I-HYB 1 202I-HYB1

385I-HYB 1 $154 \mathrm{I}-\mathrm{HYB} 1$ 207 I-HYB 1 275I-HYB 1 567 I-HYB 1 202I-HYB I
AAAAACAAAGCACCCAGATCGAGACTTTCACGGACGAGGAGGAGGAGGAG---GNGGANN 57 AAAAACAAAGCACCCAGATCGAGACTTTCACGGAGGAGGAGGAGGAGGAG---TCGGGTA 57 AAAAACAAAGCACCCAGATCGAGACTTTCACGGAGGAGGAGGAGGAGGAG---TCGGGTA 57 AAAAACAAAGCACCCAGATCGAGACTTTCACGGAGGAGGAGGAGGAGGAG---TCGGGTA 57 AAAAACAAAGCACCCAGATCGAGACTTTCACGGAGGAGGAGGAGGAGGAGGAGTCGCGTA 60 AAAAACAAAGCACCCAGATCGAGACTTTCACGGAGGAGGAGGAGGAGGAGGAGTCGCGTA 60

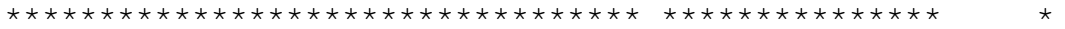

NCCCGNNCNCCNCTGNNGCCCCCGNGGCCCACANGNTGGAGAGANNGACAANCAAGAGGT 117 CCCAGATCTCGACTGCTGCCCGCGTGGCCGAGAAATTGGCGAGAAAGAGATCCGAGAGGT 117 CCCAGATCTCGACTGCTGCCCGCGTGGCCGAGAAATTGGCGAGAAAGAGATCCGAGAGGT 117 CCCAGATCTCGACTGCTGCCCGCGTGGCCGAGAAATTGGCGAGAAAGAGATCCGAGAGGT 117 CCCAGATCTCGACTGCTGCCCGCGTGGCCGAGAAATTGGCGAGAAAGAGATCCGAGAGGT 120 CCCAGATCTCGACTGCTGCCCGCGTGGCCGAGAAATTGGCGAGAAAGAGATCCGAGAGGT 120

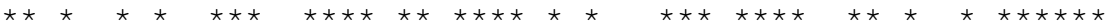

NCAATNNNCTCNCTNCTNCCGTCGNGNCCAGNTTGGNTATCNCTNNCATGGCTGCCATGG 177 TCACTTATCTCGTTGCTGCCGTCATGTCTAGTTTTGGTATCACTTCCATGGCTGTCATGG 177 TCACTTATCTCGTTGCTGCCGTCATGTCTAGTTTTGGTATCACTTCCATGGCTGTCATGG 177 TCACTTATCTCGTTGCTGCCGTCATGTCTAGTTTTGGTATCACTTCCATGGCTGTCATGG 177 TCACTTATCTCGTTGCTGCCGTCATGTCTAGTTTTGGTATCACTTCCATGGCTGTCATGG 180 TCACTTATCTCGTTGCTGCCGTCATGTCTAGTTTTGGTATCACTTCCATGGCTGTCATGG 180

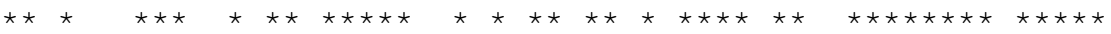

CTGTNNNGNNCGTGTNCTGGTGGN 201 CTGTTTATTACAGGTTCTGGTGGC 201 CTGTTTATTACAGGTTCTGGTGGC 201 CTGTTTATTACAGGTTCTGGTGGC 201 CTGTTTATTACAGGTTCTGGTGGC 204 CTGTTTATTACAGGTTCTGGTGGC 204

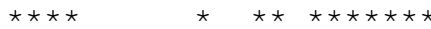


385I-HYB2 $154 I-H Y B 2$ $207 I-H Y B 2$ 275I-HYB2 $567 \mathrm{I}-\mathrm{HYB} 2$ 202I-HYB2

385I-HYB2 $154 \mathrm{I}-\mathrm{HYB} 2$ 207I-HYB2 275I-HYB2 567 I-HYB2 $202 I-H Y B 2$

385I-HYB2 $154 \mathrm{I}-\mathrm{HYB} 2$ 207I-HYB2 275I-HYB2 $567 \mathrm{I}-\mathrm{HYB} 2$ 202I-HYB2

385I-HYB2 154 I-HYB2 207I-HYB2 275I-HYB2 $567 I-H Y B 2$ 202I-HYB2

385I-HYB2 $154 I-H Y B 2$ 207I-HYB2 275I-HYB2 $567 I-H Y B 2$ 202I-HYB2

$385 \mathrm{I}-\mathrm{HYB} 2$ 154 I-HYB2 $207 \mathrm{I}-\mathrm{HYB} 2$ 275I-HYB2 $567 I-H Y B 2$ 202I-HYB2

385I-PSY $154 I-P S Y$ 207I-PSY 275I-PSY $567 I-P S Y$ 202I-PSY

385I-PSY $154 I-P S Y$ 207I-PSY 275I-PSY $567 I-P S Y$ 202I-PSY
TTTGGCACATTTGCTCTCTCTGTTGGCGCTGCCGTAAGTTCAATCACCTTCTTCCTTACA 60 TTTGGCACATTTGCTCTCTCTGTTGGTGCTGCTGTAAGTTCAATCACCTTCTTCCTTACA 60 TTTGGCACATTTGCTCTCTCTGTTGGTGCTGCTGTAAGTTCAATCACCTTCTTCCTTACA 60 TTTGGCACATTTGCTCTCTCTGTTGGTGCTGCTGTAAGTTCAATCACCTTCTTCCTTACA 60 TTTGGCACATTTGCTCTCTCTGTTGGCGCTGCCGTAAGTTCAATCACCTTCTTCCTTACA 60 TTTGGCACATTTGCTCTCTCTGTTGGCGCTGCCGTAAGTTCAATCACCTTCTTCCTTACA 60

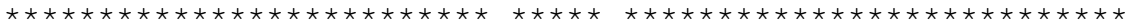

ATGATTTGAAAACAAGACTAGAATTTTGGTTCTAATAGGAGCCGCGGTGGGGATGTTACA 120 ATGATTTGAAAACAAGACTAGAATTTTGGTTCTAATAGGAGCCGCGGTGGGGATGTTACA 120 ATGATTTGAAAACAAGACTAGAATTTTGGTTCTAATAGGAGCCGCNGTGGGGATGTTACA 120 ATGATTTGAAAACAAGACTAGAATTTTGGTTCTAATAGGAGCCGCNGTGGGGATGTTACA 120 ATGATTTGAAAACAAGACTAGAATTTTGGTTCTAATAGGAGCCGCGGTGGGGATGTTACA 120 ATGATTTGAAAACAAGACTAGAATTTTGGTTCTAATAGGAGCCGCGGTGGGGATGTTACA 120

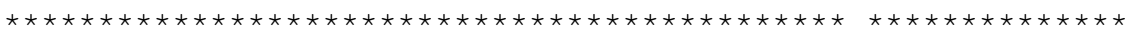

AACTTGATCGATCTTTAACATAAAAACTGTAAAAATGAGGGGCTTGTTTGAATTTTCAAT 180 AACTTGATCGATCTTTAACATAAAAACTGTAAAAATGAGGGGCTTGTGTGAATTTTCAAT 180 AACTTGATCGATCTTTAACATAAAAACTGTAAAAATGAGGGGCTTGTGTGAATTTTCAAT 180 AACTTGATCGATCTTTAACATAAAAACTGTAAAAATGAGGGGCTTGTGTGAATTTTCAAT 180 AACTTGATCGATCTTTAACATAAAAACTGTAAAAATGAGGGGCTTGTTTGAATTTTCAAT 180 AACTTGATCGATCTTTAACATAAAAACTGTAAAAATGAGGGGCTTGTTTGAATTTTCAAT 180

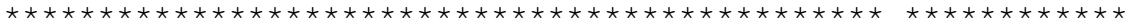

GTGAAAGCCTTTTCTGGCAAATTATATGATGATGATTCGCATTGGGTCCCTTTTTTTTTC 240 GTGAAGGCCTTTTCTGGCAAATTATATGATGATGATTCGCATTGGGTACCTTTTTTTTTC 240 GTGAAGGCCTTTTATG-CAAATTATGTGTTGATGATTAGCATTGGGTACCTTTTTTTT-C 238 GTGAAGGCCTTTTATG-CAAATTNTGTGTTGATGATTAGCATTGGGTACCTTTTTTTT-C 238 GTGAAAGCCTTTTCTGGCAAATTATATGATGATGATTCGCATTGGGTCCCTTTTTTTTTC 240 GTGAAAGCCTTTTCTGGCAAATTATATGATGATGATTCGCATTGGGTCCCTTTTTTTTTC 240

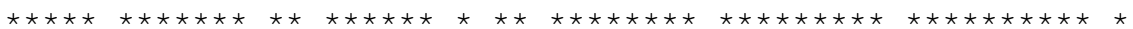

ATTTGCAGGTGGGCATGGAGTTTTGGGCACGATGGGCTCATAAAGCTCTGTGGCATGCTT 300 ATTTGCAGGTGGGCATGGAGTTTTGGGCACGATGGGCTCATAAAGCTCTGTGGCATGCTT 300 ATTTGCAGGTGGGCATGGAGTTTTGGGCACGATGGGCTCATAA-GCTCTGTGGCATGCTT 297 ATTTGCAGGTGGGCATGGAGTTTTGGGCACGATGGGCTCATAA-GCTCTGTGGCATGCTT 297 ATTTGCAGGTGGGCATGGAGTTTTGGGCACGATGGGCTCATAAAGCTCTGTGGCATGCTT 300 ATTTGCAGGTGGGCATGGANTTTTGGGCACGATGGGCTCATAAAGCTCTGTGGCATGCTT 300

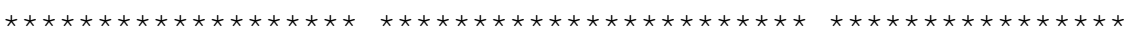

CTTT 304

CTTT 304

СTTT 301

CTTT 301

CTTT 304

CTTT 304

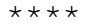

CCTGTCGACATTCAGGTTAGACTATGTTTTCAAGATCAAATTATATTTTAACAAAATGGT 60 CCTGTCGACATTCAGGTTAGACTATGTTTTCAAGATCAAATTAGATTTTAACAAAATGGT 60 CCTGTCGACATTCAGGTTAGACTATGTGTTCAAGATCAANTTAGATTTTAACAAAATGGT 60 CCTGTCGACATTCAGGTTAGACTATGTTTTCAAGATCAAATTAGATTTTAACAAAATGGT 60 CCTGTCGACATTCAGGTTAGACTATGTTTTCAAGATCAAATTAGATTTTAACAAAATGGT 60 CCTGTCGACATTCAGGTTAGACTATGTTTTCAAGATCAAATTAGATTTTAACAAAATGGC 60

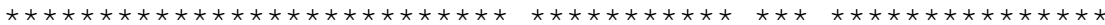

TGTTATAGTACTCTCTCTACTCTCTTAAGTGTACTTGTATTAAATTAAAATAAGGAACAA 120 TGTTATAGTACTCTCTCTACTCTCTTAAGTGTACTTGTATTAAATTAAAATAAGGAACAA 120 TGTTATAGTACTCTCTCTACTATCTTAAGTGTACTTGTATTAAATTAAAATAAGGAACAA 120 TGTTATAGTACTCTCTCTACTATCTTAAGTGTACTTGTATTAAATTAAAATAAGGAACAA 120 TGTTATAGTACTCTCTCTACTATCTTAAGTGTACTTGTATTAAATTACAATAAGGAACAA 120 TGTTATAGTACTCTCTCTACTATCTTAAGTATACTTGTATTAAATTAAAATAAGGAACAA 120

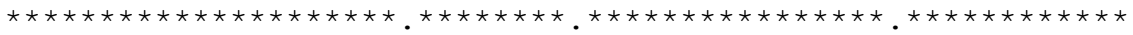


Chapter 1: Online resources

$385 I-P S Y$ $154 I-P S Y$ 207I-PSY 275I-PSY $567 I-P S Y$ 202I-PSY

385I-PSY $154 I-P S Y$ 207I-PSY 275I-PSY $567 I-P S Y$ 202I-PSY

$385 I-P S Y$

$154 \mathrm{I}-\mathrm{PSY}$

207I-PSY

275I-PSY

$567 I-P S Y$

202I-PSY

385I-IDCAX 154 I-IDCAX 207I-IDCAX 275I-IDCAX 567 I-IDCAX 202I-IDCAX

385I-IDCAX 154 I-IDCAX 207I-IDCAX 275I-IDCAX 567 I-IDCAX 202I-IDCAX

385I-IDCAX 154 I-IDCAX 207I-IDCAX 275I-IDCAX 567 I-IDCAX 202I-IDCAX

385I-IDCAX 154 I-IDCAX 207I-IDCAX 275I-IDCAX 567 I-IDCAX 202I-IDCAX
CTTCTGCTTTCTAATTGGTTTTTAAAACATTAAGCCTTGATGCATAATGACAGACCTTAT 180 СTTCTGCTTTCTAATTGGTTTTTAAAACATTAANCCTTGATGCATAATGACAGACCTTAT 180 CTTCTGCTTTCTAATTGGTTTTTAAAACATTAAGCCTTGATGCATAATGACAGACCTTAT 180 CTTCTGCTTTCTAATTGGTTTTTAAAACATTAAGCCTTGATGCATAATGACAGACCTTAT 180 CT---GCTTTCTAATTGGTTTTTAAAACATTAAGCCTTGATGCATAATGATAGACCTTAT 177 CT---GCTTTCTAATTGGTTTTTAAAACATTAAGCCTTGATGCATAATGATAGACCTTAT 177

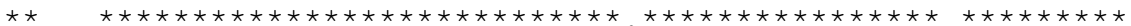

TTACATTTAATTGAGTCATACCATTTTTGCATTTTCAATTTATCCAGGAGACCGAAGATG 240 TTACATTTAATTGAGTCATGCCATTTTTGCATTTTCAATTTATCCNNGAGACCGAAGATG 240 TTACATTTAATTGAGTCATGCCATTTTTGCATTTTCAATTTATCCTAGAGACCGAAGATG 240 TTACATTTAATTGAGTCATGCCATTTTTGCATTTTCAATTTATCCTAGAGACCGAAGATG 240 TTACATTTAATTGAGTCATGCCATTTTTGCATTTTCAATTTATCCTAGAGACCGAAGATG 237 TTACATTTAATTGAGTCATGCCATTTTTGCATTTTCAATTTATCCTAGAGACCGAAGATG 237

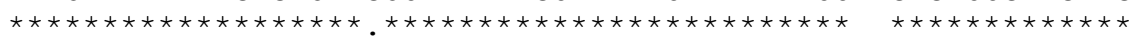

TGATGAG 247

TGATGAG 247

TGATGAG 247

TGATGAG 247

TGATGAG 244

TGATGAG 244

TAAGCTGCATTTAACCCTTTTTTTTGGTTGGGTCTTTTCCGCCATTCAGTTTGAAGTTC 60 TAAGCTGCATTTAACCCTTTTTTTTGGTTGGGTCTTTTCCGCCATTCAGTTTGAAGTTC 60 TAAGCTGCATTTAACCCTTTTTTTTGGTTGGGTCTTTTCCGCCATTCAGTTTGAAGTTC 60 TAAGCTGCATTTAACCCTTTTTTTTTGGTTGGGTCTTTTCCGCCATTCAGTTTGAAGTTC 60 TAAGCTGCATTTAACCCTTTTTTTTTGGTTGGGTCTTTTCCGCCATTCAGTTTGAAGTTC 60 TAAGCTGCATTTAACCCTTTTTTTTTGGTTGGGTCTTTTCCGCCATTCAGTTTGAAGTTC 60

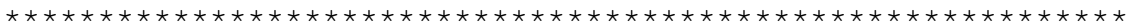

СTCTGTTTTACTCAGTGTCTAATTTAGCTTTATTTTATCTTTNNNNNNNNNNNNNNNNNN 120 CTCTGTTTTACTC--NNNNNNNNNNNNNNNNNNNNNNNNNNNNNNNNNNNNNNNNNNNNN 118 CTCTGTTTTACTCAGTGTCTAATTTAGCTTTATTTTATCTTTATCTTCTCANATATATGC 120 СTCTGTTTTACTCAGTGTCTAATTTAGCTTTATTTTATCTTTATCTTCTCANATATATGC 120 CTCTGTTTTACTCAGTGTCTAATTTAGCTTTATTTTATCTTTGTCTTCTCAGATATATGC 120 СTCTGTTTTACTCAGTGTCTAATTTAGCTTTATTTTATCTTTGTCTTCTCAGATATATGC 120

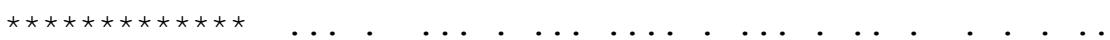

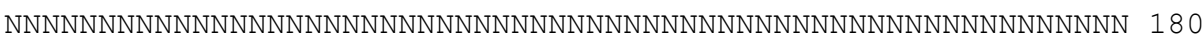

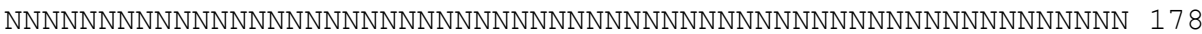
TGTTTCAATTACCATTCGTATTGTGGTAAGTGCACCAAATATATTCCAAAAATCTCC--- 177 TGTTTCAATTACCATTCGTATTGTGGTAAGTGCACCAAATATATTCCAAAAATCTCC--- 177 TGTTTCAATTACCATTCGTATTGTGGTAAGTGTACCAAATATATTCCAAAA-TCTCCGTA 179 TGTTTCAATTACCATTCGTATTGTGGTAAGTGTACCAAATATATTCCAAAA-TCTCCGTA 179 $\begin{array}{llllllll}\ldots & \ldots & \ldots & \ldots & \ldots & \ldots & \ldots & .\end{array}$

NNNNNNNNNNNNNNNNNNNNNNNNNNNNNNNNNNNNNNNNNNNNNNNNNNNNNNNNNN 238

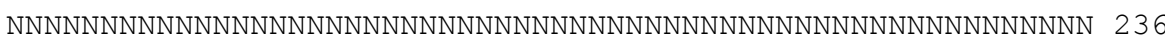
--ATTGATAATCGAAGCCTGCCAATCTCAATCATTAATATTGACTATCTCCCAATTGC 233 --ATTGATAATCGAAGCCTGCCAATCTCAATCATTAATATTGACTATCTCCCAATTGC 233 CTATTGATAATCGAAGCCTGCCAATCTCAATCATTAATATTGACTATCTCCCAATTGC 237 CTATTGATAATCGAAGCCTGCCAATCTCAATCATTAATATTGACTATCTCCCAATTGC 237

$$
\ldots \text {. }
$$

385 I-IDATGRC 154 I-IDATGRC 207I-IDATGRC 275I-IDATGRC 567 I-IDATGRC 202I-IDATGRC
GGCAATGAAAACAATGAGATAGAGATCTGCCTTGAGAGTGGTGAGTAGATCGTGGCCAAC 60 GGCAATGAAAACAATGAGATACAGATCTGCCTTGAGAGTGGTGAGTAGATCGTGGCCAAC 60 GGCAATGAAAACAATGAGATAGAGATCTGCCTTGAGAGTGGTGAGTAGATCGTGGCCAAC 60 GGCAATGAAAACAATGAGATAGAGATCTGCCTTGAGAGTGGTGAGTAGATCGTGGCCAAC 60 GGCAATGAAAACAATGAGATAGAGATCTGCCTTGAGAGTGGTGAGTAGATCGTGGCCAAC 60 GGCAATGAAAACAATGAGATAGAGATCTGCCTTGAGAGTGGTGAGTAGATCGTGGCCAAC 60

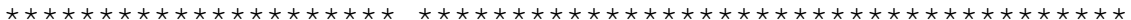


385I-IDATGRC 154I-IDATGRC 207I-IDATGRC 275I-IDATGRC 567 I-IDATGRC 202I-IDATGRC

385I-IDATGRC 154I-IDATGRC 207I-IDATGRC 275I-IDATGRC 567I-IDATGRC 202I-IDATGRC

385I-IDATGRC 154I-IDATGRC 207I-IDATGRC 275I-IDATGRC 567 I-IDATGRC 202I-IDATGRC

385I-IDAPV 154 I-IDAPV 207I-IDAVP 275I-IDAVP 567I-IDAVP 202I-IDAVP 560I-IDAVP

385I-IDAPV 154 I-IDAPV 207I-IDAVP 275I-IDAVP 567I-IDAVP 202I-IDAVP 560I-IDAVP

385I-IDAPV 154I-IDAPV 207I-IDAVP 275I-IDAVP 567I-IDAVP 202I-IDAVP 560I-IDAVP
AAAAAATTATATGGTCTAAGCTACAT-_-_-_-_-_-_-_-_GCATCTGGCCTGCCATA 103 AAAAAATTATATGGTCTAAGCTACAA----------------GCATCTGGCCTGCCATA 103 AAAAAATTATATGGTCTAAGCTACATGCATCTCTAAGCTACATGCATCTGGCCTGCCATA 120 AAAAAATTATATGGTCTAAGCTACATGCATCTCTAAGCTACATGCATCTGGCCTGCCATA 120 AAAAAATTATATGGTCTAAGCTACAT---------------GCATCTGGCCTGCCATA 103 AAAAAATTATATGGTCTAAGCTACAT----------------GCATCTGGCCTGCCATA 103

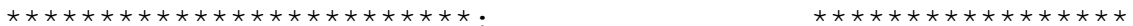

TCATTATCTAGTGCCTTATCTATGTTCATTCAATCGCATCCTGCCTGCGTTAATTGAGTC 163 TCATTATCTAGTGCCTTATCTATGTTCATTCAATCGCATCCTGCCTGCGTTAATTGAGTC 163 TCATTATCTAGTGCCTTATCTATGTTCATTCAATCGCATCCTGCCTGCGTTAATTGAGTC 180 TCATTATCTAGTGCCTTATCTATGTTCATTCAATCGCATCCTGCCTGCGTTAATTGAGTC 180 TCATTATCTAGTGCCTTATCTATGTTCATTCAATCGCATCCTGCCTGCGTTAATTGAGTC 163 TCATTATCTAGTGCCTTATCTATGTTCATTCAATCGCATCCTGCCTGCGTTAATTGAGTC 163

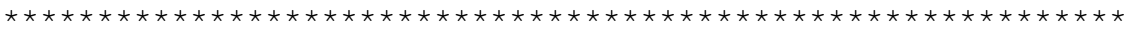

CCATTTCATCGGCCATTAATGAGGAgGACCAACAATCTTGAAA 206 CCATTTCATCGGCCATTAATGAGGAGGACCAACAATCTTGAAA 206 CCATTTCATCGGCCATTAATGAGGAGGACCAACAATCTTGAAA 223 CCATTTCATCGGCCATTAATGAGGAGGACCAACAATCTTGAAA 223 CCATTTCATCGGCCATTAATGAGGAGGACCAACAATCTTGAAA 206 CCATTTCATCGGCCATTAATGAGGAGGACCAACAATCTTGAAA 206

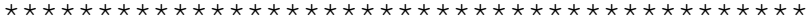

CAGCTATTGGAAAGTTTGTAAAATTGTTTACACTTAAATTCGAACTTGTATCTGTTGAT 60 CAGCTATTGGAAAGGTTTGTAAAATTGTTTACACTTAAATTCGAACTTGTATCTGTTGAT 60 CAGCTATTGGAAAGGTTTGTAAAATTGTTTACACTTAAATTCGAACTTGTATCTGTTGAT 60 CAGCTATTGGAAAGGTTTGTAAAATTGTTTACACTTAAATTCGAACTTGTATCTGTTGAT 60 CAGCTATTGGAAAGGTTTGTAAAATTGTTTACACTTAAATTNGAACTNGTATCTGTTGAT 60 CAGCTATTGGAAAGGTTTGTAAAATTGTTTACACTTAAATTNGAACTNGTATCTGTTGAT 60 CAGCTATTGGAAAGGTTTGTAAAATTGTTTACACTTAAATTTGAACTCGTATCTGTTGAT 60

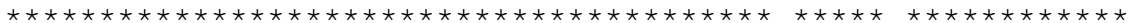

------GCATGTCTTGTATCAGCTGCTTTTCCATATTGTTGCTTTGAGAAATATTAGATC 114 ------GCATGTCTTGTATCAGCTGCTTTTCCATATTGTTGCTTTGAGAAATATTAGATC 114 ------GCATGTCTTGTATCAGCTACTTTTCCATATTGTTGCTTTGAGAAATATTAGATC 114 ------GCATGTCTTGTATCAGCTACTTTTCCATATTGTTGCTTTGAGAAATATTAGATC 114 ------GCATGTCTTGTATCAGCTACTTTTCCATATTGTTGCTTTGAGAAATATTAGATC 114 ------GCATGTCTTGTATCAGCTACTTTTCCATATTGTTGCTTTGAGAAATATTAGATC 114 GCTGATGCATGTCTTGTATCAGCTGCTTTTCCATATTGTTGCTTTGAGAAATATTAGATC 120

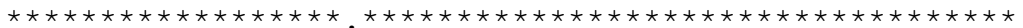

TTCATCCAAATAACTTGAGAGATGTTTTATGCCTGTCTCC 154 TTCATCCAAATAACTTGAGAGATGTTTTATGCCTGTCTCC 154 TTCATCCAAATAACTTGAGAGATGTTTTATGCCTGTCTCC 154 TTCATCCAAATAACTTGAGAGATGTTTTATGCCTGTCTCC 154 TTCATCCAAATAACTTGAGAGATGTTTTATGCCTGTCTCC 154 TTCATCCAAATAACTTGAGAGATGTTTTATGCCTGTCTCC 154 TTCATCCAAATAACTTGAGAGATGTTTTATGCCTGTCTCC 160 $* * * * * * * * * * * * * * * * * * * * * * * * * * * * * * * * * * * * * * * *$ 
Online Resource 4. Statistics data of InDel markers diversity

\begin{tabular}{|c|c|c|c|c|c|c|c|c|c|c|c|c|c|c|c|c|c|}
\hline \multirow[b]{2}{*}{ Marker name } & \multicolumn{5}{|c|}{ All citrus accessions } & \multicolumn{3}{|c|}{ C. reticulata } & \multicolumn{3}{|c|}{ C. maxima } & \multicolumn{3}{|c|}{ C. medica } & \multicolumn{3}{|c|}{3 basic taxa } \\
\hline & $N$ & $H_{0}$ & $H_{\mathrm{e}}$ & $F_{W}$ & $X^{2}$ & $N$ & $H_{0}$ & $H_{\mathrm{e}}$ & $\mathbf{N}$ & $H_{0}$ & $H_{\mathrm{e}}$ & $N$ & $H_{0}$ & $H_{\mathrm{e}}$ & $F_{\text {is }}$ & $\mathbf{F}_{\mathrm{it}}$ & $F_{\text {st }}$ \\
\hline IDCHI & 4 & 0.10 & 0.23 & 0.572 & $6.87^{*}$ & 2 & 0.03 & 0.03 & 1 & 0 & 0 & 3 & 0.50 & 0.62 & 0.125 & 0.762 & 0.728 \\
\hline IDEMA & 3 & 0.19 & 0.28 & 0.321 & 2.60 & 2 & 0.18 & 0.17 & 1 & 0 & 0 & 1 & 0 & 0 & -0.062 & 0.762 & 0.776 \\
\hline IDTRPA & 2 & 0.34 & 0.33 & -0.049 & 0.07 & 2 & 0.34 & 0.29 & 2 & 0.30 & 0.27 & 1 & 0 & 0 & -0.168 & -0.149 & 0.015 \\
\hline IDPEPC1 & 2 & 0.19 & 0.35 & 0.466 & $6.92^{*}$ & 1 & 0 & 0 & 1 & 0 & 0 & 1 & 0 & 0 & - & 1 & 1 \\
\hline IDPEPC2 & 2 & 0.07 & 0.20 & 0.664 & $7.89^{*}$ & 1 & 0 & 0 & 1 & 0 & 0 & 1 & 0 & 0 & - & 1 & 1 \\
\hline IDLCY2 & 3 & 0.30 & 0.38 & 0.210 & 1.51 & 1 & 0.48 & 0.41 & 1 & 0 & 0 & 1 & 0 & 0 & -0.175 & 0.541 & 0.609 \\
\hline IDHYB1 & 3 & 0.16 & 0.27 & 0.407 & $4.03^{*}$ & 2 & 0.17 & 0.16 & 2 & 0.30 & 0.27 & 1 & 0 & 0 & -0.090 & 0.680 & 0.706 \\
\hline IDHYB2 & 2 & 0.07 & 0.25 & 0.732 & $11.98^{*}$ & 1 & 0 & 0 & 1 & 0 & 0 & 1 & 0 & 0 & - & 1 & 1 \\
\hline IDPSY & 2 & 0.06 & 0.19 & 0.707 & $8.63^{*}$ & 1 & 0 & 0 & 1 & 0 & 0 & 1 & 0 & 0 & - & 1 & 1 \\
\hline IDCAX & 5 & 0.56 & 0.69 & 0.198 & 2.45 & 3 & 0.62 & 0.51 & 1 & 0 & 0 & 1 & 0 & 0 & -0.200 & 0.636 & 0.697 \\
\hline IDAtGRC & 2 & 0.07 & 0.20 & 0.664 & $7.89^{*}$ & 1 & 0 & 0 & 2 & 0.30 & 0.27 & 1 & 0 & 0 & -0.143 & 0.876 & 0.892 \\
\hline IDAVP & 2 & 0.08 & 0.12 & 0.326 & 1.10 & 1 & 0 & 0 & 1 & 0 & 0 & 2 & 0.67 & 0.48 & -0.474 & 0.655 & 0.766 \\
\hline
\end{tabular}

$(N)$ Allele number; $\left(H_{0}\right)$ Observed heterozygosity; $\left(H_{\mathrm{e}}\right)$ Expected heterozygosity; $\left(F_{\mathrm{w}}\right)$ Wright fixation Index over the whole

population; $\left(F_{\mathrm{is}}, F_{\mathrm{it}}\right.$ and $\left.F_{\mathrm{st}}\right)$ Weir and Cockerham Index over the subset of $C$. maxima, C.medica and $C$. reticulata accessions. (-)

Not possible to calculate. $X^{2}$ confirmed no significant differences between the expected and observed heterozygosity, $F_{\mathrm{w}}(\alpha=0.05$;

$\left.X^{2}<3,84\right)$. ${ }^{*}$ Means significant differences 
Online Resource 5. Statistics data of SSR markers diversity

\begin{tabular}{|c|c|c|c|c|c|c|c|c|c|c|c|c|c|c|c|c|c|}
\hline \multirow[b]{2}{*}{ Marker name } & \multirow[b]{2}{*}{$L G$} & \multicolumn{4}{|c|}{ All citrus accessions } & \multicolumn{3}{|c|}{ C. reticulata } & \multicolumn{3}{|c|}{ C. maxima } & \multicolumn{3}{|c|}{ C. medica } & \multicolumn{3}{|c|}{3 basic taxa } \\
\hline & & $N$ & $H_{0}$ & $H_{\mathrm{e}}$ & $F_{\mathrm{W}}$ & $N$ & $H_{0}$ & $H_{\mathrm{e}}$ & $\mathbf{N}$ & $H_{0}$ & $H_{\mathrm{e}}$ & $N$ & $H_{0}$ & $H_{\mathrm{e}}$ & $F_{\text {is }}$ & $F_{\text {it }}$ & $F_{\text {st }}$ \\
\hline MEST121 & 1 & 7 & 0.58 & 0.62 & 0.074 & 2 & 0.59 & 0.44 & 5 & 0.40 & 0.76 & 2 & 0 & 0.44 & 0.101 & 0.409 & 0.343 \\
\hline MEST1 & 1 & 10 & 0.60 & 0.70 & 0.140 & 4 & 0.62 & 0.62 & 5 & 0.60 & 0.71 & 2 & 0.50 & 0.38 & 0.033 & 0.345 & 0.322 \\
\hline MEST431 & 1 & 5 & 0.44 & 0.57 & 0.215 & 3 & 0.34 & 0.30 & 2 & 0.10 & 0.10 & 3 & 0.33 & 0.61 & 0.056 & 0.699 & 0.681 \\
\hline TAA15 & 1 & 9 & 0.63 & 0.77 & 0.179 & 9 & 0.69 & 0.74 & 1 & 0 & 0 & 1 & 0 & 0 & 0.083 & 0.547 & 0.505 \\
\hline mCrClR02D09 & 2 & 11 & 0.55 & 0.74 & 0.252 & 7 & 0.86 & 0.73 & 5 & 0.40 & 0.67 & 2 & 0 & 0.32 & 0.037 & 0.296 & 0.269 \\
\hline TAA41 & 2 & 12 & 0.72 & 0.86 & 0.164 & 8 & 0.72 & 0.79 & 2 & 0.30 & 0.45 & 3 & 0.17 & 0.54 & 0.235 & 0.459 & 0.293 \\
\hline mCrCIR06B07 & 2 & 5 & 0.48 & 0.64 & 0.251 & 3 & 0.41 & 0.49 & 3 & 0.80 & 0.55 & 3 & 0.67 & 0.49 & -0.011 & 0.389 & 0.396 \\
\hline $\mathrm{mCrCl01C07}$ & 2 & 9 & 0.81 & 0.83 & 0.025 & 4 & 0.79 & 0.62 & 4 & 0.80 & 0.59 & 2 & 0.17 & 0.49 & -0.175 & 0.286 & 0.392 \\
\hline mCrClR05A05 & 2 & 13 & 0.57 & 0.80 & 0.295 & 9 & 0.52 & 0.76 & 6 & 1 & 0.78 & 5 & 0.33 & 0.53 & 0.209 & 0.351 & 0.18 \\
\hline mCrCIR04H06 & 2 & 6 & 0.44 & 0.68 & 0.347 & 4 & 0.48 & 0.52 & 1 & 0 & 0 & 2 & 0.33 & 0.28 & 0.135 & 0.655 & 0.601 \\
\hline MEST46 & 2 & 7 & 0.70 & 0.76 & 0.077 & 5 & 0.79 & 0.63 & 4 & 0.20 & 0.47 & 1 & 0 & 0 & -0.075 & 0.425 & 0.466 \\
\hline CAC15 & 2 & 3 & 0.44 & 0.39 & -0.148 & 2 & 0.31 & 0.26 & 2 & 0.80 & 0.50 & 1 & 0 & 0 & -0.314 & 0.116 & 0.327 \\
\hline $\mathrm{mCrClR}$ & 2 & 10 & 0.73 & 0.85 & 0.138 & 6 & 0.86 & 0.75 & 5 & 0.20 & 0.62 & 3 & 0.50 & 0.63 & 0.217 & & 0.242 \\
\hline CAC: & 3 & 3 & 0.62 & 0.56 & -0.105 & 2 & 0.41 & 0.33 & 2 & 0.80 & 0.48 & 1 & 0 & 0 & -0.373 & & 0.527 \\
\hline MEST256 & 3 & 9 & 0.31 & 0.66 & 0.527 & 6 & 0.28 & 0.68 & 2 & 0.50 & 0.38 & 2 & 0.50 & 0.38 & 0.385 & 0.567 & 0.296 \\
\hline $\mathrm{mCr}$ & 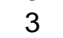 & 10 & 0.67 & 0.80 & 0.166 & 7 & 0.89 & 0.77 & 4 & 0.10 & 0.69 & 2 & 0.60 & 0.42 & 0.096 & & 0.245 \\
\hline MES & 3 & 5 & 0.60 & 0.67 & 0.104 & 5 & 0.72 & 0.65 & 2 & 0.30 & 0.26 & 1 & 0 & 0 & -0.100 & 0.378 & 0.434 \\
\hline $\mathrm{mC}$ & 4 & 8 & 0.81 & 0.8 & 0.0 & 5 & 0.86 & 0.74 & 3 & 0.60 & 0.45 & 1 & 0 & 0 & -0.158 & & 0.443 \\
\hline $\mathrm{mC}$ & 4 & 10 & 0.82 & 0.81 & -0.018 & 5 & 0.79 & 0.73 & 4 & 0.70 & 0.53 & 5 & 0.67 & 0.72 & -0.068 & 0.2 & 0.264 \\
\hline $\mathrm{mC}$ & 4 & 6 & 0.6 & 0.8 & 0.2 & 5 & 0.59 & 0.74 & 2 & 0.40 & 0.3 & 1 & 0 & 0 & 0.172 & & 0.432 \\
\hline $\mathrm{mCr}$ & 4 & 9 & 0.69 & 0.80 & 0.141 & 4 & 0.69 & 0.66 & 3 & 0.60 & 0.45 & 2 & 0.17 & 0.49 & 0.032 & 0.432 & 0.413 \\
\hline MEST15 & 5 & 5 & 0.72 & 0.75 & 0.040 & 5 & 0.79 & 0.62 & 1 & 0 & 0 & 1 & 0 & 0 & -0.241 & & 0.609 \\
\hline MEST & 5 & 7 & 0.7 & 0.75 & 0.0 & 5 & 0.76 & 0.60 & 3 & 0.90 & 0.54 & 1 & 0 & 0 & -0.311 & & 0.452 \\
\hline $\mathrm{mCrC}$ & 5 & 6 & 0.37 & 0.50 & 0.273 & 2 & 0.03 & 0.03 & 3 & 0.80 & 0.61 & 1 & 0 & 0 & -0.248 & 0.771 & 0.816 \\
\hline & 5 & 7 & 0.3 & 0.7 & 0.5 & 6 & 0.69 & 0.74 & 2 & 0 & 0.42 & 1 & 0 & 0 & 0.243 & & 0.261 \\
\hline $\mathrm{mc}$ & 5 & 4 & 0.20 & 0.50 & 0.6 & 2 & 0.38 & 0.31 & 2 & 0 & 0.44 & 1 & 0 & 0 & -0.053 & 0. & 0.662 \\
\hline & 5 & 8 & 0.6 & 0. & & 6 & 0.31 & 0.38 & 3 & 0.50 & 0. & 1 & 0 & 0 & 0.134 & & 0.49 \\
\hline ME & 5 & 4 & 0.42 & 0.50 & 0.1 & 3 & 0.10 & 0.10 & 3 & 0.20 & 0.58 & 1 & 0 & 0 & 0.451 & 0.825 & 0.681 \\
\hline $\mathrm{mC}$ & 5 & 6 & 0.54 & 0.63 & 0.1 & 3 & 0.14 & 0.13 & 3 & 0.70 & 0.57 & 3 & 0.17 & 0.57 & 0.100 & & 0.663 \\
\hline MES & 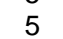 & 14 & 0.6 & 0.8 & 0.2 & 8 & 0.6 & 0.72 & 5 & 0.80 & 0.63 & 3 & 0 & 0.67 & 0.136 & & 0.257 \\
\hline $\mathrm{mC}$ & 6 & 8 & 0.46 & 0.60 & 0.244 & 3 & 0.14 & 0.19 & 5 & 0.90 & 0.69 & 1 & 0 & 0 & -0.020 & 0. & 0.689 \\
\hline & 0 & 13 & & & & 7 & & 0.77 & 5 & 0.89 & 0. & 1 & 0 & 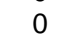 & -0.089 & & 0.367 \\
\hline $\mathrm{mCr}$ & 6 & 8 & 0.7 & 0.75 & 0.0 & 5 & 0. & 0.57 & 4 & 1 & 0.74 & 3 & 0.67 & 0. & -0.061 & 0. & 0.29 \\
\hline CiO & 6 & 0 & 0.3 & 0.7 & & 5 & & 0.61 & 1 & 1 & . & 3 & 0 & 0.63 & & & 0.515 \\
\hline MES & 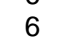 & 11 & 0.8 & 0.8 & -0.0 & 8 & 0. & 0.79 & 5 & 0.90 & 0.6 & 1 & 0 & 0 & -0.137 & & 0.295 \\
\hline mCrCIR01E02 & 6 & 7 & 0.5 & 0.72 & 0.201 & 4 & 0.55 & 0.62 & 4 & 0.78 & 0.67 & 1 & 0 & 0 & 0.081 & & 0.323 \\
\hline mCrCIR01C06 & 6 & 12 & 0.8 & 0.8 & -0.0 & 5 & 0.6 & 0.62 & 6 & 0.90 & 0. & 3 & 0.3 & 0.57 & -0.045 & & 0.285 \\
\hline TAA & 6 & 6 & 0.50 & 0.59 & 0.1 & 2 & 0.24 & 0.21 & 2 & 0.50 & 0.38 & 2 & 0.17 & 0.15 & -0.174 & 0.674 & 0.722 \\
\hline MEST1 & 7 & 3 & 0.32 & 0.43 & 0.2 & 3 & 0.07 & 0.07 & 1 & 0 & 0 & 1 & 0 & 0 & -0.007 & & 0.905 \\
\hline 303B07 & 7 & 9 & 0. & & & 4 & 0. & 0.33 & 2 & 0.20 & 0.42 & 3 & 0.17 & 0.40 & 0.141 & & 0.612 \\
\hline $\mathrm{Ci} 07 \mathrm{C07}$ & 7 & 7 & 0.5 & 0.7 & 0.222 & 7 & 0. & 0.80 & 3 & 0.75 & 0.53 & 3 & 0.67 & 0.50 & 0.105 & & 0.081 \\
\hline $\mathrm{mC}$ & 8 & 7 & 0.6 & 0.7 & 0.124 & 6 & 0.61 & 0.59 & 1 & 0 & 0 & 2 & 0 & 0.28 & 0.104 & 0.536 & 0.482 \\
\hline mCrCIR02G02 & 8 & 13 & 0.7 & 0.7 & 0.066 & 7 & 0.79 & 0.73 & 6 & 0.60 & 0.67 & 4 & 0.67 & 0.58 & -0.016 & 0.193 & 0.206 \\
\hline $\mathrm{Ci02F07}$ & 8 & 10 & 0.31 & 0.58 & 0.469 & 4 & 0.14 & 0.16 & 4 & 0.38 & 0.73 & 1 & 0 & 0 & 0.366 & 0.827 & 0.726 \\
\hline
\end{tabular}




\begin{tabular}{|c|c|c|c|c|c|c|c|c|c|c|c|c|c|c|c|c|c|}
\hline mCrCIR07B05 & 8 & 10 & 0.49 & 0.78 & 0.370 & 6 & 0.41 & 0.75 & 5 & 0.70 & 0.65 & 2 & 0.17 & 0.15 & 0.336 & 0.514 & 0.268 \\
\hline mCrCIR01F04a & 8 & 10 & 0.80 & 0.84 & 0.055 & 7 & 0.86 & 0.80 & 5 & 0.89 & 0.72 & 1 & 0 & 0 & -0.073 & 0.252 & 0.302 \\
\hline MEST86 & 8 & 6 & 0.53 & 0.73 & 0.274 & 3 & 0.72 & 0.63 & 5 & 0.30 & 0.67 & 1 & 0 & 0 & 0.051 & 0.410 & 0.379 \\
\hline Ci07C09 & 9 & 8 & 0.69 & 0.70 & 0.016 & 6 & 0.45 & 0.43 & 4 & 0.70 & 0.57 & 2 & 0.17 & 0.15 & -0.076 & 0.508 & 0.542 \\
\hline mCrClR07F11 & 9 & 12 & 0.77 & 0.83 & 0.079 & 6 & 0.66 & 0.59 & 3 & 0.80 & 0.65 & 2 & 0.50 & 0.49 & -0.104 & 0.325 & 0.389 \\
\hline Сi02B07 & 9 & 9 & 0.71 & 0.78 & 0.083 & 8 & 0.72 & 0.72 & 5 & 0.30 & 0.42 & 2 & 0.33 & 0.28 & 0.061 & 0.377 & 0.337 \\
\hline
\end{tabular}

(LG) Linkage group; $(M)$ Allele number. $\left(H_{0}\right)$ Observed heterozygosity; $\left(H_{\mathrm{e}}\right)$ Expected heterozygosity; $\left(F_{w}\right)$

Wright fixation Index over the whole population; $\left(F_{\text {is }}, F_{\text {it }}\right.$ and $\left.F_{\mathrm{st}}\right)$ Weir and Cockerham Index over the

subset of $C$. maxima, C.medica and $C$. reticulata accessions 
Online Resource 6. LD in the whole data set (InDel and SSR markers). Subset of primers selected in red

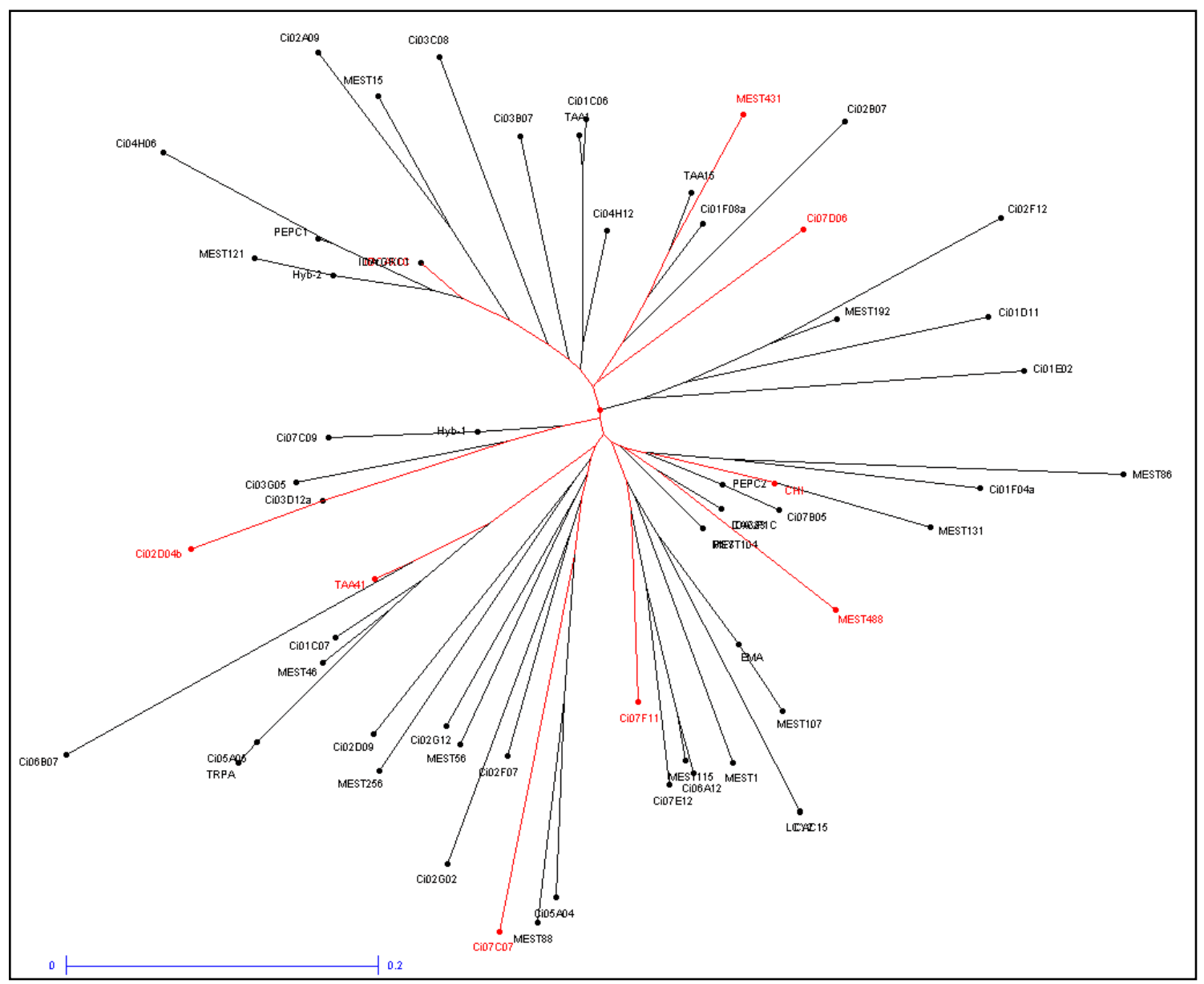


Online Resource 7. NJ tree under topological constraints. Structure of the three ancestor groups was used as initial tree and the rest of the population was positioned (constraint) on this previous topology. Samples in brown were used as initial structuration

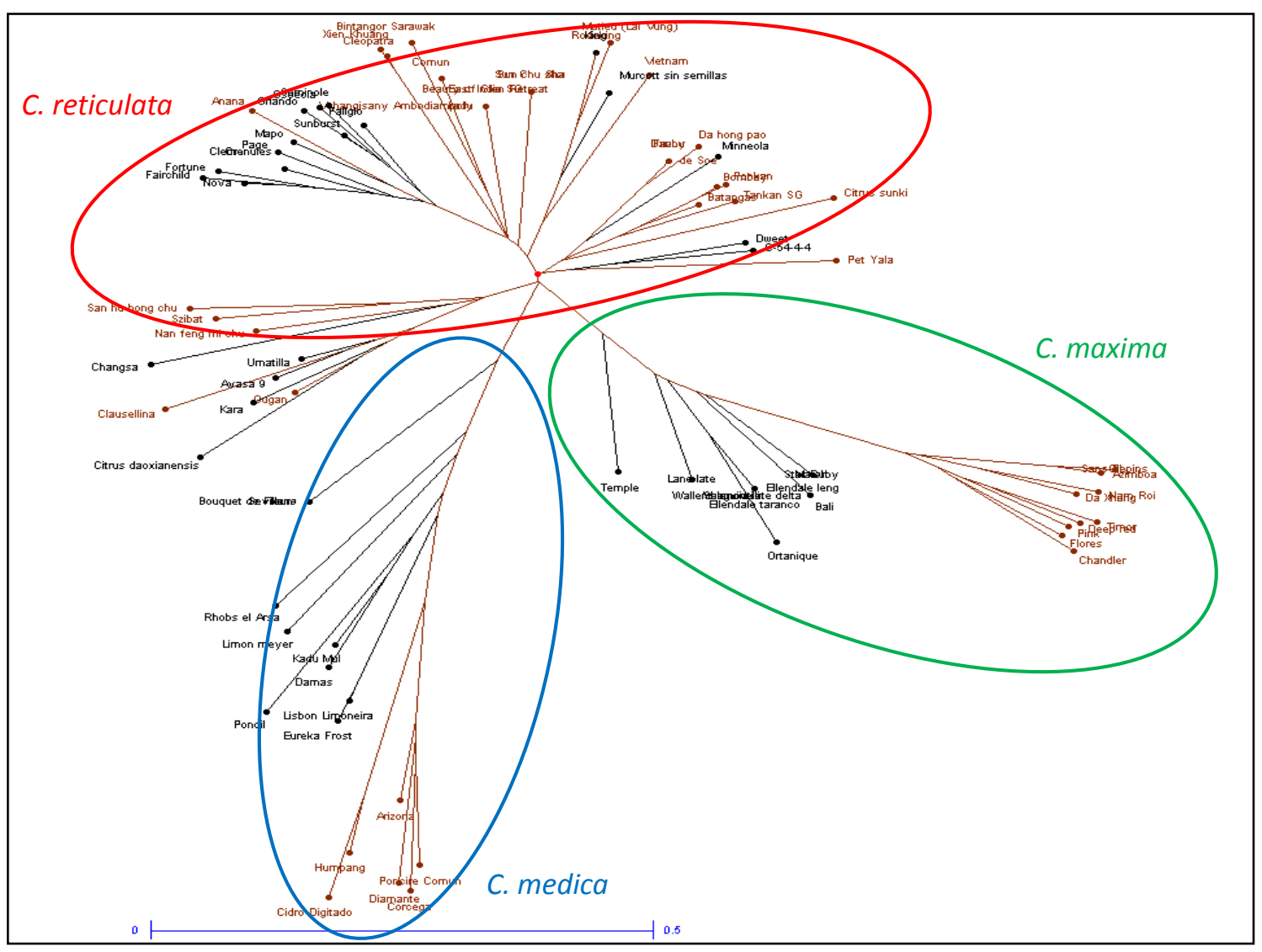





\section{CHAPTER 2}

A nuclear phylogenetic analysis: SNPs, indels and SSRs deliver new insights into the relationships in the 'true citrus fruit trees' group (Citrinae, Rutaceae) and the origin of cultivated species.

Andres Garcia-Lor, Franck Curk, Hager Snoussi-Trifa, Raphael Morillon, Gema Ancillo, François Luro, Luis Navarro and Patrick Ollitrault

Annals of Botany (2013) 111: 1-19 



\section{Abstract}

- $\quad$ Background and Aims

Despite differences in morphology, the genera representing 'true citrus fruit trees' are sexually compatible, but their phylogenetic relationships remain unclear. Most of the important commercial 'species' of Citrus are believed to be of interspecific origin. By studying polymorphisms of 27 nuclear genes, the average molecular differentiation between species was estimated, and some phylogenetic relationships between 'true citrus fruit trees' were clarified.

\section{Methods}

Sanger sequencing of PCR-amplified fragments from 18 genes involved in metabolite biosynthesis pathways and nine putative genes for salt tolerance, was performed for 45 genotypes of Citrus and relatives of Citrus to mine SNP and indel polymorphisms. Fifty nuclear SSRs were also analysed.

- Key results

A total of $16238 \mathrm{~kb}$ of DNA was sequenced for each genotype, and 1097 single nucleotide polymorphisms (SNPs) and 50 indels were identified. These polymorphisms were more valuable than SSRs for inter-taxon differentiation. Nuclear phylogenetic analysis revealed that Citrus reticulata and Fortunella are joined in a cluster that is differentiated from the clade that includes three other basic taxa of cultivated citrus ( $C$. maxima, $C$. medica and $C$. micrantha). These results confirm the taxonomic subdivision between the subgenera Metacitrus and Archicitrus. A few genes displayed positive selection patterns within or between species, but most of them displayed neutral patterns. The phylogenetic inheritance patterns of the analysed genes were inferred for commercial Citrus species.

\section{- $\quad$ Conclusions}

Numerous molecular polymorphisms (SNPs and indels), which are potentially very useful for the analysis of interspecific genetic structures, have been identified. The nuclear phylogenetic network for Citrus and its sexually compatible relatives was consistent with the geographic origins of these genera. The positive selection observed for a few genes will orient further works to analyse the molecular basis of the variability of the associated traits. This study presents new insights into the origin of $C$. sinensis. 


\section{INTRODUCTION}

Aurantioideae (Rutaceae) are considered to be a monophyletic group (Scott et al., 2000; Groppo et al., 2008; Morton, 2009) and Ruta appears to be sister to Aurantioideae (Scott et al., 2000; Bayer et al., 2009). Furthermore, Groppo et al. (2008) suggest that Aurantioideae should be recognized as a tribe and be included in a subfamily together with Rutoideae, Toddalioideae and Flindersioideae. Although new insights in the circumscription of the tribes of Aurantioideae have been recently released (Bayer et al., 2009; Morton, 2009), it remains unresolved. In the classification of Swingle and Reece (1967), which remains the most used by citrus researchers, Aurantioidae is divided in two tribes, Clauseneae and Citreae. Citreae includes, among others, subtribe Citrinae, which is in turn divided into six genera (Fortunella, Eremocitrus, Poncirus, Clymenia, Microcitrus and Citrus) that comprise the important 'true citrus fruit trees' group (Swingle and Reece, 1967; Krueger and Navarro, 2007).

Among these genera, Citrus is by far the most economically important. It is believed to have originated in south-eastern Asia, in an area that includes China, India and the Indochinese peninsula and nearby archipelagos (Krueger and Navarro, 2007). Citrus taxonomy is still controversial due to the large degree of morphological diversity found within this group, the sexual compatibility between the species and the apomixis of many genotypes. Two major classification systems based on morphological and phenotypic data are currently used, i.e., those of Swingle and Reece (1967) and Tanaka (1977), who recognized 16 and 162 species, respectively. Here we adopt the classification system of Swingle and Reece (1967), which is more in line with the main clustering system derived from the molecular analysis described in this report. More recently, Mabberley (1997) proposed a new classification system for edible citrus that recognizes three species and four hybrid groups. In agreement with a pioneering numerical taxonomic study (Barret and Rhodes, 1976), the classification system of Mabberley confirms that three main taxa [C. medica L. (citrons), C. maxima (Burm.) Merr. (pummelos) and C. reticulata Blanco (mandarins)] were the ancestors of cultivated Citrus. However, the subdivision into four hybrid groups remains questionable, and relatively few authors have adopted the classification system of Mabberley. More recent studies involving the diversity of morphological characteristics (Ollitrault et al., 2003) and the analysis of primary metabolites (Luro et al., 2011) and secondary metabolites (Fanciullino et al., 2006a), have indicated that the phenotypic diversity of edible citrus species primarily resulted from the initial differentiation between these three basic taxa. Molecular marker studies using restriction fragment length polymorphism (RFLP; Federici et al., 1998), random amplified polymorphic DNA (RAPD) and sequence characterized amplified regions (SCAR; Nicolosi et al., 2000), simple sequence repeats (SSRs; Luro et al., 2001; Barkley et al., 2006), SSR and insertion-deletion (indels; Garcia-Lor et al., 2012a) and single nucleotide polymorphisms (SNPs; Ollitrault et al., 2012a) have confirmed the central role played by these three taxa but also pointed out that $C$. micrantha, a member of subgenus Papeda, is a potential parent of some limes $(C$. aurantifolia Christm.). Swingle and Reece (1967) differentiated between the subgenera Papeda and Citrus. The genome of most of the important commercial Citrus spp. (secondary species) can be 
considered to be a mosaic of large DNA fragments of the ancestral species that resulted from a few inter-specific recombination events (Garcia-Lor et al., 2012a).

Fortunella is generally considered to be a separate genus (Swingle and Reece, 1967), but it closely resembles Citrus. According to Swingle (1943), this genus includes four species (F. margarita, F. japonica, F. hindsii and F. polyandra) and Fantz (1988) included two hybrid taxa in Fortunella (F. obovata, F. Crassifolia). Its origin is northern China, and it is well adapted to cold areas due to its propensity for prolonged winter dormancy and late flowering. Its fruits, commonly called kumquats, are edible, and Fortunella trees are appreciated for their ornamental qualities. Poncirus is another genus that originated in northern China, and for a long time, it was considered to be monotypic ( $P$. trifoliata). However, a new species belonging to this genus, $P$. polyandra, was found in Yunnan (China) in the 1980s (Ding et al., 1984). Poncirus trifoliata is the only species of 'true citrus fruit trees' with deciduous leaves. It is highly tolerant to cold and resistant to several citrus pathogens. It is therefore an important source of germplasm for citrus rootstock breeding.

According to Krueger and Navarro (2007), Microcitrus includes five species that originated in Australia ( $M$. australis, $M$. australasica, M. inodora, $M$. garrowayii and $M$. maindeniana) and two from Papua New Guinea (M. papuana and M. warbugiana). Microcitrus australasica, the finger lime, is cultivated on a small scale for its fruit with aromatic, spherical juice vesicles. Eremocitrus is a monospecific genus (E. glauca) that is native to the Australian desert. This genus is cold-tolerant and xerophytic. Eremocitrus and Microcitrus are closely related, morphologically and molecularly (Swingle and Reece, 1967; Bayer et al., 2009). They are graft-compatible with Citrus and other related genera.

Despite considerable morphological differentiation, Citrus, Fortunella, Poncirus, Microcitrus and Eremocitrus are sexually compatible genera (Krueger and Navarro, 2007). Studies based on plastid sequences (Abkenar et al., 2004; Morton, 2009; Bayer et al., 2009) concur that the six genera of the tribe Citrinae (Fortunella, Eremocitrus, Poncirus, Clymenia, Microcitrus and Citrus) form a monophyletic clade. However, these authors did not fully agree on the organization within this clade. Clymenia polyandra appeared in the same subclade as Citrus, Fortunella and Poncirus in the analysis of Abkenar et al. (2004), but Morton (2009) and Bayer et al. (2009) found it in the Eremocitrus and Microcitrus subclade. Moreover, Bayer et al. (2009) included Oxanthera and Feroniella in the clade of the 'true citrus fruit trees'. To analyse the gene pool of 'true citrus fruit trees', with potential gene flow between sexually compatible taxa, some of which share the same diversification area, phylogenetic analysis based on nuclear sequences should be more informative than the analysis of maternally inherited plastid sequences (Ramadugu et al., 2011). However, the phylogenetic relationships between 'true citrus fruit trees' based on the analysis of nuclear genomes have not been clearly elucidated.

In genetic studies of Citrus, SSR analysis (Gulsen and Roose, 2001a; Luro et al., 2001, 2008; Barkley et al., 2006; Ollitrault et al., 2010) is seen as a powerful tool because SSRs are co-dominant, randomly dispersed throughout the plant genome, generally highly polymorphic 
and locus-specific. However, Barkley et al. (2009) showed that homoplasy might limit the usefulness of SSRs as tags to elucidate the phylogenetic origin of specific DNA fragments in citrus. Moreover, the high mutation rate of SSRs can often lead to an underestimation of subpopulation divergence (Coates et al., 2009). In recent studies, Garcia-Lor et al. (2012a) and Ollitrault et al. (2012) analysed the value of nuclear indels as genetic markers in Citrus. These studies showed that indels are more suitable than SSRs for differentiating between the three basic taxa of cultivated Citrus. However, the relatively low frequency of indels limits their utility.

SNPs are the most abundant type of DNA sequence polymorphism (Brookes, 1999). Due to the high frequency of occurrence of SNPs and their relatively dense and uniform distribution in genomes, SNPs are an important source of variability and are therefore useful for many applications, including the development of saturated genetic maps, cultivar identification, detection of genotype/phenotype associations and marker-assisted breeding (Botstein and Risch, 2003; Morales et al., 2004; Xing et al., 2005; Lijavetzky et al., 2007). The frequency of occurrence of SNPs in the genomes of eukaryotes depends on the domestication and breeding history, mating system and frequency of mutation, recombination and other features (Buckler and Thornsberry, 2002; Rafalski and Morgante, 2004). Although individual SNPs are less informative than other marker types for population genetic studies because of their biallelic nature, they have several advantages over other marker types due to the high frequency of SNP occurrence, the easy automation of SNP genotyping, the low-scoring error rates and the high levels of reproducibility of SNP analysis results between laboratories (Morales et al., 2004; Helyar et al., 2011).

Many efforts have been made to detect SNPs in plants. SNPs have been used to perform comparative diversity analysis and genotyping, to reveal genetic structures and to assess molecular evolutionary patterns in many plant species including Norway spruce (Heuertz et al., 2006), sunflower (Kolkman et al., 2007), grapevine (Lijavetzky et al., 2007), European aspen (Ingvarsson, 2005) and eucalyptus (Külheim et al., 2009). Some studies have been performed in Citrus, but these studies were generally limited due to narrow genetic basis of the discovery panel. Novelli et al. (2004) searched for SNPs among several sweet orange lines. Terol et al. (2008) identified 6617 putative SNPs from Nules clementine BAC end sequences, from which 622 were successfully transferred to the entire genus using GoldenGate array technology (Ollitrault et al., 2012a). Dong et al. (2010) mined SNPs from sweet orange and satsuma mandarin expressed sequence tag (EST) databases.

The ascertainment bias associated with a low genetic basis of the discovery panel has been widely discussed for humans and animals (Clark et al., 2005; Rosenblum and Novembre, 2007; Albrechtsen et al., 2010), and it was observed for Citrus at the genus level when diversity studies with SNP markers mined in clementine were performed (Ollitrault et al., 2012a). It is therefore important to develop a good sampling strategy for SNP discovery (Garvin et al., 2010; Helyar et al., 2011) that would help to elucidate the true differentiation level between basic taxa and related genera at the nuclear level. 
In the present study, we searched for SNP and indel polymorphisms in 45 accessions of Citrus, Poncirus, Fortunella, Microcitrus and Eremocitrus, with Severinia buxifolia employed as outgroup, using Sanger sequencing of amplified DNA fragments from 18 genes involved in primary and secondary metabolite biosynthetic pathways that determine citrus fruit quality (sugars, acids, flavonoids and carotenoids) and nine putative salt tolerance genes. In addition to the identification of useful intra- and interspecific SNP and indel markers, this study addresses the following questions: (1) What are the phylogenetic relationships at the nuclear level between different Citrus spp. and between genera? (2) What is the level of intra- and interspecific diversity between the Citrus taxa at the origin of the cultivated forms? (3) Did the evolution of genes involved in different metabolic pathways and some putative stress adaptation genes follow a similar neutral pattern regarding the history and reproductive biology of Citrus, or did some genes experience selective evolution? (4) What is the phylogenetic inheritance pattern of the analysed genes in secondary Citrus spp.? 


\section{MATERIALS AND METHODS}

\section{Plant material}

Leaf material from 44 true citrus accessions and one relative (Severinia buxifolia) used as the outgroup [Supplementary Information 1] was collected, and DNA was extracted using the DNeasy plant mini kit (Qiagen S.A., Madrid, Spain). The samples represented all major Citrus species (seven C. reticulata, five C. maxima, five C. medica, and four representatives of the subgenus Papeda) and five Fortunella spp., two Microcitrus spp., one Eremocitrus sample and three Poncirus trifoliata, all of which are sexually compatible with Citrus. These eight groups are considered to be ancestral populations. Some representatives of secondary species were added (two diploid clementines and one haploid clementine, two $C$. sinensis, two $C$. aurantium, one $C$. paradisi, one $C$. limon and one $C$. aurantifolia) and two hybrids, including one tangor $(C$. reticulata $\times C$. sinensis) and one tangelo ( $C$. paradisi $\times C$. reticulata). These 12 genotypes are known to be hybrids derived from the ancestral populations and are economically important cultivars. Haploid clementine (Aleza et al., 2009) is currently used by the International Citrus Genome Consortium to establish the whole genome reference sequence of citrus. It was used in the present study to test whether some genes were duplicated. Forty-two accessions were obtained from the IVIA Citrus Germplasm Bank of pathogen-free plants (Navarro et al., 2002), and three were obtained from the INRA/CIRAD collection. All accessions were used for Sanger sequencing of gene fragments and indel and SSR genotyping.

\section{Gene fragment sequencing}

Eighteen genes involved in primary and secondary metabolite biosynthesis pathways that determine citrus fruit quality (sugars, acids, flavonoids and carotenoids) and nine putative salt tolerance genes were selected. The selection of the 27 gene fragments was based on the quality of sequencing chromatograms for all genotypes. Primers were designed using Primer3 (Rozen and Skaletsky, 2000) to amplify fragments ranging from 190 to $941 \mathrm{bp}$, according to the ESTs available in GenBank (http://www.ncbi.nlm.nih.gov/genbank/; Table 1). PCR amplifications were performed using a Mastercycler Ep Gradient $S$ thermocycler (Eppendorf) in a final volume of $25 \mu \mathrm{L}$ containing $0.027 \mathrm{U} / \mu \mathrm{l}$ Taq DNA polymerase (Fermentas), $1 \mathrm{ng} / \mu \mathrm{L}$ of genomic DNA, 10x PCR buffer (Fermentas), $0.2 \mathrm{mM}$ of each dNTP, $1.5 \mathrm{mM} \mathrm{MgSO} 4$ and $0.2 \mu \mathrm{M}$ of each primer. The following PCR program was applied: denaturation at $94^{\circ} \mathrm{C}$ for $5 \mathrm{~min}$ and 40 cycles of $30 \mathrm{~s}$ at $94^{\circ} \mathrm{C}, 1 \mathrm{~min}$ at $55^{\circ} \mathrm{C}$ or $60^{\circ} \mathrm{C}$ (according to the melting temperature of the primers), 2 min at $72^{\circ} \mathrm{C}$, and a final elongation step of $4 \mathrm{~min}$ at $72^{\circ} \mathrm{C}$. PCR product purification was done using a QIAquick PCR Purification Kit (Qiagen S.A.). Amplicons of the 45 genotypes were sequenced using the Sanger method from the 5 ' end using fluorescently labelled dideoxynucleotides (Big Dye Terminator Cycle Sequencing Kit v3.1). 
Chapter 2: Materials and methods

Table 1. Primer sequences for the genes that were studied

\begin{tabular}{|c|c|c|c|c|}
\hline Biosyntetic pathway & Gene & Primers & AT & GBA \\
\hline \multirow[t]{10}{*}{ Flavonoids } & \multirow[t]{2}{*}{ Chalcone isomerase $(\mathrm{CHI})$} & F:TTGTTCTGATGGCCTAATGG & 58 & DY263683 \\
\hline & & R:AAAGGCTGTCACCGATGAAT & 58 & \\
\hline & \multirow[t]{2}{*}{ Chalcone synthase (CHS) } & F:GATGTTGGCCGAGTAATGCT & 60 & CV885475 \\
\hline & & R:ATGCCAGGTCCAAAAGCTAA & 59 & \\
\hline & \multirow[t]{2}{*}{ Flavonol synthase (FLS) } & F:GGAGGTGGAGAGGGTCCAAG & 59 & AB011796 \\
\hline & & R:GGGCCACCACTCCAAGAGC & 61 & \\
\hline & \multirow[t]{2}{*}{ Flavonoid 3'-hydroxylase (F3'H) } & F:CTCGAGCCTTCCTCAAAACC & 60 & HQ634392 \\
\hline & & R:AACAAGCACAATCCCCATTC & 57 & \\
\hline & \multirow[t]{2}{*}{ Dihydroflavonol 4-reductase (DFR) } & F:CTGGGTTTATCGGTTCATGG & 60 & DQ084722 \\
\hline & & R:TCCACAGCACCTGTGAACAT & 60 & \\
\hline \multirow[t]{8}{*}{ Acids } & \multirow[t]{2}{*}{ Malic enzyme (EMA) } & F:ACATGACGACATGCTTCTGG & 58 & CB417399 \\
\hline & & R:CGTAGCCACGCCTAGTTCAT & 60 & \\
\hline & \multirow[t]{2}{*}{$\begin{array}{l}\text { Malate dehydrogenase (MDH) } \\
\text { (MH) }\end{array}$} & F:ATGGCCGCTACATCAGCTAC & 60 & DQ901430 \\
\hline & & R:TGCAACCCCСTTTTCAATAC & 59 & \\
\hline & \multirow[t]{2}{*}{ Aconitase (ACO) } & F:AAGCCATGGGTCAAAACAAG & 59 & AF073507 \\
\hline & & R:GATTTCCCAGTGTCGGTTGT & 59 & \\
\hline & \multirow{2}{*}{$\begin{array}{l}\text { Vacuolar citrate/H+ symporter } \\
\text { (TRPA) }\end{array}$} & F:GGCGCCACTCCTACCTTCCC & 62 & EF028327 \\
\hline & & R:CGGTCATTGAAGAGTGCTCCCC & 60 & \\
\hline \multirow[t]{6}{*}{ Sugars } & \multirow[t]{2}{*}{ Acid invertase (INVA) } & F:ATTGCGGATGTGAAGAAAGG & 56 & AB074885 \\
\hline & & R:TTTGCCATGCTTTGAGTGAG & 56 & \\
\hline & \multirow{2}{*}{$\begin{array}{l}\text { Phosphoenolpyruvate carboxylase } \\
\text { (PEPC) }\end{array}$} & F:AGCCAATGGGATTTCTGACA & 60 & EF058158 \\
\hline & & R:GCCAAGCCACACAGGTAAAT & 60 & \\
\hline & \multirow[t]{2}{*}{ Phosphofructokinase (PKF) } & F:CGCCGACCTCAGTCCCGTC & 63 & AF095520 \\
\hline & & R:GCTGCACGCCCCATAAGCCG & 64 & \\
\hline \multirow[t]{12}{*}{ Carotenes } & \multirow{2}{*}{$\begin{array}{l}\text { 1-deoxyxylulose 5-phosphate } \\
\text { synthase (DXS) }\end{array}$} & F:GGCGAGGAAGCGACGAAGATGG & 62 & DN959423 \\
\hline & & R:GGATCAGAACTGGCCCTGGCG & 62 & \\
\hline & \multirow[t]{2}{*}{ Phytoene synthase (PSY) } & F:GCTCGTTGATGGGCCTAATGC & 59 & AB037975 \\
\hline & & R:CGGGCGTAAGAGGGATTTTGC & 59 & \\
\hline & \multirow[t]{2}{*}{$\bar{\beta}$-Carotene hydroxylase (HYB) } & F:AGCCCTTCTGTCTCCTCACA & 59 & AF315289 \\
\hline & & R:CCGTGGAATTTATCCGAGTG & 59 & \\
\hline & Lycopene $\beta$-cyclase 2 (LCY2) & F:GCATGGCAACTCTTCTTAGCCCG & 60 & FJ516403 \\
\hline & & R:AGCTCGCAAGTAAGGCCATTCC & 61 & \\
\hline & Lycopene $\beta$-cyclase (LCYB) & F:GAATTCTTGCCCCAAGTTCA & 60 & AY16696 \\
\hline & & R:TATGGGCCACAAATCTTTCC & 59 & \\
\hline & 9-cis-epoxy hydroxy carotenoid & F:GCAGTCAAATTCAACAAAGG & 55 & DQ309332 \\
\hline & dyoxygenase 3 (NCED3) & R:AATCCCAAATCTTGACACCT & 55 & \\
\hline Aldarate and & Ascorbate oxydase (AOC) & F:TCAGTGAGAACCCTAAAGC & 58 & DY293375 \\
\hline ascorbate & & R:CAGTACAACCCCAGTAAGC & 60 & \\
\hline metabolism & Ascorbate peroxidase (LAPX) & F:CAGCGGGGACTTATGACG & 58 & EU719653 \\
\hline & & R:GCCCTCCGGTAACTTCAAC & 59 & \\
\hline Cellular & MRP-like ABC transporter (MRP4) & F:AGAAGCAGCATGGAAGATGG & 60 & CD574223 \\
\hline Detoxification & & R:CCGATCGGTTGGCATACTC & 62 & \\
\hline & Cation chloride cotransporter & F:GCAGCTTGCTACCTACATTGAC & 63 & FN662480 \\
\hline & $(\mathrm{CCC} 1)$ & R:ACTGAACTCCACATCCCAAAAG & 61 & \\
\hline & High-affinity $\mathrm{K}+$ transporter 1 & F:GTCCATGGAGAAAAAGAACC & 58 & DY297409 \\
\hline & (HKT1) & R:TGCTAGTGTCCGTGAAGAAG & 60 & \\
\hline & NADH kinase (NADK2) & F:TGCAGAGACAAGATATTCCC & 58 & $\overline{\text { DN619491 }}$ \\
\hline & & R:ATGTGAGGTGAGAAATCCC & 58 & \\
\hline Salt tolerance & Aquaporin PIP1A (PIP1) & F:GACACTCGGCCTGTTCTTG & 62 & CK938271 \\
\hline & & R:TCCGGTAATTGGGATGGTAG & 60 & \\
\hline & Salt overly sensitive 1 (SOS1) & F:ACCAGTCAGACAACCATTTG & 55 & DN959478 \\
\hline & & R:CCAATTAGCACCTCATAGAGAC & 58 & \\
\hline Sucrose and starch & Tréhalose-6-phosphate synthase & F:TGCAGAACCTGTAATGAAGC & 58 & FC875388 \\
\hline metabolism & (TSC) & R:CTGGTAGGATGCCGACTTAG & 62 & \\
\hline
\end{tabular}

(AT) Annealing temperature ${ }^{\circ} \mathrm{C}$; (GBA) GenBank accession number.

\section{Sequence polymorphism analysis}

Sequences were aligned using BioEdit (Hall, 1999), SeqMan version 7.0. (http://www.dnastar.com) and SATé-II (Liu et al., 2012). The homogeneity of the alignment obtained with the three software programs was checked and heterozygosity or homozygosity of 
all genotypes verified visually in the chromatogram for all SNP positions. Estimates of nucleotide polymorphisms (segregating sites, $S$, nucleotide diversity, $\pi$ ) and between-species divergences were obtained using DnaSP v. 5.10 .01 (http://www.ub.es/dnasp). The genomic DNA sequences were subjected to blast analysis using the protein databases (blastx) at NCBI to identify the coding and non-coding regions. DnaSP was also used to calculate the statistical test of neutrality, Tajima's $D$ (Tajima, 1989a, b).

For each target gene fragment, the haplotype number and the haplotype diversity were estimated with DnaSP software using coalescent process simulations. Unbiased expected heterozygosity, observed heterozygosity, fixation index value $\left(F_{\mathrm{w}}\right.$; Wright, 1978) and the $F_{\text {stat }}$ parameter $\left(F_{\mathrm{st}}\right)$ were calculated using GENETIX v. 4.03 software (Belkhir et al., 2002).

\section{Indel marker development}

Primer pairs for 12 indel markers are already available for the 'true citrus fruit trees' group (Garcia-Lor et al., 2012a). New primer pairs for genes with indel polymorphisms were designed with Primer3 in conserved regions flanking the indel polymorphism (http://biotools.umassmed.edu/bioapps/primer3; Supplementary Information 2) to amplify fragments smaller than $400 \mathrm{bp}$ that were subsequently subjected to fragment size polymorphism analysis in a capillary fragment analyser as described by Garcia-Lor et al. (2012a).

\section{SSR markers}

The 50 SSRs markers used for the diversity analysis within Citrus by Garcia-Lor et al. (2012a) were used to complete the genotyping for the accessions of the other genera. The list of primers that were used, the PCR conditions that were employed and the method used for capillary electrophoresis can be found in Garcia-Lor et al. (2012a).

\section{Phylogenetic analysis}

Phylogenetic analysis was performed by joining the 27 sequences together for each genotype (eight taxa), creating a sequence with a total length of $16238 \mathrm{bp}$. Indels were excluded from the analysis. Several analyses were performed to determine which model best matched our data using the Phylemon 2.0 website (http://phylemon.bioinfo.cipf.es; Sánchez et al., 2011), which integrates different tools for molecular evolution, phylogenetics, phylogenomics and hypothesis testing. PhyML Best AIC Tree (v. 1.02b) software, which uses a model test program (Posada and Crandall, 1998) that performs hierarchical Likelihood Ratio Tests (LRTs) in an ordered way using Akaike's information criteria (AIC), was used to select the model that most closely fitted the data (lowest AIC value), taking into account the nucleotide substitution 
model, the proportion of invariable sites $(I)$, the nucleotide frequency $(F)$ and the gamma distribution $(G)$.

The construction of the maximum-likelihood (ML) tree was performed using 1000 bootstraps to assess the branch support using the $\mathrm{SH}$-like approximate likelihood ratio test (ranges from 0 to 1), assuming uniform rates among sites and deleting gaps and missing sites. Trees obtained in Phylemon (newick format) were drawn using the TreeDyn 198.3 tool found at www.phylogeny.fr (Dereeper et al., 2008).

Neighbour-Joining (NJ) analysis

Population diversity organisation based on the SNP data was analysed with DARwin software (Perrier and Jacquemoud-Collet, 2006) as explained by Garcia-Lor et al. (2012a).

\section{Principal Coordinate Analysis (PCoA)}

PCoA was performed using GENEALEX6 software (Peakall and Smouse, 2006). The genomic sequence data were used to obtain a pairwise genetic distance matrix, which was standardised and used for PCoA. 


\section{RESULTS}

SNP and indel discovery and analysis of polymorphic loci diversity

SNPS

SNPs were not encountered in any of the 27 genetic sequences of the haploid clementine. This confirms that there were no duplicated genes in our sample of 27 genes. A total of $16238 \mathrm{bp}$ were sequenced for each of the accessions analysed, from which $10427 \mathrm{bp}$ were coding regions and 5811 bp were non-coding sequences (Table 2). A total of 1097 SNPs were found in the 'true citrus fruit trees' samples. Another 262 SNPs were found in the outgroup, Severinia buxifolia. 'true citrus fruit trees' had an average of $52.89 \mathrm{SNPs} / \mathrm{kb}$ for coding regions and 98.39 SNPs/kb for non-coding regions. Considering only Citrus, $28.96 \mathrm{SNPs} / \mathrm{kb}$ were found in coding regions and $51.45 \mathrm{SNPs} / \mathrm{kb}$ were found in non-coding regions. In the 'true citrus fruit trees', most of the SNP loci were biallelic, while $21(1.86 \%)$ revealed three alleles. Among the polymorphisms described, $59.18 \%$ were transitions $(A / G \approx C / T)$ and $40.82 \%$ were transversions $(A / C \approx A / T>G / T>C / G)$. For the 'true citrus fruit trees', but excluding secondary Citrus spp., the average polymorphism rate was $51.76 \mathrm{SNPs} / \mathrm{kb}$ for coding regions and 95.43 SNPs/kb for non-coding regions, with a total of 1066 SNP loci. Among the basic Citrus taxa, Papeda had 252 polymorphic loci (12.18 SNP/kb in coding region and $21.51 \mathrm{SNP} / \mathrm{kb}$ in noncoding region), followed by $C$. reticulata $(236,15.15 \mathrm{SNP} / \mathrm{kb}$ in coding region and $13.94 \mathrm{SNP} / \mathrm{kb}$ in non-coding region), C. maxima (107, 4.70 SNP/kb in coding region and $9.98 \mathrm{SNP} / \mathrm{kb}$ in noncoding region) and $C$. medica (70, 2.21 SNP/kb in coding region and $8.09 \mathrm{SNP} / \mathrm{kb}$ in non-coding region). Large differences in the number of polymorphic loci were observed among close relatives including Fortunella (227), Microcitrus (171), Eremocitrus (93) and Poncirus (53). Among the secondary species and hybrids, $C$. aurantium had 211 polymorphic sites, $C$. limon had 173, C. sinensis had 162, C. aurantifolia had 158, C. paradisi had 115 and clementine had 119. Interestingly, among the 31 alleles found exclusively in the secondary species (not present in any other true citrus species), 15 were heterozygous in $C$. aurantium. Four of these alleles (found in the genes INVA, LCY2, DXS and AOC) were shared with $C$. limon.

The average rate of heterozygosity observed in the eight ancestral taxa was very low $\left(H_{0}=0.051\right)$, and $27.79 \%$ of the SNPs detected were homozygous in all individuals $\left(H_{0}=0\right)$. The most heterozygous site was at locus F3'H (SNP51), with a $H_{0}=0.39$. We estimated the average rates of inter-accession polymorphism (SNPs/kb) within and between the ancestral taxa (Table 3). Considering only Citrus spp., the average rates of intra- and inter-taxon polymorphisms were 1.76 SNPs/kb and $11.31 \mathrm{SNPs} / \mathrm{kb}$, respectively. Intra-taxon SNP rates varied from 0.65 for $C$. maxima to 3.37 for Papeda (C. hystrix, C. inchangensis, C. micrantha). Interspecific rates in Citrus varied from 8.56 between C. reticulata and Papeda to 14.43 between $C$. medica and Papeda. The SNP rate between $C$. reticulata and $C$. maxima, the two 
Table 2. Polymorphisms of nucleotide sequences of genes for all samples analysed

\begin{tabular}{|c|c|c|c|c|c|c|c|c|c|c|c|c|c|c|}
\hline Gene & CS & TS & GS & SC & SNC & SNPc & Freq. & SNPnc & Freq. & $\pi_{\text {nonsvn }} / \pi_{\text {svn }}$ & indelc & Freq. & indelnc & Freq. \\
\hline $\mathrm{CHI}$ & 652 & 721 & 721 & 206 & 446 & 11 & 53.40 & 68 & 152.47 & 1.38 & 0 & 0 & 8 & 17.94 \\
\hline $\mathrm{CHS}$ & 565 & 659 & 659 & 574 & 0 & 20 & 35.40 & - & - & 0.06 & 0 & 0 & - & - \\
\hline FLS & 473 & 763 & 763 & 419 & 54 & 41 & 97.85 & 6 & 111.11 & 0.12 & 0 & 0 & 3 & 55.56 \\
\hline $\mathrm{F}^{\prime} \mathrm{H}$ & 783 & 1000 & 1400 & 569 & 214 & 40 & 70.30 & 20 & 93.46 & 0.55 & 0 & 0 & 3 & 14.02 \\
\hline DFR & 421 & 1017 & 1650 & 171 & 250 & 7 & 40.94 & 26 & 104.00 & 0.25 & 0 & 0 & 3 & 12.00 \\
\hline EMA & 428 & 166 & 450 & 131 & 297 & 7 & 53.44 & 27 & 90.91 & 2.27 & 1 & 7.63 & 4 & 13.47 \\
\hline $\mathrm{MDH}$ & 712 & 1209 & 1250 & 712 & 0 & 28 & 39.33 & - & - & 1.06 & 0 & 0 & - & - \\
\hline ACO & 695 & 1196 & 2000 & 250 & 445 & 5 & 20.00 & 39 & 87.64 & 0.02 & 0 & 0 & 2 & 4.49 \\
\hline TRPA & 795 & 987 & 1300 & 657 & 138 & 40 & 60.88 & 15 & 108.70 & 0.43 & 0 & 0 & 1 & 7.25 \\
\hline INVA & 908 & 679 & 1100 & 515 & 393 & 36 & 69.90 & 38 & 96.69 & 0.23 & 0 & 0 & 1 & 2.54 \\
\hline PEPC & 694 & 1201 & 2000 & 61 & 633 & 2 & 32.79 & 51 & 80.57 & 0.00 & 0 & 0 & 4 & 6.32 \\
\hline PKF & 775 & 807 & 1650 & 406 & 369 & 16 & 39.41 & 31 & 84.01 & 0.88 & 0 & 0 & 3 & 8.13 \\
\hline DXS & 722 & 935 & 1500 & 327 & 395 & 13 & 39.76 & 37 & 93.67 & 0.29 & 0 & 0 & 3 & 7.59 \\
\hline PSY & 606 & 727 & 2100 & 97 & 509 & 5 & 51.55 & 40 & 78.59 & 0.39 & 0 & 0 & 2 & 3.93 \\
\hline HYB & 680 & 787 & 1600 & 379 & 301 & 19 & 50.13 & 27 & 89.70 & 0.91 & 1 & 2.638 & 2 & 6.64 \\
\hline LCY2 & 738 & 850 & 850 & 738 & 0 & 65 & 88.08 & 2 & - & 0.27 & 5 & 6.77 & - & - \\
\hline LCYB & 941 & 1206 & 1500 & 941 & 0 & 37 & 39.32 & - & - & 0.13 & 0 & 0 & - & - \\
\hline NCED3 & 560 & 650 & 650 & 560 & 0 & 22 & 39.29 & - & - & 0.39 & 0 & 0 & - & - \\
\hline$A O C$ & 675 & 801 & 800 & 675 & 0 & 37 & 54.81 & - & - & 0.12 & 0 & 0 & - & - \\
\hline MRP4 & 774 & 782 & 900 & 363 & 411 & 14 & 38.57 & 24 & 58.39 & 0.29 & 0 & 0 & 1 & 2.43 \\
\hline $\mathrm{CCC} 1$ & 762 & 805 & 850 & 762 & 0 & 33 & 43.31 & - & - & 0.06 & 0 & 0 & - & - \\
\hline HKT1 & 238 & 1003 & 1200 & 116 & 122 & 10 & 86.21 & 9 & 73.77 & 0.17 & 0 & 0 & 1 & 8.20 \\
\hline LAPX & 282 & 321 & 400 & 145 & 137 & 11 & 75.86 & 8 & 58.39 & 0.19 & 0 & 0 & - & - \\
\hline NADK2 & 339 & 787 & 1200 & 65 & 274 & 3 & 46.15 & 25 & 91.24 & 2.12 & 0 & 0 & 1 & 3.65 \\
\hline PIP1 & 190 & 346 & 500 & 103 & 87 & 5 & 48.54 & 21 & 241.38 & 0.01 & 0 & 0 & 0 & 0.00 \\
\hline SOS1 & 495 & 579 & 1000 & 358 & 137 & 22 & 61.45 & 12 & 87.59 & 0.18 & 0 & 0 & 1 & 7.30 \\
\hline TSC & 335 & 505 & 800 & 136 & 199 & 7 & 51.47 & 17 & 85.43 & 0.58 & 0 & 0 & 0 & 0.00 \\
\hline Total & 16238 & & & 10427 & 5811 & 556 & 52.89 & 541 & 98.39 & & 7 & 0.66 & 43 & 7.58 \\
\hline
\end{tabular}

(CS) Cleaned sequence (bp); (TS) Theoretical size EST; (GS) Genomic size; SC (Sequence Coding region); SNC (Sequence Non-coding region); (SNPc) SNPs in the coding region; (Freq) SNPs frequency per Kb; (SNPnc) SNPs in the non-coding region; $\left(\boldsymbol{\pi}_{\text {nonsyn }} / \pi_{\text {syn }}\right)$ average nonsynonymous/synonimous substitution rate; (indelc) indels in coding region; (indelnc) indels in non-coding region.

See Table 1 for gene abbreviations. 
species believed to have given rise to $C$. sinensis, $C$. aurantium, $C$. paradisi and clementine, was 10.16 SNPs/kb. Comparing genera, the lowest density of SNPs was found in Poncirus trifoliata (0.55 SNPs/kb), but the highest level of inter-species differentiation was found between the latter and C. medica (18.18 SNPs/kb).

The average number of SNPs per kb that were specific to one taxon (observed at least in one genotype of the considered taxon but not in other taxa) was very similar for C. reticulata, C. medica, Papeda, Fortunella and Poncirus, with an average of 6.6, while lower rates were observed for Microcitrus (4.93), C. maxima (4.25) and Eremocitrus (3.3). No polymorphisms were observed between accessions of the same secondary species when two cultivars per species were studied (clementine, C. sinensis, C. aurantium).

Table 3. Inter accession polymorphism levels within and between taxa, and frequency of SNPS found in only a single taxon. Diagonal: average dissimilarities between two accessions within taxa (SNP/kb). Intersection: average dissimilarities between two accessions between taxa $(\mathrm{SNP} / \mathrm{Kb})$. Last lane: frequency of SNP found only in one taxon (SNP/Kb)

\begin{tabular}{|c|c|c|c|c|c|c|c|c|}
\hline SNP/Kb & C. reticulata & C. maxima & C. medica & Papeda & Fortunella & Microcitrus & Eremocitrus & Poncirus \\
\hline C. reticulata & 1.54 & & & & & & & \\
\hline C. maxima & 10.16 & 0.65 & & & & & & \\
\hline C. medica & 13.92 & 11.13 & 1.50 & & & & & \\
\hline Papeda & 8.56 & 9.66 & 14.43 & 3.37 & & & & \\
\hline Fortunella & 8.70 & 7.95 & 12.27 & 5.71 & 6.04 & & & \\
\hline Microcitrus & 9.99 & 10.09 & 13.77 & 9.74 & 8.74 & 2.41 & & \\
\hline Eremocitrus & 9.62 & 9.96 & 13.17 & 10.24 & 8.82 & 2.85 & - & \\
\hline Poncirus & 13.37 & 13.17 & 18.18 & 13.85 & 13.00 & 14.90 & 14.98 & 0.55 \\
\hline Specific SNPs & 6.77 & 4.25 & 6.28 & 6.47 & 6.65 & 4.93 & 3.33 & 6.84 \\
\hline
\end{tabular}

Diagonal: average dissimilarities between two accessions within taxa (SNP per kb). Intersection: average dissimilarities between two accessions between taxa (SNP per kb). Last lane: frequency of SNPs found only in one taxon (SNP per kb). (CR) C. reticulata; $(C M A X) C$. maxima; (CMED) C. medica; (PAP) Papeda; (FOR) Fortunella; (M) Microcitrus; (E) Eremocitrus; (P) Poncirus.

Indels

Fifty indel polymorphisms were found. The average indel frequency in coding regions was 0.66 per $\mathrm{kb}$, while the non-coding regions contained an average of 7.58 per $\mathrm{kb}$. The most frequent indel was a mononucleotide (20 out of 50), but di-, tri-, tetra- and hexa-nucleotides were also abundant (20 out of 50 in total). Larger indels were less common. The largest indel, which contained $56 \mathrm{bp}$, was found in the PKF gene.

Comparison of diversity revealed at the intra- and inter-taxa level by SNPS, indels and SSRS

We compared the diversity structures revealed by the identification of SNPs, indel markers defined from mined indel polymorphisms and 50 SSRs markers [previously used by Garcia-Lor et al. (2012b) to describe the genetic structure within Citrus]. Among the 50 indel sites identified, 25 were selected to develop indel markers. Twelve indel markers were published by Garcia-Lor et al. (2012b), and the primers for the 13 remaining markers can be found in Supplementary Information 2. 
Average data for all of the SNP, indel and SSR loci analysed in this study are presented in Table 4. The lowest average number of alleles $(N)$, and the observed $\left(H_{0}\right)$ and expected heterozygosity $\left(H_{\mathrm{e}}\right)$ in the combined eight taxa, were revealed in the SNP markers $(N=2.008$, $\left.H_{0}=0.045, H_{\mathrm{e}}=0.173\right)$. SSR markers had the highest values $\left(N=11.080, H_{0}=0.486, H_{\mathrm{e}}=\right.$ $0.822)$, and indel markers displayed intermediate values $\left(N=3.308, H_{0}=0.125, H_{\mathrm{e}}=0.317\right)$. At the interspecific level in Citrus, an increasing order of $H_{\mathrm{e}}$ values was observed for $C$. medica, $C$. maxima, and C. reticulata in all markers types (SNP, indel, SSR). However, the relative values were variable. For example, the ratios between $C$. maxima and $C$. reticulata were 0.54 or 0.92 for SNPs and SSRs, respectively.

The average $F_{\mathrm{w}}$ values (excluding secondary species) for the three types of markers showed that there was a large deficit of heterozygous individuals observed in the population ( $F_{\mathrm{w}}$ $\left.\mathrm{SNP}=0.741, F_{\mathrm{w} \text { indel }}=0.605, F_{\mathrm{w} \mathrm{SSR}}=0.409\right)$, which points to a high level of differentiation between the taxa. The Fst values of the differentiation between taxa (excluding secondary species) $\left(F_{\mathrm{st} \mathrm{SNP}}=0.644 ; F_{\text {st indel }}=0.596 ; F_{\mathrm{st} \mathrm{SSR}}=0.392\right)$ were similar to $F_{\mathrm{w}}$ values, indicating that the taxon subdivision represents most of the genetic stratification. SNPs and indels revealed a higher inter-taxon structure than SSRs. At the intraspecific level, the only taxon that showed a consistently higher level of heterozygosity than was expected for all three marker types was Poncirus trifoliata.

Table 4. Statistical summary of the diversity of SNP, indel and SSR markers

\begin{tabular}{|c|c|c|c|c|c|c|c|c|c|c|c|c|}
\hline & \multicolumn{4}{|c|}{ SNP } & \multicolumn{4}{|c|}{ Indel } & \multicolumn{4}{|c|}{ SSR } \\
\hline & $\mathrm{He}$ & Ho & Fw & $\mathbf{N}$ & $\mathrm{He}$ & Ho & Fw & $\mathbf{N}$ & $\mathrm{He}$ & Ho & Fw & $\mathbf{N}$ \\
\hline C. reticulata & 0.067 & 0.061 & 0.091 & 1.212 & 0.225 & 0.245 & -0.093 & 1.615 & 0.586 & 0.569 & 0.029 & 3.680 \\
\hline C. maxima & 0.036 & 0.034 & 0.050 & 1.097 & 0.083 & 0.096 & -0.155 & 1.231 & 0.540 & 0.549 & -0.016 & 2.900 \\
\hline C. medica & 0.022 & 0.006 & 0.737 & 1.059 & 0.027 & 0.031 & -0.124 & 1.077 & 0.268 & 0.179 & 0.331 & 1.860 \\
\hline Papeda & 0.088 & 0.048 & 0.450 & 1.223 & 0.113 & 0.051 & 0.545 & 1.308 & 0.775 & 0.480 & 0.380 & 3.520 \\
\hline Fortunella & 0.075 & 0.065 & 0.140 & 1.207 & 0.260 & 0.231 & 0.112 & 1.923 & 0.616 & 0.575 & 0.067 & 3.674 \\
\hline Microcitrus & 0.082 & 0.069 & 0.163 & 1.150 & 0.077 & 0.077 & 0.000 & 1.077 & 0.713 & 0.610 & 0.145 & 2.700 \\
\hline Eremocitrus & 0.085 & 0.085 & 0.000 & 1.085 & 0.000 & 0.000 & 0.000 & 1.000 & 0.563 & 0.563 & 0.000 & 1.563 \\
\hline Poncirus & 0.024 & 0.034 & -0.416 & 1.049 & 0.046 & 0.077 & -0.665 & 1.077 & 0.309 & 0.440 & -0.423 & 1.660 \\
\hline Total AT & 0.173 & 0.045 & 0.741 & 2.008 & 0.317 & 0.125 & 0.605 & 3.308 & 0.822 & 0.486 & 0.409 & 11.080 \\
\hline Whole dataset & 0.166 & 0.072 & 0.568 & 2.036 & 0.317 & 0.172 & 0.457 & 4.154 & 0.814 & 0.554 & 0.320 & 11.560 \\
\hline
\end{tabular}

Mean values are represented in the table. $\left(H_{\mathrm{e}}\right)$ Unbiased expected heterozygosity; $\left(H_{0}\right)$ Heterozygosity observed; $\left(F_{\mathrm{w}}\right)$ Wright fixation Index; $(N)$ Allele number; (AT) Ancestral taxa

\section{Statistical test of neutrality and haplotype structure in the 'true citrus fruit trees' excluding secondary cultivated citrus species and hybrid cultivars.}

The nucleotide variation observed for the gene sequences analysed is summarised for each taxon in Table 5, and the data presented for each gene is provided in [Supplementary Information 3]. Average total nucleotide diversity $\left(\pi_{T}\right)$ was 0.012 for the entire sample set, ranging from 0.003 for citron to 0.009 for the Papeda group. Nucleotide diversity in silent and synonymous substitution sites was similar between the taxa and for the entire population, but non-synonymous nucleotide diversity was 3.52 times lower than the synonymous one (average $\Pi_{\text {nonsyn }}=0.006$ ). The non-synonymous substitution rate varied from 0.000 (PEPC, ACO and PIP1) to 0.010 (CHI, PSY, NADK2), and the ratio of non-synonymous to synonymous diversity ranged from 0.000 at PEPC (high conservative selection) to 2.273 at the EMA locus, which 
suggests that selective constraints and/or the history of adaptive evolution vary between genes. The average non-synonymous/silent substitution rate was 0.345 for all of the genes and the entire population, indicating purifying selection. Within taxa, only the $C$. reticulata group at the HYB locus $\left(\pi_{\text {nonsyn }} / \pi_{\text {syn }}=1.421\right)$ and the F3'H locus $\left(\pi_{\text {nonsyn }} / \pi_{\text {syn }}=1.767\right)$ displayed higher nonsynonymous than synonymous diversity. There were some groups with null synonymous mutations in the exons, so the $\pi_{\text {nonsyn }} / \pi_{\text {syn }}$ ratio was not possible to calculate. In the entire sample set, several loci displayed a non-synonymous/synonymous ratio $>1$, including $\mathrm{CHI}$ $\left(\pi_{\text {nonsyn }} / \pi_{\text {syn }}=1.377\right)$, EMA ( $\left.\pi_{\text {nonsyn }} / \pi_{\text {syn }}=2.273\right)$ and NADK2 $\left(\pi_{\text {nonsyn }} / \pi_{\text {syn }}=2.117\right)$. Taking into account only the basic taxa (excluding secondary species and recent hybrids), four loci showed values $>1$, including $\mathrm{CHI}\left(\pi_{\text {nonsyn }} / \pi_{\text {syn }}=1.381\right)$, EMA $\left(\pi_{\text {nonsyn }} / \pi_{\text {syn }}=1.511\right)$, PSY $\left(\pi_{\text {nonsyn }} / \pi_{\text {syn }}=\right.$ $3.533)$ and NADK2 $\left(\pi_{\text {nonsyn }} / \pi_{\text {syn }}=2.043\right)$. The PKF locus had a $\pi_{\text {nonsyn }} / \pi_{\text {syn }}$ value of 0.883 for the entire population and 1.072 for the ancestral taxa group. For the entire population MDH and HYB loci had a $\pi_{\text {nonsyn }} / \pi_{\text {syn }}$ value of 1.065 and 0.914 respectively.

The level of differentiation between the taxa (evaluated by $F_{\mathrm{st}}$; Supplementary Information 3) was relatively homogenous among the genes. Highest and lowest values were found for SOS1 $\left(F_{\mathrm{st}}=0.814\right)$ and PIP1 $\left(F_{\mathrm{st}}=0.438\right)$, respectively, with an average of $0.644+/-$ 0.036 .

No significative Tajima's $D$ value was found in any of the genes in the entire population [Supplementary Information 3].

Table 5. Summary of nucleotide diversity and divergence within and between species

\begin{tabular}{lccccccccc}
\hline \multicolumn{1}{c}{ Taxa } & $\boldsymbol{S}$ & $\boldsymbol{\Pi}_{\boldsymbol{T}}$ & $\boldsymbol{\Pi}_{\text {sil }}$ & $\boldsymbol{\Pi}_{\text {syn }}$ & $\boldsymbol{\pi}_{\text {nonsyn }}$ & $\boldsymbol{\pi}_{\text {nonsyn }} / \boldsymbol{\pi}_{\text {syn }}$ & $\boldsymbol{N}_{\boldsymbol{h}}$ & $\boldsymbol{H}_{\mathrm{d}}$ & $\boldsymbol{H}_{\mathrm{d}}(\mathbf{S D})$ \\
\hline C. reticulata & 8.926 & 0.005 & 0.008 & 0.010 & 0.003 & 0.411 & 4.407 & 0.593 & 0.096 \\
C. maxima & 3.926 & 0.004 & 0.005 & 0.004 & 0.001 & 0.191 & 3.222 & 0.521 & 0.116 \\
C. medica & 2.815 & 0.003 & 0.004 & 0.004 & 0.001 & 0.256 & 2.037 & 0.296 & 0.068 \\
Fortunella & 8.481 & 0.006 & 0.009 & 0.008 & 0.003 & 0.285 & 5.185 & 0.683 & 0.097 \\
Papeda & 9.630 & 0.009 & 0.015 & 0.014 & 0.003 & 0.292 & 4.519 & 0.871 & 0.126 \\
Microcitrus & 5.889 & 0.006 & 0.009 & 0.011 & 0.003 & 0.184 & 2.926 & 0.760 & 0.198 \\
Eremocitrus & 3.407 & 0.006 & 0.009 & 0.013 & 0.004 & 0.154 & 1.778 & 0.772 & 0.380 \\
Poncirus & 2.407 & 0.003 & 0.005 & 0.003 & 0.000 & 0.088 & 2.148 & 0.469 & 0.099 \\
\hline Main taxa & 39.667 & 0.013 & 0.021 & 0.020 & 0.006 & 0.555 & 23.074 & 0.926 & 0.016 \\
Whole Pop & 40.926 & 0.012 & 0.021 & 0.020 & 0.005 & 0.495 & 28.333 & 0.901 & 0.015 \\
\hline max & 9.630 & 0.009 & 0.015 & 0.014 & 0.004 & 0.411 & 5.185 & 0.871 & 0.380 \\
min & 2.407 & 0.003 & 0.004 & 0.003 & 0.000 & 0.088 & 1.778 & 0.296 & 0.068 \\
\hline
\end{tabular}

(S) Segregating sites, $\left(\pi_{T}\right)$ Nucleotide diversity total, $\left(\pi_{\text {sil }}\right)$ Nucleotide diversity silent sites, $\left(\pi_{\text {syn }}\right)$ Nucleotide diversity synonymous sites, ( $\left.\pi_{\text {nonsyn/syn }}\right)$ Ratio nucleotide diversity nonsynonymous/synonymous sites, $\left(N_{\mathrm{h}}\right)$ Number of haplotypes, $\left(H_{\mathrm{d}}\right)$ Haplotype diversity, (SD) Standard deviation. Max and min: maximum and minimum values within the basic taxa

The average number of haplotypes per locus in the entire population was 28.33 , with a maximum value of 5.185 haplotypes in Fortunella and a minimum value of 1.778 in Eremocitrus. Regarding the four main ancestors in Citrus, Papeda had the highest number of haplotypes (4.519), followed by C. reticulata (4.407), C. maxima (3.222) and C. medica (2.037). At intra- 
taxon level, haplotype diversity ranged from 0.871 for the Papeda to 0.296 for $C$. medica (Table $5)$.

\section{Phylogenetic analysis}

Among all of the models tested via Phylemon website (, the model with the best fit was $\mathrm{TVM}+\mathrm{I}+\mathrm{G}+\mathrm{F}$ (with $\mathrm{SH}$-like branch supports alone). This model takes into account the nucleotide substitution model TVM 'Transitional model' (five substitution classes: AC, AT, CG, GT, AG = $C T)$, the proportion of invariable sites (I), the nucleotide frequency $(F)$ and the gamma distribution $(G)$. The phylogenetic relationships between Citrus species and their relatives inferred from ML method using this model are represented in Figure 1. Branch support (BS) is given in all branches. The different 'true citrus fruit trees' genotypes were rooted using Severinia buxifolia as outgroup.

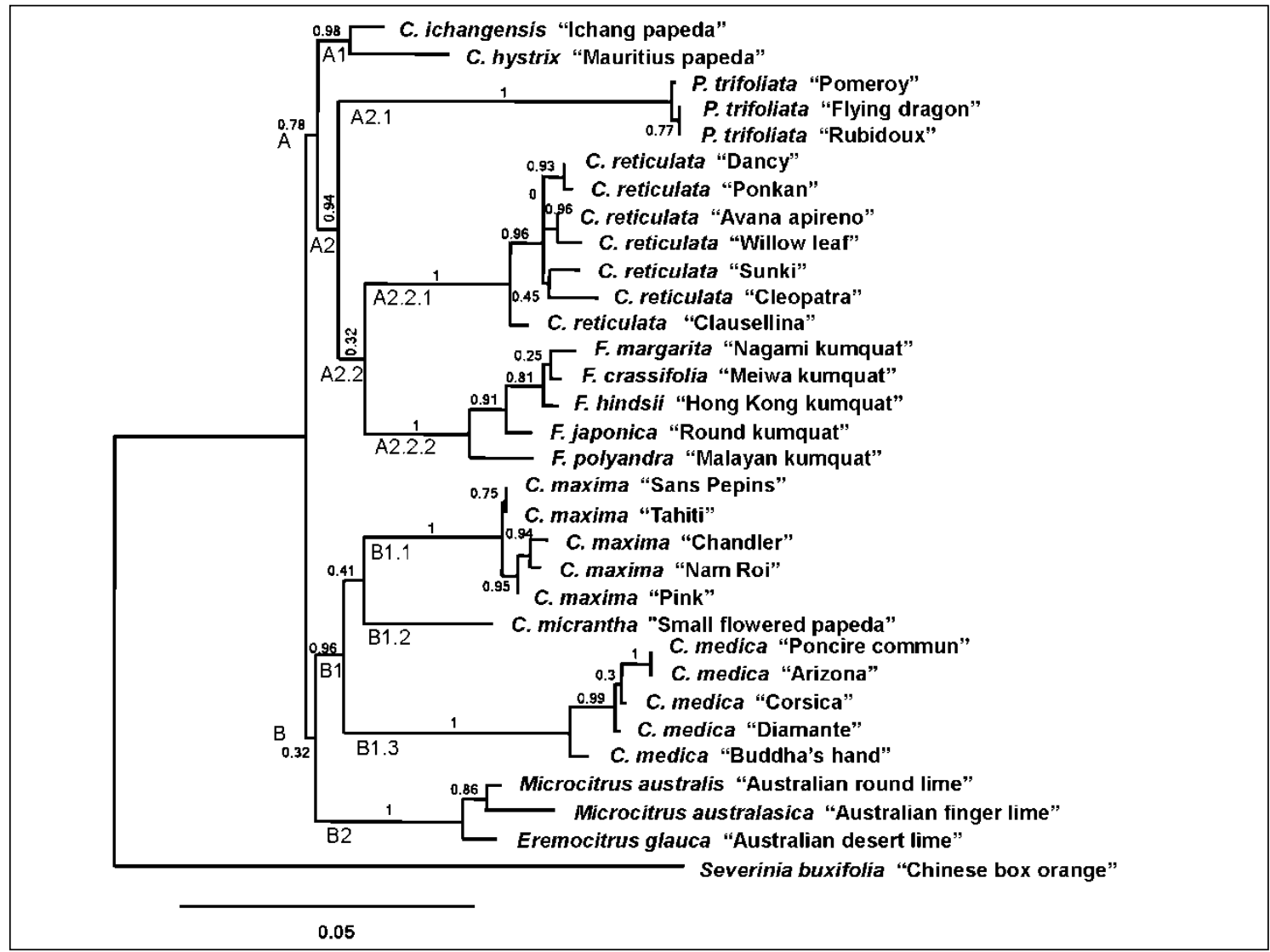

Figure 1. Phylogenetic relationship between Citrus ancestral taxa (C. reticulata, C. maxima, $C$. medica, Papeda) and relatives (Fortunella, Microcitrus, Eremocitrus, Poncirus trifoliata). Phyml Best AIC Tree (v. 1.02b), model TVM+I+G+F (with SH-like branch supports alone)

The first two clades ( $A$ and $B$ ) are each divided in two subclades. The clade $A$ has a medium BS (0.78), joining a subclade A1 (BS $=0.98$ ) of two Papeda species ( $C$. hystrix and $C$. ichangensis) and a strong subclade A2 (BS $=0.94$ ) including all Poncirus trifoliata (monospecific subclade $A 2.1, B S=1$ ), all the $C$. reticulata accessions (monospecific subclade A2.2.1, BS =1) and all Fortunella accessions (monogeneric subclade A2.2.2, BS $=1$ ). Fortunella and $C$. 
reticulata are joined in a subclade A2.2 with a low BS (0.32). On the other side of the tree, clade $B$ (low $B S=0.32$ ) includes two groups. The first group, $B 1(B S=0.96)$, is divided into three specific subclades highly supported, $C$. maxima accessions $(B 1.1$; $B S=1)$, C. micrantha $(B 1.2$; only one accession) and $C$. medica (B1.3; $\mathrm{BS}=1$ ) accessions. The second subclade B2 (BS = 1) includes Microcitrus and Eremocitrus, two strongly associated genera of Australian origin. Papeda is the only group that does not display a monophyletic structure, the accessions of each of the other groups (Poncirus, C. reticulata, Fortunella, C. maxima and C. medica, Microcitrus and Eremocitrus) are all joined in specific clades clearly differentiated from the other taxa.

This phylogenetic structure is similar, for several strong grouping, to the structure observed using Neighbour Joining (NJ) analysis based on SNP data (Figure 2). In the NJ tree, the association between $C$. reticulata and Fortunella $(B S=0.96)$ is maintained, as are the $C$. maxima / C. medica ( $\mathrm{BS}=0.8)$ and Microcitrus / Eremocitrus $(\mathrm{BS}=1)$ associations. The Papeda group is shifted from one group to the other. Poncirus trifoliata appears as the most distant species, it is the first one that separates from the others. This in agreement with the high differentiation level of Poncirus with all other taxa (Table 3).

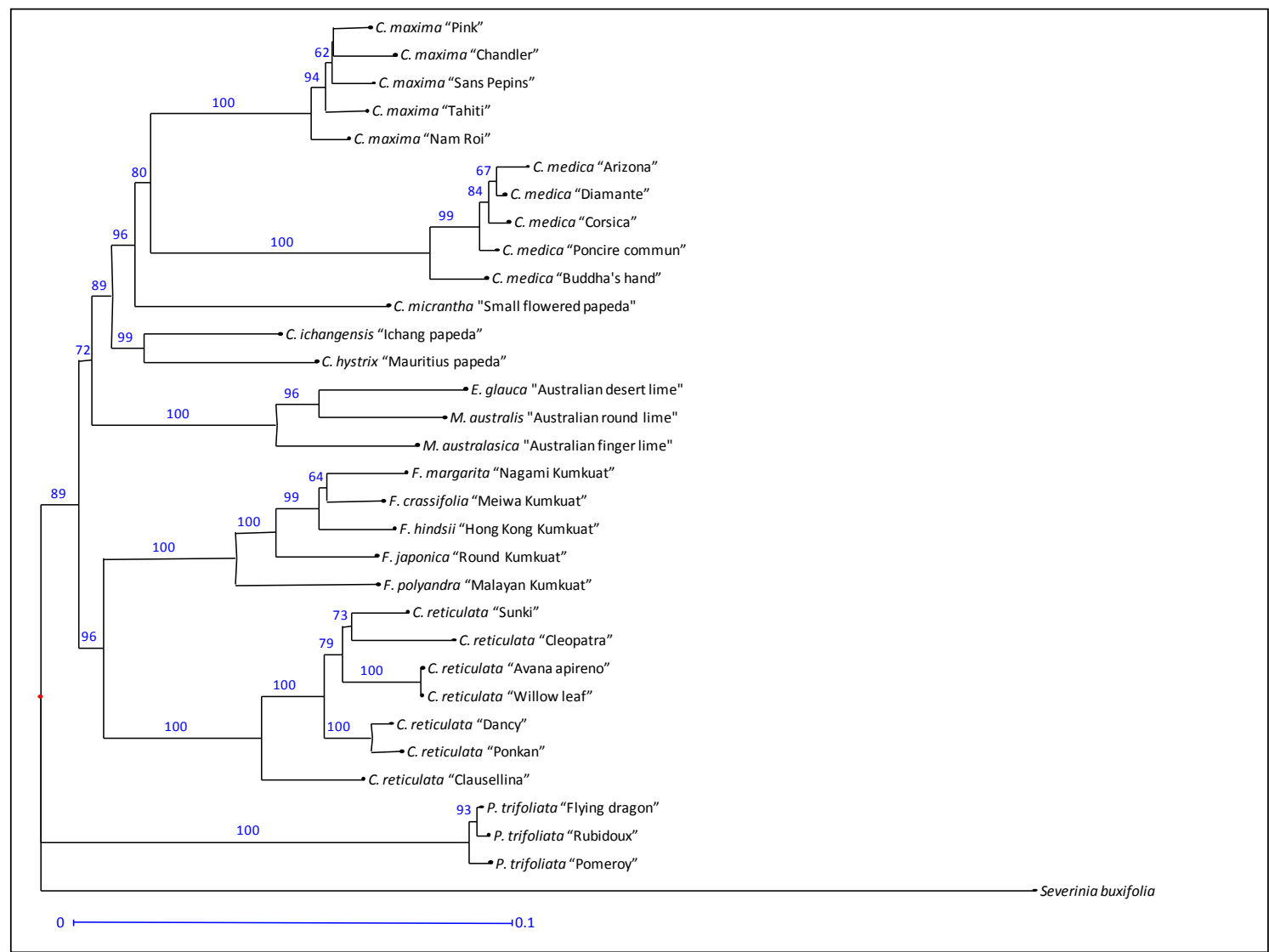

Figure 2. NJ tree with 1097 SNP markers in the ancestral Citrus species and relatives (1000 bootstraps performed). Branch support over $50 \%$ are shown

When the secondary species and interspecific hybrids were added to the analysis [Supplementary Information 4], the NJ representation was modified, the relationships described before are not maintained. Citrus reticulata appears to be more closely related to $C$. maxima 
than to Fortunella, and C. medica is not so closely related to $C$. maxima as was suggested by the Phylemon and Darwin analysis that excluded the hybrid genotypes.

\section{Genome structure of citrus secondary species and hybrids}

We used factorial analysis to examine the potential contribution of the ancestral species to the inheritance of 27 genes in secondary cultivated species (Table 6). For the SNPs of these 27 genes, almost $70 \%$ of the diversity in Citrus species is explained by the first two axes (Figure 3). The basic Citrus taxa are clearly distinguished. Secondary species are positioned between their putative parental gene pools: $C$. sinensis is between $C$. maxima and $C$. reticulata, $C$. paradisi is between $C$. sinensis and $C$. maxima, $C$. limon is between $C$. aurantium and $C$. medica and $C$. aurantifolia between $C$. medica and $C$. micrantha (Figure 3 ). With the goal of performing a gene-by-gene analysis of the phylogenetic inheritance in the secondary species, we performed a PCoA for each gene using the basic taxa of cultivated citrus as active individuals, and we projected the secondary species genotypes onto the defined axes. The phylogenetic inheritance was inferred from the position of the secondary species in the PCoA relative to the ancestral species and the analysis of SNP allelic locus configurations. The genetic structure of the FLS locus (Figure 4) is presented as an example of phylogenetic assignation. Grapefruit, sweet orange, sour orange, tangor 'King' and tangelo 'Orlando' are in an intermediate position between the $C$. reticulata (mandarin; $M$ ) and C. maxima (pummelo; $P$ ) groups. It was therefore assumed that these species should have inherited one allele of this gene from each of these ancestral groups (interspecific heterozygosity MP). This was confirmed by examining the allelic configuration at each SNP locus. Using the same approach, lemon appears to be heterozygous (MC) for the $C$. reticulata and C. medica (citron; C) alleles, while clementine appears to have inherited two $C$. reticulata alleles (MM).

For most genes (18/27) clementines appear to have inherited C. reticulata alleles in phylogenetic homozygosity. However, nine genes appear to be heterozygous between $C$. reticulata and $C$. maxima. For all the genes analysed, the estimated contribution of $C$. reticulata was $83.3 \%$, while the estimated contribution of C. maxima was $16.7 \%$. 


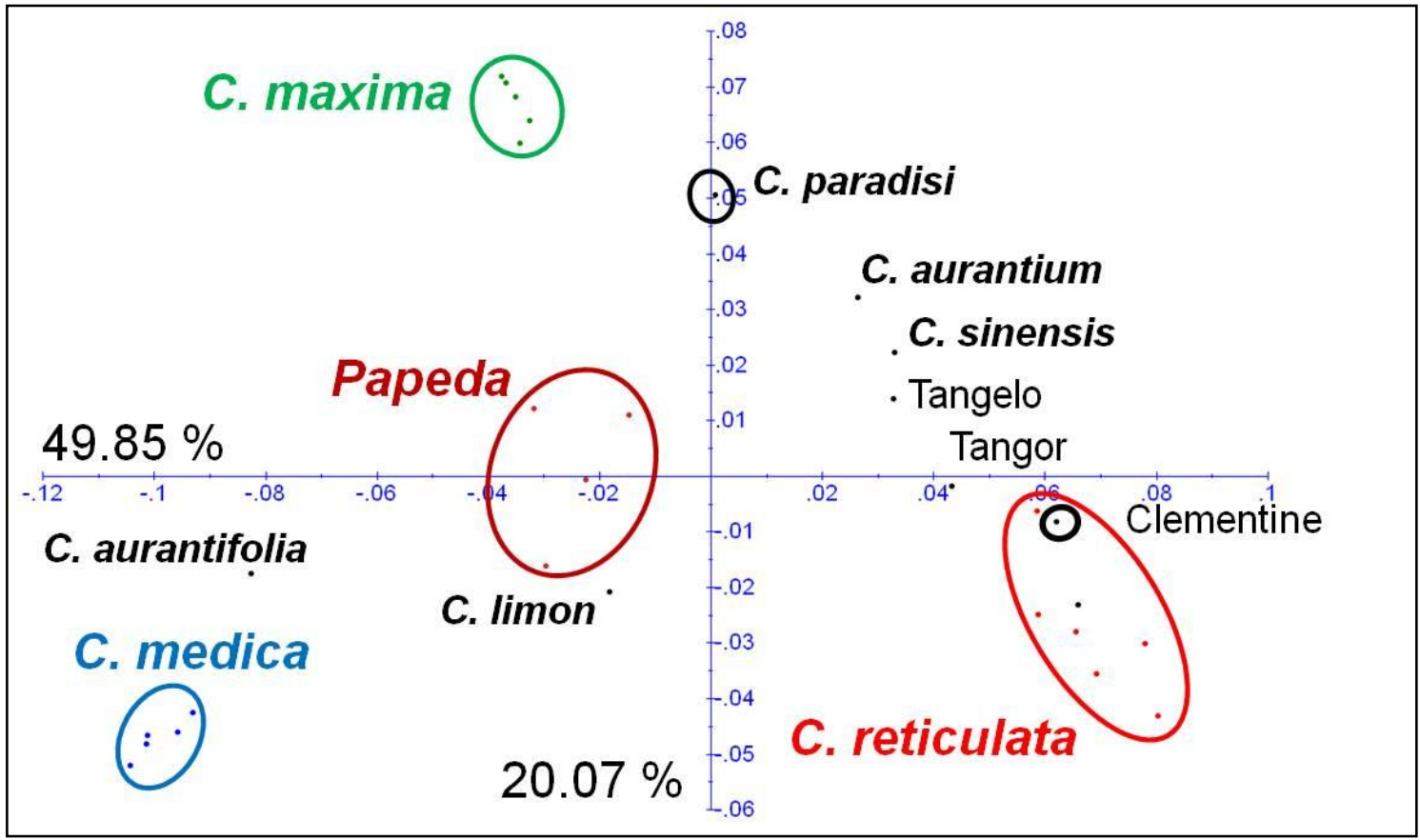

Figure 3. Genetic relationship between secondary Citrus species and basic taxa (factorial analysis; axes 1/2)

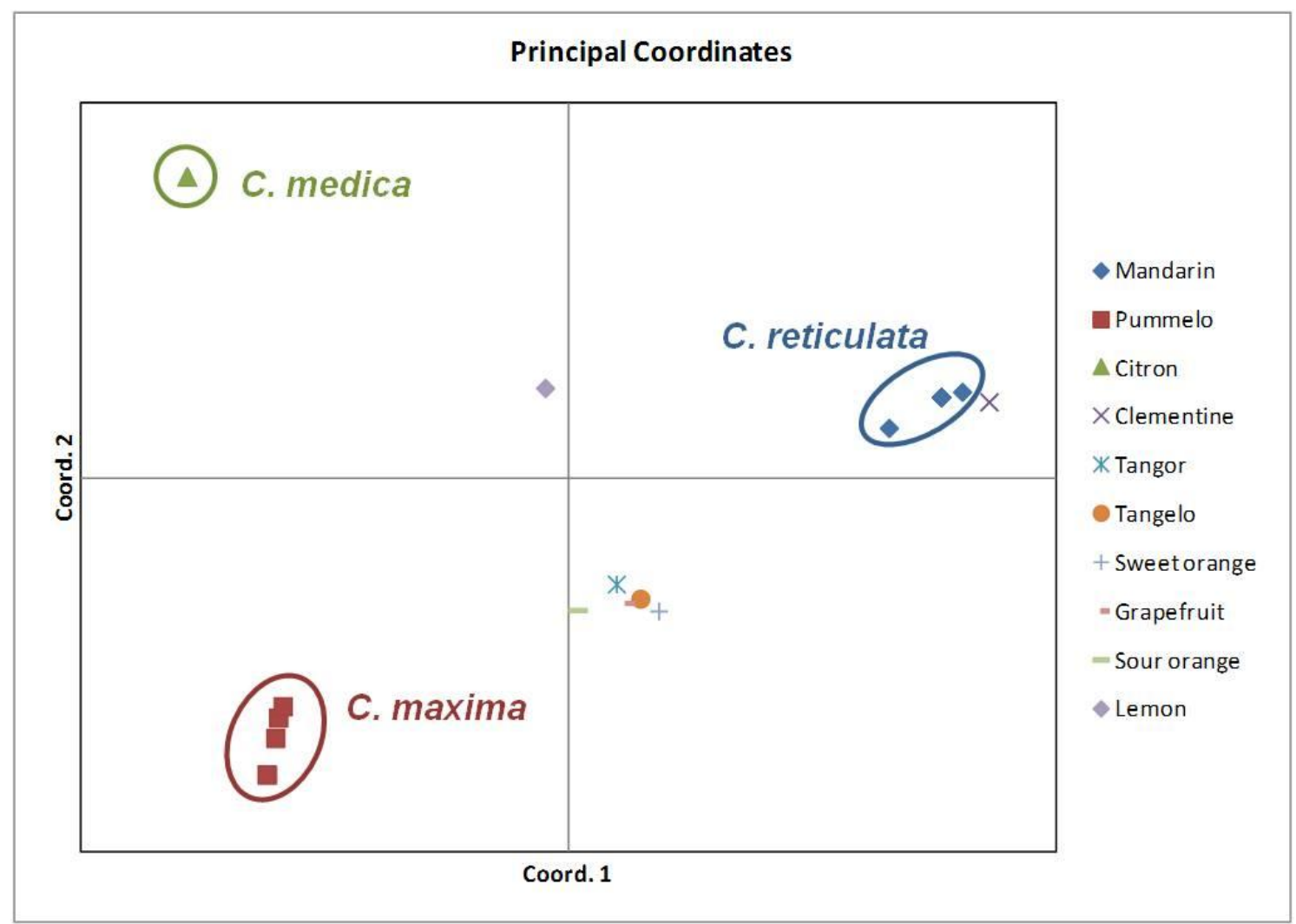

Figure 4. Genetic organizational analysis (principal co-ordinates) of secondary species and recent hybrids (flavonoid synthase gene) 
Table 6. Phylogenetic origins of genes of secondary species and hybrids

\begin{tabular}{|c|c|c|c|c|c|c|c|c|c|c|c|c|c|c|c|c|}
\hline Gene & & & & & & & & & & $\mathrm{AU}$ & & CL & & $\mathrm{K}$ & & \\
\hline $\mathbf{C H I}$ & $M$ & $P$ & $M$ & $P$ & $P$ & $P$ & $M$ & $P$ & C & C & C & M/P? & $M$ & $M$ & $M$ & $P$ \\
\hline CHS & $\mathrm{M}$ & $\mathrm{M}$ & $\mathrm{M}$ & $\mathrm{M}$ & $\mathrm{M}$ & $\mathrm{P}$ & $\mathrm{M}$ & $\mathrm{P}$ & C & PAP & C & $\mathrm{M}$ & $\mathrm{M}$ & $\mathrm{M}$ & $\mathrm{M}$ & $\mathrm{M}$ \\
\hline FLS & $\mathrm{M}$ & $M$ & $\mathrm{M}$ & $P$ & $M$ & $\mathrm{P}$ & $M$ & $P$ & C & PAP & C & $M$ & $M$ & $P$ & $M$ & $P$ \\
\hline F3'H & $\mathrm{M}$ & $M$ & $M$ & $M$ & $P$ & $P$ & $M$ & $P$ & C & PAP & C & $M$ & $M$ & $M$ & $M$ & $M$ \\
\hline DFR & $\mathrm{M}$ & $P$ & $M$ & $P$ & $P$ & $\mathrm{P}$ & $M$ & $P$ & C & PAP & C & $M$ & $M$ & $M$ & $M$ & $P$ \\
\hline EMA & $\mathrm{M}$ & $M$ & $M$ & $M$ & $M$ & $\mathrm{P}$ & $M$ & $P$ & C & PAP & C & $M$ & $M$ & $M$ & $M$ & $M$ \\
\hline MDH & $\mathrm{M}$ & $M$ & $M$ & $P$ & $P$ & $\mathrm{P}$ & $M$ & $P$ & C & PAP & C & $P$ & $M$ & $P$ & $M$ & $P$ \\
\hline ACO & $\mathrm{M}$ & $M$ & $M$ & $M$ & $M$ & $\mathrm{P}$ & $M$ & $P$ & $?$ & $?$ & C & $M$ & $M$ & $M$ & $M$ & $M$ \\
\hline TRPA & $\mathrm{M}$ & $\mathrm{P}$ & $\mathrm{P}$ & $P$ & $\mathrm{P}$ & $\mathrm{P}$ & $M$ & $P$ & C & PAP & C & $M$ & $M$ & $P$ & $M$ & $\mathrm{P}$ \\
\hline INVA & $\mathrm{M}$ & $M$ & $M$ & $P$ & $P$ & $\mathrm{P}$ & $M$ & $P$ & C & PAP & C & $P$ & $M$ & $P$ & $M$ & $P$ \\
\hline PEPC & $\mathrm{M}$ & $M$ & $M$ & $P$ & $P$ & $P$ & $M$ & $P$ & $C$ & PAP & C & $P$ & $M$ & $M$ & $M$ & $P$ \\
\hline PKF & $\mathrm{M}$ & $\mathrm{P}$ & $M$ & $\mathrm{P}$ & $\mathrm{P}$ & $\mathrm{P}$ & $?$ & $P$ & C & PAP & C & $\mathrm{M}$ & $M$ & $P$ & $M$ & $P$ \\
\hline DXS & $\mathrm{M}$ & $M$ & $M$ & $\mathrm{P}$ & $M$ & $\mathrm{P}$ & $M$ & $P$ & C & PAP & C & $\mathrm{M}$ & $\mathrm{M}$ & $P$ & $M$ & $P$ \\
\hline PSY & $\mathrm{M}$ & $M$ & $\mathrm{M}$ & $\mathrm{P}$ & $\mathrm{M}$ & $\mathrm{P}$ & $M$ & $P$ & C & PAP & C & $\mathrm{M}$ & $M$ & $M$ & $M$ & $M$ \\
\hline HYB & $\mathrm{M}$ & $M$ & $\mathrm{M}$ & $M$ & $\mathrm{M}$ & $\mathrm{P}$ & $M$ & $\mathrm{P}$ & $?$ & ? & C & $\mathrm{M}$ & $M$ & $M$ & $M$ & $M$ \\
\hline LCY2 & $\mathrm{M}$ & $\mathrm{P}$ & $\mathrm{M}$ & $\mathrm{P}$ & $M$ & $P$ & $M$ & $P$ & C & PAP & C & $M$ & $M$ & $\mathrm{P}$ & $M$ & $M$ \\
\hline LCYB & $\mathrm{M}$ & $\mathrm{P}$ & $\mathrm{M}$ & $P$ & $\mathrm{M}$ & $\mathrm{P}$ & $M$ & $P$ & C & PAP & C & $\mathrm{M}$ & $\mathrm{M}$ & $M$ & $M$ & $M$ \\
\hline NCED3 & $\mathrm{M}$ & $\mathrm{P}$ & $P$ & $\mathrm{P}$ & $\mathrm{P}$ & $\mathrm{P}$ & $M$ & $P$ & C & PAP & C & P & $\mathrm{M}$ & $P$ & $M$ & $P$ \\
\hline AOC & $\mathrm{M}$ & $M$ & $M$ & $M$ & $M$ & $\mathrm{P}$ & $M$ & $P$ & C & PAP & C & $\mathrm{M}$ & $\mathrm{M}$ & $M$ & $M$ & $M$ \\
\hline MRP4 & $\mathrm{M}$ & $M$ & $\mathrm{M}$ & $M$ & $\mathrm{M}$ & $\mathrm{P}$ & $M$ & $P$ & C & PAP & C & $\mathrm{M}$ & $M$ & $\mathrm{M}$ & $M$ & $M$ \\
\hline CCC1 & $\mathrm{M}$ & $\mathrm{P}$ & $\mathrm{P}$ & $P$ & $M$ & $P$ & $M$ & $P$ & C & PAP & C & $M$ & $M$ & $P$ & $\mathrm{P}$ & $P$ \\
\hline HKT1 & $\mathrm{M}$ & $\mathrm{P}$ & $M$ & $P$ & $\mathrm{M}$ & $\mathrm{P}$ & $M$ & $P$ & C & PAP & C & $\mathrm{M}$ & $M$ & $P$ & $M$ & $M$ \\
\hline LAPX & $\mathrm{M}$ & $M$ & $M$ & $\mathrm{P}$ & $\mathrm{M}$ & $\mathrm{P}$ & $M$ & $P$ & C & PAP & C & $\mathrm{M}$ & $?$ & $P$ & $M$ & $P$ \\
\hline NADK2 & $\mathrm{M}$ & $\mathrm{M}$ & $\mathrm{M}$ & $\mathrm{P}$ & $\mathrm{P}$ & $\mathrm{P}$ & $M$ & $\mathrm{P}$ & C & PAP & C & $\mathrm{M}$ & $M$ & $M$ & $P$ & $P$ \\
\hline PIP1 & $\mathrm{M}$ & $\mathrm{M}$ & $\mathrm{M}$ & $M$ & $M$ & $\mathrm{P}$ & $?$ & $\mathrm{P}$ & $?$ & $?$ & C & $P$ & $\mathrm{M}$ & $\mathrm{M}$ & $M$ & $M$ \\
\hline Sos1 & $\mathrm{M}$ & $M$ & $M$ & $\mathrm{P}$ & $P$ & $\mathrm{P}$ & $\dot{M}$ & $P$ & $\dot{C}$ & PAP & C & $P$ & $M$ & $P$ & $M$ & $P$ \\
\hline TSC & $\mathrm{M}$ & $M$ & $M$ & $\mathrm{P}$ & $M$ & $\mathrm{P}$ & $M$ & $\mathrm{P}$ & C & PAP & C & $M$ & $M$ & $M$ & $M$ & $\mathrm{P}$ \\
\hline
\end{tabular}

Citrus sinensis appears to contain more alleles from $C$. reticulata $(59.3 \%)$ than from $C$. maxima (40.7\%). It inherited two alleles from C. maxima (PP) for three genes and two alleles from C. reticulata (MM) for eight genes. The remainder of the genes appear to be in phylogenetic heterozygosity from both gene pools (MP).

Citrus paradisi has 11 genes that were solely inherited from C. maxima, while the rest of the genes were heterozygously inherited from $C$. maxima and $C$. reticulata. The contributions from the parental lines were therefore $70.4 \%$ for $C$. maxima and $29.6 \%$ for $C$. reticulata.

Citrus aurantium contains two loci with parental origins that were not possible to define due to the presence of specific alleles at the SNP loci. The other loci were heterozygous $C$. maxima / C. reticulata (MP). Therefore, for the loci with complete phylogenetic assignation, the contributions of $C$. maxima and $C$. reticulata were each $50 \%$.

Citrus aurantifolia contains three genes with phylogenetic origins that were not possible to infer. Most of the other genes showed interspecific heterozygosity between $C$. medica and Papeda. However, $\mathrm{CHI}$ appeared to be homozygous for $C$. medica alleles (CC). Therefore, for the 24 genes that could be analysed, the contributions of $C$. medica and Papeda were 53 and $47 \%$, respectively. 
Citrus limon showed the most diverse combination of parental contribution patterns. Twenty genes resembled a combination of $C$. medica and $C$. reticulata genes, six genes resembled a combination of $C$. medica and $C$. maxima genes, and one locus could not clearly be identified. For the genes that could be identified, C. medica contributed $50 \%, C$. reticulata contributed $38.5 \%$ and C. maxima contributed $11.5 \%$ to the C. limon genome.

'King', which is assumed to be a tangor (C. reticulata $\times$ C. sinensis), and tangelo 'Orlando' (C. paradisi x $C$. reticulata) contained some genes that exhibited interspecific heterozygosity ( $C$. reticulata and $C$. maxima; MP) and some that displayed monospecific inheritance (MM or PP). The relative contributions of the C. reticulata and C. maxima gene pools were, respectively, 75.93 and $24.07 \%$ for 'King' and 66.67 and $33.33 \%$ for 'Orlando'. 


\section{DISCUSSION}

SNP and indel discovery and analysis of the relative utility of these markers compared to SSRs for use in diversity and phylogenetic studies.

In 'true citrus fruit trees', the average number of SNPs per kb in non-coding regions is almost two times higher than in coding regions. This value is high compared to the value obtained for Eucalyptus spp. (1.5 times higher; Külheim et al., 2009). The mean frequency of SNPs/kb found in exons was 28.96 for Citrus, which is higher than in other species such as Populus tremula, with 16.7 SNPs/Kb (Ingvarsson, 2005), and in maize, with $23.25 \mathrm{SNPs} / \mathrm{Kb}$ (Yamasaki et al., 2005). Regarding the SNP frequency in Citrus spp. the values were lower [C. reticulata (15.15 SNP/kb), C. maxima (4.70 SNP/kb), C. medica (2.21 SNP/kb)]. Moreover, the value is lower than that found in Quercus crispula, with 40 SNPs/Kb (Quang et al., 2008) and Eucalyptus camaldulensis, with 47.62 SNPs/Kb (Külheim et al., 2009). The percentage of transition and transversion events are similar to those found in other species, such as oil palm (0.58 and 0.42, respectively; Riju et al., 2007). In Citrus, these results are in agreement with results reported by Dong et al. (2010), Terol et al. (2008) and Novelli et al. (2004). In contrast, the transition fraction was found to be substantially higher in poplar (70\%; Tuskan et al., 2006).

The nucleotide diversity value observed in the 'true citrus fruit trees' and in C. reticulata $(\pi=0.005)$ was similar to the values observed in grapevine ( $\pi=0.005$; Lijavetzky et al., 2007), maize $(\pi=0.006$; Ching et al., 2002) and rye ( $\pi=0.006$; Li et al., 2011), while the value was approximately five times higher than those observed in soybean $(\pi=0.00097$; Zhu et al., 2003) and human $(\pi=0.001$; Sachidanandam et al., 2001). Compared with the diversity data within Citrus obtained with SNPs mined in clementine (Ollitrault et al., 2012a), it appears that the relative diversity levels of the three basic taxa were quite different. Indeed, the Nei diversity values $\left(H_{\mathrm{e}}\right)$ of $C$. maxima and $C$. medica over $C$. reticulata were $0.23(0.063 / 0.279)$ and 0.20 $(0.057$ / 0.279), respectively, while the values obtained in the present study were 0.53 (0.036 / $0.067)$ and 0.33 (0.022/0.067), respectively, confirming the conclusion of Ollitrault et al. (2012a) that the ascertainment bias due to the scarcity and specificity of the discovery panel of the SNPs mined in clementine resulted in an overestimation of the relative diversity within $C$. reticulata. Analysis of the average inter-accession polymorphism within and between species reveals that for the three basic taxa of cultivated Citrus ( $C$. reticulata, C. maxima, C. medica), the ratios between and within species were high. For example, within $C$. reticulata and between C. reticulata and C. maxima, the ratio was close to 6.6 (10.16/1.54). Therefore, the analysis of SNP density along the genome should help differentiate between genomic regions with interspecific heterozygosity (MP for example) and those that result from intraspecific inheritance (MM or PP, for example) in the genomes of secondary species.

The information obtained by studying the allelic diversity of the analysed genes will allow us to optimise molecular tools for both genomic and transcriptomic studies. The identification of conserved areas can be used to develop primers or hybridization sequences to 
limit sources of bias such as null alleles or differential allelic PCR competition or hybridisation. Identification of the different alleles of these genes also opens the way for allele-specific expression studies.

The frequencies of indels per $\mathrm{kb}$ in the 'true citrus fruit trees' species were 0.66 and 7.58 in exon and intron sequences, respectively. These frequencies are comparable to values reported for other species such as maize (18 genes studied, $6935 \mathrm{bp}$ ), where 0.43 and 11.76 indels/kb were found in coding and non-coding regions, respectively (Ching et al., 2002), and Brassica (557 clone sequences, 1396498 bp), with 0.45 and 7.42 indel/kb in coding and noncoding regions, respectively (Park et al., 2010). In melon (34 ESTs sequenced, \pm 15000 bp), indels occurred less frequently in introns (approximately $0.60 / \mathrm{kb}$ ), and no indels were found inside coding regions (Morales et al., 2004). In grapevine (230 gene fragments sequenced, > $1 \mathrm{Mb}$ ), very low levels of indel polymorphism were found, with 0.11 and 2.25 indel/kb in coding and non-coding regions, respectively (Lijavetzky et al., 2007).

Considering the eight basic taxa together, the fixation index $\left(F_{\mathrm{w}}\right)$ values and the differentiation index values $\left(F_{\mathrm{st}}\right)$ between taxa obtained using three types of markers (SSRs, SNPs, indels) confirmed the high degree of stratification in differentiated taxa with limited gene flows. However, the levels of diversity revealed by the three types of markers were quite different. The indel markers developed in this study confirmed that indels are very efficient tools for inter-specific differentiation, as was demonstrated by Garcia-Lor et al. (2012a) and Ollitrault et al. (2012). The indel markers developed in this study had an average $F_{\mathrm{st}}$ value of 0.596 , similar to that obtained using SNP markers $\left(F_{\mathrm{st}}=0.644\right)$, whereas with $50 \mathrm{SSR}$ markers analysed for the same accessions, the $F_{\text {st }}$ value was only 0.392. In contrast, the SNP loci and indels mined from our much diversified interspecific panel appeared, on average, to be less polymorphic to describe intraspecific polymorphism. However, in our study, which includes several genotypes for each species, we also identified numerous SNP loci that revealed intraspecific diversity that should be useful for germplasm characterisation and management. Unlike SSRs and indel sequences, SNPs can be employed in high-throughput screening and in relatively low-cost genotyping methods. Their utility is limited, however, due to the fact that they are usually present only as diallelic polymorphisms.

\section{Evolution of citrus genes}

In 'true citrus fruit trees', the average ratio of non-synonymous to silent SNP rates per site $\left(\pi_{\text {nonsyn }} / \pi_{\text {sil }}\right)$ was 0.345 . Within Citrus spp. similar values were found in C. reticulata $(0.385)$ and $C$. medica (0.339), but higher in C. maxima (0.577). This is higher than the 0.17 and 0.21 ratios observed in white spruce (Pavy et al., 2006) and in Arabidopsis thaliana (in a study of 242 genes; Zhang et al., 2002), respectively. These relatively low values indicate that, on average, white spruce open reading frames and nuclear genes in $A$. thaliana are probably under higher purifying selection pressure than the genes of 'true citrus fruit trees'. This can probably be attributed to the wide diversity encompassed by 'true citrus fruit trees' and the high genetic and 
phenotypic differentiation between the different taxa that have experienced allopatric evolution (even if they are still sexually compatible). The minimum value of $\pi_{\text {nonsyn }} / \pi_{\text {sil }}$ in our entire data set was 0 at the PEPC locus, and the maximum value was 1.09 at the NADK2 locus. The nonsynonymous substitution rate varied from 0.000 in PEPC to 0.010 in $\mathrm{CHI}$, which suggests that selective constraints vary between loci (Fu et al., 2010).

In the carotenoid biosynthetic pathway, different key steps have been found to be associated with differentiation between cultivated Citrus spp. (Kato et al., 2004; Fanciullino et al., 2006a, 2007). Several studies have tried to clarify the regulation of carotenoid biosynthesis (Rodrigo et al., 2004; Kato et al., 2004; Kim et al., 2001), but this regulation has not yet been fully elucidated.

PSY drives the formation of phytoene, the first product in the carotenoid biosynthetic pathway and a major step in the differentiation between cultivated basic taxa (Fanciullino et al., 2006, 2007). Considering the eight taxa studied, it appears that PSY is under positive selection $\left(\pi_{\text {nonsyn }} / \pi_{\text {syn }}=3.533\right)$ and is associated with a high level of allelic differentiation between the taxa $\left(F_{\text {st }}=0.750\right)$, which is higher than the average. There were nine sites with SNP polymorphisms between $C$. reticulata and the other taxa that produced changes in the amino acid composition that may be responsible for their differentiation. In contrast, in C. reticulata, no changes were found (excepted for one heterozygous change in the cultivar 'Ponkan'). Further functional analysis of the different alleles of this gene should provide insights into the molecular basis of phenotypic differentiation.

LCYB is a key enzyme required for the conversion of lycopene into $\beta$-carotenoids (Fanciullino et al., 2006a; Alquézar et al., 2009). Fanciullino et al. (2007) proposed that allelic variation at this locus should strongly limit this biosynthetic step in C. maxima. The numerous amino acid changes observed in $C$. maxima compared with $C$. reticulata might be associated with this limitation due to changes in the functionality of the pummelo allele.

HYB also plays a major role in the carotenoid biosynthetic pathway (Fanciullino et al., $2006 a)$ by catalysing the transformation of $\beta$-carotene into $\beta$-cryptoxanthin and zeaxanthin. Citrus reticulata produces these compounds, while $C$. maxima do not converts $\beta$-carotene into $\beta$-cryptoxanthin and zeaxanthin and $C$. medica only convert $\beta$-carotene into $\beta$-cryptoxanthin. Within $C$. reticulata, the ratio between non-synonymous/synonymous substitutions was higher than one (positive selection) at the HYB locus, which might be related to the significant variation in $\beta$-cryptoxanthin levels found among C. reticulata cultivars (Fanciullino et al., 2006a). The $\beta$ cryptoxanthin content greatly enhances fruit colour and has probably been under humaninduced selection during domestication.

Regarding the flavonoid pathway, positive selection was found to occur in C. reticulata at the F3'H locus, which belongs to the cytochrome P450 family and catalyses the hydroxylation of flavonoids at the 3' position of the B-ring, leading to the production of hydroxylated flavonols, proanthocyanidins (condensed tannins) and anthocyanins (Winkel-Shirley, 2001). This gene plays an important role in flavonoid biosynthesis in Arabidopsis (Schoenbohm et al., 2000) and 
grapevine (Bogs et al., 2006) and was previously isolated in clementine by Garcia-Lor et al. (2012b). Schoenbohm et al. (2000) demonstrated that in yeast, this enzyme could convert naringenin or dihydrokaempferol into eriodictyol or dihydroquercetin, respectively. Therefore, the changes in non-synonymous amino acid composition in the mandarin group (C. reticulata) may be associated with the different flavonol compositions found in some studies (Gattuso et al., 2007). At the $\mathrm{CHI}$ locus, a greater number of non-synonymous vs. synonymous substitutions were not found to have occurred in the eight subpopulations studied, but at the interspecific level, the ratio was higher than 1 , meaning that the gene was probably subjected to positive selection during the interspecific differentiation process. This gene controls the second step of the flavonoid biosynthetic pathway (Winkel-Shirley, 2001), and it was shown that it can alter flavonoid levels in citrus leaves (Koca et al., 2009). Understanding F3'H and CHI regulation and allelic functionality could be important for the analysis of molecular determinants of flavonoid composition in citrus fruits.

In the biosynthesis of acidic compounds, EMA displayed non-synonymous/synonymous ratios greater than one $\left(\pi_{\text {nonsyn }} / \pi_{\text {syn }}=2.273\right)$ and evidenced positive selection at the interspecific level. EMA is involved in the last steps of the citric acid cycle, catalysing the transformation of malate into pyruvate, the precursor of citrate formation (Kay and Weitzman, 1987). Malic enzyme is activated by the accumulation of citric acid cycle intermediates, allowing excess intermediates to leave the cycle and re-enter as acetyl groups, producing more citric acid. Citric acid content is strongly differentiated between Citrus taxa and ranges from $0.005 \mathrm{~mol} / \mathrm{L}$ for oranges and grapefruits to $0.30 \mathrm{~mol} / \mathrm{L}$ for lemons and limes (Penniston et al., 2008).

None of the sugar biosynthesis genes exhibited positive selection. It is well known that the total concentration of sugars increases throughout maturation in all Citrus spp. (Albertini et al., 2006). The null level of non-synonymous divergence at PEPC is consistent with strong selection for conserved amino acid sequences in this gene, which plays a crucial role in such important processes as $\mathrm{C} 4$ and Crassulacean acid metabolism (CAM) photosynthesis.

In the entire sample set, taking into account only the eight ancestral taxa (excluding secondary species and recent hybrids), NADK2 displayed a non-synonymous/synonymous ratio greater than $1\left(\pi_{\text {nonsyn }} / \pi_{\text {syn }}=2.117\right.$ and $\pi_{\text {nonsyn }} / \pi_{\text {syn }}=2.043$, respectively). NADK (NAD kinase) catalyses the ATP-dependent phosphorylation of $\mathrm{NAD}(\mathrm{H})$ (Berrin et al., 2005). In A. thaliana, there are three isoforms of NADK. Two isoforms, NADK1 and NAD $(H) K 3$, are cytosolic and one, NADK2, is found in the chloroplast (Turner et al., 2004, 2005; Chai et al., 2005, 2006). These isoforms play an essential role in the phosphorylation of $\mathrm{NAD}(\mathrm{H})$ and have been linked to plant stress response. Chai et al. (2005) showed that manipulation of AtNADK2 levels affected plastid NADPH levels, and null mutants were stunted, with a pale yellow colour, and were hypersensitive to abiotic stress.

Differences found in the coding regions of NADK2, and thus variations in amino acid sequences between the taxa, might affect the responses of these genotypes to abiotic stresses. Full sequencing of this gene and functional analysis of the different alleles could greatly 
increase our understanding of the role that this gene plays in increasing stress tolerance in Citrus and its relatives.

For all of the genes discussed here, the sequence data highlight amino acid variability of corresponding proteins that were probably subjected to selection. Therefore, these genes are good candidates for further complete sequencing studies (including promoter sequencing) and allelic functional studies to decipher the molecular basis of the phenotypic variability in the species examined.

Despite the previous discussion concerning the possible selective pressure exerted on some of the genes studied, the genetic organization of Citrus obtained from the SNP data (Figure 1) is similar to the genetic organization elucidated in previous SSR studies (Ollitrault et al., 2010, Garcia-Lor et al., 2012a). This suggests that the same basic type of evolutionary components led to the diversity structures of both types of markers. Therefore, a predominantly neutral selection pattern can be assumed for most of the current SNP markers. The minimum $F_{\text {st }}$ value was 0.438 at the PIP1 locus and the maximum value was 0.814 at the SOS1 locus for the differentiation of the eight taxa analysed in this work, i.e. C. reticulata, C. maxima, $C$. medica, Papeda, Fortunella, Microcitrus, Eremocitrus and Poncirus trifoliata. This study sheds light on the important differentiation between the taxa and demonstrates that SNP markers are efficient tools for phylogenetic studies and inheritance analysis of secondary species.

\section{Phylogenetic relationships}

For a biologically complex crop such as citrus, information obtained from nuclear gene sequences is more useful than the information gleaned from maternally inherited plastid sequences (Ramadugu et al., 2011; Puritz et al., 2012) due to the possibility of gene flow between sexually compatible species and the fact that the species belong to the same area of diversification. Previous phylogenetic molecular analyses using plastid markers showed that all 'true citrus fruit trees' species constitute a clade that is differentiated from other genera (de Araújo et al., 2003; Bayer et al., 2009).

In our study, all accessions of the same species form a clade with mainly high branch support values. Two species in the Papeda group, C. hystrix and C. ichangensis, are closely related. The other species of subgenus Papeda, C. micrantha, is separated from the two previous ones, possibly due to its geographical origin and distribution. The origin of $C$. micrantha is believed to be in the Philippines, whereas $C$. hystrix and $C$. ichangensis are of continental origin, in Burma, Thailand and Indo-China (Tanaka, 1954). Therefore, Swingle and Reece's (1967) subdivision of the genus into subgenera Papeda and Citrus seems to be inadequate.

An important observation maintained through the $\mathrm{ML}$ phylogenetic trees and the $\mathrm{NJ}$ cluster analysis is that $C$. reticulata and Fortunella form a cluster clearly differentiated from another cluster including $C$. maxima, C. medica and C. micrantha. The close relationship 
between C. reticulata and Fortunella matches the results obtained by Penjor et al. (2010) that were based on the analysis of $r c b L$ plastid gene sequences, but it differs from the results obtained from the analysis of amplified fragment length polymorphism (AFLP) molecular markers (Pang et al., 2007) and SSR markers (Barkley et al., 2006) and Swingle and Reece's (1967) treatment of Fortunella. In the ML phylogenetic analysis, $P$. trifoliata was found to belong to the same clade as C. reticulata and Fortunella with strong branch support (0.94). However, in the NJ analysis $P$. trifoliata appears as the more distant to all the 'true citrus fruit trees' taxa analysed, in agreement with our estimation of the inter-taxon differentiations. The strongly supported clade $(B 1 ; B S=0.96)$ including $C$. medica, $C$. maxima and $C$. micrantha of subgenus Papeda is also observed in the $\mathrm{NJ}$ analysis. However, our results are in contrast to information derived from other studies, including the analysis of nine plastid markers by Bayer et al. (2009), the analysis of SSR, SRAP and (CAPS)-SNP markers (Amar et al., 2011), SSRs (Barkley et al., 2006) and RAPD, SCAR and plastid markers (Nicolosi et al., 2000). All of these studies suggested that $C$. maxima and $C$. reticulata share a clade and are separated from $C$. medica. The inconsistency with previous nuclear studies may be due to the inclusion of secondary species of interspecific origin in these previous studies, which might have led to the artefactual clustering of the $C$. maxima and $C$. reticulata gene pools due to the numerous accessions resulting from hybridisation between these gene pools. Our phylogenetic $M L$ analysis (Figure 1) and the NJ analysis done with the SNPs in the absence of secondary species (Figure 2) are consistent, while the $\mathrm{NJ}$ tree that includes the secondary species [Supplementary Information 4] displays clustering of $C$. maxima and $C$. reticulata with low branch support. This illustrates the bias associated with the inclusion of genotypes of inter-taxon origin in NJ cluster analyses. Another source of bias in molecular studies might be the choice of molecular marker type and the genotype panel used for its development. In our study, using Sanger sequencing, all SNPs from all accessions are revealed, so there was no bias towards any of the ancestral species.

The consistent clades observed in the ML phylogenetic study are in agreement with the geographical distribution of species divided by the 'Tanaka line' (Tanaka, 1954). Fortunella, Poncirus and $C$. reticulata (clade A2) share the same area of diversification, where subgenus Metacitrus predominates (East Asiatic floral zone) (Tanaka, 1954), whereas the C. medica and C. maxima clade (B1) is in agreement with the area of distribution where the subgenus Archicitrus, described by Tanaka (1954), predominates (Indo-Malayan floral zone). Some phenotypic traits differentiate these two clades. For example, Fortunella, Poncirus and $C$. reticulata are facultative apomictic species with high carotenoid contents, while C. maxima and C. medica are monoembryonic non-apomictic species, which have strong limitations in the carotenoid pathway. The speciation between Fortunella, Poncirus and C. reticulata might be explained by their different flowering periods (precocious in Poncirus and late in Fortunella). However, gene flow probably occurred by accidental, out-of-time flowering. Despite sharing the Indo-Malayan floral zone (Tanaka, 1954), C. maxima and C. medica were geographically separated, with a more intertropical specialization for $C$. maxima. 
Eremocitrus and Microcitrus were found to be associated in all our analyses. This result is consistent with the conclusions of Barrett and Rhodes (1976), based on morphological traits, and also with previous molecular phylogenetic analysis (e.g. Bayer et al., 2009). The phylogenetic placement of these Australian genera within the 'true citrus fruit trees' remains unclear, due to the lack of branch support for the deeper branches in the phylogenetic trees.

\section{Secondary species structure}

The origin of secondary species and many recent hybrids formed by interspecific hybridisation between the basic Citrus taxa (C. maxima, C. reticulata, C. medica and $C$. micrantha) has been well documented in several molecular studies (Nicolosi et al., 2000; Barkley et al., 2006; Garcia-Lor et al., 2012a; Ollitrault et al., 2012a), and the relative contribution of the ancestral taxa to their genomes was estimated by Barkley et al. (2006) and Garcia-Lor et al. (2012a). However, these two studies were based on SSRs and these estimations could be biased by the frequent homoplasy observed for these markers (Barkley et al., 2009). The genomes of secondary species can be considered to be mosaics of large DNA fragments of ancestral species that resulted from a few interspecific recombination events (Garcia-Lor et al., 2012a). However, the phylogenetic structures of secondary species in concrete points of the genome remain obscure. For C. sinensis, C. aurantium, C. paradisi and clementine, previous molecular studies (Nicolosi et al., 2000; Barkley et al., 2006; Garcia-Lor et al., 2012a; Ollitrault et al., 2012a) also showed that intra-taxon diversity resulted only from mutation and/or epigenetic variation without further sexual recombination events. Therefore, these species generally present very low or null molecular intercultivar diversity in genetic markers such as SSRs or SNPs. Such low molecular diversity was confirmed in this work for secondary taxa for which two cultivars were sequenced (C. sinensis, C. aurantium and Clementine). Due to this intra-secondary taxon diversification history, most of the conclusions about the mosaic structure inferred from one or two genotypes should be extended to other cultivars of the same secondary species.

Clementine is believed to have resulted from a cross between mandarin 'Willowleaf and sweet orange (Nicolosi et al., 2000; Ollitrault et al., 2012a), which means that there were contributions from both the $C$. reticulata and C. maxima gene pools (Garcia-Lor et al., 2012a). From the analysis of 27 genes, the observation that there was a majority of mandarin/mandarin phylogenetic homozygosity and very little mandarin/pummelo heterozygosity is in agreement with this hypothesis. The proportion of the pummelo genome estimated from these 27 sequences $(16.7 \%)$ is higher than the one estimated from SSR markers $(7 \%)$ by Garcia-Lor et al. (2012a).

Several hypotheses have been proposed for the origin of $C$. sinensis. According to Barrett and Rhodes (1976), Torres et al. (1978), Scora (1988), Nicolosi et al. (2000) and Moore (2001), sweet orange should be a direct interspecific hybrid between a pummelo (C. maxima) and a mandarin (C. reticulata), whereas Roose et al. (2009) and Garcia-Lor et al. (2012a) 
suggested that $C$. sinensis resulted from a backcross 1 (BC1) [(C. maxima $\times$ C. reticulata) $\times C$. reticulata]. The identification of interspecific phylogenetic heterozygosity MP and phylogenetic homozygosity PP and MM (Table 6 ) in the $C$. sinensis genome contradicts these two models. Indeed, the presence of both types of phylogenetic homozygosity (reported for the first time for pummelo homozygosity) implies that both parents of sweet orange were of interspecific origin. The presence of intraspecific heterozygous SNPs for some genes in phylogenetic homozygosity (EMA and HYB; data not shown) also contradicts the hypothesis that $C$. sinensis resulted from an $F_{2}$ interspecific hybrid (self-fecundation of an interspecific $F_{1}$ ).

Sour orange (C. aurantium) is thought by some authors to be a natural hybrid of a mandarin and a pummelo (Scora, 1975; Barrett and Rhodes, 1976; Nicolosi et al., 2000; Uzun et al., 2009). The interspecific heterozygosity (MP, Table 6) observed for all interpretable loci is in agreement with this hypothesis. However, specific SNP alleles were found in C. aurantium, indicating that the parental pummelo or mandarin was not part of the germplasm analysed and that sweet orange and sour orange were not related as considered by some authors.

Grapefruit (C. paradisi) is thought to have arisen from a natural hybridization between C. maxima and $C$. sinensis in the Caribbean after the discovery of the New World by Christopher Columbus (Barrett and Rhodes, 1976, de Moraes et al., 2007, Ollitrault et al., 2012a). The results obtained in this study help to confirm this theory, as many loci were homozygous for the C. maxima genome and other loci showed interspecific heterozygosity (MP, Table 6). Nicolosi et al. (2000) proposed that Mexican lime (C. aurantifolia) is a hybrid between C. medica and C. micrantha. This theory fits with our data for 23 out of 27 genes. For, three genes, it was not possible to decipher the mosaic structure and for the gene leading to a CC conclusion it should be supposed that PCR competition resulted in an apparent Papeda null allele (C0). The tri-hybrid origin (C. medica, C. reticulata, C. maxima) accepted for C. limon (Nicolosi et al., 2000; Barkley et al., 2006; Garcia-Lor et al., 2012a) was confirmed by our sequence data for the lemon cultivar 'Eureka', which has contributions from its ancestors $(C$. medica: $50 \%$, C. reticulata $38.46 \%$ and C. maxima $11.54 \%$, Table 6 ) that are similar to those described by Garcia-Lor et al. (2012a). Moreover, the systematic presence of a C. medica allele, and the fact that lemon shares heterozygosity with some rare sour orange alleles support the hypothesis proposed by Nicolosi et al. (2000) that lemon resulted from a direct hybridisation between $C$. medica and $C$. aurantium.

Both tangors $(C$. reticulata $\times C$. sinensis $)$ and tangelos $(C$. paradisi $\times C$. reticulata) were bred from recombination between the $C$. reticulata and $C$. maxima gene pools. The SNP pattern for tangelo 'Orlando', originated from a controlled cross between a grapefruit and a 'Dancy' mandarin (Hodgson, 1967), with both mandarin and pummelo allele inheritance is logical. Our results also confirm that the tangor 'King' classified by Tanaka (1977) as C. nobilis is most probably a tangor with at least one mandarin allele for each gene and MP heterozygosity inheritance for some genes. 
With the next release of the pseudo-chromosome sequence assembly of the reference haploid clementine genome (Gmitter, 2012), the assignation of the phylogenetic origin of these 27 genes will contribute to the deciphering of the interspecific mosaic genome structure of the secondary species. Moreover, this allelic assignation in genotypes of interspecific origin, coupled with further analysis of functionality of the alleles of the different ancestral species, will provide a very promising pathway for understanding the molecular basis of phenotypic variability in this highly stratified gene pool in which the organization of phenotypic and molecular diversity is closely linked. 


\section{CONCLUSION AND PERSPECTIVES}

Sanger sequencing of 27 nuclear gene fragments for 45 genotypes resulted in the identification of a great number of molecular polymorphisms (1097 SNPs and 50 indels). For the indels, half of the mined polymorphisms have been used to define new markers. A significant number of the mined SNP loci should be converted into efficient markers to perform high throughput genotyping studies that will be important for the management of Citrus collections and marker/trait association studies. The nuclear phylogenetic analyses of Citrus and its sexually compatible relatives showed coherence with the geographic distribution and differentiation proposed by Tanaka (1954), with C. reticulata and Fortunella appearing to be closely related. A cluster that joins $C$. medica, $C$. maxima and the Papeda species $C$. micrantha was consistently revealed.

In the near future, by using the entire Citrus genome as a reference and resequencing data from the main secondary species, the resulting estimations of the relative levels of withinand between-taxon differentiation will be useful for deciphering the interspecific mosaic structure of the Citrus secondary cultivated species and modern cultivars. The present study has allowed us to assign a phylogenetic inheritance of the genes that were examined for most of the genotypes of interspecific origin under study. One of our major results concerns $C$. sinensis, which has alleles of three genes that appear to have been inherited solely from the $C$. maxima gene pool and alleles of eight genes that appear to have been inherited from $C$. reticulata. This result contradicts the hypothesis that $C$. sinensis originated directly from $F_{1}$ or by BC1 hybridization between the C. maxima and C. reticulata gene pools. However, our study confirms previous hypotheses concerning the origins of the other secondary species.

Positive selection was observed for a few genes within or between the species studied, suggesting that these genes may play a key role in phenotypic differentiation. These genes are therefore major candidates for future studies, including complete gene sequencing and functional analysis of different alleles to analyse the molecular basis of the phenotypic variability of corresponding traits. 
SUPPLEMENTARY INFORMATION CHAPTER 2 

Supplementary Information 1. Genotypes used in this study

\begin{tabular}{|c|c|c|c|c|}
\hline Group & Scientific name (Swingle) & Scientific name (Tanaka) & Cultivar & Ref. ${ }^{*}$ \\
\hline Mandarin & C.reticulata var. austera & C. reshni Hort. ex Tan. & Cleopatra & 3851 \\
\hline Mandarin & C.reticulata Blanco & C. deliciosa Ten & Willow leaf & 1541 \\
\hline Mandarin & C.reticulata Blanco & C.reticulata Blanco & Ponkan & 482 \\
\hline Mandarin & C.reticulata var. austera & C. sunki Hort. ex Tan. & Sunki & 2391 \\
\hline Mandarin & C.reticulata Blanco & C. tangerina Hort. ex Tan. & Dancy & 4341 \\
\hline Mandarin & C.reticulata Blanco & C unshiu (Mak.) Marc. & Clausellina & 191 \\
\hline Mandarin & C.reticulata Blanco & C. deliciosa Ten & Avana apireno & $189 \mid$ \\
\hline Pummelo & C. maxima (Burm.) Merr. & C. maxima (Burm.) Merr. & Chandler & $207 \mid$ \\
\hline Pummelo & C. maxima (Burm.) Merr. & C. maxima (Burm.) Merr. & Pink & $275 \mid$ \\
\hline Pummelo & C. maxima (Burm.) Merr. & C. maxima (Burm.) Merr. & Nam Roi & 5901 \\
\hline Pummelo & C. maxima (Burm.) Merr. & C. maxima (Burm.) Merr. & Tahiti & $727 \mathrm{C}$ \\
\hline Pummelo & C. maxima (Burm.) Merr. & C. maxima (Burm.) Merr. & Sans Pepins & $710 \mathrm{C}$ \\
\hline Citron & C. medica L. & C. medica L. & Corsica & 5671 \\
\hline Citron & C. medica L. & C. medica L. & Buddha's hand & 2021 \\
\hline Citron & C. medica L. & C. medica L. & Diamante & 5601 \\
\hline Citron & C. medica L. & C. medica $\mathrm{L}$. & Arizona & $169 \mid$ \\
\hline Citron & C. medica L. & C. medica L. & Poncire commun & $701 \mathrm{C}$ \\
\hline Papeda & C. micrantha Wester & C. micrantha Wester & Small flowered papeda & 6261 \\
\hline Papeda & C. hystrix DC. & C. hystrix DC. & Mauritius papeda & $178 \mid$ \\
\hline Papeda & C. ichangensis Swing. & C. ichangensis Swing. & Ichang papeda & 3581 \\
\hline Papeda & C. macroptera Montr. & C. macroptera Montr. & Melanesian papeda & $279 \mid$ \\
\hline Fortunella & F. hindsii (Champ.) Swing. & F. hindsii (Champ.) Swing. & Hong Kong kumkuat & 2811 \\
\hline Fortunella & Fortunella hybrid & F. crassifolia Swing. & Meiwa kumkuat & 2801 \\
\hline Fortunella & F. japonica (Thunb.) Swing. & F. japonica (Thunb.) Swing. & Round kumkuat & 3811 \\
\hline Fortunella & F. polyandra (Ridl.) Tan & F. polyandra (Ridl.) Tan. & Malayan kumquat & 3751 \\
\hline Fortunella & F. margarita (Lour.) Swing. & F. margarita (Lour.) Swing. & Nagami kumkuat & 381 \\
\hline Microcitrus & $\begin{array}{l}\text { Microcitrus australasica (F. Muell.) } \\
\text { Swing. }\end{array}$ & $\begin{array}{c}\text { Microcitrus australasica (F. Muell.) } \\
\text { Swing. }\end{array}$ & Australian finger lime & 1501 \\
\hline Microcitrus & Microcitrus australis (F. Muell.) Swing. & $\begin{array}{l}\text { Microcitrus australis (F. Muell.) } \\
\text { Swing. }\end{array}$ & Australian round lime & 3131 \\
\hline Eremocitrus & Eremocitrus glauca (Lindl.) & Eremocitrus glauca (Lindl.) & Australian desert lime & 3461 \\
\hline Poncirus & Poncirus trifoliata (L.) Raf. & Poncirus trifoliata (L.) Raf. & Pomeroy & 3741 \\
\hline Poncirus & Poncirus trifoliata (L.) Raf. & Poncirus trifoliata (L.) Raf. & Rubidoux & $217 \mid$ \\
\hline Poncirus & Poncirus trifoliata (L.) Raf. & Poncirus trifoliata (L.) Raf. & Flying dragon & 5371 \\
\hline Haploid & C.reticulata Blanco & C. clementina Hort. ex Tan. & Haploid & HapClem \\
\hline Clementine & C. reticulata Blanco & C. clementina Hort. ex Tan. & Clemenules & 221 \\
\hline Clementine & C. reticulata Blanco & C. clementina Hort. ex Tan. & Arrufatina & 581 \\
\hline Tangelo & C. reticulata $\times$ C. paradisi & C. reticulata $\times$ C. paradisi & Orlando & 1011 \\
\hline Tangor & C. reticulata $\times$ C. sinensis & C. nobilis Lour. & King & $477 \mid$ \\
\hline Sweet orange & C. sinensis (L.) Osb & C. sinensis (L.) Osb & Valencia Late Delta & $363 \mid$ \\
\hline Sweet orange & C. sinensis (L.) Osb & C. sinensis(L.) Osb & Salustiana & $125 I$ \\
\hline Grapefruit & C. paradisi Macf & C. paradisi Macf & Marsh & 1761 \\
\hline Sour orange & C. aurantium $\mathrm{L}$. & C. aurantium $\mathrm{L}$. & Sevillano & $117 \mid$ \\
\hline Sour orange & C. aurantium $\mathrm{L}$. & C. aurantium $\mathrm{L}$. & Bouquet de Fleurs & 1391 \\
\hline Lime & C. aurantifolia (Christm.) Swing. & C. aurantifolia (Christm.) Swing. & Mexican & $164 \mid$ \\
\hline Lemon & C. limon (L.) Burm & C. limon (L.) Burm & Eureka & $297 \mid$ \\
\hline Severinia & Severinia buxifolia (Poir.) Tenore & Severinia buxifolia (Poir.) Tenore & Chinese box orange & 1471 \\
\hline
\end{tabular}

*(I) IVIA germplasm; (C) INRA/CIRAD germplasm. 
Supplementary Information 2. New InDel primers developed from polymorphisms found during sequencing of the candidate genes

\begin{tabular}{|c|c|c|c|c|c|c|}
\hline PRIMER & GBA & SEQUENCE & Lenght & $\mathrm{Tm}$ & PCR & $\begin{array}{l}\text { Product } \\
\text { Size }\end{array}$ \\
\hline IDCHI2 & DY263683 & $\begin{array}{l}\text { F:AATCAATTATTTTCCACATT } \\
\text { R:ATTACACGTAACGCAAGA }\end{array}$ & $\begin{array}{l}20 \\
18\end{array}$ & $\begin{array}{c}48.91 \\
53.2\end{array}$ & 50 & $94-96$ \\
\hline IDFLS1 & AB011796 & $\begin{array}{l}\text { F:GATCATCTCTTCCACAGG } \\
\text { R:GAAAATAAATTATTTATACATTTTGTTT }\end{array}$ & $\begin{array}{l}18 \\
28\end{array}$ & $\begin{array}{l}50.64 \\
52.86\end{array}$ & 50 & 144-158 \\
\hline IDFLS2 & AB011796 & $\begin{array}{l}\text { F:AAACAAAATGTATAAATAATTTATTTTC } \\
\text { R:AGCATGTACTCAATGTCG }\end{array}$ & $\begin{array}{l}28 \\
18\end{array}$ & $\begin{array}{l}52.86 \\
49.76\end{array}$ & 50 & 184-204 \\
\hline IDF3'H1 & HQ634392 & $\begin{array}{l}\text { F:AAAGGCTCACCATCACCAAC } \\
\text { R:AAAATGAACAACACAAAGAAAGACC }\end{array}$ & $\begin{array}{l}20 \\
25\end{array}$ & $\begin{array}{c}59.97 \\
55.2\end{array}$ & 55 & $180-196$ \\
\hline IDDFR1 & DQ084722 & $\begin{array}{l}\text { F:CCACGCCTATGGACTTTGAG } \\
\text { R:TCAATGTTATGCGGCTGTTC }\end{array}$ & $\begin{array}{l}20 \\
20\end{array}$ & $\begin{array}{l}60.65 \\
59.69\end{array}$ & 55 & $181-192$ \\
\hline IDDFR2 & DQ084722 & $\begin{array}{l}\text { F:ACTGTTCGCGATCCTGGT } \\
\text { R:GCAACTCCAGCAAATGTTTC }\end{array}$ & $\begin{array}{l}18 \\
20\end{array}$ & $\begin{array}{l}59.21 \\
58.35\end{array}$ & 55 & $140-156$ \\
\hline IDINVA1 & AB074885 & $\begin{array}{l}\text { F:GAGCTCCCCTTTTGCTTAAT } \\
\text { R:AGTAGCTGAGCCAACATCAA }\end{array}$ & $\begin{array}{l}20 \\
20\end{array}$ & $\begin{array}{l}57.58 \\
56.09\end{array}$ & 55 & $218-220$ \\
\hline IDINVA2 & AB074885 & $\begin{array}{l}\text { F:CCTTCTGGTTCTTGCAGAT } \\
\text { R:TATTGACATCATTTGCCTCA }\end{array}$ & $\begin{array}{l}19 \\
20\end{array}$ & $\begin{array}{l}55.35 \\
55.01\end{array}$ & 55 & $233-237$ \\
\hline IDINVA3 & AB074885 & $\begin{array}{l}\text { F:TTCTGAGGCAAATGATGTCAA } \\
\text { R:CGAATGATCCACCTGCAAAT }\end{array}$ & $\begin{array}{l}21 \\
20\end{array}$ & $\begin{array}{l}59.26 \\
60.86\end{array}$ & 55 & $203-206$ \\
\hline IDPEPC3 & EF058158 & $\begin{array}{l}\text { F:TTTGTGATGTTCCACAAATG } \\
\text { R:CTACCATTAGCCGATTGTTC }\end{array}$ & $\begin{array}{l}20 \\
20\end{array}$ & $\begin{array}{c}55.3 \\
54.93\end{array}$ & 55 & $130-133$ \\
\hline IDPFK1 & AF095520 & $\begin{array}{l}\text { F:AAAACCCTTTCAAAATCGTC } \\
\text { R:CCGATTTTCAACTTCTCATC }\end{array}$ & $\begin{array}{l}20 \\
20\end{array}$ & $\begin{array}{l}55.85 \\
54.84\end{array}$ & 55 & $246-248$ \\
\hline IDPSY2 & AB037975 & $\begin{array}{l}\text { F:TTGAGTCATGCCATTTTTGC } \\
\text { R:ATTGGGTTAAGGGTCCACTG }\end{array}$ & $\begin{array}{l}20 \\
20\end{array}$ & $\begin{array}{l}59.67 \\
58.76\end{array}$ & 55 & $347-364$ \\
\hline
\end{tabular}

(GBA) Genebank accession 
Supplementary Information 3. Nucleotide diversity and divergence for each gene and taxa. Mand (C. reticulata), Pum (C. maxima), Cit (C. medica), For (Fortunella), Pap (Papeda, wild citrus), Mic (Microcitrus), Ere (Eremocitrus), Pon (Poncirus trifoliata), AncTaxa (C. reticulata, $C$. maxima, C. medica, wild citrus). (Pop) Population, (S) Segregating sites, ( $\left.\pi_{T}\right)$ Total nucleotide diversity, $\left(\pi_{\text {sil }}\right)$ Nucleotide diversity silent sites, $\left(\pi_{\text {syn }}\right)$ Nucleotide diversity synonymous sites, $\left(\pi_{\text {nonsyn }}\right)$ Nucleotide diversity nonsynonymous sites, $\left(\pi_{\text {nonsyn/syn }}\right)$ Ratio Nucleotide diversity nonsynonymous/synonymous sites, $\left(\boldsymbol{\pi}_{\text {nonsyn }} / \boldsymbol{\pi}_{\text {sil }}\right)$ Ratio Nucleotide diversity nonsynonymous/silent sites, ( $\left.D_{\text {tajima }}\right)$ Tajima's D neutrality test, $\left(\mathrm{N}_{\mathrm{h}}\right)$ Number of haplotypes, $\left(H_{\mathrm{e}}\right)$ Haplotype diversity, (SD) Standard deviation, $\left(F_{\mathrm{st}}\right)$ Wright's differentiation index. See Table 1 for locus abbreviations

\begin{tabular}{|c|c|c|c|c|c|c|c|c|c|c|c|c|c|}
\hline \multirow[b]{2}{*}{ Locus } & \multirow[b]{2}{*}{ Taxa } & \multirow[b]{2}{*}{$\mathbf{S}$} & \multirow[b]{2}{*}{$\Pi_{\mathbf{T}}$} & \multirow[b]{2}{*}{$\boldsymbol{\pi}_{\text {sil }}$} & \multicolumn{3}{|c|}{ Polymorphism } & \multirow[b]{2}{*}{$\boldsymbol{T}_{\text {nonsyn }} / \boldsymbol{T}_{\text {sil }}$} & \multicolumn{5}{|c|}{ Haplotype diversity } \\
\hline & & & & & $\mathbf{T}_{\text {syn }}$ & $\Pi_{\text {nonsyn }}$ & $\Pi_{\text {nonsyn }} / \Pi_{\text {syn }}$ & & $\mathbf{D}_{\text {tajima }}$ & $\mathbf{N}_{\mathrm{h}}$ & $H_{\mathrm{e}}$ & (SD) & $F_{\text {st }}$ \\
\hline \multirow[t]{10}{*}{$\mathrm{CHI}$} & Mand & 20 & 0.009 & 0.010 & 0.011 & 0.006 & 0.522 & 0.541 & & 7 & 0.833 & 0.072 & \\
\hline & Pum & 6 & 0.003 & 0.002 & 0.000 & 0.007 & - & 3.036 & & 5 & 0.756 & 0.130 & \\
\hline & Cit & 21 & 0.013 & 0.017 & 0.007 & 0.002 & 0.320 & 0.136 & & 3 & 0.622 & 0.138 & \\
\hline & For & 12 & 0.007 & 0.007 & 0.000 & 0.006 & - & 0.848 & & 5 & 0.667 & 0.163 & \\
\hline & Pap & 22 & 0.014 & 0.016 & 0.000 & 0.007 & - & 0.425 & & 5 & 0.933 & 0.122 & \\
\hline & Mic & 8 & 0.008 & 0.010 & 0.000 & 0.004 & - & 0.448 & & 2 & 0.667 & 0.204 & \\
\hline & Ere & 0 & 0.000 & 0.000 & 0.000 & 0.000 & - & - & & 1 & 0.000 & 0.000 & \\
\hline & Pon & 1 & 0.001 & 0.001 & 0.000 & 0.000 & - & 0.000 & & 2 & 0.600 & 0.129 & \\
\hline & AncTaxa & 73 & 0.026 & 0.032 & 0.008 & 0.011 & 1.381 & 0.361 & -0.300 & 28 & 0.959 & 0.010 & 0.757 \\
\hline & $\begin{array}{l}\text { Whole Pop } \\
\text { SD }\end{array}$ & 76 & $\begin{array}{l}0.024 \\
0.001\end{array}$ & 0.030 & 0.008 & 0.010 & 1.377 & 0.350 & -0.407 & 34 & 0.958 & 0.008 & \\
\hline \multirow[t]{11}{*}{ CHS } & Mand & 1 & 0.001 & 0.003 & 0.003 & 0.000 & 0.000 & 0.000 & & 2 & 0.440 & 0.112 & \\
\hline & Pum & 0 & 0.000 & 0.000 & 0.000 & 0.000 & - & - & & 1 & 0.000 & 0.000 & \\
\hline & Cit & 0 & 0.000 & 0.000 & 0.000 & 0.000 & - & - & & 1 & 0.000 & 0.000 & \\
\hline & For & 4 & 0.001 & 0.005 & 0.005 & 0.000 & 0.096 & 0.096 & & 3 & 0.378 & 0.181 & \\
\hline & Pap & 5 & 0.004 & 0.009 & 0.009 & 0.002 & 0.207 & 0.207 & & 5 & 0.933 & 0.122 & \\
\hline & Mic & 4 & 0.003 & 0.008 & 0.008 & 0.002 & 0.289 & 0.289 & & 2 & 0.500 & 0.265 & \\
\hline & Ere & 1 & 0.002 & 0.008 & 0.008 & 0.000 & 0.000 & 0.000 & & 2 & 1.000 & 0.500 & \\
\hline & Pon & 0 & 0.000 & 0.000 & 0.000 & 0.000 & - & - & & 1 & 0.000 & 0.000 & \\
\hline & AncTaxa & 20 & 0.004 & 0.016 & 0.016 & 0.001 & 0.079 & 0.079 & -1.256 & 14 & 0.885 & 0.015 & 0.698 \\
\hline & Whole Pop & 20 & 0.004 & 0.015 & 0.014 & 0.001 & 0.065 & 0.064 & -1.258 & 15 & 0.857 & 0.018 & \\
\hline & SD & & 0.000 & & & & & & & & & & \\
\hline \multirow[t]{11}{*}{ FLS } & Mand & 14 & 0.008 & 0.015 & 0.019 & 0.002 & 0.442 & 0.145 & & 7 & 0.817 & 0.073 & \\
\hline & Pum & 4 & 0.004 & 0.007 & 0.005 & 0.003 & 0.567 & 0.372 & & 5 & 0.844 & 0.080 & \\
\hline & Cit & 0 & 0.000 & 0.000 & 0.000 & 0.000 & - & - & & 1 & 0.000 & 0.000 & \\
\hline & For & 7 & 0.007 & 0.017 & 0.018 & 0.003 & 0.151 & 0.167 & & 6 & 0.889 & 0.075 & \\
\hline & Pap & 14 & 0.014 & 0.040 & 0.033 & 0.004 & 0.137 & 0.113 & & 6 & 1.000 & 0.096 & \\
\hline & Mic & 8 & 0.010 & 0.025 & 0.030 & 0.004 & 0.121 & 0.142 & & 4 & 1.000 & 0.177 & \\
\hline & Ere & 10 & 0.022 & 0.046 & 0.064 & 0.012 & 0.191 & 0.267 & & 2 & 1.000 & 0.500 & \\
\hline & Pon & 4 & 0.004 & 0.008 & 0.011 & 0.003 & 0.240 & 0.332 & & 5 & 0.933 & 0.122 & \\
\hline & AncTaxa & 45 & 0.021 & 0.055 & 0.059 & 0.007 & 0.122 & 0.131 & -0.329 & 34 & 0.958 & 0.014 & 0.608 \\
\hline & Whole Pop & 47 & 0.020 & 0.055 & 0.062 & 0.007 & 0.120 & 0.135 & -0.211 & 48 & 0.960 & 0.011 & \\
\hline & SD & & 0.001 & & & & & & & & & & \\
\hline \multirow[t]{11}{*}{ F3'H } & Mand & 10 & 0.004 & 0.003 & 0.003 & 0.005 & 1.767 & 1.714 & & 6 & 0.747 & 0.111 & \\
\hline & Pum & 4 & 0.002 & 0.001 & 0.000 & 0.004 & - & 6.066 & & 4 & 0.733 & 0.101 & \\
\hline & Cit & 6 & 0.003 & 0.005 & 0.000 & 0.002 & - & 0.383 & & 4 & 0.778 & 0.091 & \\
\hline & For & 21 & 0.012 & 0.011 & 0.013 & 0.014 & 1.048 & 1.312 & & 7 & 0.933 & 0.062 & \\
\hline & Pap & 10 & 0.006 & 0.005 & 0.010 & 0.006 & 0.619 & 1.136 & & 6 & 1.000 & 0.096 & \\
\hline & Mic & 10 & 0.007 & 0.012 & 0.019 & 0.006 & 0.327 & 0.534 & & 3 & 0.833 & 0.222 & \\
\hline & Ere & 0 & 0.000 & 0.000 & 0.000 & 0.000 & - & - & & 1 & 0.000 & 0.000 & \\
\hline & Pon & 1 & 0.001 & 0.002 & 0.000 & 0.000 & - & 0.000 & & 2 & 0.600 & 0.129 & \\
\hline & AncTaxa & 55 & 0.010 & 0.013 & 0.016 & 0.008 & 0.515 & 0.612 & -1.285 & 33 & 0.970 & 0.009 & 0.574 \\
\hline & Whole Pop & 60 & 0.009 & 0.012 & 0.014 & 0.008 & 0.554 & 0.643 & -1.474 & 36 & 0.949 & 0.013 & \\
\hline & SD & & 0.001 & & & & & & & & & & \\
\hline DFR & Mand & 1 & 0.000 & 0.000 & 0.000 & 0.001 & - & - & & 2 & 0.143 & 0.119 & \\
\hline & Pum & 1 & 0.000 & 0.001 & 0.000 & 0.000 & - & 0.000 & & 2 & 0.200 & 0.154 & \\
\hline & Cit & 4 & 0.004 & 0.006 & 0.025 & 0.000 & 0.000 & 0.000 & & 5 & 0.822 & 0.097 & \\
\hline & For & 7 & 0.007 & 0.010 & 0.006 & 0.000 & 0.000 & 0.000 & & 6 & 0.867 & 0.085 & \\
\hline & Pap & 7 & 0.008 & 0.012 & 0.009 & 0.000 & 0.000 & 0.000 & & 5 & 0.933 & 0.122 & \\
\hline & Mic & 4 & 0.005 & 0.008 & 0.000 & 0.000 & - & 0.000 & & 3 & 0.833 & 0.222 & \\
\hline & Ere & 4 & 0.010 & 0.011 & 0.000 & 0.007 & - & 0.660 & & 2 & 1.000 & 0.500 & \\
\hline & Pon & 3 & 0.004 & 0.005 & 0.000 & 0.000 & - & 0.000 & & 3 & 0.733 & 0.155 & \\
\hline & AncTaxa & 32 & 0.013 & 0.017 & 0.024 & 0.005 & 0.194 & 0.280 & -0.893 & 26 & 0.928 & 0.020 & 0.675 \\
\hline & Whole Pop & 32 & 0.011 & 0.015 & 0.019 & 0.005 & 0.248 & 0.308 & -0.949 & 34 & 0.898 & 0.026 & \\
\hline & SD & & 0.001 & & & & & & & & & & \\
\hline EMA & Mand & 3 & 0.004 & 0.005 & 0.000 & 0.000 & - & 0.000 & & 3 & 0.667 & 0.075 & \\
\hline & Pum & 1 & 0.000 & 0.001 & 0.000 & 0.000 & - & 0.000 & & 2 & 0.200 & 0.154 & \\
\hline & Cit & 1 & 0.001 & 0.002 & 0.000 & 0.000 & - & 0.000 & & 2 & 0.533 & 0.095 & \\
\hline & For & 10 & 0.007 & 0.008 & 0.006 & 0.002 & 0.308 & 0.246 & & 7 & 0.911 & 0.077 & \\
\hline & Pap & 2 & 0.007 & 0.000 & 0.011 & 0.003 & 0.255 & - & & 3 & 0.733 & 0.155 & \\
\hline
\end{tabular}




\begin{tabular}{|c|c|c|c|c|c|c|c|c|c|c|c|c|c|}
\hline & Mic & 8 & 0.010 & 0.013 & 0.016 & 0.000 & 0.000 & 0.000 & & 3 & 0.833 & 0.222 & \\
\hline & Ere & 3 & 0.007 & 0.010 & 0.032 & 0.000 & 0.000 & 0.000 & & 2 & 1.000 & 0.500 & \\
\hline & Pon & 5 & 0.005 & 0.007 & 0.000 & 0.000 & - & 0.000 & & 3 & 0.600 & 0.215 & \\
\hline & AncTaxa & 34 & 0.014 & 0.017 & 0.003 & 0.005 & 1.511 & 0.289 & -0.732 & 21 & 0.921 & 0.018 & 0.677 \\
\hline & $\begin{array}{l}\text { Whole Pop } \\
\text { SD }\end{array}$ & 34 & $\begin{array}{l}0.013 \\
0.001\end{array}$ & 0.016 & 0.002 & 0.005 & 2.273 & 0.323 & -0.622 & 27 & 0.914 & $(0.016)$ & \\
\hline \multirow[t]{10}{*}{ MDH } & Mand & 6 & 0.002 & 0.004 & 0.004 & 0.001 & 0.179 & 0.179 & & 3 & 0.908 & 0.115 & \\
\hline & Pum & 2 & 0.002 & 0.000 & 0.000 & 0.002 & - & - & & 2 & 0.538 & 0.075 & \\
\hline & Cit & 0 & 0.000 & 0.000 & 0.000 & 0.000 & - & - & & 1 & 0.556 & 0.000 & \\
\hline & For & 10 & 0.005 & 0.011 & 0.011 & 0.004 & 0.338 & 0.338 & & 7 & 0.000 & 0.077 & \\
\hline & Pap & 6 & 0.004 & 0.007 & 0.007 & 0.003 & 0.418 & 0.418 & & 4 & 0.867 & 0.129 & \\
\hline & Mic & 5 & 0.004 & 0.011 & 0.011 & 0.002 & 0.235 & 0.235 & & 3 & 0.821 & 0.222 & \\
\hline & Ere & 4 & 0.006 & 0.000 & 0.000 & 0.007 & - & - & & 2 & 0.833 & 0.500 & \\
\hline & Pon & 1 & 0.001 & 0.000 & 0.000 & 0.001 & - & - & & 2 & 1.000 & 0.129 & \\
\hline & AncTaxa & 31 & 0.007 & 0.014 & 0.014 & 0.005 & 0.356 & 0.356 & -0.768 & 21 & 0.929 & 0.015 & 0.677 \\
\hline & $\begin{array}{l}\text { Whole Pop } \\
\text { SD }\end{array}$ & 31 & $\begin{array}{l}0.006 \\
0.000\end{array}$ & 0.012 & 0.012 & 0.005 & 1.065 & 0.394 & -0.835 & 23 & 0.600 & 0.014 & \\
\hline \multirow[t]{10}{*}{$\mathrm{ACO}$} & Mand & 3 & 0.001 & 0.001 & 0.000 & 0.001 & - & 0.778 & & 3 & 0.473 & 0.136 & \\
\hline & Pum & 9 & 0.007 & 0.010 & 0.008 & 0.000 & 0.000 & 0.000 & & 2 & 0.556 & 0.075 & \\
\hline & Cit & 0 & 0.000 & 0.000 & 0.000 & 0.000 & - & - & & 1 & 0.000 & 0.000 & \\
\hline & For & 7 & 0.004 & 0.005 & 0.000 & 0.000 & - & 0.000 & & 7 & 0.911 & 0.077 & \\
\hline & Pap & 6 & 0.004 & 0.006 & 0.000 & 0.000 & - & 0.000 & & 3 & 0.733 & 0.155 & \\
\hline & Mic & 14 & 0.012 & 0.016 & 0.018 & 0.000 & 0.000 & 0.000 & & 4 & 0.031 & 0.177 & \\
\hline & Ere & 6 & 0.009 & 0.012 & 0.031 & 0.000 & 0.000 & 0.000 & & 2 & 1.000 & 0.500 & \\
\hline & Pon & 4 & 0.003 & 0.004 & 0.000 & 0.000 & - & 0.000 & & 4 & 0.867 & 0.129 & \\
\hline & AncTaxa & 44 & 0.009 & 0.012 & 0.006 & 0.000 & 0.030 & 0.014 & -1.184 & 26 & 0.935 & 0.016 & 0.554 \\
\hline & $\begin{array}{l}\text { Whole Pop } \\
\text { SD }\end{array}$ & 45 & $\begin{array}{l}0.008 \\
0.001\end{array}$ & 0.011 & 0.005 & 0.000 & 0.024 & 0.010 & -1.173 & 30 & 0.908 & 0.019 & \\
\hline \multirow[t]{10}{*}{ TRPA } & Mand & 14 & 0.005 & 0.008 & 0.011 & 0.003 & 0.286 & 0.423 & & 3 & 0.385 & 0.149 & \\
\hline & Pum & 5 & 0.001 & 0.002 & 0.003 & 0.001 & 0.327 & 0.414 & & 3 & 0.378 & 0.181 & \\
\hline & Cit & 0 & 0.000 & 0.000 & 0.000 & 0.000 & - & - & & 1 & 0.000 & 0.000 & \\
\hline & For & 8 & 0.003 & 0.005 & 0.002 & 0.002 & 0.779 & 0.341 & & 7 & 0.911 & 0.077 & \\
\hline & Pap & 10 & 0.005 & 0.017 & 0.014 & 0.006 & 0.430 & 0.355 & & 5 & 0.933 & 0.122 & \\
\hline & Mic & 15 & 0.010 & 0.012 & 0.017 & 0.008 & 0.486 & 0.682 & & 4 & 1.000 & 0.177 & \\
\hline & Ere & 7 & 0.009 & 0.013 & 0.025 & 0.006 & 0.242 & 0.469 & & 2 & 1.000 & 0.500 & \\
\hline & Pon & 4 & 0.002 & 0.006 & 0.004 & 0.000 & 0.000 & 0.000 & & 3 & 0.733 & 0.155 & \\
\hline & AncTaxa & 56 & 0.014 & 0.020 & 0.025 & 0.010 & 0.411 & 0.514 & -0.705 & 26 & 0.918 & 0.019 & 0.688 \\
\hline & $\begin{array}{l}\text { Whole Pop } \\
\text { SD }\end{array}$ & 57 & $\begin{array}{l}0.012 \\
0.001\end{array}$ & 0.018 & 0.022 & 0.009 & 0.430 & 0.518 & -0.745 & 32 & 0.883 & 0.022 & \\
\hline \multirow[t]{10}{*}{ INVA } & Mand & 22 & 0.008 & 0.010 & 0.022 & 0.004 & 0.190 & 0.401 & & 8 & 0.867 & 0.060 & \\
\hline & Pum & 11 & 0.004 & 0.004 & 0.010 & 0.004 & 0.397 & 0.848 & & 6 & 0.778 & 0.137 & \\
\hline & Cit & 6 & 0.002 & 0.003 & 0.003 & 0.002 & 0.614 & 0.656 & & 3 & 0.622 & 0.138 & \\
\hline & For & 9 & 0.004 & 0.006 & 0.015 & 0.001 & 0.091 & 0.226 & & 5 & 0.800 & 0.100 & \\
\hline & Pap & 22 & 0.012 & 0.019 & 0.028 & 0.004 & 0.148 & 0.219 & & 6 & 1.000 & 0.096 & \\
\hline & Mic & 13 & 0.008 & 0.011 & 0.017 & 0.003 & 0.177 & 0.268 & & 4 & 1.000 & 0.177 & \\
\hline & Ere & 0 & 0.000 & 0.000 & 0.000 & 0.000 & - & - & & 1 & 0.000 & 0.000 & \\
\hline & Ponc & 2 & 0.001 & 0.001 & 0.004 & 0.002 & 0.345 & 1.462 & & 2 & 0.733 & 0.155 & \\
\hline & AncTaxa & 69 & 0.014 & 0.017 & 0.039 & 0.008 & 0.197 & 0.449 & -0.640 & 34 & 0.970 & 0.009 & 0.593 \\
\hline & $\begin{array}{l}\text { Whole Pop } \\
\text { SD }\end{array}$ & 72 & $\begin{array}{l}0.014 \\
0.000\end{array}$ & 0.019 & 0.031 & 0.007 & 0.226 & 0.368 & -0.514 & 49 & 0.975 & 0.006 & \\
\hline \multirow[t]{10}{*}{ PEPC } & Mand & 3 & 0.001 & 0.002 & 0.000 & 0.000 & - & 0.000 & & 3 & 0.001 & 0.138 & \\
\hline & Pum & 3 & 0.001 & 0.002 & 0.000 & 0.000 & - & 0.000 & & 4 & 0.001 & 0.152 & \\
\hline & Cit & 1 & 0.001 & 0.001 & 0.000 & 0.000 & - & 0.000 & & 2 & 0.001 & 0.095 & \\
\hline & For & 12 & 0.006 & 0.006 & 0.000 & 0.000 & - & 0.000 & & 4 & 0.006 & 0.101 & \\
\hline & Pap & 5 & 0.003 & 0.004 & 0.000 & 0.000 & - & 0.000 & & 4 & 0.800 & 0.172 & \\
\hline & Mic & 10 & 0.008 & 0.008 & 0.033 & 0.000 & 0.000 & 0.000 & & 3 & 0.833 & 0.222 & \\
\hline & Ere & 4 & 0.006 & 0.006 & 0.066 & 0.000 & 0.000 & 0.000 & & 2 & 1.000 & 0.500 & \\
\hline & Ponc & 5 & 0.004 & 0.004 & 0.000 & 0.000 & - & 0.000 & & 3 & 0.733 & 0.155 & \\
\hline & AncTaxa & 52 & 0.014 & 0.015 & 0.016 & 0.000 & 0.000 & 0.000 & -0.821 & 25 & 0.945 & 0.013 & 0.714 \\
\hline & $\begin{array}{l}\text { Whole Pop } \\
\text { SD }\end{array}$ & 53 & $\begin{array}{l}0.013 \\
0.000\end{array}$ & 0.014 & 0.012 & 0.000 & 0.000 & 0.000 & -0.757 & 33 & 0.950 & 0.011 & \\
\hline \multirow[t]{10}{*}{ PKF } & Mand & 9 & 0.003 & 0.004 & 0.003 & 0.003 & 0.914 & 0.681 & & 4 & 0.659 & 0.120 & \\
\hline & Pum & 1 & 0.000 & 0.000 & 0.000 & 0.000 & - & 0.000 & & 2 & 0.200 & 0.154 & \\
\hline & Cit & 2 & 0.001 & 0.000 & 0.000 & 0.002 & - & - & & 2 & 0.356 & 0.159 & \\
\hline & For & 6 & 0.002 & 0.003 & 0.000 & 0.000 & - & 0.000 & & 3 & 0.378 & 0.181 & \\
\hline & Pap & 12 & 0.008 & 0.010 & 0.000 & 0.005 & - & 0.517 & & 4 & 0.867 & 0.129 & \\
\hline & Mic & 2 & 0.002 & 0.000 & 0.000 & 0.004 & - & - & & 3 & 0.833 & 0.222 & \\
\hline & Ere & 4 & 0.005 & 0.007 & 0.000 & 0.003 & - & 0.492 & & 2 & 1.000 & 0.500 & \\
\hline & Pon & 0 & 0.000 & 0.000 & 0.000 & 0.000 & - & - & & 1 & 0.000 & 0.000 & \\
\hline & AncTaxa & 38 & 0.009 & 0.012 & 0.005 & 0.006 & 1.072 & 0.491 & -0.855 & 21 & 0.925 & 0.014 & 0.647 \\
\hline & $\begin{array}{l}\text { Whole Pop } \\
\text { SD }\end{array}$ & 44 & $\begin{array}{l}0.009 \\
0.000\end{array}$ & 0.011 & 0.006 & 0.006 & 0.883 & 0.514 & -1.058 & 27 & 0.937 & 0.010 & \\
\hline \multirow[t]{3}{*}{ DXS } & Mand & 14 & 0.006 & 0.009 & 0.009 & 0.002 & 0.227 & 0.228 & & 6 & 0.767 & 0.084 & \\
\hline & Pum & 4 & 0.003 & 0.004 & 0.007 & 0.000 & 0.000 & 0.000 & & 4 & 0.733 & 0.101 & \\
\hline & Cit & 2 & 0.001 & 0.001 & 0.006 & 0.001 & 0.235 & 1.219 & & 3 & 0.689 & 0.104 & \\
\hline
\end{tabular}




\begin{tabular}{|c|c|c|c|c|c|c|c|c|c|c|c|c|c|}
\hline & For & 7 & 0.004 & 0.006 & 0.005 & 0.001 & 0.301 & 0.230 & & 7 & 0.911 & 0.077 & \\
\hline & Pap & 17 & 0.012 & 0.016 & 0.015 & 0.007 & 0.466 & 0.434 & & 6 & 1.000 & 0.096 & \\
\hline & Mic & 4 & 0.003 & 0.004 & 0.006 & 0.002 & 0.304 & 0.534 & & 3 & 0.833 & 0.222 & \\
\hline & Ere & 7 & 0.010 & 0.013 & 0.026 & 0.004 & 0.153 & 0.296 & & 2 & 1.000 & 0.500 & \\
\hline & Pon & 4 & 0.003 & 0.005 & 0.000 & 0.000 & - & 0.000 & & 2 & 0.533 & 0.172 & \\
\hline & AncTaxa & 51 & 0.015 & 0.021 & 0.018 & 0.006 & 0.348 & 0.289 & -0.321 & 32 & 0.967 & 0.009 & 0.659 \\
\hline & Whole Pop & 52 & 0.014 & 0.020 & 0.019 & 0.005 & 0.285 & 0.271 & -0.394 & 39 & 0.947 & 0.014 & \\
\hline & SD & & 0.001 & & & & & & & & & & \\
\hline \multirow{10}{*}{ PSY } & Mand & 15 & 0.010 & 0.012 & 0.012 & 0.010 & 0.886 & 0.886 & & 8 & 0.850 & 0.075 & \\
\hline & Pum & 3 & 0.002 & 0.000 & 0.000 & 0.003 & - & - & & 3 & 0.711 & 0.086 & \\
\hline & Cit & 3 & 0.002 & 0.004 & 0.004 & 0.002 & 0.495 & 0.495 & & 2 & 0.467 & 0.132 & \\
\hline & For & 6 & 0.005 & 0.009 & 0.009 & 0.004 & 0.443 & 0.443 & & 4 & 0.778 & 0.091 & \\
\hline & Pap & 8 & 0.007 & 0.008 & 0.025 & 0.000 & 0.000 & 0.000 & & 4 & 0.867 & 0.129 & \\
\hline & Mic & 0 & 0.000 & 0.000 & 0.000 & 0.000 & - & - & & 1 & 0.000 & 0.000 & \\
\hline & Ere & 0 & 0.000 & 0.000 & 0.000 & 0.000 & - & - & & 1 & 0.000 & 0.000 & \\
\hline & Pon & 3 & 0.003 & 0.010 & 0.010 & 0.001 & 0.119 & 0.119 & & 3 & 0.733 & 0.155 & \\
\hline & AncTaxa & 45 & 0.013 & 0.014 & 0.003 & 0.011 & 3.533 & 0.775 & -0.646 & 23 & 0.953 & 0.010 & 0.707 \\
\hline & $\begin{array}{l}\text { Whole Pop } \\
\text { SD }\end{array}$ & 45 & $\begin{array}{l}0.013 \\
0.001\end{array}$ & 0.026 & 0.026 & 0.010 & 0.389 & 0.389 & -0.526 & 28 & 0.950 & 0.011 & \\
\hline \multirow[t]{10}{*}{ HYB } & Mand & 10 & 0.006 & 0.004 & 0.005 & 0.008 & 1.421 & 1.704 & & 5 & 0.780 & 0.085 & \\
\hline & Pum & 4 & 0.002 & 0.002 & 0.002 & 0.001 & 0.534 & 0.633 & & 4 & 0.733 & 0.120 & \\
\hline & Cit & 0 & 0.000 & 0.000 & 0.000 & 0.000 & - & - & & 1 & 0.000 & 0.000 & \\
\hline & For & 25 & 0.013 & 0.014 & 0.000 & 0.013 & - & 0.918 & & 10 & 1.000 & 0.045 & \\
\hline & Pap & 5 & 0.003 & 0.001 & 0.000 & 0.006 & - & 4.657 & & 4 & 0.800 & 0.172 & \\
\hline & Mic & 7 & 0.007 & 0.010 & 0.000 & 0.002 & - & 0.221 & & 4 & 1.000 & 0.177 & \\
\hline & Ere & 4 & 0.006 & 0.005 & 0.000 & 0.007 & - & 1.337 & & 2 & 1.000 & 0.500 & \\
\hline & Pon & 4 & 0.003 & 0.002 & 0.000 & 0.004 & - & 2.697 & & 3 & 0.733 & 0.155 & \\
\hline & AncTaxa & 52 & 0.014 & 0.015 & 0.018 & 0.012 & 0.669 & 0.795 & -0.821 & 25 & 0.945 & 0.013 & 0.624 \\
\hline & $\begin{array}{l}\text { Whole Pop } \\
\text { SD }\end{array}$ & 47 & $\begin{array}{l}0.012 \\
0.001\end{array}$ & 0.015 & 0.010 & 0.009 & 0.914 & 0.618 & -0.368 & 37 & 0.956 & 0.009 & \\
\hline \multirow[t]{11}{*}{ LCY2 } & Mand & 26 & 0.016 & 0.026 & 0.026 & 0.011 & 0.413 & 0.413 & & 7 & 0.857 & 0.065 & \\
\hline & Pum & 2 & 0.001 & 0.004 & 0.004 & 0.000 & 0.000 & 0.000 & & 3 & 0.378 & 0.181 & \\
\hline & Cit & 0 & 0.000 & 0.000 & 0.000 & 0.000 & - & - & & 1 & 0.000 & 0.000 & \\
\hline & For & 27 & 0.014 & 0.028 & 0.028 & 0.007 & 0.263 & 0.263 & & 9 & 0.978 & 0.054 & \\
\hline & Pap & 11 & 0.008 & 0.017 & 0.017 & 0.004 & 0.256 & 0.256 & & 4 & 0.867 & 0.129 & \\
\hline & Mic & 5 & 0.004 & 0.007 & 0.007 & 0.003 & 0.361 & 0.361 & & 3 & 0.833 & 0.222 & \\
\hline & Ere & 5 & 0.007 & 0.016 & 0.016 & 0.004 & 0.276 & 0.276 & & 2 & 1.000 & 0.500 & \\
\hline & Pon & 0 & 0.000 & 0.000 & 0.000 & 0.000 & - & - & & 1 & 0.000 & 0.000 & \\
\hline & AncTaxa & 64 & 0.014 & 0.030 & 0.030 & 0.007 & 0.246 & 0.246 & -0.956 & 25 & 0.938 & 0.014 & 0.522 \\
\hline & Whole Pop & 65 & 0.014 & 0.029 & 0.029 & 0.008 & 0.274 & 0.274 & -0.794 & 31 & 0.940 & 0.011 & \\
\hline & SD & & 0.001 & & & & & & & & & & \\
\hline \multirow[t]{10}{*}{ LCYB } & Mand & 11 & 0.002 & 0.006 & 0.006 & 0.000 & 0.062 & 0.062 & & 2 & 0.143 & 0.119 & \\
\hline & Pum & 6 & 0.003 & 0.007 & 0.007 & 0.002 & 0.298 & 0.298 & & 3 & 0.600 & 0.131 & \\
\hline & Cit & 0 & 0.000 & 0.000 & 0.000 & 0.000 & - & - & & 1 & 0.000 & 0.000 & \\
\hline & For & 2 & 0.000 & 0.001 & 0.001 & 0.000 & 0.281 & 0.281 & & 2 & 0.200 & 0.154 & \\
\hline & Pap & 14 & 0.007 & 0.026 & 0.026 & 0.002 & 0.083 & 0.083 & & 6 & 1.000 & 0.096 & \\
\hline & Mic & 5 & 0.003 & 0.005 & 0.005 & 0.002 & 0.430 & 0.430 & & 3 & 0.833 & 0.222 & \\
\hline & Ere & 5 & 0.005 & 0.019 & 0.019 & 0.001 & 0.071 & 0.071 & & 2 & 1.000 & 0.500 & \\
\hline & Pon & 0 & 0.000 & 0.000 & 0.000 & 0.000 & - & - & & 1 & 0.000 & 0.000 & \\
\hline & AncTaxa & 37 & 0.009 & 0.028 & 0.028 & 0.004 & 0.141 & 0.141 & 0.253 & 20 & 0.898 & 0.019 & 0.723 \\
\hline & $\begin{array}{l}\text { Whole Pop } \\
\text { SD }\end{array}$ & 37 & $\begin{array}{l}0.009 \\
0.000\end{array}$ & 0.028 & 0.028 & 0.004 & 0.134 & 0.134 & 0.433 & 24 & 0.898 & 0.018 & \\
\hline \multirow[t]{11}{*}{ NCED3 } & Mand & 8 & 0.003 & 0.003 & 0.003 & 0.003 & 0.761 & 0.761 & & 4 & 0.659 & 0.090 & \\
\hline & Pum & 2 & 0.002 & 0.003 & 0.003 & 0.001 & 0.461 & 0.461 & & 3 & 0.711 & 0.086 & \\
\hline & Cit & 0 & 0.000 & 0.000 & 0.000 & 0.000 & - & - & & 1 & 0.000 & 0.000 & \\
\hline & For & 1 & 0.001 & 0.000 & 0.000 & 0.001 & - & - & & 2 & 0.556 & 0.075 & \\
\hline & Pap & 7 & 0.005 & 0.012 & 0.012 & 0.003 & 0.293 & 0.293 & & 5 & 0.933 & 0.122 & \\
\hline & Mic & 2 & 0.002 & 0.004 & 0.004 & 0.001 & 0.311 & 0.311 & & 3 & 0.833 & 0.222 & \\
\hline & Ere & 3 & 0.005 & 0.008 & 0.008 & 0.005 & 0.622 & 0.622 & & 2 & 1.000 & 0.500 & \\
\hline & Pon & 0 & 0.000 & 0.000 & 0.000 & 0.000 & - & - & & 1 & 0.000 & 0.000 & \\
\hline & AncTaxa & 21 & 0.008 & 0.015 & 0.015 & 0.006 & & 0.391 & -0.096 & 16 & 0.922 & 0.012 & 0.715 \\
\hline & Whole Pop & 21 & 0.008 & 0.015 & 0.015 & 0.006 & 0.387 & 0.387 & 0.231 & 21 & 0.929 & 0.010 & \\
\hline & SD & & 0.000 & & & & & & & & & & \\
\hline \multirow[t]{11}{*}{ AOC } & Mand & 9 & 0.007 & 0.021 & 0.029 & 0.001 & 0.039 & 0.054 & & 4 & 0.736 & 0.075 & \\
\hline & Pum & 1 & 0.001 & 0.002 & 0.003 & 0.000 & 0.000 & 0.000 & & 2 & 0.467 & 0.132 & \\
\hline & Cit & 1 & 0.000 & 0.000 & 0.000 & 0.000 & - & - & & 2 & 0.200 & 0.154 & \\
\hline & For & 5 & 0.002 & 0.005 & 0.007 & 0.001 & 0.155 & 0.210 & & 5 & 0.800 & 0.100 & \\
\hline & Pap & 1 & 0.001 & 0.003 & 0.004 & 0.000 & 0.000 & 0.000 & & 2 & 0.533 & 0.172 & \\
\hline & Mic & 9 & 0.007 & 0.013 & 0.017 & 0.005 & 0.312 & 0.423 & & 3 & 0.833 & 0.222 & \\
\hline & Ere & 0 & 0.000 & 0.000 & 0.000 & 0.000 & - & - & & 1 & 0.000 & 0.000 & \\
\hline & Pon & 0 & 0.000 & 0.000 & 0.000 & 0.000 & - & - & & 1 & 0.000 & 0.000 & \\
\hline & AncTaxa & 35 & 0.010 & 0.024 & 0.032 & 0.004 & 0.133 & 0.181 & 0.851 & 16 & 0.909 & 0.018 & 0.785 \\
\hline & Whole Pop & 37 & 0.010 & 0.024 & 0.032 & 0.004 & 0.116 & 0.158 & -0.390 & 18 & 0.894 & 0.017 & \\
\hline & SD & & 0.001 & & & & & & & & & & \\
\hline MRP4 & Mand & 2 & 0.001 & 0.001 & 0.000 & 0.000 & - & 0.309 & & 3 & 0.385 & 0.149 & \\
\hline
\end{tabular}




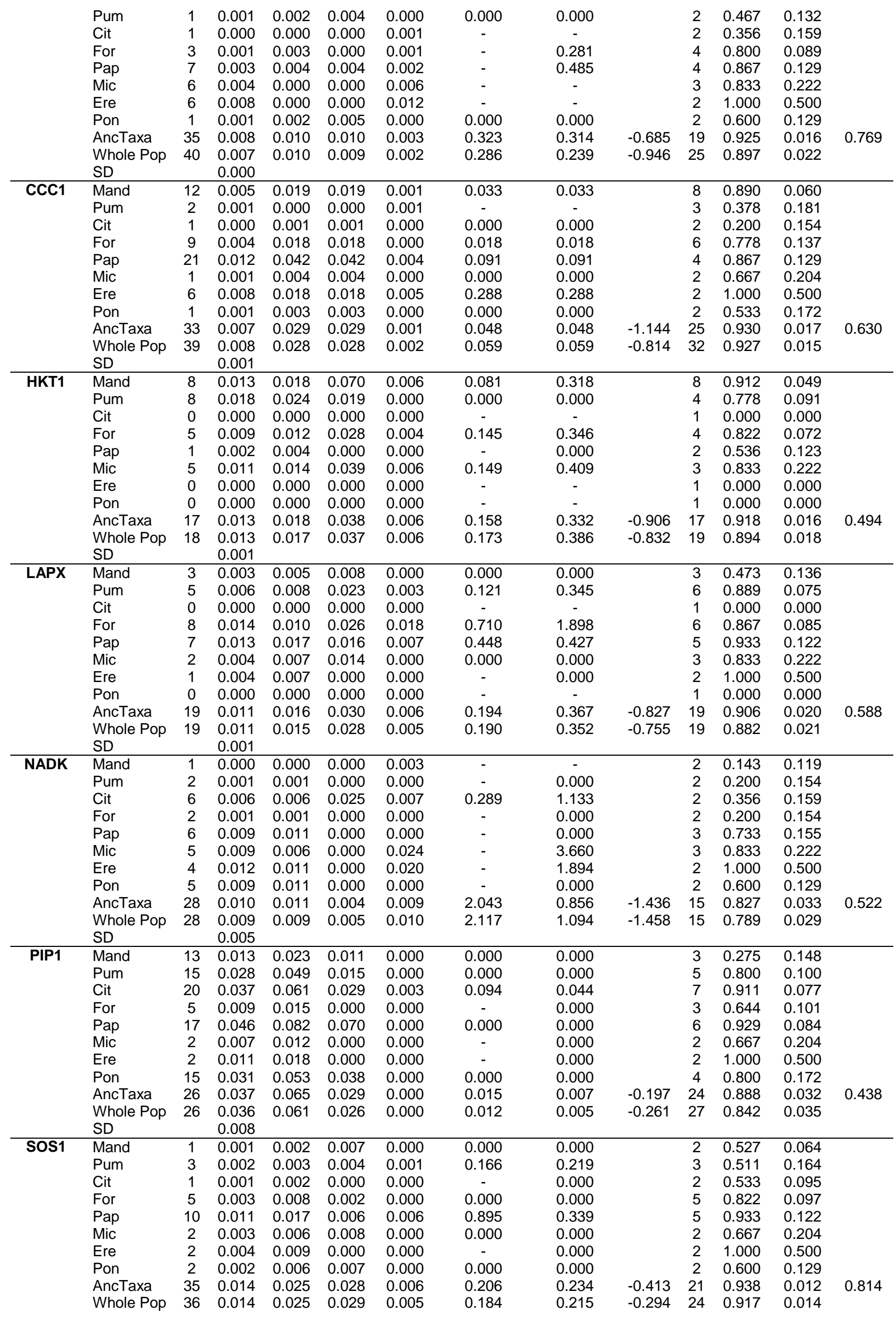




\begin{tabular}{|c|c|c|c|c|c|c|c|c|c|c|c|c|c|}
\hline & SD & & 0.001 & & & & & & & & & & \\
\hline \multirow[t]{10}{*}{ TSC } & Mand & 2 & 0.003 & 0.004 & 0.000 & 0.000 & - & 0.000 & & 3 & 0.670 & 0.007 & \multirow{10}{*}{0.542} \\
\hline & Pum & 1 & 0.002 & 0.000 & 0.000 & 0.005 & - & - & & 2 & 0.533 & 0.009 & \\
\hline & Cit & 0 & 0.000 & 0.000 & 0.000 & 0.000 & - & - & & 1 & 0.000 & 0.000 & \\
\hline & For & 6 & 0.005 & 0.007 & 0.020 & 0.000 & 0.000 & 0.000 & & 4 & 0.644 & 0.023 & \\
\hline & Pap & 7 & 0.010 & 0.011 & 0.010 & 0.008 & 0.795 & 0.673 & & 6 & 1.000 & 0.096 & \\
\hline & Mic & 3 & 0.005 & 0.007 & 0.018 & 0.000 & 0.000 & 0.000 & & 3 & 0.833 & 0.049 & \\
\hline & Ere & 4 & 0.012 & 0.018 & 0.037 & 0.000 & 0.000 & 0.000 & & 2 & 1.000 & 0.250 & \\
\hline & Pon & 0 & 0.000 & 0.000 & 0.000 & 0.000 & - & - & & 1 & 0.000 & 0.000 & \\
\hline & AncTaxa & 24 & 0.008 & 0.010 & 0.009 & 0.005 & 0.509 & 0.488 & -1.601 & 17 & 0.907 & 0.016 & \\
\hline & Whole Pop & 24 & 0.007 & 0.009 & 0.007 & 0.004 & 0.583 & 0.472 & -1.597 & 18 & 0.880 & 0.000 & \\
\hline
\end{tabular}


Supplementary Information 4. NJ tree with all the SNP markers in the whole population studied, ancestral Citrus species, relatives, secondary species and interspecific hybrids (1000 bootstraps performed). Branch support over $50 \%$ represented

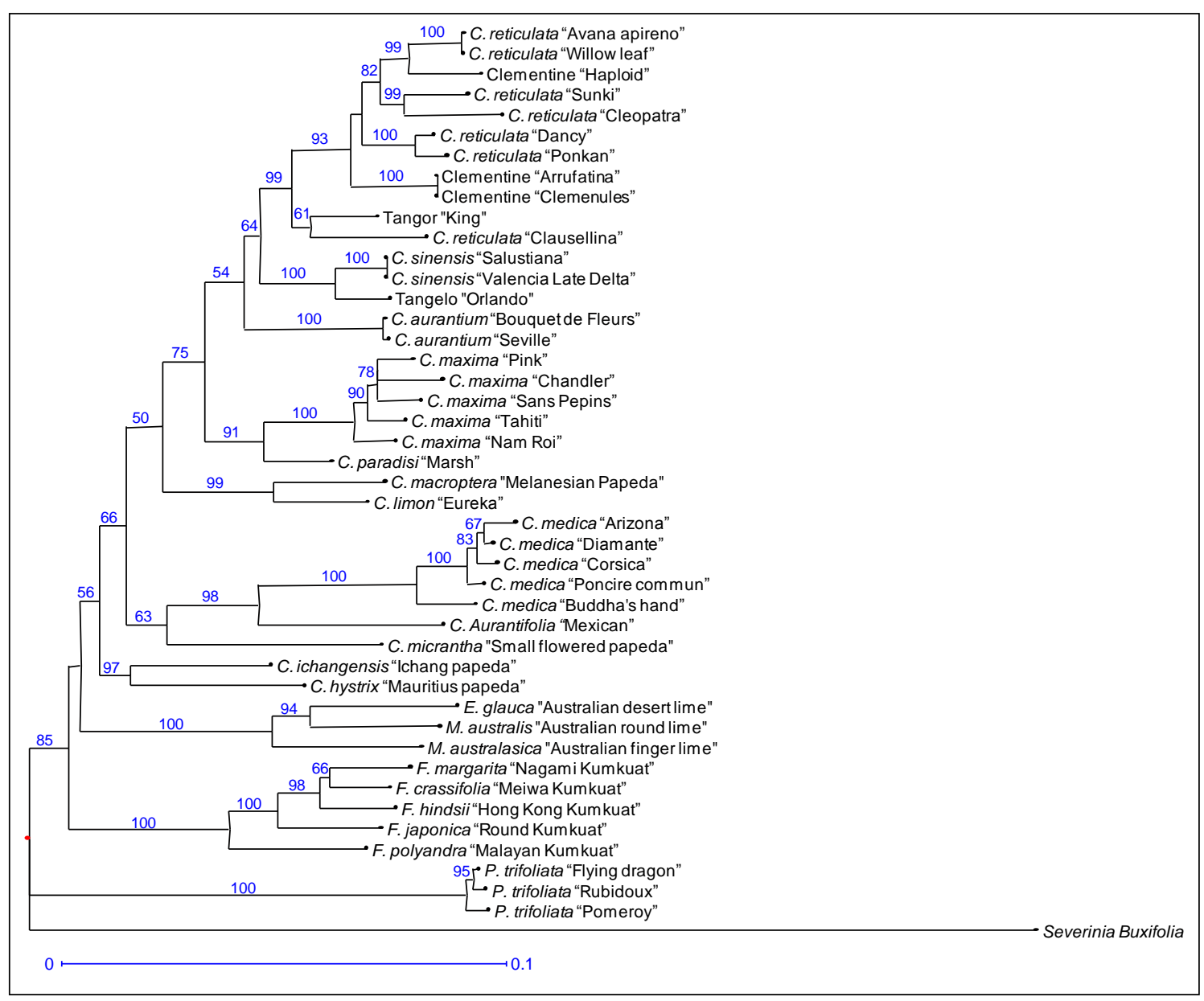


ANNEX CHAPTER 2 



\section{Clymenia's phylogeny within the 'true citrus fruit trees'.}

Clymenia polyandra (Tan.) Swing. is one of the six genera of the 'true citrus fruit trees' (Citrus, Poncirus, Fortunella, Microcitrus, Eremocitrus and Clymenia). The genus Clymenia is closely related to Citrus, but it is not well characterized. Chemotaxonomic work (Berhow et al., 2000) suggests that Clymenia is closely allied with Fortunella and may be a hybrid between Fortunella and Citrus. Clymenia is considered a primitive genus in the 'true citrus fruit trees group' and may be a link between that group and the 'near citrus fruit trees' group (Krueger and Navarro, 2007).

It was not included in our previous study Garcia-Lor et al. (2013a) due to the unavailability of the vegetal material. After obtaining the DNA extract, we proceeded to the sequencing of the 18 genes involved in primary and secondary metabolite biosynthesis pathways that determine citrus fruit quality (sugars, acids, flavonoids and carotenoids) and nine putative genes involved in stress response as it was described in Garcia-Lor et al. (2013a).

From sequencing data, the available Clymenia accession appeared totally homozygous. It presented 60 specific SNP loci (not present in the other genera) in homozygosity, 31 in the coding regions and 29 in the non-coding regions.

Eight specific InDels were found in the Clymenia sequences, seven in the non-coding regions (2bp in ACO, 4bp in INVA, 1bp in DXS, 1bp in PSY, 18bp and 3bp in MPR4 and 1bp in $\mathrm{PIP} 1 \mathrm{~A})$ and one (1bp) in the coding region of PIP1A gene fragment.

Among all models tested using Phylemon website (http://phylemon.bioinfo.cipf.es; Sánchez et al., 2011) for the phylogenetic analysis with SNP data, the model with the best fit was JC (with $\mathrm{SH}$-like branch supports alone). This model takes into account the nucleotide substitution model JC (one substitution class; $A=T=C=G$ ). The phylogenetic relationships between Citrus species and their relatives inferred from maximum likelihood method using this model are represented in Figure 1. Branch support (BS) is represented in all branches. The different 'true citrus fruit trees' genotypes were rooted using Severinia buxifolia as outgroup. Clymenia, Microcitrus and Eremocitrus forms a clade with a high branch support $(\mathrm{BS}=1)$.

Swingle (1967) described Clymenia as one of the six genus belonging to the 'true citrus fruit tress' group. It differs from all the species of the subgenus Citrus of the genus Citrus in some morphologic characters, like the leaves and the pulp-vesicles, but it is obviously related. Berhow et al. (2000) suggests that Clymenia is closely related with Fortunella and may be a hybrid between Fortunella and Citrus. In our analysis, Clymenia is placed in the same clade than Microcitrus and Eremocitrus, which are clearly differentiated from Citrus and Fortunella clusters. Moreover, the null amount of heterozygosity in the gene fragments analysed testifies that 
Clymenia polyandra cannot be an interspecific or intergeneric hybrid. Our analysis is in agreement with Bayer et al. (2009) and Morton (2009), who observed Clymenia closely to Microcitrus and Eremocitrus in a phylogenetic study with cpDNA markers. Moreover, Swingle and Reece (1967) observed that C. medica is closely related to Clymenia and as our results show, the branch including Clymenia, Microcitrus and Eremocitrus is sister of the one formed by C. maxima and C. medica, confirming their probable close relationship.

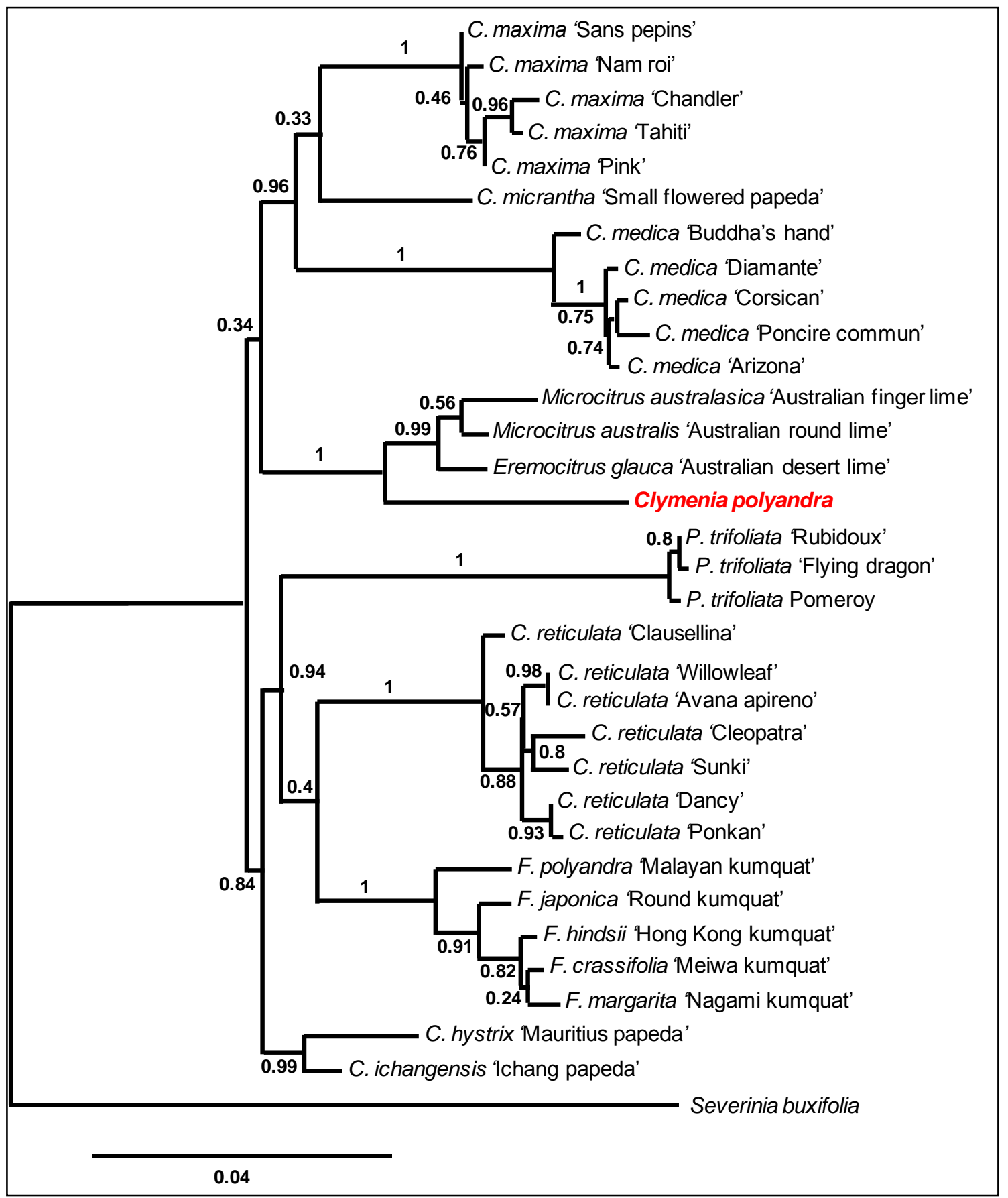

Figure 1. Phylogeny of the 'true citrus fruit trees' genera for the 27 genes sequenced. 


\section{CHAPTER 3}

\section{Citrus (Rutaceae) SNP markers based on Competitive Allele-Specific PCR; transferability across the Aurantioideae subfamily}

Andres Garcia-Lor, Gema Ancillo, Luis Navarro, and Patrick Ollitrault

Applications in Plant Sciences (2013) 1: 1200406 



\section{Abstract}

- $\quad$ Premise of the study

Single nucleotide polymorphism (SNP) markers based on Competitive Allele-Specific PCR (KASPar) were developed from sequences of three Citrus species. Their transferability was tested in 63 Citrus genotypes and 19 relative genera of the subfamily Aurantioideae to estimate the potential of SNP markers, selected from a limited intrageneric discovery panel, for ongoing broader diversity analysis at the intra- and intergeneric levels and systematic germplasm bank characterization.

- $\quad$ Methods and Results

Forty-two SNP markers were developed using KASPar technology. Forty-one were successfully genotyped in all of the Citrus germplasm, where intra- and interspecific polymorphisms were observed. The transferability and diversity decreased with increasing taxonomic distance.

\section{- $\quad$ Conclusions}

SNP markers based on the KASPar method developed from sequence data of a limited intrageneric discovery panel provide a valuable molecular resource for genetic diversity analysis of germplasm within a genus and should be useful for germplasm fingerprinting at a much broader diversity level. 


\section{INTRODUCTION}

Single nucleotide polymorphisms (SNPs) are the most frequent type of DNA sequence polymorphism. Their abundance and uniform distribution in genomes make them very powerful genetic markers. Several SNP genotyping methods have been developed. For low-to-medium throughput genotyping, the KBioscience Competitive Allele-Specific PCR genotyping system (KASPar; KBioscience Ltd., Hoddeston, United Kingdom) appears to be an interesting approach (Cuppen, 2007) that has been successfully applied in animals and plants (Nijman et al., 2008; Bauer et al., 2009; Cortés et al., 2011). For genetic diversity studies with SNP markers, it is very important to determine the representativeness of the discovery panel (Albrechtsen et al., 2010). Ascertainment bias of the SNP markers affects the evaluation of genetic parameters, as was observed for the Citrus genus using SNP markers mined in a single Clementine cultivar (Ollitrault et al., 2012a). Recently, Garcia-Lor et al. (2013a) sequenced 27 amplified nuclear gene fragments for 45 genotypes of Citrus, which resulted in the identification of 1097 SNPs. Taking advantage of these previously obtained SNP data, the objective of this work was to implement a set of polymorphic SNP markers for systematic germplasm bank characterization within the Citrus genus and to investigate their transferability across the Aurantioideae [Engler] subfamily. More generally, the objective was to estimate the usefulness of SNP markers developed using KASPar technology, which were selected from a limited intrageneric discovery panel, for broader diversity analysis at the intra- and intergeneric levels. 


\section{METHODS AND RESULTS}

The 42 SNP markers used in this study were selected from SNPs identified by GarciaLor et al. (2013a) in 27 nuclear genes. Most cultivated citrus (except for $C$. aurantifolia Christm.) Swingle) arose from interspecific hybridization of three ancestral taxa: $C$. medica L., C. reticulata Blanco, and C. maxima (Burm.) Merr. (Nicolosi et al., 2000; Barkley et al., 2006; Garcia-Lor et al., 2012a). Therefore, we selected SNPs between and within these three taxa (based on seven C. reticulata, five $C$. maxima, and five $C$. medica accessions). Primers were defined by KBioscience (http://www.kbioscience.co.uk/) from each SNP-locus flanking sequence (Appendix S1). Two allele-specific oligonucleotides and one common oligonucleotide were defined for each locus (Table 1). The KASPar system uses two Förster Resonance Energy Transfer (FRET) cassettes, where fluorometric dye is conjugated to the primer but quenched via resonance energy transfer. In this system, sample DNA is amplified in a thermal cycler using allele-specific primers, leading to the separation of fluorometric dye and quencher when the FRET cassette primer is hybridized with DNA (Cuppen, 2007). Normalized signals of each SNP allele ( $x$ and $y$ ) were provided by KBioscience services. Automatic allele calls provided by KlusterCaller software were visually checked with two-dimensional plot representations using SNPViewer software (KBioscience Ltd.).

Eighty-four accessions (Appendix 1) were genotyped for the 42 SNP markers. The sample set included representatives of the two tribes of the Aurantioideae (Clausenae and Citreae). In Clausenae, the subtribe Clauseniae was represented by four genotypes (three genera). Within the Citreae, three subtribes were represented: Triphasilinae (one genus was included), Balsamocitrinae (represented by six genera), and Citrinae (11 genera represented). For the Citrinae, we adopted the subdivision of this tribe into three groups (as proposed by Swingle and Reece, 1967), namely the primitive citrus fruit group (four accessions of four genera), the near citrus fruit group (three accessions of two genera), and the 'true citrus fruit trees' group (48 accessions of six genera). High-molecular-weight genomic DNA was extracted from leaf samples using a DNeasy Plant Mini Kit (Qiagen, Madrid, Spain) according to the manufacturer's instructions.

From the 42 SNP primers tested, only one did not produce polymorphisms. To check the accuracy of the allele call for the 41 other markers, we compared the KASPar genotyping data with Sanger sequencing data available for 35 accessions of the 'true citrus fruit trees' (GarciaLor et al., 2013a). The conformity level was $95.41 \%$, while $2.99 \%$ did not agree and $1.60 \%$ were missing data.

The allele number and the percentage of missing data are presented for each taxon (Table 2). The expected $\left(H_{\mathrm{e}}\right)$ and observed heterozygosity $\left(H_{0}\right)$ were evaluated for $C$. reticulata, C. maxima, C. medica, the Citrus genus, and the 'true citrus fruit trees' excluding the Citrus 
genus. Data analysis was conducted with Powermarker version 3.25 (Liu and Muse, 2005) and Darwin (Perrier and Jacquemoud-Collet, 2006) software.

The missing data rate was very low in Citrus $(0.9 \%)$ and, generally, in the 'true citrus fruit trees' group ( $0.6 \%$, excluding the Citrus genus). The missing data rate increased to $6.5 \%$ and $6.7 \%$ in the close citrus and primitive citrus groups of the Citrinae subtribe, respectively, reaching a level of $9.8 \%$ and $22.4 \%$ for the two other subtribes of the Citreae tribe, the Triphasilinae and the Balsamocitrinae, respectively. Missing data reached $26.8 \%$ in the Clauseniae tribe. These results indicate an increasing loss of transferability with increasing taxonomic distance. As expected due to the discovery panel, the Citrus genus was the most polymorphic (an average of two alleles per locus; $H_{\mathrm{e}}=0.30$ and $H_{0}=0.23$ ), followed by the 'true citrus fruit trees' group excluding the Citrus genus (alleles per locus $[A]=1.32 ; H_{\mathrm{e}}=0.09$ and $H_{0}$ $=0.02$ ). Diversity within and between the other taxa decreased considerably (data not shown). However, despite this important loss of polymorphism, all citrus relatives were differentiated when missing amplification was considered to represent null alleles, providing molecular fingerprinting for traceability in germplasm bank management.

Among the Citrus ancestral taxa, $C$. reticulata was the most polymorphic $\left(A=1.37 ; H_{\mathrm{e}}=\right.$ $0.11)$, followed by $C$. medica $\left(A=1.15 ; H_{\mathrm{e}}=0.04\right)$, and $C$. maxima $\left(A=1.10 ; H_{\mathrm{e}}=0.03\right)$. Considering as subpopulation the three species used in the discovery panel the $F_{\mathrm{st}}$ value was very high (0.842). The high level of differentiation between $C$. reticulata, $C$. maxima, and $C$. medica for this SNP panel was well illustrated by NJ analysis (Figure 1). The relative position of the accessions of secondary species (C. aurantium L., C. aurantifolia, C. limon (L.) Osbeck, C. paradisi Macf., and C. sinensis (L.) Osbeck) and hybrids (clementine, tangor, and tangelo) agrees with previous molecular studies (Nicolosi et al., 2000; Ollitrault et al., 2012a; Garcia-Lor et al., 2012a). Therefore, these markers should be useful as phylogenetic tracers of DNA fragments in secondary cultivated citrus species. 
Table 1. Characteristics of 41 SNP primers used for genotyping of the Aurantioideae family

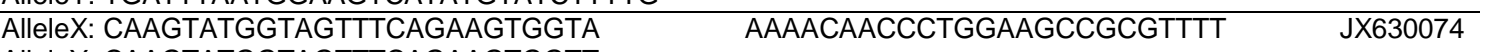

$\begin{array}{lc}\text { Common primer } & \text { GBA } \\ \text { GTTTAGCCCGCACTTTCTTTCTCTTT } & \text { JX630064 }\end{array}$

TCTCTGTTTTGAAGCTAATTCCCACTCAA JX630065

\begin{tabular}{ll} 
CTGAAGCTAATTTGCAGACATGGAACATT & JX630065 \\
\hline CTCGGACCATAATCAGCAAAGACCAT & JX630066
\end{tabular}

GACCAAAGGGACAGAATCTAATGAGTTTA JX630066

\begin{tabular}{ll} 
GCAATCGAGGGTATAAAATCACCAATGTT & JX630066 \\
\hline GTGCATTTAAGAACTGAGAAGGCATAGAA & JX630067
\end{tabular} GAAGGCATAGAATATTCCAYTAGGTTTGAA $\overline{\text { JX630067 }}$ GGACTTTTTCAGGTTTTGCATGTTGTCAA JX630068 \begin{tabular}{ll} 
CAGTAAGGTTTTCACGGCGCCATAT & JX630069 \\
\hline GGCACATTCTCTACTAACAAATCCATGTA & JX630069
\end{tabular}

TCCCAGTGGCCACTGGCATCAT JX630070
\begin{tabular}{ll} 
ACAGCGGAGTCCAATGTGGAGTTTA & JX630071 \\
\hline CCTGCAAATATACATACACAATGTTCCAAA & JX630071
\end{tabular} \begin{tabular}{ll} 
CTGGTGTGAGGTTCAACTCCAAGAA & JX630072 \\
\hline GATGACCTCTTCAACATCAACGCCAA & JX630072
\end{tabular}

ACCTTAGGTCATGAAGCCCCAACAA $\quad J X 630073$
GTTAAGTTCCATGAAAGGAGAAGACTCTT JX630074 \begin{tabular}{ll} 
TGCGACTTTGTTGATCCTGGAGGTT & JX630075 \\
\hline GGCCATCGACGATTTTGAAAGGGTT & JX630076
\end{tabular}

CCGAACAGATTTGGAAACAATTTCGCAAT JX630076


Table 1. Continued

\begin{tabular}{|c|c|c|c|c|}
\hline NADK2-M285 & NADH kinase (NADK2) & $\begin{array}{l}\text { AlleleX: CATCTTCTCTTGGTGATACAAGAAAGAA } \\
\text { AlleleY: ATCTTCTCTTGGTGATACAAGAAAGAG }\end{array}$ & AACTCATTTCTAGATCTGATGAGCAGGTT & JX630077 \\
\hline DFR-M240 & Dihydroflavonol 4-reductase (DFR) & $\begin{array}{l}\text { AlleleX: CCGAAGAGGGAAACTTTGATGAAG } \\
\text { AlleleY: CCGAAGAGGGAAACTTTGATGAAC }\end{array}$ & GAAAAACTCCAGTGCAGCCTCGAAT & JX630078 \\
\hline LAPX-M238 & Ascorbate peroxidase (LAPX) & $\begin{array}{l}\text { AlleleX: GAATTGACCATGGTTTGTGTTTTATTTTC } \\
\text { AlleleY: GAATTGACCATGGTTTGTGTTTTATTTTG }\end{array}$ & GGCAACAACTCCAGCCAACTTCAA & JX630079 \\
\hline PSY-M30 & Phytoene synthase (PSY) & $\begin{array}{l}\text { AlleleX: GTCCATTTGATATGCTTGATGCTGG } \\
\text { AlleleY: GTCCATTTGATATGCTTGATGCTGC }\end{array}$ & CGACAGGAAATTTGGTTACTGTATCTGAT & JX630080 \\
\hline PSY-C461 & Phytoene synthase (PSY) & $\begin{array}{l}\text { AlleleX: CGCAGGCCTATTAAACTCTTGTCA } \\
\text { AlleleY: CGCAGGCCTATTAAACTCTTGTCT }\end{array}$ & AAGTTCTGCATGCTACCCTTCTCAATATT & JX630080 \\
\hline AOC-M290 & Ascorbate oxydase (AOC) & $\begin{array}{l}\text { AlleleX: AAGGGGTGCATCTGAGCCAAAG } \\
\text { AlleleY: AAAGGGGTGCATCTGAGCCAAAA }\end{array}$ & CTGCGTTGAAAACTAATGGTACTGTACTT & JX630081 \\
\hline AOC-C593 & Ascorbate oxydase (AOC) & $\begin{array}{l}\text { AlleleX: GCCATACCCATGGAATTCGGCT } \\
\text { AlleleY: GCCATACCCATGGAATTCGGCA }\end{array}$ & GGGGTAACTGGAGGGCTCCATT & JX630081 \\
\hline DXS-C545 & 1-deoxyxylulose 5-phosphate synthase (DXS) & $\begin{array}{l}\text { AlleleX: ACCAAATGCATCATGAACGCTTTCC } \\
\text { AlleleY: ACCAAATGCATCATGAACGCTTTCG }\end{array}$ & GGGGCTTGCAGGATTCCCCAAA & JX630082 \\
\hline DXS-M618 & 1-deoxyxylulose 5-phosphate synthase (DXS) & $\begin{array}{l}\text { AlleleX: GGTCTTGGTATGTACTTCG } \\
\text { AlleleY: CTGCTGGTCTTGGTATGTACTTCA }\end{array}$ & CCTACAATTTCTCTAGATTGATGAAAGGAA & JX630082 \\
\hline FLS-P129 & Flavonol synthase (FLS) & $\begin{array}{l}\text { AlleleX: GGCTTCCGCGATGGAACGTA } \\
\text { AlleleY: GGCTTCCGCGATGGAACGTG }\end{array}$ & CGATCTCGACGACCCCGTTCAA & JX630083 \\
\hline FLS-M400 & Flavonol synthase (FLS) & $\begin{array}{l}\text { AlleleX: CCGTCTTCTATCAACTACCGCTTT } \\
\text { AlleleY: CGTCTTCTATCAACTACCGCTTC }\end{array}$ & TTCACCGGTAAGAAGGAGGGTTGTT & JX630083 \\
\hline LCY2-M379 & Lycopene $\beta$-cyclase 2 (LCY2) & $\begin{array}{l}\text { AlleleX: TGATGAGTTTGAAGACATAGGACTTG } \\
\text { AlleleY: GTTGATGAGTTTGAAGACATAGGACTTA }\end{array}$ & CGGCCAAGTTTTGTCCAAACAGTCTA & JX566716 \\
\hline LCYB-M480 & Lycopene $\beta$-cyclase (LCYB) & $\begin{array}{l}\text { AlleleX: GAATAACCTTAATAACTTTAGCTTGGTGG } \\
\text { AlleleY: GAATAACCTTAATAACTTTAGCTTGGTGA }\end{array}$ & GCTGCAAAAATGCATAACCAATGGTGTTA & JX630084 \\
\hline LCYB-P736 & Lycopene $\beta$-cyclase (LCYB) & $\begin{array}{l}\text { AlleleX: GATTCGCATCTGAACAACAATTCGG } \\
\text { AlleleY: CGCATCTGAACAACAATTCGC }\end{array}$ & GAAAAGTAGGAATTTTGCTATTTGCCTCTT & JX630084 \\
\hline HYB-M62 & $\beta$-Carotene hydroxylase (HYB) & $\begin{array}{l}\text { AlleleX: AAAACAAAACATACGGTGAAAGAGTTGAT } \\
\text { AlleleY: AACAAAACATACGGTGAAAGAGTTGAG }\end{array}$ & GGCTTCTTTAATGGCAAAAACCGAAGAAA & AF315289 \\
\hline HYB-C433 & $\beta$-Carotene hydroxylase (HYB) & $\begin{array}{l}\text { AlleleX: GAGCAAATGTGCCAAACATTTCAGC } \\
\text { AlleleY: AGAGCAAATGTGCCAAACATTTCAGT }\end{array}$ & GTACAGGGTGGAGAGGTGCCTT & JX630087 \\
\hline TSC-C80 & Tréhalose-6-phosphate synthase (TSC) & $\begin{array}{l}\text { AlleleX: TCTTGACCACTTGGAAAATGTTCTTT } \\
\text { AlleleY: CTTGACCACTTGGAAAATGTTCTTG }\end{array}$ & GCCTCTTTTGACAACAACAGGCTCAT & JX630084 \\
\hline NCED3-M535 & $\begin{array}{l}\text { 9-cis-epoxy hydroxy carotenoid dyoxygenase } 3 \\
\text { (NCED3) }\end{array}$ & $\begin{array}{l}\text { AlleleX: GACACCTTGTTCTTGTCATAAATCACA } \\
\text { AlleleY: ACACCTTGTTCTTGTCATAAATCACC }\end{array}$ & CAAGTGGTGTTCAAGTTGAATGAGATGAT & JX630086 \\
\hline
\end{tabular}

(ID) SNP locus name; Gene (Genes amplified); SNP-specific primers (Allele $X$ and $Y$ ); Common primer (Reverse primer); Allele $X$ and $Y$ (Alleles identified). GBA (GenBank accessions of the genes amplified). Genomic sequences of $C$. reshni included in GenBank are in Appendix S1 (see Supplemental Data with the online version of this article). 
Table 2. Results of initial primer screening in different Citrus species and subtribes of the subfamily Aurantioideae.

\begin{tabular}{|c|c|c|c|c|c|c|c|c|c|c|c|c|c|c|c|c|c|c|c|c|c|c|c|c|c|c|c|}
\hline \multirow[b]{2}{*}{ Marker } & \multicolumn{3}{|c|}{$\begin{array}{l}\text { C. reticulata } \\
(N=12)\end{array}$} & \multicolumn{3}{|c|}{$\begin{array}{l}\text { C. maxima } \\
(N=11)\end{array}$} & \multicolumn{3}{|c|}{$\begin{array}{l}\text { C. medica } \\
(\mathrm{N}=6)\end{array}$} & \multicolumn{2}{|c|}{$\begin{array}{l}\text { Citrus } \\
(N=32) \\
\end{array}$} & \multicolumn{2}{|c|}{$\begin{array}{c}\text { True citrus* } \\
(N=16)\end{array}$} & \multicolumn{2}{|c|}{$\begin{array}{c}\text { Balsamocitrinae } \\
(N=6)\end{array}$} & \multicolumn{2}{|c|}{$\begin{array}{c}\text { Near Citrus } \\
(N=3)\end{array}$} & \multicolumn{2}{|c|}{$\begin{array}{c}\text { Primitive Citrus } \\
(N=4)\end{array}$} & \multicolumn{2}{|c|}{$\begin{array}{c}\text { Triphasilinae } \\
(N=1)\end{array}$} & \multicolumn{3}{|c|}{$\begin{array}{c}\text { Clauseniae } \\
(N=4)\end{array}$} & \multicolumn{3}{|c|}{$\begin{array}{c}\text { Aurantioideae } \\
(N=84)\end{array}$} \\
\hline & $\bar{A}$ & $H_{0}$ & $\overline{H_{\mathrm{e}}}$ & $\bar{A}$ & $H_{0}$ & $H_{\mathrm{e}}$ & $\bar{A}$ & $H_{0}$ & $H_{\mathrm{e}}$ & $A$ & $\mathrm{MD}$ & $\bar{A}$ & MD & $A$ & $\mathrm{MD}$ & $A$ & $H_{0}$ & $A$ & MD & $A$ & $\mathrm{MD}$ & $A$ & $\mathrm{MD}$ & $A$ & $H_{0}$ & $H_{e}$ & $\mathrm{MD}$ \\
\hline EMA-M30 & 2 & 0.73 & 0.37 & 1 & 0.00 & 0.00 & 1 & 0.00 & 0.00 & 2 & 3.13 & 1 & 0.00 & 1 & 66.67 & 0 & 100.00 & 0 & 100.00 & 1 & 0.00 & 1 & 75.00 & 2 & 0.29 & 0.26 & 17.86 \\
\hline ACO-P353 & 1 & 0.00 & 0.00 & 2 & 0.55 & 0.37 & 1 & 0.00 & 0.00 & 2 & 0.00 & 1 & 0.00 & 2 & 33.33 & 1 & 0.00 & 2 & 0.00 & 1 & 0.00 & 1 & 25.00 & 2 & 0.16 & 0.27 & 3.57 \\
\hline F3H-M309 & 2 & 0.33 & 0.30 & 1 & 0.00 & 0.00 & 1 & 0.00 & 0.00 & 2 & 0.00 & 1 & 0.00 & 1 & 16.67 & 1 & 0.00 & 1 & 0.00 & 1 & 0.00 & 1 & 0.00 & 2 & 0.07 & 0.09 & 1.19 \\
\hline F3H-C341 & 1 & 0.00 & 0.00 & 1 & 0.00 & 0.00 & 2 & 0.17 & 0.37 & 2 & 0.00 & 1 & 0.00 & 1 & 0.00 & 1 & 0.00 & 1 & 0.00 & 1 & 0.00 & 1 & 0.00 & 2 & 0.04 & 0.10 & 1.19 \\
\hline PEPC-M316 & 1 & 0.00 & 0.00 & 1 & 0.00 & 0.00 & 1 & 0.00 & 0.00 & 2 & 3.13 & 1 & 0.00 & 1 & 16.67 & 1 & 0.00 & 1 & 25.00 & 1 & 0.00 & 1 & 50.00 & 2 & 0.11 & 0.29 & 5.95 \\
\hline SOS1-M50 & 1 & 0.00 & 0.00 & 1 & 0.00 & 0.00 & 1 & 0.00 & 0.00 & 2 & 0.00 & 2 & 0.00 & 1 & 0.00 & 1 & 0.00 & 1 & 0.00 & 1 & 0.00 & 1 & 75.00 & 2 & 0.12 & 0.35 & 3.57 \\
\hline CCC1-M85 & 2 & 0.67 & 0.37 & 1 & 0.00 & 0.00 & 1 & 0.00 & 0.00 & 2 & 0.00 & 2 & 0.00 & 2 & 0.00 & 1 & 0.00 & 1 & 0.00 & 1 & 0.00 & 1 & 50.00 & 2 & 0.24 & 0.31 & 2.38 \\
\hline TRPA-M593 & 2 & 0.58 & 0.33 & 1 & 0.00 & 0.00 & 1 & 0.00 & 0.00 & 2 & 0.00 & 1 & 0.00 & 1 & 0.00 & 1 & 0.00 & 1 & 0.00 & 1 & 0.00 & 1 & 25.00 & 2 & 0.20 & 0.37 & 1.19 \\
\hline INVA-M437 & 1 & 0.00 & 0.00 & 1 & 0.00 & 0.00 & 1 & 0.00 & 0.00 & 2 & 0.00 & 1 & 0.00 & 1 & 50.00 & 1 & 0.00 & 1 & 0.00 & 1 & 0.00 & 1 & 50.00 & 2 & 0.13 & 0.29 & 5.95 \\
\hline MDH-M519 & 2 & 0.42 & 0.33 & 1 & 0.00 & 0.00 & 1 & 0.00 & 0.00 & 2 & 0.00 & 1 & 0.00 & 1 & 16.67 & 1 & 0.00 & , & 25.00 & 1 & 0.00 & 1 & 50.00 & 2 & 0.18 & 0.24 & 4.76 \\
\hline ATMR-M728 & 1 & 0.00 & 0.00 & 1 & 0.00 & 0.00 & 1 & 0.00 & 0.00 & 2 & 3.13 & 2 & 6.25 & 1 & 83.33 & 1 & 33.33 & 1 & 0.00 & 1 & 0.00 & 0 & 100.00 & 2 & 0.15 & 0.37 & 14.29 \\
\hline CHS-P57 & 1 & 0.00 & 0.00 & 1 & 0.00 & 0.00 & 1 & 0.00 & 0.00 & 2 & 0.00 & 1 & 0.00 & 2 & 0.00 & 1 & 0.00 & 1 & 0.00 & 1 & 0.00 & 1 & 0.00 & 2 & 0.08 & 0.26 & 0.00 \\
\hline CHIII & 2 & 0.09 & 0.08 & 1 & 0.00 & 0.00 & 2 & 0.17 & 0.14 & 2 & 3.13 & 2 & 6.25 & 2 & 33.33 & 1 & 0.00 & 2 & 0.00 & 1 & 0.00 & 1 & 50.00 & 2 & 0.22 & 0.37 & 7.14 \\
\hline PKF-M186 & 1 & 0.00 & 0.00 & 1 & 0.00 & 0.00 & 1 & 0.00 & 0.00 & 2 & 0.00 & 1 & 0.00 & 0 & 100.00 & 1 & 33.33 & 1 & 75.00 & 0 & 100.00 & 1 & 25.00 & 2 & 0.13 & 0.37 & 14.29 \\
\hline NADK2-M285 & 1 & 0.00 & 0.00 & 1 & 0.00 & 0.00 & 2 & 0.33 & 0.24 & 2 & 0.00 & 2 & 6.25 & 1 & 50.00 & 1 & 33.33 & 1 & 25.00 & 0 & 100.00 & 1 & 25.00 & 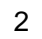 & 0.20 & 0.34 & 9.52 \\
\hline DFR-M240 & 1 & 0.00 & 0.00 & 1 & 0.00 & 0.00 & 1 & 0.00 & 0.00 & 2 & 3.13 & 2 & 0.00 & 1 & 83.33 & 2 & 33.33 & 2 & 0.00 & 0 & 100.00 & 1 & 0.00 & 2 & 0.17 & 0.37 & 10.71 \\
\hline LAP) & 2 & 0.50 & 0.35 & 1 & 0.00 & 0.00 & 1 & 0.00 & 0.00 & 2 & 0.00 & 1 & 0.00 & 1 & 0.00 & 1 & 0.00 & 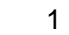 & 0.00 & 1 & 0.00 & 1 & 75.00 & 2 & 0.22 & 0.26 & 3.57 \\
\hline & 2 & 0.67 & 0.35 & 1 & 0.00 & 0.00 & 1 & 0.00 & 0.00 & 2 & 0.00 & 2 & 0.00 & 1 & 0.00 & 1 & 0.00 & 1 & 0.00 & 1 & 0.00 & 1 & 25.00 & 2 & 0.27 & 0.37 & 1.19 \\
\hline AOC-M290 & 2 & 0.45 & 0.29 & 1 & 0.00 & 0.00 & 1 & 0.00 & 0.00 & 2 & 6.25 & 1 & 0.00 & 2 & 16.67 & 2 & 0.00 & 2 & 0.00 & 1 & 0.00 & 2 & 0.00 & 2 & 0.28 & 0.30 & 3.57 \\
\hline$D X$ & 2 & 0.50 & 0.30 & 1 & .00 & 0.00 & 1 & 0.00 & 0.00 & 2 & 0.00 & 0 & 0.00 & 2 & 16.67 & 2 & 0.0 & 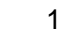 & 0.00 & 1 & 0.00 & 1 & 50.00 & (2) & 0.21 & 0.27 & 3.57 \\
\hline FLS & 2 & 0.50 & 0.30 & 1 & 0.00 & 0.00 & 1 & 0.00 & 0.00 & 2 & 0.00 & 1 & 0.00 & 2 & 16.67 & 1 & 0.00 & 1 & 0.00 & 1 & 0.00 & 0 & 0.00 & 2 & 0.18 & 0.27 & 1.19 \\
\hline & 2 & 0.67 & 0.35 & 1 & 0.00 & 0.00 & 1 & 0.00 & 0.00 & 2 & 0.0 & 1 & 0.00 & 1 & 0.00 & 1 & $0 . c$ & 1 & 0. & 1 & 0.0 & 1 & 0.00 & 2 & 0.27 & 0.26 & 1.19 \\
\hline P736 & 1 & 0.00 & 0.00 & 2 & 0.18 & 0.37 & 1 & 0.00 & 0.00 & 2 & 0.00 & 1 & 0.00 & 1 & 66.67 & 1 & 0.0 & 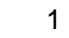 & 0.0 & 1 & 0.00 & 1 & 25.00 & 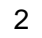 & 0.06 & 0.16 & 5.95 \\
\hline M480 & 2 & 0.33 & 0.24 & 1 & 0.00 & 0.00 & 1 & 0.00 & 0.00 & 2 & 0.00 & 2 & 0.00 & 1 & 0.00 & 1 & 0.00 & 1 & 0.0 & 1 & 0.00 & 2 & 25.00 & 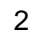 & 0.23 & 0.34 & 1.19 \\
\hline HYE & 2 & 0.42 & 0.33 & 1 & 0.00 & 0.00 & 1 & 0.00 & 0.00 & 2 & 3.1 & 2 & 0.00 & 1 & 0.00 & 1 & $0 .($ & 1 & 25.00 & 1 & 0.0 & 1 & 75.00 & & 0.27 & 0.37 & 5.95 \\
\hline CCC1-P727 & 2 & 0.58 & 0.37 & 1 & 0.00 & 0.00 & 1 & 0.00 & 0.00 & 2 & 0.00 & 1 & 0.00 & 1 & 0.00 & 1 & 0.00 & 1 & 0.00 & 1 & 0.00 & 1 & 25.00 & 2 & 0.16 & 0.34 & 1.19 \\
\hline & 1 & 0.00 & 0.00 & 1 & 0.00 & 0.00 & 1 & 0.00 & 0.00 & 2 & 3. & 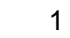 & & 1 & & 1 & $0 .($ & 1 & & 1 & 0.0 & 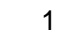 & 0.00 & & 0.07 & 0.16 & 1.19 \\
\hline ACC & 1 & 0.00 & 0.00 & 1 & 0.00 & 0.00 & 1 & 0.00 & 0.00 & 2 & 0.0 & 1 & 0. & 1 & 33.33 & 1 & 0.0 & 1 & 0.0 & 1 & 0.00 & 1 & 25.00 & 2 & 0.06 & 0.19 & 3.57 \\
\hline & 1 & 0.00 & 0.00 & 2 & 0.10 & 0.0 & 1 & 0.00 & 0.00 & 2 & 6.2 & 1 & 0. & 1 & & 1 & 0. & & 0. & 0 & 100.00 & 1 & 0.00 & 0 & 0.10 & 0.24 & 4.76 \\
\hline 535 & 1 & 0.00 & 0.00 & 1 & 0.00 & 0.00 & 1 & 0.00 & 0.00 & 2 & 0.0 & 1 & 0. & 1 & 16.67 & 1 & $0 .($ & 1 & 0. & 1 & 0.0 & 1 & 25.00 & 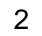 & 0.13 & 0.29 & 2.38 \\
\hline INVA-P855 & 1 & 0.00 & 0.00 & 1 & 0.00 & 0.00 & 2 & 0.33 & 0.24 & 2 & 0.00 & 2 & 0.00 & 2 & 16.67 & 2 & 0.00 & 2 & 0.00 & 2 & 1.00 & 2 & 0.00 & 2 & 0.22 & 0.37 & 2.38 \\
\hline & 1 & 0.00 & 0.00 & 1 & 000 & 0.00 & 1 & 0.00 & 0.00 & 2 & 0.00 & 2 & 6.25 & 1 & 33 & 1 & $0 .($ & 1 & & 1 & 0.00 & 1 & 50.00 & & 0.18 & 0.37 & 5.95 \\
\hline ATMR-C372 & 1 & 0.00 & 0.00 & 1 & 0.00 & 0.00 & 2 & 0.50 & 0.37 & 2 & 0.00 & 1 & 0.00 & 1 & 16.67 & 1 & 0.00 & 1 & 0.00 & 1 & 0.00 & 1 & 25.00 & 2 & 0.09 & 0.12 & 2.38 \\
\hline & 1 & 0.00 & 0.00 & 1 & 0.00 & 0.00 & 1 & 0.00 & 0.00 & 2 & 0.00 & 1 & 0.00 & 1 & 66.67 & 1 & 0.0 & 1 & 0. & 1 & 0.00 & 1 & 25.00 & & 0.06 & 0.31 & 5.95 \\
\hline PKF & 1 & 0.00 & 0.00 & 1 & 0.00 & 0.00 & 1 & 0.00 & 0.00 & 2 & 3.13 & 1 & 0.00 & 1 & 0.00 & 1 & 0.00 & 1 & 0.00 & 1 & 0.00 & 1 & 0.00 & 2 & 0.05 & 0.14 & 1.19 \\
\hline PSY-C461 & 1 & 0.00 & 0.00 & 1 & 0.00 & 0.00 & 1 & 0.00 & 0.00 & 2 & 0.00 & 1 & 0.00 & 1 & 33.33 & 1 & 0.00 & 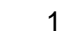 & 0.0 & 1 & 0.00 & 1 & 25.00 & 2 & 0.06 & 0.17 & 3.57 \\
\hline AOC-C593 & 1 & 0.00 & 0.00 & 1 & 0.00 & 0.00 & 1 & 0.00 & 0.00 & 2 & 0.00 & 1 & 0.00 & 1 & 0.00 & 1 & 0.00 & 1 & 0. & 1 & 0.00 & 1 & 25.00 & 0 & 0.06 & 0.17 & 1.19 \\
\hline HYB & 1 & 0.00 & 0.00 & 1 & 0.00 & 0.00 & 1 & 0.00 & 0.00 & 2 & 0.00 & 1 & 0. & 2 & 0.00 & 1 & 33.33 & 1 & 0. & 1 & 0.00 & 1 & 0.00 & 2 & 0.10 & 0.19 & 1.19 \\
\hline PEP & 1 & 0.00 & 0.00 & 1 & 0.00 & 0.00 & 1 & 0.00 & 0.00 & 2 & 0.00 & 1 & 0.00 & 1 & 16.67 & 1 & 0.00 & 2 & 0.00 & 1 & 0.00 & 1 & 0.00 & 2 & 0.08 & 0.18 & 1.19 \\
\hline Mean & 1.37 & 0.18 & 0.11 & 1.10 & 0.03 & 0.03 & 1.15 & 0.04 & 0.04 & 2 & 0.91 & 1.32 & 0.61 & 1.22 & 22.36 & 1.07 & 6.50 & 1.12 & 6.71 & 93 & 9.78 & .07 & 26.83 & 2 & 0.15 & 0.26 & 4.15 \\
\hline
\end{tabular}

$N$ : sample size; $A$ : number of alleles; $H_{0}$ : observed heterozygosity; $H_{\mathrm{e}}$ : expected heterozygosity; MD: missing data (\%); ${ }^{*}$ True citrus excluding the Citrus genus. 


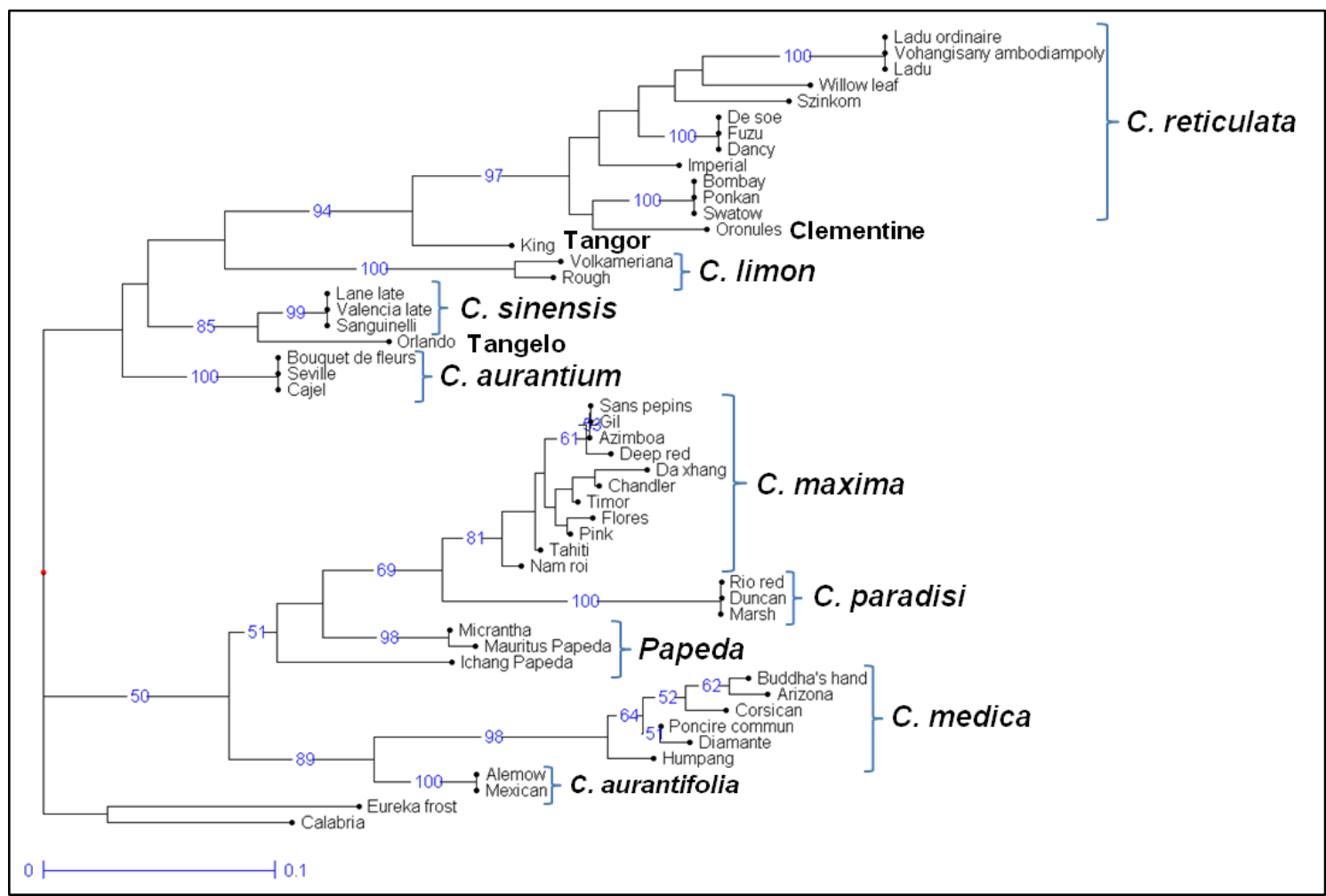

Figure 1. Neighbor-joining analysis based on simple matching dissimilarities from 41 SNP loci for 50 accessions belonging to the genus Citrus, including secondary species and hybrids. Numbers near nodes are bootstrap values based on 1000 resamplings (only values $>50 \%$ are indicated) 


\section{CONCLUSIONS}

Forty-one SNP markers were successfully developed from SNP loci mined by Sanger sequencing in a discovery panel including 17 genotypes of the three main cultivated Citrus ancestral taxa. The genotyping data displayed high conformity with previous sequencing data. Genotyping was highly successful within the Citrus genus, and the genetic organization displayed by this SNP marker panel was in agreement with previous studies. The frequency of missing data was higher for the citrus relatives and increased with taxonomic distances within the Aurantioideae subfamily, suggesting incomplete transferability. The polymorphism revealed within the relatives of the 'true citrus fruit trees' group remained relatively high but decreased strongly when considering the other citrus relatives. However, all citrus relative genotypes were differentiated. The markers that were developed appeared to be useful for phylogenic studies within the 'true citrus fruit trees'. Therefore, SNP markers based on the KASPar method developed from sequence data of a limited intra-generic discovery panel provide a valuable molecular resource for genetic diversity analysis of germplasm within a genus and should be useful for germplasm fingerprinting at a much broader diversity level. 
APPENDIX CHAPTER 3 


\section{Appendix 1. Analyzed accessions}

Species name, latin name or common name, accession number, ex-situ germplasm bank.

IVIA: Carretera Moncada, Naquera, km4.4, Apartado Oficial ,46113 Moncada (Valencia), Spain.

INRA/CIRAD: Station INRA 20230 San Giuliano, France.

\section{Citreae}

Balsamocitrinae: Aegle marmelos (L.) Corr., 345, IVIA; Aeglopsis chevalieri Swing., 308, IVIA; Afraegle paniculata (Schum.) Engl., 273, IVIA; Balsamocitrus dawei Stapf., 372, IVIA; Feroniella oblata Swing., 585, IVIA; Swinglea glutinosa (Blanco) Merr., 292, IVIA.

\section{Citrinae}

\section{True citrus fruit:}

Citrus: C. maxima: Azimboa, 420, IVIA; Chandler, 207, IVIA; Da xanh, 589, IVIA; Deep red, 277, IVIA; Flores, 673, INRA/CIRAD; Gil, 321, IVIA; Nam roi, 590, IVIA; Pink, 275, IVIA; Sans Pepins, 710, INRA/CIRAD; Tahiti, 727, INRA/CIRAD; Timor, 707, INRA/CIRAD. C. medica: Arizona, 169, IVIA; Buddha hand, 202, IVIA; Corsican, 567, IVIA; Diamante, 560, IVIA; Humpang, 722, INRA/CIRAD; Poncire Commun, 701, INRA/CIRAD. C. reticulata: Bombay, 518, INRA/CIRAD; Dancy, 434, IVIA; De soe, 713, INRA/CIRAD; Imperial, 576, IVIA; Fuzhu, 571, IVIA; Ladu, 595, INRA/CIRAD; Ladu ordinaire, 590, INRA/CIRAD; Ponkan, 482, IVIA; Swatow, 175, INRA/CIRAD; Szinkom, 597, INRA/CIRAD; Vohangisany ambodiampoly, 437, SRA; Willow leaf, 154, IVIA. Papeda: C. hystrix DC.: Combava, 178, IVIA; C. ichangensis Swing.: Papeda Ichang, 358, IVIA; C. micrantha Wester: Micrantha, IVIA.

Secondary species: C. aurantifolia: Alemow, 288, IVIA; Calabria, 254, IVIA; Mexican, 164, IVIA. C. aurantium: Bouquet de fleurs, 139, IVIA; Cajel, 108, IVIA; Seville, 117, IVIA. C. limon: Eureka frost, 297, IVIA; Rough lemon, 333, IVIA; Volkamer lemon, 432, IVIA; C. paradisi: Duncan, 274, IVIA; Marsh, 176, IVIA; Rio red, 289, IVIA. C. sinensis: Lane late, 198, IVIA; Sanguinelli, 34, IVIA; Valencia late, 363, IVIA.

Hybrids: Clementine, Clemenules, 22, IVIA; Tangelo, Orlando, 101, IVIA; Tangor, King, 477, IVIA.

Clymenia polyandra (Tan.) Swing., 584, IVIA.

Eremocitrus: E. Glauca, 346, IVIA.

Fortunella: F. crassifolia, 280, IVIA; F. hinsii, 281, IVIA; F. japonica, 381, IVIA; F. margarita, 38, IVIA; Fortunella sp., 98, IVIA. 
Microcitrus: M. australasica, 150, IVIA; M. australis, 313, IVIA; M. australis x $M$. Australasica, 378, IVIA; Australian Wild Lime, 314, IVIA; New Guinea Wild Lime, 315, IVIA.

Poncirus trifoliata: Flying Dragon, 537, IVIA; Pomeroy, 374, IVIA; Rich 75, 236, IVIA; Rubidoux, 217, IVIA.

Near citrus fruit: Atalantia ceylanica (Arn.) Oliv., 172, IVIA; Atalantia citroides Pierre ex Guill., 284, IVIA; Citropsis gilletiana Swing. and M.Kell, 517, IVIA.

Primitive citrus fruit: Hesperethusa crenulata (Roxb.) Roem., 580, IVIA; Pleiospermium sp., 380, IVIA; Severinia buxifolia, 147, IVIA; Severinia disticha (Blanco) Swing., 418, IVIA.

Triphasilinae: Triphasia trifolia (Burm. F.) P. Wils., 182, IVIA.

\section{Clauseneae}

Clauseniae: Clausena excavata Burm. f., 311, IVIA; Clausena lansium (Lour.) Skeels, 343, IVIA; Glycosmis pentaphylla (Retz.) Corrêa, 148, IVIA; Murraya koenigii (L.) Spreng., 377, IVIA. 


\section{Appendix S1}

\section{Genomic sequences of $C$. reshni included in GenBank corresponding to each SNP locus. SNPs genotyped for the considered loci are shown between brackets.}

$>$ Locus LCY2-M379. GenBank accession: JX566716 [organism=Citrus reshni] PCR product lycopene $\beta$-cyclase 2 genomic DNA.

GTTTCGCAAATAATTGATTCAACATCATCACATTCATTTTCGCTATTTCCATTAGGCCGCCAAAATGCAT GTTCAAGAAAGGCGGATCATCATCATCATCACAGGATCCGGACAAGCAAGTTTGGTAACTTCCTAGAGTT GACACCGGAGTCGGAACCTGAATTCTTAGTCTTTGATCTCCCCTGGTTTCATCCGTCCGATCGTATTCGA TATGACGTGATCATCATTGGCACTGGACCTGCCGGCCTCCGTCTAGCTGAGCAAGTCTCATCGCGTCATG GTATCAAGGTATGTTGTGTTGATCCTTCACCTCTTTCTACGTGGCCTAACAACTATGGAGTTTGGGTTGA TGAGTTTGAAGACATAGGACTT[A/G] TAGACTGTTTGGACAAAACTTGGCCGATGACTTGTGTTTTTAT TAATGATCACAAGACCAAGTATCTAGACAGGCCCTACGGTCGTGTTAGTAGAAATATTTTGAAGACAAAG TTATTAGAGAATTGTGTTTAAATGGCGTTAGGTTTCATAAGGCTAAAGTTTGGCATGTGAATCATCAGG AGTTCGAGTCTTCGATTGTTTGTGATGATGGRAATGAGATTAAGGCTAGCTTGATTGTTGATGCTAGTGG CTTTGCTAGTAGTTTTGTTGASTATGATAAGCCAAGAAACCATGGATACCAAATTGCTCATGGGATTTTA GCTGAGGTTGAGAGTCACCCTTTTGATTTAGATAAA

$>$ Locus EMA-M30. GenBank accession: JX630064 [organism=Citrus reshni] PCR product Malic enzyme (EMA) genomic DNA.

GTTTAGCCCGCACTTTCTTTCTCTTTCTG [т/с] TTCCTGACATCTAAATTATATGAATAGGCTTTTGTT GTCAAATGGACTGAAATAATTAGGATGCAACAGAAATTAACTGCATRTTGCACCACCATTTAAGAACAGT TTGTTACAATGTGAACAAGTCCACTGGAAAAATCCATTAACAAATATTTGAATTAGCCGTGAACGTAAGT GTTCTCTTGGCAAACGTGTAAAATCRTTAGAGCTTGTTTACTTGGTGATTGATAAACTAGTTGTGTTTTA TTCACCGGCAGCGGAAGCCTTGGCAAAACAAGTGACAGAAGAGAACTTTGAGAAGGGATTGATCTACCCA CCATTTTCTAATATTAGAAAAATTTCAGCCAATATAGCTGCTAATGTTGCTGCTAAGGCATATGAACTA

$>$ Locus ACO-P353. GenBank accession: JX630065 [organism=Citrus reshni] PCR product aconitase genomic DNA.

TTGCTTTTCCATGTGGTTGTATATTTACAAAATTAAGTTACATGGTCCTGTTTCAATGTCTGTAGTGGCC TGCAAAAGTACTTGAACCAACAAGGTTTTCACATTGTTGGCTATGGCTGCACTACTTGTATTGGAAACTC TGGAGATCTTGATGAATCAGTTGCTACTGCAATTACAGAAAATGGTAACTGTTAATTATCTTTGGTACCT TTTAGAATCAGTTTAGACTGCATTACAAACTTTAGCATAAGTTTTAATCTGGTTACACATTAACTCTCAA ACCATTTACATCATAATTTTGTGGCAGTTTGTGATCCATCATTCTCTGTTTTGAAGCTAATTCCCACTC AA [C/T] ATTTTACTGGTTTTCTCTGCAGACATTGTTGCAGCTGCTGTGCTTTCCGGTAATCGGAACTTT GAAGGTCGTGTACATCCTTTGACAAGAGCTAACTATCTTGCATCTCCTCCATTAGTTGTTGCTTATGCCC TTGCTGGCACAGTAAGTATATAACTTCTAGTCAAATATTCTTATAGAATTGTTGCTATCCTTATGATCTG AAGCTAATTTGCAGACATGGAACATTATTATAATTTACAACTAGGAGTTGAAACTTTCTTTCATAAGCCT TTATGCTAGTTACATGACATGCTTTTGAATCAACCAATGTCCATAATCCGTTAATTTTTTATTTTAAAA

$>$ Locus ACO-C601. GenBank accession: JX630065 [organism=Citrus reshni] PCR product aconitase genomic DNA.

TTGCTTTTCCATGTGGTTGTATATTTACAAAATTAAGTTACATGGTCCTGTTTCAATGTCTGTAGTGGCC TGCAAAAGTACTTGAACCAACAAGGTTTTCACATTGTTGGCTATGGCTGCACTACTTGTATTGGAAACTC TGGAGATCTTGATGAATCAGTTGCTACTGCAATTACAGAAAATGGTAACTGTTAATTATCTTTGGTACCT TTTAGAATCAGTTTAGACTGCATTACAAACTTTAGCATAAGTTTTAATCTGGTTACACATTAACTCTCAA ACCATTTACATCATAATTTTTGTGGCAGTTTGTGATCCATCATTCTCTGTTTTGAAGCTAATTCCCACTC AACATTTTACTGGTTTCTCTGCAGACATTGTTGCAGCTGCTGTGCTTTCCGGTAATCGGAACTTTGAAG GTCGTGTACATCCTTTGACAAGAGCTAACTATCTTGCATCTCCTCCATTAGTTGTTGCTTATGCCCTTGC TGGCACAGTAAGTATATAACTTCTAGTCAAATATTCTTATAGAATTGTTGCTATCCTTATGATCTGAAGC TAATTTGAaGACATGGAACATTATTATAATTTACAACTAG [G/A] AGTTGAAACTTTCTTTCATAAGCCT TTATGCTAGTTACATGACATGCTTTTGAATCAACCAATGTCCATAATCCGTTAATTTTTTATTTTAAAA 
$>$ Locus F3'H-P30. GenBank accession: JX630066 [organism=Citrus reshni] PCR product flavonoid 3',5'-hydroxylase genomic DNA. F3'H-M309 and $\mathrm{F}^{\prime} \mathrm{H}-\mathrm{C} 341$.

CGCCGGTGCACCCACTTGGCCTACGACGC [ T/C] CAAGACATGGTCTTTGCTGATTATGGTCCGAGGTGG AAACTCTTAAGAAAGATAAGCAATCTGCACATGCTTGGTGGAAAAGCCCTATATGATTGGAGTAACGTGC GTAACATTGAGCTAGGCCACATGCTTCGAGCCATTTGTGAGTCTAGCCAGCGAAACGAGCCCGTGGTGGT CCCGGAGATGTTGACGTACGCCATGGCAAACATGATAGGTCAAGTCATACTAAGCCGTCGAGTTTTTGTG ACCAAAGGGACAGAATCTAATGAGTTTAAGGACATGGTGGTAGAGCTCATGACGTCAGCTGGATTTTTCA ACATTGGTGATTTTATACCCTCGATTGCTTGGTTGGATTTACAAGGGATCGAGCGTGGGATGAAGAAATT ACATAACAGATTTGATGTCCTGTTAACAAAGATGATTGAAGAGCACATGGCTTCAACTWATGAACGTAAA AGGAAGCCAGATTTTCTCGACATTGTCATGGCTAATAGAGAAAATTCTGATGGAGAAAGGCTCACCATCA CCAACATCAAAGCACTTCTCTTGGTAATTTGTGTCTTCAAAACTTTACCCTTTTTTTTATCTCACTTTTG TATTTATTATTACGCTCATGYATTTAAGGTTATCAAAGTTGCACTTACGAAATATTTATTTCATACctcg tgcctcTTGGTCTTTCTTTGTGTTGTTCATTTTTGTACATATGTGAAATGCAGTATAATCTTGATAAATA TATTATTCT

$>$ Locus F3'H-M309. GenBank accession: JX630066 [organism=Citrus reshni] PCR product flavonoid 3',5'-hydroxylase genomic DNA.

CGCCGGTGCACCCACTTGGCCTACGACGCTCAAGACATGGTCTTTGCTGATTATGGTCCGAGGTGGAAAC TCTTAAGAAAGATAAGCAATCTGCACATGCTTGGTGGAAAAGCCCTATATGATTGGAGTAACGTGCGTAA CATTGAGCTAGGCCACATGCTTCGAGCCATTTGTGAGTCTAGCCAGCGAAACGAGCCCGTGGTGGTCCCG GAGATGTTGACGTACGCCATGGCAAACATGATAGGTCAAGTCATACTAAGCCGTCGAGTTTTTGTGACCA AAGGGACAGAATCTAATGAGTTTAAGGA [T/C]ATGGTGGTAGAGCTCATGACGTCAGCTGGATTTTTCA ACATTGGTGATTTTATACCCTCGATTGCTTGGTTGGATTTACAAGGGATCGAGCGTGGGATGAAGAAATT ACATAACAGATTTGATGTCCTGTTAACAAAGATGATTGAAGAGCACATGGCTTCAACTWATGAACGTAAA AGGAAGCCAGATTTTCTCGACATTGTCATGGCTAATAGAGAAAATTCTGATGGAGAAAGGCTCACCATCA CCAACATCAAAGCACTTCTCTTGGTAATTTGTGTCTTCAAAACTTTACCCTTTTTTTTATCTCACTTTTG TATTTATTATTACGCTCATGYATTTAAGGTTATCAAAGTTGCACTTACGAAATATTTATTTCATACctcg tgcctcTTGGTCTTTCTTTGTGTTGTTCATTTTTGTACATATGTGAAATGCAGTATAATCTTGATAAATA TATTATTCT

$>$ Locus F3'H-C341. GenBank accession: JX630066 [organism=Citrus reshni] PCR product flavonoid 3',5'-hydroxylase genomic DNA.

CGCCGGTGCACCCACTTGGCCTACGACGCTCAAGACATGGTCTTTGCTGATTATGGTCCGAGGTGGAAAC TCTTAAGAAAGATAAGCAATCTGCACATGCTTGGTGGAAAAGCCCTATATGATTGGAGTAACGTGCGTAA CATTGAGCTAGGCCACATGCTTCGAGCCATTTGTGAGTCTAGCCAGCGAAACGAGCCCGTGGTGGTCCCG GAGATGTTGACGTACGCCATGGCAAACATGATAGGTCAAGTCATACTAAGCCGTCGAGTTTTTGTGACCA AAGGGACAGAATCTAATGAGTTTAAGGACATGGTGGTAGAGCTCATGACGTCAGCTGGAT [T/A] TTTCA ACATTGGTGATTTTATACCCTCGATTGCTTGGTTGGATTTACAAGGGATCGAGCGTGGGATGAAGAAATT ACATAACAGATTTGATGTCCTGTTAACAAAGATGATTGAAGAGCACATGGCTTCAACTWATGAACGTAAA AgGAAGCCAGATTTTCTCGACATTGTCATGGCTAATAGAGAAAATTCTGATGGAGAAAGGCTCACCATCA CCAACATCAAAGCACTTCTCTTGGTAATTTGTGTCTTCAAAACTTTACCCTTTTTTTTATCTCACTTTTG TATTTATTATTACGCTCATGYATTTAAGGTTATCAAAGTTGCACTTACGAAATATTTATTTCATACctcg tgсctсTTGGTCTTTCTTTGTGTTGTTCATTTTTGTACATATGTGAAATGCAGTATAATCTTGATAAATA TATTATTCT

$>$ Locus PEPC-M316. GenBank accession: JX630067 [organism=Citrus reshni] PCR product phosphoenolpyruvate carboxylase genomic DNA.

AATTttAACTCTCCTTGTCAAGTTTGAACCATAAACTGCCAATTATTGATCTATTTGTGATGTTCCACAA ATGACTTTTGTAGGAACACTAAACCTCTGAAGTCCATTCTACCTTTWAYRCCTTAATTAAAGAATTTTGA AAATTCWTTTTGTCTAAATGATTTTGAACAATCGGCTAATGGTAGATATTGTACCAACTTTTTATATGTA ATATGAAATTTTGGTATTTATGTAGYCTTATTTATTGGAAAGTGCATTTAAGAACTGAGAAGGCATAGA ATATTCCA [T/C] TAGGTTTGAAGAAATTCATTGCTCTTTAAGTCAGCTTTAAGTGAATATCCTTGTTAT AAACTTTAGTGAGAGTGAATGCATTGGAGTCTCTCTTCCAGCAATTTGCTATTTTATATGAAGTTCTCTT TCCCAYAACAGACTAGCTRAGCTTCAATTTTGATTTTCTTTTCTGAATGARTTTTGAAAATATTCGATAG GACAATACTGAAATTTTGCATTGTGGCTCTCACTTCTTATTTGATTTAATATTTAGAGAMAATTYMTTT TTATTAATTTGATTTMTTTYTTCCTATAGTTCCTGGAGCCTCTAGARCTCTGTTACAGATCACTCTGTGC TTGTGGTGATCGGCCAATAGCCGATGGAAGCCTTCTTGATT 
$>$ Locus PEPC-C328. GenBank accession: JX630067 [organism=Citrus reshni] PCR product phosphoenolpyruvate carboxylase genomic DNA.

AATTttAACTCTCCTTGTCAAGTTTGAACCATAAACTGCCAATTATTGATCTATTTGTGATGTTCCACAA ATGACTTTTGTAGGAACACTAAACCTCTGAAGTCCATTCTACCTTTWAYRCCTTAATTAAAGAATTTTGA AAATTCWTTTTGTCTAAATGATTTTGAACAATCGGCTAATGGTAGATATTGTACCAACTTTTTATATGTA ATATGAAATTTGgTTATTTATGTAGYCTTATTTATTGGAAAGTGCATTTAAGAACTGAGAAGgCATAGA ATATTCCAYTAGGTTTGAAG [G/A] AATTCATTGCTCTTTAAGTCAGCTTTAAGTGAATATCCTTGTTAT AAACTTTAGTGAGAGTGAATGCATTGGAGTCTCTCTTCCAGCAATTTGCTATTTTATATGAAGTTCTCTT TCCCAYAACAGACTAGCTRAGCTTCAATTTTGATTTTCTTTTCTGAATGARTTTTGAAAATATTCGATAG GACAATACTGAAATTTTTGCATTGTGGCTCTCACTTCTTATTTGATTTAATATTTAGAGAMAATTYMTTT TTATTAATTTGATTTMTTYTTCCTATAGTTCCTGGAGCCTCTAGARCTCTGTTACAGATCACTCTGTGC TTGTGGTGATCGGCCAATAGCCGATGGAAGCCTTCTTGATT

$>$ Locus SOS1-M50. GenBank accession: JX630068 [organism=Citrus reshni] PCR product Salt Overly Sensitive 1 genomic DNA.

TATGTTTACCCACTGGACTTTTTCAGGTTTTGCATGTTGTCAAAACCAG [G/A] CAAGTAACTTACTCAG TACTAAACCATTTGATTGATTACATCCAAAATCTTGAGAAGGTTGGCTTGTTAGAAGAAAAGGAGATGCT TCATCTTCATGATGCTGTCCAGGTATCTTTTTTTGCATTGATCTTCATTCTATGCACTATACTTTATTT AGTTCTTTGTACAATTTAGTATTATTTTCTTGCAGTCTGACTTGAAAAGGCTTCTAAGGAATCCTCCTTT GGTGAAGTTTCCCAAAATAAGTGATTTGATTTGTGCCCATCCCTTGCTAAGGGAGCTTCCTCCCAGTGTC CGTGAACCACTTGAACTTTCCACAAAAGAAATCATGAAACTCAGTGGCATGACACTGTACAGGGAGGGGT CCAAGCCAAGTGGTATCTGGCTTATATCTAACGGTGTTGTTAAGGTAAATAATGTGTTTACATGGAAAAA TTGTATCCT

$>$ Locus CCC1-M85. GenBank accession: JX630069 [organism=Citrus reshni] PCR product cation-chloride cotransporter genomic DNA.

TATGTCAGAAGGCTTCCGTGGAATTGTCCAGACCATGGGTCTTGGTAATCTCAAGCCCAACATTGTGGTT ATGAGGTATCCAGA [G/A] ATATGGCGCCGTGAAAACCTTACTGAAATCCCAGCCACCTTTGTTGGAATA ATTAATGACTGTATTGTTGCTAACAAGGCYGTTGTTATTGTCAAGGGCCTTGATGAATGGCCCAATGAGT ACCAAAGGCAATATGGTACAATCGATTTGTATTGGATTGTRAGAGACGGAGGTCTCATGCTCTTACTCTC TCAGCTCCTGCTTACAAAGGAGAGCTTTGAAAGCTGTAAGATTCAAGTCTTCTGCATTGCTGAGGAGGAT TCAGATGCAGCGGTGCTGAAGGCTGATGTAAAGAAGTTCCTATATGATCTTCGGATGCAGGCTGAAGTTA TTGTTATATCTATGAAATCATGGGATGAGCAAACAGAGAATGGACCTCAACAAGATGAATCATTGGATGC TTTTATTGCTGCTCAGCATCGGATTAAAAATTACCTGGCTGAAATGAAGGCTGAAGCTCAGAAATCAGGG ACTCCGTTGATGGCTGATGGGAAGCCGGTGGTCGTGAATGAGCAACAGGTGGAGAAGTTTCTTTACACAA CATTGAAGCTGAATTCGACAATACTGAGACACTCGAGAATGGCTGCAGTTGTGCTTGTTAGTCTACCGCC GCCTCCGATCAACCACCCAGCTTACTGCTACATGGAATACATGGATTTGTTAGTAGAGAATGTGCC

$>$ Locus CCC1-P727. GenBank accession: JX630069 [organism=Citrus reshni] PCR product cation-chloride cotransporter genomic DNA.

TATGTCAGAAGGCTTCCGTGGAATTGTCCAGACCATGGGTCTTGGTAATCTCAAGCCCAACATTGTGGTT ATGAGGTATCCAGAGATATGGCGCCGTGAAAACCTTACTGAAATCCCAGCCACCTTTGTTGGAATAATTA ATGACTGTATTGTTGCTAACAAGGCYGTTGTTATTGTCAAGGGCCTTGATGAATGGCCCAATGAGTACCA AAGGCAATATGGTACAATCGATTTGTATTGGATTGTRAGAGACGGAGGTCTCATGCTCTTACTCTCTCAG CTCCTGCTTACAAAGGAGAGCTTTGAAAGCTGTAAGATTCAAGTCTTCTGCATTGCTGAGGAGGATTCAG ATGCAGCGGTGCTGAAGGCTGATGTAAAGAAGTTCCTATATGATCTTCGGATGCAGGCTGAAGTTATTGT TATATCTATGAAATCATGGGATGAGCAAACAGAGAATGGACCTCAACAAGATGAATCATTGGATGCTTTT ATTGCTGCTCAGCATCGGATTAAAAATTACCTGGCTGAAATGAAGGCTGAAGCTCAGAAATCAGGGACTC CGTTGATGGCTGATGGGAAGCCGGTGGTCGTGAATGAGCAACAGGTGGAGAAGTTTCTTTACACAACATT GAAGCTGAATTCGACAATACTGAGACACTCGAGAATGGCTGCAGTTGTGCTTGTTAGTCTACCGCCGCCT CCGATCAACCACCCAGCTTACTGCTA [T/C] ATGGAATACATGGATTTGTTAGTAGAGAATGTGCC 
$>$ Locus TRPA-M593. GenBank accession: JX630070 [organism=Citrus reshni] PCR product vacuolar citrate/H+ symporter genomic DNA.

CACTTCACATTGAAACCATTTTCACACCAAACAATTTCTACATCTTCCTGGGACCTCTCCTGTGCGCTGT TATATGTGTATGTGTGAAGCTCGATGGGCAGGCGACAAGCAGGAACATGTTGGGTATTCTTGCTTGGGTC TTCGCTTGGTGGCTCACGGAGGCCGTACCCATGCCCATTACCTCTATGGCGCCTCTGTTTCTGTTCCCTC TGTTTGGTATTTCTTCTGCTGATGCTGTTGCTCATTCTTACATGGATGATGTTATTGCCCTCGTTCTTGG TAGCTTTATTCTTGCTCTCGCCGTTGAGCACTACAACATTCACAGAAGATTGGCCTTAAATGTAAGTTCC CATAATGCATCATCATCATCATGTCATTAATCGTTACGATTTCTTTTTCAGAAAAATTATCAGTGACAAA AGATGAATTAATTATGTATGGACAATCCTATACCATATAATATATATTAATAACTACAGATAACTATTCT ATTCTGTGGAGAGCCAATGAATCCGCCCTTGCTGCTTCTTGGGATATGTGGCACGACAGCATTCGTGAGC ATGTGGATGCATAACGTGGCAGCAGCAGTGAT [C/G] ATGATGCCAGTGGCCACTGGGATCTTACAGAAC TTGCCAGAGGTTCATCTTCAATCAACCCTTGTTAGGAAGTATTGCAAAGCTGTGGTGCTCGGGGTCATCT ACTCTGCAGCCGTAGGAGGGATGAGCACACTTACTGGAACAGGTGTTAATCTAATATTGGTCGGGATGTG GAAGACCTATTTTCCAGAAGCAAACCCGT

$>$ Locus INVA-M437. GenBank accession: JX630071 [organism=Citrus reshni] PCR product acid invertase genomic DNA.

AтTCATGGTTATTTATTTATAATTGAGCTCCCCTTTTGCTTAATATATTAAAGCAGTAACAACTTTGGGT AATATGCTACAGGGCATTCCAAGGACAGTGGCGCTTGATACAAAAACTGGTAGTAATCTCCTYCAATGGC CAGTGGAGGAAGTAGACAGTTTGCGATTGACCAGCAAAGAATTTAAAAAGATTGAGCTCAAGCCAGGGTC AGTGATGCCGCTTGATGTTGGCTCAGCTACTCAGGTATGGAGATAGAGATACATTTATGCTTAATTAGTT TGTCGATATCTCAATTTGAAAAGCACAAAGTAGGCAAATATAGCTTACATGGAAATGTTTGGGCAATGTG AACAGCTGGACATAGTGGCCGAGTTTGAGCTAGACAAGGCGGCTTTAGAGAAAACAGCGGAGTCCAATGT GGAGTTTAGCTGCAGTTCCAGC [T/C] AAGGATCTGCTGAACGCGGAGCATTAGGCCCCTTTGGCCTTCT GGTTCTTGCAGATGACAGCCTAWCCGAGCAAACTCCAGTCTATTTCTACATTGCGAAAGGAAAGGATGGA AGTCTCAAGACTTACTTCTGCACTGATCAATCAAGGTACCGTATTAATTACATGACTYGACTCTTGCATC AAATTAAATCAARCCACGTGCAATGGTGTAATCCATTACTTAGCGCATTGTTAATTTCTTGTAGATCTTC TGAGGCAAATGATGTCAATAAATCAAAATATGGTAGCTTTGTTCCAGTACTGGAAGGCGAGAAATTCTCA ATGAGAGTATTGGTGAGCATATATCATGTTATTGTCCAAACGAACACATGTACATGTTGGCACTGTCAAT AGAATCCTCACAATCAATTTGGAACATTGTGTATGTATATTTGCAGGTGGATCATTCGATAGTCGAA

$>$ Locus INVA-P855. GenBank accession: JX630071 [organism=Citrus reshni] PCR product acid invertase genomic DNA.

АTTCATGGTTATTTATTTATAATTGAGCTCCCCTTTTGCTTAATATATTAAAGCAGTAACAACTTTGGGT AATATGCTACAGGGCATTCCAAGGACAGTGGCGCTTGATACAAAAACTGGTAGTAATCTCCTYCAATGGC CAGTGGAGGAAGTAGACAGTTTGCGATTGACCAGCAAAGAATTTAAAAAGATTGAGCTCAAGCCAGGGTC AGTGATGCCGCTTGATGTTGGCTCAGCTACTCAGGTATGGAGATAGAGATACATTTATGCTTAATTAGTT TGTCGATATCTCAATTTGAAAAGCACAAAGTAGGCAAATATAGCTTACATGGAAATGTTTGGGCAATGTG AACAGCTGGACATAGTGGCCGAGTTTGAGCTAGACAAGGCGGCTTTAGAGAAAACAGCGGAGTCCAATGT GGAGTTTAGCTGCAGTTCCAGCGAAGGATCTGCTGAACGCGGAGCATTAGGCCCCTTTGGCCTTCTGGTT CTTGCAGATGACAGCCTAWCCGAGCAAACTCCAGTCTATTTCTACATTGCGAAAGGAAAGGATGGAAGTC TCAAGACTTACTTCTGCACTGATCAATCAAGGTACCGTATTAATTACATGACTYGACTCTTGCATCAAAT TAAATCAARCCACGTGCAATGGTGTAATCCATTACTTAGCGCATTGTTAATTTCTTGTAGATCTTCTGAG GCAAATGATGTCAATAAATCAAAATATGGTAGCTTTGTTCCAGTACTGGAAGGCGAGAAATTCTCAATGA GAGTATTGGTGAGCATATATCATGTTATTGTCCAAACGAACACATGTACATGTTGGCACTGTCAATAGAA TCCTCACAA [ T/C] CAATTTGGAACATTGTGTATGTATATTTGCAGGTGGATCATTCGATAGTCGAA

$>$ Locus MDH-MP69. GenBank accession: JX630072 [organism=Citrus reshni] PCR product malate dehydrogenase genomic DNA.

GCCTTTGGCCCCAAGGCAGGCCAACTTCCACAGTCAAAACCCTCTGGTGTGAGGTTCAACTCCAAGAA [A /C] TCACTTGTGAGTTTCAGTGGCCTCAAGGCAGTGACATCAGTTATCTGTGAATCAGATACCTCTTTCT TGAACAAGGAGAGTTGTTCAGCTCTTCGAAGCACTTTTGCAAGAAAAGCCCAAAGTTCAGAGCAGAGGCC TCAGAATGCCCTACAGCCTCAGGCTTCTTTTAAAGTAGCAGTTCTTGGAGCTGCTGGTGGAATAGGTCAA CCCTTAGCACTTCTAATCAAGATGTCCCCACTAGTATCAGCCCTTCACCTCTATGATGTAATGAATGTCA AGGGAGTTGCTGCTGACCTCAGTCACTGCAACACTCCCTCTCAAGTTCTGGATTTCACAGGACCTGAAGA ATTAGCCAGTGCTTTGAAAGGGGTGAATGTCGTCGTCATACCTGCTGGAGTTCCAAGAAAGCCTGGGATG ACCCGTGATGACCTCTTCAACATCAACGCCAATATAGTAAAGACCTTGGTTGAGGCTGTTGCTGATAACT GCCCTGATGCCTTCATCCATATTATCAGCAATCCAGTTAATTCAACAGTGCCAATTGCTGCAGAAGTTCT 
GAAGCAGAAGGGTGTTTATGATCCGAAGAAGCTTTTTGGTGTTACCACACTGGATGTCGTGAGAGCAAAC ACCTTTGTTGCTCAAA

$>$ Locus MDH-M519. GenBank accession: JX630072 [organism=Citrus reshni] PCR product malate dehydrogenase genomic DNA.

GCCTTTGGCCCCAAGGCAGGCCAACTTCCACAGTCAAAACCCTCTGGTGTGAGGTTCAACTCCAAGAAAT CACTTGTGAGTTTCAGTGGCCTCAAGGCAGTGACATCAGTTATCTGTGAATCAGATACCTCTTTCTTGAA CAAGGAGAGTTGTTCAGCTCTTCGAAGCACTTTTGCAAGAAAAGCCCAAAGTTCAGAGCAGAGGCCTCAG AATGCCCTACAGCCTCAGGCTTCTTTTAAAGTAGCAGTTCTTGGAGCTGCTGGTGGAATAGGTCAACCCT TAGCACTTCTAATCAAGATGTCCCCACTAGTATCAGCCCTTCACCTCTATGATGTAATGAATGTCAAGGG AGTTGCTGCTGACCTCAGTCACTGCAACACTCCCTCTCAAGTTCTGGATTTCACAGGACCTGAAGAATTA GCCAGTGCTTTGAAAGGGGTGAATGTCGTCGTCATACCTGCTGGAGTTCCAAGAAAGCCTGGGATGACCC GTGATGACCTCTTCAACATCAACGCCAA [T/C] ATAGTAAAGACCTTGGTTGAGGCTGTTGCTGATAACT GCCCTGATGCCTTCATCCATATTATCAGCAATCCAGTTAATTCAACAGTGCCAATTGCTGCAGAAGTTCT GAAGCAGAAGGGTGTTTATGATCCGAAGAAGCTTTTTGGTGTTACCACACTGGATGTCGTGAGAGCAAAC ACCTTTGTTGCTCAAA

$>$ Locus ATMR-C372. GenBank accession: JX630073 [organism=Citrus reshni] PCR product MRP-like ABC transporter genomic DNA.

CAGGTAGCTGGCCTTAGATTATTACTTATTACAGTTTCTTGAAAACTGATATAAATATATTTGTTTGAGC AGCCACGGATCATGTTCAGTACCAACTGTTAAATTACAACTGATCTAGGCCTCCTCAATTGATATTGCTT GGGATAAATTACTGATTATTTACCATAACATGTTAAAAACTTTGGCAAACAGGTCAGATATCGCTCCAAC ACTCCTCTGGTTCTCAAAGGTATTACACTCAGCATTCACGGGGGAGAGAAGATTGGTGTAGTTGGGCGTA CAGGAAGTGGGAAGTCAACTTTAATTCAAGTTTTCTTTAGGCTGGTGGAGCCTTCAGGAGGGAGAATCAT TATTGATGGAATCGACATTTC [G/A] TTGTTGGGGCTTCATGACCTAAGGTCTCGCTTTGGGATCATTCC TCAAGAACCTGTCCTTTTTGAAGGAACTGTGAGAAGCAACATTGATCCAATTGGTCAGTATTCAGATGAA GAAATCTGGAAGGTATGCCATTCCTTTTTTCTGATATGTGTCTCCTACATTTATGATCAAAGTTTGTGGG TCTGTTTGCTGCATTAGCTAACTTATTATTATTTTTGAGAGCCTCGAGCGATGTCAACTTAAAGATGTG GTAGCTGCAAAGCCTGATAAACTCGATTCTTTAGGTAACTTCACTTCCTCCCTTTTCCTTGAATTTTCAG TTTGATTAAAGGAAGTCATATGTATCTTTTTAGAAGCTAAAACATGCCAAAATGTTGAACTTTGTAGTG GCTGATAG

$>$ Locus ATMR-M728. GenBank accession: JX630073 [organism=Citrus reshni] PCR product MRP-like ABC transporter genomic DNA.

CAGGTAGCTGGCCTTAGATTATTACTTATTACAGTTTCTTGAAAACTGATATAAATATATTTGTTTGAGC AGCCACGGATCATGTTCAGTACCAACTGTTAAATTACAACTGATCTAGGCCTCCTCAATTGATATTGCTT GGGATAAATTACTGATTATTTACCATAACATGTTAAAAACTTTGGCAAACAGGTCAGATATCGCTCCAAC ACTCCTCTGGTTCTCAAAGGTATTACACTCAGCATTCACGGGGGAGAGAAGATTGGTGTAGTTGGGCGTA CAGGAAGTGGGAAGTCAACTTTAATTCAAGTTTTCTTTAGGCTGGTGGAGCCTTCAGGAGGGAGAATCAT TATTGATGGAATCGACATTTCATTGTTGGGGCTTCATGACCTAAGGTCTCGCTTTGGGATCATTCCTCAA GAACCTGTCCTTTTTGAAGGAACTGTGAGAAGCAACATTGATCCAATTGGTCAGTATTCAGATGAAGAAA TCTGGAAGGTATGCCATTCCTTTTTTCTGATATGTGTCTCCTACATTTATGATCAAAGTTTGTGGGTCTG TTTGCTGCATTAGCTAACTTATTATTATTTTTGTAGAGCCTCGAGCGATGTCAACTTAAAGATGTGGTAG CTGCAAAGCCTGATAAACTCGATTCTTTAGGTAACTTCACTTCCTCCCTTTTCCTTGAATTTTCAGTTTG ATTTAATGGAAGTCATATGTATCTTTT [T/C] AGAAGCTAAAACATGCCAAAATGTTGAACTTTGTAGTG GCTGATAG

> Locus CHS-P57. GenBank accession: JX630074 [organism=Citrus reshni] PCR product chalcone synthase genomic DNA.

GGCCTCCGTGTTGCTAAAGACATAGCTGAAAACAACCCTGGAAGCCGCGTTTTGCT [ T/A] ACCACTTCT GAAACTACCATACTTGGGTTTCGCCCACCAAACAAGTCCCGCCCTTATGACCTTGTTGGGGCAGCTCTCT TTGGTGATGGAGCTGCTGCTGTGATCGTTGGAGCTGACCCATTCCTGGATAAAGAGTCTTCTCCTTTCAT GGAACTTAACTATGCAGTCCAACAATTCTTACCAGGGACACAGAATGTCATCGATGGGCGTCTTTCTGAA GAGGGTATAAACTTCAAGCTTGGCAGGGACCTTCCTCAGAAGATTGAAGAAAATATTGAGGAGTTTTGCA AGAAGCTCATGGCCAAAGCTGGTTTACAAGATTTCAATGATTTGTTCTGGGCAGTTCATCCTGGAGGACC GGCAATTCTGAACCGACTGGAAAGCAATCTCAAGTTGAATAATCAGAAGCTTGAATGCAGCAGGAGGGCA TTGATGGATTATGGGAATGTGAGCAGCAACACTATCTTTTATGTTATGGATTATATGAGGGAGGAGTTGA AGAGGAAAGGAGATGAGG 
$>$ Locus CHS-M183. GenBank accession: JX630074 [organism=Citrus reshni] PCR product chalcone synthase genomic DNA.

GGCCTCCGTGTTGCTAAAGACATAGCTGAAAACAACCCTGGAAGCCGCGTTTTGCTTACCACTTCTGAAA CTACCATACTTGGGTTTCGCCCACCAAACAAGTCCCGCCCTTATGACCTTGTTGGGGCAGCTCTCTTTGG TGATGGAGCTGCTGCTGTGATCGTTGGAGCTGACCCATTCCT [G/C] GATAAAGAGTCTTCTCCTTTCAT GGAACTTAACTATGCAGTCCAACAATTCTTACCAGGGACACAGAATGTCATCGATGGGCGTCTTTCTGAA GAGGGTATAAACTTCAAGCTTGGCAGGGACCTTCCTCAGAAGATTGAAGAAAATATTGAGGAGTTTTGCA AGAAGCTCATGGCCAAAGCTGGTTTACAAGATTTCAATGATTTGTTCTGGGCAGTTCATCCTGGAGGACC GGCAATTCTGAACCGACTGGAAAGCAATCTCAAGTTGAATAATCAGAAGCTTGAATGCAGCAGGAGGGCA TTGATGGATTATGGGAATGTGAGCAGCAACACTATCTTTTATGTTATGGATTATATGAGGGAGGAGTTGA AGAGGAAAGGAGATGAGG

$>$ Locus CHI-M598. GenBank accession: JX630075 [organism=Citrus reshni] PCR product chalcone isomerase genomic DNA.

TATATTATAATCAATTATTTTCCACATTAATTAACTAATAATAATTTTGAAGAATACTAAAGAGTTTATA CATTTCTTTTTTCCTTTGCGTTACGTGTAATGATAATAATTAACAATACAGGTGCATTAAATATTTAA ATTCACACTATCCGTATGGGAATCCTTTTCCGTCATAAACGCTGCTTAAAGAGTAGTGAACGTCAGTACT WCACTCAAAATCTAAAACAGAATCCAACAGAAGAMACCAACGGCGAAAATCCGTTACCTGTGACGACGTC TCTGAAGAACTCAACGGATTCCGTCAACTCCTCYGCAGTCTTCCCCTTCCATTTGCCGGCGAGTAACGGC ACGGCGTYMTCCTCCAAGTACACTCCTATCGCCGTGAACTTCACGAACTTCCCTTCAATCTCCAATCCTC TCTCCCCTGCCACGTCAGCGTCAAGAGCACCGAGACGTTAAAAACAAGTGAAATACAATGATGAAACAAM AGTCAAATCATACAATCCGCCGGYGGTGCGCAGGRTACTAGCATACTACTAACCTGCGCCGCCGAGGAAA TGCGACTTTGTTGATCCTGGAGGTTGCA [C/G] GGACGGCGTGAAAGTGACGTTCTCGACCTGCAGTTCG GTGACGGACGGTGAGGG

$>$ Locus PKF-C64. GenBank accession: JX630076 [organism=Citrus reshni] PCR product phosphofructokinase genomic DNA.

TTCAGTTTATAGCGAACTCCAAACGAGTCGAATCGATCACGCACTCCCTCTCCCTTCTGTTCT [C/A] AA AAACCCTTTCAAAATCGTCGATGGCCCCGCTAGCTCCGCCGCCGGCAATCCAGGTCAGTTTCGTACTACC ACTTCATCAATAAAACAATTTTCGTCCGTAACATTACAGATTCAAGATCTTTTCTTTTTGTCATATATAG ATGAGATTGCGAAATTGTTTCCAAATCTGTTCGGGCAACCGTCCGCATTGTTGGTGCCGAACGGTGCTGA CGCGGTGCGATCTGATGAGAAGTTGAAAATCGGCGTCGTCTTGTCTGGAGGTCAGGCGCCAGGTGGACAC AATGTGATCTCTGGAATCTATGGTGAGTATAAATCTGAAAATGTAATATAAGCGTGATTTGTGTGAAAAT TGGCCTTTTAAACGTGATTTGCTTATGTTTTGGTGGCAGATTACTTGCAGGATCGCGCGAAAGGGAGTGT ACTGTATGGATTCAGAGGAGGTCCAGCTGGAATCATGAAGTGCAAATACGTTGAWCTAACTTCCGATTAT AтTTAтCCCTATAGAAACCAGGTATAACTTTGAGTATAATGTCAATGTTTTGAGTAATAAATAGTACATA TTAATTAATCTTTGTAGAATTAGACCATTTGCATATTAAATTTTGGCTTGACAAGTAAATGTAAAATGT GCATGTTAAAGAAATGAAGTAAGCATCTAACCCCTTTG

$>$ Locus PKF-M186. GenBank accession: JX630076 [organism=Citrus reshni] PCR product phosphofructokinase genomic DNA.

TTCAGTTTATAGCGAACTCCAAACGAGTCGAATCGATCACGCACTCCCTCTCCCTTCTGTTCTCAAAAAC CCTTTCAAAATCGTCGATGGCCCCGCTAGCTCCGCCGCCGGCAATCCAGGTCAGTTTCGTACTACCACTT CATCAATAAAACAATTTTCGTCCGTAACATTACAGATTCAAGA [T/C] CTTTTCTTTTTGTCATATATAG ATGAGATTGCGAAATTGTTTCCAAATCTGTTCGGGCAACCGTCCGCATTGTTGGTGCCGAACGGTGCTGA CGCGGTGCGATCTGATGAGAAGTTGAAAATCGGCGTCGTCTTGTCTGGAGGTCAGGCGCCAGGTGGACAC AATGTGATCTCTGGAATCTATGGTGAGTATAAATCTGAAAATGTAATATAAGCGTGATTTGTGTGAAAAT TGGCCTTTTAAACGTGATTTGCTTATGTTTTGGTGGCAGATTACTTGCAGGATCGCGCGAAAGGGAGTGT ACTGTATGGATTCAGAGGAGGTCCAGCTGGAATCATGAAGTGCAAATACGTTGAWCTAACTTCCGATTAT ATTTATCCCTATAGAAACCAGGTATAACTTTGAGTATAATGTCAATGTTTTGAGTAATAAATAGTACATA TTAATTAATCTTTGTAGAATTAGACCATTTGCATATTAAATTTTGGCTTGACAAGTAAATGTAAAATGT GCATGTTAAAGAAATGAAGTAAGCATCTAACCCCTTTG 
$>$ Locus NADK2-M285. GenBank accession: JX630077 [organism=Citrus reshni] PCR product NADH kinase genomic DNA.

GTATTAGTGTTGAAAAAGCCTGGGCCAGCACTCATGGAAGAAGCTAAAGAGGTACCATGCAAAGTCTTTT ATGTAATGTCAAAATAGTTTTTTGAATTCACTTTGAAGCGATTCTTACATCTAAACAAATGTTTGTATT AAGAAGATGCATATTATTGTGTTTCAGTTGCTCTACTTGATAATATGTCAACTAAACCTTCTACATTGCT GATCTGTATTTCCATATCCACTCTATAAATATGTAGCTGCTATAACTCATTTCTAGATCTGATGAGCAGG TTGC [т/с] TCTTTCTTGTATCACCAAGAGAAGATGAATATTCTTGTTGAGCCAGATGTGCAC

$>$ Locus DFR-M240. GenBank accession: JX630078 [organism=Citrus reshni] PCR product dihydroflavonol 4-reductase genomic DNA.

GGCTATGCTGTTCGTGCTACTGTTCGCGATCCTGGTCTGGTTCATTTGCTGATCTTAATTAATTTTTGTT AAACATTATCATAAATTTGCAAGTTCAACAGAATTTTAAAATGACTGTGGGCTATACGACAGATAACAAA AAGAAAGTGAAACATTTGCTGGAGTTGCCGAAGGCAAGCACTCACCTGACTTTATGGAAAGCCGATTTAG CCGAAGAGGGAAACTTTGATGAA [G/C] CGATTCGAGGCTGCACTGGAGTTTTTCATCTGGCCACGCCTA TGGACTTTGAGTCCAAGGATCCTGAGGTATCGGTATCATCGTTACTCTTTAGTCTTTAGTTTCTTTTGAA TAATACCAATAAATATTTATCCCGTTCATCGCAGATTTTTTTTTTTTTTTTTAATTTTGAA

$>$ Locus LAPX-M238. GenBank accession: JX630079 [organism=Citrus reshni] PCR product ascorbate peroxidase genomic DNA.

TTTTGGGACGATCAGGCACCCAGATGAGCTTGCTCATGAGGCTAACAATGGTCTTGATATTGCTGTCAGG CTCTTGGAGCCCATCAAGCAGCAGTTTCCTATCTTGTCCTACGCTGATTTCTATCAGGTAATTATTATTT ATATCCAACTGTTGACTACAGAAAATGATTTGCTTTATGATCACTTTCTATGGATTACTTTGGATTGGTG AATTGACCATGGTTTGTGTTTTATTTT[C/G] TTGAAGTTGGCTGGAGTTGTTGCCGTTGAAGTTACCGG AGGGCA

$>$ Locus PSY-M30. GenBank accession: JX630080 [organism=Citrus reshni] PCR product phytoene synthase genomic DNA.

GGGTCGTCCATTTGATATGCTTGATGCTG[G/C]ATTATCAGATACAGTAACCAAATTTCCTGTCGACAT TCAGGTTAGACTATGTTTTCAAGATCAAATTAKATTTTAACAAAATGGTTGTTATAGTACTCTCTCTACT CTCTTAAGTGTACTTGTATTAAATTAAAATAAGGAACAACTTCTGCTTTCTAATTGGTTTTTAAAACATT AAGCCTTGATGCATAATGACAGACCTTATTTACATTTAATTGAGTCATRCCATTTTTGCATTTTCAATTT ATCCAGGAGACCGAAGATGTGATGAGGTGATGCTACATGCTTACTAAGAACAATTCCGTTTCTCTAAATT GCTCCATTATTTATTAGGACTCTTGAAGTTAACAGATAGCAATAGTGAATTTACTTCTCTGAAAAATTTA CTTATCTGAAAACAAAGTTCTGCATGCTACCCTTCTCAATATTCAGACAAGAGTTTAATAGGCCTGCGAT ATCTAAATAAAGGATGCAGTTTATGACTGAACCACCTCCCTGCAACGTTATCTTTTGTACCTTGATCTTT CTTCAGAAAATGTTCTATTAAAAGTATTTCCAGTGGACCCTTAACCCAAT

$>$ Locus PSY-C461. GenBank accession: JX630080 [organism=Citrus reshni] PCR product phytoene synthase genomic DNA.

GGGTCGTCCATTTGATATGCTTGATGCTGCATTATCAGATACAGTAACCAAATTTCCTGTCGACATTCAG GTTAGACTATGTTTTCAAGATCAAATTAKATTTTAACAAAATGGTTGTTATAGTACTCTCTCTACTCTCT TAAGTGTACTTGTATTAAATTAAAATAAGGAACAACTTCTGCTTTCTAATTGGTTTTTAAAACATTAAGC CTTGATGCATAATGACAGACCTTATTTACATTTAATTGAGTCATRCCATTTTTGCATTTTCAATTATCC AGGAGACCGAAGATGTGATGAGGTGATGCTACATGCTTACTAAGAACAATTCCGTTTCTCTAAATTGCTC CATTATTTATTAGGACTCTTGAAGTTAACAGATAGCAATAGTGAATTTACTTCTCTGAAAAATTTACTTA TCTGAAAACAAAGTTCTGCATGCTACCCTTCTCAATATTC [T/A] GACAAGAGTTTAATAGGCCTGCGAT ATCTAAATAAAGGATGCAGTTTATGACTGAACCACCTCCCTGCAACGTTATCTTTTGTACCTTGATCTTT CTTCAGAAAATGTTCTATTAAAAGTATTTCCAGTGGACCCTTAACCCAAT

$>$ Locus AOC-M290. GenBank accession: JX630081 [organism=Citrus reshni] PCR product ascorbate oxydase genomic DNA.

CTGACAAGATTCTTCCATGCCCACGTTGTAATAGTATGGACACTAAGTTCTGCTACTACAACAATTACAA TGTAAACCAACCACGACACTTCTGCAAGAACTGCCAGAGATACTGGACAGCTGGTGGGACAATGCGTAAT GTACCTGTAGGTGCTGGTCGTCGAAAGAACAAGAACTCAGCTTCTCACTACCGTCACATAACTGTCTCGG AAGCCCTCCAAAACGTCCGAACTGATGTTCCGAATGGGGTCCACCATCCTGCGTTGAAAACTAATGGTAC TGTACTTAC [C/T] TTTGGCTCAGATGCACCCCTTTGTGAATCAATGGCATCAGTTCTGAATATTGCTGA TAAAACAATGAGGAATTGCACGAGAAATGGGTTTCATAAACCTGAGGAGTTGAGAATTCGACTTACTTAC 
AGAGGTGGAGAAAATGGGGATAATTATGCACATGGATCTCCGGTGCCAGTTTCAAATTCAAAGGATGAGG CAGGCAAAACTACTTCACAGGAGGCAGTTGTGCAGAATTGTCAAGGCTTCCCTCCTCATGTGGCTTGCTT TCCTGGGGCTCCGTGGCCATACCCATGGAATTCGGCTCAATGGAGCCCTCCAGTTACCCCACCTGCGATC CTTCCTCCAGGCTTCCCTATGCCATTCTACCCTCCAGCAGCTTACTGGG

$>$ Locus AOC-C593. GenBank accession: JX630081 [organism=Citrus reshni] PCR product ascorbate oxydase genomic DNA.

CTGACAAGATTCTTCCATGCCCACGTTGTAATAGTATGGACACTAAGTTCTGCTACTACAACAATTACAA TGTAAACCAACCACGACACTTCTGCAAGAACTGCCAGAGATACTGGACAGCTGGTGGGACAATGCGTAAT GTACCTGTAGGTGCTGGTCGTCGAAAGAACAAGAACTCAGCTTCTCACTACCGTCACATAACTGTCTCGG AAGCCCTCCAAAACGTCCGAACTGATGTTCCGAATGGGGTCCACCATCCTGCGTTGAAAACTAATGGTAC TGTACTTACTTTTGGCTCAGATGCACCCCTTTGTGAATCAATGGCATCAGTTCTGAATATTGCTGATAAA ACAATGAGGAATTGCACGAGAAATGGGTTTCATAAACCTGAGGAGTTGAGAATTCGACTTACTTACAGAG GTGGAGAAAATGGGGATAATTATGCACATGGATCTCCGGTGCCAGTTTCAAATTCAAAGGATGAGGCAGG CAAAACTACTTCACAGGAGGCAGTTGTGCAGAATTGTCAAGGCTTCCCTCCTCATGTGGCTTGCTTTCCT GGGGCTCCGTGGCCATACCCATGGAATTCGGC [ $\mathbf{T} / \mathbf{A}]$ CAATGGAGCCCTCCAGTTACCCCACCTGCGATC CTTCCTCCAGGCTTCCCTATGCCATTCTACCCTCCAGCAGCTTACTGGG

$>$ Locus DXS-C545. GenBank accession: JX630082 [organism=Citrus reshni] PCR product 1-deoxyxylulose 5-phosphate synthase genomic DNA.

TTCATATGAAGAGTCTCTCTAAAGAGGTAAAARCGTGYGCGTCTGATTGATGGGAATCCTGTTCTTTCTT GAGGATATTTCATTTGTTCATAACATAGTTCGTACAATTTTCAGGATCTTGAACAACTGGCAGCAGAGCT TAGAGCAGATATTGTTAACAGTGTATCGAAGACAGGTGGGCATCTTAGTGCAAACTTAGGAGTGGTGGAG CTAACACTTGCTTTGCATCGTGTTTTCAACACACCTGACGATAAAATTATATGGGATGTTGGCCATCAGG TAATTAATTGAAGACACTTGTTAATTCGCTACTGCCCTGTCTCAAACGAATCATGGCTGAACAAATTAAA GACCCAAACATATATCAGTGTTACTGAATGGCTGACCTTGAATCCTGCAGGCTTATGTACACAAAATTCT GACTGGAAGAAGATCCAGAATGAACACCATGAGGAAGACTTCGGGGCTTGCAGGATTCCCCAAAAGAGA [ G/C] GAAAGCGTTCATGATGCATTTGGTGCAGGACATAGTTCCACAAGCATCTCTGCTGGTCTTGGTATG TACTTCACTCTCTTAATATTTTCCTTTCATCAATCTAGAGAAATTGTAGGATGCAGAATACATAATTGAG AАTTTCСтAАTCTAAтCAтATTTTTTAATAATAGGTATGGC

$>$ Locus DXS-M618. GenBank accession: JX630082 [organism=Citrus reshni] PCR product 1-deoxyxylulose 5-phosphate synthase genomic DNA.

TTCATATGAAGAGTCTCTCTAAAGAGGTAAAARCGTGYGCGTCTGATTGATGGGAATCCTGTTCTTTCTT GAGGATATTTCATTTGTTCATAACATAGTTCGTACAATTTTCAGGATCTTGAACAACTGGCAGCAGAGCT TAGAGCAGATATTGTTAACAGTGTATCGAAGACAGGTGGGCATCTTAGTGCAAACTTAGGAGTGGTGGAG CTAACACTTGCTTTGCATCGTGTTTTCAACACACCTGACGATAAAATTATATGGGATGTTGGCCATCAGG TAATTAATTGAAGACACTTGTTAATTCGCTACTGCCCTGTCTCAAACGAATCATGGCTGAACAAATTAAA GACCCAAACATATATCAGTGTTACTGAATGGCTGACCTTGAATCCTGCAGGCTTATGTACACAAAATTCT GACTGGAAGAAGATCCAGAATGAACACCATGAGGAAGACTTCGGGGCTTGCAGGATTCCCCAAAAGAGAG GAAAGCGTTCATGATGCATTTGGTGCAGGACATAGTTCCACAAGCATCTCTGCTGGTCTTGGTATGTACT TC [G/A] CTCTCTTAATATTTTCCTTTCATCAATCTAGAGAAATTGTAGGATGCAGAATACATAATTGAG

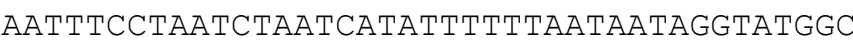

$>$ Locus FLS-P129. GenBank accession: JX630083 [organism=Citrus reshni] PCR product flavonol synthase genomic DNA.

TTCAAATGGCACAATTCCAGCAGAGTTCGTAAGACCCGAAAAAGAACAGCCAGCAAGCACAACGTACCAC GGCCCCGCTCCTGAAATCCCCACGATCGATCTCGACGACCCCGTTCAAGACAGACTCG [ T/C] ACGTTCC ATCGCGGAAGCCAGCCGGGAGTGGGGGATTTTCCAGGTTACAAACCACGGGATACCTAGTGACCTCATCG GTAAACTGCAAGCCGTCGGCAAAGAATTTTTTGAGCTCCCTCAGGAAGAGAAAGAAGTGTATTCTCGTCC GGCTGATGCAAAAGACGTGCAAGGATACGGCACAAAGTTACAGAAAGAAGTCGAAGGAAAGAAATCTTGG GTTGATCATCTCTTCCACAGGGTTTGGCCTCCGTCTTCTATCAACTACCGCTTCTGGCCCAACAACCCTC CTTCTTACCGGTGAATGTTATGCATCTCTTATCTTTTTCAATTCTTTT 
$>$ Locus FLS-M400. GenBank accession: JX630083 [organism=Citrus reshni] PCR product flavonol synthase genomic DNA.

TTCAAATGGCACAATTCCAGCAGAGTTCGTAAGACCCGAAAAAGAACAGCCAGCAAGCACAACGTACCAC GGCCCCGCTCCTGAAATCCCCACGATCGATCTCGACGACCCCGTTCAAGACAGACTCGTACGTTCCATCG CGGAAGCCAGCCGGGAGTGGGGGATTTTCCAGGTTACAAACCACGGGATACCTAGTGACCTCATCGGTAA ACTGCAAGCCGTCGGCAAAGAATTTTTTGAGCTCCCTCAGGAAGAGAAAGAAGTGTATTCTCGTCCGGCT GATGCAAAAGACGTGCAAGGATACGGCACAAAGTTACAGAAAGAAGTCGAAGGAAAGAAATCTTGGGTTG ATCATCTCTTCCACAGGGTTTGGCCTCCGTCTTCTATCAACTACCGCTT [C/T] TGGCCCAACAACCCTC CTTCTTACCGGTGATGTTATGCATCTCTTATCTTTTTCAATTCTTTT

$>$ Locus LCYB-M480. GenBank accession: JX630084 [organism=Citrus reshni] PCR product lycopene $\beta$-cyclase genomic DNA.

AAGATTCAGAACCAGGAGCTTAGGTTTGGTCTCAAGAAGTCTCGTCAAAAGAGGAATATGAGTTGTTTCA TTAAGGCTAGTAGTAGTGCTCTTTTGGAGCTAGTTCCTGAAACCAAGAAGGAAAATCTTGAATTTGAGCT TCCCATGTATGACCCATCAAAGGGCCTTGTTGTAGACCTAGCAGTTGTCGGTGGTGGCCCAGCTGGGCTT GCTGTTGCTCAGCAAGTTTCAGAGGCGGGGCTTTCGGTTTGCTCGATTGATCCATCTCCCAAATTGATTT GGCCAAATAATTATGGTGTTTGGGTGGATGAATTTGAGGCCATGGATTTGCTTGATTGCCTTGATACTAC TTGGTCTGGTGCTGTTGTGCACATTGATGATAATACAAAGAAGGATCTTGATAGACCTTATGGCAGAGTT AATAGGAAGTTGCTGAAGTCGAAAATGCTGCAAAAATGCATAACCAATGGTGTTAAGTT [G/C] CACCAA GCTAAAGTTATTAAGGTTATTCATGAAGAGTCCAAATCTTTGTTGATTTGCAATGATGGTGTGACAATTC AGGCTGCCGTGGTTCTTGATGCTACGGGATTCTCTAGGTGTCTTGTGCAGTATGATAAACCCTATAATCC AGGTTACCAAGTGGCATATGGAATACTAGCTGAGGTAGAAGAGCACCCGTTTGATTTAGACAAGATGGTT TTCATGGATTGGAGAGATTCGCATCTGAACAACAATTCGGAGCTCAAAGAGGCAAATAGCAAAATTCCTA СтTTTCTTTATGCCATGCCCTTTTCGTCAAACAGGATATTTCTTGAAGAGACTTCGCTAGTGGCGCGGCC TGGAGTGCCAATGAAAGATATCCAGGAAAGAATGGTGGCTAGATTAAAGCACTTAGGCATAAAAGTTAGA AGCATTGAAGAGGATGAGCATTGTGTCATTCCGAT

$>$ Locus LCYB-P736. GenBank accession: JX630084 [organism=Citrus reshni] PCR product lycopene $\beta$-cyclase genomic DNA.

AAGATTCAGAACCAGGAGCTTAGGTTTGGTCTCAAGAAGTCTCGTCAAAAGAGGAATATGAGTTGTTTCA TTAAGGCTAGTAGTAGTGCTCTTTTGGAGCTAGTTCCTGAAACCAAGAAGGAAAATCTTGAATTTGAGCT TCCCATGTATGACCCATCAAAGGGCCTTGTTGTAGACCTAGCAGTTGTCGGTGGTGGCCCAGCTGGGCTT GCTGTTGCTCAGCAAGTTTCAGAGGCGGGGCTTTCGGTTTGCTCGATTGATCCATCTCCCAAATTGATTT GGCCAAATAATTATGGTGTTTGGGTGGATGAATTTGAGGCCATGGATTTGCTTGATTGCCTTGATACTAC TTGGTCTGGTGCTGTTGTGCACATTGATGATAATACAAAGAAGGATCTTGATAGACCTTATGGCAGAGTT AATAGGAAGTTGCTGAAGTCGAAAATGCTGCAAAAATGCATAACCAATGGTGTTAAGTTCCACCAAGCTA AAGTTATTAAGGTTATTCATGAAGAGTCCAAATCTTTGTTGATTTGCAATGATGGTGTGACAATTCAGGC TGCCGTGGTTCTTGATGCTACGGGATTCTCTAGGTGTCTTGTGCAGTATGATAAACCCTATAATCCAGGT TACCAAGTGGCATATGGAATACTAGCTGAGGTAGAAGAGCACCCGTTTGATTTAGACAAGATGGTTTTCA TGGATTGGAGAGATTCGCATCTGAACAACAATTCG [G/C]AGCTCAAAGAGGCAAATAGCAAAATTCCTA СTTTTCTTTATGCCATGCCCTTTTCGTCAAACAGGATATTTCTTGAAGAGACTTCGCTAGTGGCGCGGCC TGGAGTGCCAATGAAAGATATCCAGGAAAGAATGGTGGCTAGATTAAAGCACTTAGGCATAAAAGTTAGA AGCATTGAAGAGGATGAGCATTGTGTCATTCCGAT

$>$ Locus TSC-C80. GenBank accession: JX630085 [organism=Citrus reshni] PCR product trehalose-6-phosphate synthase genomic DNA.

GTGGCACCACCAGCACGCCGACCCTCATTTTGGCTCATGCCAGGCTAAAGAGCTTCTTGACCACTTGGAA AATGTTCTT[T/G] CTAATGAGCCTGTTGTTGTCAAAAGAGGCCAACACATTGTTGAGGTCAAGCCACAG GTATGTCAACATCAATCTTTTTAATACAGTTGTTACATAAACTTATATGATATGTTACGAAGAAACGGTG TAATGCCCTTTGTTTTATATCTCATTGATATTGCTCGGATGATCATTCTAATGTGGTGAATTGGGTAGGG AGTAAGCAAAGGCATTGTTGTAAAAAACTTGATTTCAACTATGCGAAGTAGGGGGAAGT

$>$ Locus NCED3-M535. GenBank accession: JX630086 [organism=Citrus reshni] PCR product 9-cis-epoxy hydroxy carotenoid dyoxygenase 3 genomic DNA.

CCGTTTTGTTCAAGAACGTAGCTTAGGCCRCCCCGTATTCCCCAAAGCCATTGGCGAGCTTCACGGCCAC ACGGGCATCGCAAGATTGCTTCTCTTCTACAGCAGAGCGCTCTTCGGTCTCGTTGACCCCAGCCACGGCA 
CTGGCGTTGCCAACGCCGGCCTTGTTTACTTCAACAACCGTTTGTTGGCCATGTCTGAAGATGACTTGCC TTATCACGTGCGCGTCACTCCATCCGGCGACCTCAAAACGGTCGGCCGTTTCKACTTCAGCGGCCAGCTC AAGTCCACGATGATAGCTCATCCGAAAGTTGATCCCGTGACGGGTGATTTGTTTGCTCTGAGTTATGACG TTGTCAAGAAGCCTTACTTGAAGTACTTTCGGTTTTCGCCCCAAGGGATCAAGTCTCCGGACGTTGAGAT TCCCCTTGAGGAGCCTACAATGATGCATGATTTCGCAATCACTGAGAATTTTGTTGTGGTGCCTGACCAG CAAGTGGTGTTCAAGTTGAATGAGATGATCCGAGGTGGCTCCCC [T/G] GTGATTTATGACAAGAACAAG GTGT

$>$ Locus HYB-C433. GenBank accession: JX630087 [organism=Citrus reshni] PCR product $\beta$-Carotene hydroxylase genomic DNA.

GTGGCAAATGGAGGTACTTCAAACAAATCACACATGTCCTAATGTTATTGGTTGGTTRTATGAA CAGAAAATTTCGCCCCTCTTTTGATGATGCTTACATGTTATGTATCCGTACAGGGTGGAGAGGTGCCTTT A [G/A] CTGAAATGTTTGGCACATTTGCTCTCTCTGTTGGTGCTGCTGTAAGTTCAATCACCTTCTTCCT TACAATGATTTGAAAACAAGACTAGAATTTTGGTTCTRATAGGAGCCGCGGTGGGGATGTTACAAACTTG ATCGATCTTTAACATAAAAACTGTAAAAATGAGGGGCTTGTGTGAATTTTCAATGTGAAGGCCTTTTCTG GCAAATTATATGATGATGATTCGCATTGGGTACC 


\section{CHAPTER 4}

Genetic diversity and population-structure analysis of mandarin germplasm by nuclear (SSR, indel) and mitochondrial markers.

Andres Garcia-Lor, François Luro, Gema Ancillo, Luis Navarro, and Patrick Ollitrault 



\section{Abstract \\ - Background and Aims}

The mandarin horticultural varietal group is highly polymorphic. It is closely related with one of the basic taxa of the cultivated citrus (Citrus reticulata), but it also includes genotypes introgressed by other species. The precise contribution of ancestral species to the mandarin group is not known. The goals of this work were: 1) to characterise the mandarin germplasm using nuclear (SSR, indel) and mitochondrial markers; 2) to evaluate genetic diversity and detect redundancies; 3 ) to quantify the contributions of the citrus ancestral genomes to the mandarin germplasm; and 4) to determine the genetic structure within the mandarin group.

\section{- $\quad$ Methods}

Fifty microsatellite (SSR), 24 insertion-deletion (indel), and four mitochondrial (mtDNA) indel markers were analysed for 223 genotypes. The Structure software was applied to nuclear data to check and quantify potential interspecific introgressions in the mandarin germplasm and to determine the optimal number of clusters within it.

- Key results

The C. maxima and Papeda genomes were the main genomes introgressed in the $C$. reticulata background of the mandarin germplasm. By Structure analysis, seven clusters were revealed at the nuclear level $(\mathrm{N})$ within the mandarin germplasm. Five of these clusters should be parental mandarin groups (N1-N5), and the other two included genotypes of known or supposed hybrid origin (N6 and N7). The contributions of these parental groups to the mandarin genotypes were estimated.

The mitochondrial indel analysis revealed four mitotypes in which mandarin and 'mandarin-like' genotypes were represented. Two cytoplasmic (C) groups clusterized pure mandarins ( $\mathrm{C} 1$ and $\mathrm{C} 2$ ) while interspecific mandarin hybrids were found associated with the two other mitotypes (C3 and $\mathrm{C} 4)$.

\section{- $\quad$ Conclusions}

This work provides new insights into the organisation of the mandarin germplasm and its structure at the nuclear and cytoplasmic level. These insights will be useful for better breeding and management of citrus germplasm collections. 


\section{INTRODUCTION}

Citrus is the most important fruit crop in the world, with a production of $123,755,751$ tons and a cultivated area of $8,643,502$ ha (FAOSTAT, 2010). Among the commercial citrus fruits, mandarins are the second most important group in the fresh-fruit market worldwide. Spain is the second largest mandarin producer and the largest mandarin exporter in the world, with a total production of $1,708,200$ tons in a cultivated area of 90,900 ha (FAOSTAT, 2010).

'Mandarin' is a common name given to most small, easy-peeling citrus fruits. This term includes interspecific hybrids, which make mandarins the most genetically and phenotypically polymorphic group of true Citrus (Nicolosi et al., 2000; Barkley et al., 2006; Garcia-Lor et al., 2012, 2013). Moreover, a recent phylogenetic study (Garcia-Lor et al., 2013) revealed a close relationship between genus Fortunella and the mandarin group. Mandarin germplasm was classified as C. reticulata Blanco by Swingle and Reece (1967) and Mabberley (1997). On the contrary, Webber (1943) classified mandarin genotypes into four different groups: king, satsuma, mandarin, and tangerine. Tanaka (1954) divided mandarins into five groups that included 36 species, based on morphological differences in the tree, leaves, flowers, and fruits. Group 1 included C. nobilis Lour. (cultivars like 'King'), C. unshiu Marc. (satsumas) and C. yatsushiro Hort. ex Tanaka; group 2 included C. keraji Hort. ex Tanaka, C. oto Hort. ex Yuichiro and $C$. toragayo Hort. ex Yuichiro; group 3 included 14 species, including some of the most economically important varieties, such as C. reticulata ('Ponkan'), C. deliciosa Tenore ('Willowleaf' or 'Common mandarin'), C. clementina Hort. ex Tanaka (clementines) and $C$. tangerina Hort. ex Tanaka ('Dancy'); group 4 included C. reshni Hort. ex Tanaka ('Cleopatra'), C. sunki Hort. ex Tanaka ('Sunki') and C. tachibana (Mak.) Tanaka; and group 5 included the species C. depressa Hayata ('Shekwasha') and C. lycopersicaeformis (Lush.) Hort. ex Tanaka. Hodgson (1967) divided the mandarins into four species: C. unshiu (satsuma), C. reticulata ('Ponkan', 'Dancy', clementine), C. deliciosa ('Willowleaf') and C. nobilis ('King').

None of these citrus classification systems is perfect, but the Tanaka system seems better adapted to the horticultural features of each group, whereas the Swingle system simplifies it to the extreme. At present, $C$. reticulata (mandarin) is considered to be one of the four ancestral groups of the cultivated citrus (Barrett HC, 1976; Nicolosi et al., 2000; Krueger and Navarro, 2007), along with C. maxima (Burm.) Merr. (pummelo), C. medica L. (citron) and C. micrantha Wester (papeda). The centre of diversification of C. reticulata is located in Asia, from Vietnam to Japan (Tanaka, 1954). This group is highly polymorphic, as revealed by molecular markers (Coletta Filho et al., 1998; Ollitrault et al., 2012a), chromosomal banding patterns (Yamamoto and Tominaga, 2003) and phenotypic characters, such as fruit pomology and the chemical variability of peel and leaf oils (Lota et al., 2000; Fanciullino et al., 2006), as well as tolerance to biotic and abiotic stresses. Several germplasm collections have been characterised by morphological characteristics and/or molecular markers (Koehler-Santos et al., 2003; Tapia Campos et al., 2005; Barkley et al., 2006). This phenotypic and genetic variability reflects a long history of cultivation, in which many mutations and natural hybridisations have 
given rise to the existing diversity within this mainly facultatively apomictic group. The intraspecific organisation of mandarins and the determinants of the group's phenotypic diversity remain poorly understood.

In addition to the taxonomic complexity of the mandarin group, the genotypes introduced in citrus germplasm collections are sometimes of doubtful origin. The origin of these genotypes can be from plant explorations in regions of natural genetic diversity, selection of new materials from hybridisations or mutations, or by exchange between germplasm collections (Krueger and Navarro, 2007). The assignation of a cultivar name and/or membership in a species can be done arbitrarily, with no molecular basis, leading to possible mistakes in assignation or duplication of material (Krueger and Navarro, 2007). For these reasons, molecular studies are important for detection of misidentifications and redundancies (Krueger and Roose, 2003).

In this work, we will use the term 'mandarin' in four different ways: 'mandarin' as a true species (C. reticulata; one of the four ancestors of the other cultivated genotypes); 'mandarin' according to the Swingle classification ( $C$. reticulata [Sw]); 'mandarin' according to the Tanaka classification (17 species represented in this work, in which C. reticulata is included [Tan]); and 'mandarin-like' genotypes that are phenotypically similar to mandarins.

The goals of this work were: 1) to characterise the mandarin germplasm using nuclear (SSR, indel) and mitochondrial markers; 2) to evaluate genetic diversity and detect redundancies; 3 ) to quantify the contributions of the citrus ancestral genomes to the mandarin germplasm; and 4) to determine the structure within the mandarin group. 


\section{MATERIALS AND METHODS}

Diversity analysis

Two-hundred-and-twenty-three genotypes were studied with regard to their nuclear diversity, using 50 SSR and 24 indel markers. Throughout the text, these genotypes will be referred to by identification number (ID), shown in Supplementary information 1. Genotype classification was performed according to the Swingle (Swingle and Reece, 1967) and Tanaka (Tanaka, 1954) systems. A summary of the genotypes used can be found in Table 1. Plant material for the analysis was collected from the germplasm collections of the Instituto Valenciano de Investigaciones Agrarias (IVIA, Valencia, Spain) and the Station de Recherches Agronomiques (CIRAD-INRA, Corsica, France). These genotypes belong to the four ancestral species (30 C. reticulata [Sw, mandarins], 11 C. maxima [pummelos], six C. medica [citrons], four Papeda [C. ichangensis Swingle, C. histrix D.C., C. latipes (Swingle) Tan. and C. micrantha], and four Fortunella [kumquats: F. crassifolia Swing., F. hindsii (Champ.) Swing., F. japonica (Thunb.) Swing., and F. margarita (Lour.) Swing.]. The 30 mandarin genotypes considered as C. reticulata by Swingle (1967) were considered by Tanaka (1977) as 17 species. The other genotypes (168 'mandarin-like' accessions, intra- and interspecific hybrids) were not assumed in any of the previously mentioned main taxa, in order to decipher their structure and determine whether their Tanaka classification in the germplasm-bank data was properly assigned in our databases. Severinia buxifolia was added as out-group for neighbourjoining analysis.

For the maternal-origin study, the same genotypes were analysed, including the ancestral species and interspecific hybrids.

\section{Genotyping}

Fifty SSR markers located along the nine linkage groups of the reference genetic map of clementine (Ollitrault et al., 2012b) and 24 indel markers identified in a discovery panel representative of genus Citrus (Garcia-Lor et al., 2012, 2013) were used (Supplementary information 2). To assess the maternal origin of the mandarin germplasm, four mitochondrial indel markers (nad2, nad5, nad7, and rrn5/rrn18; Froelicher et al., 2011) were used.

Amplifications by polymerase chain reaction (PCR) and analyses with a capillary genetic fragment analyser (CEQ/GeXP Genetic Analysis System; Beckman Coulter, Fullerton, CA, USA) were performed as described in (Garcia-Lor et al., 2012). The Genetic Analysis System software (GenomeLab GeXP, v. 10.0) was used for data collection and analysis. 
Table 1. Summary of genotypes employed in the study, their classification based on Swingle, and their classification within our databases based on the Tanaka system.

\begin{tabular}{|c|c|c|c|}
\hline Swingle system & $\begin{array}{l}\text { Species name in databases } \\
\text { based on the Tanaka system }\end{array}$ & NG/S & NGSA \\
\hline C. reticulata hybrid & C. amblycarpa & 2 & 2 \\
\hline C. reticulata & C. deliciosa & 13 & 2 \\
\hline C. reticulata & C. daoxianensis & 1 & 0 \\
\hline C. reticulata & C. depressa & 5 & 2 \\
\hline C. reticulata & C. erythrosa & 3 & 2 \\
\hline C. reticulata & C. halimii & 1 & 0 \\
\hline C. indica & C. indica & 1 & 1 \\
\hline C. hystrix & C. hystrix & 1 & 1 \\
\hline C. ichangensis & C. ichangensis & 1 & 1 \\
\hline C. ichangensis $\times$ C. reticulata var. austera & C. junos & 1 & 0 \\
\hline C. limon & C. karna & 1 & 0 \\
\hline C. reticulata & C. kinokuni & 5 & 2 \\
\hline C. latipes & C. latipes & 1 & 1 \\
\hline C. reticulata var. austera? x Fortunella? & C. madurensis & 1 & 0 \\
\hline C. maxima & C. maxima & 11 & 11 \\
\hline C. medica & C. medica & 6 & 6 \\
\hline C. micrantha & C. micrantha & 1 & 1 \\
\hline C. reticulata & C. nobilis & 7 & 2 \\
\hline C. reticulata & C. paratangerina & 2 & 2 \\
\hline C. reticulata & C. reshni & 1 & 1 \\
\hline C. reticulata & C. reticulata & 53 & 3 \\
\hline C. sinensis & C. shunkokan & 1 & 0 \\
\hline C. reticulata & C. suavissima & 1 & 1 \\
\hline C. reticulata & C. succosa & 1 & 1 \\
\hline C. reticulata & C. suhuiensis & 8 & 2 \\
\hline C. reticulata & C. sunki & 4 & 2 \\
\hline C. tachibana & C. tachibana & 1 & 1 \\
\hline C. reticulata & C. tangerina & 11 & 2 \\
\hline C. sinensis & C. tankan & 1 & 0 \\
\hline C. reticulata & C. temple & 3 & 0 \\
\hline C. reticulata & C. unshiu & 8 & 2 \\
\hline C. reticulata & Citrandarin & 1 & 0 \\
\hline Fortunella & Fortunella & 4 & 4 \\
\hline C. reticulata & Hybrid mandarin & 30 & 0 \\
\hline C. reticulata & Tangelo & 4 & 0 \\
\hline C. reticulata & Tangor & 16 & 0 \\
\hline$?$ & Bintangor & 1 & 0 \\
\hline C. reticulata & C. clementina & 3 & 0 \\
\hline$?$ & Unknown & 7 & 0 \\
\hline
\end{tabular}

(NG/S) Number of genotypes per species; (NGSA) Number of genotypes from each species included within an ancestral population.

\section{Data analysis}

The allelic data obtained with the SSR, indel, and mtDNA markers was used to calculate a genetic dissimilarity matrix using the simple matching dissimilarity index $\left(d_{i-j}\right)$ between pairs of accessions (units), with the Darwin5 software, version 5.0.159 (Perrier and Jacquemoud-Collet, 2006). Weighted neighbour-joining (NJ) analyses (Saitou and Nei, 1987) were computed with the same software to describe the population-diversity organisation, and robustness of branches was tested using 1000 bootstraps.

Population structure was inferred with the program Structure, v. 2.3.3 (http://cbsuapps.tc.cornell.edu/structure), which implements a model-based clustering method using genotype data (Pritchard et al., 2000; Falush et al., 2003). When there is a known population structure, it allows to calculate their contribution to genomes of genotypes of unknown origin. In cases of unknown population structure, the Structure program helps to 
assign the optimal number of populations within the sample data set under study, based on the parameters of Evanno et al. (2005).

F-statistics were calculated with the program GENETIX, v. 4.03 (Belkhir et al., 2002), based on the parameters of Wright (1969), and Weir and Cockerham (1984). Some other genetic population statistics were estimated from the allele data using the program PowerMarker, v. 3.25 (Liu and Muse, 2005). 


\section{RESULTS}

SSR and indel analysis

Genetic-diversity statistics were calculated for each SSR and indel marker in the entire population (Supplementary information 2). Using the SSR markers, we detected 592 alleles. Allele numbers varied between five (TAA1) and 19 (mCrClR02D04b). The average number of alleles and the $H_{\mathrm{e}}$ (expected heterozygosity) value per locus were 11.8 and 0.67 , respectively. The whole population had an observed heterozygosity $\left(H_{0}\right)$ of $0.61 . F_{\mathrm{w}}$ (Wright fixation index) values varied from -0.43 (CAC23) to 0.50 (MEST256). The average $F_{\mathrm{w}}$ value over all SSR loci was close to zero (0.05).

We detected a total of 80 alleles with the indel markers. Allele number per locus ranged from two (eight markers) to seven (IDHyb-1, IDDFR), with an average of 3.3. The values ranged from 0.02 (IDPEPC3) to 0.67 (IDDFR), with a median value of $0.20 . F_{\mathrm{w}}$ values varied from -0.50 (IDF'3H) to 0.94 (IDINVA1). The overall $H_{0}$ and $F_{\mathrm{w}}$ value among all loci were 0.20 and 0.26 , respectively.

Genetic population statistics within the whole population, i.e., all 'mandarin-like' genotypes of unknown or supposed hybrid origin and the 30 genotypes selected from all Tanaka species represented in our collections (Supplementary information 1), are summarised in Figure 1. Gene diversity (GD) and the $H_{0}$ values were higher among SSR markers than indel markers, reflecting the higher maximum allele frequencies (MAF) of the latter. Comparing the whole population (AG), all 'mandarin-like' genotypes (AM), and mandarins from Tanaka species (MT), the mean allele number decreased at each step for SSR and indel markers (SSRs: $A G=$ $11.84>\mathrm{AM}=8.6>\mathrm{MT}=6.76$; indels: $\mathrm{AG}=3.33>\mathrm{AM}=2.64>\mathrm{MT}=2.02$ ), and the $\mathrm{GD}$ was higher in $A G$ than in AM or MT for both kinds of markers. For AG, Ho was slightly lower than He, leading to slightly positive Fw for SSR and indel markers. In AM and MT, Ho values were higher than $\mathrm{He}$, providing negative $\mathrm{Fw}$ values for both kinds of markers.

\section{Rare alleles}

The 'mandarin-like' population included 25 genotypes with unique alleles (Supplementary information 3), ranging from one (12 genotypes) to 20 (C. junos Sieb. ex Tan.) unique alleles per genotype. 


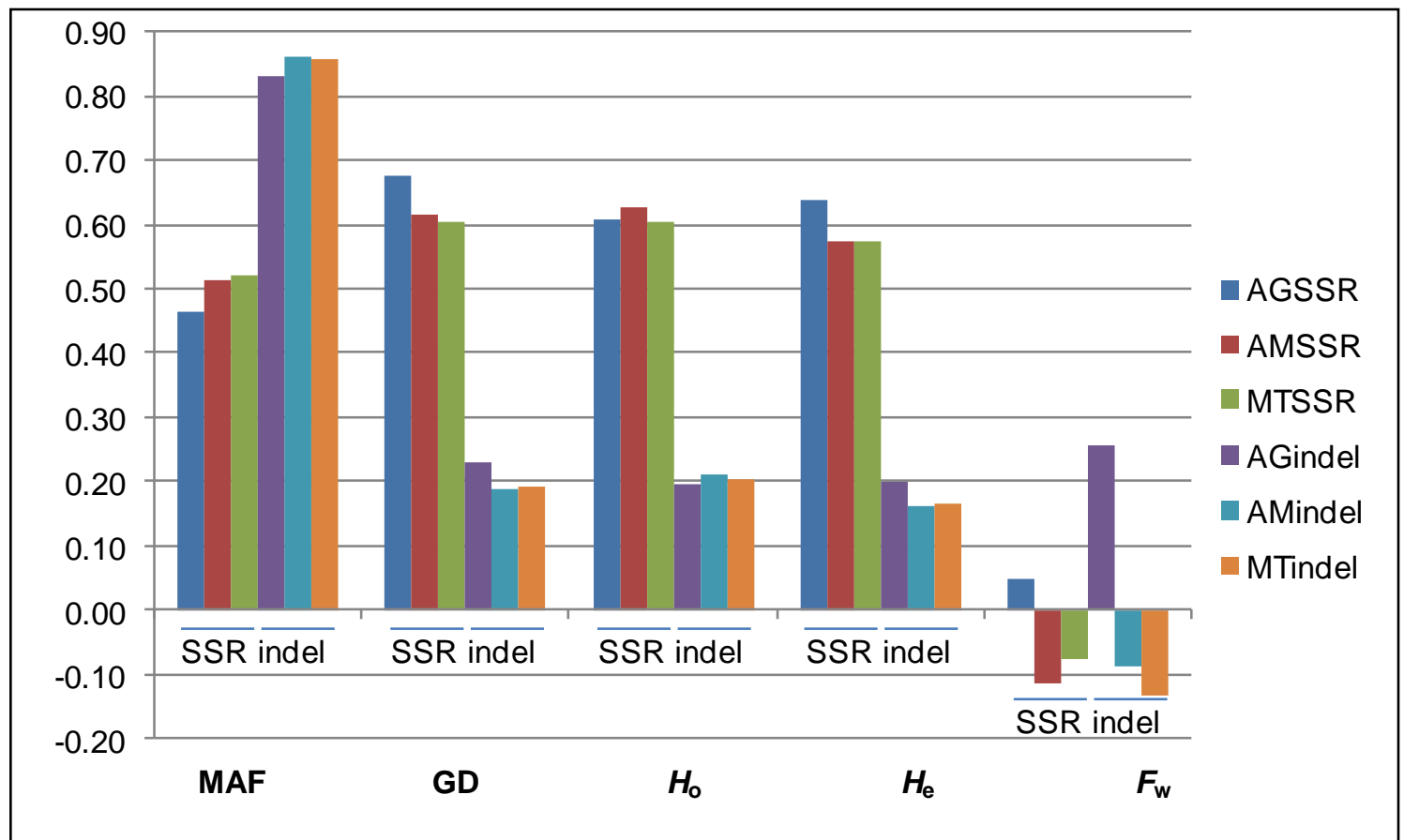

Figure 1. Genetic population statistics within the whole population, all 'mandarin-like' genotypes and Tanaka mandarin species. Comparison between SSR and indel markers.

(AGSRR) All genotypes analysed with SSR markers; (AMSSR) all mandarin-like genotypes analysed with SSR markers; (MTSSR) mandarins defined as true by Tanaka, analysed with SSR markers; (AGindel) all genotypes analysed with indel markers; (AMindel) all 'mandarin-like' genotypes analysed with indel markers; (MTindel) mandarins species defined by Tanaka, analysed with indel markers; (MAF) maximum allele frequency; (GD) gene diversity; $\left(H_{0}\right)$ observed heterozygosity; $\left(H_{\mathrm{e}}\right)$ expected heterozygosity; $\left(F_{\mathrm{w}}\right)$ Wright's fixation index.

\section{Classifications by NJ analysis}

For the whole data set (SSR and indel markers), NJ analysis (Figure 2a) revealed a clear differentiation between the five main taxa studied, the four ancestral Citrus groups (papeda, citron, pummelo, and mandarin) and kumquat, with very high bootstrap support. The combination of both SSR and indel markers revealed high intraspecific diversity in the mandarin group, which was not well resolved (low bootstrap support in many branches; Figure 2b). From the whole data set, 35 genotypes were reduced to 14 multilocus genotypes (MLGs; Supplementary information 4). Some of these were mutations of the same genotype (for example 'Willowleaf' and 'Willowleaf seedless', 'Murcott' and 'Murcott seedless', some mutations of $C$. unshiu, and the mutations of $C$. clementina), others are duplications of the same genotype that are present in both collections ('Imperial Australia' [ID-98] and 'Imperial' [ID-121]), and others are possible redundant genotypes collected in different locations. 


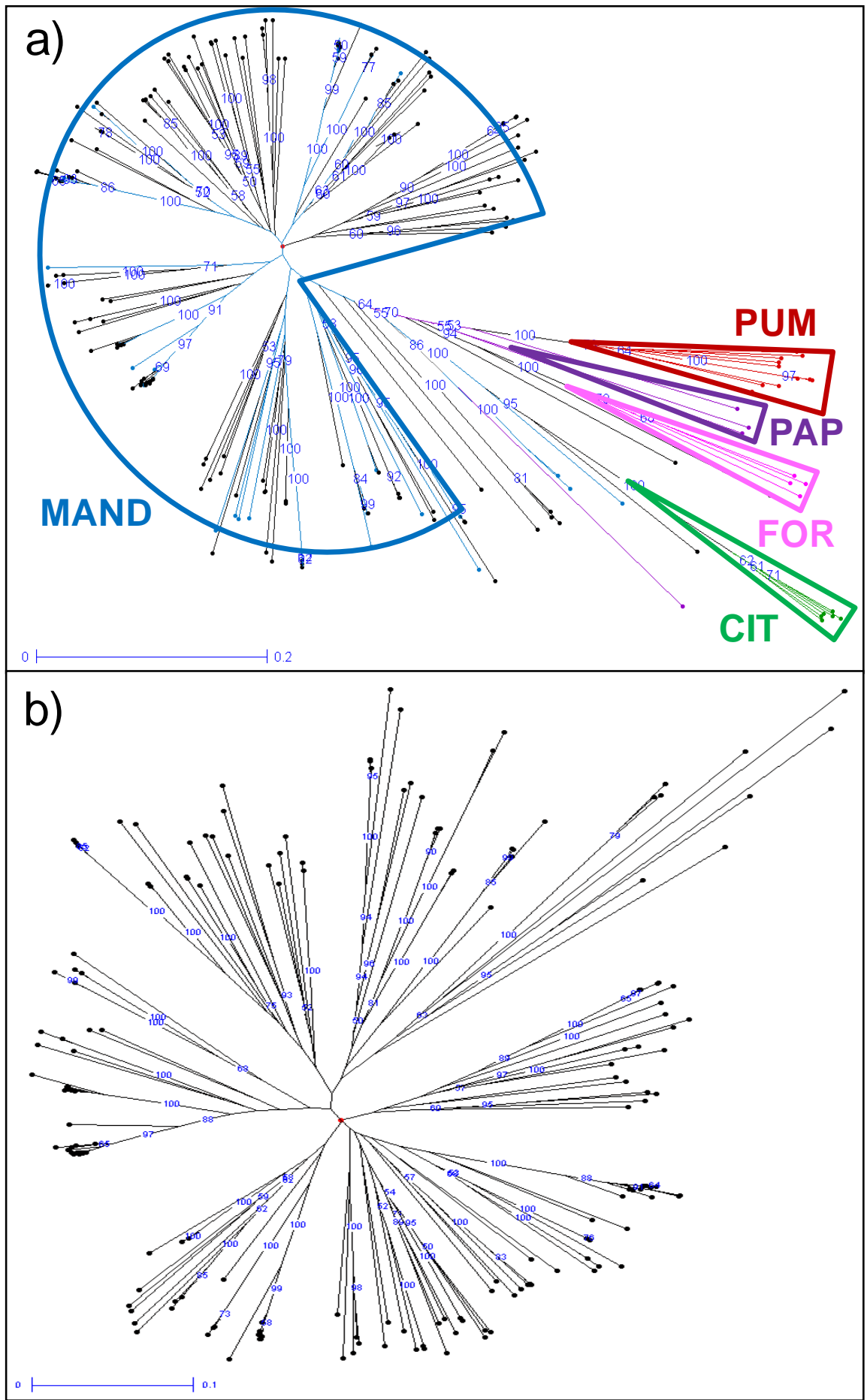

Figure 2. NJ analyses with 1000 bootstraps. Bootstrap values over 50 are represented. a) Entire data set (223 genotypes) representing the four ancestral Citrus species (C. reticulata, C. maxima, C. medica, Papeda) and Fortunella. b) 'Mandarin-like' genotypes (198, without the C. maxima, C. medica, Papeda, and Fortunella genotypes)

(MAND) Mandarin, (FOR) Fortunella, (CIT) Citron, (PAP) Papeda, (PUM) Pummelo 
Contribution of the ancestral taxa to the mandarin group and modern hybrids; analysis with the Structure software

The indel and SSR data were analysed with the Structure software to assess the contribution to the mandarin germplasm of the four ancestral Citrus taxa (C. reticulata [Sw], $C$. maxima, C. medica and Papeda) and Fortunella, using an admixture model and the option of correlated allele frequencies between populations. The degree of admixture alpha was inferred from the data. The burn-in period was set to 500000 and MCMC (Markov Chain Monte Carlo) repetitions were set to $1000000 ; 10$ runs of Structure with $K=5$ (five populations assumed) were performed. These populations were as follows: mandarin [Sw] (30 samples, representing 17 Tanaka species), pummelo (11 samples), citron (six samples), papeda (four samples) and kumquat (four samples). The other samples analysed (168) were assumed to have been derived from these ancestral populations (Supplementary information 1). Assuming an admixture model between the four ancestral citrus species and Fortunella (Supplementary information 1, genotypes 1-55), the relative proportion of these genomes in the mandarin group and recent hybrids was inferred using Structure, v. 2.3.3 (Figure 3), with the complete data set (SSRs + indel).

Twenty of the 55 genotypes assumed to belong to one of the ancestral citrus populations, as well as Fortunella, appeared to contain a certain degree of contribution from other ancestors. This was particularly the case for genotypes considered as mandarin species by Tanaka. The two $C$. amblycarpa (Hassk.) Ochse (only differing by five SSR markers) had a very high contribution from the Papeda genome ( 65\%), with the remainder ( 35\%) from $C$. reticulata. Citrus depressa (ID-5) had contributions from C. reticulata $(\sim 65 \%)$ and Papeda ( 35\%). Citrus erythrosa Hort. ex Tan. cv 'San hu hong chu' (ID-8) had almost 10\% introgression from Papeda and the remainder from C. reticulata. Citrus indica Tan. (ID-9) seems to have a tri-hybrid genome origin $(41 \%$ each from C. reticulata and C. medica; $18 \%$ from Papeda). Citrus kinonuni cv 'Vietnam à peau fine' (ID-10) had almost 10\% introgression from Papeda, with the remainder of the genome from C. reticulata. The two C. nobilis, cv 'Campeona' (ID-12) and cv 'Geleking' (ID-13), had introgressions of 10 and $23 \%$, respectively, from $C$. maxima, with the remainders of their genomes from C. reticulata. Citrus reshni (ID-165) had introgression from the Papeda genome (11\%), with the remainder from C. reticulata. Citrus suavissima Hort. ex Tan. cv 'Ougan' (ID-20) derived most of its genome from C. reticulata ( $90 \%)$, with some introgression from C. maxima ( 10\%). Citrus succosa Hort. ex Tan. cv 'Ben di zao' (ID-21) had a contribution from C. reticulata ( 90\%), with the remainder of its genome from C. maxima ( 7\%). The two C. sunki (ID-24 and ID-25) had introgression from Papeda of 13 and 20\%, respectively, with the remainders apparently from the $C$. reticulata genome. Citrus tachibana (ID-26) appeared to have equal contributions from the C. reticulata and Papeda genomes. The two $C$. unshiu (ID-29 and ID-30) had a small introgression from the $C$. maxima genome (8.80\%). Two ancestral Papeda, C. ichangensis Swing. and C. latipes (Swing.) Tan., also had contributions from C. maxima, 6.30 and $34.60 \%$, respectively. 


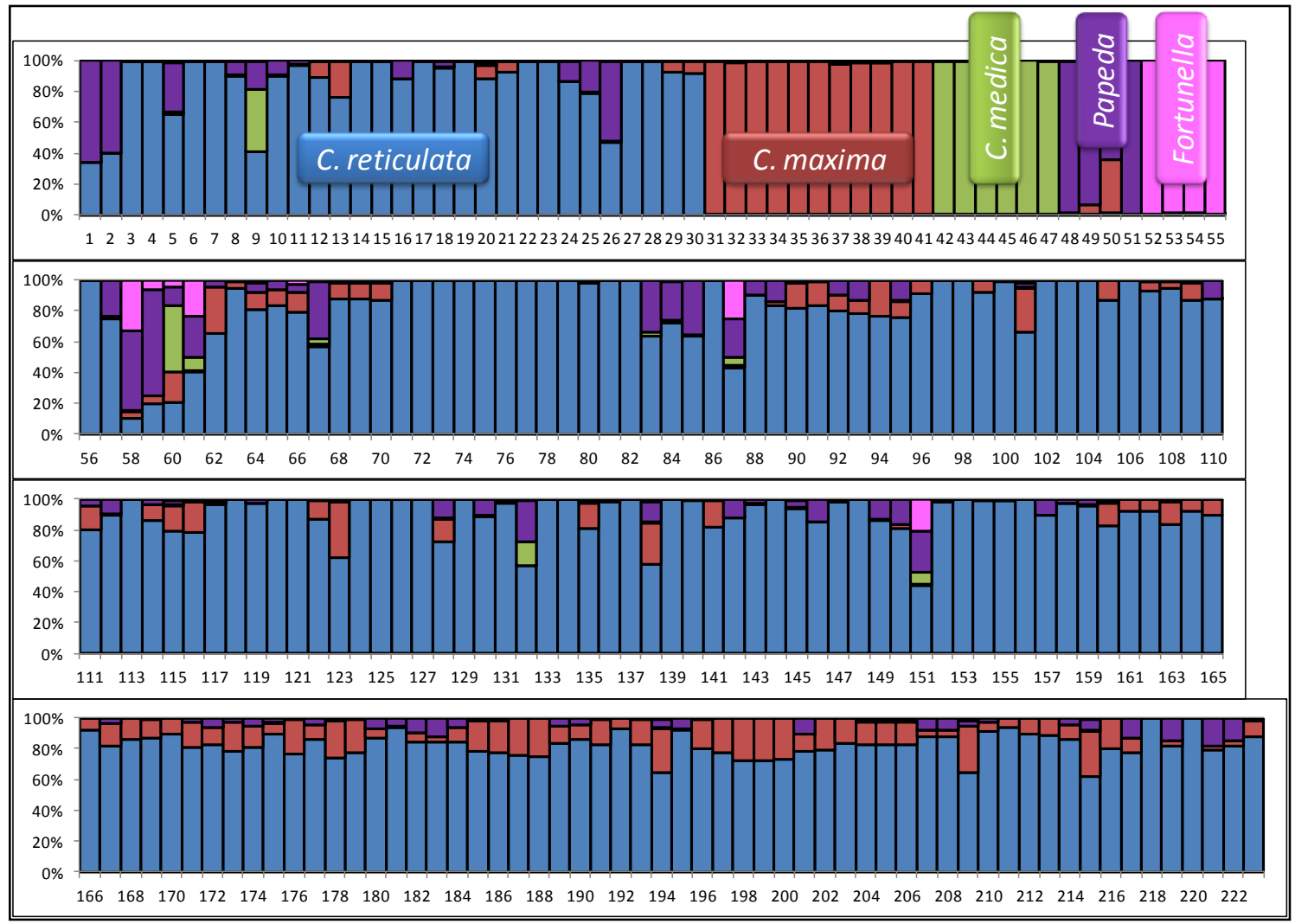

Figure 3. Structure analysis of 223 genotypes representing the four ancestral Citrus species $(C$. reticulata, C. maxima, C. medica, Papeda) and Fortunella. Dark blue, C. reticulata (1); brown, $C$. maxima (2); green, C. medica (3); purple, Papeda (4); pink, Fortunella (5). Genotypes 56-223 are genotypes without assigned populations.

The contribution of mandarin to the genomes of the 168 'mandarin-like' genotypes that were not included in any of the five pre-assumed populations (Supplementary information 1, genotypes ID-56/ID-223) was on average $\sim 85.13 \%$. Pummelo, papeda, kumquat and citron contributions were $8.00 \%, 5.14 \%, 1.03 \%$ and $0.70 \%$, respectively (Figure 4 ). Contributions in individual genotypes lower than $2 \%$ were not considered for the calculations.

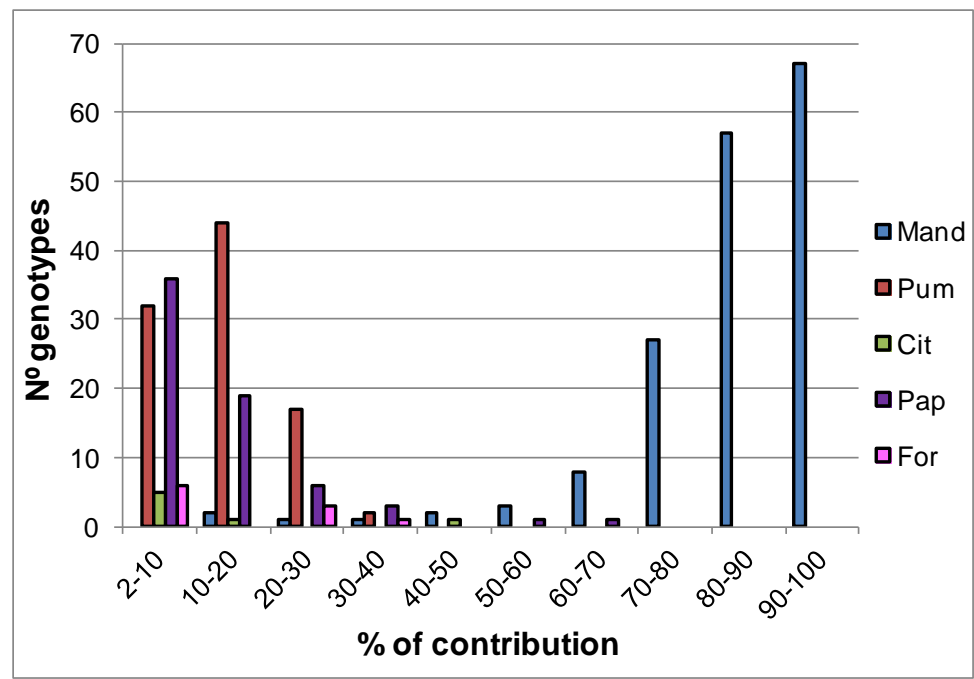

Figure 4. Contributions of the ancestral genomes (mandarin, pummelo, citron, papeda) and kumquat to the 'mandarin-like' genotypes under study.

(Mand) mandarin, (Pum) pummelo, (Cit) citron, (Pap) papeda, (For) kumquat. 
In the whole data set, only the citrus ancestors (C. maxima, C. medica and Papeda) and Fortunella did not exhibit any contribution from the mandarin genome. The 168 genotypes analysed with no assumed population had at least a $5 \%$ contribution from $C$. reticulata. Eightyfour genotypes had a C. maxima contribution of at least $5 \%$, and 95 genotypes had a $C$. maxima contribution of at least $2 \%$. Papeda contributed at least $5 \%$ to 45 genotypes, and at least $2 \%$ to 66 genotypes. Only five genotypes exhibited a contribution from C. medica of at least 5\%: C. karna Raf. (ID-60), C. madurensis Lour. (ID-61), C. kinokuni Hort. ex Tan. (ID-87), C. reticulata cv "Nicaragua" (ID-132), and C. sunki (ID-151). Two others had a contribution higher than $2 \%$. Only five genotypes [C. halimii Stone (ID-58), C. junos (ID-59), C. madurensis (ID-61), C. kinokuni (ID-87) and C. sunki (ID-151)] had a contribution from Fortunella higher than $5 \%$, and two others had a contribution higher than $2 \%$.

Clementines had a contribution from $C$. maxima $(\sim 10 \%)$, with the remainder of the genome from $C$. reticulata [Sw]. The six additional satsumas are identical to the ones included in the assumed ancestral mandarin group.

Tangelos had an on average contribution of $\sim 26 \%$ from $C$. maxima and $\sim 74 \%$ from $C$. reticulata [Sw]. Tangors had lower contributions from C. maxima (14\%) than the tangelos, and higher contributions from $C$. reticulata $(\mathrm{Sw}, 82 \%)$, as well as very small and perhaps insignificant contributions from Papeda (3\%) and Fortunella (1\%).

Some other genotypes, not directly related to mandarins, had mixed profiles: Citrus daoxianensis (ID-57) exhibited introgression from Papeda ( 23\%), with the remainder from $C$. reticulata [Sw]. Citrus halimii (ID-58) had a complex constitution: 51\% Papeda, 33\% Fortunella, $10 \%$ C. reticulata [Sw], $4 \%$ C. maxima and $1 \%$ C. medica. Citrus junos (ID-59) was $69 \%$ Papeda, 20\% C. reticulata [Sw], 6\% Fortunella and 5\% C. maxima. Citrus karna (ID-60) also had a complex mixture of genomes: $43 \%$ C. medica, $21 \%$ C. reticulata [Sw], $20 \%$ C. maxima, $12 \%$ Papeda and 4\% Fortunella. Citrus madurensis (ID-61) is another complex hybrid: $40 \%$ C. reticulata [Sw], 26\% Papeda, 23.5\% Fortunella, 8.5\% C. medica and 2\% C. maxima.

\section{Inferring clusters in the mandarin population}

The statistics used to select the correct $K$ value were the ones followed by Evanno et al., (2005): the mean likelihood, $L(K)$; the mean difference between successive likelihood values of $K, L^{\prime}(K)$; the absolute value of this difference, $L^{\prime \prime}(K)$ and $\Delta K$, which is the mean of the absolute values of $L "(K)$ divided by the standard deviation of $L(K)$. The likelihood distribution $\mathrm{L}(K)$ and $\Delta K$ were the main values used to choose the optimal $K$ value of the population. Three consecutive analyses were performed to obtain the correct number of groups within the mandarin germplasm.

The first Structure analysis was performed with the whole population (223 genotypes) with no population assignation. In this case, the optimal $\Delta K$ was 2: one population consisting of all mandarins and hybrids, and the other formed by the other parental representatives, $C$. 
maxima, C. medica, Papeda and Fortunella (Supplementary information 5). From this analysis $(K=2), 175$ accessions (Supplementary information 1 ) with a contribution above 95\% from the mandarin population were selected to perform another Structure analysis without population assignation. The highest $\Delta K$ value was obtained for $K=6$ (Supplementary information 6 ).

The third Structure analysis was done after removing all the known hybrids (clementines, tangelos, tangors and recent hybrids) from the 175 previous accessions. The genotypes 'Wallent' and tangor 'Gailang' were also removed. This analysis aimed to determine whether the groups observed previously were coherent. A sample set of 121 genotypes (Supplementary information 1) was used and, as before, the highest $\Delta K$ was observed for $K=6$ (Supplementary information 7). The two main differences between this analysis and that with 175 genotypes (explained previously), are as follows: (1) in the analysis with 175 genotypes, the C. nobilis Tanaka species formed a group, while in the analysis with 121 genotypes, $C$. nobilis was not identified as a pure group; conversely, (2) the analysis with 121 genotypes identified a group formed by a mixture of Tanaka mandarin species (C. reshni, C. kinokuni and C. reticulata) not previously recognised. The 'Ampefy' genotype was identified as an independent parental group in both analyses. 'Ampefy', 'Wallent' and 'Gailang' exhibited a high degree of mutual similarity, shared a high percentage of $C$. sinensis (L.) Osb. molecular-marker data (85.33, 97.33, and $96 \%$, respectively), and also exhibited high heterozygosity. Therefore, they are very probably interspecific hybrids, like sweet orange.

Structure analyses were compared with an NJ tree (Figure 5) to validate the clustering. Citrus nobilis (tangor 'King') and some of its hybrids appeared as a cluster in the NJ tree, as in the structure analysis with 175 genotypes. However, previous analyses (Coleta-Filho et al., 1998; Nicolosi et al., 2000; Garcia-Lor et al., 2012) considered C. nobilis as a tangor; therefore, we have not considered it as a true mandarin group. Finally, seven groups of 'mandarin-like' genotypes were identified at the nuclear level. Five were parental groups of the mandarin germplasm (Nuclear groups N1-N5) and two groups were of interspecific origin: N6, consisting of 'Ampefy' (ID-101), 'Wallent' (ID-194) and 'Gailang' (ID-215); and N7, the tangor 'King' group, consisting of 'King' (ID-201), 'Rodeking' (ID-92), 'King' (ID-93) and 'Sanh' (ID-93). Genotypes included in each of the five parental groups are presented in Table 2 in relation to the Tanaka classification.

Furthermore, combining the results from the $\mathrm{NJ}$ and Structure analyses allowed us to determine the group to which the mandarin genotypes belong (Supplementary information 8). 


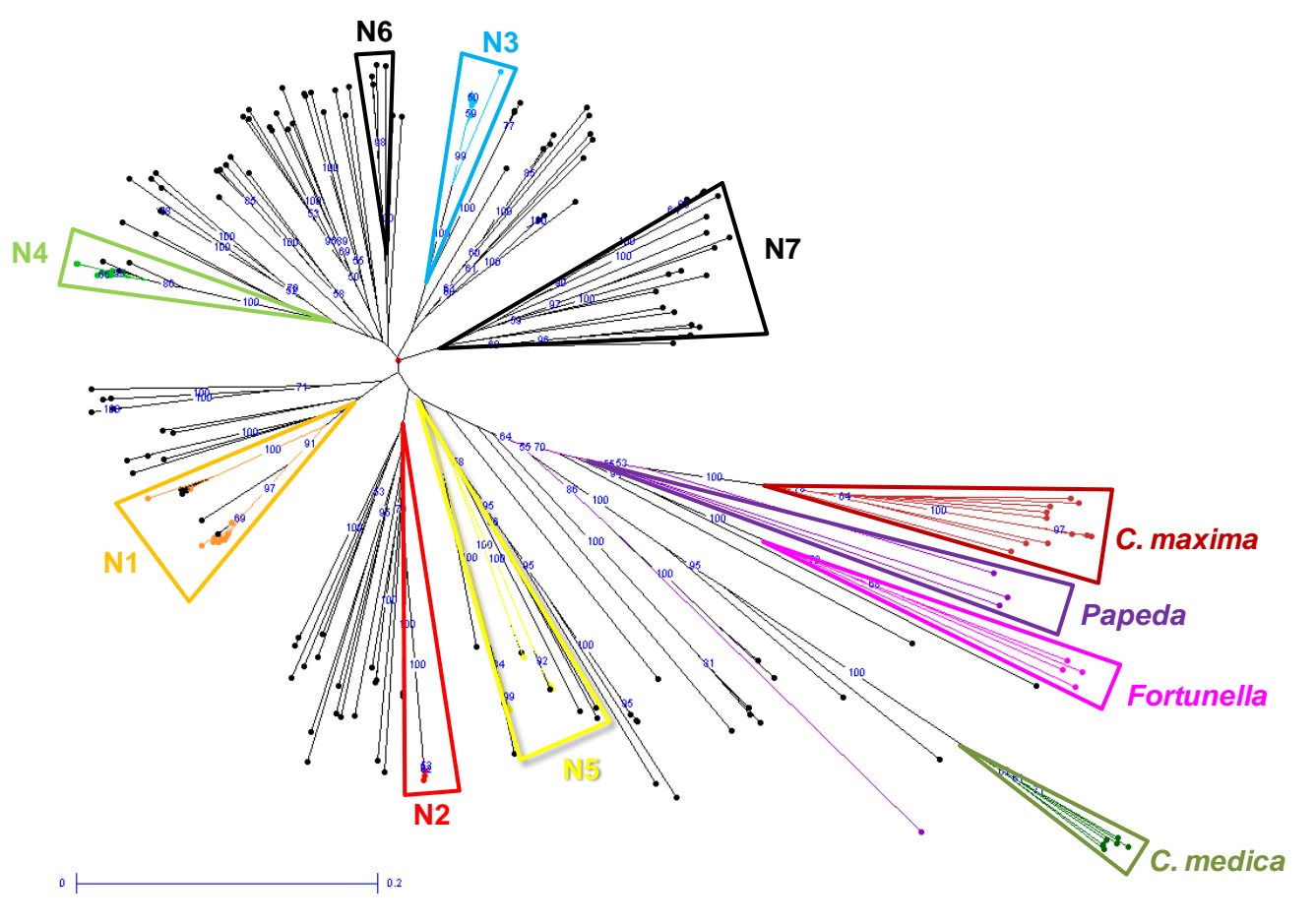

Figure 5. NJ tree analysis comparing the Structure populations found to the groups observed with the NJ tree. Bootstrap values over 50 are represented. One thousand resamplings were performed. Five mandarin groups and four parental populations (C. maxima, C. medica, Papeda, and Fortunella) were identified at the nuclear level. Orange, N1 (14/18 C. reticulata [Tan.]); red, N2 (all C. unshiu); light blue, N3 (7/9 C. deliciosa); light green, N4 (5/9 C. tangerina); yellow, N5 (C. reshni and two $C$. reticulata [Tan.]); brown, C. maxima (6); dark green, C. medica (7); purple, Papeda (8); pink, Fortunella (9). Interspecific hybrid groups: (N6) 'Ampefy', 'Gailang', and 'Wallent'; (N7) 'King' and hybrids.

(N) Nuclear group

Table 2. Parental mandarin groups identified at the nuclear level within the mandarin germplasm, based on the Structure and NJ tree analyses. Genotypes included in each group are compared with the Tanaka classification.

\begin{tabular}{lclc}
\hline Group & No genotypes & \multicolumn{1}{c}{ Tanaka Species } & $\%$ \\
\hline N1 & 17 & C. reticulata & 73.91 \\
& 3 & C. suhuiensis & 13.04 \\
& 1 & C. tangerina & 4.35 \\
& 1 & C. erythrosa & 4.35 \\
\hline N2 & 1 & Unknown & 4.35 \\
\hline N3 & 7 & C. unshiu & 100.00 \\
\hline N4 & 11 & C. deliciosa & 100.00 \\
& 5 & C. tangerina & 45.45 \\
& 3 & C. reticulata & 27.27 \\
& 1 & C. deliciosa & 9.09 \\
& 1 & C. depressa & 9.09 \\
N5 & 1 & C. paratangerina & 9.09 \\
\hline & 4 & C. reticulata & 66.67 \\
& 1 & C. kinokuni & 16.67 \\
\hline
\end{tabular}

(N) Nuclear group. 
Contribution of the various mandarin groups to the constitution of the other mandarin genomes

On the basis of the five mandarin groups identified as parental mandarins by the previous Structure analysis, a subsequent step was performed to quantify the contribution of these five groups to all genotypes of our 'mandarin-like' collection. We ran a new Structure analysis (Figure 6) with the whole collection, assigning as parental populations the five mandarin groups (N1-N5), the other Citrus ancestral populations (C. maxima, C. medica, Papeda) and Fortunella. The genotypes belonging to the other two groups identified as interspecific hybrids, N6 and N7, were removed in order to avoid biasing the contribution from the five parental mandarin groups. A list of genotypes included in this analysis (Structure 216, $K$ $=9)$ is in Supplementary information 1 .

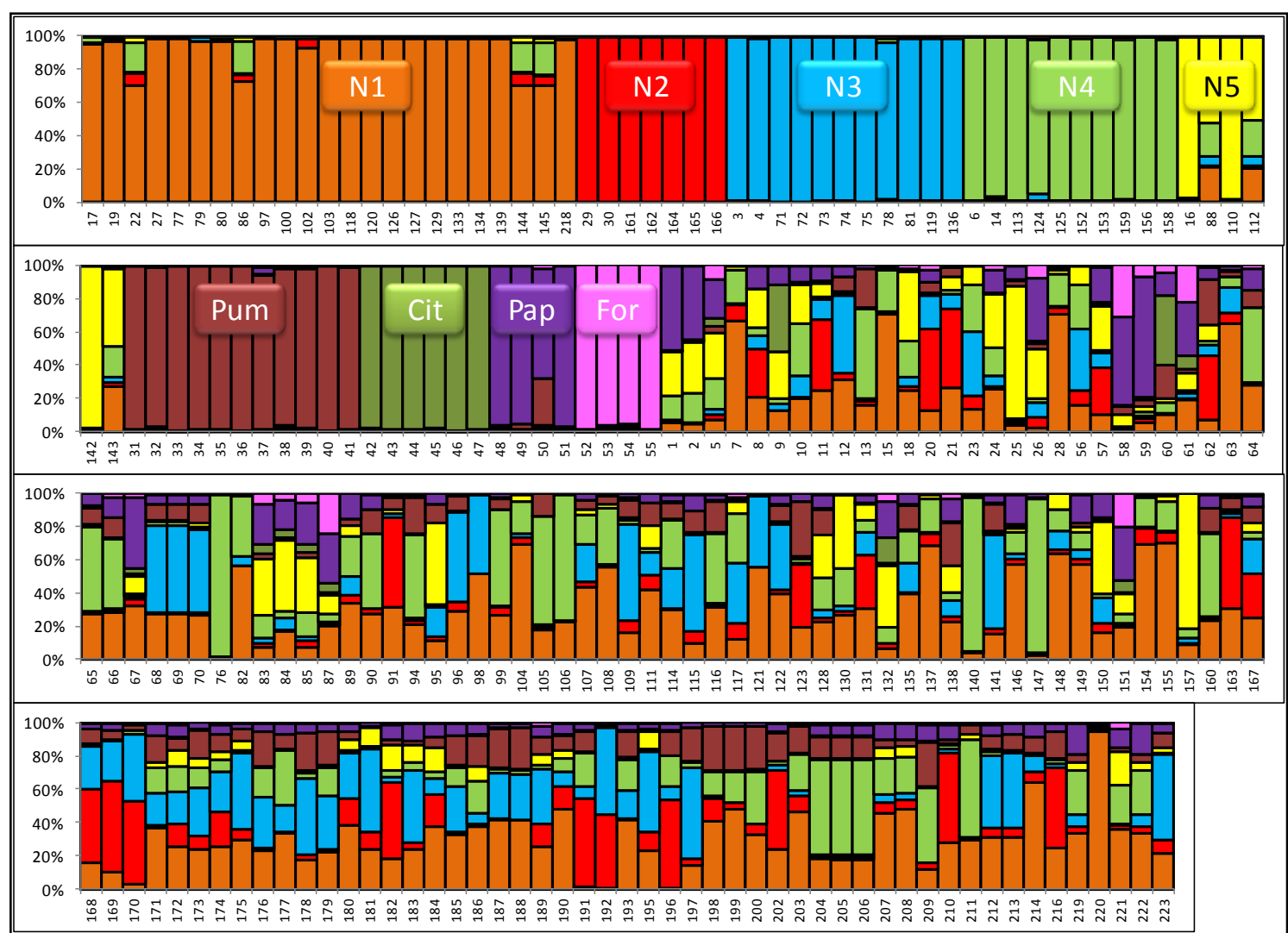

Figure 6. Structure analysis assuming nine populations $(K=9)$. Five mandarin groups and four parental populations (C. maxima, C. medica, Papeda, and Fortunella). Orange, N1 (14/18 C. reticulata [Tan.]); red, N2 (all C. unshiu); light blue, N3 (7/9 C. deliciosa); light green, N4 (5/9 C. tangerina); yellow, N5 (C. reshni and two C. reticulata [Tan.]); brown, C. maxima (6); dark green, C. medica (7); purple, Papeda (8); pink, Fortunella (9). The remaining genotypes are without assigned populations.

(N) Nuclear group; (Pum) Pummelo; (Cit) Citron; (Pap) Papeda; (For) Fortunella.

Some genotypes of the five mandarin populations assigned exhibited an admixed genome structure (Figure 6): genotypes ID-22, ID-86, ID-102, ID-144 and ID-145 from N1; ID-78 from N3; ID-124 from N4; and ID-88, ID-112 and ID-143 from N5. These genotypes exhibited contributions greater than $5 \%$ from a non-mandarin genome. Therefore, they were removed from the parental mandarin group and excluded from the calculations of population statistics 
(Table 3). $H_{0}$ was higher than $H_{\mathrm{e}}$ for the five groups for both SSR and indel markers, leading to negative $F_{\mathrm{w}}$ values. The whole 'mandarin-like' population exhibited a similar pattern. The mandarin-like genotypes exhibited complex hybrid structures with contributions from more than two genomes.

The contributions of the five mandarin parental groups defined in this study into the other mandarins under study are summarised in Figure 7. The average contribution of N1 (18 genotypes, mainly $C$. reticulata [Tan.]) to the genotypes not included in any defined population was $28.25 \%$; of N4 (nine genotypes, mainly C. tangerina), $16.69 \%$; of N3 (10 C. deliciosa genotypes ), 15.35\%; of N2 (all C. unshiu), 10.44\%; and of N5 (C. reshni (ID-16) and two C. reticulata (ID-110, ID-142), 8.88\%. The rest of the genome contributions came from Papeda (8.85\%), C. maxima (8.32\%), Fortunella (1.85\%) and C. medica (1.34\%).

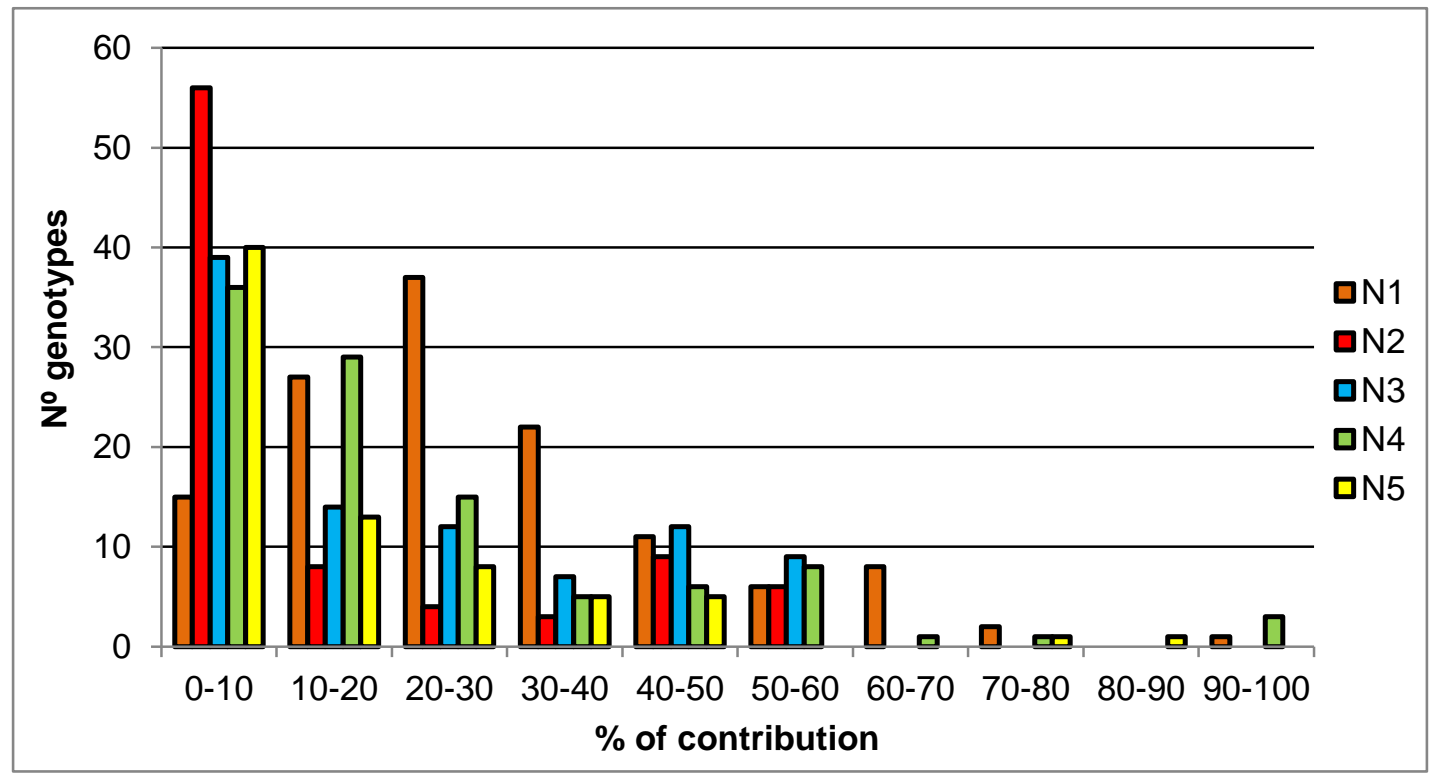

Figure 7. Contribution of the five parental mandarin groups (N1-N5) into the mandarin genome portion of each 'mandarin-like' genotype under study. Contributions lower than $2 \%$ were discarded.

To validate the contributions of the other basic taxa and Fortunella, the results of the Structure analysis presented in Figure 3 (223 genotypes, $K=5$ ) and the present analysis (Figure 6; 216 genotypes, $K=9$ ) were compared. High correlation coefficients between the two analyses were observed with regard to the contribution of the different ancestral taxa and Fortunella (C. reticulata $[\mathrm{Sw}], \mathrm{R}^{2}=0.985 ;$ C. maxima, $\mathrm{R}^{2}=0.991 ;$ C. medica, $\mathrm{R}^{2}=0.999$; Papeda, $\mathrm{R}^{2}=0.935$; and Fortunella, $\left.\mathrm{R}^{2}=0.994\right)$.

Data from hybrids with known parents were checked in order to validate the analysis of the parental-group contributions (from accessions ID-167/ID-193 and ID-195). Most of them agreed with their known origins; therefore, the origins of other genotypes can be accepted from this analysis. For example, the hybrid mandarin 'C-54-4-4' (ID-171 in Figure 6) had contributions from five different genomes, defined as populations 1, 3, 4, 6 and 7 of the present Structure analysis, which come from its supposed parents, clementines (ID-68, ID-69 and ID-70; genomes 
from populations 1, 3 and 6) and tangor 'Murcott' (ID-207 and ID-208; genomes from populations 1, 4, 6 and 7).

Another example is the hybrid mandarin 'Simeto' (ID-192 in Figure 6), which was obtained from a cross between a $C$. unshiu and $C$. deliciosa. Our study confirms this cross (almost 50\% each from C. unshiu and C. deliciosa). Tangelo 'Orlando' (ID-199 in Figure 6) is a cross between $C$. paradisi 'Duncan' and C. tangerina 'Dancy' (ID-28, $70 \%$ from C. reticulata [Tan.] and $\sim 20 \%$ from C. tangerina). The genomes contributing to 'Orlando' (ID-199) come from its supposed parents, C. maxima (26.9\%), C. reticulata [Tan.; $48.1 \%$ ] and C. tangerina (17.8\%).

On the other hand, some examples of discrepancies between the Structure results and supposed parental origin can be explained by misidentified origin. The 'Fortune' mandarin (ID178) was reported to come from a cross between a clementine and 'Dancy', made by Furr (1964). However, the structure analysis showed that 'Fortune' has a lower C. reticulata [Tan.] genome contribution (71.1\%) than the parents (clementine [83.2\%] and 'Dancy' [96.9\%]), and a higher C. maxima contribution (22.4\%) than clementine (10\%) and 'Dancy' $(0.7 \%)$. The false parental origin was confirmed by individual locus checking: in 16 out of 50 SSR markers and in one indel marker, 'Fortune' possesses a specific allele present in neither 'Dancy' nor clementine. Similar observations were made for 'Fremont' (ID-179; supposed hybrid between $C$. clementina and C. reticulata [Tan.] 'Ponkan' (ID-17) (Furr, 1964). Indeed, for 11 SSR markers, this hybrid possesses alleles that are not observed in its supposed parents. Moreover, 'Fremont' has a lower $C$. reticulata [Tan.] contribution to its genome (74.3\%) than clementine $(83.2 \%)$ and 'Ponkan' (99.2\%), and a contribution from C. maxima (20.1\%) higher than that in clementine (10\%) and 'Ponkan' (0.2\%).

\section{Mitochondrial analysis}

In the whole population, mitochondrial markers allowed discrimination of six mitotypes (Figure 8), previously described by (Froelicher et al., 2011). One Fortunella genotype (F. hindsii; ID-53) was associated with the Papeda (C. micrantha) mitotype, and one Papeda (C. latipes; ID-50) had a C. maxima mitotype. In the mandarin group (194 genotypes), four mitotypes were distinguished: two of mandarins ( $\mathrm{C} 1$ and $\mathrm{C} 2$ ), one identical to $C$. maxima (C3) and one identical to $C$. micrantha (Papeda, C4). The first mandarin mitotype (C1) included most of the genotypes studied. In the second mitotype (C2), 20 genotypes were present; 11 of them were acid mandarins (four $C$. depressa [ID-5, ID-83, ID-84, ID-85], three $C$. sunki [ID-24, ID-25, ID-150], C. reshni [ID-16], C. daoxianensis [ID-57], C. indica [ID-9] and 'Xien Khuang' [ID-142]), and nine were sweet genotypes (C. tankan Hay. [ID-63], C. kinokuni [ID-88], C. tangerina [ID-157] and six C. reticulata [Tan.]: 'Chiuka' [ID-110], 'Douhala' [ID-112], 'Lime sucrée' [ID-128], 'Macaque' [ID-130] and 'Sun chu sha' [ID-18, ID-143]. The C. maxima mitotype (C3) included the 'Ampefy' (ID-101), 'Suntara' (ID-138), 'Bendiguangju' (ID-163), 'Pet Yala' (ID-146), 'Yala' (ID-149), 'Kunembo' (ID-91), 'Ougan' (ID-20), and 'Kobayashi' (ID-123) mandarin cultivars, as well as the 
tangor 'Dweet' (ID-203; C. sinensis × 'Dancy'). The Papeda mitotype (C4) included 'Nicaragua' (ID-132), 'Vietnam' (ID-87), and one C. sunki (ID-151).

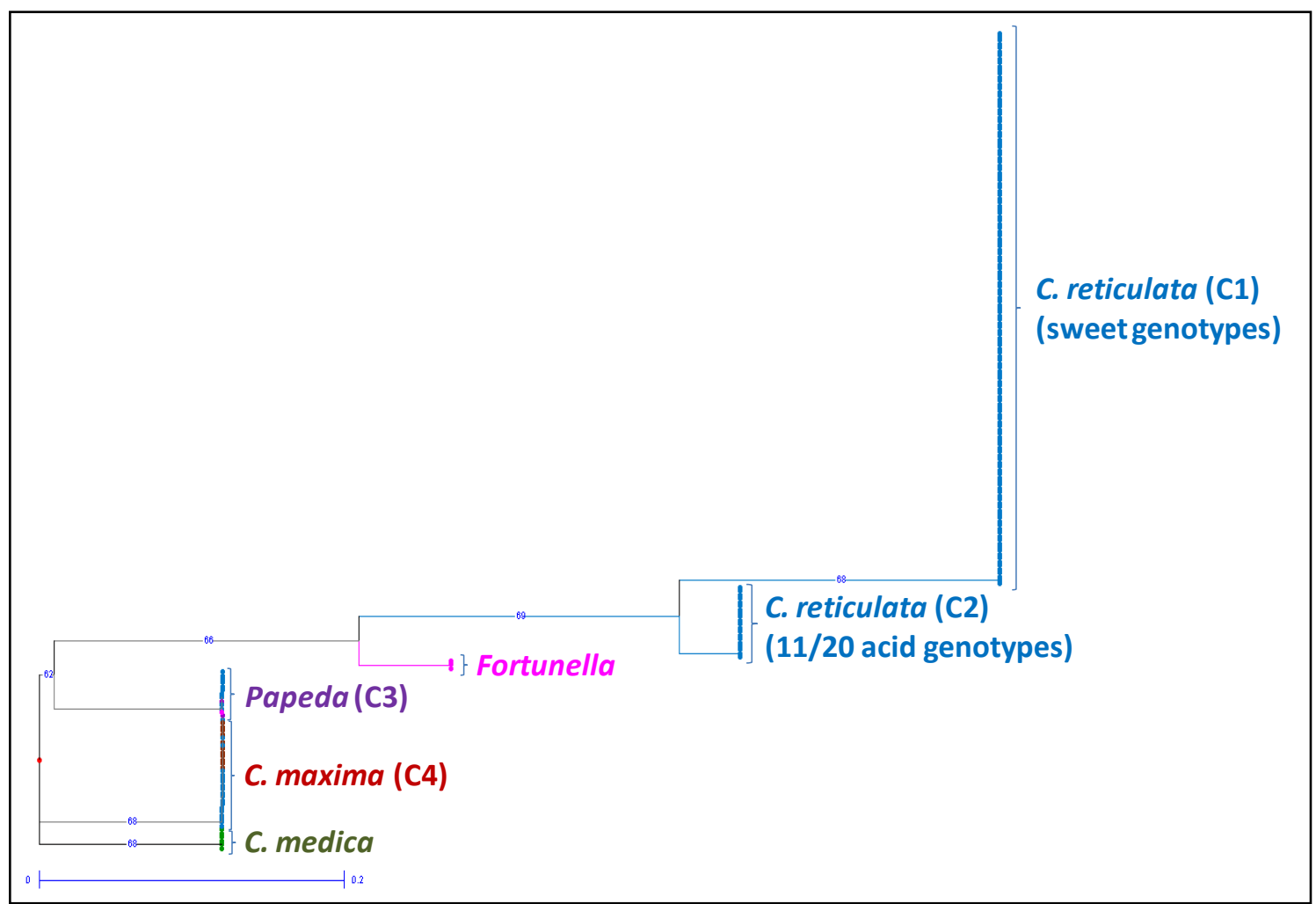

Figure 8. $\mathrm{NJ}$ tree of 223 varieties of Citrus with mitochondrial markers. Four mitotypes (C1-C4) were observed for the 'mandarin-like' genotypes: C. reticulata [Sw] $(\mathrm{C} 1, \mathrm{C} 2)$, Papeda (C3) and C. maxima (C4). 


\section{DISCUSSION}

\section{Genetic structure of the studied population}

SSR markers are more polymorphic than indel markers. The average numbers of alleles, gene diversity, and heterozygosity were all higher in SSR markers. The combination of both types of markers allowed differentiation of the mandarin group from the other ancestors and revealed diversity within the mandarin group (mainly from SSR markers), as reported by Garcia-Lor et al. (2012).

The clear differentiation of mandarins from C. maxima, C. medica, C. micrantha and Fortunella (Figure 2) has been described in several studies (Nicolosi et al., 2000; Barkley et al., 2006; Garcia-Lor et al., 2012; 2013). Moreover, as previously observed by (Federici et al., 1998) and (Barkley et al., 2006), the mandarin group was not well resolved (low bootstrap support in many branches), perhaps due to the large number of hybrids.

Several groups of accessions with identical MLGs were identified, such as 'Ellendale Leng' (ID-205) and 'Ellendale Taranco' (ID-206) (MLG10), or 'Willowleaf' (ID-3) and 'Willowleaf seedless' (ID-72, ID-73) (MLG12), which were produced by natural mutations and are probably distinguished only by point mutations. Therefore, the probability of distinguishing them by analysis of molecular markers such as SSRs or indels is very low. The groups MLG2, MLG3, MLG6, MLG11, MLG13 and MLG14 also contain such derivative mutants. On the other hand, the clusters MLG1, MLG5, MLG7, MLG8 and MLG9 include genotypes for which there is no clear prior information about their origin; therefore, they may represent either derivative mutants of this kind, or simply redundancies within the germplasm collections.

The overall $F_{\mathrm{w}}$ value among all loci and all genotypes was close to zero $(0.12 ; 0.05$ for SSR and 0.26 for indel), indicating that the observed heterozygosity was close to the expectation value under Hardy-Weinberg equilibrium, whereas higher structuration (positive $F_{\mathrm{w}}$ ) was observed by Garcia-Lor et al. (2012). This may be due to the large proportion of mandarin hybrids within the population under study. The $F_{\mathrm{w}}$ values observed for all the mandarin-like genotypes and the representatives of the Tanaka mandarin species was close to zero. Therefore, it is a favourable situation for using the Structure software, which assumes that the populations are in Hardy-Weinberg equilibrium (Pritchard et al., 2000).

Mitochondrial and nuclear data reveal interspecific hybridisation and introgression of ancestral genomes into mandarin varieties

Mitochondrial and chloroplastic markers have been previously used to reveal maternal phylogeny in Citrus (Green et al., 1986; Yamamoto et al., 1993; Bayer et al., 2009; Morton, 2009). In our study, six mitotypes were found (pummelo, micrantha, citron, mandarin mitotype C1, mandarin mitotype C2 and Fortunella), all of them observed by (Froelicher $Y$ et al., 2011), who proposed a distinction between the acid mandarin and sweet mandarin mitotypes. The mandarin germplasm (194 genotypes) was represented in four of the six identified mitotypes; 
two of them included mandarin and 'mandarin-like' genotypes (C1, C2), and two corresponded to other ancestral species (C3, C4). Our results, obtained with a large mandarin panel, show that the denomination of acid mandarin and sweet mandarin mitotypes proposed by Froelicher et al. (2011) is not apt: we found sweet mandarin genotypes that share the supposed acid mitotype (nine out of 20 sweet mandarins in the C2 mandarin mitotype). Some of the genotypes that does not fit with the hypothesis of Froelicher et al. (2011) may be result by hybridisations between the sweet and acid mandarin gene pools.

Three mandarins have a Papeda mitotype (C3), and seven have a $C$. maxima mitotype (C4). For example, 'Bendiguangju' mandarin (ID-163; C. unshiu, according to Tanaka classification) exhibited a pummelo rather than mandarin cytoplasm, as reported by Cheng et al. (2005) in a chloroplast DNA analysis and Froelicher et al. (2011) in a mitochondrial DNA analysis. At the nuclear level, however, we observed a close relationship between 'Bendiguangju' and satsumas, confirming the data of Nicolosi et al. (2000). The genotypes included in the Papeda and C. maxima mitotypes are interspecific hybrids, and not true mandarins, according to the Structure analysis; however, most of their genomes are derived from mandarins.

Among the mandarin species considered by Tanaka, we identified some interspecific hybrids, such as $C$. amblycarpa, which appears to be a cross between the papeda and mandarin gene pools with a maternal phylogeny from papeda, as already observed by Froelicher et al. (2011). These contributions from C. reticulata [Sw] and Papeda genomes were also observed in an SNP analysis (Ollitrault et al., 2012a). By contrast, Federici et al. (1998) and Barkley et al. (2006) considered $C$. amblycarpa to be the result of a cross between $C$. reticulata and $C$. aurantifolia. The latter study observed contributions of three genomes: $C$. reticulata ( 60\%), C. medica ( 25\%) and Papeda ( 15\%). Our results show that $C$. amblycarpa genotypes had a high average heterozygosity, $51.33 \%$, suggesting a potential origin from direct interspecific hybridisation.

Introgressions from other genomes were also found in other genotypes considered to be mandarin species by Tanaka: the Papeda genome (32.3\%) is present in $C$. depressa, and the C. maxima (6.8\%) genome is present in C. succosa. Similar genome contributions, albeit at different percentages, were found by Barkley et al. (2006). Those authors reported that the genome of $C$. depressa is shared between $C$. reticulata and Papeda in equal proportions, whereas we observed a higher contribution from $C$. reticulata ( 65\%) than Papeda ( 35\%).

Citrus indica clustered with the citron group at the nuclear level. It had contributions of $41 \%$ from citron and mandarin genomes and $18 \%$ from papeda, as well as a very high observed heterozygosity $(61.33 \%)$, indicating that it was originated as an interspecific hybrid. Citrus indica is present in mandarin mitotype C2, whereas Nicolosi et al. (2000) clustered C. indica with the citron on the basis of cpDNA markers.

Citrus tachibana was considered to be a wild species of mandarin by Swingle and Reece (1967), and it was clustered with the mandarins by Nicolosi et al. (2000). Our results are 
not in agreement with this theory, because $C$. tachibana clustered with the mandarin mitotype $\mathrm{C} 2$ and displays an equal contribution from the C. reticulata [Sw] and Papeda genomes at the nuclear level. The high $H_{0}(54.67 \%)$ indicates that $C$. tachibana is an interspecific hybrid, and nuclear and mitochondrial data suggest that it is a direct hybrid between a mandarin of mitotype C2 as the maternal parent and a Papeda.

It is also remarkable that some other genotypes, like $C$. unshiu and $C$. tankan, have a small contribution from C. maxima, approximately 8 and $3 \%$, respectively. This observation was also made by Nicolosi et al. (2000).

Citrus nobilis was considered as a species by Tanaka, but other authors (Coletta Filho et al., 1998; Nicolosi et al., 2000; Garcia-Lor et al., 2012; 2013a) considered it as a tangor, with introgression from the C. maxima genome. Our results confirm this pummelo introgression in the various C. nobilis analysed (King: 10,9\%; Campeona 10\%).

The other tangors, tangelos, and clementines we analysed exhibited similar contributions from ancestral genomes to those reported by Garcia-Lor et al., (2012), with higher introgression of pummelo in tangelos than in tangors. Some genotypes of unknown origin included in the study, and not related to the mandarin species defined by Tanaka, exhibited complex genomic structures.

Citrus junos appears to be a mixture of four genomes (papeda, mandarin, pummelo and kumquat). This observation is in contrast to the results obtained by Nicolosi et al. (2000), who clustered $C$. junos with the mandarins, of Mabberley (2004), who hypothesised that it was a cross between a Papeda and C. maxima and Tanaka (1954), who defined it as a relative of $C$. ichangensis. Citrus junos was considered to be a hybrid with a Papeda maternal phylogeny by Froelicher et al. (2011), a proposal that is confirmed by our results. This mixture of genomes leads to an observed heterozygosity of $46.67 \%$.

Citrus halimii had a complex genomic constitution, with the main genome contributions from Papeda (51\%), Fortunella (33\%) and C. reticulata (10\%). This result is in contrast with the results of Scora (1975) and Barkley et al. (2006), who considered C. halimii a hybrid of a citron and a kumquat based on morphological and phytochemical data and molecular data, respectively. Froelicher et al. (2011) found that $C$. halimii shared the Papeda mitotype, as we have seen in our work. However, its observed heterozygosity is low $(21.33 \%)$, and the origin of this species remains unclear.

Citrus karna is still of unknown origin and has been proposed to be a natural hybrid (Swingle and Reece, 1967), as confirmed by its very high heterozygosity (66.3\%). It appears to be a very complex admixture with five genome contributions: Citrus medica (43\%) and $C$. maxima $(20 \%)$ are the main contributors, and the cytoplasm is from C. maxima.

Our Structure analysis showed that many 'mandarin-like' genotypes are introgressed by other ancestral species, as reported by Barkley et al. (2006). In our work, the ancestor with the highest contribution to the mandarin germplasm was C. maxima, instead of the Papeda / 
Fortunella group reported by Barkley et al. (2006). However, if we reduce the analysis to the 45 mandarin genotypes used in common between the two studies, we obtain similar results, with a contribution of $6 \%$ from the Papeda / Fortunella group in Barkley et al. (2006) and an 8\% contribution from Papeda in our study. From the other two ancestral populations, C. medica and Fortunella, genome introgressions were identified in very few accessions.

It is also important to mention that recent whole-genome sequencing studies (Gmitter et al., 2012; Shimizu et al., 2012) have confirmed the introgression of ancestral genomes within some genotypes considered until now to be pure mandarins, such as 'Ponkan' or satsumas, which exhibit $C$. maxima genome introgression.

\section{Organisation of the mandarin germplasm}

The two main Citrus classification systems (Swingle and Reece, 1967; Tanaka, 1954) differ greatly in their treatments of the mandarins. The former system placed all mandarins in one species, C. reticulata, whereas the latter divided them into 36 species. Neither of the two systems is completely right, as discussed in many reports (Federici et al., 1998; Nicolosi et al., 2000; Barkley et al., 2006). Different studies have tried to define groups within the mandarins. Coletta Filho et al. (1998) studied 35 accessions of mandarins and divided them into two main groups consisting of two and seven subgroups, which agreed partially with Tanaka's (Tanaka, 1954) and Webber's (Webber HJ, 1943) taxonomic groups. Koehler-Santos et al. (2003) characterised 34 different genotypes from a Brazilian collection and described five groups, different from the ones found by Coletta Filho et al. (1998). Kacar et al. (2013) characterised 65 mandarin genotypes of the Tuzcu Citrus Variety Collection in Turkey, using 14 SSRs and 21 SRAP markers, resulting in two main groups: one including only tangelo 'Orlando', and the other including the rest (clementines, other tangelos, etc.).

In this work, a broad range of samples representing the mandarin germplasm (ancient cultivars from Asia, old and recent natural hybrids, and human-made hybrids) were analysed to clarify the structure of this highly diversified group. After three consecutive rounds of analyses with the Structure software in which the ancestral genotypes, interspecific hybrids, known recent hybrids, and hybrids detected with the programme were removed, five groups were defined as potential parental mandarins (N1-N5; Figure 6, Table 2). According to the analyses performed with the Structure software and NJ tree analysis, two more groups, including already known hybrids and their descendants, were identified as groups of the mandarin germplasm: N6, including 'Ampefy', 'Wallent' and 'Gailang'; and N7, the tangor 'King' group. The five parental mandarin groups exhibited higher allelic diversity for SSRs than for indel markers. The negative $F_{\mathrm{w}}$ values observed in these groups leads to fixation of heterozygosity within them, which may be due to apomixis and vegetative reproduction of citrus varieties. Significant differentiation between nuclear groups is confirmed by the $F_{\mathrm{st}}$ value $(0.434)$. The global mandarin population has an $F_{\mathrm{w}}$ value close to 0 , reflecting strong intergroup gene flow. 
Four nuclear groups, N1, N2, N3, and N4, share the same mandarin mitotype (C1). Most of the genotypes sharing the other mandarin mitotype (C2) are also differentiated at the nuclear level, and 16 out of the 20 genotypes are clustered with mandarin nuclear group N5. Tanaka (1954) divided the acid mandarin genotypes in two groups, with C. reshni, C. sunki and C. tachibana in one group and $C$. depressa in another, which are joined in our analysis at both the nuclear and cytoplasmic levels.

Tanaka (1954) grouped the 36 mandarin species that he considered into five clusters. One cluster included $C$. nobilis and $C$. unshiu, which are separated in two different clusters in our study, N7 and N2, respectively, the first of which is of interspecific hybrid origin, mandarin $x$ pummelo. The second cluster included species not analysed in our study. The third cluster had 14 species, including C. clementina (considered in our study as an hybrid and not a pure mandarin species), C. reticulata [Tan.], C. deliciosa, and C. tangerina, which appear in our work as different parental mandarin groups (N1, N3 and N4). The fourth Tanaka group was formed by $C$. reshni, $C$. sunki, and $C$. tachibana, and the fifth group included $C$. depressa and $C$. lycopersicaeformis. From these species, only $C$. reshni is included in a group in our analysis (N5). Citrus sunki, C. tachibana, and C. depressa seem to have resulted from Papeda introgression into a mandarin genome. Other Tanaka species, such as $C$. erythrosa and $C$. suhuiensis, seem to have originated from hybridisation between mandarin groups ( $C$. reticulata [Tan.] and C. tangerina groups).

Hodgson (1967) divided the mandarins in four groups: C. unshiu, C. reticulata [Tan.] ('Ponkan', 'Dancy', clementine), C. deliciosa and C. nobilis ('King'). Only two groups are in agreement with our results, C. unshiu (N2) and C. deliciosa (N3). A third group, C. nobilis ('King'), is identified as a parental group in our analysis (N7), but is not a true mandarin group. The fourth group defined by Hodgson, $C$. reticulata [Tan.], included a known hybrid ( $C$. clementina) and two genotypes separated between two groups in our analysis: 'Ponkan', within the $C$. reticulata [Tan.] group (N1), and 'Dancy', within the $C$. tangerina group (N4).

The contributions of the five parental mandarin groups defined in the mandarin germplasm, besides the contributions of the other ancestral taxa and Fortunella, were estimated for the entire 'mandarin-like' collection (Figure 6). This analysis revealed that the genomes of most 'mandarin-like' genotypes are complex admixtures of the five parental mandarin groups and even include contributions from the other ancestral populations.

Most of the hybrids with known origins displayed admixture coherent with the genomic structures of their supposed parents. Because most of these parents are themselves heterozygote admixed, the proportion of each genome in the hybrid variety is not inherited in an additive way (i.e., the sum of half shares of each parent), but instead depends on the recombination and segregation occurring in each parental gamete (Motohashi et al., 1992; Coletta Filho et al., 1998). 
Some accessions' admixture structure did not agree with their supposed parents. In these cases, allele checking confirmed that the supposed parental origins were erroneous. Further analyses could provide more clues toward the identification of parents for these hybrids.

\section{CONCLUSIONS}

The mandarin horticultural varietal group is highly polymorphic. Many genotypes believed to be pure mandarins have introgressions from other basic taxa in their genomes. Moreover, some of them exhibited non-mandarin maternal phylogeny. Another characteristic of the mandarin group is that many genotypes originated from crosses between mandarins. Although this work has provided new insights into mandarin structuration, future sequencing of mandarin genotypes (single genes or whole genomes) will help to perform phylogenetic analyses and precisely determine the different genomic constitutions of this highly polymorphic group. 
SUPPLEMENTARY INFORMATION CHAPTER 4 

Supplementary information 1. Genotypes used in the study of the mandarin diversity, ordered by their appearance in Figure 1.

\begin{tabular}{|c|c|c|c|}
\hline ID & Common name & Swingle system & $\begin{array}{l}\text { Database based onTanaka } \\
\text { system }\end{array}$ \\
\hline 1 & C. amblycarpa & C. reticulata hybrid & C. amblycarpa \\
\hline 2 & Nasnaran & C. reticulata hybrid & C. amblycarpa \\
\hline 3 & Willowleaf & C. reticulata & C. deliciosa \\
\hline 4 & de Chios & C. reticulata & C. deliciosa \\
\hline 5 & Citrus depressa & C. reticulata & C. depressa \\
\hline 6 & Vohangisany Ambodiampoly & C. reticulata & C. depressa \\
\hline 7 & Fuzhu & C. reticulata & C. erythrosa \\
\hline 8 & San hu hong chu & C. reticulata & C. erythrosa \\
\hline 9 & Indian Wild Orange & C. indica & C. indica \\
\hline 10 & Vietnam à peau fine & C. reticulata & C. kinokuni \\
\hline 11 & Nan feng mi chu & C. reticulata & C. kinokuni \\
\hline 12 & Campeona & C. reticulata & C. nobilis \\
\hline 13 & Geleking & C. reticulata & C. nobilis \\
\hline 14 & Ladu & C. reticulata & C. paratangerina \\
\hline 15 & Ladu ordinaire & C. reticulata & C. paratangerina \\
\hline 16 & Cleopatra & C. reticulata & C. reshni \\
\hline 17 & Ponkan & C. reticulata & C. reticulata \\
\hline 18 & Sun chu sha & C. reticulata & C. reticulata \\
\hline 19 & Bombay & C. reticulata & C. reticulata \\
\hline 20 & Ougan & C. reticulata & C. suavissima \\
\hline 21 & Ben di zao & C. reticulata & C. succosa \\
\hline 22 & de Soe & C. reticulata & C. suhuiensis \\
\hline 23 & Szinkom & C. reticulata & C. suhuiensis \\
\hline 24 & Sunki & C. reticulata & C. sunki \\
\hline 25 & Sunki & C. reticulata & C. sunki \\
\hline 26 & C. tachibana & C. tachibana & C. tachibana \\
\hline 27 & Swatow & C. reticulata & C. tangerina \\
\hline 28 & Dancy & C. reticulata & C. tangerina \\
\hline 29 & Clausellina & C. reticulata & C. unshiu \\
\hline 30 & Dobashi-Beni & C. reticulata & C. unshiu \\
\hline 31 & Azimboa & C. maxima & C. maxima \\
\hline 32 & Deep Red & C. maxima & C. maxima \\
\hline 33 & Pink & C. maxima & C. maxima \\
\hline 34 & Chandler & C. maxima & C. maxima \\
\hline 35 & Gil & C. maxima & C. maxima \\
\hline 36 & Da Xhang & C. maxima & C. maxima \\
\hline 37 & Nam Roi & C. maxima & C. maxima \\
\hline 38 & Flores & C. maxima & C. maxima \\
\hline 39 & Timor & C. maxima & C. maxima \\
\hline 40 & Sans Pepins & C. maxima & C. maxima \\
\hline 41 & Tahiti & C. maxima & C. maxima \\
\hline 42 & Arizona & C. medica & C. medica \\
\hline 43 & Corsica & C. medica & C. medica \\
\hline 44 & Buddha's hand & C. medica & C. medica \\
\hline 45 & Diamante & C. medica & C. medica \\
\hline 46 & Poncire Commun & C. medica & C. medica \\
\hline 47 & Humpang & C. medica & C. medica \\
\hline 48 & Mauritus Papeda & C. hystrix & C. hystrix \\
\hline 49 & Ichang Papeda & C. ichangensis & C. ichangensis \\
\hline 50 & Khasi Papeda & C. latipes & C. latipes \\
\hline 51 & Micrantha & C. micrantha & C. micrantha \\
\hline 52 & Meiwa Kumkuat & Fortunella hybrid & F. crassifolia \\
\hline 53 & Hong Kong Kumkuat & F. hindsii & F. hindsii \\
\hline 54 & Round Kumkuat & F. japonica & F. japonica \\
\hline 55 & Nagami Kumkuat & F. margarita & F. margarita \\
\hline 56 & Bintangor Sarawak & $?$ & $?$ \\
\hline 57 & Citrus daoxianensis & C. reticulata & C. daoxianensis \\
\hline 58 & C. halimii & C. reticulata & C. halimii \\
\hline 59 & Yuzu & $\begin{array}{l}\text { C. ichangensis } \times \text { C. reticulata } \\
\text { var. austera }\end{array}$ & C. junos \\
\hline 60 & Karna & C. limon & C. karna \\
\hline 61 & Calamondin & $\begin{array}{l}\text { C. reticulata var. austera? } \mathrm{x} \\
\text { Fortunella? }\end{array}$ & C. madurensis \\
\hline 62 & Shunkokan & $?$ & C. shunkokan \\
\hline 63 & Tankan SG & C. sinensis & C. tankan \\
\hline 64 & Temple & C. reticulata & C. temple \\
\hline 65 & Temple & C. reticulata & C. temple \\
\hline
\end{tabular}




\begin{tabular}{|c|c|c|c|}
\hline 66 & Temple Sue Linda & C. reticulata & C. temple \\
\hline 67 & Changsa & C. reticulata & C. reticulata $\times P$. trifoliata \\
\hline 68 & Clemenules & C. reticulata & C. clementina \\
\hline 69 & Oronules & C. reticulata & C. clementina \\
\hline 70 & Arrufatina & C. reticulata & C. clementina \\
\hline 71 & Avana Apireno & C. reticulata & C. deliciosa \\
\hline 72 & Willowleaf seedless & C. reticulata & C. deliciosa \\
\hline 73 & Willowleaf seedless & C. reticulata & C. deliciosa \\
\hline 74 & Salteñita & C. reticulata & C. deliciosa \\
\hline 75 & Tardivo Di Ciaculli & C. reticulata & C. deliciosa \\
\hline 76 & à peau lisse & C. reticulata & C. deliciosa \\
\hline 77 & à peau rugueuse & C. reticulata & C. reticulata \\
\hline 78 & Clemendor & C. reticulata & C. deliciosa \\
\hline 79 & Empress & C. reticulata & C. reticulata \\
\hline 80 & Late Emperor SG & C. reticulata & C. reticulata \\
\hline 81 & Montenegrina & C. reticulata & C. deliciosa \\
\hline 82 & Natal Tightskin & C. reticulata & C. deliciosa \\
\hline 83 & Shekwasha & C. reticulata & C. depressa \\
\hline 84 & Shekwasha & C. reticulata & C. depressa \\
\hline 85 & Shekwasha & C. reticulata & C. depressa \\
\hline 86 & Fuzhu & C. reticulata & C. erythrosa \\
\hline 87 & Vietnam & C. reticulata & C. kinokuni \\
\hline 88 & Vietnam & C. reticulata & C. kinokuni \\
\hline 89 & Vietnam & C. reticulata & C. kinokuni \\
\hline 90 & du Japon & C. reticulata & C. nobilis \\
\hline 91 & Kunembo & C. reticulata & C. nobilis \\
\hline 92 & Rodeking & C. reticulata & C. nobilis \\
\hline 93 & King (Laï Vung) & C. reticulata & C. nobilis \\
\hline 94 & Yellow King & C. reticulata & C. nobilis \\
\hline 95 & Anana & C. reticulata & C. reticulata \\
\hline 96 & Carvahal & C. reticulata & C. reticulata \\
\hline 97 & Emperor & C. reticulata & C. reticulata \\
\hline 98 & Imperial australia & C. reticulata & C. reticulata \\
\hline 99 & Scarlet & C. reticulata & C. reticulata \\
\hline 100 & Africa do Sul SG & C. reticulata & C. reticulata \\
\hline 101 & Ampefy & C. reticulata & C. reticulata \\
\hline 102 & Antillaise & C. reticulata & C. reticulata \\
\hline 103 & Antsalaka Diego SG & C. reticulata & C. reticulata \\
\hline 104 & Atumbua & C. reticulata & C. reticulata \\
\hline 105 & Augustino & C. reticulata & C. reticulata \\
\hline 106 & Batangas & C. reticulata & C. reticulata \\
\hline 107 & Bower & C. reticulata & C. reticulata \\
\hline 108 & Burgess & C. reticulata & C. reticulata \\
\hline 109 & Capurro SG & C. reticulata & C. reticulata \\
\hline 110 & Chiuka & C. reticulata & C. reticulata \\
\hline 111 & Cravo & C. reticulata & C. reticulata \\
\hline 112 & Douhala & C. reticulata & C. reticulata \\
\hline 113 & East India SG & C. reticulata & C. reticulata \\
\hline 114 & Enterprise & C. reticulata & C. reticulata \\
\hline 115 & Federici & C. reticulata & C. reticulata \\
\hline 116 & Fewtrell SG & C. reticulata & C. reticulata \\
\hline 117 & Gayunan & C. reticulata & C. reticulata \\
\hline 118 & Giant & C. reticulata & C. reticulata \\
\hline 119 & Hall SG & C. reticulata & C. deliciosa \\
\hline 120 & Hickson & C. reticulata & C. reticulata \\
\hline 121 & Imperial & C. reticulata & C. reticulata \\
\hline 122 & Improved & C. reticulata & C. reticulata \\
\hline 123 & Kobayashi & C. reticulata & C. reticulata \\
\hline 124 & Ladu $\times$ Szibat & C. reticulata & C. reticulata \\
\hline 125 & Ladu x Szinking & C. reticulata & C. reticulata \\
\hline 126 & Le Roux & C. reticulata & C. reticulata \\
\hline 127 & Lebon SG & C. reticulata & C. reticulata \\
\hline 128 & Lime sucrée & C. reticulata & C. reticulata \\
\hline 129 & Lukan & C. reticulata & C. reticulata \\
\hline 130 & Macaque & C. reticulata & C. reticulata \\
\hline 131 & Nanfen Miguan & C. reticulata & C. reticulata \\
\hline 132 & Nicaragua & C. reticulata & C. reticulata \\
\hline 133 & Oneco & C. reticulata & C. reticulata \\
\hline 134 & Pan American & C. reticulata & C. reticulata \\
\hline 135 & Robinson & C. reticulata & C. reticulata \\
\hline 136 & Small SG & C. reticulata & C. deliciosa \\
\hline 137 & sud-est Martinique & C. reticulata & C. reticulata \\
\hline
\end{tabular}




\begin{tabular}{|c|c|c|c|}
\hline 138 & Suntara & C. reticulata & C. reticulata \\
\hline 139 & Tshello & C. reticulata & C. reticulata \\
\hline 140 & Warnuco & C. reticulata & C. reticulata \\
\hline 141 & Willowleaf $x$ Blood & C. reticulata & C. reticulata \\
\hline 142 & Xien Khuang & C. reticulata & C. reticulata \\
\hline 143 & Sun Chu Sha & C. reticulata & C. reticulata \\
\hline 144 & de Soe & C. reticulata & C. suhuiensis \\
\hline 145 & de Soe & C. reticulata & C. suhuiensis \\
\hline 146 & Pet Yala & C. reticulata & C. suhuiensis \\
\hline 147 & Se hui gan & C. reticulata & C. suhuiensis \\
\hline 148 & Szibat & C. reticulata & C. suhuiensis \\
\hline 149 & Yala & C. reticulata & C. suhuiensis \\
\hline 150 & Sunki & C. reticulata & C. sunki \\
\hline 151 & Sunki & C. reticulata & C. sunki \\
\hline 152 & Beauty of Glen Retreat & C. reticulata & C. tangerina \\
\hline 153 & Brickaville & C. reticulata & C. tangerina \\
\hline 154 & Da hong pao & C. reticulata & C. tangerina \\
\hline 155 & Redskin & C. reticulata & C. tangerina \\
\hline 156 & Sanguine Trabut & C. reticulata & C. tangerina \\
\hline 157 & Sweet small & C. reticulata & C. tangerina \\
\hline 158 & Zanzibar SG & C. reticulata & C. tangerina \\
\hline 159 & Mandalina & C. reticulata & C. tangerina \\
\hline 160 & Parson's special & C. reticulata & C. tangerina \\
\hline 161 & Frost & C. reticulata & C. unshiu \\
\hline 162 & Okitsu & C. reticulata & C. unshiu \\
\hline 163 & Bendiguangju & C. reticulata & C. unshiu \\
\hline 164 & Pucheng & C. reticulata & C. unshiu \\
\hline 165 & Salzara & C. reticulata & C. unshiu \\
\hline 166 & Kowano & C. reticulata & C. unshiu \\
\hline 167 & $A^{\prime}-12$ & C. reticulata & $\begin{array}{l}\text { C. clementina } \times \text { (C.unshiu } \times \\
\text { C.nobilis) }\end{array}$ \\
\hline 168 & Avasa 15 & C. reticulata & C. unshiu x C. clementina \\
\hline 169 & Avasa 16 & C. reticulata & C. clementina x C. deliciosa \\
\hline 170 & Avasa 17 & C. reticulata & C. unshiu $\times$ C. clementina \\
\hline 171 & C-54-4-4 & C. reticulata & $\begin{array}{l}\text { C. clementina } \times \text { (C.reticulata } \times \\
\text { C.sinensis) }\end{array}$ \\
\hline 172 & D-19 & C. reticulata & $\begin{array}{l}\text { C. clementina } \times \text { (C.unshiu } \times \\
\text { C.nobilis) }\end{array}$ \\
\hline 173 & Daisy & C. reticulata & $\begin{array}{l}\text { (C. clementina } \times \text { C. tangerina) } \times \\
\text { (C. clementina x C.reticulata) }\end{array}$ \\
\hline 174 & $E^{\prime}-5$ & C. reticulata & $\begin{array}{l}\text { C. clementina } x \text { (C.unshiu } x \\
\text { C.nobilis) }\end{array}$ \\
\hline 175 & Encore & C. reticulata & C. nobilis $\times$ C. deliciosa \\
\hline 176 & Fairchild & C. reticulata & $\begin{array}{l}\text { C. clementina } x \text { (C. paradisi } x \\
\text { C. tangerina) }\end{array}$ \\
\hline 177 & Fallglo & C. reticulata & $\begin{array}{l}\text { (C. clementina } \times(\text { C. paradisi } x \\
\text { C. tangerina })) \times \text { C. temple }\end{array}$ \\
\hline 178 & Fortune & C. reticulata & C. clementina x C. tangerina \\
\hline 179 & Fremont & C. reticulata & C. clementina $\times$ C. reticulata \\
\hline 180 & Gold Nugget & C. reticulata & $\begin{array}{l}\text { (C. clementina } \times \text { C. nobilis }) \times \\
\text { (C. nobilis } \times \text { C. tangerina) }\end{array}$ \\
\hline 181 & Honey & C. reticulata & C. nobilis $\times$ C. deliciosa \\
\hline 182 & Kara & C. reticulata & C. unshiu $\times$ C. nobilis \\
\hline 183 & Kinnow & C. reticulata & C. nobilis $\times$ C. deliciosa \\
\hline 184 & $\mathrm{~N}-27$ & C. reticulata & $\begin{array}{l}\text { C. clementina } \times \text { (C.unshiu } \times \\
\text { C.nobilis) }\end{array}$ \\
\hline 185 & Nova & C. reticulata & $\begin{array}{l}\text { C. clementina } \times \text { (C. paradisi } \times \\
\text { C. tangerina) }\end{array}$ \\
\hline 186 & Osceola & C. reticulata & $\begin{array}{l}\text { C. clementina } \times \text { (C. paradisi } \times \\
\text { C. tangerina) }\end{array}$ \\
\hline 187 & Page & C. reticulata & $\begin{array}{l}\text { (C. paradisi } \times \text { C. tangerina) } \times C \text {. } \\
\text { clementina }\end{array}$ \\
\hline 188 & Page & C. reticulata & $\begin{array}{l}\text { (C. paradisi } \times \text { C. tangerina) } \times C \text {. } \\
\text { clementina }\end{array}$ \\
\hline 189 & Palazzelli & C. reticulata & C. clementina $\times$ C. nobilis \\
\hline 190 & Pixie & C. reticulata & (C. nobilis $\times$ C. tangerina) $\times$ ? \\
\hline 191 & Primosole & C. reticulata & C. unshiu $\times($ C. deliciosa $\times$ ?) \\
\hline 192 & Simeto & C. reticulata & C. unshiu x C. deliciosa \\
\hline 193 & Sunburst & C. reticulata & $\begin{array}{l}((C \text {. clementina } \times(C \text {. paradisi } \times \\
\text { C. tangerina })) \times((C \text {. clementina } \\
\times(C \text {. paradisi } \times \text { C. tangerina }))\end{array}$ \\
\hline 194 & Wallent & C. reticulata & $?$ \\
\hline
\end{tabular}




\begin{tabular}{|c|c|c|c|}
\hline 195 & Wilking & C. reticulata & C. nobilis $\times$ C. deliciosa \\
\hline 196 & Satsuma x Clementine & C. reticulata & $?$ \\
\hline 197 & Mapo & C. reticulata & C.deliciosa x C.paradisi \\
\hline 198 & Minneola & C. reticulata & C.paradisi x C.tangerina \\
\hline 199 & Orlando & C. reticulata & C.paradisi x C.tangerina \\
\hline 200 & Seminole & C. reticulata & C.paradisi x C.tangerina \\
\hline 201 & King & C. reticulata & C. nobilis \\
\hline 202 & Kiyomi & C. reticulata & C.unshiu $\times$ C.sinensis \\
\hline 203 & Dweet & C. reticulata & C.tangerina $\mathrm{x}$ C.sinensis \\
\hline 204 & Ellendale & C. reticulata & C.reticulata x C.sinensis \\
\hline 205 & Ellendale Leng & C. reticulata & C.reticulata x C.sinensis \\
\hline 206 & Ellendale Taranco & C. reticulata & C.reticulata $\times$ C.sinensis \\
\hline 207 & Murcott & C. reticulata & C.reticulata $\times$ C.sinensis \\
\hline 208 & Murcott seedless & C. reticulata & C.reticulata x C.sinensis \\
\hline 209 & Ortanique & C. reticulata & C.reticulata $\times$ C.sinensis \\
\hline 210 & Umatilla & C. reticulata & C.unshiu x C.sinensis \\
\hline 211 & Afourer & C. reticulata & (C. reticulata $\times$ C. sinensis) $\times$ ? \\
\hline 212 & Bergamota & C. reticulata & $?$ \\
\hline 213 & Hybrida & C. reticulata & $?$ \\
\hline 214 & Neck & C. reticulata & $?$ \\
\hline 215 & Gailang & C. reticulata & $?$ \\
\hline 216 & Kiyomi & C. reticulata & C. unshiu $\times$ C. sinensis \\
\hline 217 & (orange) Sanh & $?$ & $?$ \\
\hline 218 & Bandipur (Népal) & $?$ & $?$ \\
\hline 219 & Caibe & $?$ & $?$ \\
\hline 220 & Importé de Chine marché Hanoï & $?$ & $?$ \\
\hline 221 & Matieu (Laï Vung) & $?$ & $?$ \\
\hline 222 & Paper (Qu'yt Giay) & $?$ & $?$ \\
\hline 223 & S. E. & $?$ & $?$ \\
\hline
\end{tabular}

(ID) Identification number used in the whole article 
Supplementary information 1 (Cont.).

\begin{tabular}{|c|c|c|c|c|c|c|}
\hline ID & Germplasm bank code & PA & S $223 \mathrm{~K}=5$ & S $175 \mathrm{~K}=$ ? & $\mathrm{S} 121 \mathrm{~K}=$ ? & S $216 \mathrm{~K}=9$ \\
\hline 1 & IVIA-478 & Mandarin & 1 & 0 & 0 & -9 \\
\hline 2 & SRA-0100896 & Mandarin & 1 & 0 & 0 & -9 \\
\hline 3 & IVIA-154 & Mandarin & 1 & 1 & 1 & 3 \\
\hline 4 & SRA-0100598 & Mandarin & 1 & 1 & 1 & 3 \\
\hline 5 & IVIA-238 & Mandarin & 1 & 0 & 0 & -9 \\
\hline 6 & SRA-0100437 & Mandarin & 1 & 1 & 1 & 4 \\
\hline 7 & SRA-0100775 & Mandarin & 1 & 1 & 1 & -9 \\
\hline 8 & SRA-0100769 & Mandarin & 1 & 1 & 1 & -9 \\
\hline 9 & IVIA-550 & Mandarin & 1 & 0 & 0 & -9 \\
\hline 10 & SRA-0100766 & Mandarin & 1 & 1 & 1 & -9 \\
\hline 11 & SRA-0100839 & Mandarin & 1 & 1 & 1 & -9 \\
\hline 12 & IVIA-193 & Mandarin & 1 & 1 & 1 & -9 \\
\hline 13 & SRA-0100419 & Mandarin & 1 & 1 & 1 & -9 \\
\hline 14 & SRA-0100595 & Mandarin & 1 & 1 & 1 & 4 \\
\hline 15 & SRA-0100590 & Mandarin & 1 & 1 & 1 & -9 \\
\hline 16 & IVIA-385 & Mandarin & 1 & 1 & 1 & 5 \\
\hline 17 & IVIA-482 & Mandarin & 1 & 1 & 1 & 1 \\
\hline 18 & IVIA-483 & Mandarin & 1 & 1 & 1 & -9 \\
\hline 19 & SRA-0100518 & Mandarin & 1 & 1 & 1 & 1 \\
\hline 20 & SRA-0100680 & Mandarin & 1 & 1 & 1 & -9 \\
\hline 21 & SRA-0100582 & Mandarin & 1 & 1 & 1 & -9 \\
\hline 22 & SRA-0100713 & Mandarin & 1 & 1 & 1 & 1 \\
\hline 23 & SRA-0100597 & Mandarin & 1 & 1 & 1 & -9 \\
\hline 24 & IVIA-239 & Mandarin & 1 & 0 & 0 & -9 \\
\hline 25 & SRA-0100971 & Mandarin & 1 & 0 & 0 & -9 \\
\hline 26 & IVIA-237 & Mandarin & 1 & 0 & 0 & -9 \\
\hline 27 & SRA-0100175 & Mandarin & 1 & 1 & 1 & 1 \\
\hline 28 & IVIA-434 & Mandarin & 1 & 1 & 1 & -9 \\
\hline 29 & IVIA-019 & Mandarin & 1 & 1 & 1 & 2 \\
\hline 30 & SRA-0100681 & Mandarin & 1 & 1 & 1 & 2 \\
\hline 31 & IVIA-420 & Pummelo & 2 & 0 & 0 & 6 \\
\hline 32 & IVIA-277 & Pummelo & 2 & 0 & 0 & 6 \\
\hline 33 & IVIA-275 & Pummelo & 2 & 0 & 0 & 6 \\
\hline 34 & IVIA-207 & Pummelo & 2 & 0 & 0 & 6 \\
\hline 35 & IVIA-321 & Pummelo & 2 & 0 & 0 & 6 \\
\hline 36 & IVIA-589 & Pummelo & 2 & 0 & 0 & 6 \\
\hline 37 & IVIA-590 & Pummelo & 2 & 0 & 0 & 6 \\
\hline 38 & SRA-0100673 & Pummelo & 2 & 0 & 0 & 6 \\
\hline 39 & SRA-0100707 & Pummelo & 2 & 0 & 0 & 6 \\
\hline 40 & SRA-0100710 & Pummelo & 2 & 0 & 0 & 6 \\
\hline 41 & SRA-0100727 & Pummelo & 2 & 0 & 0 & 6 \\
\hline 42 & IVIA-169 & Citron & 3 & 0 & 0 & 7 \\
\hline 43 & IVIA-567 & Citron & 3 & 0 & 0 & 7 \\
\hline 44 & IVIA-202 & Citron & 3 & 0 & 0 & 7 \\
\hline 45 & IVIA-560 & Citron & 3 & 0 & 0 & 7 \\
\hline 46 & SRA-0100701 & Citron & 3 & 0 & 0 & 7 \\
\hline 47 & SRA-0100722 & Citron & 3 & 0 & 0 & 7 \\
\hline 48 & IVIA-178 & Papeda & 4 & 0 & 0 & 8 \\
\hline 49 & IVIA-358 & Papeda & 4 & 0 & 0 & 8 \\
\hline 50 & SRA-0100844 & Papeda & 4 & 0 & 0 & 8 \\
\hline 51 & IVIA-626 & Papeda & 4 & 0 & 0 & 8 \\
\hline 52 & IVIA-280 & Fortunella & 5 & 0 & 0 & 9 \\
\hline 53 & IVIA-281 & Fortunella & 5 & 0 & 0 & 9 \\
\hline 54 & IVIA-381 & Fortunella & 5 & 0 & 0 & 9 \\
\hline 55 & IVIA-038 & Fortunella & 5 & 0 & 0 & 9 \\
\hline 56 & SRA-0100683 & NPA & -9 & 1 & 1 & -9 \\
\hline 57 & IVIA-359 & NPA & -9 & 0 & 0 & -9 \\
\hline 58 & IVIA-278 & NPA & -9 & 0 & 0 & -9 \\
\hline 59 & IVIA-335 & NPA & -9 & 0 & 0 & -9 \\
\hline 60 & IVIA-242 & NPA & -9 & 0 & 0 & -9 \\
\hline 61 & IVIA-135 & NPA & -9 & 0 & 0 & -9 \\
\hline 62 & IVIA-241 & NPA & -9 & 0 & 0 & -9 \\
\hline 63 & SRA-0100524 & NPA & -9 & 1 & 1 & -9 \\
\hline 64 & IVIA-081 & NPA & -9 & 1 & 1 & -9 \\
\hline 65 & SRA-0100176 & NPA & -9 & 1 & 1 & -9 \\
\hline 66 & SRA-0100467 & NPA & -9 & 1 & 1 & -9 \\
\hline 67 & IVIA-452 & NPA & -9 & 0 & 0 & -9 \\
\hline 68 & IVIA-022 & NPA & -9 & 1 & 0 & -9 \\
\hline 69 & IVIA-132 & NPA & -9 & 1 & 0 & -9 \\
\hline 70 & IVIA-058 & NPA & -9 & 1 & 0 & -9 \\
\hline 71 & IVIA-189 & NPA & -9 & 1 & 1 & 3 \\
\hline 72 & IVIA-340 & NPA & -9 & 1 & 1 & 3 \\
\hline 73 & IVIA-383 & NPA & -9 & 1 & 1 & 3 \\
\hline 74 & IVIA-361 & NPA & -9 & 1 & 1 & 3 \\
\hline
\end{tabular}


IVIA-186

SRA-0100267

SRA-0100277

SRA-0100658

SRA-0100416

SRA-0100423

SRA-0100553

SRA-0100481

SRA-0100847

SRA-0100982

SRA-0100983

IVIA-571

SRA-0100914

SRA-0100800

SRA-0100764

SRA-0100279

SRA-0100326

SRA-0100431

SRA-\#22

SRA-0100441

IVIA-390

IVIA-568

IVIA-394

IVIA-576

IVIA-411

SRA-0100517

SRA-0100495

SRA-0100497

SRA-0100527

SRA-0100721

SRA-0100554

SRA-0100057

SRA-0100350

SRA-0100412

SRA-0100519

SRA-0100917

SRA-0100434

SRA-0100767

SRA-0100414

SRA-0100521

SRA-0100417

SRA-0100418

SRA-0100600

SRA-0100420

SRA-0100522

SRA-0100523

SRA-0100587

SRA-0100421

SRA-0100782

SRA-0100589

SRA-0100588

SRA-0100496

SRA-0100425

SRA-0100424

SRA-0100654

SRA-0100426

SRA-0100700

SRA-0100693

SRA-0100429

SRA-0100706

SRA-0100139

SRA-0100526

SRA-0100435

SRA-0110251

SRA-0100723

SRA-0100439

SRA-0100440

SRA-0100868

SRA-0100786

SRA-0100653

SRA-0100735

SRA-0100694

SRA-0100586

SRA-0100596

SRA-0100655

SRA-0100705

NPA

NPA

NPA

NPA

NPA

NPA

NPA

NPA

NPA

NPA

NPA

NPA

NPA

NPA

NPA

NPA

NPA

NPA

NPA

NPA

NPA

NPA

NPA

NPA

NPA

NPA

NPA

NPA

NPA

NPA

NPA

NPA

NPA

NPA

NPA

NPA

NPA

NPA

NPA

NPA

NPA

NPA

NPA

NPA

NPA

NPA

NPA

NPA

NPA

NPA

NPA

NPA

NPA

NPA

NPA

NPA

NPA

NPA

NPA

NPA

NPA

NPA

NPA

NPA

NPA

NPA

NPA

NPA

NPA

NPA

NPA

NPA

NPA

NPA

NPA

NPA 


\begin{tabular}{|c|c|c|c|c|c|}
\hline 151 & SRA-0100970 & NPA & -9 & 0 & 0 \\
\hline 152 & SRA-0100261 & NPA & -9 & 1 & 1 \\
\hline 153 & SRA-0100266 & NPA & -9 & 1 & 1 \\
\hline 154 & SRA-0100591 & NPA & -9 & 1 & 1 \\
\hline 155 & SRA-0100428 & NPA & -9 & 1 & 1 \\
\hline 156 & SRA-0100264 & NPA & -9 & 1 & 1 \\
\hline 157 & SRA-0100826 & NPA & -9 & 1 & 1 \\
\hline 158 & SRA-0100442 & NPA & -9 & 1 & 1 \\
\hline 159 & SRA-GA1145 & NPA & -9 & 1 & 1 \\
\hline 160 & IVIA-168 & NPA & -9 & 1 & 1 \\
\hline 161 & IVIA-175 & NPA & -9 & 1 & 1 \\
\hline 162 & IVIA-195 & NPA & -9 & 1 & 1 \\
\hline 163 & SRA-0100578 & NPA & -9 & 1 & 1 \\
\hline 164 & SRA-0100657 & NPA & -9 & 1 & 1 \\
\hline 165 & SRA-0100341 & NPA & -9 & 1 & 1 \\
\hline 166 & SRA-0100167 & NPA & -9 & 1 & 1 \\
\hline 167 & IVIA-424 & NPA & -9 & 1 & 0 \\
\hline 168 & IVIA-439 & NPA & -9 & 1 & 0 \\
\hline 169 & IVIA-440 & NPA & -9 & 1 & 0 \\
\hline 170 & IVIA-438 & NPA & -9 & 1 & 0 \\
\hline 171 & IVIA-453 & NPA & -9 & 1 & 0 \\
\hline 172 & IVIA-447 & NPA & -9 & 1 & 0 \\
\hline 173 & IVIA-362 & NPA & -9 & 1 & 0 \\
\hline 174 & IVIA-421 & NPA & -9 & 1 & 0 \\
\hline 175 & IVIA-155 & NPA & -9 & 1 & 0 \\
\hline 176 & IVIA-083 & NPA & -9 & 1 & 0 \\
\hline 177 & IVIA-466 & NPA & -9 & 1 & 0 \\
\hline 178 & IVIA-080 & NPA & -9 & 1 & 0 \\
\hline 179 & IVIA-082 & NPA & -9 & 1 & 0 \\
\hline 180 & IVIA-523 & NPA & -9 & 1 & 0 \\
\hline 181 & IVIA-209 & NPA & -9 & 1 & 0 \\
\hline 182 & IVIA-218 & NPA & -9 & 1 & 0 \\
\hline 183 & IVIA-033 & NPA & -9 & 1 & 0 \\
\hline 184 & IVIA-423 & NPA & -9 & 1 & 0 \\
\hline 185 & IVIA-074 & NPA & -9 & 1 & 0 \\
\hline 186 & IVIA-573 & NPA & -9 & 1 & 0 \\
\hline 187 & IVIA-079 & NPA & -9 & 1 & 0 \\
\hline 188 & IVIA-429 & NPA & -9 & 1 & 0 \\
\hline 189 & IVIA-188 & NPA & -9 & 1 & 0 \\
\hline 190 & IVIA-210 & NPA & -9 & 1 & 0 \\
\hline 191 & IVIA-414 & NPA & -9 & 1 & 0 \\
\hline 192 & IVIA-413 & NPA & -9 & 1 & 0 \\
\hline 193 & IVIA-200 & NPA & -9 & 1 & 0 \\
\hline 194 & IVIA-404 & NPA & -9 & 1 & 0 \\
\hline 195 & IVIA-028 & NPA & -9 & 1 & 0 \\
\hline 196 & SRA-0100791 & NPA & -9 & 1 & 0 \\
\hline 197 & IVIA-190 & NPA & -9 & 1 & 0 \\
\hline 198 & IVIA-084 & NPA & -9 & 1 & 0 \\
\hline 199 & IVIA-101 & NPA & -9 & 1 & 0 \\
\hline 200 & IVIA-348 & NPA & -9 & 1 & 0 \\
\hline 201 & IVIA-477 & NPA & -9 & 1 & 0 \\
\hline 202 & IVIA-405 & NPA & -9 & 1 & 0 \\
\hline 203 & IVIA-165 & NPA & -9 & 1 & 0 \\
\hline 204 & IVIA-194 & NPA & -9 & 1 & 0 \\
\hline 205 & IVIA-353 & NPA & -9 & 1 & 0 \\
\hline 206 & IVIA-575 & NPA & -9 & 1 & 0 \\
\hline 207 & IVIA-196 & NPA & -9 & 1 & 0 \\
\hline 208 & IVIA-371 & NPA & -9 & 1 & 0 \\
\hline 209 & IVIA-276 & NPA & -9 & 1 & 0 \\
\hline 210 & IVIA-100 & NPA & -9 & 1 & 0 \\
\hline 211 & SRA-0100741 & NPA & -9 & 1 & 0 \\
\hline 212 & SRA-0100164 & NPA & -9 & 1 & 0 \\
\hline 213 & SRA-0100714 & NPA & -9 & 1 & 0 \\
\hline 214 & SRA-0100674 & NPA & -9 & 1 & 0 \\
\hline 215 & SRA-0100575 & NPA & -9 & 1 & 0 \\
\hline 216 & SRA-0100704 & NPA & -9 & 1 & 0 \\
\hline 217 & SRA-\#45 & NPA & -9 & 1 & 1 \\
\hline 218 & SRA-\#NEPAL2 & NPA & -9 & 1 & 1 \\
\hline 219 & SRA-\#11 & NPA & -9 & 1 & 1 \\
\hline 220 & SRA-\#27 & NPA & -9 & 1 & 1 \\
\hline 221 & SRA-\#18 & NPA & -9 & 1 & 1 \\
\hline 222 & SRA-\#8 & NPA & -9 & 1 & 1 \\
\hline 223 & SRA-0100433 & NPA & -9 & 1 & 1 \\
\hline
\end{tabular}

(ID) Identification number used in the whole article; (PA) Population assigned in Structure software (S); (NPA) Not population assigned 
Supplementary information 2. Statistical summary of the diversity for the SSR and indel markers employed in the genotyping of the whole dataset.

\begin{tabular}{|c|c|c|c|c|c|c|c|}
\hline Marker & Type & MAF & $A$ & GD & $H_{0}$ & $H_{\mathrm{e}}$ & $F_{\mathrm{w}}$ \\
\hline mCrClR02D09 & SSR & 0.42 & 18 & 0.77 & 0.69 & 0.74 & 0.08 \\
\hline TAA41 & SSR & 0.31 & 18 & 0.82 & 0.70 & 0.80 & 0.13 \\
\hline mCrCIR06B07 & SSR & 0.53 & 8 & 0.62 & 0.47 & 0.57 & 0.18 \\
\hline mCrCIR01C07 & SSR & 0.38 & 16 & 0.76 & 0.75 & 0.73 & -0.03 \\
\hline mCrCIR05A05 & SSR & 0.31 & 16 & 0.79 & 0.57 & 0.77 & 0.25 \\
\hline mCrCIR04H06 & SSR & 0.52 & 8 & 0.66 & 0.59 & 0.61 & 0.04 \\
\hline MEST46 & SSR & 0.44 & 12 & 0.70 & 0.68 & 0.66 & -0.02 \\
\hline CAC15 & SSR & 0.77 & 6 & 0.37 & 0.42 & 0.33 & -0.26 \\
\hline mCrCIR03C08 & SSR & 0.36 & 15 & 0.79 & 0.68 & 0.77 & 0.11 \\
\hline CAC23 & SSR & 0.57 & 7 & 0.53 & 0.64 & 0.44 & -0.43 \\
\hline MEST256 & SSR & 0.55 & 14 & 0.64 & 0.30 & 0.61 & 0.50 \\
\hline mCrClR02G12 & SSR & 0.41 & 12 & 0.77 & 0.73 & 0.74 & 0.02 \\
\hline MEST131 & SSR & 0.45 & 6 & 0.64 & 0.61 & 0.57 & -0.08 \\
\hline MEST121 & SSR & 0.54 & 11 & 0.59 & 0.61 & 0.51 & -0.18 \\
\hline MEST1 & SSR & 0.49 & 13 & 0.65 & 0.65 & 0.60 & -0.08 \\
\hline MEST431 & SSR & 0.68 & 11 & 0.50 & 0.42 & 0.47 & 0.10 \\
\hline TAA15 & SSR & 0.27 & 13 & 0.83 & 0.77 & 0.81 & 0.04 \\
\hline mCrCIR03D12a & SSR & 0.27 & 18 & 0.82 & 0.81 & 0.79 & -0.02 \\
\hline mCrCIR02D04b & SSR & 0.27 & 19 & 0.81 & 0.81 & 0.79 & -0.03 \\
\hline mCrCIR03G05 & SSR & 0.35 & 10 & 0.79 & 0.62 & 0.76 & 0.18 \\
\hline mCrCIR07D06 & SSR & 0.39 & 11 & 0.74 & 0.70 & 0.71 & 0.01 \\
\hline MEST15 & SSR & 0.31 & 7 & 0.77 & 0.81 & 0.73 & -0.11 \\
\hline MEST104 & SSR & 0.45 & 8 & 0.71 & 0.73 & 0.68 & -0.08 \\
\hline mCrCIR01F08a & SSR & 0.80 & 7 & 0.35 & 0.24 & 0.34 & 0.30 \\
\hline MEST88 & SSR & 0.34 & 8 & 0.73 & 0.57 & 0.68 & 0.16 \\
\hline mCrCIR05A04 & SSR & 0.64 & 8 & 0.50 & 0.39 & 0.43 & 0.09 \\
\hline mCrCIR07E12 & SSR & 0.57 & 14 & 0.64 & 0.61 & 0.61 & 0.00 \\
\hline MEST115 & SSR & 0.73 & 6 & 0.42 & 0.39 & 0.38 & -0.03 \\
\hline mCrClR06A12 & SSR & 0.65 & 8 & 0.54 & 0.49 & 0.50 & 0.03 \\
\hline MEST56 & SSR & 0.37 & 16 & 0.78 & 0.69 & 0.75 & 0.08 \\
\hline mCrCIR04H12 & SSR & 0.72 & 11 & 0.47 & 0.35 & 0.45 & 0.23 \\
\hline MEST192 & SSR & 0.37 & 18 & 0.81 & 0.74 & 0.80 & 0.07 \\
\hline mCrClR02F12 & SSR & 0.42 & 11 & 0.72 & 0.64 & 0.68 & 0.05 \\
\hline mCrCIR01D11 & SSR & 0.41 & 9 & 0.70 & 0.33 & 0.65 & 0.49 \\
\hline MEST488 & SSR & 0.32 & 14 & 0.80 & 0.80 & 0.78 & -0.03 \\
\hline mCrCIR01E02 & SSR & 0.42 & 12 & 0.73 & 0.64 & 0.69 & 0.07 \\
\hline mCrCIR01C06 & SSR & 0.28 & 18 & 0.80 & 0.81 & 0.78 & -0.04 \\
\hline TAA1 & SSR & 0.66 & 5 & 0.48 & 0.47 & 0.41 & -0.14 \\
\hline mCrClR02A09 & SSR & 0.48 & 12 & 0.70 & 0.64 & 0.67 & 0.04 \\
\hline mCrClR02G02 & SSR & 0.31 & 16 & 0.79 & 0.82 & 0.76 & -0.08 \\
\hline mCrCIR02F07 & SSR & 0.76 & 14 & 0.41 & 0.24 & 0.40 & 0.39 \\
\hline mCrClR07B05 & SSR & 0.34 & 15 & 0.79 & 0.51 & 0.76 & 0.33 \\
\hline mCrCIR01F04a & SSR & 0.24 & 15 & 0.85 & 0.82 & 0.83 & 0.02 \\
\hline MEST86 & SSR & 0.40 & 9 & 0.69 & 0.65 & 0.63 & -0.02 \\
\hline MEST107 & SSR & 0.76 & 6 & 0.38 & 0.30 & 0.34 & 0.10 \\
\hline mCrClR03B07 & SSR & 0.59 & 13 & 0.61 & 0.49 & 0.58 & 0.15 \\
\hline mCrCIR07C07 & SSR & 0.45 & 9 & 0.73 & 0.59 & 0.70 & 0.15 \\
\hline mCrCIR07C09 & SSR & 0.55 & 10 & 0.64 & 0.68 & 0.60 & -0.13 \\
\hline mCrCIR07F11 & SSR & 0.37 & 16 & 0.80 & 0.84 & 0.77 & -0.09 \\
\hline mCrClR02B07 & SSR & 0.31 & 15 & 0.77 & 0.79 & 0.73 & -0.09 \\
\hline IDCHI & indel & 0.97 & 4 & 0.06 & 0.03 & 0.06 & 0.56 \\
\hline IDHyb-2 & indel & 0.89 & 4 & 0.20 & 0.06 & 0.19 & 0.68 \\
\hline IDLCY2 & indel & 0.78 & 3 & 0.35 & 0.36 & 0.31 & -0.17 \\
\hline IDTRPA & indel & 0.79 & 2 & 0.33 & 0.39 & 0.28 & -0.39 \\
\hline IDHyb-1 & indel & 0.92 & 7 & 0.15 & 0.10 & 0.14 & 0.32 \\
\hline IDPSY & indel & 0.97 & 2 & 0.07 & 0.01 & 0.06 & 0.79 \\
\hline IDEMA & indel & 0.84 & 5 & 0.28 & 0.24 & 0.26 & 0.07 \\
\hline IDDXS & indel & 0.95 & 4 & 0.09 & 0.03 & 0.09 & 0.70 \\
\hline IDPEPC1 & indel & 0.91 & 2 & 0.17 & 0.09 & 0.15 & 0.38 \\
\hline IDPEPC2 & indel & 0.96 & 3 & 0.07 & 0.02 & 0.07 & 0.73 \\
\hline IDCAX & indel & 0.53 & 5 & 0.60 & 0.50 & 0.53 & 0.06 \\
\hline IDAtGRC & indel & 0.96 & 2 & 0.09 & 0.03 & 0.08 & 0.67 \\
\hline IDAVP & indel & 0.98 & 2 & 0.04 & 0.02 & 0.04 & 0.42 \\
\hline IDDFR & indel & 0.35 & 7 & 0.72 & 0.70 & 0.67 & -0.03 \\
\hline IDINVA2 & indel & 0.99 & 3 & 0.01 & 0.01 & 0.01 & -0.01 \\
\hline IDDFR2 & indel & 0.99 & 4 & 0.03 & 0.03 & 0.03 & -0.02 \\
\hline IDPEPC3 & indel & 0.99 & 2 & 0.02 & 0.02 & 0.02 & -0.02 \\
\hline IDINVA1 & indel & 0.96 & 3 & 0.07 & 0.00 & 0.07 & 0.94 \\
\hline IDFLS1 & indel & 0.66 & 4 & 0.47 & 0.53 & 0.38 & -0.40 \\
\hline IDCHI2 & indel & 0.98 & 2 & 0.04 & 0.00 & 0.04 & 0.88 \\
\hline IDFLS2 & indel & 0.97 & 3 & 0.07 & 0.01 & 0.06 & 0.79 \\
\hline
\end{tabular}




\begin{tabular}{lllllllc} 
IDPKF & indel & 0.49 & 3 & 0.62 & 0.53 & 0.55 & 0.04 \\
IDF3'H & indel & 0.64 & 2 & 0.46 & 0.53 & 0.35 & -0.50 \\
IDPSY2 & indel & 0.50 & 2 & 0.50 & 0.50 & 0.37 & -0.33 \\
\hline Mean & SSR & 0.47 & 12 & 0.67 & 0.61 & 0.64 & 0.05 \\
\hline Mean & indel & 0.84 & 3 & 0.23 & 0.20 & 0.20 & 0.26 \\
\hline (MAF) & Maximum & allele frequency; & $(A)$ & Allele & number; & $(\mathrm{GD})$ & Gene \\
\hline
\end{tabular}
heterozygosity; $\left(H_{\mathrm{e}}\right)$ Expected heterozygosity; $\left(F_{\mathrm{w}}\right)$ Wright fixation index. 
Supplementary information 3. Unique alleles present in some genotypes of the entire population.

\begin{tabular}{lllr}
\hline Common name & Latin name Tanaka system & $\begin{array}{c}\text { Germplasm } \\
\text { bank code }\end{array}$ & UA \\
\hline Cleopatra & C. reshni & IVIA-385 & 2 \\
C. daoxianensis & C. daoxianensis & IVIA-359 & 1 \\
Yuzu & C. junos & IVIA-335 & 20 \\
Changsa & Citrandarin & IVIA-452 & 13 \\
Osceola & C. clementina x (C. paradisi x C. tangerina) & IVIA-573 & 1 \\
Pixie & (C. nobilis x C. tangerina) x ? & IVIA-210 & 1 \\
Wilking & C. nobilis x C. deliciosa & IVIA-028 & 1 \\
Nasnaran & C. amblycarpa & SRA-0100896 & 3 \\
San hu hong chu & C. erythrosa & SRA-0100769 & 2 \\
Vietnam & C. kinokuni & SRA-0100914 & 1 \\
Rodeking & C. nobilis & SRA-0100431 & 1 \\
Fewtrell SG & C. reticulata & SRA-0100418 & 1 \\
Imperial & C. reticulata & SRA-0100587 & 1 \\
Kobayashi & C. reticulata & SRA-0100782 & 2 \\
Nicaragua & C. reticulata & SRA-0100693 & 10 \\
Robinson & C. reticulata & SRA-0100139 & 1 \\
Suntara & C. reticulata & SRA-0110251 & 6 \\
Ougan & C. suavissima & SRA-0100680 & 1 \\
de Soe & C. suhuiensis & SRA-0100735 & 2 \\
Sunki & C. sunki & SRA-0100705 & 1 \\
Sunki & C. sunki & SRA-0100970 & 2 \\
Sunki & C. sunki & SRA-0100971 & 1 \\
C. amblycarpa & C. amblycarpa & IVIA-478 & 8 \\
Shunkokan & C. shunkokan & IVIA-241 & 4 \\
C. tachibana & C. tachibana & & 7 \\
\hline (UA) IVIA-237 & &
\end{tabular}

(UA) unique alleles 
Supplementary information 4. Genotypes not distinguished with molecular markers.

\begin{tabular}{|c|c|c|c|c|c|}
\hline $\mathbf{N}$ & Common name & Swingle system & $\begin{array}{l}\text { Database based } \\
\text { on Tanaka system }\end{array}$ & $\begin{array}{l}\text { Germplasm } \\
\text { bank code }\end{array}$ & MLG \\
\hline 1 & Xien Khuang & C. reticulata & C. reticulata & SRA-0100868 & 1 \\
\hline 2 & Chiuka & C. reticulata & C. reticulata & SRA-0100917 & 1 \\
\hline 3 & Clausellina & C. reticulata & C. unshiu & IVIA-019 & 2 \\
\hline 4 & Frost & C. reticulata & C. unshiu & IVIA-175 & 2 \\
\hline 5 & Okitsu & C. reticulata & C. unshiu & IVIA-195 & 2 \\
\hline 6 & Pucheng & C. reticulata & C. unshiu & SRA-0100657 & 2 \\
\hline 7 & Kowano & C. reticulata & C. unshiu & SRA-0100167 & 3 \\
\hline 8 & Dobashi-Beni & C. reticulata & C. unshiu & SRA-0100681 & 3 \\
\hline 9 & Lukan & C. reticulata & C. reticulata & SRA-0100654 & 4 \\
\hline 10 & Hickson & C. reticulata & C. reticulata & SRA-0100523 & 4 \\
\hline 11 & Pan American & C. reticulata & C. reticulata & SRA-0100706 & 4 \\
\hline 12 & à peau rugueuse & C. reticulata & C. deliciosa & SRA-0100277 & 4 \\
\hline 13 & Emperor & C. reticulata & C. reticulata & IVIA-394 & 4 \\
\hline 14 & Lebon SG & C. reticulata & C. reticulata & SRA-0100425 & 5 \\
\hline 15 & Le Roux & C. reticulata & C. reticulata & SRA-0100496 & 5 \\
\hline 16 & Antsalaka Diego SG & C. reticulata & C. reticulata & SRA-0100527 & 5 \\
\hline 17 & de Soe & C. reticulata & C. suhuiensis & SRA-0100653 & 6 \\
\hline 18 & de Soe & C. reticulata & C. suhuiensis & SRA-0100713 & 6 \\
\hline 19 & Caibe & ? & Unknown & SRA-\#11 & 7 \\
\hline 20 & Paper (Qu'yt Giay) & ? & Unknown & SRA-\#8 & 7 \\
\hline 21 & Sanguine Trabut & C. reticulata & C. tangerina & SRA-0100264 & 8 \\
\hline 22 & Ladu x Szinking & C. reticulata & C. reticulata & SRA-0100588 & 8 \\
\hline 23 & Vohangisany Ambodiampoly & C. reticulata & C. depressa & SRA-0100437 & 9 \\
\hline 24 & East India SG & C. reticulata & C. reticulata & SRA-0100414 & 9 \\
\hline 25 & Brickaville & C. reticulata & C. tangerina & SRA-0100266 & 9 \\
\hline 26 & Ellendale Leng & C. reticulata & $\begin{array}{l}\text { C. reticulata } \times C \text {. } \\
\text { sinensis }\end{array}$ & IVIA-353 & 10 \\
\hline 27 & Ellendale Taranco & C. reticulata & $\begin{array}{l}\text { C. reticulata } \times C \text {. } \\
\text { sinensis? }\end{array}$ & IVIA-575 & \\
\hline 28 & Tardivo Di Ciaculli & C. reticulata & C. deliciosa & IVIA-186 & 11 \\
\hline 29 & Avana Apireno & C. reticulata & C. deliciosa & IVIA-189 & 11 \\
\hline 30 & Willow leaf seedless & C. reticulata & C. deliciosa & IVIA-340 & 12 \\
\hline 31 & Willow leaf & C. reticulata & C. deliciosa & IVIA-154 & 12 \\
\hline 32 & Clemenules & C. reticulata & C. clementina & IVIA-022 & 13 \\
\hline 33 & Oronules & C. reticulata & C. clementina & IVIA-132 & 13 \\
\hline 34 & Murcott & C. reticulata & $\begin{array}{l}\text { C. reticulata } \times C \text {. } \\
\text { sinensis }\end{array}$ & IVIA-196 & 14 \\
\hline 35 & Murcott seedless & C. reticulata & $\begin{array}{l}\text { C. reticulata } \times C . \\
\text { sinensis }\end{array}$ & IVIA-371 & 14 \\
\hline
\end{tabular}

(N) Number; (MLG) Multilocus genotypes: genotypes with the same number are not possible to be distinguished between them 
Supplementary information 5. Structure analysis 223 genotypes without assuming populations. a) Optimal $\Delta K$ value (number of populations within the population studied); b) Populations observed and its contributions to the rest of the genotypes. Population one (mandarins), population two (Ancestral populations: C. maxima, C. medica, Papeda, Fortunella).

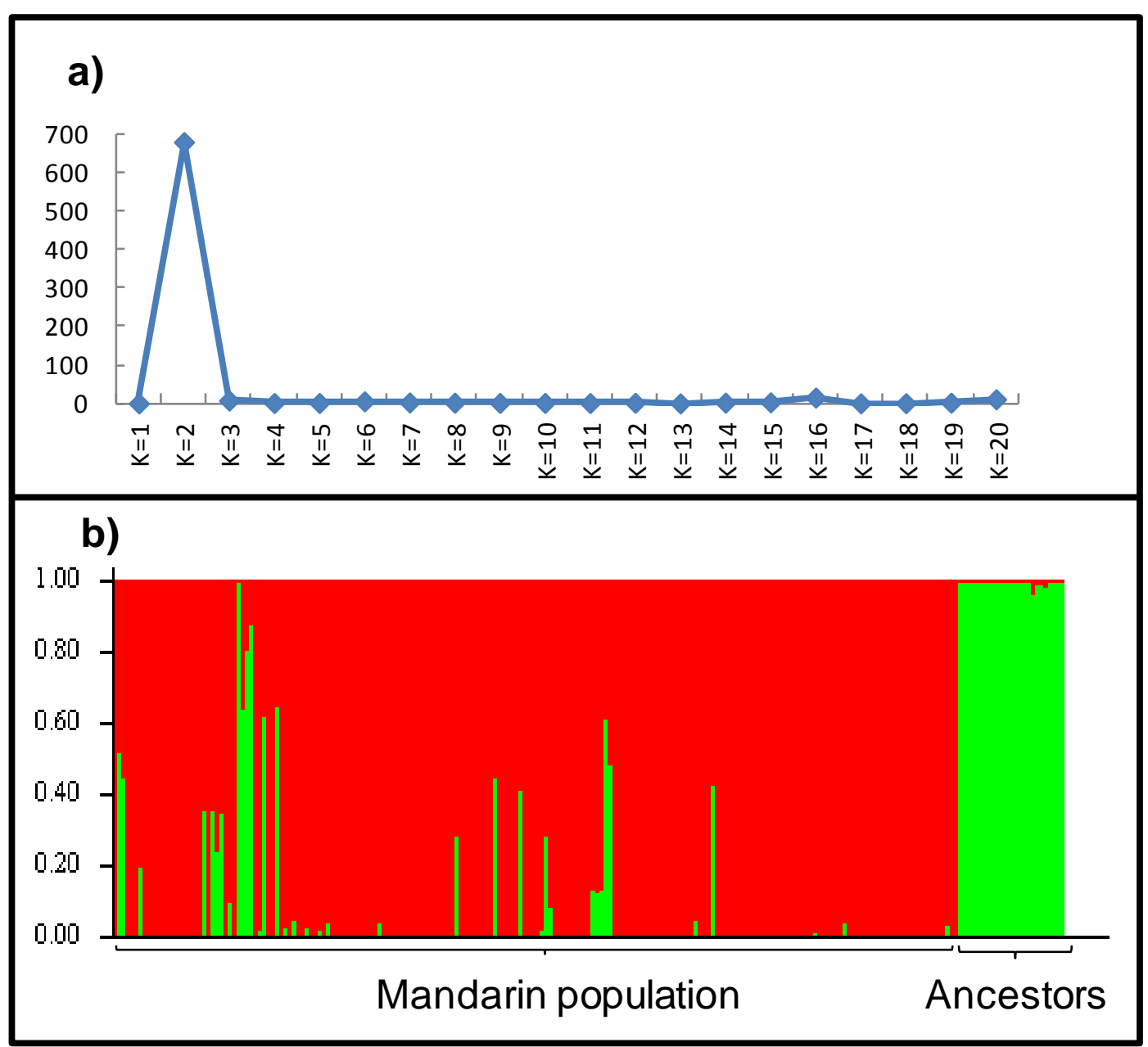


Supplementary information 6. Structure analysis 175 genotypes (>95\% of mandarin genome) without assuming populations. a) Optimal $\Delta K$ value (number of populations within the population studied); b) Populations observed $(K=6)$ and its contributions to the rest of the genotypes. Population colors: Red, mainly C. tangerina; Green, tangor 'king' and hybrids; Dark blue, mainly C. reticulata [Tan.]; Yellow, 'Ampefy', 'Wallent' and 'Gailang'; Pink, C. deliciosa; Light blue, C. unshiu.

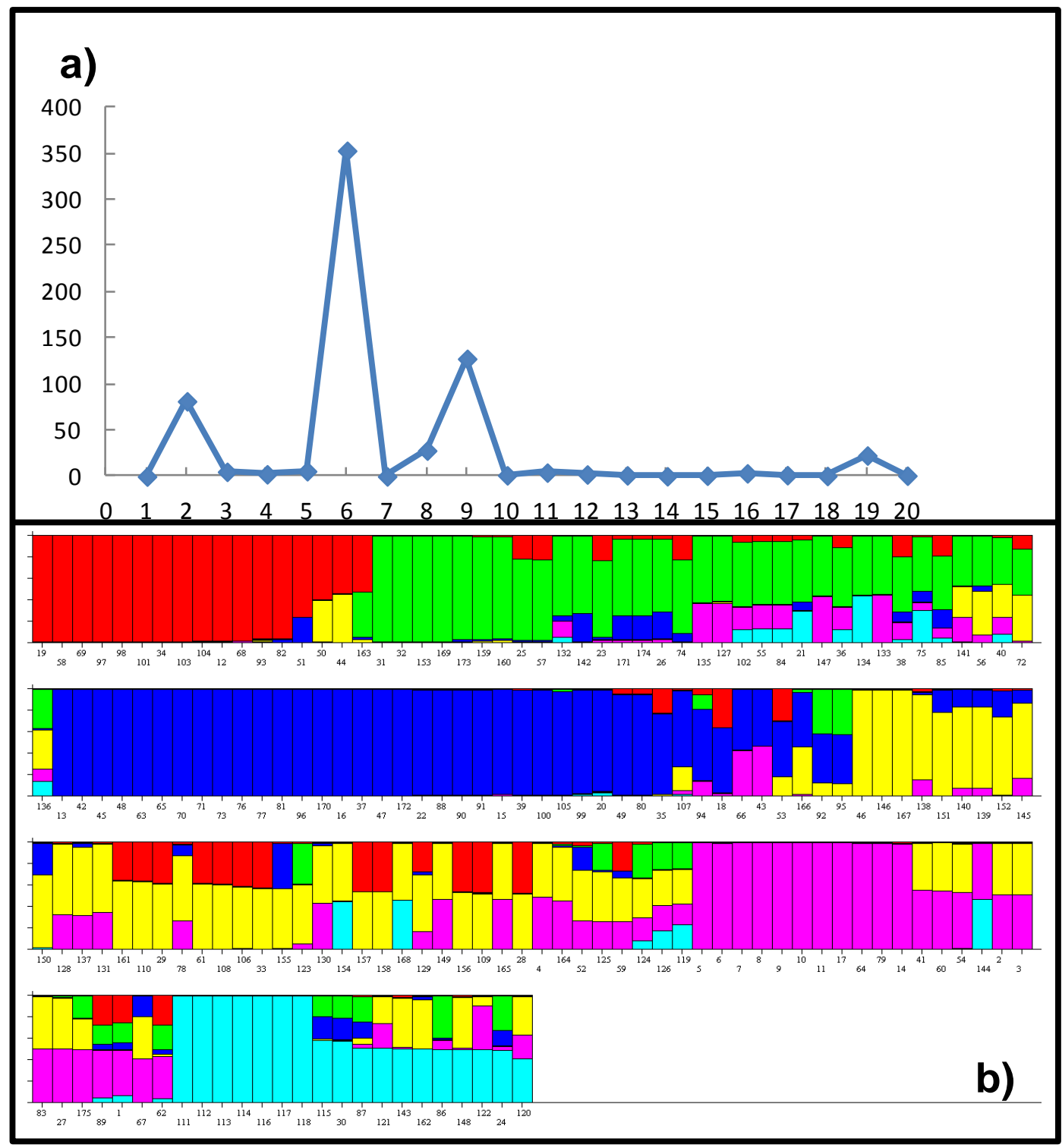


Supplementary information 7. Structure analysis 121 genotypes (mandarins without hybrids) without assuming populations. a) Optimal $\Delta K$ value (number of populations within the population studied); b) Populations observed $(K=6)$ and their contribution to the rest of the genotypes. Population colors: Red, mainly $C$. reticulata [Tan.]; Green, mixture of Tanaka's mandarin species; Dark blue, C. unshiu; Yellow, mainly C. tangerina; Pink, 'Ampefy'; Light blue, C. deliciosa.

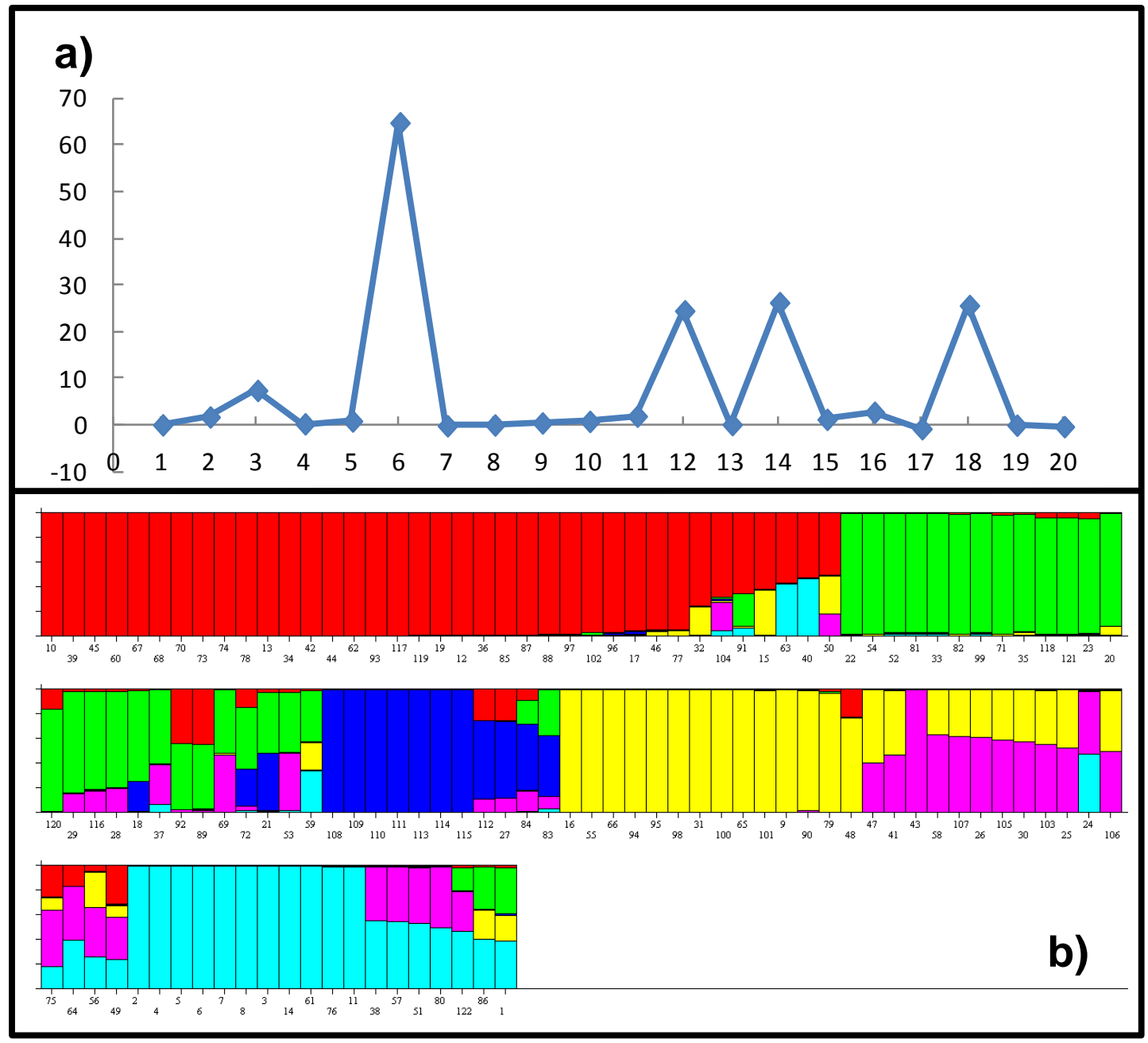


Supplementary information 8. Assignation of the mandarin genotypes into a nuclear group from the parental mandarin groups identified in this work (N1 - N5). (?) Genotype not possible to assign to any cluster.

\begin{tabular}{|c|c|c|c|c|}
\hline Unit & Common name & Latin name & Germplasm bank code & $\mathbf{N}$ \\
\hline 1 & Bintangor Sarawak & $?$ & SRA-0100683 & 3 \\
\hline 2 & Citrus daoxianensis & C. daoxianensis & IVIA-359 & 4 \\
\hline 3 & à peau lisse & C. deliciosa & SRA-0100267 & 2 \\
\hline 4 & à peau rugueuse & C. reticulata & SRA-0100277 & 1 \\
\hline 5 & Clemendor & C. deliciosa & SRA-0100658 & 3 \\
\hline 6 & de Chios & C. deliciosa & SRA-0100598 & 3 \\
\hline 7 & Empress & C. reticulata & SRA-0100416 & 1 \\
\hline 8 & Late Emperor Sg & C. reticulata & SRA-0100423 & 1 \\
\hline 9 & Montenegrina & C. deliciosa & SRA-0100553 & 3 \\
\hline 10 & Natal Tightskin & C. deliciosa & SRA-0100481 & 1 \\
\hline 11 & Avana Apireno & C. deliciosa & IVIA-189 & 3 \\
\hline 12 & Willowleaf & C. deliciosa & IVIA-154 & 3 \\
\hline 13 & Willowleaf seedless & C. deliciosa & IVIA-340 & 3 \\
\hline 14 & Willowleaf seedless & C. deliciosa & IVIA-383 & 3 \\
\hline 15 & Salteñita & C. deliciosa & IVIA-361 & 3 \\
\hline 16 & Tardivo Di Ciaculli & C. deliciosa & IVIA-186 & 3 \\
\hline 17 & Shekwasha & C. depressa & SRA-0100847 & 5 \\
\hline 18 & Shekwasha & C. depressa & SRA-0100982 & 5 \\
\hline 19 & Shekwasha & C. depressa & SRA-0100983 & 5 \\
\hline 20 & Citrus Depressa & C. depressa & IVIA-238 & 5 \\
\hline 21 & Vohangisany Ambodiampoly & C. depressa & SRA-0100437 & 2 \\
\hline 22 & Fuzhu & C. erythrosa & SRA-0100775 & $?$ \\
\hline 23 & San hu hong chu & C. erythrosa & SRA-0100769 & 4 \\
\hline 24 & Fuzhu & C. erythrosa & IVIA-571 & $?$ \\
\hline 25 & Nan feng mi chu & C. kinokuni & SRA-0100839 & 4 \\
\hline 26 & Vietnam & C. kinokuni & SRA-0100914 & 4 \\
\hline 27 & Vietnam & C. kinokuni & SRA-0100800 & 5 \\
\hline 28 & Vietnam & C. kinokuni & SRA-0100764 & $?$ \\
\hline 29 & Vietnam à peau fine & C. kinokuni & SRA-0100766 & 5 \\
\hline 30 & Du Japon & C. nobilis & SRA-0100279 & 2 \\
\hline 31 & Geleking & C. nobilis & SRA-0100419 & 2 \\
\hline 32 & King (Laï Vung) & C. nobilis & SRA-\#22 & $?$ \\
\hline 33 & Kunembo & C. nobilis & SRA-0100326 & 4 \\
\hline 34 & Rodeking & C. nobilis & SRA-0100431 & $?$ \\
\hline 35 & Yellow King & C. nobilis & SRA-0100441 & 2 \\
\hline 36 & Campeona & C. nobilis & IVIA-193 & 3 \\
\hline 37 & Ladu & C. paratangerina & SRA-0100595 & 2 \\
\hline 38 & Ladu Ordinaire & C. paratangerina & SRA-0100590 & 1 \\
\hline 39 & Cleopatra & C. reshni & IVIA-385 & 5 \\
\hline 40 & Africa Do Sul SG & C. reticulata & SRA-0100517 & 1 \\
\hline 41 & Ampefy & C. reticulata & SRA-0100495 & 2 \\
\hline 42 & Antillaise & C. reticulata & SRA-0100497 & 1 \\
\hline 43 & Antsalaka Diego Sg & C. reticulata & SRA-0100527 & 1 \\
\hline 44 & Atumbua & C. reticulata & SRA-0100721 & $?$ \\
\hline 45 & Augustino & C. reticulata & SRA-0100554 & 2 \\
\hline 46 & Batangas & C. reticulata & SRA-0100057 & 2 \\
\hline 47 & Bombay & C. reticulata & SRA-0100518 & 1 \\
\hline 48 & Bower & C. reticulata & SRA-0100350 & $?$ \\
\hline 49 & Burgess & C. reticulata & SRA-0100412 & 1 \\
\hline 50 & Capurro Sg & C. reticulata & SRA-0100519 & 2 \\
\hline 51 & Chiuka & C. reticulata & SRA-0100917 & 5 \\
\hline 52 & Cravo & C. reticulata & SRA-0100434 & $?$ \\
\hline 53 & Douhala & C. reticulata & SRA-0100767 & 5 \\
\hline 54 & East India Sg & C. reticulata & SRA-0100414 & 2 \\
\hline 55 & Enterprise & C. reticulata & SRA-0100521 & $?$ \\
\hline 56 & Federici & C. reticulata & SRA-0100417 & 3 \\
\hline 57 & Fewtrell Sg & C. reticulata & SRA-0100418 & 2 \\
\hline 58 & Gayunan & C. reticulata & SRA-0100600 & 3 \\
\hline 59 & Giant & C. reticulata & SRA-0100420 & 1 \\
\hline 60 & Hall Sg & C. deliciosa & SRA-0100522 & 3 \\
\hline 61 & Hickson & C. reticulata & SRA-0100523 & 1 \\
\hline 62 & Imperial & C. reticulata & SRA-0100587 & 1 \\
\hline 63 & Improved & C. reticulata & SRA-0100421 & 3 \\
\hline 64 & Kobayashi & C. reticulata & SRA-0100782 & 4 \\
\hline 65 & Ladu x Szibat & C. reticulata & SRA-0100589 & 2 \\
\hline 66 & Ladu x Szinking & C. reticulata & SRA-0100588 & 2 \\
\hline 67 & Le Roux & C. reticulata & SRA-0100496 & 1 \\
\hline
\end{tabular}




\begin{tabular}{|c|c|c|c|c|}
\hline 68 & Lebon Sg & C. reticulata & SRA-0100425 & 1 \\
\hline 69 & Lime Sucrée & C. reticulata & SRA-0100424 & 2 \\
\hline 70 & Lukan & C. reticulata & SRA-0100654 & 1 \\
\hline 71 & Macaque & C. reticulata & SRA-0100426 & 5 \\
\hline 72 & Nanfen Miguan & C. reticulata & SRA-0100700 & 4 \\
\hline 73 & Nicaragua & C. reticulata & SRA-0100693 & 5 \\
\hline 74 & Oneco & C. reticulata & SRA-0100429 & 1 \\
\hline 75 & Pan American & C. reticulata & SRA-0100706 & 1 \\
\hline 76 & Robinson & C. reticulata & SRA-0100139 & $?$ \\
\hline 77 & Small Sg & C. deliciosa & SRA-0100526 & 3 \\
\hline 78 & sud-est Martinique & C. reticulata & SRA-0100435 & 1 \\
\hline 79 & Sun chu sha & C. reticulata & SRA-0100786 & 5 \\
\hline 80 & Suntara & C. reticulata & SRA-0110251 & 4 \\
\hline 81 & Tshello & C. reticulata & SRA-0100723 & 1 \\
\hline 82 & Warnuco & C. reticulata & SRA-0100439 & 2 \\
\hline 83 & Willowleaf $x$ Blood & C. reticulata & SRA-0100440 & 3 \\
\hline 84 & Xien Khuang & C. reticulata & SRA-0100868 & 5 \\
\hline 85 & Anana & C. reticulata & IVIA-390 & 5 \\
\hline 86 & Carvahal & C. reticulata & IVIA-568 & 3 \\
\hline 87 & Emperor & C. reticulata & IVIA-394 & 1 \\
\hline 88 & Imperial Australia & C. reticulata & IVIA-576 & 1 \\
\hline 89 & Ponkan & C. reticulata & IVIA-482 & 1 \\
\hline 90 & Scarlet & C. reticulata & IVIA-411 & 2 \\
\hline 91 & Sun chu sha & C. reticulata & IVIA-483 & 5 \\
\hline 92 & Ougan & C. suavissima & SRA-0100680 & 4 \\
\hline 93 & Ben Di Zao & C. succosa & SRA-0100582 & 4 \\
\hline 94 & de Soe & C. suhuiensis & SRA-0100713 & $?$ \\
\hline 95 & de Soe & C. suhuiensis & SRA-0100653 & $?$ \\
\hline 96 & de Soe & C. suhuiensis & SRA-0100735 & $?$ \\
\hline 97 & Pet Yala & C. suhuiensis & SRA-0100694 & $?$ \\
\hline 98 & Se Hui Gan & C. suhuiensis & SRA-0100586 & 2 \\
\hline 99 & Szibat & C. suhuiensis & SRA-0100596 & 1 \\
\hline 100 & Szinkom & C. suhuiensis & SRA-0100597 & 3 \\
\hline 101 & Yala & C. suhuiensis & SRA-0100655 & $?$ \\
\hline 102 & Sunki & C. sunki & SRA-0100971 & 5 \\
\hline 103 & Sunki & C. sunki & SRA-0100705 & 5 \\
\hline 104 & Sunki & C. sunki & SRA-0100970 & 4 \\
\hline 105 & Sunki & C. sunki & IVIA-239 & 5 \\
\hline 106 & C. tachibana & C. tachibana & IVIA-237 & 5 \\
\hline 107 & Brickaville & C. tangerina & SRA-0100266 & 2 \\
\hline 108 & Da Hong Pao & C. tangerina & SRA-0100591 & $?$ \\
\hline 109 & Mandalina & C. tangerina & SRA-GA1145 & 2 \\
\hline 110 & Redskin & C. tangerina & SRA-0100428 & $?$ \\
\hline 111 & Sanguine Trabut & C. tangerina & SRA-0100264 & 2 \\
\hline 112 & Swatow & C. tangerina & SRA-0100175 & 1 \\
\hline 113 & Sweet Small & C. tangerina & SRA-0100826 & 5 \\
\hline 114 & Zanzibar Sg & C. tangerina & SRA-0100442 & 2 \\
\hline 115 & Beauty of Glen Retreat & C. tangerina & SRA-0100261 & 2 \\
\hline 116 & Dancy & C. tangerina & IVIA-434 & 1 \\
\hline 117 & Parson's Special & C. tangerina & IVIA-168 & 2 \\
\hline 118 & Tankan Sg & C. tankan & SRA-0100524 & 1 \\
\hline 119 & Temple & C. temple & SRA-0100176 & 2 \\
\hline 120 & Temple Sue Linda & C. temple & SRA-0100467 & 2 \\
\hline 121 & Temple & C. temple & IVIA-81 & 2 \\
\hline 122 & Clausellina & C. unshiu & IVIA-19 & 4 \\
\hline 123 & Dobashi-Beni & C. unshiu & SRA-0100681 & 4 \\
\hline 124 & Frost & C. unshiu & IVIA-175 & 4 \\
\hline 125 & Okitsu & C. unshiu & IVIA-195 & 4 \\
\hline 126 & Bendiguangju & C. unshiu & SRA-0100578 & 4 \\
\hline 127 & Kowano & C. unshiu & SRA-0100167 & 4 \\
\hline 128 & Pucheng & C. unshiu & SRA-0100657 & 4 \\
\hline 129 & Salzara & C. unshiu & SRA-0100341 & 4 \\
\hline 130 & (Orange) Sanh & Unknown & SRA-\#45 & $?$ \\
\hline 131 & Bandipur (Népal) & Unknown & SRA-\#NEPAL2 & 1 \\
\hline 132 & Caibe & Unknown & SRA-\#11 & $?$ \\
\hline 133 & Importé De Chine Marché Hanoï & Unknown & SRA-\#27 & 1 \\
\hline 134 & Matieu (Laï Vung) & Unknown & SRA-\#18 & $?$ \\
\hline 135 & Paper (Qu'yt Giay) & Unknown & SRA-\#8 & $?$ \\
\hline 136 & S. E. & Unknown & SRA-0100433 & 3 \\
\hline
\end{tabular}

(N) Nuclear group. 


\section{DISCUSSION}



Citrus is one of the most important fruit crops in the world due to its economic importance. Despite the fact that its diversity (Krueger and Navarro, 2007) and origin have been widely studied (Webber et al., 1967; Calabrese, 1992) the taxonomy, diversity and phylogeny of Citrus remain controversial. This is due to the large degree of morphological diversity found within this group, the sexual compatibility between the species and the apomixis of many genotypes (Scora, 1975).

In this $\mathrm{PhD}$ thesis a broad diversity of germplasm within the Citrus genus and Citrus relatives from the Aurantioideae subfamily has been studied in order to clarify their organization and phylogeny using different kind of molecular markers and different genotyping platforms.

\section{New set of complementary markers have been developed.}

Many different kinds of markers have been used to study the citrus diversity, from morphological characteristics (Barret and Rhodes, 1976; Ollitrault et al., 2003), quantification of primary (Luro et al., 2011) and secondary metabolites (Fanciullino et al., 2006a), to molecular markers, isoenzymes (Herrero et al., 1996; Ollitrault et al., 2003), RFLP (Federici et al., 1998), RAPD, SCAR (Nicolosi et al., 2000), AFLP (Liang et al., 2007) and SSR (Luro et al., 2001; Barkley et al., 2006).

Several works have been recently published with the aim of developing diagnostic markers of the inter-specific differentiation in citrus. In the framework of this thesis, Garcia-Lor et al. (2012a) released for the first time in citrus insertion-deletion (indel) markers, and Garcia-Lor et al. (2013a) identified SNP markers mined in a large diversity panel, while (Ollitrault et al., 2012a) analysed the value of SNPs mined in a single genotype of clementine. These recent papers, and the other previously cited, agree that most of the important commercial citrus species (secondary species) can be considered a mosaic of large DNA fragments of three ancestral species (C. medica L. -citrons-, C. maxima (Burm.) Merr. -pummelos- and $C$. reticulata Blanco -mandarins-) that resulted from a few inter-specific recombination events (Curk et al., 2012). It is also accepted that $C$. micrantha, a member of the Papeda subgenus, is a potential parent of some limes (C. aurantifolia (L.) Christm.).

Indel markers developed in this thesis (Garcia-Lor et al., 2012a; 2013a) seemed to be better phylogenetic markers than SSRs, as they are less polymorphic (low allele number) but display a higher organisation of genetic diversity at the interspecific level $\left(F_{\mathrm{st}}\right.$ value higher than SSR). On the other hand, SSR markers showed a higher level of polymorphism and a better differentiation between varieties at intraspecific level.

Indels are more common in non-coding regions than in coding regions, as has been shown in other species like Brassica (Park et al., 2010), melon (Morales et al., 2004), or maize (Ching et al., 2002). Indels play an important role in sequence divergence between closely related DNA sequences in animals, plants, insects and bacteria (Bapteste, 2002; Väli et al., 2008; Vasemägi et al., 2010). In humans, it has been suggested that indels are a major source 
of gene defects. When they occur in coding regions they probably have functional roles and are considered to be a significant source of evolutionary change in eukaryotic and bacterial evolution (Britten et al., 2003). They can also be included in genetic linkage maps, as it is the case of clementine (Ollitrault et al., 2012b).

The high level of SSR markers polymorphisms is due the high evolution rate of the number of repeats (Weber and Wong, 1993; Jarne and Lagoda, 1996), that can vary depending on the number of repeats or base composition (Bachtrog et al., 2000). However, due to this important rate of variation, homoplasy should be relatively frequent, as Barkley et al. (2009) demonstrated in citrus and this limits the value of SSRs as phylogenetic markers.

Considering indel and SSR characteristics discussed before, these markers are complementary in diversity studies. Therefore, we have combined both kind of markers for the quantification of the exact contribution of ancestral genomes to the secondary species and some modern hybrids (Garcia-Lor et al., 2012a) and for the study of the organization of the mandarin germplasm diversity (Garcia-Lor et al., submitted) coming from two germplasm collections: IVIA Citrus Germplasm Bank of pathogen-free plants (Navarro et al., 2002), and the collection at the Station de Recherches Agronomiques (INRA/CIRAD).

From the 1097 SNPs identified by Garcia-Lor et al. (2013a) in a study based on Sanger sequencing of gene fragments in a broad discovery panel, forty-one of the mined SNP loci selected from a limited intra-generic discovery panel (C. reticulata, C. maxima and C. medica) were converted into efficient markers based on Competitive Allele-Specific PCR to perform a genotyping study through the KASPar genotyping system (KBiosciences) (Garcia-Lor et al., 2013b). The aim was to test their transferability across the Aurantioideae subfamily (Swingle and Reece, 1967). This genotyping method lost efficiency as the genetic distance was increasing. Within the Citrus genus, the secondary species and hybrids the missing data level was very low. It increased slightly in the close citrus and primitive citrus groups of the Citrinae subtribe, reaching higher levels for the two other subtribes of the Citreae tribe, the Triphasilinae and the Balsamocitrinae. The highest missing data level was found in the Clauseniae tribe. The conformity level between KASPar genotyping and Sanger sequencing was $95.41 \%$ (2.99\% did not agree and $1.60 \%$ were missing data).

Moreover, 53 SNP loci where successfully integrated in a GoldenGate array and used for genetic diversity analysis (Ollitrault et al., 2012a) and genetic mapping (Ollitrault et al., 2012b). The level of conformity in Ollitrault et al. (2012a) was $99.2 \%$ with Sanger sequencing, confirming that this technique it is still a good method for SNP discovery.

These SNP markers will be important for the management of citrus germplasm collections and marker/trait association studies. 


\section{New insights have been obtained on the phylogeny of ancestral taxa.}

For a biologically complex crop like citrus, the information obtained from nuclear gene sequences is more useful than the information from maternally-inherited chloroplast or mitochondrial sequences (Ramadugu et al., 2011; Puritz et al., 2012) due to the possibility of gene flow between sexually compatible species and the fact that the species belong to the same area of diversification. We have performed a study based on Sanger sequencing of gene fragments in a broad discovery panel (Garcia-Lor et al., 2013a; annex chapter 2) to clarify the phylogenetic relationships between 'true citrus fruit trees' of the subtribe Citrinae (Fortunella, Eremocitrus, Poncirus, Microcitrus, Clymenia and Citrus). The starting dataset employed in this study was selected in order to avoid the ascertainment bias associated with a low genetic basis of a small discovery panel (Rosenblum and Novembre, 2007; Albrechtsen et al., 2010; Ollitrault et al., 2012a).

Nuclear phylogenetic analysis revealed that all 'true citrus fruit trees' species constitute a monophyletic clade, as it was previously shown (de Araújo et al., 2003; Bayer et al., 2009). The latter added two more species to this group, Oxanthera and Feroniella (not present in our study). An important observation was that $C$. reticulata and Fortunella are joined in a cluster that is differentiated from the clade that includes the three other basic taxa of cultivated citrus $(C$. maxima, C. medica and $C$. micrantha). These results confirm the taxonomic subdivision between the subgenera Metacitrus (East Asiatic floral zone) and Archicitrus (Indo-Malayan floral zone) and the geographical distribution of species divided by the 'Tanaka line' (Tanaka, 1954). Interestingly, some phenotypic traits (like the carotenoid content) differentiate these two clades. On one hand, Fortunella, Poncirus and $C$. reticulata are facultative apomictic species with high carotenoid contents, and on the other hand, C. maxima and C. medica are monoembryonic non-apomictic species, which have strong limitations in the carotenoid pathway. The apomixis might have been transferred to the secondary species via $C$. reticulata genome (Garcia-Lor et al., 2013a). The speciation between Fortunella, Poncirus and C. reticulata, that share the same geographic distribution, might be explained by their different flowering periods (very precocious in Poncirus and late in Fortunella). However, gene flow probably occurred by accidental out-oftime flowering. Despite sharing the Indo-Malayan floral zone (Tanaka, 1954), C. maxima and C. medica were geographically separated, with a more intertropical specialisation for C. maxima.

The genus Clymenia (Annex chapter 2) is placed in the same clade than Microcitrus and Eremocitrus, which are clearly differentiated from Citrus and Fortunella clusters. Moreover, the null amount of heterozygosity in the gene fragments analysed indicates that Clymenia cannot be an interspecific or intergeneric hybrid. Our analysis is in agreement with Bayer et al. (2009) and Morton (2009), who observed Clymenia closely to Microcitrus and Eremocitrus in a phylogenetic study with cpDNA markers. From morphological data Swingle and Reece (1967) proposed that $C$. medica was closely related to Clymenia. In our results, the branch including Clymenia, Microcitrus and Eremocitrus is sister of the one formed by C. maxima and C. medica, confirming their probable relationship. 
The higher level of non-synonymous to silent SNP rates per site $\left(\pi_{\text {nonsyn }} / \pi_{\text {sil }}\right)$ found in citrus species than in other species, like white spruce (Pavy et al., 2006) or Arabidopsis thaliana (Zhang et al., 2002), may be due to a lower purifying selection pressure in the 'true citrus fruit trees'. This can probably be attributed to the wide diversity encompassed by 'true citrus fruit trees' and the high genetic and phenotypic differentiation between the different taxa that have experienced allopatric evolution under highly differentiated environmental conditions.

Despite the fact that some genes exhibit selective pressure, the genetic organization found in citrus with SNP data is similar to previous SSR studies (Ollitrault et al., 2010; GarciaLor et al., 2013a), which suggests that the diversity existing in both kind of markers comes from similar types of evolution. For this reason, a neutral evolution pattern can be assumed in most of the SNP markers identified.

\section{The origin of the secondary commercial species has been assessed.}

As mentioned before, secondary species ( $C$. sinensis -sweet orange-, C. aurantium sour orange-, C. paradisi-grapefruit-, C. limon-lemon- and C. aurantifolia-lime-) and many recent hybrids come from interspecific hybridisations between the basic Citrus taxa ( $C$. maxima, C. reticulata, $C$. medica and C. micrantha). Within these secondary species, we do not found intercultivar polymorphism at intraspecific level for $C$. sinensis, $C$. aurantium and $C$. paradisi (SSR, indel, mtDNA and SNP markers), whereas these species are highly heterozygous (SSRs, indels, SNPs). The same observation was made for clementine cultivars. Our results agree with previous molecular studies (Barkley et al., 2006; Luro et al., 2008) and confirm that most of the inter-varietal polymorphisms within these secondary species and in clementines and satsumas, arose from punctual mutation or movement of transposable elements (Breto et al., 2001). Therefore, the quantification of the ancestral genomes contributions and the mosaic genome structure inferred from one or two genotypes can be extended to other cultivars of the same secondary species.

An important result of this research concerns to the origin of sweet orange (C. sinensis). Roose et al., (2009) and (Garcia-Lor et al., 2012a) showed that sweet orange posses almost a $75 \%$ of $C$. reticulata genome and a $25 \%$ from $C$. maxima, which indicated that a backcross 1 (BC1) [(C. maxima $\times C$. reticulata) $\times C$. reticulata] should be the most probable origin of $C$. sinensis. This BC1 theory was also proposed by $\mathrm{Xu}$ et al. (2013) from whole genome sequencing data. This theory differed with the hypothesis of Nicolosi et al. (2000) and Barkley et al. (2006) who proposed that sweet orange arose from a direct hybridization between $C$. maxima and C. reticulata. We have shown (Garcia-Lor et al., 2012a) that the two previous hypotheses were not in agreement with the genomic organisation of sweet orange. Indeed, based in multilocus SNP analysis we demonstrated the presence of nuclear genomic fragments in phylogenetic homozygosity inherited from C. maxima or C. reticulata. This result leads to state that the two parents of sweet orange were of interspecific origin (Garcia-Lor et al., 2013a). 
This conclusion was further confirmed by the whole genome sequencing analysis performed by the International Citrus Genome Consortium (Gmitter et al., 2012).

It was proposed that grapefruit (C. paradisi) arose from a natural cross between $C$. maxima and C. sinensis (de Moraes et al., 2007; Ollitrault et al., 2012a). From SSR and indel data we have estimated (Garcia-Lor et al., 2012a) that the genomic contributions of $C$. reticulata and C. maxima were respectively around $60 \%$ and $40 \%$. This was confirmed with SNP data by (Garcia-Lor et al., 2013a).

Citrus aurantium (sour orange) is thought to come from a natural hybridisation between C. maxima and C. reticulata (Nicolosi et al., 2000; Uzun et al., 2009). Our research (Garcia-Lor et al., 2013a) showed a contribution from $C$. reticulata and C. maxima of $50 \%$. Interestingly we also found that the genotype mandarin 'Suntara' share a lot of rare alleles with $C$. aurantium and could be either a parent or a hybrid from C. aurantium (Garcia-Lor et al., 2012a).

This work has confirmed the hypothesis proposed by Nicolosi et al., (2000) for the origin of $C$. limon (lemon), that resulted from a direct cross between $C$. medica and $C$. aurantium, as we have observed a tri-hybrid genome constitution (C. medica, C. maxima and C. reticulata) (Garcia-Lor et al., 2012a, 2013a). Citrus aurantifolia (Mexican lime) was proposed by (Nicolosi et al., 2000) to be a hybrid between C. medica and a Papeda. Most of our data fits with this theory, but in some SNP loci the C. micrantha (Papeda) used did not agree with this hypothesis.

Clementine is thought to have arisen from a cross between 'Willowleaf' mandarin and $C$. sinensis (Nicolosi et al., 2000; Ollitrault et al., 2012a, b). Parental contributions observed in our work were not exactly the same, but the two studies agree with the previous hypothesis (GarciaLor et al., 2012a, 2013a).

\section{The genetic organisation of the mandarin germplasm was revealed.}

An important focus of our research was the diversity of the mandarin-like genotypes, which are an increasing component of the citrus fresh fruit market (second most important group worldwide, FAOSTAT, 2010). The mandarin horticultural varietal group is highly polymorphic (Moore, 2001) and it is highly related with one of the basic taxa of the cultivated citrus $(C$. reticulata). It also includes genotypes introgressed by other species, like tangors (hybrids between $C$. reticulata and $C$. sinensis) and tangelos (hybrids between $C$. reticulata and C. paradisi). The precise contribution of the ancestral species to the mandarin group was not known.

Several botanical classifications have been proposed for mandarins. For Swingle and Reece (1967) all mandarins are included in C. reticulata, Webber (1943) divided the mandarins in four groups ('King', satsuma, mandarin and tangerine), Hodgson (1967) classified the mandarins in four species [C. unshiu (satsumas), C. reticulata ('Ponkan', 'Dancy', clementines), C. deliciosa ('Willowleaf') and C. nobilis ('King')], while Tanaka (1961) considered 36 mandarin species included in five groups. In addition to the taxonomic complexity of this citrus group, the 
incorrect passport information of some genotypes and the redundancy present in citrus germplasm collections are extra problems (Krueger and Roose, 2003).

From molecular data, it is well documented that the mandarin group (C. reticulata) is clearly differentiated from the other Citrus species, C. maxima, C. medica and C. micrantha (Nicolosi et al., 2000; Barkley et al., 2006; Garcia-Lor et al., 2012a). Some works have tried to clarify the organization of the mandarin group (Coletta Filho et al., 1998; Koehler-Santos et al., 2003; Yamamoto and Tominaga, 2003; Tapia Campos et al., 2005), but they are not conclusive. Recently, Froelicher et al. (2011) divided the mandarins in two groups, acid and sweet, based on mitochondrial indel markers. In this $\mathrm{PhD}$ thesis, joining the information coming from 50 SSRs and 25 indel markers dispersed throughout the genome, the introgression of other genomes $(C$. maxima, C. medica, Papeda or Fortunella) was quantified in a broad representation of the mandarin like germplasm (198 genotypes). The genome with the higher contribution is $C$. maxima, followed by Papeda, C. medica and Fortunella in a few genotypes. Similar contributions were observed by Barkley et al. (2006) in some genotypes. Our analysis clearly shows that some mandarins considered by Tanaka as species are not true mandarins, since they are hybrids between different ancestral taxa. This is the case of $C$. amblycarpa, $C$. depressa, C. tachibana, C. succosa (C. reticulata and Papeda genomes) and $C$. indica that has $C$. reticulata and $C$. medica genomic contributions. These results indicate that the Tanaka classification is not accurate and should be revised.

We have analysed the mandarin germplasm organization with two approaches, the Structure software (it uses a model-based clustering method using genotype data) and Neighbour Joining analysis (based in the simple matching dissimilarity index $\left(d_{i-j}\right)$ between pairs of accessions). Both analyses come to the agreement that five groups can be defined to be the parental mandarins at nuclear level. Four are related with some Tanaka species $[C$. reticulata (N1), C. unshiu (N2), C. deliciosa (N3), C. tangerina (N4), while the last group includes different mandarin types (N5; acid mandarins, small fruit mandarins)]. Two more clusters including genotypes with clearly identified interspecific introgressions and their descendants were identified within the 'mandarin-like' germplasm, 'Ampefy', 'Wallent' and 'Gailang' group (N6, it shares a high percentage of more than $90 \%$, of allelic similarity with the sweet oranges) and the tangor 'King' group (N7), which is parent of many hybrids.

Considering the five mandarin parental groups defined in this thesis, the contribution of these groups to the constitution of the other mandarin genomes was studied with the software Structure.

Most of the hybrids with known origin had a coherent genome structure when compared with their parents. In some cases they do not display totally additive contributions from their ancestors, which is logical considering the heterozygosity of their parents and the different reconstruction of the genomes through the mating process (Motohashi et al., 1992; Coletta Filho et al., 1998). In other cases, our data contradict previous information in some genotypes, as it happened with 'Fortune' and 'Fremont' hybrids, which were supposed to come from a cross 
between C. clementina and C. tangerina 'Dancy' and C. clementina x C. reticulata 'Ponkan', respectively, made by Furr (1964).

Mitochondrial markers are very useful to analyse the maternal phylogeny in citrus (Green et al., 1986; Yamamoto et al., 1993). In the mandarin germplasm studied in this work, four mitotypes were found. Two of them (C1, C2) were identified respectively by (Froelicher et al., 2011) as sweet and acid mandarin mitotypes. However, in our study with more mandarin genotypes, C2 included acid but also sweet genotypes. The acid mandarins included in the C2 mytotype belong to two groups of acid genotypes identified by Tanaka (1954), C. reshni, C. sunki and $C$. tachibana in one group and $C$. depressa in another one. The mandarin mitochondrial mitotype group (C1) identified as 'sweet mandarin mitotype' by Froelicher et al. (2011) is divided in four groups with nuclear markers, C. reticulata (N1), C. unshiu (N2), C. deliciosa (N3), and C. tangerina (N4). The other two mitotypes observed correspond to the Papeda (C3; three genotypes) and the $C$. maxima mitotypes (C4; seven genotypes). The nuclear genetic structure of these ten last genotypes, sharing the C. maxima and Papeda mitotypes, were clear interspecific admixture, not true mandarins.

\section{The genetic organization precludes association genetic studies based on linkage} disequilibrium at the Citrus level but suggest potential application at mandarin germplasm level.

The data obtained with the three kinds of markers used for the diversity and phylogenetic studies (Indel, SSR and SNPS), revealed that the Citrus gene pool is highly structured in direct relation with the ancestral taxa differentiation. The deficit of heterozygous genotypes observed in the whole sample indicates a strong population subdivision (Hartl and Clark, 1997) and, therefore, a low gene flow between $C$. medica, $C$. reticulata and $C$. maxima. The differentiation between these sexually compatible taxa can be explained by the origin in three geographic zones and by an initial allopatric evolution. Citrus maxima originated in the Malay Archipelago and Indonesia, C. medica evolved in North-eastern India and the nearby region of Burma and China and $C$. reticulata diversification occurred over a region including Vietnam, Southern China and Japan (Webber et al., 1967; Scora, 1975). This allopatric evolution resulted in a global genotypic and phenotypic divergence due to different selective pressures (found in some of the genes studied), mutation and genetic drift. Later on, human activity facilitated migration and hybridization among the differentiated gene pools of the basic taxa. However, the partial apomixis observed in most of the secondary species, which probably arose from the $C$. reticulata germplasm, has strongly limited the interspecific gene flow.

This evolution of Citrus resulted in a high and generalised Linkage Disequilibrium (LD) revealed in this PhD thesis (chapter 1; Garcia-Lor et al., 2012a). This structure precludes association genetic studies at the genus level without developing additional recombinant populations from interspecific hybrids. 
The decay of LD with increasing genetic distance, found in the mandarin group (our unpublished data), a less structured population, was lower than in the Citrus population. These results suggest that a LD-based association studies at the species level could be affordable. Anyway, the development of additional intraspecific hybrids, such as BC1 or F2, between mandarins or the generation of hybrids between a mandarin and interspecific species, would improve the success of genetic association studies by decreasing the LD between distant loci and limiting the risk of false associations between a marker and a phenotype, even though the marker is not physically linked to the locus responsible for the phenotypic variation.

\section{Evolutionary patterns of different genes should be related with phenotypic polymorphisms.}

Some genes of the different biosynthetic pathways studied presented interesting evolutionary patterns. Carotenoids are involved in different processes, like photosynthesis, fruit color, and precursors of vitamin A and have antioxidant capacity (Demmig-Adams et al., 1996; Lee, 2002; Rao and Rao, 2007). Therefore, changes in the sequences of genes involved in their biosynthesis may have important consequences in these processes. Our analysis showed that the phytoene synthase (PSY), the first gene in the pathway, presented some amino acid changes considering the eight taxa studied, but not within individual taxon. Moreover, data indicates that it has undergone positive selection. The lycopene $\beta$-cyclase (LCYB) is an important enzyme for the conversion of lycopene into $\beta$-carotenoids (Fanciullino et al., 2006b; Alquézar et al., 2009). In our study, some amino acid changes were found different between $C$. maxima and $C$. reticulata that might be associated with the limitation in the conversion of lycopene in C. maxima (Fanciullino et al., 2007). The $\beta$-carotene hydroxylase (HYB) is a very important enzyme involved in the catalyzation of $\beta$-carotene into $\beta$-cryptoxanthin and zeaxanthin (Fanciullino et al., 2006b). We found strong differences between the three main citrus ancestors. Citrus reticulata continue the pathway and accumulate the products, however, $C$. maxima stops at this level and $C$. medica only convert $\beta$-carotene into $\beta$-cryptoxanthin.

Flavonoids are nother important compounds in fruit quality, which can give color to the leaves and flowers, are involved in the auxin transport, attract pollinators and are also antioxidant (Kaur and Kapoor, 2001; Winkel-Shirley, 2001). The enzyme chalcone isomerase $(\mathrm{CHI})$ controls the second step of the flavonoid biosynthesis. In our work it appeared to be under positive selection at the inter-specific level due to differences between taxa. A second gene, the flavonoid 3'-hydroxylase (F3'H), showed positive selection only in C. reticulata. It has been shown to be important in flavonoid biosynthesis in Arabidopsis (Schoenbohm et al., 2000) and grapevine (Bogs et al., 2006). Therefore, understanding $\mathrm{F}^{\prime} \mathrm{H}$ and $\mathrm{CHI}$ regulation and allelic functionality could be important for the analysis of molecular determinants of flavonoid composition in citrus fruits.

Within the genes studied in the acid biosynthesis, only the malic enzyme (EMA), which is involved in the last steps of the citric acid cycle, showed positive selection at interspecific 
level, therefore it could be related with the different acid content existing between Citrus taxa (Penniston et al., 2008).

Another important characteristic in the citrus fruit quality is the sugar content, which increases along the maturation process (Albertini et al., 2006), but none of the genes studied presented positive selection and they are highly conserved.

For the genes related to plant stress response, the NADH kinase (NADK2) displayed a non-synonymous/synonymous ratio greater than 1 . This enzyme plays an important role in the phosphorylation of NAD $(\mathrm{H})$ and have been shown to change the sensitivity to abiotic stress in A. thaliana (Chai et al., 2005). 


\section{Future prospects}

This work has released new information about the genetic relationships of taxa in the Citrus genus and relative species that will help in the breeding of new, high-quality citrus cultivars and the conservation of the existing material.

Sanger sequencing of nuclear genes has provided information on the mosaic structure of secondary species and recent hybrids (Garcia-Lor et al., 2013a). Parallel sequencing of individual DNA molecules (454 Roche pyrosequencing) will allow to define multilocus haplotypes of heterozygous genotypes and to perform a deeper phylogenetic assignement of DNA fragments of the main cultivated species (Curk et al., 2012).

For all of the genes discussed in this report displaying amino acid variability of corresponding proteins (probably subjected to selection), it would be interesting to complete their full sequence (including promoter sequencing) and to perform allelic functional studies to decipher the molecular basis of the phenotypic variability in the species that were examined. It would also be interesting to obtain polymorphism information of partial or full sequence of the genes, missing in this work, from the biosynthesis pathway analysed.

Another contribution of this work has been the proper characterization of the two citrus germplasm collections analysed with molecular markers which will help in their management, the determination of which accessions must be preserved or removed in order not to lose diversity, and also which should be introduced to cover lack of diversity. A database including all the data generated in this work is being implemented and will help citrus breeders and geneticists in their research.

Gene banks are founded with the aim to conserve the genetic diversity of crop species, but large germplasm collections lead to management problems (space, maintenance cost, etc.) (van Hintum et al., 2000). In this context, the concept of core collections was proposed to reduce the size of large germplasm collections (10-15\% of the initial collection) and keep the maximum variability (at least the $80 \%$ ), leading to a better use of the genetic resources present in the germplasms (Frankel and Brown, 1984; Pessoa-Filho et al., 2010). In the near future, it will be afford for the first time in Citrus the establishment of a core collection, specifically in $C$. reticulata, which is the second most important group in the fresh fruit market worldwide. 
CONCLUSIONS 

According to the results obtained in this $\mathrm{PhD}$ thesis the following general conclusions can be established:

1) The development of nuclear indel markers, for the first time in citrus, has allowed us to demonstrate its usefulness for diversity and phylogenetic studies in the genus Citrus. They can become an important source of genetic markers with easy and inexpensive genotyping.

2) The comparison between indel, SNP and SSR markers shows their application as complementary molecular markers. Indel and SNP markers appear to be better phylogenetic markers for tracing the contributions of the ancestral species to the secondary species and modern cultivars and the SSR markers are more useful for intraspecific diversity analysis.

3) The contribution of each basic taxa (C. reticulata, C. maxima, C. medica and $C$. micrantha) to the genomes of secondary species and modern cultivars has been quantified, and the their origins are in agreement with those previously proposed in the case of sour orange, grapefruit, lemon and lime.

4) Regarding the sweet orange, it seems to have a different origin to what was previously proposed. The first study with indel and SSR markers suggested that $C$. sinensis could not be a direct cross between a mandarin ( $C$. reticulata) and a pummelo (C. maxima), as it was previously believed. It could be the result of a backcross 1 (BC1) [(C. maxima $\times$ C. reticulata) $\times$ C. reticulata]. The study with SNP markers lead to the conclusion that the two parents of sweet orange were of interspecific origin due to the presence of nuclear genomic fragments in phylogenetic homozygosity inherited from C. maxima and C. reticulata.

5) No intercultivar polymorphisms had been previously found at intraspecific level for C. sinensis, C. aurantium and C. paradisi. Even in the attempt to find polymorphisms by gene seguencing (Garcia-Lor et al., 2013a) and SNP genotyping (Garcia-Lor et al., 2013b) in several secondary species genotypes, no polymorphisms were detected which confirms that most of the inter-varietal polymorphisms within these secondary species arise from punctual mutation or movement of transposable elements.

6) The initial differentiation between the basic species and a limited number of interspecific meiosis generated a genetic organisation of the citrus gene pool with high and generalised linkage disequilibrium. This structure does not allow association genetic studies at the genus level without the development of additional recombinant populations from interspecific hybrids. However, it could be possible to perform association genetic studies at intraspecific level in a less structured pool such as $C$. reticulata, where most of the breeding programs are been developed in several countries. 
7) The core subset of markers identified can differentiate between accessions and study their origin. It could be useful for quick and inexpensive genotyping at interspecific and intraspecific level in existing or new accessions in germplasm banks.

8) Some of the SNP loci mined in this study have been converted into efficient markers to perform high throughput genotyping studies in Illumina GoldenGate Array and have been used for diversity analysis and genetic mapping. They will be useful for the management of citrus germplasm collections and marker/trait association studies.

9) Generally neutral evolution has been observed in the 27 genes studied (carotenoid, flavonoid, acid biosynthesis pathways and some related to plant response to stresses), but for a few genes [phytoene synthase (PSY), lycopene $\beta$-cyclase (LCYB), $\beta$-carotene hydroxylase (HYB), chalcone isomerase $(\mathrm{CHI})$, flavonoid 3'hydroxylase $\left(\mathrm{F}^{\prime} \mathrm{H}\right)$, malic enzyme (EMA), NADH kinase 2 (NADK2)] positive selection was observed within or between the species studied, suggesting that these genes may play a key role in phenotypic differentiation. These seven genes are therefore major candidates for future studies, including complete gene sequencing and functional analysis of different alleles to analyse the molecular basis of the phenotypic differentiation of corresponding traits.

10) The nuclear phylogeny of Citrus and its sexually compatible relatives showed coherence with the geographic distribution and differentiation proposed by the 'Tanaka line' (Tanaka, 1954). Citrus reticulata and Fortunella share the same area of diversification, where the subgenus Metacitrus predominates (East-Asiatic floral zone), and appeared to be closely related. The cluster that joins $C$. medica and $C$. maxima is in agreement with the area of distribution where the subgenus Archicitrus predominates (Indo-Malayan floral zone).

11) The present study already allowed us to assign a phylogenetic inheritance of the genes that were examined for most of the genotypes of interspecific origin under study. With the next release of the pseudo chromosome sequence assembly of the reference haploid clementine genome (Gmitter et al., 2012), the assignation of the phylogenetic origin of these 27 genes will contribute to the deciphering of the interspecific mosaic genome structure of the secondary species.

12) Sanger sequencing it is still an important resource for many kinds of studies and it has a high level of accuracy as it has been shown in the works of Ollitrault et al. (2012a), where $99.2 \%$ of the SNPs in common were in agreement with the GoldenGate genotyping, and Garcia-Lor et al. (2013b), where the level of conformity with KASpar genotyping was $95.41 \%$, while $2.99 \%$ did not agree and $1.60 \%$ was missing data. 
13) SNP genotyping based on Competitive Allele-Specific PCR (KASpar) appears to be an interesting approach for low-to-medium throughput genotyping. The SNP markers developed from sequence data of a limited intra-generic discovery panel (three ancestral species, C. medica, C. reticulata, and C. maxima), provide a valuable molecular resource for genetic diversity analysis of germplasm within a genus and should be useful for germplasm fingerprinting at a much broader diversity level.

14) The transferability of these SNP markers to the genera of the subfamily Aurantioideae was not complete. The frequency of missing data was higher for the citrus relatives than within the Citrus genus and increased with taxonomic distances within the Aurantioideae subfamily.

15) The genotypes from the germplasm collections of the Instituto Valenciano de Investigaciones Agrarias (IVIA) and the Station de Recherches Agronomiques (CIRAD-INRA) have been well characterized through different kinds of molecular markers. This study has detected some redundancies and has improved the management of the citrus collections existing in their orchards. This data has updated the databases existing in both research centers.

16) Regarding the mandarin horticultural varietal group, it has been shown that it is a highly polymorphic group and that many genotypes, believed to be pure mandarins, have shown introgression in their genomes from C. maxima, C. medica, Papeda and Fortunella, even though some of them presented non-mandarin maternal origin.

17) A new organization of the mandarin germplasm has been defined in this study, showing that many genotypes have originated from the cross between mandarins, besides the genotypes that presented other ancestral genome contributions.

18) Although new insights in the mandarin germplasm structure have been released in this work, there is still a lot of work to do to clarify more precisely their phylogeny. Future sequencing of mandarin genotypes (single genes or whole genomes) will help to perform phylogenetic analysis and decipher the exact genome constitution of this highly polymorphic group.

19) In the near future, by using the entire citrus genome as a reference and resequencing data from the main secondary species, the resulting estimations of the relative levels of within and between taxa differentiation will be useful for deciphering the interspecific mosaic structure of the citrus secondary cultivated species and modern cultivars. 

LITERATURE CITED 

Abdurakhmonov IY, Abdukarimov A. 2008. Application of Association Mapping to Understanding the Genetic Diversity of Plant Germplasm Resources. International Journal of Plant Genomics ID 574927, doi:10.1155/2008/574927.

Abkenar AA, Isshiki S, Tashiro Y. 2004. Phylogenetic relationships in the "true citrus fruit trees" revealed by PCR-RFLP analysis of cpDNA. Scientia Horticulturae 102: 233-242.

Agrama HA, Yan WG. 2009. Association mapping of straighthead disorder induced by arsenic in Oryza sativa. Plant Breeding 128: 551-558.

Ahmad R, Struss D, Southwick S. 2003. Development and characterization of microsatellite in citrus. Journal American. Society Horticultural Science 128: 584-590.

Albertini MV, Carcouet E, Pailly O, Gambotti C, Luro F, Berti L. 2006. Changes in organic acids and sugars during early stages of development of acidic and acidless citrus fruit. Journal of Agricultural and Food Chemistry 54: 8335-8339.

Albrechtsen A, Nielsen FC, Nielsen R. 2010. Ascertainment Biases in SNP Chips Affect Measures of Population Divergence. Molecular biology and evolution 27: 2534-2547.

Aleza P, Juarez J, Hernandez M, Pina JA, Ollitrault P, Navarro L. 2009. Recovery and characterization of a Citrus clementina Hort. ex Tan. 'Clemenules' haploid plant selected to establish the reference whole Citrus genome sequence. BMC plant biology 9: 110.

Aleza P, Cuenca J, Juárez J, Pina JA, Navarro L. 2010. 'Garbí' Mandarin: a new latematuring triploid hybrid. HortScience 45: 139-141.

Aleza P, Froelicher Y, Schwarz S, Hernández M, Juárez J, Morillon R, Navarro L, Ollitrault P. 2011. Tetraploidization events by chromosome doubling of nucellar cells are frequent in apomictic citrus and are dependent on genotype and environment. Annals of Botany 108: 3750.

Alquézar B, Zacarias L, Rodrigo MJ. 2009. Molecular and functional characterization of a novel chromoplast-specific lycopene beta-cyclase from Citrus and its relation to lycopene accumulation. Journal of experimental botany 60: 1783-1797.

Amar MH, Biswas MK, Zhang Z, Guo W. 2011. Exploitation of SSR, SRAP and CAPS-SNP markers for genetic diversity of Citrus germplasm collection. Scientia Horticulturae 128: 220227.

de Araújo EF, de Queiroz LP, Machado MA. 2003. What is Citrus? Taxonomic implications from a study of $\mathrm{cp}$-DNA evolution in the tribe Citreae (Rutaceae subfamily Aurantioideae). Organisms Diversity \& Evolution 3: 55-62.

Bachtrog D, Agis M, Imhof M, Schlötterer C. 2000. Microsatellite Variability Differs Between Dinucleotide Repeat Motifs-Evidence from Drosophila melanogaster. Molecular biology and evolution 17: 1277-1285.

Bapteste EP, Hervé. 2002. The Potential Value of Indels as Phylogenetic Markers: Position of Trichomonads as a Case Study. Molecular Biology and Evolution 19: 972-977

Barkley NA, Roose ML, Krueger RR, Federici CT. 2006. Assessing genetic diversity and population structure in a citrus germplasm collection utilizing simple sequence repeat markers (SSRs). TAG Theoretical and Applied Genetics 112: 1519-1531. 
Barkley NA, Krueger RR, Federici CT, Roose ML. 2009. What phylogeny and gene genealogy analyses reveal about homoplasy in citrus microsatellite alleles. Plant Systematics and Evolution 282: 71-86.

Barrett HC and Rhodes AM. 1976. A numerical taxonomic study ofaffinity relationships in cultivated Citrus and its close relatives. Systematic Botany 1: 105-136.

Bastianel M, Schwarz SF, Coleta Filho HD, Lin LL, Machado M, Koller OC. 1998. Identification of zygotic and nucellar tangerine seedlings (Citrus spp.) using RAPD. Genetics and Molecular Biology 21.

Bauer F, Elbers CC, Adan RAH, Loos RJF. 2009. Obesity genes identified in genome-wide association studies are associated with adiposity measures and potentially with nutrient-specific food preference. American Journal of Clinical Nutrition 90: 951-959.

Bausher M, Shatters R, Chaparro J, Dang P, Hunter W, Niedz R. 2003. An expressed sequence tag (EST) set from Citrus sinensis L. Osbeck whole seedlings and the implications of further perennial source investigations. Plant Science 165: 415-422.

Bayer RJ, Mabberley DJ, Morton C, et al. 2009. A molecular phylogeny of the orange subfamily(Rutaceae: Aurantioideae) using nine cpDNA sequences. American Journal of Botany 96: 668-685

Behrouz Golein, Talaie A, Zamani Z, Ebadi A, Behjatnia A. 2005. Assessment of genetic variability in some Iranian sweet oranges (Citrus sinensis [L.] Osbeck) and mandarins (Citrus reticulata Blanco) using SSR markers. International Journal of Agriculture and Biology 7: 167170.

Belkhir K, Borsa P, Goudet J, Chikhi L, Bonhomme F. 2002. GENETIX v. 4.03, Logiciel sous Windows pour la génétique des populations. Laboratoire Génome et Population, Université de Montpellier 2, Montpellier, France. http://www.univ-montp2.fr.

Berhow MA, Hasegawa S, Kwan K, Bennett RD. 2000. Limonoids and the chemotaxonomy of Citrus and the Rutaceae family. In: Berhow, M.A., Hasegawa, S. and Manners, G.D., ed. Citrus Limonoids: Functional Chemicals in Agriculture and Food. American Chemical Society, Washington DC, 212-228.

Bernet GP, Gorris MT, Carbonell EA, Cambra M, Asins MJ. 2008. Citrus tristeza virus resistance in a core collection of sour orange based on a diversity study of three germplasm collections using QTL-linked markers. Plant Breeding 127: 398-406

Berrin J, Pierrugues O, Brutesco C, et al. 2005. Stress induces the expression of AtNADK-1, a gene encoding a NAD(H) kinase in Arabidopsis thaliana. Molecular Genetics and Genomics 273: 10-19.

Biswas M, Xu Q, Deng X. 2010. Utility of RAPD, ISSR, IRAP and REMAP markers for the genetic analysis of Citrus spp. Sci. Horticult. 124: 254-261.

Bogs J, Ebadi A, McDavid D, Robinson SP. 2006. Identification of the Flavonoid Hydroxylases from Grapevine and Their Regulation during Fruit Development. Plant Physiology 140: 279-291.

Botstein D, Risch N. 2003. Discovering genotypes underlying human phenotypes: past successes for mendelian disease, future approaches for complex disease. Nature Genetics 33: 228-237. 
Bouvier F, Backhaus RA, Camara B. 1998. Induction and control of chromoplast-specific carotenoid genes by oxidative stress. Journal of Biological Chemistry 273: 30651-30659.

Bové JM. 2006. Huanglongbing: A destructive, newly-emerging, century-old disease of citrus. Journal of Plant Pathology 88: 7-37.

Bramley PM. 2002. Regulation of carotenoid formation during tomato fruit ripening and development. 53: 2107-2113.

Breseghello F, Sorrells M. 2006. Association Analysis as a Strategy for Improvement of Quantitative Traits in Plants Crop. Sci. 46.

Bretó MP, Ruiz C, Pina JA, Asins MJ. 2001. The diversification of Citrus clementina Hort. ex Tan., a vegetatively propagated crop species. Molecular phylogenetics and evolution 21: 285293.

Britten RJ, Rowen L, Williams J, Cameron RA. 2003. Majority of divergence between closely related DNA samples is due to indels. Proceedings of the National Academy of Sciences of the United States of America 100: 4661-4665.

Brookes AJ. 1999. The essence of SNPs. Gene 234: 177-186.

Brown AHD. 1989. Core collections: a practical approach to genetic resources management. Genome, 31, 818-824.

Buckler E, Thornsberry J. 2002. Plant molecular diversity and applications to genomics. Current Opinion in Plant Biology 5: 107-111.

Cacciola S, Lio GMS. 2008. Management Of Citrus Diseases Caused By Phytophthora Spp. In: A Ciancio, KG Mukerji, eds. Springer Netherlands, 61-84.

Cai Q, Guy CL, Moore GA. 1994. Extension of the linkage map in Citrus using random amplified polymorphic DNA (RAPD) markers and RFLP mapping of cold-acclimation-responsive loci. Theoretical and Applied Genetics 89: 606-614.

Calabrese F. 1992. The history of citrus in the Mediterranean countries and Europe. International Society of Citriculture 1: 35-38.

Calabrese F. 1998. La favolosa storia degli agrumi. L'EPOS Società Editrice. Palermo, Italia: 172.

Cameroon J, Frost H. 1968. Genetic, breeding and nucellar embryony. In: Reuther, W.; Batchelor, L.D.; Webber, H.J. (eds) The Citrus Industry. V2. University of California, Berkeley, U.S.A.

Casa AM, Pressoir G, Brown PJ, Mitchell SE, Rooney WL, Tuinstra MR, Francks CD, Kresovich S. 2008. Community resources and strategies for association mapping in sorghum. Crop Science 48: 30-40.

Chai MF, Chen QJ, An R, Chen YM, Chen J, Wang XC. 2005. NADK2, an Arabidopsis chloroplastic NAD kinase, plays a vital role in both chlorophyll synthesis and chloroplast protection. Plant Molecular Biology 59: 553-564.

Chai MF, Wei PC, Chen QJ, et al. 2006. NADK3, a novel cytoplasmic source of NADPH, is required under conditions of oxidative stress and modulates abscisic acid responses in Arabidopsis. The Plant Journal 47: 665-674. 
Chen CX, Bowman KD, Choi YA, Dang PM, Rao MN, Huang S, Soneji JR, McCollum TG, Gmitter FG Jr. 2008. EST-SSR genetic maps for Citrus sinensis and Poncirus trifoliata. Tree Genetics and Genomes 4: 1-10.

Cheng Y, De Vicente MC, Meng H, Guo W, Tao N, Deng X. 2005. A set of primers for analyzing chloroplast DNA diversity in Citrus and related genera. Tree physiology 25: 661-672.

Chin H, Roberts E. 1980. Recalcitrant Crop Seeds. Tropical Press SDN. BHD, Kuala Lumpur.

Ching A, Caldwell KS, Jung M, Dolan M, Smith OS, Tingey S, Morgante M, Rafalski AJ. 2002. SNP frequency, haplotype structure and linkage disequilibrium in elite maize inbred lines. BMC Genetics 3: 19.

Clark AG, Hubisz MJ, Bustamante CD, Williamson SH, Nielsen R. 2005. Ascertainment bias in studies of human genome-wide polymorphism. Genome research 15: 1496-1502.

Coates BS, Sumerford DV, Miller NJ, Kim KS, Sappington TW, Siegfried BD, Lewis LC. 2009. Comparative Performance of Single Nucleotide Polymorphism and Microsatellite Markers for Population Genetic Analysis. Journal of Heredity 100: 556-564.

Coletta Filho HD, Machado MA, Targon MLPN, Moreira MCPQDG, Pompeu J Jr. 1998. Analysis of the genetic diversity among mandarins (Citrus spp.) using RAPD markers. Euphytica 102: 133-139.

Copeland L, Turner JF. 1987. The regulation of glycolysis and the pentose phosphate pathway. In A Marcus, ed, The Biochemistry of Plants: A Comprehensive Treatise, Davies DD. Academic Press, New York 11: 107-125.

Corazza-Nunes M, Machado MA, Nunes WMC, Cristofani M, Targon MLPN. 2002. Assessment of genetic variability in grapefruits (Citrus paradisi Macf.) and pummelos ( $C$. maxima (Burm.) Merr.) using RAPD and SSR markers. Euphytica 126: 169-176.

Cortés A, Chavarro M, Blair M. 2011. SNP marker diversity in common bean (Phaseolus vulgaris L.). Theoretical and Applied Genetics 123: 827-845.

Cuenca J, Aleza P, Juarez J, Pina JA, Navarro L. 2010. 'Safor' mandarin: a new citrus midlate triploid hybrid. HortScience 45: 977-980.

Cuenca J, Froelicher Y, Aleza P, Juarez J, Navarro L, Ollitrault P. 2011. Multilocus halftetrad analysis and centromere mapping in citrus: evidence of SDR mechanism for $2 n$ megagametophyte production and partial chiasma interference in mandarin cv 'Fortune'. Heredity 107: 462-470.

Cuenca J, Aleza P, Iborra E, Vicent A, Ollitrault P, Navarro L. 2012. Location of a chromosome region linked to Alternaria Brown Spot resistance from the evaluation of triploid mandarin populations. XII International Citrus Congress- Valencia, Spain. S02O14: 42.

Cunningham FX, J., Pogson B, ZaiRen S, McDonald KA, DellaPenna D, Gantt E. 1996. Functional analysis of the $\beta$ and $\varepsilon$ lycopene cyclase enzymes of Arabidopsis reveals a mechanism for control of cyclic carotenoid formation. Plant Cell 8: 1613-1626.

Cuppen E. 2007. Genotyping by Allele-Specific Amplification (KASPar). Cold Spring Harbor Protocols 9: 172-173.

Curk F, Ancillo G, Garcia-Lor A, Luro F, Navarro L, Ollitrault P. 2012. Multilocus haplotyping by parallel sequencing to decipher the interspecific mosaic genome structure of cultivated citrus. XII International Citrus Congress- Valencia, Spain. S01006: 28. 
Das A. 2003. Citrus canker: a review. Journal of Applied Horticulture 5: 52-60.

Davies FS, Albrigo LG. 1994. Cítricos. Ed Acribia, Zaragoza, España.

Del Caro A, Piga A, Vacca V, Agabbio M. 2004. Changes of flavonoids, vitamin C and antioxidant capacity in minimally processed citrus segments and juices during storage. Food Chemistry 84: 99-105.

Delseny M, Han B, Hsing YI. 2010. High throughput DNA sequencing: the new sequencing revolution. Plant Science 179: 407-422.

Demmig-Adams B, Gilmore A, Adams W. 1996. In vivo functions of carotenoids in higher plants. FASEB Journal 10: 403-412.

Deng Z, Gentile A, Nicolosi E, Continella G, Tribulato E. 1996. Parentage determination of some citrus hybrids by molecular markers. Proc Int Soc Citricul 2: 849-854.

Dereeper A, Guignon V, Blanc G, et al. 2008. Phylogeny.fr: robust phylogenetic analysis for the non-specialist. Nucleic acids research 36: W465-W469.

Deu M, Glaszmann JC. 2004. Linkage disequilibrium in sorghum. In Proceedings of the Plant and Animal Genome XII Conference, San Diego, 10- 14 January, Town \& Country Convention Center, San Diego, CA, W10

Dhuique-Mayer C, Caris-Veyrat C, Ollitrault P, Curk F, Amiot MJ. 2005. Varietal and interspecific influence on micronutrient contents in citrus from the Mediterranean area. Journal of Agricultural and Food Chemistry 53: 2140-2145.

Ding S, Zhang X, Bao Z, Ling M. 1984. A new species of Poncirus from China. Acta Botanica Yunnanica 6: 292-293.

Dong J, Qing-liang Y, Fu-sheng W, Li C. 2010. The mining of citrus EST-SNP and its application in cultivar discrimination. Agricultural Sciences in China 9: 179-190.

Duran-Vila N. 1995. Cryopreservation of germplasm of citrus. In: Anonymous Biotechnology in agriculture and forestry, cryopreservation of plant germplasm I. Springer, Berlin, 70-96.

Duran-Vila N, Pina J, Ballester J, Juarez, J, Roistacher CN, Rivera-Bustamante R, Semancik, JS. 1988. The citrus exocortis disease: a complex of viroid RNAs. Proceedings of the International Organization of Citrus Virologists 10: 152-164.

Ellwood SR, D'Souza NK, Kamphuis LG, Burgess TI, Nair RM, Oliver RP. 2006. SSR analysis of the Medicago truncatula SARDI core collection reveals substantial diversity and unusual genotype dispersal throughout the Mediterranean basin. TAG Theoretical and Applied Genetics 112: 977-983.

Engelmann F. 1997. In vitro conservation methods. In: Ford-Lloyd, B.V., Newburry, J.H. and Callow, J.A. (eds), ed. Biotechnology and Plant Genetic Resources: Conservation and Use. CABI: Wallingford, UK, 119.

Erickson L. 1968. The general physiology of citrus. In: W Reuther, LD Batchelor, H Webber, eds, The Citrus Industry, Vol II. University of California Press, Berkley.

Erlund I. 2004. Review of the flavonoids quercetin, hesperetin, and naringenin. Dietary sources, bioactivities, bioavailability, and epidemiology. Nutrition Research 24: 851-874. 
Escribano P, Viruel MA, Hormaza Jl. 2008. Comparison of different methods to construct a core germplasm collection in woody perennial species with simple sequence repeat markers. A case study in cherimoya (Annona cherimola, Annonaceae), an underutilised subtropical fruit tree species. Annals of Applied Biology 153: 25-32.

Evanno G, Regnaut S, Goudet J. 2005. Detecting the number of clusters of individuals using the software structure: a simulation study. Molecular ecology 14: 2611-2620.

Fajardo DS, Bonte DR, Jarret RL. 2002. Identifying and selecting for genetic diversity in Papua New Guinea sweetpotato Ipomoea batatas (L.) Lam. germplasm collected as botanical seed. Genetic Resources and Crop Evolution 49: 463-470.

Falush D, Stephens M, Pritchard JK. 2003. Inference of Population Structure Using Multilocus Genotype Data: Linked Loci and Correlated Allele Frequencies. Genetics 164: 1567-1587.

Fanciullino AL, Dhuique-Mayer C, Luro F, Casanova J, Morillon R, Ollitrault P. 2006a. Carotenoid diversity in cultivated citrus is highly influenced by genetic factors. Journal of Agricultural and Food Chemistry 54: 4397-4406.

Fanciullino AL, Tomi F, Luro F, Desjobert JM, Casanova J. 2006b. Chemical variability of peel and leaf oils of mandarins. Flavour and Fragrance Journal 21: 359-367.

Fanciullino AL, Dhuique-Mayer C, Luro F, Morillon R, Ollitrault P. 2007. Carotenoid biosynthetic pathway in the Citrus genus: number of copies and phylogenetic diversity of seven genes. Journal of Agricultural and Food Chemistry 55: 7405-7417.

Fanciullino AL, Cercos M, Dhique-Mayer, Froelicher Y, Talón M, Ollitrault P, Morillon R. 2008. Changes in carotenoid content and biosynthetic gene expression in juice sacs of four orange varieties (Citrus sinensis) differing in flesh fruit color. Journal of Agricultural and Food Chemistry 56: 3628-3638.

Fang D, Roose ML, Krueger RR, Federici CT. 1997. Fingerprinting trifoliate orange germ plasm accessions with isozymes, RFLPs, and inter-simple sequence repeat markers. Theoretical and Applied Genetics 95: 211-219.

Fang D, Krueger RR, Roose ML. 1998. Phylogenetic relationships among selected Citrus germplasm accessions revealed by inter-simple sequence repeat (ISSR) markers. Journal of the American Society for Horticultural Science 123: 612-617.

Fantz PR. 1988. Nomenclature of the Meiwa and Changshou kumquats, intrageneric hybrids of Fortunella. HortScience 23: 249-250.

Food and Agriculture Organization of the United Nations, FAOSTAT database. Available at http://faostat.fao.org/

Federici CT, Fang DQ, Scora RW, Roose ML. 1998. Phylogenetic relationships within the genus Citrus (Rutaceae) and related genera as revealed by RFLP and RAPD analysis. Theoretical and Applied Genetics 96: 812-822.

Fideghelli C, Sansavini S. 2002. The fruit industry and the role of research in the Mediterranean Basin. Acta Horticulturae (ISHS) 582: 69-76.

Flint-Garcia SA, Thornsberry JM, Buckler ES. 2003. Structure of linkage disequilibrium in plants. Annual Review Plant Biology 54: 357-374. 
Forment J, Gadea J, Huerta L, et al. 2005. Development of a citrus genome-wide EST collection and cDNA microarray as resources for genomic studies. Plant Molecular Biology 57: 375-391.

Fournier-Level A, Le Cunff L, Gomez C, Doligez A, Ageorges A, Roux C, Bertrand Y, Souquet JM, Cheynier V, This P. 2009. Quantitative Genetic Bases of Anthocyanin Variation in Grape (Vitis vinifera L. ssp. sativa) Berry: A Quantitative Trait Locus to Quantitative Trait Nucleotide Integrated Study. Genetics 183: 1127-1139.

Frankel O, Brown A. 1984. Current plant genetic resources - a critical appraisal. In: VL Chopra, B Joshi, R Sharma, H Bansal, eds. In Genetics: New Frontiers. Oxford and IBH Publishing: New Delhi, India., 1-13.

Froelicher Y, Dambier D, Bassene JB, Costantino G, Lotfy S, Didout C, Beaumont V, Brottier P, Risterucci AM, Luro F, Ollitrault P. 2008. Characterization of microsatellite markers in mandarin orange (Citrus reticulata Blanco). Molecular ecology resources 8: 119-122.

Froelicher Y, Mouhaya W, Bassene JB, Costantino G, Kamiri M, Luro F, Morillon R, Ollitrault P. 2011. New universal mitochondrial PCR markers reveal new information on maternal citrus phylogeny. Tree Genetics and Genomes 7: 49-61.

Frydman A, Weisshaus O, Bar-Peled M, Huhman DV, Sumner LW, Marin FR, Lewinsohn E, Fluhr R, Gressel J, Eyal Y. 2004. Citrus fruit bitter flavors: isolation and functional characterization of the gene $\mathrm{Cm} 1,2 \mathrm{Rh}$ T $\mathrm{T}$ encoding a 1,2 rhamnosyltransferase, a key enzyme in the biosynthesis of the bitter flavonoids of citrus. The Plant Journal 40: 88-100.

Fu B, Chen M, Zou M, Long M, He S. 2010. The rapid generation of chimerical genes expanding protein diversity in zebrafish. BMC Genomics 11: 657.

Furr J. 1964. New tangerines for the desert. Calif. Citrog. 49: 266-276.

Garcia-Lor A, Luro F, Navarro L, Ollitrault P. 2012a. Comparative use of InDel and SSR markers in deciphering the interspecific structure of cultivated citrus genetic diversity: a perspective for genetic association studies. Molecular Genetics and Genomics 287: 77-94.

Garcia-Lor A, Garcia-Martinez J, Perez-Amador M. 2012b. Identification of ovule and seed genes from Citrus clementina. Tree Genetics \& Genomes 8: 227-235.

Garcia-Lor A, Curk F, Snoussi-Trifa H, Morillon R, Ancillo G, Luro F, Navarro L, Ollitrault P. 2013a. A nuclear phylogenetic analysis; SNPs, indels and SSRs deliver new insights into the relationships in the "true citrus fruit trees" group (Citrinae, Rutaceae) and the origin of cultivated species. Annals of botany 111: 1-19.

Garcia-Lor A, Ancillo G, Navarro L, Ollitrault P. 2013b. Citrus (Rutaceae) SNP markers based on Competitive Allele-Specific PCR; transferability across the Aurantioideae subfamily. Applications in Plant Sciences 1: doi:10.3732/apps.1200406.

Garris AJ, McCouch SR, Kresovich S. 2003. Population structure and its effect on haplotype diversity and linkage disequilibrium surrounding the xa5 locus of rice (Oryza sativa L.). Genetics 165: 759-769.

Garvin M, Saitoh K, Gharret A. 2010. Application of single nucleotide polymorphisms to nonmodel species: a technical review. Molecular Ecology Resources 10: 915-934.

Gattuso G, Barreca D, Gargiulli C, Leuzzi U, Caristi C. 2007. Flavonoid composition of Citrus juices. Molecules 12: 1641-1673. 
Gaydou EM, Bianchini JP, Randriamiharisoa RP. 1987. Orange and mandarin peel oils differentiation using polymethoxylated flavone composition. Journal of Agricultural and Food Chemistry 35: 525-529.

Genebank Standards. 1994. Food and Agriculture Organization of the United Nations, Rome, International Plant Genetic Resources Institute, Rome.

Germanà C, Sardo V. 1988. Correlations among some physiological and climatic parameters in orange trees. International Citrus Congress (6th: 1988 : Tel Aviv, Israel): Margraf 1: 525-534.

Ghislain M, DaPeng Z, Fajardo D, Huamán Z, Hijmans RJ. 1999. Marker-assisted sampling of the cultivated Andean potato Solanum phureja collection using RAPD markers. Genetic Resources and Crop Evolution 46: 547-555.

Gilmore AM, Yamamoto HY. 1993. Linear models relating xanthophylls and lumen acidity to non-photochemical fluorescence quenching. Evidence that antheraxanthin explains zeaxanthinindependent quenching. Photosynthesis Research 35: 67-78.

Gmitter FG Jr., Chen CX, Rao MN, Soneji JR. 2007. Citrus fruits. In: Kole KR (Ed.) Fruits and Nuts, Genome Mapping and Molecular Breeding in Plants. Springer, Heidelberg 4: 265-279.

Gmitter FG Jr., Ollitrault P, Machado M, Reforgiato-Recupero G, Talon M, Roose ML, Navarro L, Wu G, Jaillon O, Morgante M, Rokhsar DS. 2012. Genome sequence analysis and comparisons reveal ancestral hybridization and admixture events in the origins of some citrus cultivars. XII International Citrus Congress- Valencia, Spain. S03001: 61.

Golein B, Talaie A, Zamani Z, Ebadi A, Behjatnia A. 2005. Assessment of genetic variability in some Iranian sweet oranges (Citrus sinensis [L.] Osbeck) and mandarins (Citrus reticulata Blanco) using SSR markers. International Journal of Agriculture and Biology 7: 167-170.

Gómez-Cadenas A, Tadeo FR, Talon M, Primo-Millo E. 1996. Leaf abscission induced by ethylene in water-stressed intact seedlings of Cleopatra mandarin requires previous abscisic acid accumulation in roots. Plant Physiology 112: 401-408.

González-Arnao M, Juárez J, Ortega C, Navarro L, Duran-Vila N. 2003. Cryopreservation of ovules and somatic embryos of citrus using the encapsulation-dehydration technique. Cryo Letters 24: 85-94.

Goodwin TW. 1980. The biochemistry of the carotenoids. 2nd edn. Vol.1. London: Chapman and Hall.

Grauke LJ, Thompson TE, Marquard RD. 1995. Evaluation of pecan (Carya illinoinensis (Wangenh.) K. Koch) germplasm collections and designation of a core subset. HortScience 30: 950-954.

Green RM, Vardi A, Galun E. 1986. The plastome of Citrus. Physical map, variation among Citrus cultivars and species and comparison with related genera. Theoretical and Applied Genetics 72: 170-177.

Grenier C, Bramel-Cox P, Noirot M, Rao KEP, Hamon P. 2000. Assessment of genetic diversity in three subsets constituted from the ICRISAT sorghum collection using random vs non-random sampling procedures. A. Using morpho-agronomical and passport data. Theoretical and Applied Genetics 101: 190-196.

Groppo M, Pirani J, Salatino M, Blanco S, Kallunki J. 2008. Phylogeny of Rutaceae based on two noncoding regions from cpDNA. American Journal of Botany 95: 985-1005.

Gross M. 2004. Flavonoids and cardiovascular disease. Pharmaceutical Biology 42: 21-35. 
Gulsen O, Roose ML. 2001a. Chloroplast and nuclear genome analysis of the parentage of lemons. Journal of the American Society for Horticultural Science 126: 210-215.

Gulsen O, Roose ML. 2001b. Determination of genetic diversity and phylogenetic relations to citrus ancestors in lemons by DNA markers. Bahce 30: 53-63.

Gulsen O, Roose ML. 2001c. Lemons: diversity and relationships with selected Citrus genotypes as measured with nuclear genome markers. Journal of the American Society for Horticultural Science 126: 309-317.

Gulsen O, Uzun A, Canan I, Seday U, Canihos E. 2010. A new citrus linkage map based on SRAP, SSR, ISSR, POGP, RGA and RAPD markers. Euphytica 173: 265-278.

Gupta PK, Rustgi S, Kulwal PL. 2005. Linkage disequilibrium and association studies in higher plants: present status and future prospects. Plant Molecular Biology 57: 461-485.

Hall T. 1999. BioEdit: a user-friendly biological sequence alignment editor and analysis program for Windows 95/98/NT. Nucleic Acids Symposium Series 41: 95-98.

Hao CY, Zhang XY, Wang LF, Dong YS, Shang XW, Jia JZ. 2006. Genetic diversity and core collection evaluations in common wheat germplasm from the Northwestern Spring Wheat Region in China. Molecular Breeding 17: 69-77.

Hartl DL, Clark AG. 1997. Principles of population genetics. Sinauer Associates Incorporated: Sunderland, US.

Hayashi K, Yoshida H, Ashikawa I. 2006. Development of PCR-based allele-specific and InDel marker sets for nine rice blast resistance genes. TAG Theoretical and Applied Genetics 113: $251-260$.

Helyar SJ, Hemmer-Hansen J, Bekkevold D, Taylor MI, Ogden R Limborg MT, Cariani A, Maes GE, Diopere E, Carvalho GR, Nielsen EE. 2011. Application of SNPS for population genetics of nonmodel organisms: new opportunities and challenges. Molecular ecology resources 11 Suppl 1: 123-136.

Herrero R, Asíns MJ, Carbonell EA, Navarro L. 1996. Genetic diversity in the orange subfamily Aurantioideae. I. Intraspecies and intragenus genetic variability. Theoretical and Applied Genetics 92: 599-609.

Heuertz M, De Paoli E, Källman T, Larsson H, Jurman I, Morgante M, Lascoux M, Gyllenstrand N. 2006. Multilocus Patterns of Nucleotide Diversity, Linkage Disequilibrium and Demographic History of Norway Spruce [Picea abies (L.) Karst]. Genetics 174: 2095-2105.

Hirschberg J. 2001. Carotenoid biosynthesis in flowering plants. Current opinion in plant biology 4: 210-218.

Hodgson RW. 1967. Horticultural varieties of Citrus. In: Reuther W, Webber HJ, Batchelor LD. eds. The Citrus industry. Berkeley, CA: University of California Press, 431-589.

Hu J, Zhu J, Xu H. 2000. Methods of constructing core collections by stepwise clustering with three sampling strategies based on the genotypic values of crops. Theoretical and Applied Genetics 101: 264-268.

Hyoungshin P, Kreunen SS, Cuttriss AJ, DellaPenna D, Pogson BJ. 2002. Identification of the carotenoid isomerase provides insight into carotenoid biosynthesis, prolamellar body formation, and photomorphogenesis. Plant Cell 14: 321-332. 
HyunPyo K, KunHo S, HyeunWook C, SamSik K. 2004. Anti-inflammatory plant flavonoids and cellular action mechanisms. Journal of Pharmacological Sciences 96: 229-245.

Ingvarsson PK. 2005. Nucleotide Polymorphism and Linkage Disequilibrium Within and Among Natural Populations of European Aspen (Populus tremula L., Salicaceae). Genetics 169: 945953.

IPGRI. 1999. Descriptors for Citrus. International Plant Genetic Resources Institute, Rome, Italy.

Isaacson T, Ronen G, Zamir D, Hirschberg J. 2002. Cloning of tangerine from tomato reveals a carotenoid isomerase essential for the production of $\beta$-carotene and xanthophylls in plants. Plant Cell 14: 333-342.

Jaeger B, Goldbach H, Sommer K. 2000. Release from lime induced iron chlorosis by CULTAN in fruit trees and its characterisation by analysis. Acta Horticulturae 531: 107-113.

Jarne P, Lagoda PJL. 1996. Microsatellites, from molecules to populations and back Trends in ecology \& evolution 11: 424-429.

Johnson RC, Hodgkin T. 1999. Core collections for today and tomorrow. International Plant Genetic Resources Institute (IPGRI): Rome, Italy.

Jombart T, Devillard S, Balloux F. 2010. Discriminant analysis of principal components: a new method for the analysis of genetically structured populations. BMC Genetics 11: 94.

Jung Y, Kwon H, Kang S, Kang J, Kim S. 2005. Investigation of the phylogenetic relationships within the genus Citrus (Rutaceae) and related species in Korea using plastid trnL-trnF sequences. Scientia Horticulturae 104: 179-188.

Kacar Y, Uzun A, Polat I, Yesiloglu T, Yilmaz B, Gulsen O, Tuzcu O, Kamiloglu M, Kurt S, Seday U. 2013. Molecular characterization and genetic diversity analysis of mandarin genotypes by SSR and SRAP markers. Journal of Food Agriculture \& Environment 11: 516-521.

Kamiri M, Stift M, Srairi I, Costantino G, Moussadik AE, Hmyene A, Bakry F, Ollitrault P, Froelicher Y. 2011. Evidence for non-disomic inheritance in a Citrus interspecific tetraploid somatic hybrid between C. reticulata and C. limon using SSR markers and cytogenetic analysis. Plant Cell Reports 30: 1415-1425.

Kato M, Ikoma Y, Matsumoto H, Sugiura M, Hyodo H, Yano M. 2004. Accumulation of Carotenoids and Expression of Carotenoid Biosynthetic Genes during Maturation in Citrus Fruit. Plant Physiology 134: 824-837.

Kato M, Matsumoto H, Ikoma Y, Okuda H, Yano M. 2006. The role of carotenoid cleavage dioxygenases in the regulation of carotenoid profiles during maturation in citrus fruit. Journal of experimental botany 57 : 2153-2164.

Kaur C, Kapoor HC. 2001. Antioxidants in fruits and vegetables - the millennium's health. International Journal of Food Science \& Technology 36: 703-725.

Kawaii S, Tomono Y, Katase E, Ogawa $\quad$ K, $\quad$ Yano $\quad$ M. 1999. HL-60 differentiating activity and flavonoid content of the readily extractable fraction prepared from citrus juices. J Agric Food Chem. 47: 128-135.

Kay J, Weitzman P. 1987. Krebs' citric acid cycle: half a century and still turning. London: Biochemical Society. 
Kijas JMH, Fowler JCS, Thomas MR. 1995. An evaluation of sequence tagged microsatellite site markers for genetic analysis within Citrus and related species. Genome 38: 349-355.

Kijas JMH, Thomas MR, Fowler JCS, Roose ML. 1997. Integration of trinucleotide microsatellites into a linkage map of Citrus. Theoretical and Applied Genetics 94: 701-706.

Kim I, Ko K, Kim C, Chung W. 2001. Isolation and characterization of cDNAs encoding $\beta$ carotene hydroxylase in Citrus. Plant Science 161: 1005-1010.

Koca U, Berhow MA, Febres VJ, Champ KI, Carrillo-Mendoza O, Moore GA. 2009. Decreasing unpalatable flavonoid components in Citrus: the effect of transformation construct. Physiologia Plantarum 137: 101-114.

Koehler-Santos P, Dornelles ALC, Freitas LB. 2003. Characterization of mandarin citrus germplasm from Southern Brazil by morphological and molecular analyses. Pesquisa Agropecuária Brasileira 38: 797-806.

Kolkman J, Berry S, Leon A, et al. 2007. Single Nucleotide Polymorphisms and Linkage Disequilibrium in Sunflower. Genetics 177: 457-468.

Kotzé J. 1981. Epidemiology and control of citrus black spot in South Africa. Plant Disease 65: 945-950.

Krueger RR, Navarro L. 2007. Citrus germplasm resources. In: Khan IA, ed. Citrus Genetics, Breeding and Biotechnology. Wallingford, UK: CAB International, 45-140.

Krueger RR, Roose ML. 2003. Use of molecular markers in the management of citrus germplasm resources. Journal of the American Society for Horticultural Science 128: 827-837.

Kubo T, Hohjo I, Hiratsuka S. 2001. Sucrose accumulation and its related enzyme activities in the juice sacs of satsuma mandarin fruit from trees with different crop loads. Scientia Horticulturae 91: 215-225.

Külheim C, SuatHui Y, Maintz J, Foley WJ, Moran GF. 2009. Comparative SNP diversity among four Eucalyptus species for genes from secondary metabolite biosynthetic pathways. BMC Genomics 10: 452.

Lee HS. 2002. Characterization of major anthocyanins and the color of red-fleshed budd blood orange (Citrus sinensis). Journal of Agricultural and Food Chemistry 50: 1243-1246.

Lee RF. 2004. Certification Programs for Citrus. In: Naqvi SAMH (ed.) Diseases of Fruits and Vegetables, Springer Netherlands 1: 291-305.

Li W, Liu G, He S. 1992. Leaf isozymes of mandarin. Proc Int Soc Citricult 1: 217-220.

Li Y, Haseneyer G, Schon C, Ankerst D, Korzun V, Wilde P, Bauer E. 2011. High levels of nucleotide diversity and fast decline of linkage disequilibrium in rye (Secale cereale L.) genes involved in frost response. BMC Plant Biology 11: 6.

Liang G, Xiong G, Guo Q, He Q, Li X. 2007. AFLP analysis and the taxonomy of Citrus. Acta Horticulturae 760: 137-142.

Lijavetzky D, Cabezas J, Ibáñez A, Rodríguez V, Martínez-Zapater J. 2007. High throughput SNP discovery and genotyping in grapevine (Vitis vinifera L.) by combining a re-sequencing approach and SNPlex technology. BMC Genomics 8: 424. 
Liu K, Muse S. 2005. PowerMarker: an integrated analysis environment for genetic marker analysis. Bioinformatics 21: 2128-2129.

Liu YZ, Deng XX. 2007. Citrus breeding and genetics in China. The Asian and Australasian Journal of Plant Science and Biotechnology 1: 23-28.

Liu K, Warnow TJ, Holder MT, Nelesen SM, Yu J, Stamatakis AP, Linder CR. 2012. SATé-II: Very Fast and Accurate Simultaneous Estimation of Multiple Sequence Alignments and Phylogenetic Trees. Systematic Biology 61: 90-106.

Lo Piero AR, Puglisi I, Rapisarda P, Petrone G. 2005. Anthocyanins Accumulation and Related Gene Expression in Red Orange Fruit Induced by Low Temperature Storage. Journal of Agricultural and Food Chemistry 53: 9083-9088.

Lota ML, Serra DR, Tomi F, Casanova J. 2000. Chemical variability of peel and leaf essential oils of mandarins from Citrus reticulata Blanco. Biochemical systematics and ecology 28: 61-78.

Lotfy S, Luro F, Carreel F, Froelicher Y, Rist D, Ollitrault P. 2003. Application of cleaved amplified polymorphic sequence method for analysis of cytoplasmic genome among Aurantioideae intergeneric somatic hybrids. Journal of the American Society for Horticultural Science 128: 225-230.

Luro F, Laigret F, Bove JM, Ollitrault P. 1995. DNA amplified fingerprinting, a useful tool for determination of genetic origin and diversity analysis in Citrus. HortScience 30: 1063-1067.

Luro F, Rist D, Ollitrault P. 2001. Evaluation of genetic relationships in Citrus genus by means of sequence tagged microsatellites. Acta Horticulturae 546: 237-242.

Luro F, Maddy F, Jacquemond C, Froelicher Y, Morillon R, Rist D, Ollitrault P. 2004. Identification and evaluation of diplogyny in clementine (Citrus clementina) for use in breeding. Acta Horticulturae 663: 841-847.

Luro FL, Costantino G, Terol J, Argout X, Allario T, Wincker P, Talon M, Ollitrault P, Morillon R. 2008. Transferability of the EST-SSRs developed on Nules clementine (Citrus clementina Hort ex Tan) to other Citrus species and their effectiveness for genetic mapping. BMC genomics 9: 287.

Luro F, Gatto J, Costantino G, Pailly O. 2011. Analysis of genetic diversity in Citrus. Plant Genetic Resources 9: 218.

Mabberley DJ. 1997. A classification for edible Citrus (Rutaceae). Telopea 7: 167-172.

Mabberley DJ. 2004. Citrus (Rutaceae): a review of recent advances in etymology, systematics and medical applications. Blumea 49: 481-498.

Malosetti M, Abadie T. 2001. Sampling strategy to develop a core collection of Uruguayan maize landraces based on morphological traits. Genetic Resources and Crop Evolution 48: 381 390.

Marita JM, Rodriguez JM, Nienhuis J. 2000. Development of an algorithm identifying maximally diverse core collections. Genetic Resources and Crop Evolution 47: 515-526.

Martinez-Godoy M, Mauri N, Juarez J, Marques MC, Santiago J, Forment J, Gadea J. 2008. A genome-wide $20 \mathrm{~K}$ citrus microarray for gene expression analysis. BMC Genomics 9: 318.

McIntosh CA, Latchinian L, Mansell RL. 1990. Flavanone-specific 7-O-glucosyltransferase activity in Citrus paradisi seedlings: purification and characterization. Archives of Biochemistry and Biophysics 282: 50-57. 
McKhann HI, Camilleri C, Bérard A, Bataillon T, David JL, Reboud X, Le Corre V, Caloustian C, Gut IG, Brunel D. 2004. Nested core collections maximizing genetic diversity in Arabidopsis thaliana. Plant Journal 38: 193-202.

Middleton E, Kandaswami C. 1992. Effects of flavonoids on immune and inflammatory cell functions. Biochem Pharmacol 43: 1167-1179.

Mills R, Luttig C, Larkins C, Beauchamp A, Tsui C, Pittard WS, Devine SE. 2006. An initial map of insertion and deletion (INDEL) variation in the human genome. Genome research 16: 1182-1190.

Moore GA. 2001. Oranges and lemons: clues to the taxonomy of Citrus from molecular markers. Trends in Genetics 17: 536-540.

de Moraes A, dos Santos Soares Filho W, Guerra M. 2007. Karyotype diversity and the origin of grapefruit. Chromosome Research 1: 115-121.

Morales M, Roig E, Monforte AJ, Arús P, Garcia-Mas J. 2004. Single-nucleotide polymorphisms detected in expressed sequence tags of melon (Cucumis melo L.). Genome 47: $352-360$.

Moreno P, Ambrós S, Albiach-martí MR, Guerri J, Peña L. 2008. Citrus tristeza virus: a pathogen that changed the course of the citrus industry. Molecular Plant Pathology 9: 251-268.

Morton CM. 2009. Phylogenetic relationships of the Aurantioideae (Rutaceae) based on the nuclear ribosomal DNAITS region and three noncoding chloroplast DNA regions, atpB-rbcL spacer, rps16, and trnL-trnF. Organisms, Diversity\&Evolution 9: 52-68.

Motohashi T, Matsuyama T, Akihama T. 1992. DNA fingerprinting in Citrus cultivars. Proc Int Soc Citriculture : 221-224

Mouly PP, Arzouyan CR, Gaydou EM, Estienne JM. 1994. Differentiation of citrus juices by factorial discriminant analysis using liquid chromatography of flavanone glycosides. Journal of Agricultural and Food Chemistry 42: 70-79.

Navarro L, Roistacher C, Murashige T. 1975. Improvement of Shoot-Tip Grafting Invitro for Virus-Free Citrus. Journal of the American Society for Horticultural Science 100: 471-479.

Navarro L, Ballester J, Juárez J, Pina J, Arregui J, Bono R. 1981. Development of a program for desease-free citrus budwood in Spain. Proc. Int. Soc. Citriculture 1: 452-456.

Navarro L, Pina J, Juarez J, Ballester-OImos JF, Arregui JM, Ortega C, Navarro A, DuranVila N, Guerri J, Moreno P, Cambra M, Zaragoza S. 2002. The Citrus Variety Improvement Program in Spain in the period 1975-2001. In: N Duran-Vila, R Milne, J da Graça, eds. Proceedings of the 15th Conference of the International Organization of Citrus Virologists. Riverside, California, 306-316.

Navarro L. 2005. Necesidades y problemáticas de la mejora sanitaria y genética de los cítricos en España. Phytoma. 170: 2-5.

Navarro L, Aleza P, Juárez J. 2006a. Mejora de la calidad de los cítricos. In: G. Llácer, M.J. Díez, J.M. Carrillo y M.L. Badenes (eds), Mejora Genética de la calidad de las plantas. Sociedad Española de Ciencias Hortícolas. Sociedad Española de Genética. Universidad Politécnica de Valencia, España. 579-596.

Navarro L, Juárez J, Aleza $\mathbf{P}$, et al. 2006b. Selección de nuevos mandarinos triploides. Agraria Comunitat Valenciana. 2ª́poca, año 2 7: 23-26. 
Nicolosi E, Deng ZN, Gentile A, Malfa S, Continella G, Tribulato E. 2000. Citrus phylogeny and genetic origin of important species as investigated by molecular markers. Theoretical and Applied Genetics 100: 1155-1166.

Nicolosi E. 2007. Origin and taxonomy. In: Khan I (ed) Citrus genetics, breeding and biotechnology. CAB International: Wallington, 19-43.

Nijman I, Kuipers S, Verheul M, Guryev V, Cuppen E. 2008. A genome-wide SNP panel for mapping and association studies in the rat. BMC Genomics 9: 95.

Nogata Y, Sakamoto K, Shiratsuchi H, Ishii T, Yano M, Ohta H. 2006. Flavonoid composition of fruit tissues of citrus species. Bioscience, Biotechnology and Biochemistry 70: 178-192.

Nordborg M, Borevitz JO, Bergelson J, Berry CC, Chory J, Hagenblad J, Kreitman M, Maloof JN, Noyes T, Oefner PJ, Stahl EA, Weigel D. 2002. The extent of linkage disequilibrium in Arabidopsis thaliana. Nature genetics 30: 190-193.

Novelli VM, Takita MA, Machado MA. 2004. Identification and analysis of single nucleotide polymorphisms (SNPs) in citrus. Euphytica 138: 227-237.

Novelli VM, Cristofani M, Souza AA, Machado MA. 2006. Development and characterization of polymorphic microsatellite markers for the sweet orange (Citrus sinensis L. Osbeck). Genetics and Molecular Biology 29: 90-96.

Olivares-Fuster Ó, Hernández-Garrido M, Guerri J, Navarro L. 2007. Plant somatic hybrid cytoplasmic DNA characterization by single-strand conformation polymorphism. Tree physiology 27: 785-792.

de Oliveira RP, Cristofani M, Machado MA. 2002. Genetic mapping for citrus variegated chlorosis resistance. Laranja 23: 247-261.

de Oliveira RP, Aguilar-Vildoso $\mathrm{Cl}$, Cristofani M, Machado MA. 2004. Skewed RAPD markers in linkage maps of Citrus. Genetics and Molecular Biology 27: 437-441.

Ollitrault F, Terol J, Pina JA, Navarro L, Talon M, Ollitrault P. 2010. Development of SSR markers from Citrus clementina (Rutaceae) BAC end sequences and interspecific transferability in Citrus. American Journal of Botany 97: e124-9.

Ollitrault F, Terol J, Alonso Martin A, Pina JA, Navarro L, Talon M, Ollitrault P. 2012. Development of InDel markers from Citrus clementina (Rutaceae) BAC-end sequences and interspecific transferability in Citrus. American Journal of Botany. 99: 268-273.

Ollitrault P, and Luro F. 2001. Citrus. In Tropical Plant Breeding. 55.

Ollitrault P, Jacquemond C, Dubois C, Luro F. 2003. Citrus. In: Hannon P, Seguin M, Perrier X, Glaszmann JC (eds). Genetic diversity of cultivated tropical plants. Montpellier/Enfield, NH: CIRAD/Science Publishers, Inc., 193-217.

Ollitrault P, Navarro L. 2012. Citrus. In: M Badenes, D Byrne, eds. Fruit Breeding. Springer New York Dordrecht Heildelberg London, 623-662.

Ollitrault P, Terol J, Garcia-Lor A, Bérard A, Chauveau A, Froelicher Y, Belzile C, Morillon R, Navarro L, Brunel D, Talon, M. 2012a. SNP mining in C. clementina BAC end sequences; transferability in the Citrus genus (Rutaceae), phylogenetic inferences and perspectives for genetic mapping. BMC Genomics 13: 13. 
Ollitrault P, Terol J, Chen C, Federici CT, Lotfy S, Hippolyte I, Ollitrault F, Bérard A, Chauveau A, Costantino G, Kacar Y, Mu L, Cuenca J, Garcia-Lor A, Froelicher Y, Aleza P, Boland A, Billot C, Navarro L, Luro F, Roose ML, Gmitter FG, Talon M, Brune D. 2012b. A reference genetic map of $C$. clementina hort. ex Tan.; citrus evolution inferences from comparative mapping. BMC Genomics 13: 593.

Olson JA. 1989. Provitamin A function of carotenoids: the conversion of $\beta$-carotene into vitamin A. Journal of Nutrition 119: 105-108.

Omura M, Ueda T, Kita M, Komatsu A, Takanokura Y, Shimada T, Endo-Inagaki T, Nesumi H, Yoshida T. 2000. EST Mapping of Citrus. Proceedings of the International Society of Citriculture IX Congress. Orlando, FL, USA., 71-74.

Pang XM, Hu CG, Deng XX. 2003. Phylogenetic relationships among Citrus and its relatives as revealed by SSR markers. Acta Genet Sin 30: 81-87.

Pang XM, Hu CG, Deng XX. 2007. Phylogenetic relationships within Citrus and its related genera as inferred from AFLP markers. Genetic Resources and Crop Evolution 54: 429-436.

Park S, Yu HJ, Mum JH, Lee SC. 2010. Genome-wide discovery of DNA polymorphism in Brassica rapa. Mol Genet Genomics 283: 135-145.

Pavy N, Parsons L, Paule C, MacKay J, Bousquet J. 2006. Automated SNP detection from a large collection of white spruce expressed sequences: contributing factors and approaches for the categorization of SNPs. BMC Genomics 7: 174.

Peakall R, Smouse P. 2006. Genalex 6: genetic analysis in Excel. Population genetic software for teaching and research. Molecular Ecology Notes 6: 288-295.

Peeters JP, Martinelli JA. 1989. Hierarchical cluster analysis as a tool to manage variation in germplasm collections. Theoretical and Applied Genetics 78: 42-48.

Penjor T, Anai T, Nagano Y, Matsumoto R, Yamamoto M. 2010. Phylogenetic relationships of Citrus and its relatives based on rbcL gene sequences. Tree Genetics and Genomes 6: 931939.

Penniston K, Nakada S, Holmes R, Assimos D. 2008. Quantitative Assessment of Citric Acid in Lemon Juice, Lime Juice, and Commercially-Available Fruit Juice Products. Journal of Endourology 3: 567-570.

Perrier X, Jacquemoud-Collet J. 2006. DARwin software. http://darwin.cirad.fr/darwin 5.0.158.

Perrotta G, Graniti A. 1988. Phomatracheiphila (Petri) Kanchaveli \& Ghikashvili. In: Smith IM, Duarez J, Lelliott RA, Phillips DH, Archer SA (eds). In: European Handbook of the Plant Disease. Blackwell Scientific Publications, Oxford, 396-398.

Pessoa-Filho M, Rangel P, Ferreira M. 2010. Extracting samples of high diversity from thematic collections of large gene banks using a genetic-distance based approach. BMC Plant Biology 10: 127.

Pino Del Carpio D, Basnet R, De Vos R, Maliepaard C, Paulo M, Bonnema G. 2011. Comparative Methods for Association Studies: A Case Study on Metabolite Variation in a Brassica rapa Core Collection. PLoS ONE 6: e19624. doi:10.1371/journal.pone.0019624.

Plaxton WC. 1996. The organization and regulation of plant glycolisis.. Annual reviews of plant physiology and plant molecular biology 47: 185-214. 
Posada D, Crandall KA. 1998. MODELTEST: testing the model of DNA substitution. Bioinformatics 14: 817-818.

Praloran J. 1977. Los agrios. Técnicas agrícolas y producciones tropicales. Editorial Blume, Barcelona.

Price A,L Patterson NJ, Plenge RM, Weinblatt ME, Shadick NA, Reich D. 2006. Principal components analysis corrects for stratification in genome-wide association studies. Nature Genetics 38: 904-909.

Pritchard JK, Stephens M, Donnelly P. 2000. Inference of population structure using multilocus genotype data. Genetics 155: 945-959.

Puritz J, Addison J, Toonen R. 2012. Next-Generation Phylogeography: A Targeted Approach for Multilocus Sequencing of Non-Model Organisms. PLOS ONE 7: e34241. doi:10.1371/journal.pone.0034241.

Quang N, Ikeda S, Harada K. 2008. Nucleotide variation in Quercus crispula Blume. Heredity 101: 166-174.

Rafalski JA. 2010. Association genetics in crop improvement. Current opinion in plant biology 13: $174-180$

Rafalski A, Morgante M. 2004. Corn and humans: recombination and linkage disequilibrium in two genomes of similar size. Trends in Genetics 20: 103-111.

Ramadugu C, Keremane L, Lee R, Roose M. 2011. Single nucleotide polymorphisms in Citrus and members of Aurantioideae. Plant \& Animal Genomes XIX Conference, San Diego, CA. W147.

Raman H, Raman R, Wood R, Martin P. 2006. Repetitive indel markers within the ALMT1 gene conditioning aluminium tolerance in wheat (Triticum aestivum L.). Molecular Breeding 18: $171-183$

Rao AV, Rao LG. 2007. Carotenoids and human health. Pharmacological Research 55: 207216.

Rao MN, Soneji JR, Chen CX, Huang S, Gmitter FG, J. 2008. Characterization of zygotic and nucellar seedlings from sour orange-like citrus rootstock candidates using RAPD and EST-SSR markers. Tree Genetics and Genomes 4: 113-124.

Reich DE, Goldstein DB. 2001. Detecting association in a case-control study while correcting for population stratification. Genetic epidemiology 20: 4-16.

Remington DL, Thornsberry JM, Matsuoka Y, Wilson LM, Whitt SR, Doebley J, Kresovich S, Goodman MM, Buckler ES. 2001. Structure of linkage disequilibrium and phenotypic associations in the maize genome. Proceedings of the National Academy of Sciences of the United States of America 98: 11479-11484.

Reuther W. 1973. Climate and citrus behavior. pp. 281-337. En; Reuther W., L.D. Batchelor y H.J. Webber (eds.). Citrus industry. Vol. 3. University of California, Div. Agr. Sci., California.

Reuther W, Ríos-Castaño D. 1969. Comparison of growth, maduration and composition of citrus fruit in subtropical California and tropical Colombia. Proc. First Intl. Citrus Symp. 3: 277300. 
Riju A, Chandrasekar A, Arunachalam V. 2007. Mining for single nucleotide polymorphisms and insertions/deletions in expressed sequence tag libraries of oil palm. Bioinformation 2: 128131.

Roberts E. 1973. Predicting the storage life of seeds. Seed Science Technology 1: 499-514.

Rodrigo MJ, Marcos JF, Zacarías L. 2004. Biochemical and Molecular Analysis of Carotenoid Biosynthesis in Flavedo of Orange (Citrus sinensis L.) during Fruit Development and Maturation. Journal of Agricultural and Food Chemistry 52: 6724-6731.

Roose M, Federici C, Mu L, Kwok K, Vu C. 2009. Map-based ancestry of sweet orange and other citrus variety groups. In: Gentile A, Tribulato E. (eds.) Second International Citrus Biotechnology Symposium. Catania, Italy, 28.

Rosenblum EB, Novembre J. 2007. Ascertainment bias in spatially structured populations: a case study in the eastern fence lizard. The Journal of heredity 98: 331-336.

Rozen S, Skaletsky H. 2000. Primer3 on the WWW for general users and for biologist programmers. In: S In: Krawetz, Se Misener, eds. Bioinformatics methods and protocols: methods in molecular biology., Humana Press edn: Totowa, NJ., 365-386.

Russo G, Recupero S, Puglisi A, Recupero G. 2004. New triploid citrus hybrids by Italian genetic improvement. Rivista di Frutticoltura e di Ortofloricoltura. 66: 14-18.

Sachidanandam R, Weissman D, Schmidt S, et al. 2001. A map of human genome sequence variation containing 1.42 million single nucleotide polymorphisms. Nature 409: 928-933.

Sadka A, Dahan E, Or E, Roose ML, Marsh KB, Cohen L. 2001. Comparative analysis of mitochondrial citrate synthase gene structure, transcript level and enzymatic activity in acidless and acid-containing Citrus varieties. Australian Journal of Plant Physiology 28: 383-390.

Saitou N, Nei M. 1987. The Neighbor-joining Method: A New Method for Reconstructing Phylogenetic Trees. Molecular Biology Evolution 4: 406-425.

Sánchez R, Serra F, Tárraga J, Medina I, Carbonell J, Pulido L, de María A, CapellaGutíerrez S, Huerta-Cepas J, Gabaldón T, Dopazo J, Dopazo H. 2011. Phylemon 2.0: a suite of web-tools for molecular evolution, phylogenetics, phylogenomics and hypotheses testing. Nucleic Acids Research 39: 1-5.

Sandmann G. 2001. Carotenoid biosynthesis and biotechnological application. Archives of Biochemistry and Biophysics 385: 4-12.

Sanz ML, Villamiel M, Martínez-Castro I. 2004. Inositols and carbohydrates in different fresh fruit juices. Food Chemistry 87: 325-328.

Scarano M, Tusa N, Abbate L, Lucretti S, Nardi L, Ferrante S. 2003. Flow cytometry, SSR and modified AFLP markers for the identification of zygotic plantlets in backcrosses between 'Femminello' lemon cybrids ( $2 \mathrm{n}$ and $4 \mathrm{n}$ ) and a diploid clone of 'Femminello' lemon (Citrus limon L. Burm. F.) tolerant to mal secco disease. Plant Science 164: 1009-1017.

Schijlen EGWM, Vos CHR, Tunen AJ, Bovy AG. 2004. Modification of flavonoid biosynthesis in crop plants. Phytochemistry 65: 2631-2648.

Schoenbohm C, Martens S, Eder C, Forkmann G, Weisshaar B. 2000. Identification of the Arabidopsis thaliana flavonoid 3'-hydroxylase gene and functional expression of the encoded P450 enzyme. Biological Chemistry. 381: 749-753. 
Scora RW. 1975. On the history and origin of citrus. Bulletin of the Torrey Botanical Club 102: 369-375.

Scora RW, Kumamoto J, Soost RK,Nauer EM. 1982. Contribution to the origin of the grapefruit Citrus paradisi (Rutaceae). Systematic Botany 7: 170-177.

Scora RW. 1988. Biochemistry, taxonomy and evolution of modern cultivated Citrus. In: Goren R, Mendel K. (eds.) Proceedings of the 6th International Citrus Congress., Balaban Publishers; Weikersheim, Germany: Margraf Scientific Books edn: Philadelphia/Rehovot, 277-289.

Scott K, Mclntyre C, Playford J. 2000. Molecular analyses suggest a need for a signifi cant rearrangment of Rutaceae subfamilies and a minor reassessment of species relationships within Flindersia. Plant Systematics and Evolution 223: 15-27.

Shimada T, Fujii H, Endo T, Yazaki J, Kishimoto N, Shimbo K, Kikuchi S, Omura M. 2005. Toward comprehensive expression profiling by microarray analysis in citrus: monitoring the expression profiles of 2213 genes during fruit development. Plant Science 168: 1383-1385.

Shimada T, Nakano R, Shulaev V, Sadka A, Blumwald E. 2006. Vacuolar citrate/ $\mathrm{H}^{+}$ symporter of citrus juice cells. Planta 224: $472-480$.

Shimizu T, Fujii H, Nishikawa F, Shimada T, Kotoda N, Yano K, Endo T. 2009. Data mining of citrus sequence data sets to develop microarrays for expression and genomic analysis. Plant \& Animal Genome XVII Conference, San Diego, California, 414.

Shimizu T, Fujii H, Kotoda N, Yano K, Endo T. 2011. Data mining of citrus expression sequence data sets and application for functional genomic study. Acta Horticulturae 892: 29-36.

Shimizu T, Yoshiuka T, Nagasaki H, Kaminuma E, Toyoda A, Fujiyama A, Nakamura Y. 2012. Whole genome sequencing and mapping analysis for idenfiying polymorphism among 11 citrus varieties. XII International Citrus Congress- Valencia, Spain. S03O03, 62.

Simsek O, Kacar YA, Yesiloglu T, Ollitrault P. 2011. Determination by SSCP markers of the allelic diversity of candidate genes for tolerance to iron chlorosis in citrus germplasm. : 85-91.

Soost R, Cameroon J. 1969. Tree and fruit characters of Citrus triploid from tetraploid by diploid crosses. Hilgardia 20: 569-579.

Soost R, Cameron J. 1975. Citrus. In: Janick, J. and Moore, J.N. (eds) Advances in Fruit Breeding. Purdue University Press, West Lafayette, Indiana, 507-540.

Storey R, Walker RR. 1999. Citrus and salinity. Scientia Horticulturae 78: 39-81.

Swingle W. 1939. Clymenia and Burkillanthus, new genera also three new species of Pleiospermium (Rutaceae - Aurantioideae). J. Arnold Arbor. 20: 250-263.

Swingle W. 1943. The botany of Citrus and its wild relatives in the orange subfamily. In: Webber HJ, Batchelor LD (eds) The citrus industry. History, world distribution, botany and wild relatives. Berkeley CA: University of California 1: 129-474.

Swingle W, Reece P. 1967. The botany of Citrus and its wild relatives. In: Reuther W, Webber HJ, Batchelor LD (eds) The citrus industry. The botany of Citrus and its wild relatives. Berkeley CA: University of California 1: 190-430.

Tadeo F, Cercós M, Colmenero-Flores J, et al. 2008. Molecular Physiology of Development and Quality of Citrus. In: Anonymous Advances in Botanical Research. Academic Press, 147223. 
Tajima F. 1989a. DNA polymorphism in a subdivided population: the expected number of segregating sites in the two-subpopulation model. Genetics 123: 229-240.

Tajima F. 1989b. Statistical method for testing the neutral mutation hypothesis by DNA polymorphism. Genetics 123: 585-595.

Talon M, Gmitter Jr. FG. 2008. Citrus Genomics. International Journal of Plant Genomics. Article ID 528361, 17 pages, doi:10.1155/2008/528361.

Tanaka T. 1954. Species problem in Citrus (Revisio Aurantiacearum IX). Japanese Society for Promotion of Science, Tokyo, Japan.

Tanaka T. 1961. Citologia: semi-centennial commemoration papers on citrus studies. Citologia Supporting Foundation: Osaka, Japan, 114.

Tanaka T. 1977. Fundamental discussion of Citrus classification. Study in Citrologia, Osaka 14: 1-6.

Tanksley SD, McCouch SR. 1998. Seed banks and molecular maps: unlocking genetic potential from the wild. Crop Genetic Resources : 49-52.

Tapia Campos E, Gutiérrez Espinosa MA, Warburton ML, Santacruz Varela A, Villegas Monter Á. 2005. Characterization of mandarin (Citrus spp.) using morphological and AFLP markers. Interciencia 30: 687-693.

Terol J, Conesa A, Colmenero JM, Cercos M, Tadeo F, Agustí J, Alós E, Andres F, Soler G, Brumos J, Iglesias DJ, Götz S, Legaz F, Argout X, Courtois B, Ollitrault P, Dossat C, Wincker P, Morillon R, Talon M. 2007. Analysis of 13000 unique Citrus clusters associated with fruit quality, production and salinity tolerance. BMC genomics 8: 31 .

Terol J, Naranjo MA, Ollitrault P, Talon M. 2008. Development of genomic resources for Citrus clementina: characterization of three deep-coverage BAC libraries and analysis of 46,000 BAC end sequences. BMC genomics 9: 423.

Terol J, Carbonell J, Alonso R, et al. 2012. Sequencing of 150 citrus varieties: linking genotypes to phenotypes. XII International Citrus Congress-Valencia, Spain. S03002: 61.

The Arabidopsis Genome Initiative. 2000. Analysis of the genome sequence of the flowering plant Arabidopsis thaliana. Nature 408: 796-813.

Thornsberry JM, Goodman MM, Doebley J, Kresovich S, Nielsen D, Buckler ES. 2001. Dwarf8 polymorphisms associate with variation in flowering time. Nature genetics 28: 286-289.

Tokunaga T, Nii M, Tsumura T, Yamao M. 2005. Production of triploids and breeding seedless cultivar 'Tokushima $3 \mathrm{X}$ No.1' from tetraploid $\mathrm{x}$ diploid crosses in sudachi (Citrus sudachi Shirai). Horticultural Research 4: 11-15.

Torres AM, Soost RK, Diedenhofen U. 1978. Leaf isozymes as genetic markers in Citrus. American Journal of Botany 65: 869-881.

van Treuren R, Tchoudinova I, Soest LJM, Hintum TJL. 2006. Marker-assisted acquisition and core collection formation: a case study in barley using AFLPs and pedigree data. Genetic Resources and Crop Evolution 53: 43-52.

Tucker GA. 1993. Introduction. In : Biochemistry of fruit ripening, Seymour G, Taylor J, Tucker G (eds.) London: Chapman and Hall: 1-37. 
Tucker GA. 2003. Nutritional enhancement of plants. Current opinion in biotechnology 14: 221225.

Tudela D, Primo-Millo E. 1992. 1-Aminocyclopropane-1-carboxylic acid transported from roots to shoots promotes leaf abscission in Cleopatra mandarin (Citrus reshni Hort. ex Tan.) seedlings rehydrated after water stress. Plant Physiology 100: 131-137.

Turner W, Waller J, Vanderbeld B, Snedden W. 2004. Cloning and characterization of two NAD kinases from Arabidopsis: identification of a calmodulin binding isoform. Plant Physiology 135: $1243-1255$.

Turner W, Waller J, Snedden W. 2005. Identification, molecular cloning and functional characterization of a novel NADK kinase from Arabidopsis thaliana (thale cress). Biochemical Journal 385: 217-223.

Tuskan GA, DiFazio S, Jansson S, et al. 2006. The genome of black cottonwood, Populus trichocarpa (Torr. \& Gray). Science 313: 1596-1604.

Uzun A, Yesiloglu T, Aka-Kacar Y, Tuzcu O, Gulsen O. 2009. Genetic diversity and relationships within Citrus and related genera based on sequence related amplified polymorphism markers (SRAPs). Scientia Horticulturae 121: 306-312.

Väli Ü, Brandström M, Johansson M, Ellegren H. 2008. Insertion-deletion polymorphisms (indels) as genetic markers in natural populations. BMC Genetics 9: 8.

van Hintum TJL, Brown AHD, Spillane C, Hodgkin T. 2000. Core collections of plant genetic resources. IPGRI Technical Bulletin No. 3. Rome, Italy: International Plant Genetic Resources Institute.

Varshney R, Graner A, Sorrells M. 2005. Genic microsatellite markers in plants: features and applications. Trends in Biotechnology 23: 48-55.

Vasemägi A, Gross R, Palm D, Paaver T, Primmer CR. 2010. Discovery and application of insertion-deletion (INDEL) polymorphisms for QTL mapping of early life-history traits in Atlantic salmon. BMC Genomics 11: 156.

Vicent A, Badal J, Asensi MJ, Sanz N, Armengol J, García-Jiménez J. 2004. Laboratory Evaluation of citrus cultivars susceptibility and influence of fruit size on Fortune mandarin to infection by Alternaria alternata pv. citri. European Journal of Plant Pathology 110: 245-251.

Vicent A, Armengol J, Sales R, García-Jiménez J, Alfaro-Lassala F. 2000. First Report of Alternaria Brown Spot of Citrus in Spain. Plant Disease 84: 1044-1044.

Viruel M. 2010. Mejora genética y recursos fitogenéticos: "Nuevos avances en la conservación y utilización de los recursos fitogenéticos". Editores: JM Carrillo, MJ Díez, M Pérez de la Vega, F Nuez. Edita: Ministerio de Medio Ambiente y Medio Rural y Marino. ISBN: 978-84-491-10146. Pp: 319-349.

Volk G, Bonnart R, Shepherd A, Krueger RR, Lee R. 2012. Cryopreservation of citrus for long-term conservation. XII International Citrus Congress, Valencia-Spain. S01002: 27.

Wang ML, Barkley NA, Yu JK, Dean RE, Newman ML, Sorrells ME, Pederson GA. 2005. Transfer of simple sequence repeat (SSR) markers from major cereal crops to minor grass species for germplasm characterization and evaluation. Plant Genetic Resources 3: 45.

Watkins WS, Ricker CE, Bamshad MJ, Carroll ML, Nguyen SV, Batzer MA, Harpending HC, Rogers AR, Jorde LB. 2001. Patterns of ancestral human diversity: an analysis of Aluinsertion and restriction-site polymorphisms. American Journal of Human Genetics 68: 738-752. 
Webber HJ. 1943. Cultivated varieties of citrus. In: Webber HJ, Batchelor DL (eds.) The citrus industry. History, world distribution, botany and varieties, Berkeley CA: University of California, 1: 475-668.

Webber HJ, Reuther W, Lawton H. 1967. History and development of the citrus industry. In: Reuther W, Webber HJ, Batchelor LD (eds) The citrus industry. The botany of Citrus and its wild relatives. Berkeley CA: University of California, 1: 1-39.

Weber JL, Wong C. 1993. Mutation of human short tandem repeats. Human molecular genetics 2: 1123-1128.

Weir BS, Cockerham CC. 1984. Estimating F-statistics for the analysis of population structure. Evolution 38: 1358-1370.

Williams T, Roose M. 2004. 'TDE2' Mandarin hybrid (Shasta Gold Mandarin), 'TDE3' Mandarin hybrid (Tahoe Gold Mandarin) and 'TDE4' MAndarin hybrid (Yosemite Gold Mandarin): Three New Mid and Late-Season Triploid Seedless Mandarin Hybrids from California. Proceedings International Society Citriculture 1: 394-398.

Winkel-Shirley B. 2001. Flavonoid biosynthesis. A colorful model for genetics, biochemistry, cell biology, and biotechnology. Plant Physiology 126: 485-493.

Wright S. 1969. Evolution and the genetics of populations. The theory of gene frequencies. The University of Chicago Press: Chicago, vol2.

Wright S. 1978. Evolution and the genetics of populations. A treatise in four volumes. Variability within and among natural populations. The University of Chicago Press: Chicago, vol 4.

Xing C, Schumacher F, Xing G, Lu Q, Wang T, Elston R. 2005. Comparison of microsatellites, single-nucleotide polymorphisms (SNPs) and composite markers derived from SNPs in linkage analysis. BMC Genetics 6: S29.

Xu Q, Chen L, Ruan X, et al. 2013. The draft genome of sweet orange (Citrus sinensis). Nature genetics 45: 59-66.

Yakushiji H, Morinaga K, Nonami H. 1998. Sugar accumulation and partitioning in Satsuma mandarin tree tissues and fruit in response to drought stress. Journal of the American Society for Horticultural Science 123: 719-726.

Yamamoto M, Kobayashi S, Nakamura Y, Yamada Y. 1993. Phylogenic relationships of Citrus revealed by diversity of cytoplasmic genomes. In: Hayashi T, Omura M, Scott NS (eds.). Techniques on gene diagnosis and breeding in fruit trees. Research Station, Okitsu, Japan, 3946.

Yamamoto M, Tominaga S. 2003. High chromosomal variability of mandarins (Citrus spp.) revealed by CMA banding. Euphytica 129: 267-274.

Yamasaki M, Tenaillon MI, Bi IV, Schroeder SG, Sanchez-Villeda H, Doebley JF, Gaut BS, McMullen MD. 2005. A large-scale screen for artificial selection in maize identifies candidate agronomic loci for domestication and crop improvement. Plant Cell 17: 2859-2872.

Yan WG, Yong L, Agrama HA, Dagang L, Fangyuan G, Xianjun L, Guangjun R. 2009. Association mapping of stigma and spikelet characteristics in rice (Oryza sativa L.). Molecular Breeding 24: 277-292. 
Yang Y, YueZhi P, Xun G, MouTian F. 2010. Genetic variation in the endangered Rutaceae species Citrus hongheensis based on ISSR fingerprinting. Genetic Resources and Crop Evolution 57: 1239-1248.

Yonekura-Sakakibara K, Saito K. 2006. Review: genetically modified plants for the promotion of human health. Biotechnology Letters 28: 1983-1991.

Yu J, Pressoir G, Briggs WH, Vroh Bi I, Yamasaki M, Doebley JF, McMullen MD, Gaut BS, Nielsen DM, Holland JB, Kresovich S, Buckler ES. 2006. A unified mixed-model method for association mapping that accounts for multiple levels of relatedness. Nature Genetics 38: 203.

Yu JM, Buckler ES. 2006. Genetic association mapping and genome organization of maize. Current opinion in biotechnology 17: 155-160.

Zaragoza S. 2007. Aproximación a la historia de los cítricos. Origen, dispersión y evolución de su uso y cultivo. Tesis doctoral. Universidad Politécnica de Valencia. Departamento de Producción Vegetal, Valencia, España.

Zhang Y, Zhang Q, Yang Y, Luo Z. 2009. Development of japanese persimmon core collection by genetic distance sampling based on SSR markers. Agric Sci China 8: 276-284.

Zhang L, Vision TJ, Gaut BS. 2002. Patterns of Nucleotide Substitution Among Simultaneously Duplicated Gene Pairs in Arabidopsis thaliana. Molecular biology and evolution 19: 1464-1473.

Zhao KY, Aranzana MJ, Kim S, Lister C, Shindo C, Tang CL, Toomajian C, Zheng HG, Dean C, Marjoram P, Nordborg M. 2007. An Arabidopsis example of association mapping in structured samples. PLoS Genetics 3: e4.

Zhu C, Gore M, Buckler ES, Yu J. 2008. Status and prospects of association mapping in plants. Plant Genome 1: 5-20.

Zhu YL, Song QJ, Hyten DL, Van Tassell CP, Matukumalli LK, Grimm DR, Hyatt SM, Fickus EW, Young ND, Cregan PB. 2003. Single-Nucleotide Polymorphisms in Soybean. Genetics 163: 1123-1134. 
ANNEX 



\section{OTHER WORKS PERFORMED ALONG WITH THE PhD THESIS}

Beside the work included in this PhD thesis, I contributed to the research of the IVIA/CIRAD laboratory in citrus genetics. I have been therefore associated to three papers published in peered reviewed articles.

Some of the indels and SNP markers developed during this thesis have been employed for the establishment of the reference genetic map of C. clementina (Ollitrault et al., 2012b), which constitutes a good framework for further marker-trait association studies, and helped the chromosome assembly of the reference whole genome citrus sequence (Gmitter et al., 2012).

Several of these SNP markers were also included on a GoldenGate array platform in addition to more than 600 SNPs mined in clementine BAC-end sequences to genotype 54 accession covering the main Citrus species and 52 inter-specific hybrids between pummelo and clementine (Ollitrault et al., 2012a). The SNP data confirmed the important stratification of the gene pools around C. maxima, $C$. medica and $C$. reticulata as well as previous hypothesis on the origin of secondary species. The implemented SNP marker set will be very useful for comparative genetic mapping in Citrus and genetic association in C. reticulata.

Besides the previous two works, I was involved in the characterization of the diversity of Tunisian citrus rootstocks (Snoussi et al., 2012). Two hundred and one local accessions belonging to four facultative apomictic species (C. aurantium, sour orange; $C$. sinensis, orange; C. limon, lemon; and C. aurantifolia, lime) were collected and genotyped using 20 nuclear SSR markers and four indel mitochondrial markers. Multi-locus genotypes (MLGs) were compared to references from French and Spanish collections. The Tunisian citrus rootstock genetic diversity is predominantly due to high heterozygosity and differentiation between the four varietal groups. The phenotypic diversity within the varietal groups has resulted from multiple introductions, somatic mutations and rare sexual recombination events. Finally, this diversity study enabled the identification of a core sample of accessions for further physiological and agronomical evaluations. These core accessions will be integrated into citrus rootstock breeding programs for the Mediterranean Basin.

On the other hand, several works have been presented as poster and oral communications in different congresses as first author and some other as collaborations with other colleagues:

\section{Articles in international journals}

- Ollitrault P, Terol J, Garcia-Lor A, Bérard A, Chauveau A, Froelicher Y, Belzile C, Morillon R, Navarro L, Brunel D, Talon, M. 2012a. SNP mining in C. clementina BAC end sequences; transferability in the Citrus genus (Rutaceae), phylogenetic inferences and perspectives for genetic mapping. BMC Genomics 13: 13.

- Ollitrault P, Terol J, Chen C, Federici CT, Lotfy S, Hippolyte I, Ollitrault F, Bérard A, Chauveau A, Costantino G, Kacar Y, Mu L, Cuenca J, Garcia-Lor A, Froelicher 
Y, Aleza P, Boland A, Billot C, Navarro L, Luro F, Roose ML, Gmitter FG, Talon M, Brune D. 2012b. A reference genetic map of $C$. clementina hort. ex Tan.; citrus evolution inferences from comparative mapping. BMC Genomics 13: 593.

- Snoussi H, Duval MF, Garcia-Lor A, Belfalah Z, Froelicher Y, Risterucci AM, Perrier X, Jacquemoud-Collet JP, Navarro L, Harrabi M, Ollitrault P. 2012. Assessment of the genetic diversity of the Tunisian citrus rootstock germplasm. BMC Genetics 13: 16 .

\section{Congress oral communications}

- Garcia-Lor A, Luro F, Ancillo G, Ollitrault P, Navarro L. Genetic diversity and population structure of the mandarin germplasm revealed by nuclear and mitochondrial markers analysis. XII International Citrus Congress- Valencia, Spain. November $18^{\text {th }}$ 23 ${ }^{\text {rd }}$ 2012. S01O03, Pag. 27.

- Curk F, Ancillo G, Garcia-Lor A, Luro F, Navarro L, Ollitrault P. Multilocus haplotyping by parallel sequencing to decipher the interspecific mosaic genome structure of cultivated citrus. XII International Citrus Congress- Valencia, Spain. November $18^{\text {th }}-23^{\text {rd }}$ 2012. S01O06, Pag. 28.

- Ollitrault P, Terol J, Chen C, Federici CT, Lotfy S, Hippolyte I, Ollitrault F, Bérard A, Chauveau A, Cuenca J, Costantino G, Kacar Y, Mu L, Garcia-Lor A, Froelicher Y, Aleza P, Boland A, Billot C, Navarro L, Luro F, Roose ML, Gmitter Jr. FG, Talón M, Brunel D. A reference genetic map of Citrus clementina; citrus evolution inferences from comparative mapping. XII International Citrus Congress- Valencia, Spain. November $18^{\text {th }}-23^{\text {rd }} 2012$. S03O05, Pag. 63.

\section{Congress posters}

- Garcia-Lor A, Luro F, Navarro L, Ollitrault P. Analysis of genetic diversity and population structure of Citrus Germplasm using nuclear (SSRs, indels) and mitochondrial markers. $2^{\text {nd }}$ International Symposium on Genomics of Plant Genetic Resources. Bologna (Italy). 24-27 April 2010. P3.31.

- Garcia-Lor A, Luro F, Navarro L, Ollitrault P. Análisis de la diversidad genética y de la estructura poblacional del Germoplasma de mandarino mediante marcadores moleculares nucleares (SSRs, indels) y mitocondriales. V Congreso de Mejora Genética de Plantas. Madrid, 7-9 Julio 2010. Pag. 253-254.

- Garcia-Lor A, Curk F, Luro F, Navarro L, Ollitrault P. Nuclear and maternal phylogeny within Citrus and four related genera based on nuclear gene sequence SNPs and mitochondrial indels. Plant Genome Evolution. Amsterdam, The Netherlands, 4-6 September 2011. P2.23.

- Garcia-Lor A, Curk F, Snoussi H, Morillon R, Ancillo G, Luro F, Navarro L, Ollitrault P. Nuclear phylogeny of Citrus and four related genera. XII International Citrus Congress- Valencia, Spain. November $18^{\text {th }}-23^{\text {rd }}$ 2012. S01P08, Pag. 31.

- Curk F, Garcia-Lor A, Snoussi H, Froelicher Y, Ancillo G, Navarro L, Ollitrault P. New insights on limes and lemons origin from targeted nuclear gene sequencing and cytoplasmic markers genotyping. XII International Citrus Congress- Valencia, Spain. November $18^{\text {th }}-23^{\text {rd }}$ 2012. S01P09, Pag. 32.

- Ollitrault P, Garcia-Lor A, Terol J, Curk F, Ollitrault F, Talon M, Navarro L. Comparative values of SSRs, SNPs and indels for citrus genetic diversity analysis. XII International Citrus Congress- Valencia, Spain. November $18^{\text {th }}-23^{\text {rd }}$ 2012. S02P05, Pag. 44.

- Curk F, Ancillo G, Garcia-Lor A, Luro F, Ollitrault P, Navarro L. Multilocus SNPs analysis allows phylogenetic assignation of DNA fragments to decipher the interspecific mosaic genome structure of cultivated Citrus. Plant Genome Evolution. Amsterdam, The Netherlands, 4-6 September 2011. P2.21. 
- Snoussi H, Duval MF, Garcia-Lor A, Perrier X, Jacquemoud-Collet JC, Navarro L, Ollitrault $\mathbf{P}$. Analysis of genetic diversity in Tunisian citrus rootstocks. XII International Citrus Congress- Valencia, Spain. November $18^{\text {th }}-23^{\text {rd }} 2012$. S01P11, Pag. 33.

- Terol J, Chen C, Federici CT, Lotfy S, Hippolyte I, Ollitrault F, Bérard A, Chauveau A, Costantino G, Kacar Y, Mu L, Cuenca J, Garcia-Lor A, Froelicher Y, Aleza P, Boland A, Billot C, Navarro L, Luro F, Roose ML, Gmitter FG, Talon M, Brune D. A Reference Linkage Map of C. clementina Based on SNPs, SSRs and Indels. Plant \& Animal Genomes XIX Conference. January 15-19, 2011. Town \& Country Convention Center San Diego, USA. P.477. 


\title{
A reference genetic map of $C$. clementina hort. ex Tan.; citrus evolution inferences from comparative mapping
}

Patrick Ollitrault ${ }^{12^{*}}$, Javier Terol ${ }^{3}$, Chunxian Chen ${ }^{4}$, Claire T Federici, Samia Lotfy ${ }^{1,6}$, Isabelle Hippolyte ${ }^{1}$, Frédérique Ollitrault ${ }^{2}$, Aurélie Bérard ${ }^{7}$, Aurélie Chauveau', Jose Cuenca ${ }^{2}$, Gilles Costantino ${ }^{8}$, Yildiz Kacar', Lisa Mu ${ }^{5}$, Andres Garcia-Lor ${ }^{2}$, Yann Froelicher', Pablo Aleza ${ }^{2}$, Anne Boland ${ }^{10}$, Claire Billot', Luis Navamo ${ }^{2}$, François Luro ${ }^{8}$, Mikeal L Roose ${ }^{5}$, Frederick G Gmitter ${ }^{4}$, Manuel Talon $^{3}$ and Dominique Brunel ${ }^{7}$

\begin{abstract}
Background: Most modem citrus cultivars have an interspecific origin. As a foundational step towards deciphering the interspecific genome structures, a reference whole genome sequence was produced by the International Citrus Genome Consortium from a haploid derived from Clementine mandarin. The availability of a saturated genetic map of Clementine was identified as an essential prerequisite to assist the whole genome sequence assembly. Clementine is believed to be a 'Mediterranean' mandarin $\times$ sweet orange hybrid, and sweet orange likely arose from interspecific hybridizations between mandarin and pummelo gene pools. The primary goals of the present study were to establish a Clementine reference map using codominant markers, and to perform comparative mapping of pummelo, sweet orange, and Clementine.

Results: Five parental genetic maps were established from three segregating populations, which were genotyped with Single Nucleotide Polymorphism (SNP), Simple Sequence Repeats (SSR) and Insertion-Deletion (Indel) markers. An initial medium density reference map ( 961 markers for $1084.1 \mathrm{cM}$ ) of the Clementine was established by combining male and female Clementine segregation data. This Clementine map was compared with two pummelo maps and a sweet orange map. The linear order of markers was highly conserved in the different species. However, significant differences in map size were observed, which suggests a variation in the recombination rates. Skewed segregations were much higher in the male than female Clementine mapping data. The mapping data confirmed that Clementine arose from hybridization between 'Mediterranean' mandarin and sweet orange. The results identified nine recombination break points for the sweet orange gamete that contributed to the Clementine genome.

Conclusions: A reference genetic map of citrus, used to facilitate the chromosome assembly of the first citrus reference genome sequence, was established. The high conservation of marker order observed at the interspecific level should allow reasonable inferences of most citrus genome sequences by mapping next-generation sequencing (NGS) data in the reference genome sequence. The genome of the haploid Clementine used to establish the citrus reference genome sequence appears to have been inherited primarily from the "Mediterranean' mandarin. The high frequency of skewed allelic segregations in the male Clementine data underline the probable extent of deviation from Mendelian segregation for characters controlled by heterozygous loci in male parents.

Keywords: C. clementina, C. sinensis, C. maxima, SSRs, SNPs, Indels, Genetic maps
\end{abstract}

Corespondence patsckollitraidieciad fr

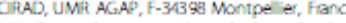

MiA Centro Proteccion Vegetal y tiotechnologia Cra Moncada-Náquera

full ist of author information is avalable at the end of the artick

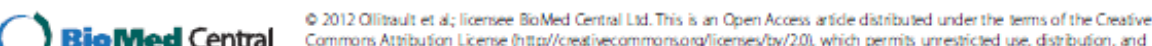
repodxcion in any medum, povided the orignal wokk is propely cited. 


\title{
SNP mining in C. clementina BAC end sequences; transferability in the Citrus genus (Rutaceae), phylogenetic inferences and perspectives for genetic mapping
}

Patrick Ollitrault ${ }^{12^{*}}$, Javier Terol ${ }^{3}$, Andres GarciaLor ${ }^{2}$, Aurélie Bérard ${ }^{4}$, Aurélie Chauveau ${ }^{4}$, Yann Froelicher ${ }^{1}$, Caroline Belzile $e^{2}$, Raphaël Morillon ${ }^{1,3}$, Luis Navarro ${ }^{2}$, Dominique Brunel ${ }^{4}$ and Manuel Talon ${ }^{3}$

\begin{abstract}
Background: With the increasing availability of EST databases and whole genome sequences, SNPs have become the most abundant and powerful polymorphic markers. However, SNP chip data generally suffers from ascertainment biases caused by the SNP discovery and selection process in which a small number of individuals are used as discovery panels. The ongoing International Citrus Genome Consortium sequencing project of the highly heterozygous Clementine and sweet orange genomes will soon result in the release of several hundred thousand SNPs. The primary goals of this study were: (i) to estimate the transferability within the genus Citrus of SNPs discovered from Clementine BACend sequencing (BES), (ii) to estimate bias associated with the very narrow discovery panel, and (iii) to evaluate the usefulness of the Clementine-derived SNP markers for diversity analysis and comparative mapping studies between the different cultivated Gitrus species.

Results: Fifty-four accessions covering the main Citrus species and 52 interspecific hybrids between pummelo and Clementine were genotyped on a GoldenGate array platform using 1,457 SNPs mined from Clementine BES and 37 SNPs identified between and within $C$. maxima, $C$ medica, $C$ reticulata and $C$. micrantha. Consistent results were obtained from 622 SNP loci. Of these markers, 116 displayed incomplete transferability primarily in $C$ medica, $C$. maxima and wild Gitrus species. The two primary biases associated with the SNP mining in Clementine were an overestimation of the $C$. reticulata diversity and an underestimation of the interspecific differentiation. However, the genetic stratification of the gene pool was high, with very frequent significant linkage disequilibrium. Furthermore, the shared intraspecific polymorphism and accession heterozygosity were generally enough to perform interspecific comparative genetic mapping.

Conclusions: A set of 622 SNP markers providing consistent results was selected. Of the markers mined from Clementine, $80.5 \%$ were successfully transferred to the whole Gtrus gene pool. Despite the ascertainment biases in relation to the Clementine origin, the SNP data confirm the important stratification of the gene pools around $C$ maxima, $C$ medica and $C$ reticulata as well as previous hypothesis on the origin of secondary species. The implemented SNP marker set will be very useful for comparative genetic mapping in Citrus and genetic association in $C$ reticulata.
\end{abstract}

- Corespondence patrickolitraulegiradit

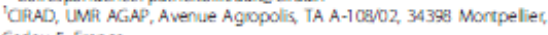

Cedex 5, france

Full list of author information is avalable at the end of the article

Biomed Central

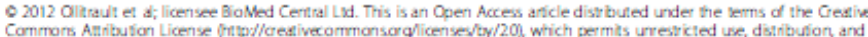
reprodution in aly medum, providad the crigral watk is gropel ly cled 


\title{
Assessment of the genetic diversity of the Tunisian citrus rootstock germplasm
}

Hager Snoussi ${ }^{*}$, Marie-France Duval ${ }^{2}$, Andres Garcia-Lor ${ }^{3}$, Zina Belfalah', Yann Froelicher ${ }^{2}$, Ange-Marie Risterucci ${ }^{2}$, Xavier Perrier ${ }^{2}$, Jean-Pierre Jacquemoud-Collet ${ }^{2}$, Luis Navarro ${ }^{3}$, Moncef Harrabi ${ }^{4}$ and Patrick Ollitrault ${ }^{2.3 *}$

\begin{abstract}
Background: Citrus represents a substantial income for farmers in the Mediterranean Basin. However, the Mediterranean citrus industry faces increasing biotic and abiotic constraints. Therefore the breeding and selection of new rootstocks are now of the utmost importance. In Tunisia, in addition to sour orange, the most widespread traditional rootstock of the Mediterranean area, other citrus rootstocks and well adapted to local environmental conditions, are traditionally used and should be important genetic resources for breeding. To characterize the diversity of Tunisian citrus rootstocks, two hundred and one local accessions belonging to four facultative apomictic species ( $C$. aurantium, sour orange; $C$. sinensis, orange; $C$. limon, lemon; and $C$ aurantifolia, lime) were collected and genotyped using 20 nuclear SSR markers and four indel mitochondrial markers. Multi-locus genotypes (MLGs) were compared to references from French and Spanish collections.

Results: The differentiation of the four varietal groups was well-marked. The groups displayed a relatively high allelic diversity, primarily due to very high heterazygosity. Sixteen distinct MLGs were identified. Ten of these were noted in sour oranges. However, the majority of the analysed sour orange accessions corresponded with only two MLGs, differentiated by a single allele, likely due to a mutation. The most frequent MLG is shared with the reference sour oranges. No polymorphism was found within the sweet orange group. Two MLGs, differentiated by a single locus, were noted in lemon. The predominant MLG was shared with the reference lemons. Limes were represented by three genotypes. Two corresponded to the 'Mexican lime' and 'limonette de Marrakech' references. The MLG of 'Chiiri' lime was unique.

Conclusions: The Tunisian citrus rootstock genetic diversity is predominantly due to high heterozygosity and differentiation between the four varietal groups. The phenotypic diversity within the varietal groups has resulted from multiple introductions, somatic mutations and rare sexual recombination events. Finally, this diversity study enabled the identification of a core sample of accessions for further physiological and agronomical evaluations. These core accessions will be integrated into citrus rootstock breeding programs for the Mediterranean Basin.
\end{abstract}

\section{Background}

Worldwide production of citrus in 2009 reached greater than 120 million tons [1], making citrus the leading cultivated tree crop in the world. Oranges represent the majority of citrus production ( $54 \%$ in 2009 ) with over 67 million tons in 2009 [1]. The other significant cultivated citrus are mandarins, lemons and grapefruits. The

* Comespondence: hagers noussiegmaicom, patsckolita utecirad fr Honiculhural Laboratory, Tunisian National Agronomic fesearch institute NAFAT, fue Hedi Karray, 2049 Ariana, Tunisa

Department BIOS, TGU AGAP, intemational Center for of Agrioulura heseasch for Development (CikAD), Avenue Agropolik, TA A-75/102, F-3439

intorion is aralable at the end of the artele citrus production of the Mediterranean Basin is second only to Brazil. Cultivars are vegetatively propagated by bud-grafting onto seedling rootstocks. This ensures tree uniformity, early tree production, and tolerance to pathogens including Phytophthora sp., parasitic nematodes and viruses. Rootstocks are also significant in the adaptation of the tree to several abiotic constraints affecting the Mediterranean citriculture. These include water resource scarcity and soil salinity. Citrus rootstocks are generally apomictic and seed-propagated. Therefore, both scions and rootstocks are clonally propagated. Sour orange (C. aurantium L.), one of the most important citrus rootstocks in the world, is still the 


\section{Congress oral communications}

S01003

Genetic diversity and population structure of the mandarin germplasm revealed by nuclear and mitochondrial markers analysis

Garcia-Lor A. ${ }^{1}$, Luro F. $^{2}$, Ancillo G. ${ }^{1}$, Ollitrault P. ${ }^{3}$, and Navarro L. ${ }^{1}$

${ }^{1}$ Instituto Valenciano de Investigaciones Agrarias (IVIA), Centro de Proteccion Vegetal Y Biotecnología, Spain; ${ }^{2}$ Institut National de la Recherche Agronomique (INRA), Unité de recherche GEQA, France; and ${ }^{3}$ Centre de coopération Internationale en Recherche Agronomique pour le Développement (CIRAD), BIOS, France. angarcia@ivia.es

Mandarins ( $C$. reticulata) are considered as one of the four main species involved in the origin of cultivated citrus. However, the classification of the mandarin germplasm is still controversial and numerous cases of introgression from other species are known or suspected in this germplasm. The main objective of this work was to analyze the genetic diversity structure of mandarin germplasm and its relationship with the other citrus species. Fifty microsatellite (SSR) markers, 25 Insertion-Deletion (InDel) nuclear markers and four mitochondrial InDel markers were genotyped for 223 accessions. 'Structure' software was applied on nuclear data to check and quantify potential interspecific introgressions in the mandarin germplasm, mainly the pummelo and papeda genomes. Within the mandarin germplasm without identified introgression, seven clusters were revealed by 'Structure' analysis. Five of them should be true basic mandarin groups and the other two include genotypes of known or supposed hybrid origin. The contributions of these seven groups to the mandarin genotypes were estimated. The mitochondrial InDel analysis revealed eight mitotypes, in which the mandarin germplasm was represented in four of them. In this work, new insights in the organization of mandarin germplasm and its structure have been found, and different mandarin core collections were determined. This will allow a better management and use of citrus germplasm collections and to perform genetic association studies. 
S01006

Multilocus haplotyping by parallel sequencing to decipher the interspecific mosaic genome structure of cultivated citrus

Curk F. ${ }^{1}$, Ancillo G. ${ }^{2}$, Garcia-Lor A. ${ }^{2}$, Luro F.1, Navarro L. ${ }^{2}$, and Ollitrault P. ${ }^{3}$

${ }^{1}$ INRA, UR1103 Génétique et Ecophysiologie de la Qualité des Agrumes (INRA UR GEQA), France; ${ }^{2}$ Instituto Valenciano de Investigaciones Agrarias (IVIA), Centro de Protección Vegetal y Biotecnología, Spain; and ${ }^{3}$ Centre de Coopération International en Recherche Agronomique pour le Développement (CIRAD), BIOS, France. curk@corse.inra.fr

Recent studies support the theory that four basic taxa (Citrus medica, Citrus maxima, Citrus reticulata and Citrus micrantha) have generated all cultivated Citrus species. It is supposed that the genomes of most of the actual citrus cultivars are interspecific mosaics of large DNA fragments issued from a limited number of interspecific meiotic events. In the present work, we analyzed how haplotypic multilocus study of closely linked SNPs allows phylogenetic assignment of DNA fragments for the main cultivated species. We have developed a new method based on universal primers to prepare the amplicons to be analyzed by 454 technology (Roche). It was applied for direct multilocus haplotyping of 12 gene fragments of 48 Citrus genotypes. Moreover, Sanger sequencing was performed on a subset of these amplicons (seven gene fragments of 24 citrus genotypes) to validate the 454 results. Consensus haplotype sequences were successfully identified from 454 sequencing. Sanger and 454 results were mostly identical. C. reticulata was the most polymorphic basic taxa. The average differentiation between the basic taxa was about $20 \mathrm{SNPs} / \mathrm{kb}$. These polymorphisms were enough for unambiguous multilocus differentiation of the basic species and assignment of phylogenetic origin for each haplotype of the secondary species. Multilocus haplotyping by parallel sequencing will be a powerful tool to decipher the interspecific mosaic genome structure of cultivated citrus. 


\section{$\mathrm{S} 03005$}

A reference genetic map of Citrus clementina; citrus evolution inferences from comparative mapping

Ollitrault P. ${ }^{1}$, Terol J. ${ }^{2}$, Chen C. ${ }^{3}$, Federici C.T. ${ }^{4}$, Lotfy S. ${ }^{5}$, Hippolyte I. ${ }^{1}$, Ollitrault F. ${ }^{6}$, Bérard A. ${ }^{7}$, Chauveau A. ${ }^{7}$, Cuenca J. ${ }^{6}$, Costantino G. ${ }^{8}$, Kacar Y. ${ }^{9}$, Mu L. ${ }^{4}$, Garcia-Lor A. ${ }^{6}$, Froelicher Y. ${ }^{1}$, Aleza P. ${ }^{6}$, Boland A. ${ }^{10}$, Billot C. ${ }^{1}$, Navarro L. ${ }^{6}$, Luro F. $^{8}$, Roose M.L. ${ }^{3}$ , Gmitter Jr. F.G. ${ }^{3}$, Talón M. ${ }^{2}$, and Brunel D. ${ }^{7}$

1 Centre de Coopération Internationale en Recherche Agronomique pour le Développement (CIRAD), BIOS, France $;^{2}$ Instituto Valenciano de Investigacion Agrarias (IVIA), Genomic Center, Spain; ${ }^{3}$ Citrus Research and Education Center, University of Florida (CREC), USA; ${ }^{4}$ University of California, Riverside (UCR), Botany and Plant science, USA; ${ }^{5}$ Institut National de la Recherche Agronomique (INRA), Morroco; ${ }^{6}$ Instituto Valenciano de Investigacion Agrarias (IVIA), Centro de Protección Vegetal y Biotecnología, Spain; ${ }^{7}$ Institut National de la Recherche Agronomique (INRA), UR EPGV, France; ${ }^{8}$ Institut National de la Recherche Agronomique (INRA), UR GEQA, France; ${ }^{9}$ Faculty of Agriculture, University of Çukurova, Department of Horticulture, Turkey; and ${ }^{10}$ Centre de I'Energie Atomique (CEA), DSV/Institut de Génomique, France. patrick.ollitrault@cirad.fr

The availability of a saturated genetic map of clementine was identified by the ICGC as an essential prerequisite to assist the assembly of the reference whole genome sequence based on a 'Clemenules' clementine derived haploid. The primary goals of the present study were to establish a clementine reference map, and to perform comparative mapping with pummelo and sweet orange. Five parental genetic maps were established with SNPs, SSRs and InDels. A medium density reference map (961 markers for $1084.1 \mathrm{cM}$ ) of clementine was established and used by the ICGC to facilitate the chromosome assembly of the haploid genome sequence. Comparative mapping with pummelo and sweet orange revealed that the linear order of markers was highly conserved. The map should allow reasonable inferences of most citrus genomes by mapping next-generation sequencing data against the haploid reference genome sequence. Significant differences in map size were observed between species, suggesting variations in the recombination rates. Skewed segregations were frequent and higher in the male than female clementine. The mapping data confirmed that clementine arose from hybridization between 'Mediterranean' mandarin and sweet orange and identified nine recombination break points for the sweet orange gamete that contributed to the clementine genome. Moreover it appears that the genome of the haploid clementine used to establish the citrus reference genome sequence has been inherited primarily from the 'Mediterranean' mandarin. 
Congress posters

Analysis of genetic diversity and population structure of the Citrus Germplasm using nuclear markers (SSRs, INDELs) and mitochondrial markers.

A. Garcia-Lor ${ }^{1}$, F. Luro ${ }^{2}$, L. Navarro ${ }^{1}$ and P. Ollitrault ${ }^{1,3}$

${ }^{1}$ Instituto Valenciano de Investigaciones Agrarias (IVIA), Moncada (Valencia), Spain

${ }^{2}$ Institut National de Recherche Agronomique (INRA), San Giuliano, France

3 Centre de coopération Internationale en Recherche Agronomique pour le Développement (CIRAD), Montpellier, France

Previous molecular markers studies (ISSR, RAPD, SCAR, AFLP and SSR) have shown that most of the genetic diversity of cultivated Citrus (except $C$. aurantifolia) comes from the recombination between three main species: $C$. medica (citron), $C$. reticulata (mandarin) and $C$. maxima (pummelo). However the precise contribution of these basic species to the genome constitution of secondary species (C. sinensis, C. limon, C. aurantium, C. paradisi) and recent hybrids is not known.

In this study, 58 nuclear markers and 4 mitochondrial markers were used to investigate the genetic diversity among 106 Citrus accessions, representing the three main ancestors groups, secondary species and several hybrids from the $20^{\text {th }}$ century breeding programs. For the nuclear analysis, 50 simple sequence repeats (SSRs) developed from genomic libraries and ESTs databases were used. Moreover, 10 Insertion-Deletion (INDEL) markers were developed from genomic sequences of some primary and secondary metabolites determining the citrus fruit quality (sugars, acids, flavonoids and carotenoids. All the SSR markers and one INDEL are included in a consensus genetic map of Clementine $x$ Chandler and are distributed along all the linkage groups, representing positively the global diversity of Citrus.

Genetic diversity statistics were calculated for each SSR and INDEL marker, within the entire population and within and between the different specified Citrus groups. The organizations of the genetic diversity among all the accessions were determined by constructing neighbor-joining trees for the different sets of primers.

INDEL markers are less polymorphic than SSRs, display a higher structuration of genetic diversity and appear as better phylogenetic markers to trace the contribution of the three ancestral species.

Population structure was studied using the Structure software, version 2.2.3, (http://cbsuapps.tc.cornell.edu/structure) which implements a model-based clustering method for inferring population structure using genotype data. The relative proportion of ancestral taxa genomes in the secondary species and recent hybrids was assigned.

Mitochondrial markers revealed the maternal phylogeny of citrus germplasm accessions in agreement with previous studies with chloroplastic markers.

This analysis allowed a better understanding of the organization of genetic diversity among citrus cultivars, opening the way for a better management of citrus germplasm bank and breeding programs. 
Análisis de la diversidad genética y de la estructura poblacional del Germoplasma de mandarino mediante marcadores moleculares nucleares (SSRs, INDELs) y mitocondriales.

A. Garcia-Lor ${ }^{1}$, F. Luro ${ }^{3}$, L. Navarro ${ }^{1}$ y P. Ollitrault ${ }^{1-2}$

${ }^{1}$ Centro de Protección Vegetal y Biotecnología, IVIA. Ctra. Moncada-Náquera km 4.5 46113 Moncada, Valencia.

${ }^{2}$ Centre de coopération Internationale en Recherche Agronomique pour le Développement (CIRAD), UPR 75, Avenue Agropolis - TA A-75/02-34398, Montpellier, cedex5, France.

${ }^{3}$ Unité de recherche GEQA, Institut National de la de Recherche Agronomique (INRA), San Giuliano, France.

Palabras clave: cítricos, variabilidad, microsatélite, marcadores filogenéticos, C. reticulata, inserción, delección.

\section{INTRODUCCIÓN}

Estudios previos con marcadores moleculares (ISSR, RAPD, SCAR, AFLP y SSR) han mostrado que la mayor parte de la diversidad genética de los cítricos cultivados (excepto $C$. aurantifolia) procede de la recombinación entre tres especies principales: C. medica L. (cidro), C. reticulata Blanco (mandarino) y C. maxima L. Osbeck (zamboa) (Swingle and Reece, 1967; Tanaka, 1977). Sin embargo, la contribución precisa de estas especies al grupo mandarino no es conocida. Por ello, en este trabajo se han empleado además de marcadores microsatélites (SSR), marcadores de inserción-delección (INDEL). Estos últimos son menos polimórficos que los marcadores microsatélites, presentan una mayor organización de la diversidad genética y parecen ser mejores marcadores filogenéticos para determinar la contribución de las especies ancestrales a la colección de mandarinos. El origen materno del citoplasma de las variedades estudiadas ha sido analizado mediante marcadores de tipo mitocondrial, siendo éste concordante con estudios previos realizados con marcadores cloroplásticos.

\section{MATERIALES Y MÉTODOS}

El material vegetal empleado consta de 84 variedades del banco de germoplasma del IVIA (formado mayoritariamente por variedades de origen americano y europeo, de aparición relativamente reciente) y 124 variedades del banco de germoplasma de Córcega (formado mayoritariamente por variedades ancestrales de origen asiático).

Se emplearon 50 marcadores moleculares nucleares SRRs (Simple Sequence Repeat) (Kijas et al., 1995; Luro et al., 2008, Froelicher et al., 2008) que están distribuidos a lo largo de todo el genoma, según el mapa genético consenso de Clementino x Chandler (obtenido por Patrick Ollitrault y colaboradores), lo cual hace que los resultados que se han obtenido representen la variabilidad genética global. Además se utilizaron 8 marcadores INDEL, desarrollados a partir de secuencias genómicas de genes implicados en la biosíntesis de metabolitos primarios y secundarios que determinan la calidad de los cítricos (flavonoides, azúcares, acidez y carotenos), como son: Chalcona isomerasa (CHI), Enzima málico (EMA), Fosfoenolpiruvato carboxilasa (PEPC), Transportador vacuolar citrato $/ \mathrm{H}^{+}$(TRPA), Deoxixilulosa 5 -fosfato sintasa (DXS), $\beta$-Caroteno hidroxilasa $(\mathrm{Hy}-\mathrm{b})$ y Fitoeno sintasa (PSY).

Para genotipar los SSRs e INDEL se empleó el Analizador Genético Automático $\mathrm{CEQ}^{\mathrm{TM}} 8000$ de Beckman Coulter. Los resultados fueron analizados mediante diversas herramientas de análisis genético: DARwin (http://darwin.cirad.fr/darwin) para hacer análisis de grupo, GENEPOP 4.0 (http://genepop.curtin.edu.au/index.html) para determinar parámetros de genética poblacional y Structure version 2.2.3, (http://cbsuapps.tc.cornell.edu/structure) para representar la organización genética de la población estudiada, definiendo grupos y observando la contribución relativa de cada uno de ellos a los distintos genotipos de la población. 


\section{RESULTADOS Y DISCUSIÓN}

Como se muestra en los datos obtenidos para la población de mandarino (Tabla 1), para los marcadores SSR la diversidad genética es elevada, así como el número medio de alelos por locus en comparación con lo observado con los marcadores INDEL. Esto es debido principalmente a su mayor polimorfismo (PIC). Los marcadores microsatélites parecen ser mejores para la diferenciación intraespecífica y los marcadores INDEL para la diferenciación interespecífica. Existen muchas variedades clasificadas como $C$. reticulata Blanco (según Tanaka) que se encuentran dispersas en la población, lo cual indica que podrían estar sujetas a una diferenciación mayor, incluso asignar variedades a otras especies. Con el programa Structure se diferencian entre 8 y 10 grupos dentro del germoplasma de mandarino, así como la proporción relativa de estos y de las especies ancestrales en cada variedad, siendo acorde con los resultados obtenidos con DARwin. Los valores muy bajos del coeficiente de endogamia (FIS) confirman la existencia de mezcla genética frecuente entre los diferentes grupos de mandarino.

Los datos de marcadores mitocondriales han permitido diferenciar tres orígenes maternales al nivel de los mandarinos (dos mitotipos de mandarino y uno de zamboa), confirmando la introgresión de zamboa en algunas variedades de mandarino. La alta variabilidad genética observada en el grupo mandarino y los distintos parámetros genéticos analizados, muestran una situación favorable para realizar estudios de genética de asociación entre caracteres genotípicos y fenotípicos. Además, se pretende establecer una colección base que represente la variabilidad global del grupo mandarino.

\section{Referencias}

Froelicher, Y. et al. 2008. Characterization of microsatellite markers in mandarin orange (Citrus reticulata Blanco). Molecular ecology resources 8: 119-122.

Kijas, J.M.H. et al. 1995. An evaluation of sequence tagged microsatellite site markers for genetic analysis within Citrus and related species. Genome 38: 349-355

Luro et al. 2008. Transferability of the EST-SSRs developed on Nules clementine (Citrus clementina Hort ex Tan) to other Citrus species and their effectiveness for genetic mapping. BMC Genomics 9: 287.

Swingle, WT. and Reece, PC. 1967. The botany of Citrus and its wild relatives. In: Reuter W, Webber HJ, Batchelor LD (eds) The Citrus Industry 1: 190-430.

Tanaka, T. 1977. Fundamental discussion of Citrus classification. Stud Citrologia 14: 1-6.

Tabla 1. Estadísticas población grupo mandarino.

\begin{tabular}{|l|c|c|}
\hline & INDEL & SSRs \\
\hline № medio de alelos/locus & 3.38 & 8.22 \\
\hline Heterocigosidad esperada & 0.14 & 0.61 \\
\hline Heterocigosidad observada & 0.15 & 0.62 \\
\hline PIC(Polimorphic Information Content) & 0.14 & 0.71 \\
\hline FIS (Coeficiente de endogamia) & -0.09 & -0.01 \\
\hline
\end{tabular}




\title{
[P2.23]
}

Nuclear and maternal phylogeny within Citrus and four related genera based on nuclear genes sequence SNPs and mitochondrial InDels

\author{
A. Garcia-Lor ${ }^{* 1}$, F. Curk ${ }^{1,2}$, F. Luro ${ }^{2}$, L. Navarro ${ }^{1}$, P. Ollitrault ${ }^{1,3}$ \\ ${ }^{1} I V I A$, Spain, ${ }^{2}$ INRA, France, ${ }^{3} \mathrm{CIRAD}$, France
}

Despite considerable morphological differentiation Citrus, Fortunella, Poncirus, Microcitrus and Eremocitrus genera are sexually compatible. Species of these genera are mainly diploid $(2 n=18)$. If the origin of cultivated Citrus from four basic taxa (C. maxima, $C$. medica, $C$. reticulata and $C$. micrantha) is now well documented, their phylogenetic relationships with Citrus wild species and related genera is still unclear. In the present work we analyse their nuclear and maternal phylogeny by using respectively SNPs on gene sequences and mitochondrial InDels.

A total of $7.15 \mathrm{~kb}$ were amplified by PCR from 11 genes (Table1) and sequenced (Sanger) for 33 genotypes. The varietal sample was composed of 7 C. reticulata, 5 C. maxima, 5 C. medica, 4 papeda, 5 Fortunella, 3 Poncirus, 2Microcitrus, 1 Eremocitrus. Severinia buxifolia was used as outgroup. SNPs were mined using BioEdit and SegMan softwares and phylogenetic analysis done in "http://phylemon.bioinfo.cipf.es" with different approaches (Phylip (v. 3.68), PhymIBest AIC Tree (v. 1.02b), PhyML (v. 3.00). For maternal phylogeny, 4 InDel markers developed by (Froelicher et al. 2011) have been used.

The average frequency per Kb of SNPs and InDels were respectively 59.88 and1.33 in coding region and 110.99 and 16.31 in non-coding ones. A total of 506SNP and 23 InDels were identified (Table1). Within Citrus, the papeda group was the most polymorphic species, with 185 polymorphisms, followed by C. reticulata (125), C. maxima (48), and C. medica (27).

A new mitotype was observed for Microcitrus australasica while two different mitotypes were identified for Fortunella. Nuclear and mitochondrial phylogenetic analysis reveal that $C$. reticulata andFortunella form a consistent clade clearly differentiated from the clade includingthe other basic taxa of cultivated citrus (C. maxima, C. medica and C. micrantha).

Inclusion of more genes sequences is undergoing and will improve the resolution of the phylogenetic analysis.

Table 1. Statistics in the population studied.

\begin{tabular}{lccccccc}
\hline Gene & CS & CDS & NCS & SCF & SNCF & ICF & INCF \\
\hline Chalcone isomerase & 652 & 206 & 446 & 53.40 & 170.40 & 0 & 17.94 \\
Chalcone synthase & 565 & 565 & 0 & 35.40 & - & 0 & - \\
Flavonol Synthase & 473 & 419 & 54 & 90.69 & 111.11 & 0 & 55.56 \\
Flavonoid 3'-hydroxylase & 613 & 569 & 44 & 70.30 & 45.45 & 0 & 0 \\
Enzyme malique & 428 & 128 & 300 & 54.69 & 86.67 & 7.81 & 13.33 \\
Vacuolar citrate/H+ symporter & 795 & 657 & 138 & 60.88 & 115.94 & 0 & 7.25 \\
Malate dehydrogenase & 712 & 712 & 0 & 39.33 & - & 0 & - \\
Acid invertase & 673 & 409 & 264 & 85.57 & 136.36 & 0 & 3.79 \\
Lycopene $\beta$-cyclase & 738 & 738 & 0 & 88.08 & - & 6.78 & - \\
Lycopene $\beta$-cyclase & 941 & 941 & 0 & 39.32 & - & 0 & - \\
9-cis-epoxy hydroxy carotenoid dyoxygenase & 560 & 560 & 0 & 41.07 & - & 0 & - \\
\hline
\end{tabular}

(CS) Cleaned sequence (bp); (CDS) Coding sequence (bp); (NCS) Non-coding sequence (bp); (SCF) SNP frequency in coding region, $\mathrm{x} / \mathrm{Kb}$; (SNCF) SNP frequency in non-coding region; (ICF) InDel frequency in coding region, $\mathrm{x} / \mathrm{kb}$; (INCF) InDel frequency in non-coding region 
S01P08

Nuclear phylogeny of Citrus and four related genera and Ollitrault P.

Garcia-Lor A. ${ }^{1}$, Curk F. ${ }^{2}$, Snoussi H. ${ }^{3}$, Morillon R. ${ }^{4}$, Ancillo G. ${ }^{1}$, Luro F. ${ }^{2}$, Navarro L. ${ }^{1}$,

${ }^{1}$ Instituto Valenciano de Investigaciones Agrarias (IVIA), Centro de Protección Vegetal y Biotecnología, Spain; ${ }^{2}$ INRA, UR1103 Génétique et Ecophysiologie de la Qualité des Agrumes (INRA UR GEQA), DGAP, France; ${ }^{3}$ Institut National de la Recherche Agronomique de Tunisie (INRAT), Laboratoire d'Horticulture, Tunisie; and ${ }^{4}$ Centre de coopération Internationale en Recherche Agronomique pour le Développement (CIRAD), BIOS, France. angarcia@ivia.es

Despite considerable differences in morphology, the genera representing "true citrus fruit trees" are sexually compatible, but their phylogenetic relationships remain unclear. Most of the important commercial species of Citrus are believed to be of interspecific origin. By studying SNP and InDel polymorphisms of 27 nuclear genes on 45 genotypes of Citrus and related taxa, the average molecular differentiation between species was estimated, and the phylogenetic relationship between "true citrus fruit trees" was clarified. A total of 16238 bp of DNA was sequenced for each genotype, and 1097 SNPs and 50 InDels were identified. Nuclear phylogenetic analysis revealed that Citrus reticulata and Fortunella form a clade clearly differentiated from the other two basic taxa of cultivated citrus (Citrus maxima, Citrus medica). A few genes displayed positive selection patterns within or between species, but most of them displayed neutral patterns. The phylogenetic inheritance patterns of the analysed genes were inferred for commercial Citrus species. The SNPs and InDels identified are potentially very useful for the analysis of interspecific genetic structures. The nuclear phylogeny of Citrus and its sexually compatible relatives was consistent with their geographic origin. The positive selection observed for a few genes will orient further work to analyze the molecular basis of the variability of the associated traits. This study presents new insights into the origin of Citrus sinensis. 
S01P09

New insights on limes and lemons origin from targeted nuclear gene sequencing and cytoplasmic markers genotyping Ollitrault P. ${ }^{4}$

Curk F. ${ }^{1}$, Garcia-Lor A. ${ }^{2}$, Snoussi H. ${ }^{3}$, Froelicher Y. ${ }^{4}$, Ancillo G. ${ }^{2}$, Navarro L. ${ }^{2}$, and

${ }^{1}$ INRA, UR1103 Génétique et Ecophysiologie de la Qualité des Agrumes (INRA UR GEQA), DGAP, France; ${ }^{2}$ Instituto Valenciano de Investigaciones Agrarias (IVIA), Centro de Protección Vegetal y Biotecnología, Spain; ${ }^{3}$ INRAT (Institut National de la Recherche Agronomique de Tunisie), Tunisia; and ${ }^{4}$ Centre de Coopération International en Recherche Agronomique pour le Développement (CIRAD), BIOS, France. curk@corse.inra.fr

It is believed that Citrus medica, Citrus maxima, Citrus reticulata and Citrus micrantha have generated all cultivated Citrus species. Depending on the classification, lemons and limes are classified either into two species, Citrus limon and Citrus aurantifolia (Swingle and Reece) or into more than 30 (Tanaka). In order to study the molecular phylogeny of this Citrus group, we analyzed 20 targeted sequenced nuclear genes and used 3 mitochondrial and 3 chloroplastic markers for 21 lemons and limes compared with representatives of the 4 basic taxa. We observed 3 main groups, each one derived from direct interspecific hybridizations: (1) the Mexican lime group (C. aurantifolia), including Citrus macrophylla, arising from hybridization between papeda (C. micrantha) and citron (C. medica); (2) the yellow lemon group (C. limon) that are hybrids between sour orange (Citrus aurantium, which is believed to be a hybrid betweenC. Maxima and C. reticulata) and citron; and (3) a rootstock lemon/lime group (Rough lemon and Rangpur lime) that are hybrids between the acid small mandarin group and citron. We also identified different probable backcrosses and genotypes with more complex origins. None of the analyzed limes and lemons shared the C. medica cytoplasm, while this taxon is the common nuclear contributor of all limes and lemons. Limes and lemons appear to be a very complex citrus varietal group with the contribution of the 4 basic taxa. Neither the Swingle and Reece nor the Tanaka classifications fit with the genetic evidence. 
S02P05

Comparative values of SSRs, SNPs and InDels for citrus genetic diversity analysis

Ollitrault P. ${ }^{1}$, Garcia-Lor A. ${ }^{2}$, Terol J.3, Curk F. ${ }^{4}$, Ollitrault F. ${ }^{2}$, Talon M. ${ }^{3}$, and Navarro L. ${ }^{2}$

${ }^{1}$ Centre de Coopération Internationale en Recherche Agronomique pour le Développement (CIRAD), BIOS, France; ${ }^{2}$ Instituto Valenciano de Investigaciones Agrarias (IVIA), Centro de Protección Vegetal y Biotecnología, Spain; ${ }^{3}$ Instituto Valenciano de Investigaciones Agrarias (IVIA), Centro de Genómica, Spain; and ${ }^{4}$ Institut National de la Recherche Agronomique (INRA), GAP, France. patrick.ollitrault @cirad.fr

SSRs have long been considered as almost ideal markers for genetic diversity analysis. With the increasing availability of sequencing data, SNPs and InDels become major classes of codominant markers with genome wide coverage. We have analyzed the respective values of SSRs, InDels, and SNPs for intra and interspecific Citrus genetic diversity analysis. Moreover, we have compared the diversity structure revealed by markers mined in a single heterozygous genotype (the clementine) and markers mined in a large interspecific survey. A random set of 25 markers was selected for each marker class to genotype 48 citrus accessions. SSRs were the most polymorphic markers at the intraspecific level allowing complete varietal differentiation within basic taxa (Citrus reticulata, Citrus maxima, Citrus medica). However, SSRs gave the lowest values for interspecific differentiation, followed by SNPs and InDels, that displayed low intraspecific variability but high interspecific differentiation. A clear effect of the discovery panel was observed for SNPs and InDels. The ascertainment biases associated with the clementine heterozygosity mining resulted mainly in an over estimation of within C. reticulata diversity and an underestimation of the interspecific differentiation. Therefore SSRs are very useful for intraspecific structure analysis while SNPs and InDels mined in large discovery panel will be more powerful to decipher the interspecific mosaic structure of secondary cultivated species. 
[P2.21]

Multilocus snps analysis allows phylogenetic assignation of DNA fragments to decipher the interspecific mosaic genome structure of cultivated Citrus

F. Curk ${ }^{* 1,2}$, G. Ancillo ${ }^{2}$, A. Garcia-Lor ${ }^{2}$, F. Luro ${ }^{1}$, P. Ollitrault3,2, L. Navarro ${ }^{2}$

${ }^{1}$ INRA, France, ${ }^{2}$ IVIA, Spain, ${ }^{3} \mathrm{CIRAD}$, France

All current studies seem to support the theory that four basic taxa ( $C$. medica, $C$. maxima, C. reticulata and C. micrantha) have generated all cultivated Citrus species. It is supposed that the genomes of most of the modern Citrus cultivars, vegetatively propagated, are interspecific mosaic of large DNA fragments issued from a limited number of inter-specific meiosis. In the present work we analyse how multilocus study of closely linked SNPs allows a phylogenetic assignation of DNA fragments of the main cultivated species.

Genomic fragments of 25 genes dispersed in the different chromosomes covering more than $12,5 \mathrm{~Kb}$ were amplified by PCR and sequenced (Sanger) for 24 accessions representative of 10 species. Moreover we checked the potential of parallel pyrosequencing (454 Roche) for direct multilocus haplotyping of heterozygous genotypes. Amplified fragments from 7 genes in 8 genotypes were obtained by using an original new method based on universal primers. $C$. clementina (Clementine) was used as model for secondary species. Citrus reticulata was the most polymorph basic taxa with an average of $4.2 \mathrm{SNPs} / \mathrm{kb}$. The average differentiation between the basic taxa was about $20 \mathrm{SNPs} / \mathrm{kb}$. For each amplified gene fragment, this polymorphism was enough for unambiguous multilocus differentiation of the basic species and assignation of a phylogenetic origin for the secondary species. A preliminary reconstitution of phylogenetic structure of chromosome 3 is proposed for sweet orange, sour orange, grapefruit, lemon and lime. Consensus haplotype sequences were successfully obtained from 454 sequencing with genotype sequence in total agreement with Sanger control. Each haplotype sequence of Clementine was univocally assigned to one of the haplotype clusters of the basic taxa. Phylogenetic origin of specific DNA fragments can be assigned from multilocus analysis of closely linked SNPs. Multilocus haplotyping by parallel sequencing of individual DNA molecule will be a very powerful tool to decipher the interspecific mosaic genome structure of cultivated citrus.

Keywords: snp, mosaic sturcutre genome, phylogeny, Citrus 


\section{S01P11}

Analysis of genetic diversity in Tunisian citrus rootstocks

Snoussi H. ${ }^{1}$, Duval M.F. ${ }^{2}$, Garcia-Lor A. ${ }^{3}$, Perrier X. ${ }^{2}$, Jacquemoud-Collet J.C. ${ }^{2}$, Navarro L. ${ }^{3}$, and Ollitrault $P{ }^{2}{ }^{2}$

${ }^{1}$ Tunisian National Agronomic Research Institute (INRAT), Horticultural Laboratory, Tunisia; ${ }^{2}$ International Center for of Agricultural Research for Development (CIRAD), Department BIOS. TGU. AGAP, France; and ${ }^{3}$ Instituto Valenciano de Investigaciones Agrarias (IVIA), Centro de Protección Vegetal y Biotecnología, Spain. hagersnoussi@gmail.com

Breeding and selection of new citrus rootstocks are nowadays of the utmost importance in the Mediterranean Basin because the citrus industry faces increasing biotic and abiotic constraints. In Tunisia, citrus contributes significantly to the national economy, and its extension is favored by natural conditions and economic considerations. Sour orange, the most widespread traditional rootstock of the Mediterranean area, is also the main one in Tunisia. In addition to sour orange, other citrus rootstocks well adapted to local environmental conditions are traditionally used and should be important genetic resources for breeding. Prior to initiation of any breeding program, the exploration of Tunisian citrus rootstock diversity was a priority. Two hundred and one local accessions belonging to four facultative apomictic species (Citrus aurantium, sour orange; Citrus sinensis, sweet orange; Citrus limon, lemon; and Citrus aurantifolia, lime) were collected and genotyped using 20 nuclear SSR markers and four InDel mitochondrial markers. Sixteen distinct Multi-locus genotypes (MLGs) were identified and compared to references from French and Spanish collections. The differentiation of the four varietal groups was well-marked. Each group displayed a relatively high allelic diversity, primarily due to very high heterozygosity. The Tunisian citrus rootstock genetic diversity is predominantly due to high heterozygosity and differentiation between the four varietal groups. The phenotypic diversity within the varietal groups has resulted from multiple introductions, somatic mutations and rare sexual recombination events. This diversity study enabled the identification of a core sample of accessions for further physiological and agronomic evaluations. These core accessions will be integrated into citrus rootstock breeding programs for the Mediterranean Basin. 


\section{Reference SNPs, SSRs and InDels C. clementina linkage map}

Patrick Ollitrault ${ }^{1,2}$, Javier Terol ${ }^{3}$, Chunxian Chen ${ }^{4}$ Claire T. Federici ${ }^{5}$, Samia Lotfy ${ }^{6,1}$, Isabelle Hippolyte ${ }^{1}$, Frédérique Ollitrault ${ }^{2}$, Aurélie Bérard ${ }^{7}$, Gilles Costantino ${ }^{8}$, Lisa Mu $^{5}$, Yildiz Kacar $^{9}$, Jose Cuenca ${ }^{2}$, Andres Garcia ${ }^{2}$, Yann Froelicher ${ }^{1}$, Anne Boland ${ }^{10}$, Claire Billot ${ }^{11}$, Luis Navarro, François Luro', Mikeal L. Roose ${ }^{5}$, Frederick G. Gmitter ${ }^{4}$, Manuel Talon ${ }^{3}$ and Dominique Brunel ${ }^{7}$

1 CIRAD, UPR 75, Avenue Agropolis, TA A-75/02, 34398 Montpellier, Cedex 5, France

2 Centro de Protection Vegetal y Biotechnologia, IVIA, Apartado Oficial ,46113 Moncada (Valencia), Spain

3 Centro de genomica, IVIA, Apartado Oficial , 46113 Moncada (Valencia), Spain

4 Citrus Research and Education Center, University of Florida, Lake Alfred, FL 33850, USA

5 Department of Botany and Plant Sciences, University of California, Riverside, CA 92521, USA

6 Institut National de la Recherche Agronomique, BP 293, 14000 Kénitra, Morocco

7 INRA, UR EPGV, 2 rue Gaston Cremieux, 91057, Evry, France

8 INRA, UR GEQA San Giuliano 20230 San Nicolao, France

Adana, Turkey

9 Department of Horticulture, Faculty of Agriculture, University of Çukurova, 01330,

10 CNG, 2 rue Gaston Cremieux, 91057, Evry, France France

11 CIRAD, UMR DAP, Avenue Agropolis - TA A-96 / 03, 34398 Montpellier Cedex 5,

Corresponding author: patrick.ollitrault@cirad.fr

An haploid C. clementina was chosen by the International Citrus Genomic Consortium (ICGC) to establish the reference whole Citrus genome sequence. The implementation of a dense clementine linkage map was part of the objectives of this global collaborative project. Two inter-specific populations between $C$. clementina and $C$. maxima were used for this purpose. 156 hybrids of Nules Clementine x Pink pummelo and 200 hybrids of Chandler pummelo $x$ Nules clementine were genotyped with 1003 markers. 306 were SSRs markers (66 from genomic bank, 207 from ESTs and 33 from clementine BACEnd sequences -BES-), 34 were Indels markers mined from BES and 663 SNPs mined from Clementine BES or identified by candidate gene sequencing. 901 markers were successfully mapped in the 9 clementine linkage groups. Important segregation distortion were observed for clementine when used as male parent while it followed Mendelian segregation for most markers when used as female parent. However marker order was mostly conserved between the male and female maps; thus, data of the two populations were joined to establish the reference Clementine genetic map. Total Clementine linkage map size is $1250 \mathrm{cM}$ with linkage groups from $105 \mathrm{cM}$ until $210 \mathrm{cM}$. This map is strongly anchored on a large diploid clementine BAC library resource. It is a powerful tool for Citrus genetic and supports the alignment of the haploid Clementine whole genome sequence in the framework of the collaborative project of the ICGC. 


